


\title{
ARTE Y AGRICULTURA Estrategias artísticas para la transición a una agricultura sustentable
}

Tesis doctoral presentada por:

Celia Puerto Espinós

\author{
Dirigida por: \\ Dr. José Albelda Raga \\ Dra. María Paula Santiago Martín de Madrid
}

Universitat Politècnica de València

Julio 2021

Programa de doctorado en

Arte: Producción e Investigación

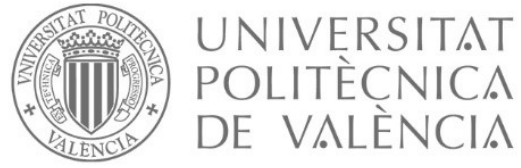



A la memoria de mi padre, Salvador Puerto Cantó, humilde agricultor que nos transmitió su amor por el campo. 



\section{AGRADECIMIENTOS}

Esta investigación ha sido posible gracias a la colaboración de muchas personas. En primer lugar, quiero agradecer a mi director, José Albelda Raga, y a mi directora, María Paula Santiago Martín de Madrid, por haber sido mis guías en este largo camino y por toda la ayuda prestada. También, un agradecimiento a la Universitat Politècnica de València por la financiación obtenida para la elaboración de esta tesis con el Programa de Ayudas de Investigación y Desarrollo (PAID-01-17).

A João Carlos de Castro Silva por su tutorización durante la estancia en el Centro de Investigación y Estudios en Bellas Artes (CIEBA) de Lisboa, Portugal. $Y$ a todos los y las artistas y agricultores y agricultoras que muy amablemente han compartido la experiencia de sus proyectos, concretamente a Kultivator, Mandarina Borda, Culturhaza, Kultivarte y Quinta Das Relvas.

Asimismo, gracias a mi familia, Tyrone Anthony Thompson, a mi madre, a mi padre, a mi hermano y mis hermanas. Gracias a todas las personas que me han acompañado y apoyado en el transcurso de este estudio, especialmente a Chiara Sgaramella y Miriam del Saz. Gracias a Silvia Molinero, Alicia Ramírez, Nuria Sánchez y Anthony Brian Thompson. Finalmente, gracias a todos los y las artistas, agricultores y agricultoras, investigadores e investigadoras que gracias a sus trabajos ha sido posible realizar esta tesis. 



\section{RESUMEN}

La presente investigación se centra en buscar los vínculos entre la práctica artística y la agrícola. Tras el estudio de ambas, se demuestra cómo se apoyan y nutren entre sí. Se realiza una breve revisión histórica de los 10.000 años de agricultura evidenciando cómo ha sido un tema muy relevante en las primeras manifestaciones gráfico-plásticas y el papel que ha ocupado en los movimientos artísticos posteriores hasta centrarnos en el arte contemporáneo. El estudio pretende dar a conocer las posibilidades que ofrece el arte utilizando estrategias artísticas y estéticas para fomentar prácticas agrícolas sustentables. Para ello, se hace uso de una metodología cualitativa y de investigación a través del arte con la elección de un repertorio de proyectos artísticos y su análisis. Finalmente, se eligen cinco casos de estudio actuales donde se trabaja el arte y la agricultura desde diferentes vías de investigación para analizarlos con más profundidad. 


\section{ABSTRACT}

This research focuses on the relationship between artistic and agricultural practice. After studying both, it shows how they support and nourish each other. A brief historical review of the 10,000 years of agriculture is carried out, showing how it has been a very relevant theme in the first graphic-plastic manifestations and the role it has played in later artistic movements and, more recently, in contemporary art. The study aims to highlight the possibilities offered by art using aesthetic strategies to promote sustainable agricultural practices. In order to do so, qualitative methodologies and art based research are used to analyse a series of art contemporany projects. Finally, five case studies where art and agriculture converge are chosen for an in-depth study. 


\section{RESUM}

La present investigació se centra en buscar els vincles entre la pràctica artística i l'agrícola. Després de l'estudi d'ambdues, es demostra com se secunden i nodreixen entre si. Es realitza una breu revisió històrica dels 10.000 anys d'agricultura evidenciant com ha sigut un tema molt rellevant en les primeres manifestacions gràfic-plàstiques i el paper que ha ocupat en els moviments artístics posteriors fins a centrar-nos en l'art contemporani. L'estudi pretén donar a conéixer les possibilitats que ofereix l'art utilitzant estratègies artístiques i estètiques per a fomentar pràctiques agrícoles sustentables. Per tant, es fa ús d'una metodologia qualitativa i d'investigació a través de l'art amb l'elecció d'un repertori de projectes artístics i la seua anàlisi. Finalment, es trien cinc casos d'estudi actuals on es treballa l'art i l'agricultura des de diferents vies d'investigació per a analitzar-los amb més profunditat. 



\section{ÍNDICE}

$\begin{array}{ll}\text { INTRODUCCIÓN } & 21\end{array}$

\section{CAPÍTULO 1.}

1.1. La agricultura a través de las manifestaciones artísticas: desde los inicios al siglo XVIII

1.1.1. La representación de la agricultura en el arte antiguo

1.1.1.1. El arte prehistórico: la revolución agrícola a través

de sus manifestaciones artísticas

1.1.1.2. Arte y agricultura en Mesopotamia 35

1.1.1.3. La agricultura en el arte egipcio 38

1.1.1.4. El arte griego y la agricultura 42

1.1.1.5. Representación agrícola en el arte romano 44

1.1.2. El arte medieval y la agricultura, siglo $\mathrm{V}$ al siglo XV 46

1.1.3. La agricultura en el arte de la Edad Moderna,

siglo XV al siglo XVIII 
1.2. El arte y la agricultura en las manifestaciones artísticas del siglo XIX

1.3. El arte y la agricultura en el contexto del siglo XX

1.3.1. La visión de la agricultura a través de las vanguardias artísticas del siglo XX

1.3.2. La agricultura vista desde el arte de últimas tendencias del siglo XX

1.4. El papel del arte español del siglo XXI visibilizando la agricultura

1.5. Conclusiones del capítulo

CAPÍTULO 2.

Agricultura industrial y su visión desde las prácticas artísticas

2.1. Un modelo insostenible y destructor:

la agricultura industrial y sus consecuencias

2.1.1. Los inicios

96

2.1.2. La contaminación y el arte que la vislumbra

2.2. Agrotóxicos: el Roundup y el arte que lo cuestiona

104

2.2.1. Intoxicación por agrotóxicos, caso Argentina

108

2.2.2. La lucha de Fabian Tomasi y el arte emergente

a partir de su historia

2.2.3. Los efectos de los agrotóxicos a través de la obra de Pablo Ernesto Piovano

2.3. Principal empresa transnacional de la agroquímica y el arte que la cuestiona

2.4. Organismos genéticamente modificados y el arte que los cuestiona

2.4.1. Breve contexto social y estratégico de los organismos genéticamente modificados

2.4.2. El arte que cuestiona el maíz transgénico

2.5. Lavado verde, la visión a través del arte documental y publicitario 
2.5.2. La propaganda corporativa a través de la obra de Kirsten Stolle

2.5.3. La lucha desde el activismo y la estética asociada

2.5.4. La visión de la agroindustria desde el

documental/videoarte

\section{CAPÍTULO 3.}

Agricultura sustentable y su manifestación a través del arte

3.1. Aproximación a conceptos y modelos de cultivo agrícola sustentable

3.1.1. Agricultura tradicional, familiar, local o indígena

3.1.2. Agricultura biodinámica

3.1.3. Agricultura orgánica, biológica o ecológica

3.1.4. Agricultura natural de no intervención

3.1.5. Permacultura

3.2. Recursos artísticos en la difusión de la práctica agrícola sustentable

3.2.1. El arte urbano que ensalza la agricultura 169

3.2.2. Los murales de Joseba Murúzabal (España, 1984)

174

3.3. Talleres artísticos en el contexto agrícola sustentable 178

3.3.1. Vivens Hortis, Cartagena, España 180

3.3.2. Re.Colectivo, Asturias, España 181

3.3.3. Viridian, Valencia, España 183

3.4. La obra artística en el campo agrícola 185

3.4.1. Intervención en terreno agrícola, Lucía Loren (España, 1973)

3.4.2. El laberinto de maíz ecológico:

The Corn Maze In The Plains (E.U.A., 2000) 
3.4.3. Arte Tanbo: arte de campo de arroz (Japón, 1993)

3.5. Del campo agrícola al espacio expositivo

3.5.1. Las pinturas de José Cruz García Albarado

(México, 1974)

198

3.5.2. La cultura de la alimentación chilena a través de

la obra de Natascha de Cortillas Diego (Chile, 1967)

201

3.5.3. Los dibujos de Jose Ismael Manco Parra

(Colombia, 1982)

205

3.6. Conclusiones capítulo

207

CAPÍTULO 4.

Arte y permacultura

211

4.1. Principios de la permacultura 212

4.2. Conexión del cuerpo con la tierra 223

4.2.1. Salud y bienestar 226

4.2.2. El arte de la toma de conciencia 227

4.2.3. El pensamiento positivo 229

4.3. La belleza asociada al diseño de huertas

permaculturales 231

4.4. Arte como visibilizador de la permacultura 239

4.5. El arte del aprovechamiento de los recursos 246

4.6. El arte y la permacultura como creador del grupo/comunidad 250

4.7. Conclusiones capítulo 257

CAPÍTULO 5. Estudio de casos específicos 261

5.1. Kultivator: arte y agricultura en Öland, Suecia 262

5.1.1. Las intervenciones artísticas en Kultivator 264

5.1.2. La escuela Ölands Folkhögskola 269

5.1.3. Conclusión 271 
5.2. Enriqueta Rocher y su asociación Mandarina Borda

5.2.1. Introducción

5.2.2. El nacimiento de Trastellaor

273

5.2.3. Los creadores en Trastellaor

275

5.2.3.1. Cápsula I

276

5.2.3.2. La Naranja Borde

277

5.2.3.3. Recetario hecho con amor borde

278

5.2.3.4. Ad infinitum

279

5.2.4. Conclusión

280

5.3. Culturhaza: arte y agroecología en Córdoba (España)

280

5.3.1. El Agrolandart de Culturhaza

284

5.3.2. Las colaboraciones con Culturhaza

288

5.3.3. Conclusión

290

5.4. Kultivarte: arte y permacultura en el Algarve, Portugal

291

5.4.1. Las artes en Kultivarte

293

5.4.2. La escasez de agua

294

5.4.3. Apoyos e ideas futuras de proyecto

295

5.4.4. Conclusión

296

5.5. Quinta Das Relvas, Branca, Portugal 298

5.5.1. Residencias artísticas, cursos y workshops 299

5.5.2. Colaboraciones y financiación 302

5.5.3. Conclusión 304

5.6. Conclusiones conjuntas 305

$\begin{array}{ll}\text { CONCLUSIONES } & 309\end{array}$

CONCLUSIONS

321

BIBLIOGRAFÍA 
VIDEOGRAFÍA

ANEXO I. Entrevista Kultivator

ANEXO II. Entrevista Mandarina Borda

361

ANEXO III. Entrevista Culturhaza

369

ANEXO IV. Entrevista Kultivarte

385

ANEXO V. Entrevista Quinta Das Relvas

ANEXO VI. Obra propia

405

ÍNDICE DE IMÁGENES

413 




\section{INTRODUCCIÓN}

La presente investigación se centra en la búsqueda de los nexos existentes entre el arte y la agricultura. Entendemos el arte como una herramienta que nos conduce a visualizar la situación agrícola actual, además, desdela mirada de los y las artistas se generan creaciones simbólicas que aportan una visión sensible del cultivo de alimentos. Así pues, el concepto de agricultura aborda el conjunto de prácticas y técnicas de tratamiento y cultivo de la tierra para la producción de alimentos. Especialmente, el estudio visibiliza la aportación de las prácticas artísticas en el fomento de la agricultura sustentable. En apariencia, la relación entre arte y agricultura no resulta socialmente manifiesta, no es algo que parezca evidente, como sí puede serlo el arte público urbano, por ejemplo. Sin embargo, una breve revisión histórica de los 10.000 años de agricultura nos demostrará que, dado su protagonismo en la consolidación de las culturas con asentamientos fijos en el territorio, y con una contribución decisiva al florecimiento de las grandes civilizaciones de la antigüedad, la agricultura ha sido un tema central y recurrente en las manifestaciones artísticas del pasado.

En realidad, no ha dejado de serlo nunca: las prácticas agrícolas, las escenas rurales y costumbristas, han sido igualmente motivo del arte pictórico desde 
el Renacimiento hasta la Modernidad, y también en algunas concreciones de las vanguardias artísticas del siglo XX. Pero a finales del siglo pasado y en los inicios del siglo XXI ha adquirido una nueva fuerza desde el arte ecológico y el arte reivindicativo que defiende al campesinado del Gran Sur y a sus pueblos originarios, frente al totalitarismo del agronegocio y los cultivos extensivos e intensivos que destruyen los ecosistemas y envenenan y empobrecen a los pueblos.

Finalmente, no solo encontramos una alianza con profundas sinergias positivas entre el arte ecológico y la agricultura sustentable, sino que ella misma, en muchos proyectos, se concibe como un acto creativo en defensa de la vida, de la diversidad, del diseño creativo. En una tradición milenaria que parte de las chacras del altiplano andino y nos lleva hasta la permacultura contemporánea. Alimentación, salud y belleza hilvanadas por una estética ecológica y reivindicativa: todo un compromiso por la vida y por el arte.

Para ello, hemos dedicado el primer capítulo de esta investigación a realizar un recorrido por la evolución agrícola desde el Neolítico hasta la actualidad, visto desde las primeras manifestaciones gráfico-plásticas hasta el arte contemporáneo, buscando esa unión entre arte y agricultura. La investigación empieza con un enfoque más globalizado y general para hacernos una idea de los vínculos entre la práctica agrícola y artística. En el transcurso de los capítulos vamos progresivamente acotando, el grueso de la investigación se centra en el siglo XXI, ya que nos interesa analizar las posibilidades que ofrecen los proyectos de arte actuales en su fomento de prácticas agrícolas más sustentables.

Por otra parte, nos centramos especialmente en proyectos e iniciativas de España por ser nuestro país de origen y haber crecido en un contexto agrícola familiar. Sin embargo, hemos dado saltos a otros países donde hemos detectado proyectos relevantes, con larga trayectoria y continuidad. Así pues, en los capítulos siguientes, se abarca el papel del arte en la agricultura industrial (capítulo 2), el fomento de las prácticas agrícolas sustentables a través de las estrategias artísticas (capítulo 3), y la función del arte en la 
permacultura (capítulo 4). Finalmente, se ha reservado un quinto capítulo para el estudio de casos específicos, donde hemos entrevistado a responsables de proyectos, realizado trabajo de campo y analizado los mismos con mayor profundidad. Por ejemplo, la asociación Kultivator en Suecia, una organización que trabaja con el vínculo del arte y la agricultura, donde nos desplazamos hasta su ubicación en Öland (Suecia) para entrevistarles y conocer de cerca su trabajo.

Cabe señalar que a lo largo de la investigación se citan proyectos y artistas de países sudamericanos, ya que hemos tenido en cuenta la situación que se vive en este subcontinente debido a las grandes explotaciones de monocultivos que se destinan, principalmente, para elaborar los piensos que alimentan el ganado europeo. Esa explotación ha conllevado que emerjan iniciativas en defensa de la cultura rural e indígena, y a que artistas recreen nuevas realidades donde se visibiliza el difícil contexto en el que se encuentran los campesinos y las campesinas. Se cita, especialmente, el caso de Argentina por la repercusión que ha tenido, gracias al esfuerzo de artistas, médicos, periodistas y familias visibilizando la situación tan delicada en la que se encuentran por las consecuencias derivadas del uso desmedido de agrotóxicos, de las grandes extensiones de monocultivos, de los transgénicos y de las abusivas prácticas de empresas como la de Monsanto. Consideramos que dado el momento de globalización en el que nos encontramos, resulta relevante para la investigación citar proyectos artísticos de otros países que nos puedan aportar la visión desde su contexto. No obstante, todas las propuestas citadas tienen un mismo fin, la defensa de la cultura agrícola sustentable. Así pues, para este estudio se plantea la siguiente hipótesis:

$>$ El arte como medio de comunicación y educación, es una buena herramienta para plasmar tanto la gran problemática que vivimos en la actualidad con una producción de alimentos excesivamente industrializada y monopolizada, como para plantear sus posibles soluciones (agricultura ecológica, permacultura, huertos urbanos...).

Dicho planteamiento se lleva a cabo con los siguientes objetivos generales: 
1. Entender y profundizar en la crisis ecológico-social que vivimos actualmente y cómo la producción de alimentos intensiva, industrializada y monopolizada contribuye a su aceleración.

2. Localizar y estudiar a artistas que trabajen en su obra cuestiones de labores en el campo, principalmente en la parte agrícola.

3. Explorar la capacidad del arte para crear empatía con la situación que tiene que vivir una parte de la población mundial debido a las producciones de alimentos transgénicos.

4. Analizar, a través de la obra artística, cómo afecta la producción de alimentos a gran escala tanto en el continente europeo como en el sudamericano.

5. Observar los elementos estéticos y métodos compositivos en las prácticas de cultivo más sustentables, como la permacultura.

Para llevar a cabo los objetivos generales, planteamos los siguientes objetivos específicos:

1. Realizar una investigación detallada de proyectos colectivos donde se relaciona el arte y la agroecología, mediante el estudio de casos.

2. Analizar el impacto en la sociedad de las obras de los artistas que trabajen con estos temas.

3. Creación de obra artística propia para experimentar en la práctica aspectos teóricos enunciados en la tesis.

Por consiguiente, los métodos utilizados para llevar a cabo la investigación se enmarcan en un ámbito humanístico, haciendo uso de una metodología cualitativa con casos de estudio específicos, trabajo de campo y entrevistas. La investigación empieza con la observación y el análisis de lo ya creado, partiendo del binomio de arte-agricultura con el fin de establecer las sinergias 
existentes. Con ello, hablamos de una investigación sobre el arte, citando al académico especializado en investigación artística Henk Borgdorff, nos situamos en un punto donde,

[...] el objeto de investigación permanece intacto bajo la mirada escrutadora del investigador [...] las características comunes de este tipo de investigación y del acercamiento teórico a las mismas son la "reflexión" y la "interpretación" ya sea la investigación de naturaleza histórica y hermenéutica, filosófica y estética, crítica y analítica, reconstructiva o deconstructiva, descriptiva o explicativa (Borgdorff, 2006: 9).

Con lo cual, realizamos un recorrido histórico donde nos centramos en exponer y describir los puntos en común del arte y la agricultura, tras la lectura y la observación de libros, artículos y audiovisuales de ambos campos del conocimiento. Además, nos basamos en una metodología de investigación desde, en, a través y para las artes, como menciona la Doctora en Diseño y Comunicación Silvia Ariza en su artículo De la práctica a la investigación en el arte contemporáneo, producir conocimiento desde la creación,

[...] la investigación desde el arte y la investigación en el arte (de Laiglesia, 2009), la investigación a través y para el arte (Frayling, 1993/4) y la investigación en y para el arte (Borgdorff, 2012) son las que se relacionan de forma más cercana con lo que se conoce como la investigación basada en la práctica. [...] Un escultor que aprende cómo trabajar la madera puede leer un libro o ver a alguien hacerlo, pero no es hasta que va al taller a realizar esta actividad, que se da cuenta de la fuerza que requiere y de las propiedades del material, de su lenguaje y sus posibilidades como materia. Cuando estos descubrimientos se generan en la acción y responden a preguntas específicas o dan lugar a nuevos planteamientos, contribuyen a enriquecer la disciplina y hay un avance en el conocimiento (Ariza, 2021: 544-545).

Así pues, hacemos uso de la práctica artística como investigación donde hemos adquirido un rol participativo. Por una parte, hemos seleccionado una serie de proyectos actuales como casos de estudio que hemos analizado, realizado trabajo de campo y entrevistado. Por otra parte, hemos realizado obra propia donde hemos podido poner en práctica todo el conocimiento adquirido tras el estudio de la teoría. En efecto, tal y como señala Ariza en la cita recién mencionada, a través de la práctica se pueden alcanzar matices 
que desde la teoría son más difíciles o incluso imposibles de descubrir. Por ejemplo, tras el trabajo de campo y las prácticas en los proyectos artísticos y agroecológicos que hemos seleccionado para este estudio, se han hallado los límites y las dificultades a las que se ven sometidos, los cuales desde un ámbito de estudio únicamente teórico hubieran sido difíciles de detectar. Así pues, Ariza reflexiona que

La investigación artística tiene muchas posibilidades, algunas donde lo creado es el tema de estudio a documentar, describir o descubrir y otras donde la acción real y práctica en un contexto se convierte en la herramienta para intervenir en el mundo y dar una visión diferente del mismo; fue necesario visitar estas tipologías para entender la riqueza de la investigación que se fundamenta en la práctica artística ya que el ejercicio de creación es no solo el punto de partida para generar información original, sino la razón y el instrumento a través del cual se genera nuevo conocimiento (Ariza, 2021: 550).

De tal forma, en el abanico de posibilidades que nos ofrece la investigación desde la práctica artística y en la búsqueda de enriquecer el estudio se ha realizado obra en el contexto de convocatorias artísticas donde se ha puesto en práctica la teoría previamente estudiada. Por ejemplo, con la obra presentada en Trastellaor, convocatoria artística coordinada por la asociación sin ánimo de lucro Mandarina Borda, Palmera, Valencia (España) - la presentada en el certamen A les balconades, Valencia (España) hemos podido abarcar un problema concreto dentro del contexto agrícola valenciano y analizarlo, ofreciendo posibles respuestas a través de la creación artística y potenciando su difusión.

Estos métodos nos sirven como medios para alcanzar los objetivos fijados en el presente estudio. Cabe resaltar que se trata de una investigación interdisciplinar, se nutre del cruce de distintas miradas y de la consulta de contenidos de diversos ámbitos (agroecología, arte, ética ecológica, educación ambiental, antropología). A continuación, se muestra una tabla que contempla los cinco capítulos de la presente investigación y una serie de criterios que se han seguido para ir abordando la hipótesis y los objetivos planteados. 


\section{CAPITULO 1: \\ El arte en relación con la agricultura. Una revisión histórica.}

Objeto de análisis: la evolución agrícola vista desde las primeras manifestaciones gráfico-plásticas hasta el arte contemporáneo.

Criterios:

- Citar manifestaciones gráfico-plásticas en relación con la agricultura desde el Neolítico.

- Investigar obras de arte que puedan contextualizar y visibilizar el recorrido de la agricultura y su transformación.

- Buscar proyectos coherentes, tanto en sus discursos como en los recursos que utilizan.

\section{CAPITULO 2:}

Agricultura industrial y su visión desde las prácticas artísticas.

Objeto de análisis: Situación y consecuencias de la agricultura industrializada y su cuestionamiento desde el arte.

\section{Criterios:}

- Contextualizar la situación de la agricultura industrial y apoyarla con los proyectos artísticos que la cuestionan.

- Tratar la situación de Argentina con los transgénicos y la gran cantidad de monocultivos, visibilizándola desde las acciones artísticas producidas en el país.

- Contemplar las estrategias artísticas utilizadas por las organizaciones que defienden la soberanía alimentaria y las formas de cultivar sustentables.

- Citar propuestas audiovisuales que trabajen el vínculo arte y agricultura, ya sea desde una narrativa documental a una creativa, irónica o ficticia. 


\section{CAPITULO 3:}

Agricultura sustentable y su manifestación a través del arte.

Objeto de estudio: tras una aproximación a conceptos y modelos agrícolas sustentables se valora la aportación del arte en su apoyo y difusión.

Criterios:

- Aproximar los conceptos y métodos básicos de la agricultura sustentable.

- Dar valor a los proyectos artísticos que ensalzan y visibilizan la agricultura sustentable en el contexto del arte contemporáneo, abarcando el período desde el 2000 al 2020.

- Buscar proyectos tanto en España como en el extranjero donde se muestre una fuerte unión entre el arte y la agricultura desde la sustentabilidad.

\section{CAPITULO 4:}

\section{Arte y permacultura.}

Objeto de estudio: indagar cuál es el papel del arte en el contexto de la permacultura.

Criterios:

- Investigar el papel que ocupa el arte en la permacultura.

- Indagar sobre los aspectos emocionales, comunitarios y sanitarios que se puedan abarcar desde la colaboración del arte y la permacultura.

- Buscar proyectos que trabajen arte y permacultura en colectivo/comunidad. 


\section{CAPITULO 5:}

\section{Estudio de casos específicos.}

Objeto de estudio: elección de diferentes tipos de proyectos donde su vertiente principal es la vinculación del arte con la agricultura.

Criterios:

- Estudiar proyectos artísticos que trabajen principalmente aspectos de la agricultura.

- Contemplar proyectos que se trabajen tanto individualmente como colectivamente.

- Abordar casos de estudio que nazcan de un ámbito familiar, local, nacional o internacional.

- Buscar iniciativas con recorrido de al menos unos años que trabajen la relación del arte y la agricultura desde diferentes vías de investigación.

Finalmente, remarcamos que las propuestas artísticas elegidas para ilustrar la investigación contemplan tanto la práctica agrícola como la artística, sea a nivel conceptual o formal y en mayor o menor porcentaje de implicación, pero en todos los proyectos se consideran ambas. 



\section{CAPÍTULO 1 \\ EL ARTE EN RELACIÓN CON LA AGRICULTURA UNA REVISIÓN HISTÓRICA}

Nos situamos en la prehistoria para introducir este capítulo que, finalmente, nos llevará a centrarnos en el arte contemporáneo y sus relaciones con el mundo agrícola. Concretamente partimos de la etapa del neolítico, comienzo de la revolución agrícola, para señalar y comentar los inicios del vínculo con la representación plástica. Así pues, a partir de esa unión se puntualiza la evolución del arte junto a la agricultura en los siguientes períodos, pasando por el arte del Medievo, el arte de la Edad Moderna y la Edad Contemporánea. Se genera un breve recorrido por las obras artísticas más representativas de la agricultura, viendo pinturas, esculturas y fotografías. Todas estas pinceladas nos llevarán al siglo XXI, período en el cual se ubica la mayor parte de esta investigación, mostrando cualquier expresión artística del arte contemporáneo que visualice su unión con la agricultura.

El estudio abarca la zona europeay, puntualmente, proyectos de Sudamérica y Norteamérica. Si bien, se toma especial interés en las obras surgidas en España por ser nuestro país de origen. Por ello, se citan artistas y proyectos actuales como Culturhaza, Mandarina Borda, Lucia Loren o las iniciativas impulsadas por Fernando García Dory de acercamiento a lo rural a través de las prácticas artísticas. 


\subsection{La agricultura a través de las manifestaciones artísticas: desde los inicios al siglo XVIII}

\subsubsection{La representación de la agricultura en el arte antiguo}

En esta etapa, las creaciones artísticas producidas por el ser humano interpretaban y registraban sus formas de vivir. En un principio predominando lo mágico-simbólico y, posteriormente, lo descriptivo y narrativo del arte de Mesopotamia y Egipto. De tal forma, los elementos artísticos que se van a citar contemplan la dimensión de cómo el ser humano visualizaba su modelo agrícola a través del arte que generaba.

\subsubsection{El arte prehistórico: la revolución agrícola a través de sus manifestaciones artísticas}

Partimos de la etapa del Neolítico, marcada como el principio de los asentamientos humanos, por la estabilización climática y por el deshielo de los glaciares del hemisferio norte que dieron paso a terrenos apropiados para el cultivo. Estos cambios propiciaron nuevas formas de vivir vinculadas al laboreo. En la presente investigación se muestra interés por el vínculo que se generaba con la tierra, con la fertilidad, con la mujer, con el hombre, con la vida, con los deseos de aumentar las cosechas y con las representaciones plásticas.

El ser humano hizo uso de sus habilidades artísticas para crear pinturas representativas de sus modos de vida, las cuales ubicó en los lugares que habitaba. También, se tallaba en piedra o se modelaba en arcilla, generando esculturas totémicas con el fin de favorecer sus cultivos. En esta etapa, las pinturas empiezan a salir de la oscuridad de las cuevas convirtiéndose en ornamento de la arquitectura. Además, la figura humana comienza a tener más protagonismo junto a elementos vegetales, se observa la naturaleza con interés por los fenómenos naturales, por sus procesos y sus recursos. Destacamos el estudio de la arqueóloga María Gimbutas donde habla de una cultura matrifocal, agrícola y sedentaria que tuvo lugar en la Antigua Europa, el área sudeste del continente europeo. Se veneró a deidades femeninas y 
surgió la representación de lo que sería la diosa madre, figuras que aluden a la mujer y a la fertilidad con decoraciones de líneas onduladas o zig-zag con el fin de favorecer las buenas cosechas. "Una diosa que simbolizara la fertilidad de la tierra era la respuesta natural para un modo de vida agrícola" (Gimbutas, 2014: 247), dando lugar a la Diosa de la Vegetación. Con esta manifestación artística, se generó una asimilación entre la germinación de la semilla y la creación de la vida; es por ello por lo que la imagen de una mujer embarazada fue la elegida para venerar las tierras y la abundancia en sus cosechas. El ser humano hizo uso del simbolismo para representar las semillas como puntos o las cosechas sembradas como losanges; esas muestras aparecen tanto en las estatuillas de la Diosa como en otras figurillas o amuletos. En las siguientes imágenes podemos observar dos piezas de la Diosa de la Vegetación que Gimbutas muestra en su libro Diosas y dioses de la vieja Europa (7000-3500 a. C.).

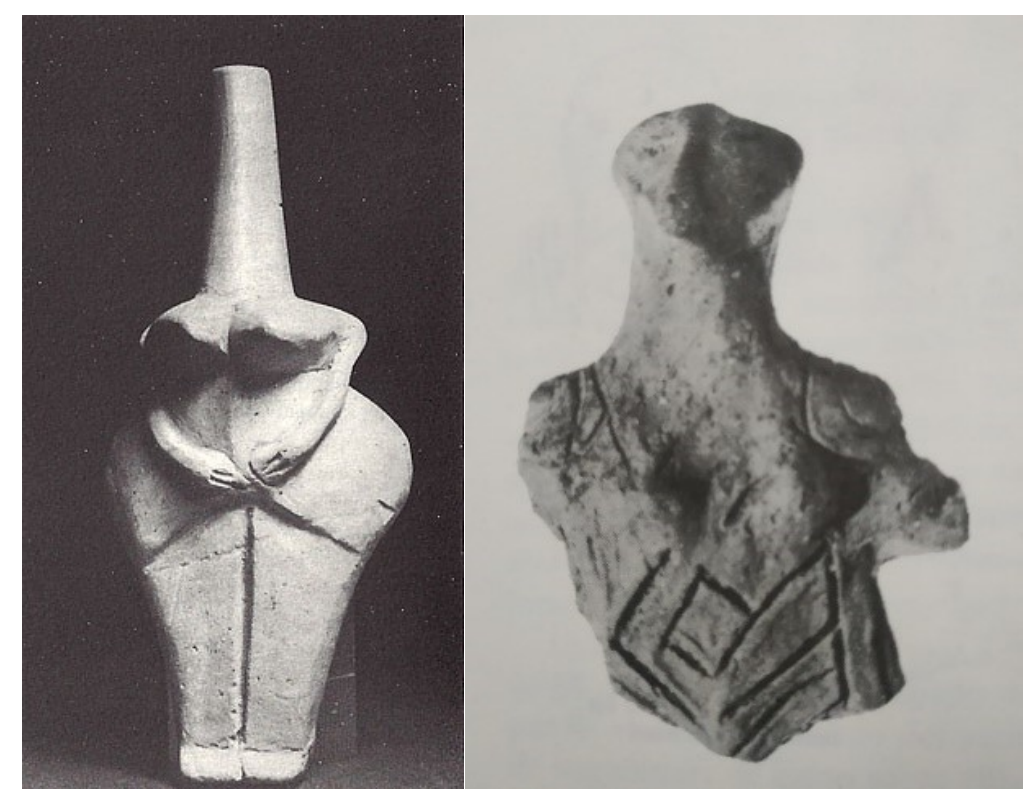

Imagen 1. Figurilla preñada, con cabeza de pilar de tipo Hamangia.

Cementerio de Cernavoda, Dobruja, c. 5000 a. C. Imagen 2. Diosa de la vegetación con máscara de cerdo. Rastu. Yacimiento del Vinca Temprano, en el oeste de Rumanía. 
Cabe destacar la curiosa conexión entre el cerdo y la Diosa de la Vegetación (imagen 2), ya que el rápido aumento del peso de los cerdos debió impresionar mucho a los agricultores que lo compararon con el maíz que crece y madura. De manera que su grasa, aparentemente, llegó a simbolizar la propia tierra convirtiéndose en animal sagrado (Gimbutas, 2014: 258). De tal forma, se empieza a observar en las pequeñas estatuillas de las diosas cómo se les añade una máscara del cerdo o se empiezan a crear figuras con la forma de este animal.

El arte expresa la respuesta mental del hombre a su medio natural, ya que con él intenta interpretar y someter la realidad, racionalizar la naturaleza y dar expresión visual a sus conceptos mitificadores (Gimbutas, 2014: 57).

Si bien representaban sus modos de vida y sus costumbres a través del arte, este también les ayudaba en la comprensión de sus actividades domésticas y agrícolas por las connotaciones religiosas y simbólicas que contiene. Por tanto, el arte no solo les representaba, sino que les aportaba conocimiento sobre su existencia. Gimbutas, desarrolla en su investigación una cultura matrifocal, agrícola y sedentaria, entendiendo por matrilineal una sociedad equitativa y solidaria donde el hombre y la mujer son tratados de forma igualitaria. Según la historiadora de la cultura y teórica de la evolución Riane Eisler,

El hecho de que las mujeres desempeñaran un papel preponderante y vigoroso en la vida y religión prehistóricas no significa que los hombres fueran vistos y tratados como inferiores. Ya que aquí, tanto los hombres como las mujeres eran hijos de la Diosa, de igual forma como eran hijos de las mujeres que encabezaban las familias y clanes. Y dado que esto, ciertamente, le dio bastante poder a las mujeres, homologándolo con la actual relación madre-hijo, parece haber sido un poder que se equiparaba más a la responsabilidad y al amor que a la opresión, los privilegios y el temor (Eisler, 2005: 31).

Tanto Eisler como Gimbutas muestran un mundo en la Antigua Europa donde prima la solidaridad, la belleza, el amor por la representación plástica y por la producción de alimentos, donde "todos los recursos de la naturaleza humana, masculinos y femeninos, se utilizaron al máximo como fuerza creativa" (Gimbutas, 2014: 291). En cambio, a mediados del 4000 a. C. 
empezaron las invasiones de pastores seminómadas indoeuropeos que irrumpieron en las sociedades matrifocales, dando paso al poder y a la dominación de unos sobre otros.

La más antigua civilización europea fue salvajemente destruida por el elemento patriarcal y nunca se recuperó, pero su legado persistió en el sustrato que alimentó posteriores desarrollos culturales europeos (Gimbutas, 2014: 292).

La sociedad basada en el ciclo agrícola y vinculada a la Diosa Madre fue irrumpida poco a poco por los nuevos colonos que impusieron su patriarcado exaltando a dioses guerreros, viriles y heroicos. Dejando de lado la veneración a lo femenino, al vínculo de la fertilidad de la mujer con la de la tierra y dando lugar a una sociedad patriarcal con una simbología que exaltaba el poder.

\subsubsection{Arte y agricultura en Mesopotamia}

El período mesopotámico abarcó más de 10.000 años, donde sucedieron grandes descubrimientos como la escritura y la rueda. Asimismo, la domesticación de las plantas y de los animales dio paso a grandes cambios culturales en las sociedades; con la acumulación de excedentes, se fomentó el comercio y la jerarquización del poder. En Mesopotamia, los asentamientos se organizaron en los alrededores de los ríos Éufrates y Tigris, los cuales les proporcionaban agua y nutrientes para sus cultivos. Además, crearon una red de canales y acequias para controlar la afluencia del río con la que consiguieron abastecer de agua zonas de secano. Gracias al control de las crecidas e inundaciones de los ríos pudieron asentar las bases de una próspera agricultura. Los canales también servían para navegar y comercializar con el excedente de las cosechas. El arqueólogo Julián Reade señala que,

En tiempos todavía prehistóricos los pueblos mesopotámicos fueron los primeros en cultivar con éxito la agricultura y en producir los suministros regulares de alimentos imprescindibles para el desarrollo de la civilización; además Mesopotamia fue, entre los años 3000 y 500 a. d JC., uno de los centros literarios más importantes del mundo (Reade, 1998:4). 
El incremento de las cosechas produjo un aumento en la población, se generaron redes comerciales y se desarrollaron las primeras ciudades, como Buqras o Yarim. Víctor J. Monserrat, del Departamento de Zoología y Antropología Física de la Universidad Complutense de Madrid, en su artículo Los artrópodos en la mitología, la ciencia y el arte de Mesopotamia, comenta que

Los mesopotámicos se preocupaban de la vida terrenal y no de la de los muertos, por tanto, las edificaciones más representativas eran el templo y el palacio como centros del poder [...]. El templo era el centro religioso, económico y político. Disponía de tierras de cultivo, rebaños, almacenes (donde se guardaban las cosechas) y talleres. Los sacerdotes organizaban los excedentes y el comercio, y empleaban a campesinos, pastores y artesanos, quienes recibían como pago parcelas de tierra para cultivo de cereales, dátiles o lana. Nunca anteriormente un espacio había sido poblado ni tanto tiempo ni por tantas personas a la vez. Las aldeas se harán ciudades amuralladas y los agricultores y artesanos diversifican tanto el trabajo como las piezas generadas. Unos gobernarán a otros, y surgirán las leyes y el derecho para proteger sus privilegios y las propiedades que se acumulan y con las que se comercia. Cada cual, en sus viviendas, junto a palacios, templos, dioses, sacerdotes, servidores, artesanos, siervos y esclavos que gestarán las ciudades y los estados, cuya estructura marcadamente jerárquica-clasista aún conservamos (Monserrat, 2012: 424).

De tal forma, la agricultura era el principal motor económico y el arte se focalizaba en exaltar el poder religioso y político, así como en mostrar sus costumbres y actividades agrícolas. En la imagen 3 podemos observar el llamado Sello de Adda, fechado el año 2300 a. C. y custodiado por el British Museum. En este sello se observan deidades tan importantes para la agricultura como el Dios Enki, el cual controlaba el agua dulce imprescindible para la agricultura y era fuente de sabiduría, su figura aparece con dos corrientes de agua que brotan de sus hombros aludiendo a los ríos Tigris y Éufrates. También, aparecen deidades como el Dios del sol, Shamash y la figura femenina de Isthar, Diosa de la fertilidad, el amor y la guerra. 

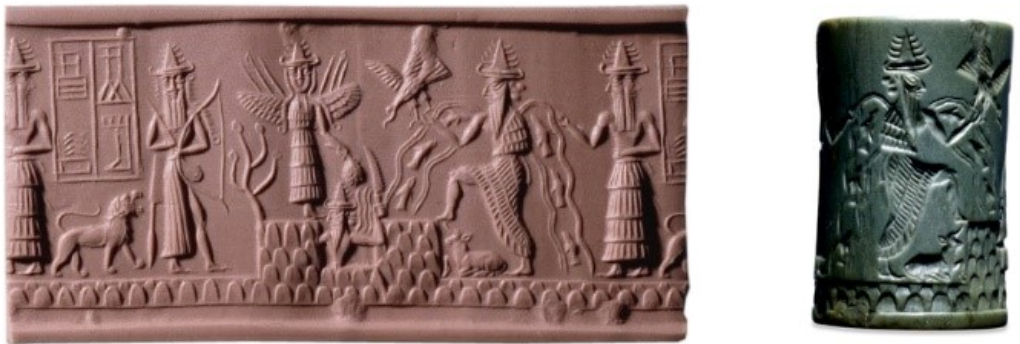

En otro sello, ubicado actualmente en el Museo del Louvre en París, podemos observar la representación del ganado sobre un campo de trigo, una escena típica de la agricultura mesopotámica. Los agricultores, después de las inundaciones, irrigaban el campo gracias a los canales, hacían entrar al ganado para que macerasen y mataran las hierbas no deseadas. Posteriormente, limpiaban de posibles piedras el campo y, una vez se secaba la tierra, la araban, gradaban y rastrillaban hasta tres veces con la azada antes de la siembra (Hani, Rodríguez, 2016: 12). En esta época las actividades agrícolas predominantes fueron los campos de cereales (la cebada fue el que más se trabajaba y el que mejor se adaptó a las inclemencias del lugar), el cultivo de palmeras datileras (las grandes extensiones de estos árboles daban cobijo a otros cultivos de hortaliza), los huertos y los jardines, junto al ganado.

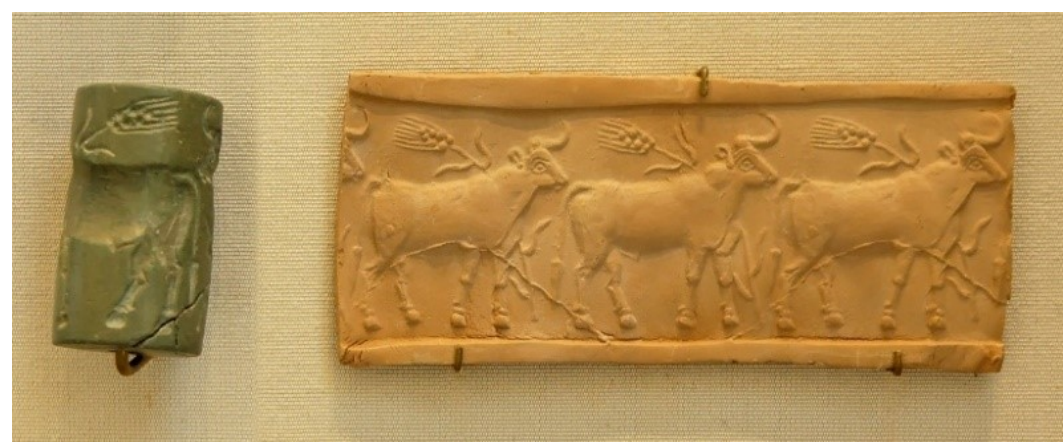

Imagen 4. Sello cilíndrico, período Uruk. Fuente: Marie-Lan Nguyen 
A lo largo del período mesopotámico se fue perfeccionando el control del fuego y se fomentó la creación de elementos cerámicos decorados. Además de las estampaciones de los sellos cilíndricos sobre la arcilla, también se realizaron objetos como vasijas, platos y vasos. El excedente de las cosechas potenció las labores de alfarería ya que se precisaba de utensilios de almacenamiento. Sin embargo, hemos destacado la creación de estos dos diseños de sellos cilíndricos por sus ilustraciones asociadas con la práctica agrícola. Por una parte, se observa la deidad, la adoración y la magia para prosperar en las cosechas y, por otra parte, se contempla la representación de figuras clave del trabajo en el campo.

\subsubsection{La agricultura en el arte egipcio}

Los egipcios reflejaron escenas de la cotidianidad de sus vidas en las pinturas, bajorrelieves y esculturas. Gracias a su representación plástica y sus manuscritos, actualmente se sabe cómo vivieron, cómo eran sus labores agrícolas, sus rituales o su economía. Se ha podido conocer que en el Antiguo Egipto la economía se basaba en la agricultura. Según el geógrafo José Iván Bolaños,

El surgimiento del Estado del Egipto antiguo se produjo hacia el 3050 antes de Cristo aproximadamente, ostentando el valle del Nilo (Bahr elNil o el-Bahr) un puesto de primer orden en la organización del mismo, pues ha influido en el desarrollo histórico, cultural, social y económico del país, constituyendo la base de una de las agriculturas de regadío más importantes del mundo (Bolaños, 2003: 76).

Los cultivos dependían de las aguas del Nilo, los sedimentos que se depositaban en las tierras por las crecidas del río las hacía fértiles. Además, construyeron canales para poder irrigar los campos lejanos. Principalmente, se cultivaban cereales como la avena, el trigo o la cebada. El pan y la cerveza eran los alimentos principales de su dieta y se tomaban diariamente. Sin embargo, también se cultivaban viñas y se hacía vino, pero se consideraba un producto de lujo, en la siguiente imagen podemos observar una escena típica del Antiguo Egipto de recolecta de uva y elaboración de vino. 


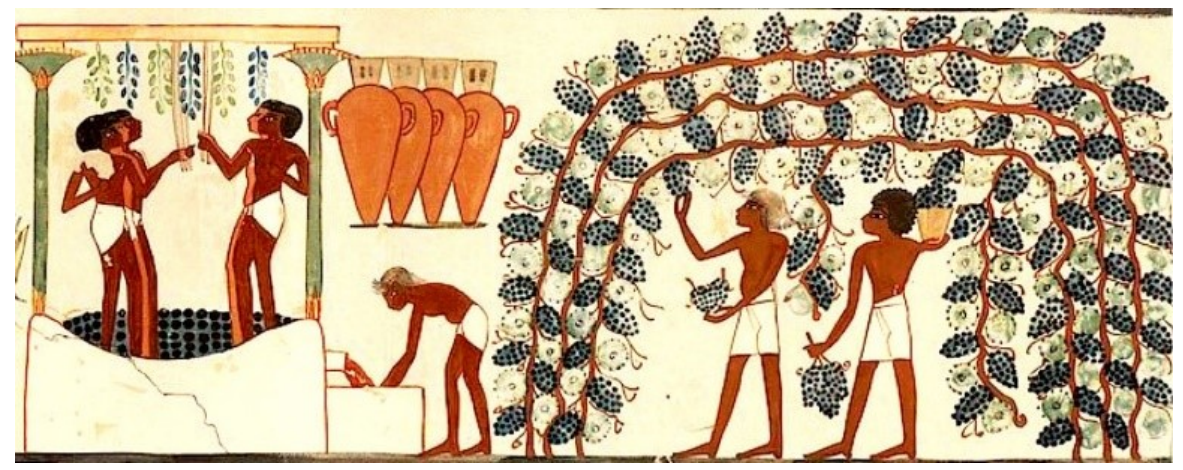

Imagen 5. Tumba de Nakht, Dinastía XVIII. Fuente: Egiptología 2.0

En otras escenas que ilustran sus pinturas también observamos cómo las herramientas que utilizaron para el trabajo en el campo eran perecederas, como la azada, el arado empujado por animales domesticados o la hoz, realizadas con madera, piedra o bronce. En la imagen 6, podemos observar un agricultor labrando el campo con la ayuda de animales bovinos.

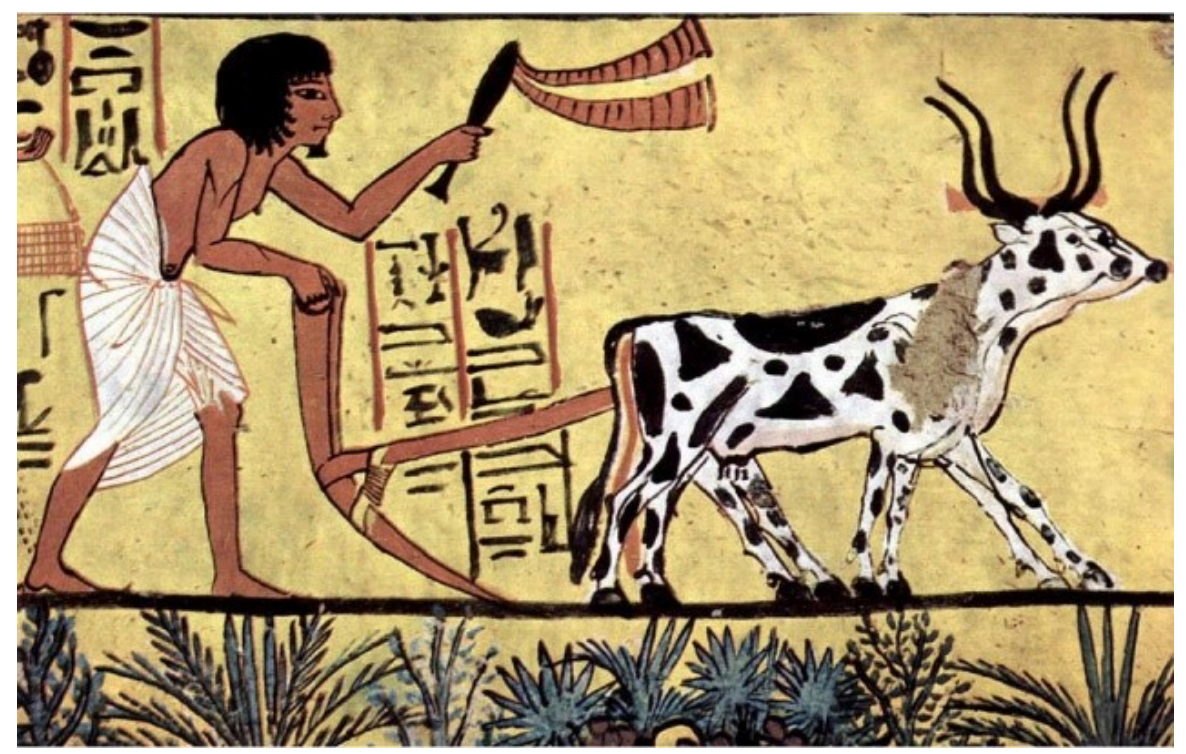

Imagen 6. Tumba de Sennedjem, Deir El-Medina. Fuente: Egiptología 2.0 
El trabajo en el campo estaba condicionado por las tres estaciones anuales que tenía el Nilo, Akhnet con las inundaciones de verano, Peret época otoñal dedicada a la siembra y Shemu estación seca dedicada a la recolección de cultivos. Así pues, era de vital importancia el nivel de inundación del río, ya que si crecía demasiado podía ser muy destructivo para los habitantes colindantes; por el contrario, si había poco caudal se daban escasas cosechas empobreciendo a la población. Según el geógrafo José Iván Bolaños,

Las inundaciones han representado un papel fundamental en la supervivencia de la civilización del antiguo Egipto, haciendo posible la instauración de todo un sistema político y, sobre todo, económico, que aportase riquezas para la población y que engrandeciera el estatus del Estado (Bolaños, 2003: 85).

La superficie que quedaba inundada sería la que se cultivaría y la que serviría de base al Estado para calcular los impuestos. Otras regiones como la Mesopotámica, vista en el apartado anterior, también estaban condicionadas por las crecidas de los ríos Éufrates y Tigris. Sin embargo, Bolaños, añade que la realidad fue muy distinta porque las crecidas de estos ríos no son sincrónicas, sino que tienen un funcionamiento irregular y presentaban consecuencias más destructivas para los habitantes del valle (Bolaños, 2003: 86). Cabe destacar el enorme esfuerzo del campesinado por sacar adelante los cultivos con las rudimentarias herramientas, con la ayuda de animales domesticados y condicionados a las crecidas de los ríos. Claudia Barros en el artículo Comer como un egipcio del proyecto Egiptología 2.0 señala que,

El campesino trabajaba la tierra, o las propiedades del Faraón, bajo la jurisdicción de un arrendatario, o de un señor noble o burgués, cultivando una variedad gigantesca de géneros alimenticios; en el momento de la cosecha, una parte sería colectada por funcionarios reales, la perteneciente al "Tesoro Público". El restante quedaba para el campesino, como pago por su labor (Barros, 2019: 58).

Sin embargo, a pesar de que el duro trabajo del agricultor era el principal motor de la economía, era una de las labores peor considerada por la sociedad. Además, el campesinado, durante las crecidas del Nilo también tenía que trabajar en el mantenimiento de las acequias o en las labores encomendadas por el Estado. 


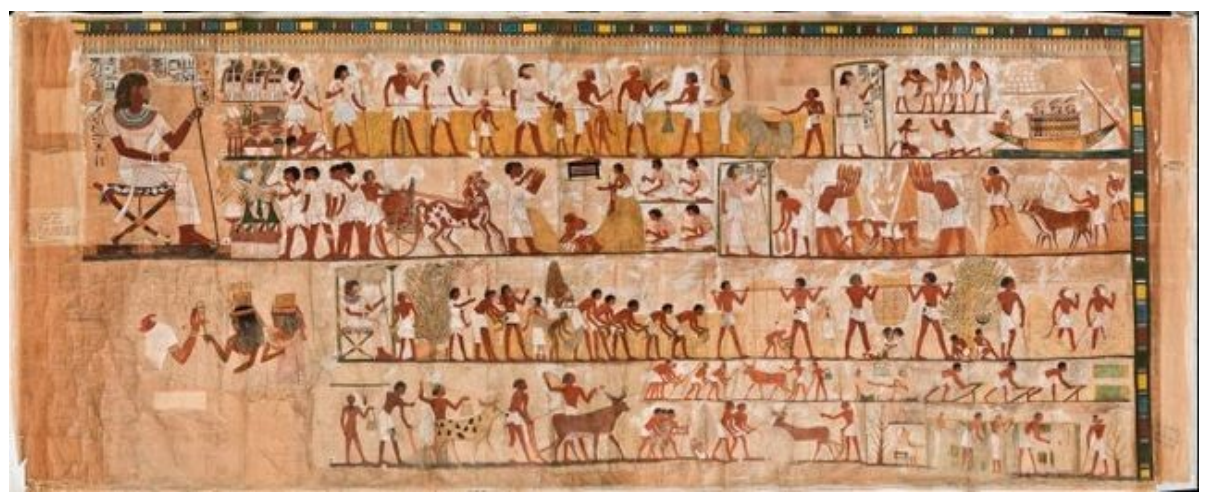

Imagen 7. Tumba de Menna, 1420 - 1411 a.C. Fuente: Arte Egipcio: escultura y pintura.

En la anterior imagen podemos observar diversas escenas típicas agrícolas que fueron pintadas en la tumba de Menna, 1420-1411 a. C., por ejemplo, arriba a la izquierda se puede observar la medición de los campos de trigo a efectos de tributación. También se observa el transporte de la cosecha, la recogida de trigo, el trabajo con el rebaño bovino o el laboreo de la tierra.

Las escenas decoraban paredes de tumbas y templos, también aparecían en los papiros, las pinturas eran realizadas por artesanos y artistas con unas características muy similares. El tamaño de las figuras humanas variaba según la clase social, los faraones eran dibujados más grandes que los demás, se solía tallar el contorno y luego pintar con pigmentos naturales. Además, también se realizaban maquetas, esculturas y bajo relieves. En la siguiente imagen podemos observar una maqueta de madera pintada que fue hallada en una tumba del Imperio Medio. La miniatura representa a un campesino arando con un par de bueyes y se asemeja a la escena pictórica que hemos observado anteriormente en la imagen 6 del campesino labrando el campo. 


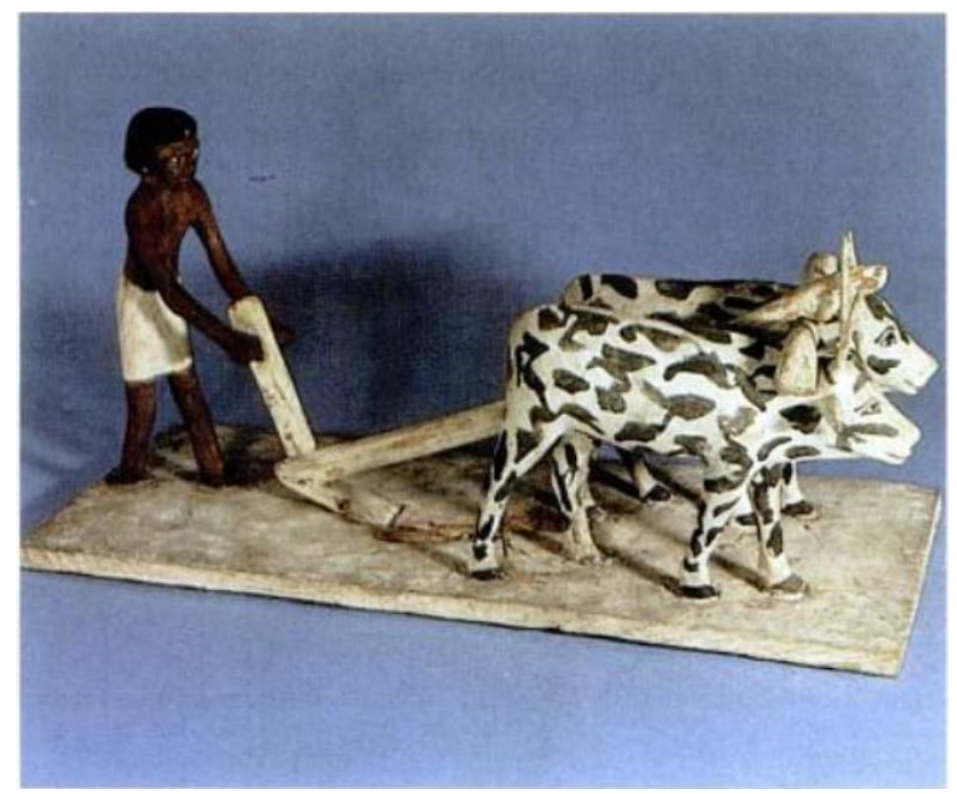

Imagen 8. Maqueta de madera pintada, $43 \mathrm{~cm}$. Tumba del Imperio Medio. Fuente: Pintura egipcia, pág. 7

\subsubsection{El arte griego y la agricultura}

En la Antigua Grecia, donde llegaron influencias y corrientes de pensamiento de las civilizaciones de Mesopotamia y Egipto, la economía se caracterizó por basarse en la agricultura. Si bien predominó un sistema esclavista, cabe destacar el análisis que realiza Julián Gallego, profesor del Departamento de Historia de la Universidad de Buenos Aires, en su artículo La agricultura en la Grecia antigua. Los labradores y el despegue de la pólis. El autor visibiliza el poder de una agricultura familiar e independiente que produce excedentes y sobrevive con mayor autonomía. Al final de la Edad Oscura emergen estas formaciones agrícolas que trabajan duramente roturando tierras menos fértiles, ya que las más productivas pertenecían a la aristocracia. Gallego comenta que,

Para el desarrollo de la pólis el asunto no radicaría tanto en que su base fuera esclavista como en la activa presencia de una clase de agricultores libres, que podían incluso incorporar algunos esclavos, pero siempre dentro de 
explotaciones basadas en el trabajo familiar, que diferían sustancialmente de las haciendas esclavistas terratenientes. Estos campesinos, propietarios plenos de sus tierras, no sometidos a explotación, orientados a la subsistencia pero que en ciertas circunstancias podían producir excedentes vendibles, han sido los protagonistas del desarrollo agrario de la Grecia antigua (siglos VIII-IV a. C.) (Gallego, 2004: 15).

El autor también destaca un movimiento de colonización de nuevas tierras ocasionado por la falta de acceso o la pérdida de estas dado el acaparamiento realizado por la nobleza y el incremento demográfico. Así se dieron migraciones por diferentes áreas del mediterráneo, desarrollándose nuevos métodos de cultivo y estableciendo cierta igualdad agraria (Gallego, 2004: 4). Si bien, considera que no hubo un equilibrio entre las clases sino un empoderamiento de agricultores autosuficientes.

Las plantaciones fundamentales de la agricultura griega se basaron en el cultivo de cereales, olivos y viñedos. Se trabajaban con la energía humana y con la yunta de bueyes; además, se regeneraba el suelo con desechos orgánicos, mostrando interés en su fertilidad. Los agricultores consideraban importante el aprovechamiento del terreno, por ello se organizaban las plantaciones, los cultivos y las tareas agrícolas con los ciclos naturales, con el fin de obtener el mayor rendimiento posible respetando el descanso de la tierra.

Las expresiones artísticas en la Antigua Grecia acompañaron a las prácticas agrícolas representando escenas cotidianas de trabajo en el campo. Destacamos la cerámica, el historiador de arte Josep Francesc Ràfols señala que

La cerámica griega, aparte de su variedad de formas según el uso al que iban destinadas las piezas, se distingue por la riqueza de su decoración; unas veces era monocromática, generalmente a base de pinturas negras; otras, eran polícromas sobresaliendo el color rojo; pero, sobre todo, ricas en escenas mitológicas, familiares y poéticas, con una gracia, finura de trazado, esbeltez de las figuras, sensación del ritmo y fuerza del movimiento que cautivan poderosamente (Ràfols, 2001: 106). 
En ese contexto, observamos las pinturas halladas en vasijas destinadas a almacenar el aceite donde se escenifica la práctica agrícola llevada a cabo en esa época. En la imagen 9 podemos observar un ánfora griega con el dibujo de la recolección de la aceituna.

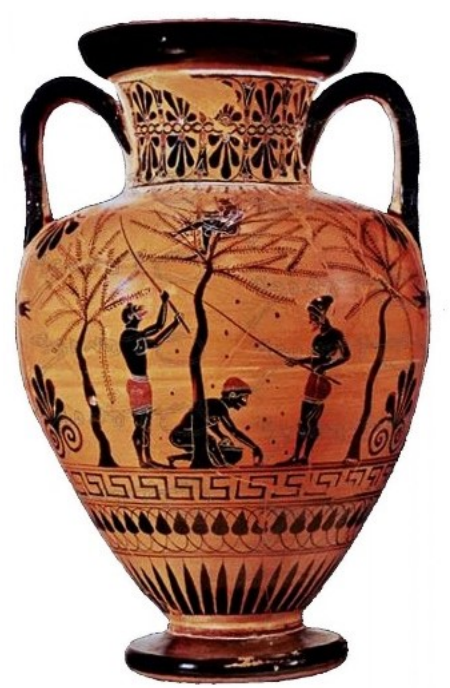

Imagen 9. Ánfora griega, Período arcaico 520 a. C. Fuente: Museo Británico, Londres.

\subsubsection{Representación agrícola en el arte romano}

La agricultura de la antigua Roma se basaba en cereales, leguminosas, hortalizas, olivos y viñas, sus prácticas agrícolas abarcan un período de más de mil años. Según apunta Martin Bakers en su libro Agricultura: de la antigua Roma al intercambio colombino,

[...] desde unos comienzos humildes la República romana (509 a. C. a 27 a. C.) y el imperio (27a. C. a 476 d. C.) se expandieron para gobernar parte de Europa, el norte de África y el Medio Oriente [...] Dentro del área mediterránea, una tríada de cultivos era lo más importante: granos, aceitunas y uvas (Bakers, 2019: 7).

La práctica agrícola se organizaba en granjas de diversos tamaños, en los comienzos de la República las granjas eran familiares y de menor tamaño. En 
cambio, con la entrada del Imperio aumentaron los latifundios, pasando las tierras a manos de romanos con un poder adquisitivo mayor. "Se consideraba un orgullo poseer no solo el pedazo de tierra más grande, sino también tener tierras que produjeran productos de alta calidad" (Bakers, 2019: 16). El trabajo agrícola era dirigido por los propietarios, pero delegaban sus órdenes y su confianza en sus supervisores, siendo el trabajo forzado realizado por esclavos. Sin embargo, con la crisis del siglo III se empieza a transitar lentamente hacia el feudalismo, pasando del trabajo con esclavos al de sirvientes.

En cuanto al arte de la Antigua Roma, cabe decir que venía influenciado por el arte etrusco y, sobre todo, por el arte griego. Sin embargo, los griegos con sus obras enaltecían a los dioses y los romanos exaltaron a los hombres. Crearon esculturas y relieves que contaban sus hazañas en la guerra, también eran creadas para glorificarles. Además, realizaron un arte utilitario, por ello abundaban las construcciones arquitectónicas: acueductos, termas, arcos de triunfo, circos, anfiteatros y basílicas, entre otros.

En referencia a la representación de la agricultura en el arte de la Antigua Roma, cabe destacar las escenas de oleicultura grabadas en un sarcófago romano de comienzos del siglo IV d. C.

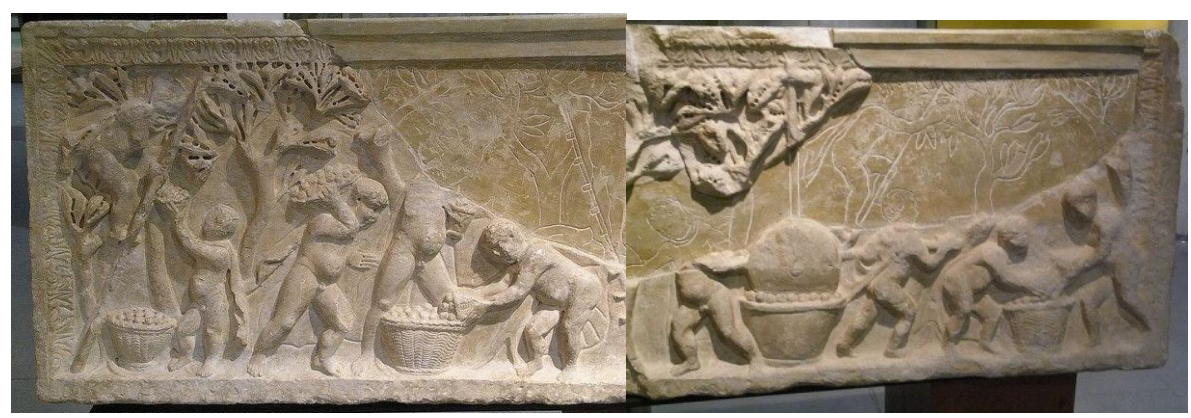

Imagen 10. Sarcófago de Arles, detalle de la parte izquierda, siglo IV d. C.

Fuente: docplayer.es Imagen 11. Sarcófago de Arles, detalle de la parte derecha, siglo IV d. C. Fuente: docplayer.es 
En la imagen 10 observamos el detalle de la parte izquierda del sarcófago, la escena completa marca las distintas fases para la elaboración del aceite. Se retrata desde la recogida hasta la molturación (imagen 11). Guadalupe López Monteagudo, Investigadora Científica del CSIC e investigadora principal del GI Mosaico Hispanorromano, señala que

La escena representada en este sarcófago constituye un documento de gran importancia para la historia económica de Roma en época bajo-imperial, al documentar distintos sistemas de recogida de aceituna, la forma de transportar el fruto en grandes cestos hasta el molino y la molturación de la aceituna en un molino circular de piedra para la obtención final del aceite (López, 2006: 399).

Esta obra realizada en una pieza de mármol de Carrara evidencia la importancia del trabajo agrícola de la época, concretamente de la producción de aceite, labor que se mantiene en la actualidad en las zonas de clima mediterráneo. En cuanto al relieve y la definición del dibujo, López señala que "la mediocridad artística con la que está realizado ha llevado a suponerlo obra de un taller local” (López, 2006: 398).

\subsubsection{El arte medieval y la agricultura, siglo $\mathrm{V}$ al siglo $\mathrm{XV}$}

La Edad Media vino marcada por la caída del Imperio Romano en el año 476, esta época se caracterizó por el inicio del dominio de la Iglesia Católica. Como hemos señalado en el apartado anterior, el motor de la economía romana era principalmente la agricultura con el comercio e intercambio de los productos cosechados. Tras la caída de su imperio y con la llegada de los pueblos bárbaros la producción agrícola y su comercialización pasaron a un nivel local, su función era el autoabastecimiento.

Tres eventos prepararon el escenario, e influirían en la agricultura durante siglos, en Europa. Primero fue la caída del Imperio Romano occidental, [...] En segundo lugar, fue una era de enfriamiento global [...] causado por erupciones volcánicas [...] Tercero, fue la peste de Justiniano (Bakers, 2019: 9).

Los sucesos que señala el autor, Martin Bakers, ocasionaron numerosas muertes, malas cosechas y hambrunas. Además, las artes se vieron afectadas, la exaltación de la belleza y el poder de los hombres y sus batallas se vio 
mermada. Sin embargo, la caída del Imperio Romano mejoró la situación de los trabajadores del campo, considerados esclavos en la época romana. Bakers señala que

La opinión popular es que la caída del Imperio Romano de Occidente causó una "edad oscura" en Europa occidental en la que el "conocimiento y la civilidad", las "artes de la elegancia" y "muchas de las artes útiles" fueron descuidadas o perdidas. Sin embargo, a la inversa, la suerte de los agricultores que constituían el 80 por ciento o más de la población total, puede haber mejorado después del Imperio Romano. La caída de Roma vio la "reducción de las cargas impositivas, el debilitamiento de la aristocracia y, en consecuencia, una mayor libertad para los campesinos". [...] un retorno a la agricultura basado más en las necesidades locales (Bakers, 2019: 11).

En cuanto al arte, en el Medievo pasó a ser encargado y financiado por la Iglesia Católica. En las siguientes páginas destacamos unas obras de arte en relación con la agricultura de esta época, donde surgen dos corrientes artísticas, el arte Románico y el arte Gótico.

La corriente artística Románica abarca el arte en Europa de finales de siglo X hasta los inicios del siglo XIII, el arte Gótico se inició en la baja Edad Media, en Francia, y fue propagándose en el resto de Europa hasta el principio del Renacimiento. Del arte del Medievo que pueda estar relacionado con la agricultura, destacamos los calendarios agrícolas. Son numerosas las obras artísticas que se realizaron diseñando anuarios con las labores agrícolas en pinturas murales, relieves escultóricos y en manuscritos. Partiendo del contexto de una sociedad iletrada, dominada por la Iglesia Católica, los calendarios agrícolas servían al campesinado (los siervos) para saber las tareas que debían realizar en cada época, marcando los descansos y las festividades. Marta Poza, autora del artículo Las labores de los meses en el Románico señala que

[...] cada mes se asocia con la representación de una labor campesina, realizada, normalmente, por un único personaje, figurado de perfil y en actitud dinámica, con el fin de subrayar los aspectos narrativos del episodio a pesar de la ausencia de composiciones amplias o de escenas integradas por múltiples figuras (Poza, 2009: 31). 
Así pues, de los calendarios que se conservan en la actualidad, destacamos el mosaico de la Catedral de Santa María Annunziata de Otranto en Italia, una obra realizada por el monje Pantaleone (imagen 12).

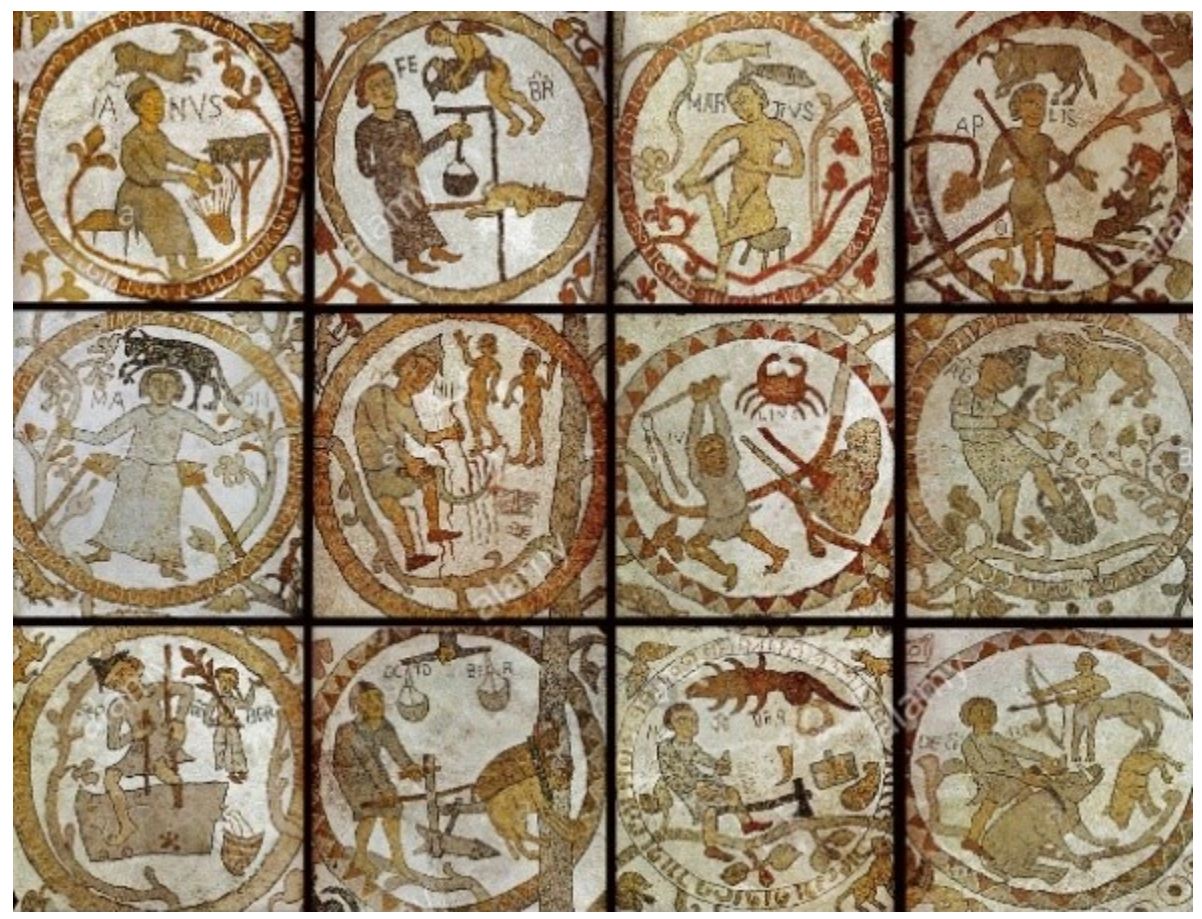

Imagen 12. Mosaico catedral de Otranto, siglo XII.

Fuente: alamy.com

En este mosaico que abarca gran parte del suelo de la zona central de la catedral, se observan tareas como el cultivo de trigo, la vendimia y la matanza del cerdo. Además, en cada uno de los meses figuran los símbolos del zodiaco.

Por otra parte, mencionamos la entrada de la Iglesia de Beleña de Sorbe en Guadalajara, España, donde se encuentra un calendario agrícola que descansa sobre una de sus arquivoltas. En este centro de culto se mantiene en perfecto estado de conservación la talla en piedra caliza de las labores agrícolas que se realizaban en el Medievo. 


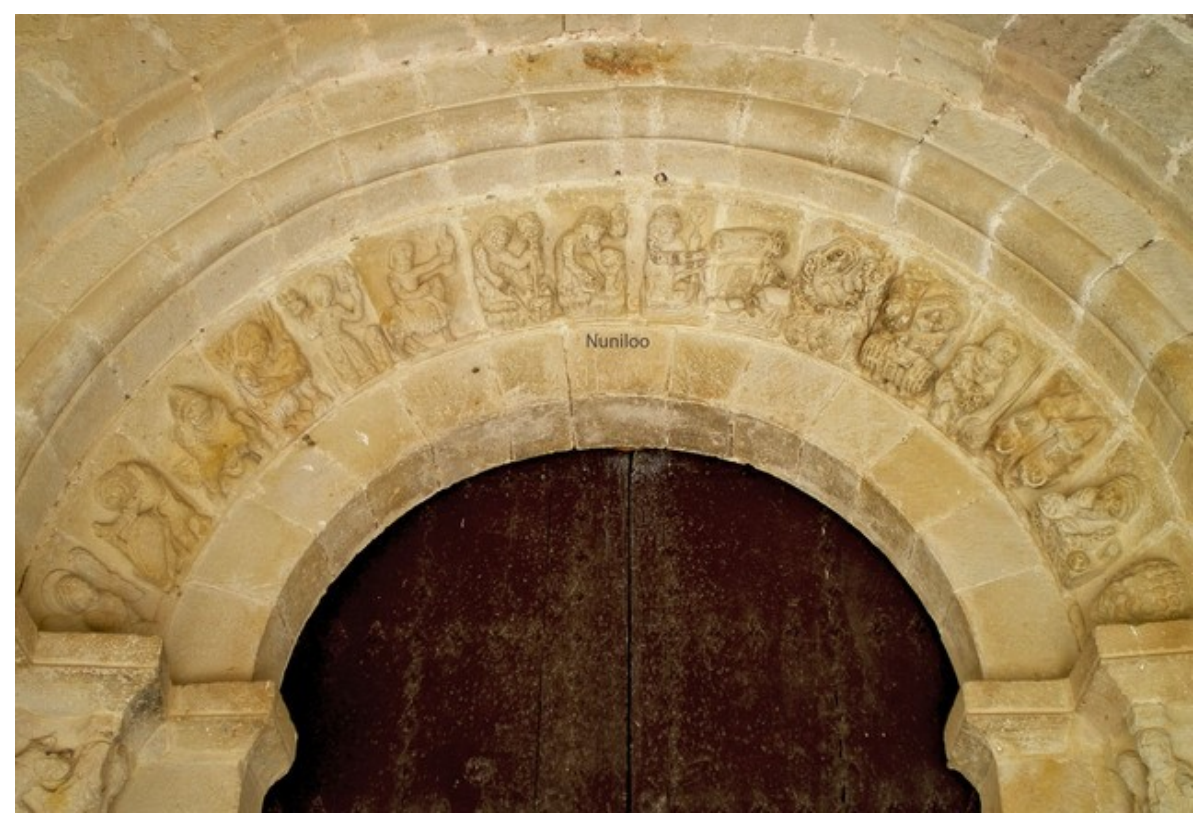

Imagen 13. Calendario Románico de Beleña de Sorbe, siglo XII.

Fuente: otraiberia.es

La corriente artística Románica fue evolucionando en el arte Gótico. En este período, el arte se centró, principalmente, en la arquitectura, escultura y pintura vinculada a los edificios religiosos. Se construyeron iglesias con pronunciada verticalidad y gran luminosidad que ensalzaban los valores religiosos y simbólicos de la época. No obstante, cabe destacar el fresco que se realizó en el Palacio Público de Siena, Italia, una de las pocas obras que no fue de orden religiosa. Esta pintura mural titulada Alegoría del Buen y el Mal gobierno, retrató escenas que alaban los bienes comunales y, otras, que cuestionan la tiranía, la avaricia y la soberbia de los poderes políticos. En esta obra se refleja una panorámica paisajística del campo y de la ciudad. Nos centramos, especialmente, en observar el detalle tan minucioso que el artista realizó del paisaje agrario (imagen 14). 


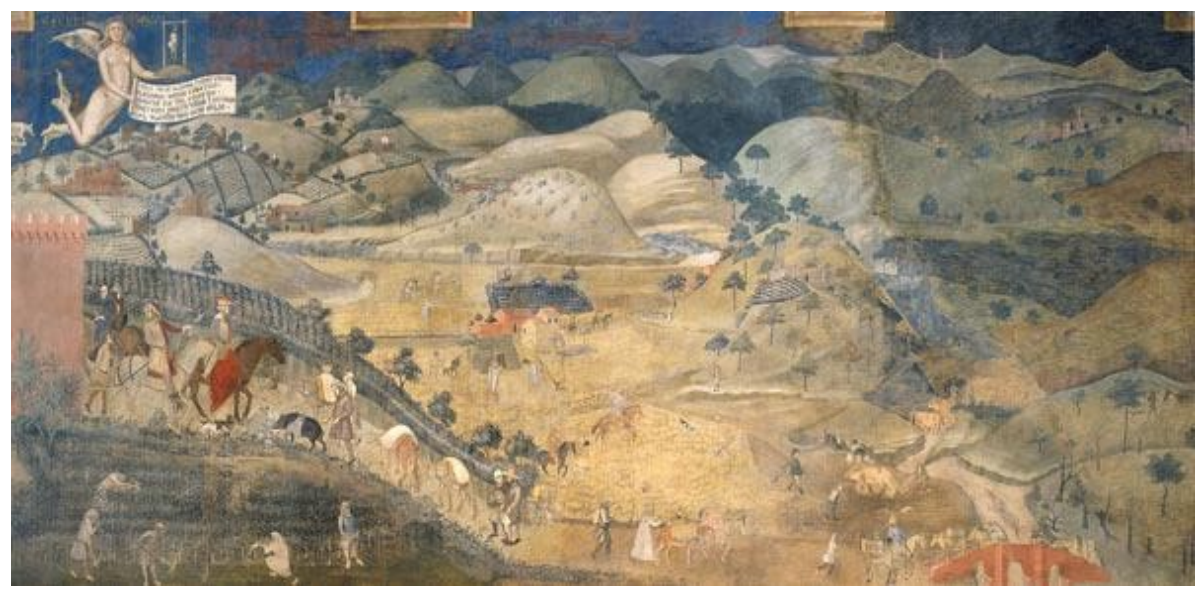

Imagen 14. Alegoría al buen gobierno, Palacio comunal de Siena, Ambrogio Lorenzetti, siglo XIV. Fuente: reprodart.com

Esta escena está retratada con un aura de alegría y libertad como fruto del buen gobierno en el campo. Arriba a la izquierda se puede observar la figura de una joven semidesnuda que, bajo el nombre de securitas, actúa de protectora de la seguridad de los campesinos.

\subsubsection{La agricultura en el arte de la Edad Moderna, siglo XV al siglo XVIII}

La transición de la Edad Media a la Edad Moderna fue marcada por el Renacimiento, surgido en Italia y expandido progresivamente al resto de Europa. Esta nueva corriente artística conllevó una gran transformación cultural. A pesar de que la iglesia seguía influenciando la sociedad, la idea de Dios ya no era el centro del universo sino el hombre. Así pues, la razón, la investigación, la reflexión personal y la admiración por las artes clásicas caracterizaron esta época.

En este contexto, cabe destacar al pintor holandés Pieter Brueghel el Viejo del Renacimiento Nórdico por su atención en el paisaje como tema central de la obra. En sus pinturas retrató el trabajo y las costumbres del campesinado. El artista realizó una serie sobre las estaciones del año; en la siguiente imagen 
podemos observar la pieza de La Cosecha referente a los meses de agosto y septiembre.

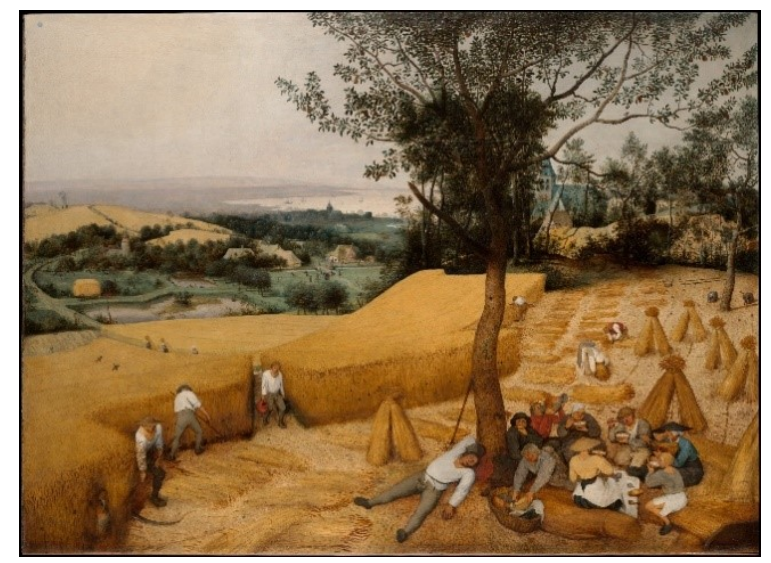

Imagen 15. La Cosecha, Renacimiento Nórdico, Pieter Brueghel el Viejo, 1565. Fuente: metmuseum.org

A pesar de la escena apacible que retrata quehaceres habituales de la época en el campo, cabe señalar que en los inicios de la Edad Moderna la agricultura vivió situaciones complejas debido a la meteorología. Mark B. Tauger, en su libro Agriculture in World History, señala que

Durante los siglos XV a XVIII, los agricultores de la mayor parte del mundo vivían en peores condiciones ambientales que en los siglos anteriores. La Pequeña Edad de Hielo trajo consigo un clima extremadamente frío con rupturas de períodos más cálidos. Los factores ambientales crearon crisis recurrentes, especialmente en el hemisferio norte: veranos fríos, inviernos helados, graves pérdidas de cosechas, y hambrunas (Tauger, 2010: 202).1

\footnotetext{
${ }^{1}$ During the fifteenth to the eighteenth centuries farmers in most of the world lived under worse evironmental conditions than in previous centuries. The Little Ice Age brought extreme cold weather with breaks of warmer periods. Enviromental factors created recurrent crises, especially in the northern hemisphere: cold summers, freezing winters, serious crop failures, ans famines. Traducción realizada en DeepL.
} 
Además, en Europa, el campesinado seguía sometido a sistemas altamente serviles.

En Europa oriental, los campesinos quedaron sometidos a una nueva e intrusiva dominación, a menudo llamada "segunda servidumbre". En Europa occidental la servidumbre disminuyó a unos pocos lugares aislados, pero la mayoría de los campesinos siguieron subordinados a una variedad de prácticas tradicionales, a las reservas de la autoridad noble y al creciente poder de los gobiernos (Tauger, 2010: 202). ${ }^{2}$

Con el descubrimiento de nuevas tierras en América y Australia se impulsó el comercio de productos y esclavos con el continente europeo. Las redes comerciales potenciaron una incipiente clase burguesa que cada vez era más influyente, sobre todo en los países protestantes.

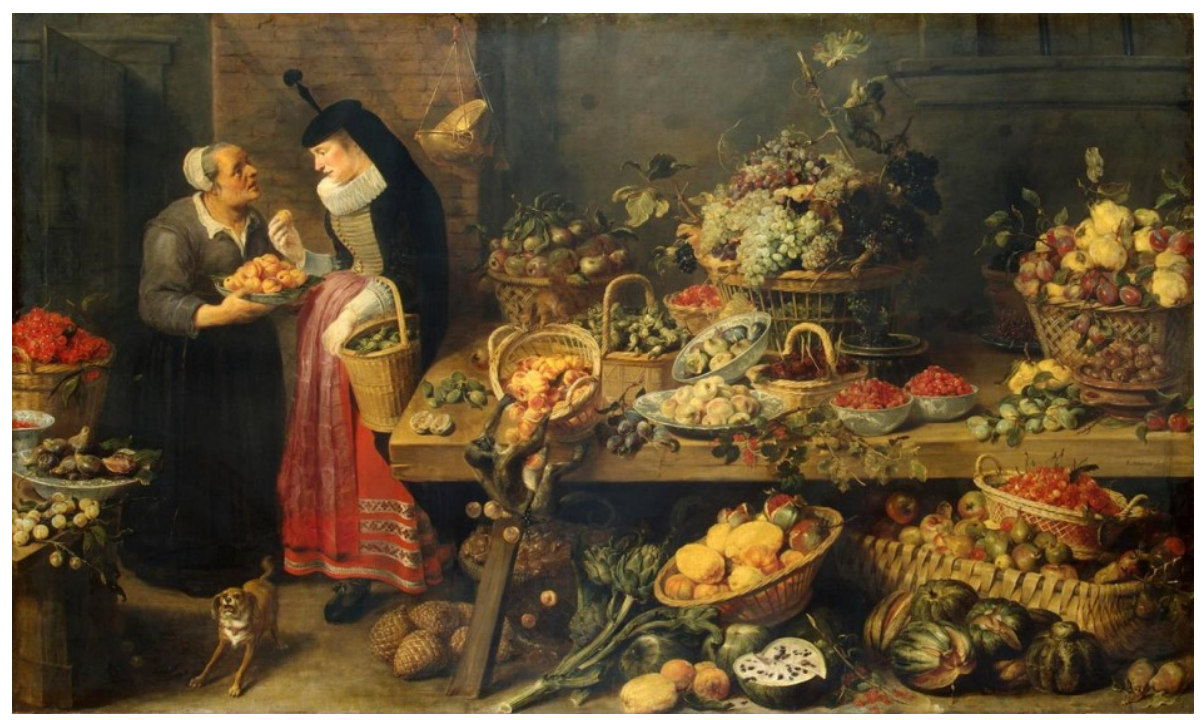

Imagen 16. Fruit stall, Frans Snyders, 1618-1621.

Fuente: arthermitage.org

\footnotetext{
${ }^{2}$ In Eastern Europe, peasants came under a new and intrusive domination often called the "second serfdom." In Western Europe serfdom declined to a few isolated locations, but most peasants remained subirndinated by a variety of traditional practices, ressertions of noble authority, and the growing power of governments. Traducción realizada en DeepL.
} 
En el siglo XVII empezó a emerger la corriente artística barroca con un arte más recargado y dramático que representaba la realidad de la sociedad. Se manifestaban escenas cotidianas con campesinado, pobres, comerciantes o artesanos (imagen 16). También, recreaban ambientes folclóricos o paisajísticos, así como pinturas de bodegones o naturaleza muerta.

\subsection{El arte y la agricultura en las manifestaciones artísticas del siglo XIX}

A finales del siglo XVIII surgió la corriente artística romántica, abarcando la primera mitad del siglo XIX. Los artistas románticos transmitían la originalidad, la nostalgia, los estados de ánimo y los sentimientos, con escenas dramáticas o melancólicas que se oponían al racionalismo de la Ilustración y del Clasicismo. En la imagen 17 podemos observar estas características en la escena de La vendimia de Goya.

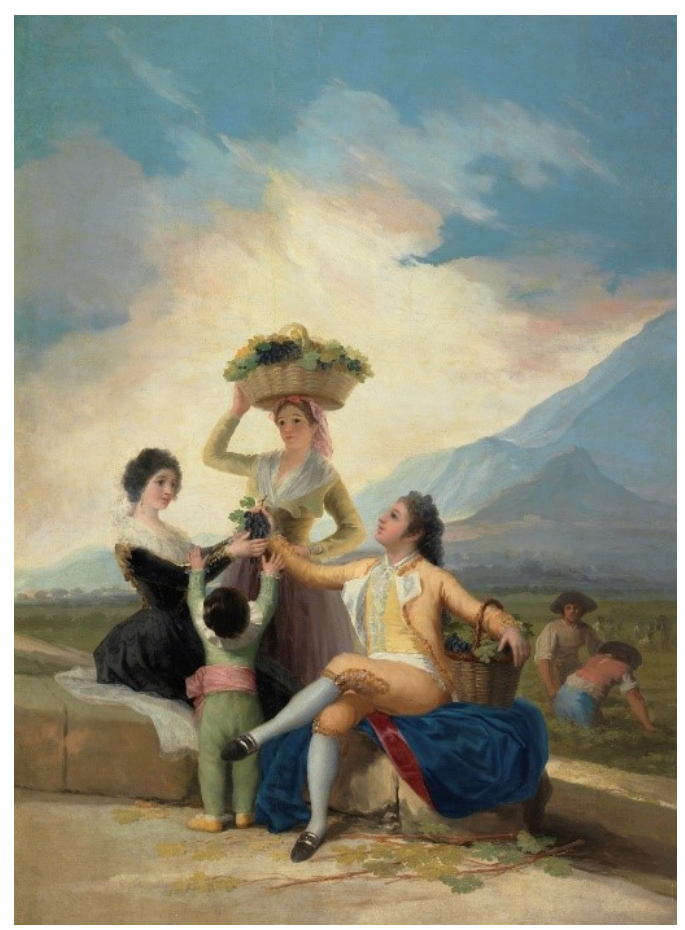

Imagen 17. La vendimia, Francisco de Goya, 1786. Fuente: museodelprado.es 
En el siglo XIX hubo varios acontecimientos que propiciaron nuevas vías en el desarrollo de la agricultura, en el libro Historia de la agronomía del profesor José Vicente Maroto señala los siguientes,

a) El descubrimiento de los procesos de la nutrición vegetaly la obtención y utilización de abonos químicos

b) Creación de las primeras escuelas superiores de Agricultura.

c) La progresiva invención de maquinaria agrícola.

d) La ampliación de los regadíos y la intensificación de los drenajes.

e) Los grandes avances conseguidos en el campo de las Ciencias Biológicas y en la Botánica concretamente (Maroto, 2014: 284).

Sin embargo, la realidad en los campos seguía siendo el trabajo duro desempeñado por un campesinado con altos niveles de pobreza. Pintores del Realismo, como Jean-François Millet, Julien Dupré o Jules Breton, nos mostraron estas situaciones a través de sus obras.

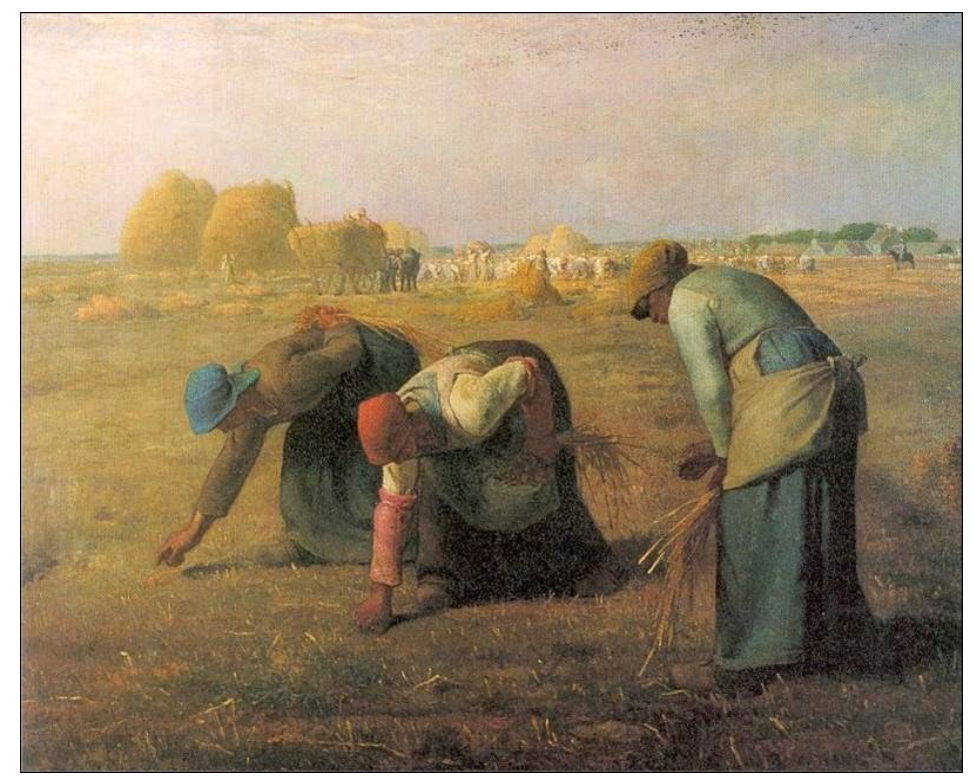

Imagen 18. Las espigadoras, Jean-François Millet, 1857 Fuente: Museo de Orsay, París. 
Millet, muestra la realidad del campo francés mediante una escena de tres mujeres que recogen las espigas con sus manos. En un aura de humildad, el pintor refleja la pobreza de las campesinas con sus vestimentas rasgadas en un atardecer que se aleja de las escenas idílicas propias del romanticismo. En la misma línea de trabajo, el pintor realista Julian Dupré visibilizó escenas de trabajo del mundo rural. En cambio, en sus pinturas observamos un relevante tratamiento de la luz que ofrece profundidad a las escenas y las dota de gran fuerza. Además, el tema principal de sus obras fue la mujer campesina, evidenciando la realidad y la dureza laboral de las mujeres en la época.

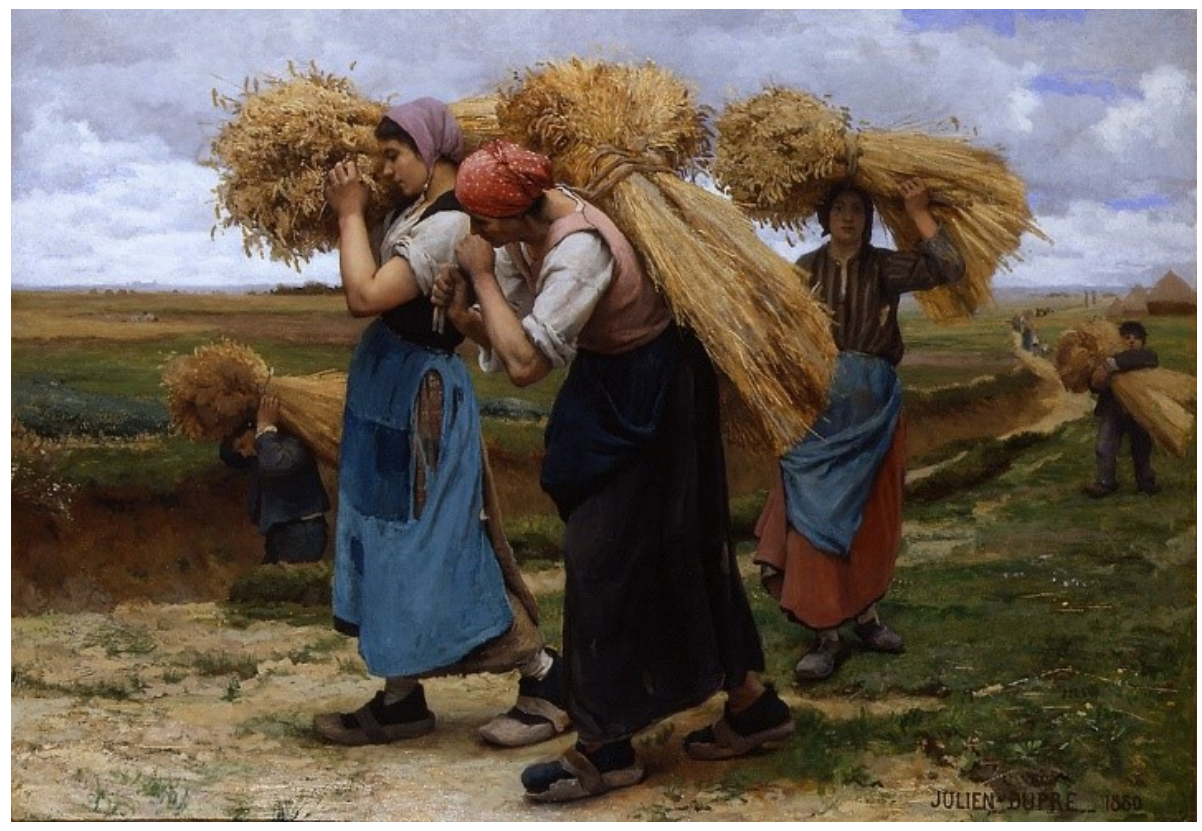

Imagen 19. Cargadoras de heno, Julien Dupré, 1880 Fuente: rehs.com

Si bien los artistas realistas mantuvieron la identidad y naturalidad de sus personajes, los impresionistas se centraron en plasmar la luz, sin dar especial relevancia al objeto o persona sobre el que se proyectaba. 
Entre los pintores del impresionismo destacamos a Camille Pissarro, el cual se interesó por el ámbito social y plasmó escenas de la vida rural francesa. En la siguiente imagen podemos observar su obra Joven campesina encendiendo fuego, realizada en una época donde el artista experimentó con el puntillismo.

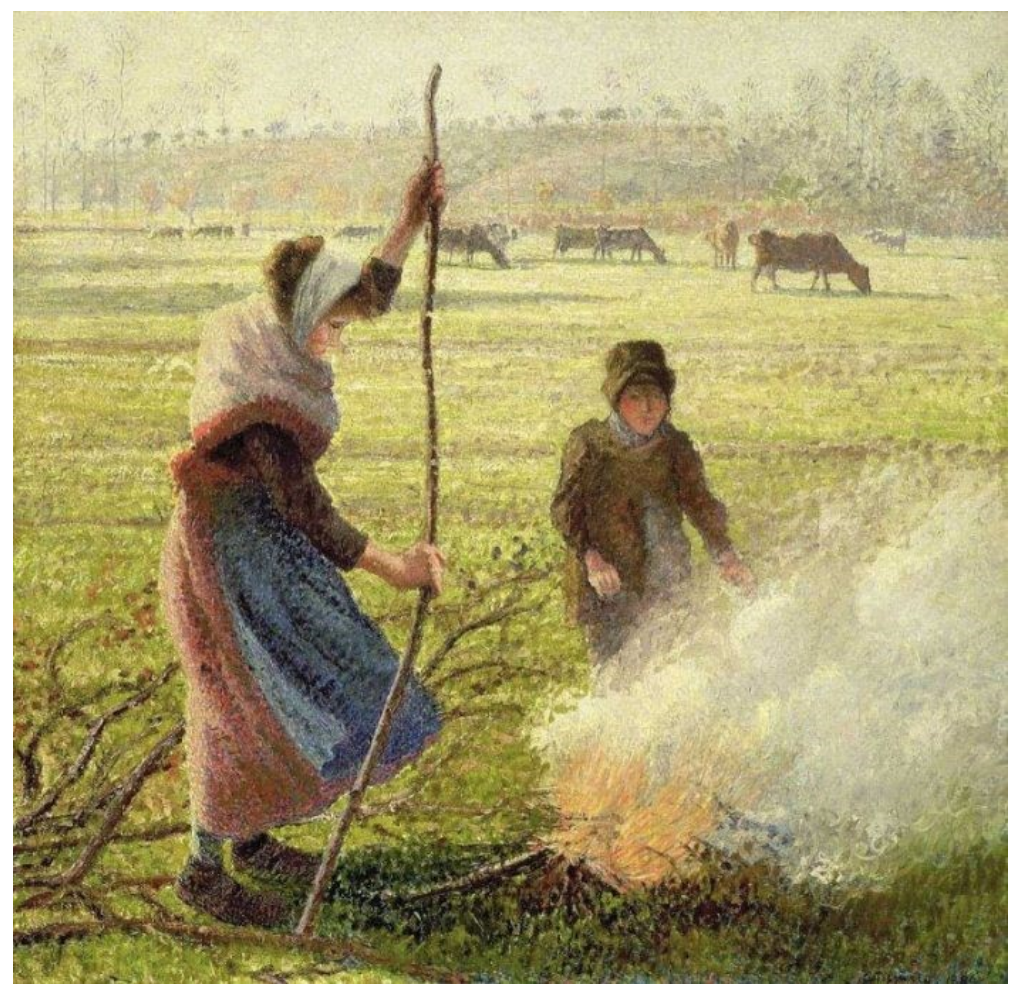

Imagen 20. Joven campesina encendiendo fuego, Camille Pissarro, 1888. Fuente: musee-orsay.fr

Cabe destacar que la agricultura en Europa a finales del siglo XIX y principios del siglo XX,

Sufrió una nueva crisis motivada principalmente por las exportaciones agrícolas de las antiguas colonias de Ultramar, de los productos menos perecederos (cereales, azúcar, lana, algodón...) a precios más baratos que los de la antigua metrópoli, principalmente porque la mecanización se había impuesto en sus vastas fincas, había disminuido la mano de obra y los precios que cobraban los 
braceros---cuando no eran esclavos o exesclavos--, eran en general bajos. Todo ello condujo, [...], a la venta de gran parte de las pequeñas propiedades agropecuarias que aún quedaban y al incremento del éxodo rural. [...] En el caso de Francia y Alemania, sin renunciar a la industrialización, se adoptaron sistemas de protección arancelaria hacia los productos agrícolas (Maroto, 2014: 307).

Esta crisis unida a la incipiente inversión en la industria provocó un éxodo rural hacia las ciudades. Asimismo, empezó a surgir la corriente Postimpresionista donde los artistas siguieron utilizando los colores vivos, el tratamiento de la luz, las marcadas pinceladas y las escenas de la vida real propias del Impresionismo. Pero, con una subjetividad y una libertad de expresión que les caracterizó. Vicent Van Gogh fue uno de los principales exponentes de este estilo pictórico. A lo largo de su vida se interesó por representar escenas de la vida campesina y del paisaje agrícola. Destacamos la obra Campo de trigo con cuervos, considerada una de las últimas obras que pintó antes de su muerte. En la pintura podemos observar las marcadas pinceladas, el movimiento, la potencia del color y el gran tratamiento de la luz.

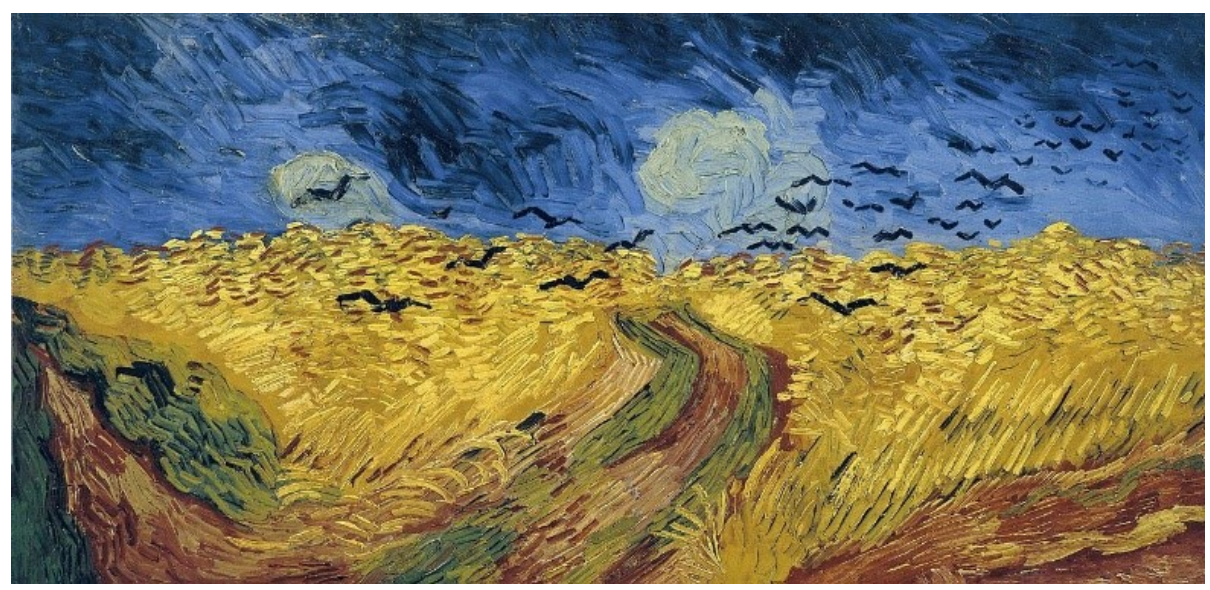

Imagen 21. Campo de trigo con cuervos, Vicent Van Gogh, 1890 Fuente: Museo Van Gogh, Ámsterdam. 
Las escenas campestres de artistas del Realismo como Millet o Breton fueron influyentes en las obras de Van Gogh. Pero, este artista utilizó una carga pictórica, un movimiento en la pincelada y una vivacidad del color sin precedentes. Van Gogh tuvo una especial simpatía por el campesinado, así se cita en La locura de Van Gogh a través de las cartas dirigidas a su hermano Theo de la Catedrática en Historia del Arte Lourdes Cirlot,

En la carta escrita desde Etten en septiembre de 1881, el pintor señalaba que "Ios campesinos eran modelos ideales, en tanto que representaban el más puro estado de lo natural frente a la afectación propia de las personas que habitaban en las grandes urbes, impregnadas de todo aquello que se relacionaba con el progreso industrial" (Cirlot, 2011: 12).

Además, la autora señala que junto a la carta el artista envío unos dibujos de campesinos, destacando uno acerca de un labriego que descansa al lado de una chimenea exhausto por el trabajo en el campo. Cirlot plantea que puede haber un paralelismo entre el agotamiento que refleja el dibujo del campesino y el que experimentaba Van Gogh en "la ardua tarea de vender su obra para obtener algo de dinero y poder comprar materiales de pintura" (Cirlot, 2011: 13).

Ya hemos señalado la situación de pobreza que sufría el campesinado en este siglo. En España, además, con la desamortización de las propiedades eclesiásticas se empobreció aún más este sector, ya que favoreció principalmente a sectores más adinerados como burgueses, políticos o señoríos.

[...] fueron muy pocos los campesinos puros que accedieron a la propiedad agraria. Ello trajo consigo unas relaciones productivas más capitalistas, con el encarecimiento de los arrendamientos rústicos, los nuevos impuestos y unas peores condiciones para los labriegos, lo que condujo a lo largo del S.XIX y el XX, al desencadenamiento de numerosos conflictos agro-sociales en Andalucía, Cataluña y Valencia que se arrastraron hasta la guerra civil española de 19361939 (Maroto, 2014: 325).

Así pues, la ley de Desamortización de los bienes eclesiásticos podría haber mejorado la situación de los agricultores y agricultoras dándoles acceso a la propiedad de tierras y potenciando los cultivos. En cambio, se optó por 
intereses particulares, la implantación de los impuestos y arrendamientos por parte de los sectores más privilegiados unidos a la crisis agrícola europea por la competencia del exterior empobreció aún más el sector agrícola español.

\subsection{El arte y la agricultura en el contexto del siglo XX}

La ciencia de la agronomía tuvo grandes avances en el siglo XX, el desarrollo científico y tecnológico dio lugar a la utilización de fertilizantes, de pesticidas, abonos de síntesis, a las mejoras vegetales y a la mecanización agraria. Si bien estos avances no estaban al alcance de todos los sectores, solo aquellos con mayor poder adquisitivo pudieron alcanzar los nuevos progresos y conseguir mayores cosechas. En los años 70 aparecieron las corrientes ecologistas que cuestionaron las nuevas prácticas en la agricultura, señalando el impacto social y medioambiental, las cuales citaremos más adelante.

En primer lugar, cabe señalar que este siglo tuvo que hacer frente a la Primera y Segunda Guerra Mundial, ocasionando periodos de escasez de productos y cartillas de racionamiento de alimentos. En Estados Unidos hubo una potente campaña publicitaria enfocada al sector agrícola y a los consumidores. En el texto de un cartel producido por el estado de Colorado en 1917, se anunciaba

Las armas y la agricultura son los dos grandes factores que traerán la victoria... Nuestras fuerzas armadas están organizadas. Las fuerzas agrícolas deben organizarse (Bernat, 2010: 3).

Asimismo, en la imagen 22 podemos observar un cartel del Consejo de Defensa del Estado de Indiana donde se instaba a los agricultores a poner un silo en su granja, con la intención de fomentar la máxima producción y el almacenamiento en la Primera Guerra Mundial. 


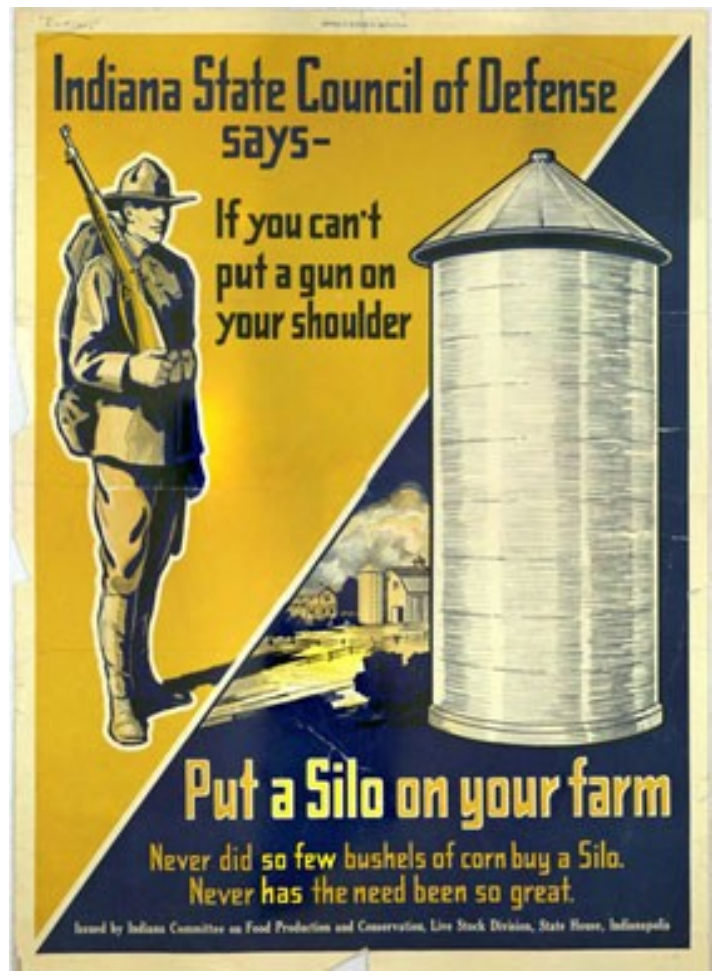

Imagen 22. Cartel Consejo de Defensa del Estado de Indiana, 1917. Fuente: Biblioteca Nacional de Agricultura

Se fomentaba el servicio a la nación y se equiparaba la labor militar con la agrícola como trabajos por el interés de la patria. La vía de comunicación que utilizó el Estado con la población fue a través de la elaboración de carteles. Durante la Primera Guerra Mundial se repartieron folletos con diseños que solían ser a dos tintas y con textos explicativos donde se instaba al agricultor a seguir los consejos que contenían por el bien del país. Los carteles eran sobrios y con contenidos claros y directos. En cambio, en la Segunda Guerra Mundial los carteles adquirieron más color y eran protagonizados por figuras femeninas con expresiones de tranquilidad y amabilidad. La diseñadora, profesora e historiadora de alimentos Cory Bernat, en su artículo War-Era Food Posters señala que, 
Mientras que los hombres realizaban las "cosas espectaculares", gran parte del trabajo diario en el hogar se dejaba a las mujeres. Las mujeres fueron cruciales para el éxito de las campañas de conservación de alimentos en la Primera Guerra Mundialy más tarde para el éxito del racionamiento obligatorio durante la Segunda Guerra Mundial (Bernat, 2010: 7).

En las siguientes imágenes podemos comparar dos carteles, en el de la izquierda producido en la Primera Guerra Mundial predomina el texto con el mensaje de Mujeres del hogar, conozca los alimentos y los valores de los alimentos, informando sobre el enlatado, fomentando el ahorro y la conservación. En cambio, en el cartel de la derecha elaborado en la Segunda Guerra Mundial se muestra una mujer patriota que puede con todo, con el rol de ama de casa y sin preocupación por los puntos de racionamiento.
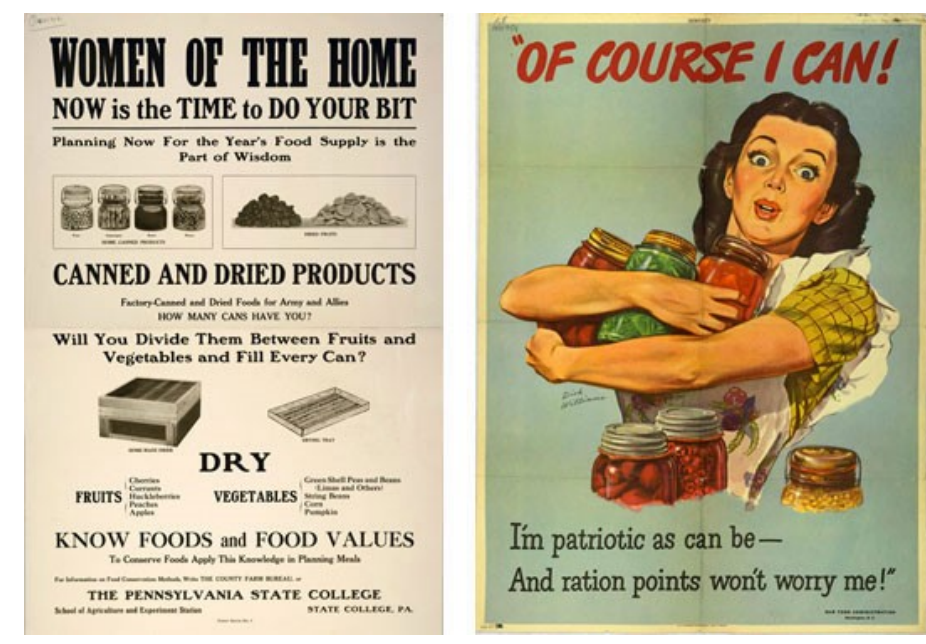

Imagen 23. The Pennsylvania State College, 1917

Fuente: Biblioteca Nacional de Agricultura. Imagen 24. OWI, 1944

Fuente: Biblioteca Nacional de Agricultura.

Los carteles, sobre todo en la Segunda Guerra Mundial, mostraban diseños más elaborados, el artista creó ilustraciones más complejas, generando una publicidad más comercial e intentando llamar la atención del consumidor. 


\subsubsection{La visión de la agricultura a través de las vanguardias artísticas del siglo XX}

Paralelamente a las situaciones de guerra y entreguerras citadas anteriormente, en la primera mitad del siglo XX, emergió un arte de vanguardia que buscaba la libertad de expresión. De entre todas las corrientes artísticas que irrumpieron en estos primeros cincuenta años del siglo XX vamos a destacar aquellas que mantuvieron el contacto con la agricultura. Cabe recordar que la aparición de la fotografía en el siglo XIX ocasionó cambios en la producción artística, sobre todo en los pintores. Algunos cambiaron el lienzo por la cámara fotográfica, otros empezaron a investigar cómo incidía la luz en las escenas que componían, el artista tenía más libertad para trabajar sus pinturas en el taller a partir de las fotografías que realizaba a paisajes o personajes, pagar a modelos para que posaran ya no era imprescindible y se empezó a experimentar con nuevas formas y posibilidades expresivas. Como señala el doctor en Historia del Arte, Jorge Latorre Izquierdo, en su artículo Fotografía y Arte: Encuentros y Desencuentros,

Fue especialmente la corriente pictórica naturalista, con sus prolongaciones en el Impresionismo, la que más se dejó influir por la visión fotográfica que, con el tiempo, renovaría totalmente la tradición pictórica occidental. Desde el seno de esta tendencia moderna, una vez liberados por la fotografía de la tradicional función de representar la naturaleza, los pintores se dirigieron por el camino de la investigación plástica pura, tratando de definir su arte como una manifestación creativa autónoma, independiente de la realidad visual, abriendo así los caminos de la Vanguardia del siglo XX (Latorre, 2012: 27).

La relación con la realidad y la forma de representarla cambió, se dieron nuevas corrientes artísticas que replanteaban las formas, la perspectiva, el volumen, el movimiento, el color y la luz. En ocasiones, el espectador tenía que reconstruir mentalmente la imagen. Centrándonos en la relación del arte con la agricultura, destacamos a Joan Miró y sus obras surrealistas, entre sus piezas citamos la serie de Campesinos. El artista en su peculiar y personal lenguaje de signos dedicó una serie de obras a elogiar al campesinado catalán. En la siguiente imagen podemos observar la síntesis que realizó del típico payés catalán. Sobre un fondo azul, Miró, esquematizó su visión del 
campesino dotándolo de elementos característicos como la barretina, pero carente de perspectiva.

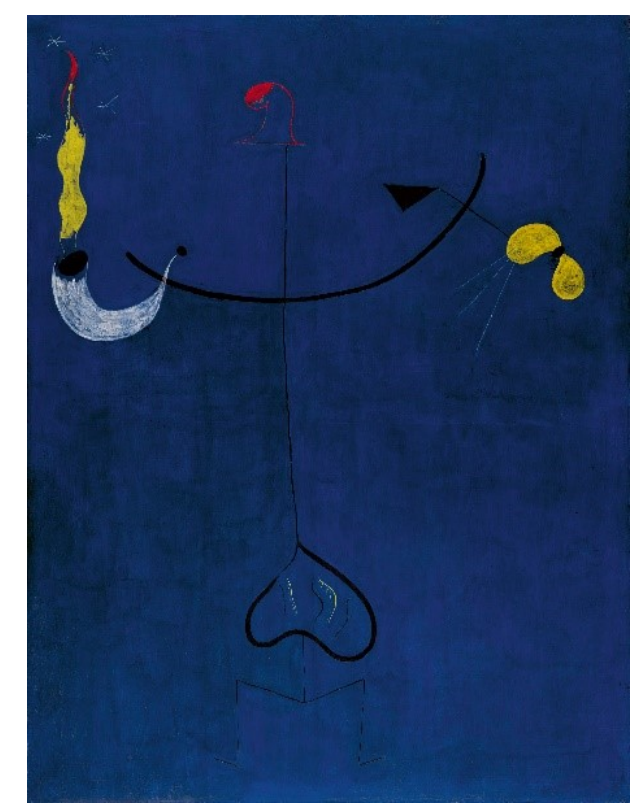

Imagen 25. Campesino catalán con guitarra, Joan Miró, 1924. Fuente: museothyssen.org

Otra obra significativa del artista en relación con el tema que nos ocupa es $L a$ Masía (imagen 26). Esta pintura muestra la esencia de la típica masía catalana, pero concretamente se trata de una masía situada en Montroig, Barcelona (España) que compraron los padres de Miró y donde él vivió muchos años. En la obra, Miró, de una forma muy poética plasma la visión de su niñez, los elementos, la naturaleza y el entorno familiar y campestre en el que vivió. En ese intento de resumir el hábitat que le rodeaba y de buscar la esencia de su infancia, el artista nos ofreció una obra donde se pueden vislumbrar las distribuciones de las masías típicas de la época y los elementos que las componían. En resumen, nos muestra la estructura de estas construcciones aisladas que estaban vinculadas a una explotación agraria y ganadera y que fueron influenciadas por las antiguas villas romanas. Se 
observa la casa principal, el cobertizo, la balsa, la zona de huerta, el granero, el espacio dedicado a los animales y los utensilios típicos de la época para las labores diarias en el campo. Consideramos que la empatía, la cercanía, el conocimiento y el vínculo que el artista creo en ese espacio desde su niñez fueron especialmente relevantes en la acción de crear una obra que ensalzara y preservara la cultura campestre catalana del momento.

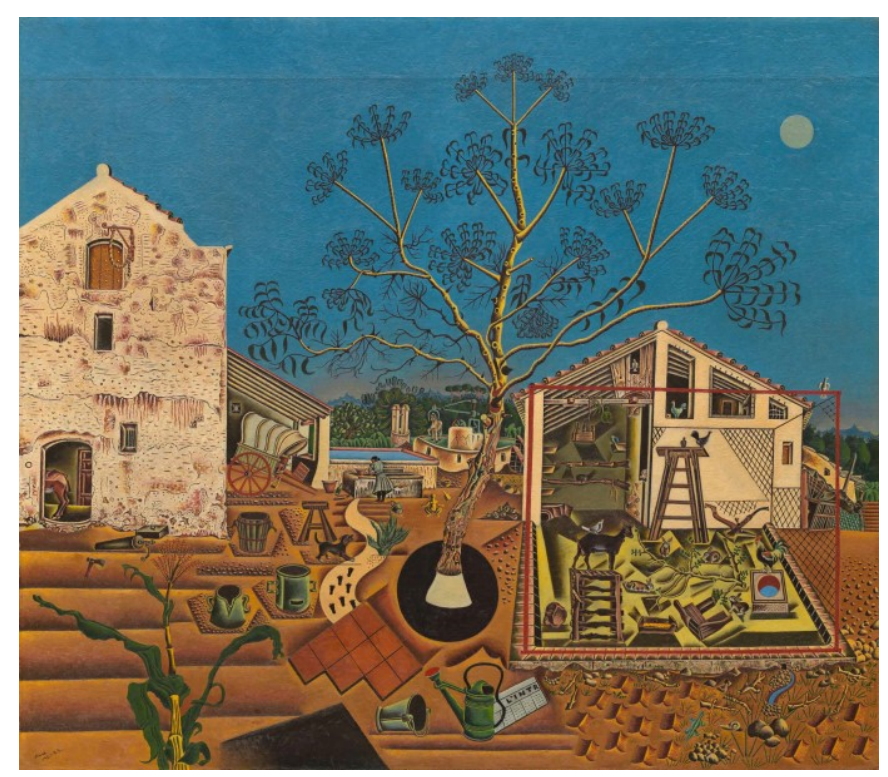

Imagen 26. La Masía, Joan Miró, 1921-1922. Fuente: www.nga.gov

Otro artista español de principios de siglo XX a destacar por su vinculación con la temática rural es el pintor Rafael Zabaleta. Su obra se enmarca en el llamado realismo expresionista español. Sin embargo, el artista experimentó diferentes fases en su evolución pictórica, pasando por el expresionismo sombrío y el rutilante hasta llegar al estilo poscubista. Este último fue influenciado por su admiración hacia la obra del artista Pablo Picasso. Entre las numerosas obras de Zabaleta destacamos las vinculadas con la representación del campesinado andaluz. Los protagonistas de sus obras 
fueron sus familiares y los campesinos de su localidad natal, a los cuales pintó con dedicación. En su serie El campesino hizo una alegoría a la figura del agricultor, fundió las líneas, las formas y los colores del personaje central con el entorno rural que habita. Se destaca el íntimo vínculo entre la tierra, el campesino y sus costumbres.

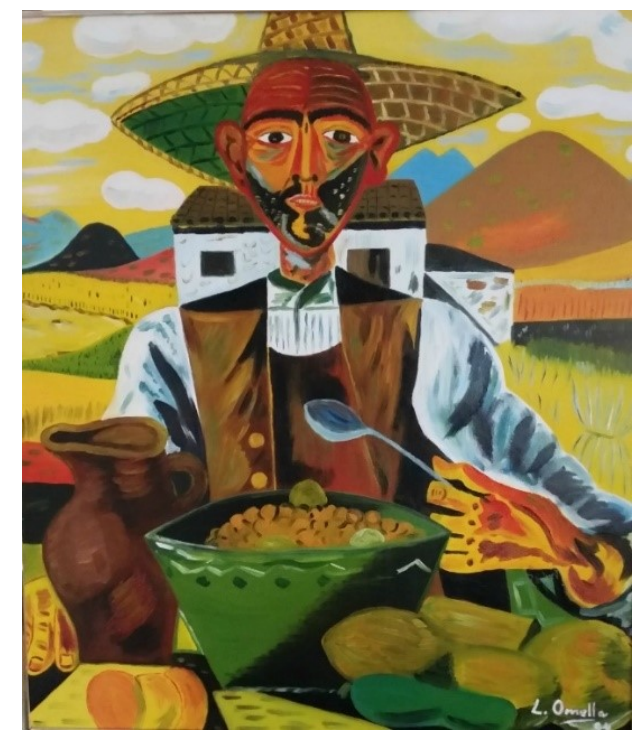

Imagen 27. Campesino comiendo, Rafael Zabaleta, 1950. Fuente: zabaletafundacion.org

Con estas pinturas de artistas españoles, enlazamos con la mención que realiza el profesor José Vicente Maroto dentro su libro Historia de la agronomía, en la sección de La Agronomía en el siglo XX. El gran desarrollo de las ciencias y las tecnologías, acerca de la gran labor de los agricultores anónimos,

No haríamos honor a la realidad agrícola española si no indicásemos de forma sucinta la ingente labor desarrollada por centenares de agricultores anónimos, que en áreas como la Comunidad Valenciana, Murcia, Cataluña, Andalucía, Canarias, etc., han introducido con su esfuerzo, muchas veces en solitario, y sin ayudas ni respaldo de ningún tipo, las más modernas tecnologías que han convertido al sector hortofrutícola español en avanzadilla económica de 
primera magnitud, habiendo sido su trabajo el que ha inducido y catalizado, en muchos casos, el avance agronómico (Maroto, 2014: 377).

Destacamos la importancia de valorar y elogiar desde todos los ámbitos de estudio el gran trabajo y esfuerzo que ha dedicado el campesinado durante siglos en la producción de la alimentación. Continuando con esa mención al agricultor y agricultora desde el arte, que es el ámbito que nos ocupa, consideramos relevante citar a los artistas estadounidenses que formaron parte de la corriente del Regionalismo en las que retrataron las escenas realistas de las zonas rurales de la América del oeste del siglo XX, principalmente. Grant Wood fue uno de los artistas vinculados a este movimiento artístico, junto a Thomas Hart Benton y John Steuart Curry.

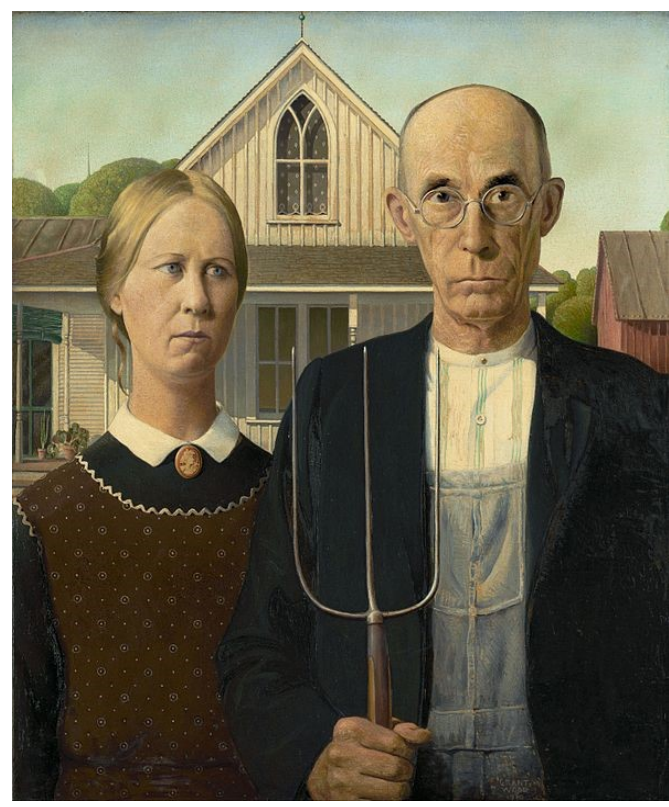

Imagen 28. Gótico estadounidense, Grant Wood, 1930. Fuente: lineassobrearte.com

En la anterior imagen podemos observar una de las obras más representativas de Wood, donde inmortalizó la estética rural estadounidense del momento. El cuadro fue un homenaje a la labor del campesinado, el 
hombre equipado con su herramienta de campo y la mujer con su delantal posaban enfrente de una casa construida con elementos de estilo neogótico.

En la imagen 29 visualizamos otra de las obras que pintó Wood donde se vislumbra un campo de maíz. Esta obra es relevante por la información que conlleva, siendo una muestra de la pureza del paisaje rural, con sus arados alineados y geométricos condicionados por la constante evolución científica y técnica en el sector agrícola. En este siglo se marcaron importantes avances como la aparición del tractor, aunque estos solo estaban al alcance de los sectores más adinerados.

La expansión, en la primera década del siglo XX, del tractor como vehículo agrícola [...], marca el inicio de una etapa en la que la mecanización en el campo es un hecho perfectamente delimitado y que se va extendiendo poco a poco hasta ámbitos hortícolas que hace tan sólo escasos años nadie hubiera podido imaginar (Maroto, 2014: 363).

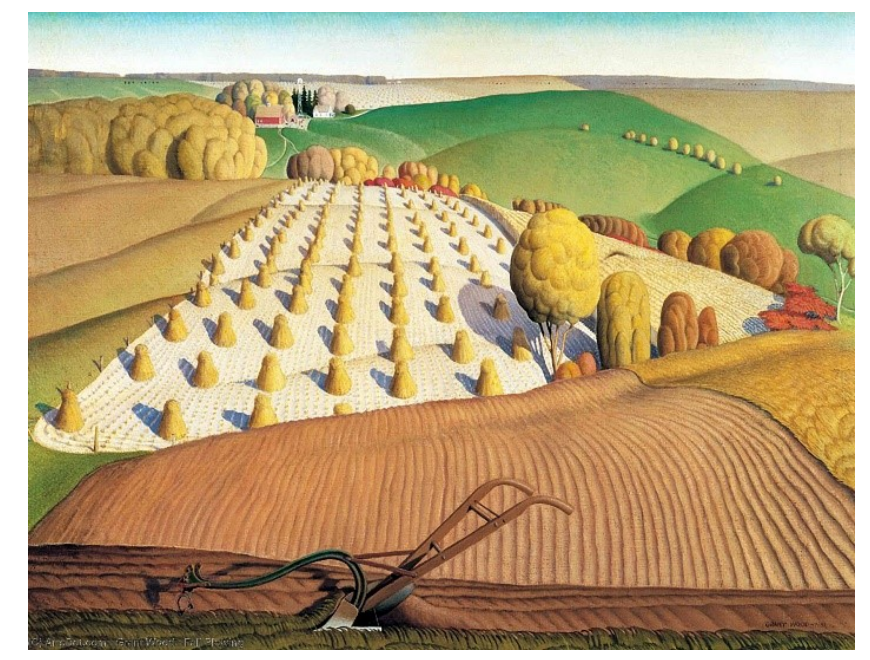

Imagen 29. Fall Plowing, Grant Wood, 1931. Fuente: picturingtheamericas.org

La corriente artística del Regionalismo abarcó el periodo de la crisis financiera mundial que se produjo durante la Gran Depresión, en los años previos a la 
Segunda Guerra Mundial. Esta época fue muy perjudicial para el sector agrícola, el comercio internacional se desplomó, la demanda cayó y con ello los precios de las cosechas, viéndose seriamente afectadas las zonas dependientes del sector primario. Los artistas que se centraron en los temas del Regionalismo ofrecieron su visión del realismo social que se vivía en las zonas más rurales, surgieron como rechazo a las vanguardias y al aceleramiento del mundo moderno. Grant Wood, Thomas Hart Benton y John Steuart Curry fueron fervientes defensores del mundo agrícola, a través de sus pinturas mostraban escenas campestres con el objetivo de hacer ver que la solución a los problemas que se vivían en las urbes por la Gran Depresión era volver a las raíces agrícolas.

El artista Thomas Hart Benton retrató en sus pinturas y murales la vida humilde y diaria del campesinado que habitaba las zonas del medio oeste. En la imagen 30 podemos observar una de sus pinturas donde unos agricultores de diferentes edades trabajan en la cosecha del trigo, las curvas del paisaje se funden con la postura de los trabajadores generando una escena sinuosa e integradora en todos sus elementos.

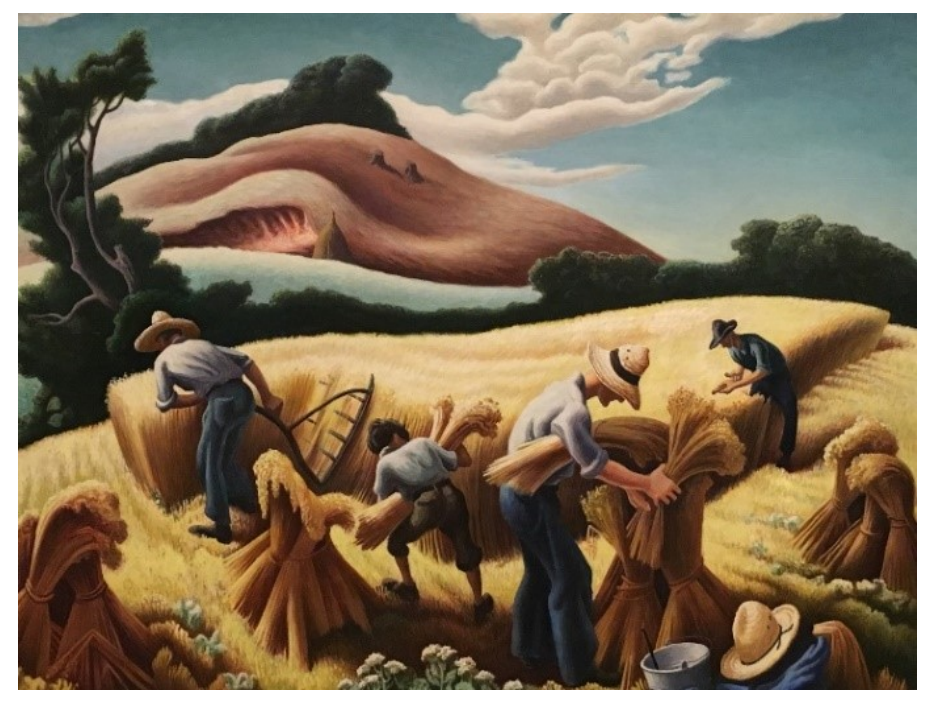

Imagen 30. Cradling Wheat. Thomas Hart Benton, 1938. Fuente: piasweethome.com 
Por otra parte, John Steuart Curry el tercero de los artistas que hemos nombrado previamente como vinculados al Regionalismo, también realizó grandes obras en alegoría y representación del trabajo y de los modos de vida de las zonas rurales del medio oeste. Curry trabajó unos años como ilustrador para varias revistas, esta faceta profesional influenció las composiciones de sus pinturas y murales posteriores, las cuales nos enlazan sutilmente con su estilo de ilustrador.

En la imagen 31 observamos la pintura Nuestra buena tierra que también fue cartel de guerra, donde el artista plasmó un agricultor con sus hijos en medio de un campo de cereal con notables ráfagas de viento. La mirada del campesino, entre triste y nostálgica, enlaza con la incertidumbre de los tiempos de guerra que se avecinaban.

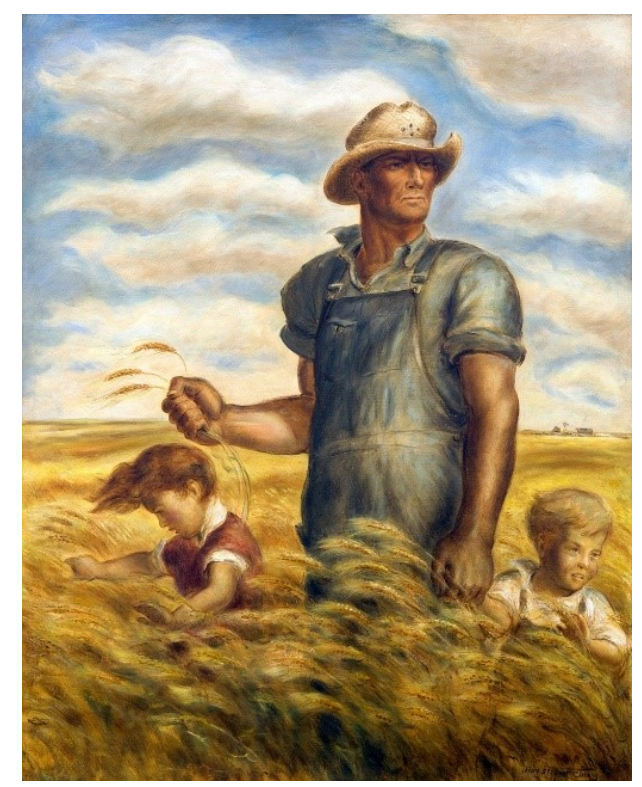

Imagen 31. Nuestra buena tierra, John Steuart Curry, 1942.

Fuente: 3 minutosdearte.com

Asimismo, como hemos podido ir viendo tanto en este siglo como en los anteriores, la figura de la mujer queda relegada a un segundo plano como 
ama de casa, cuidadora de sus hijos y trabajadora del campo. Pero, también hubo grandes mujeres artistas que la historia no visibilizó lo suficiente. Es por ello por lo que destacamos en este apartado el trabajo de la litógrafa estadounidense Mabel Dwight. A pesar de que no se le cataloga como tal en la corriente Regionalista, esta artista tuvo un fuerte compromiso social y realizó numerosas obras de la vida cotidiana de esta época. Las escenas de su obra se muestran desde la ironía y su mayor auge fue de los años 20 a los 40. Entre sus obras, de diversidad temática, destacamos Farmyard por su vinculación con las cuestiones de representación rural que nos ocupan. Esta litografía sobre papel (imagen 32), muestra una escena típica campestre de una mujer dando de comer a sus animales de corral. En la obra, realizada tras la Segunda Guerra Mundial, la artista nos muestra otras facetas de la vida rural, tal vez menos visibilizadas, donde también se incluyen los distintos animales que habitan en la granja y sus cuidados.

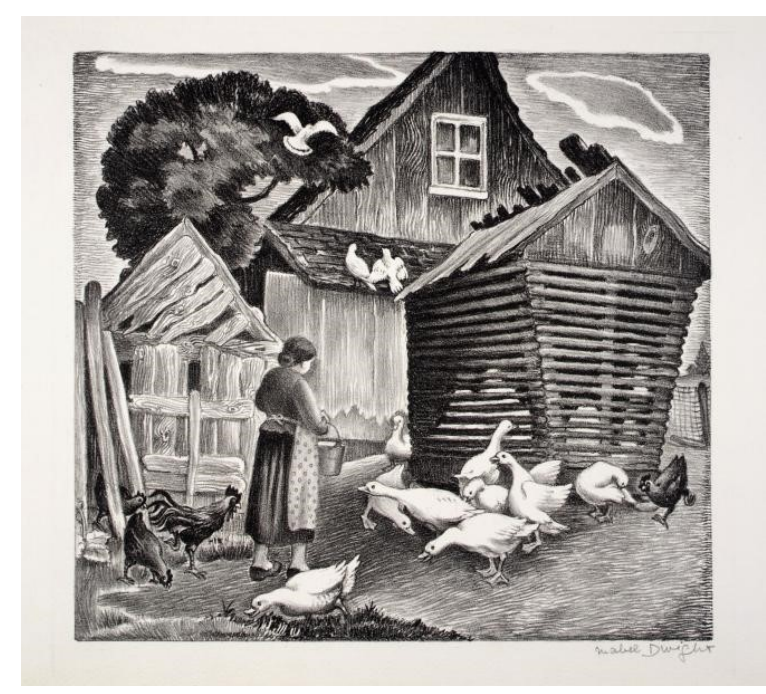

Imagen 32. Farmyard, litografía sobre papel. Mabel Dwight, 1947. Fuente: americanart.si.edu

Asimismo, cabe nombrar a la artista española Maruja Mallo la cual realizó obras de reconocido prestigio catalogadas dentro del movimiento 
surrealista. Esta artista fue una mujer que consiguió integrarse y desenvolverse en el mundo artístico de la época, el cual era regentado por hombres. Formó parte de la Generación del 27, también de la llamada Escuela de Vallecas (grupo de vanguardia español que consiguió reaparecer tras la guerra civil) y fundó el grupo de las Sinsombrero (mujeres intelectuales que rompieron con los estándares burgueses y se atrevieron a salir a la calle sin esta prenda). Alcanzó reconocimiento con su obra, pero se vio obligada a exiliarse tras el alzamiento militar y la larga guerra civil española, debido a su ideología republicana. No obstante, tras más de veinticinco años en el exilio volvió a España y luchó por recuperar su lugar dentro del mundo del arte. Mallo fue una artista que no siguió los dictámenes de la academia y busco un estilo propio, además, por sus posturas cercanas al republicanismo sus obras fueron cargadas de connotaciones sociales, críticas y reivindicativas. Así pues, destacamos una de sus obras más representativa, La sorpresa del trigo (imagen 33).

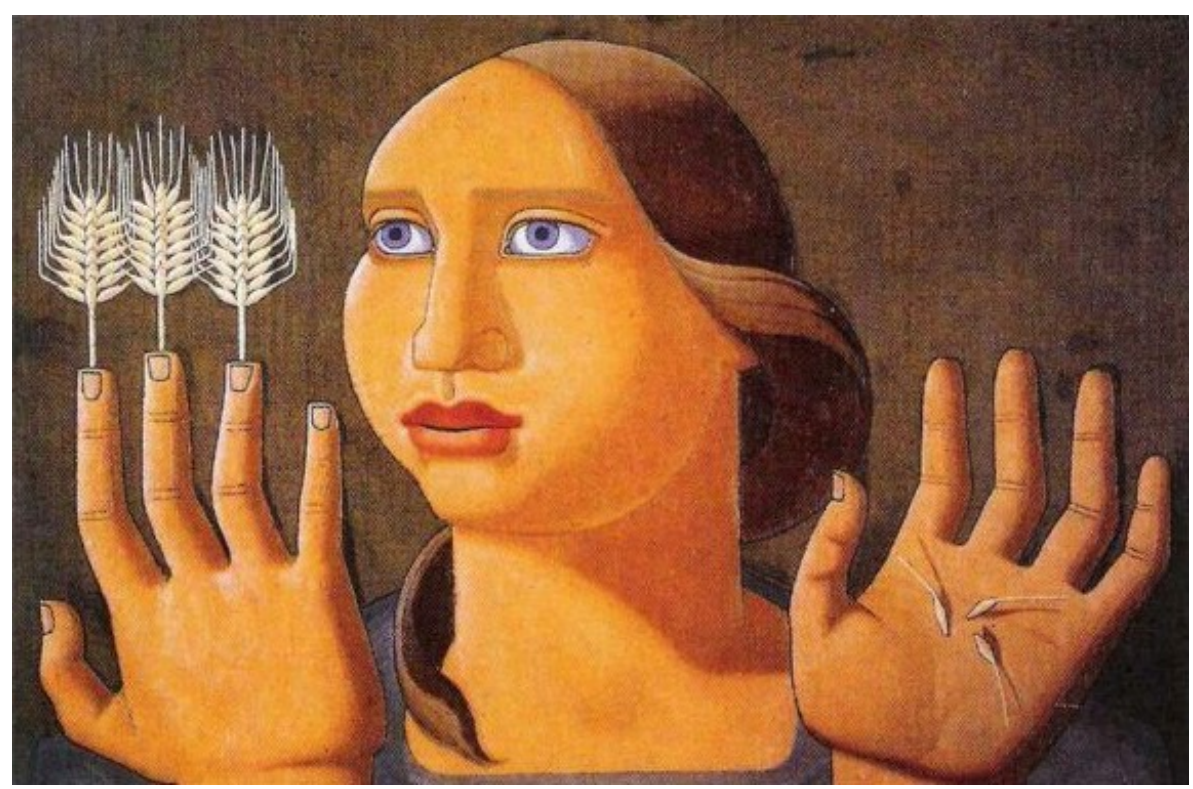

Imagen 33. La sorpresa del trigo, óleo sobre lienzo. Maruja Mallo, 1936. Fuente: sobrehistoria.com 
Esta pintura fue la primera obra de la serie titulada La religión del trabajo, muestra el rostro y las manos de una mujer que sostiene semillas y espigas de trigo. La inspiración para realizar dicho óleo vino dada mientras contemplaba la manifestación del $1^{\circ}$ de mayo en Madrid (España), entre el proletariado la artista vio un brazo alzado sosteniendo una barra de pan. Mallo, tomó conciencia de la importancia del trabajo agrícola y del pan como alimento principal de la población. Posteriormente pintó El canto de las espigas (imagen 34), ya en el exilio en Buenos Aires, pero siguiendo con la temática del trigo y ensalzando los trigales que llegó a recorrer por la España rural.

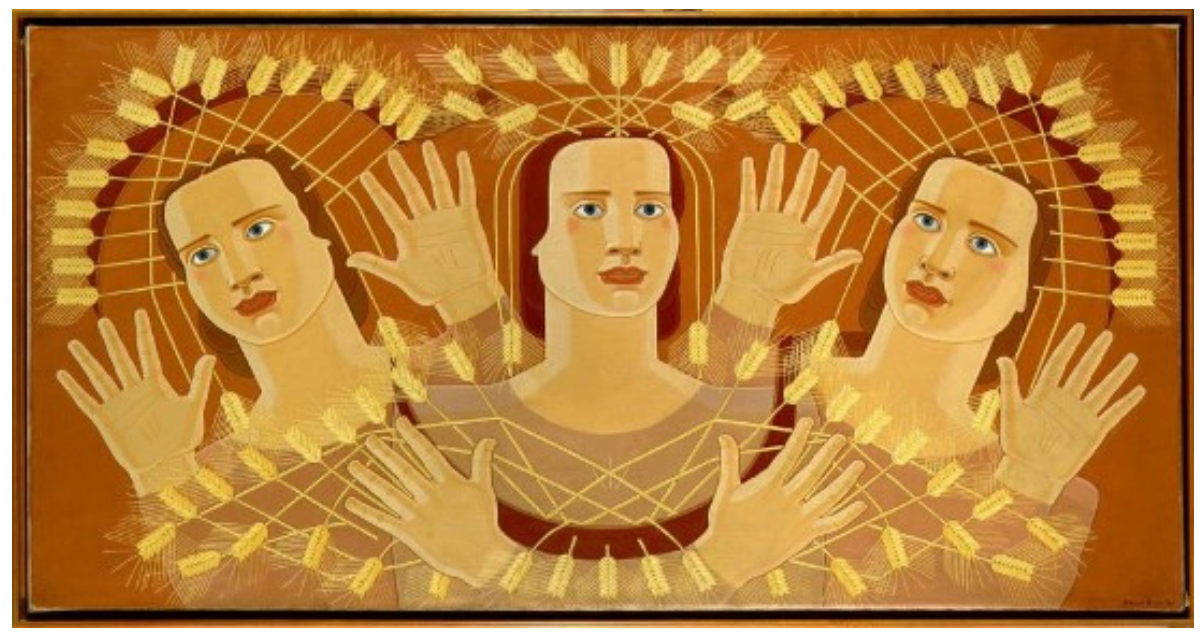

Imagen 34. El canto de las espigas, óleo sobre lienzo. Maruja Mallo, 1939. Fuente: museoreinasofia.es

Finalmente, de esta primera parte del siglo XX cabe destacar el movimiento artístico que surgió tras la Revolución Mexicana, el Muralismo Mexicano que tuvo un impacto internacional. El nuevo gobierno que se instauró en México tras la revolución encargó murales públicos de gran tamaño en los que se plasmaba la vida y la historia del pueblo. Se empezó a crear un arte de tendencia social y no mercantilista donde el soporte era el muro. Se utilizó el arte como medio de comunicación con el pueblo, los mexicanos cansados de las imposiciones de otras culturas a las que habían estado sometidos 
tuvieron la posibilidad de sentirse identificados con sus raíces a través de las monumentales obras de arte que se ubicaron en el espacio público. Destacamos los murales del Mercado Abelardo L. Rodríguez, un edificio que alberga aproximadamente 1450 metros cuadrados de murales de carácter social. Las obras fueron realizadas hasta por diez artistas diferentes y supervisados por el artista Diego Rivera, las pinturas abarcaron paredes y techos reflejando la explotación de trabajadores, campesinos y mineros.

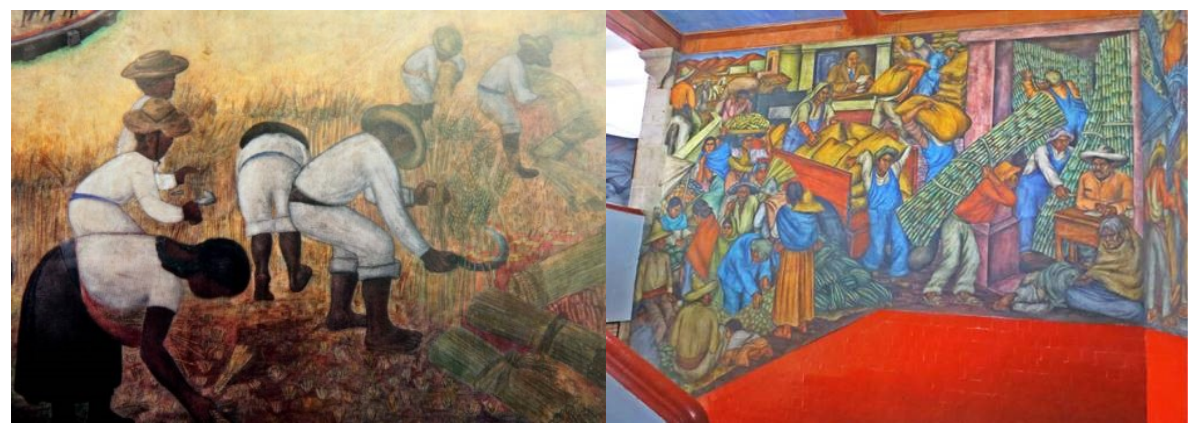

Imagen 35. Las labores del campo, detalle mural Mercado Abelardo L. Rodríguez. Ramón Alva Guadarrama, 1934-1935. Fuente: www.eluniversal.com.mx Imagen 36. La industrialización del campo, detalle mural Mercado Abelardo L. Rodríguez. Marion Greenwood, 1935. Fuente: www.scielo.org.mx

Los artistas más destacados de este movimiento fueron Diego de Rivera, José Clemente Orozco y David Alfaro Siqueiros, los cuales también viajaron a Estados Unidos, lugar donde ofrecieron su visión de arte de carácter social. Sus obras llegaron a influenciar el arte estadounidense, siendo un modelo inspirador en un momento de devastadoras consecuencias sociales y económicas debidas a la Gran Depresión. La curadora Barbara Haskell en su artículo América: Muralismo mexicano y el arte en los Estados Unidos, 19251945, destaca que,

Al plasmar temas sociopolíticos con un vocabulario pictórico que celebraba las tradiciones prehispánicas del país, los murales otorgaron a la antigua técnica del fresco una renovada vitalidad que competía de igual a igual con las tendencias de vanguardia que arrasaban en Europa, mientras que establecía, 
al mismo tiempo, una nueva relación entre el arte y el público al narrar historias relevantes para hombres y mujeres común y corrientes. No había nada en los Estados Unidos que pudiera compararse. Cautivados, los estadounidenses que visitaban México desbordaron las revistas como The Nation, New Masses, Creative Art con efusivos informes acerca de los murales (Haskell, 2020: 1).

Los tres artistas recién citados aumentaron su fama y crearon grandes obras de relevancia internacional durante su estancia en Estados Unidos. Artistas estadounidenses como Pollock quedaron asombrados con el potencial expresivo, social y comunicativo de los muralistas mexicanos. Si bien, las obras que realizaron en Estados Unidos no se ciñeron exclusivamente al soporte mural, realizando obras pictóricas sobre lienzos que fueron expuestas en diversas muestras, como la siguiente pieza de Diego de Rivera.

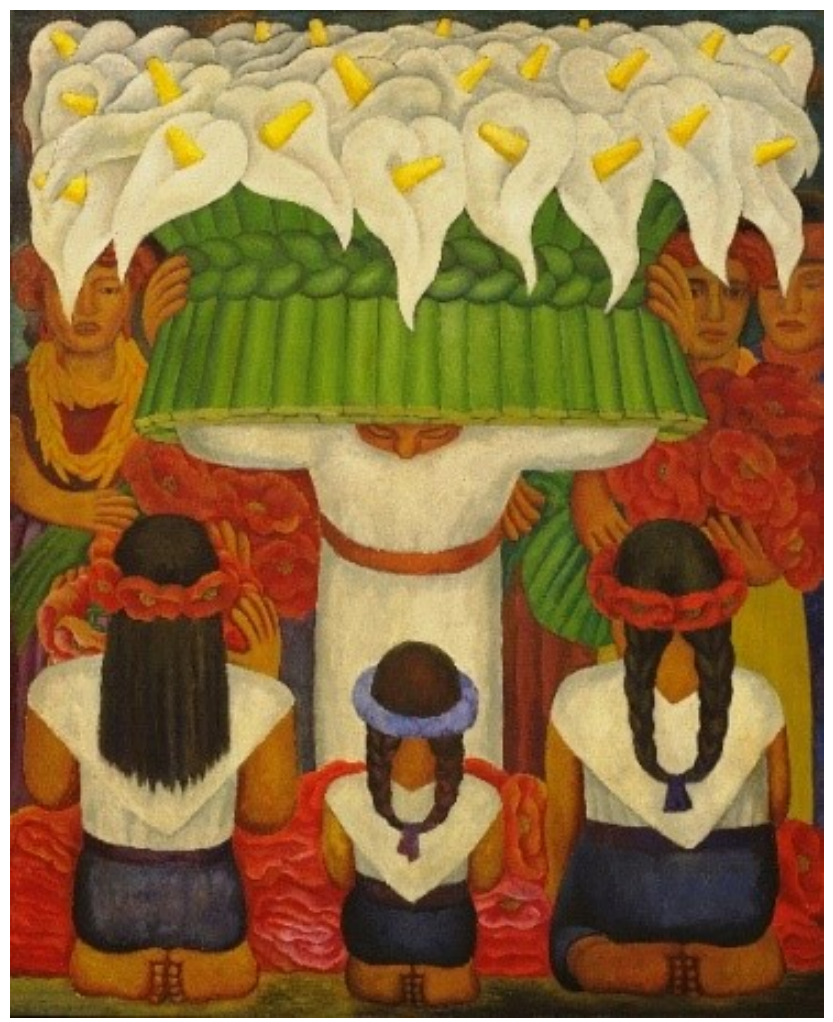

Imagen 37. Festival de las Flores: Fiesta de Santa Anita, encáustica sobre lienzo. Museo de Arte Moderno de Nueva York. Diego de Rivera, 1931. Fuente: whitney.org 


\subsubsection{La agricultura vista desde el arte de últimas tendencias del siglo XX}

En el anterior apartado ya hemos mencionado los avances científicos y tecnológicos que se fueron produciendo a lo largo del siglo XX en el sector agrícola. Centrándonos en la segunda mitad del siglo, cabe señalar que a partir de los años 60 se desarrolló la llamada Revolución verde la cual trajo un gran aumento en la producción de las cosechas, debido a las mejoras genéticas y a la aplicación de los insumos de síntesis química. No obstante, fueron unos avances destinados a los sectores de la población mundial que tuvieron suficientes recursos económicos para adquirirlos, ocasionando una gran desigualdad social. Además, cabe señalar el gran impacto ambiental que ocasionó la cantidad de productos químicos que se vertieron en los campos.

Un famoso economista, J. Fontana (2011), en países como la India, citando fuentes de este país, aunque admite que las pautas de la "Revolución Verde" incrementaron netamente las producciones de trigo y arroz, señala que los "inputs" propiciados por aquella tuvieron una influencia muy negativa sobre determinadas áreas del país, pues agotaron las reservas de agua, salinizaron los suelos, hicieron abandonar cultivos con menores exigencias en recursos, favorecieron el endeudamiento de los pequeños agricultores e incluso propiciaron el abandono de tierras, llegando a concluir que la mencionada "Revolución Verde" tuvo efectos "perversos" (Maroto, 2014: 383).

Además, este tipo de producción agrícola es totalmente dependiente de la exportación de los packs tecnológicos, dejando de lado la tradición agrícola y la conservación de la biodiversidad, ocasionando perdida de la soberanía alimentaria.

En 1963 se marcó un antes y un después en cuanto a la utilización de los insumos en la agricultura tras la publicación de Primavera Silenciosa de Rachel Carson. La bióloga y zoóloga puso en cuestionamiento la agresividad de estos productos hacia el medio ambiente y sus habitantes. La publicación de su estudio abrió nuevas investigaciones hacia los efectos nocivos de estos químicos y, posiblemente, fue el propulsor que hizo emerger las corrientes ecologistas en la década de los 70. Carson, con la publicación de sus estudios 
se enfrentó con valentía contra el capitalismo y la industria agrícola que en tiempos de postguerra estaban iniciando una contaminación planetaria sin precedentes.

La lucha de las corrientes ecologistas en la agricultura se centró en la fertilización y en el uso de químicos para el control de plagas, posteriormente también se opusieron a los organismos modificados genéticamente. Cabe señalar que a principios del siglo XX surgieron las concepciones filosóficoempiristas de Sir Albert Howard y antroposóficas de Rudolf Steiner donde a través de nueve conferencias difundieron su concepto de Agricultura Biodinámica entre los agricultores, defendiendo prácticas agrícolas más sostenibles, en el capítulo tercero de esta investigación nos adentraremos en este ámbito. También, la publicación del informe de Los límites del crecimiento y el Manifiesto por la supervivencia en la revista The Ecologist en 1972, fueron importantes publicaciones que impulsaron las nuevas corrientes ecologistas en defensa de las prácticas agrícolas sustentables.

En el ámbito del arte siguieron emergiendo corrientes artísticas que se revelaron ante el modelo capitalista y la idea de sociedad de consumo. En esta línea destacamos el Land Art, una corriente de arte contemporáneo surgida en los años 60 que se centró en trabajar en el terreno natural. La catedrática Tonia Raquejo en su libro Land Artseñala que,

No debemos, pues, entender una obra como land art solo por el mero hecho de que esté construida al aire libre. Lo que determina el carácter de esta tendencia es [...] su concepto del arte por un lado y sus reflexiones en torno al espacio y al tiempo, por otro. Land Art tampoco debe entenderse como una tendencia aislada, sino como una propuesta más dentro del amplio abanico que generó la reacción de la vanguardia al arte pop, un movimiento que tanto el arte conceptual como el arte de acción convinieron en interpretar como mercantilista por aceptar las bases del capitalismo y ensalzar la sociedad de consumo (Raquejo, 1998: 12).

Si bien los artistas de este movimiento trabajaban principalmente con elementos de la naturaleza, no por ello estaban especialmente interesados en la ecología. Bajo el amparo del término Land Art se han clasificado obras con características y finalidades distintas. Algunas de ellas de tamaño 
monumental y con gran impacto ecológico. Es por ello por lo que nos centramos en destacar artistas relevantes de la segunda mitad del siglo XX que formaron parte del llamado arte ecológico y utilizaron sus creaciones como medio de protesta ante las situaciones que se vivían en la agricultura. En este sentido, una de las artistas pioneras del arte ecológico y de los movimientos de arte ambiental fue Agnes Denes.

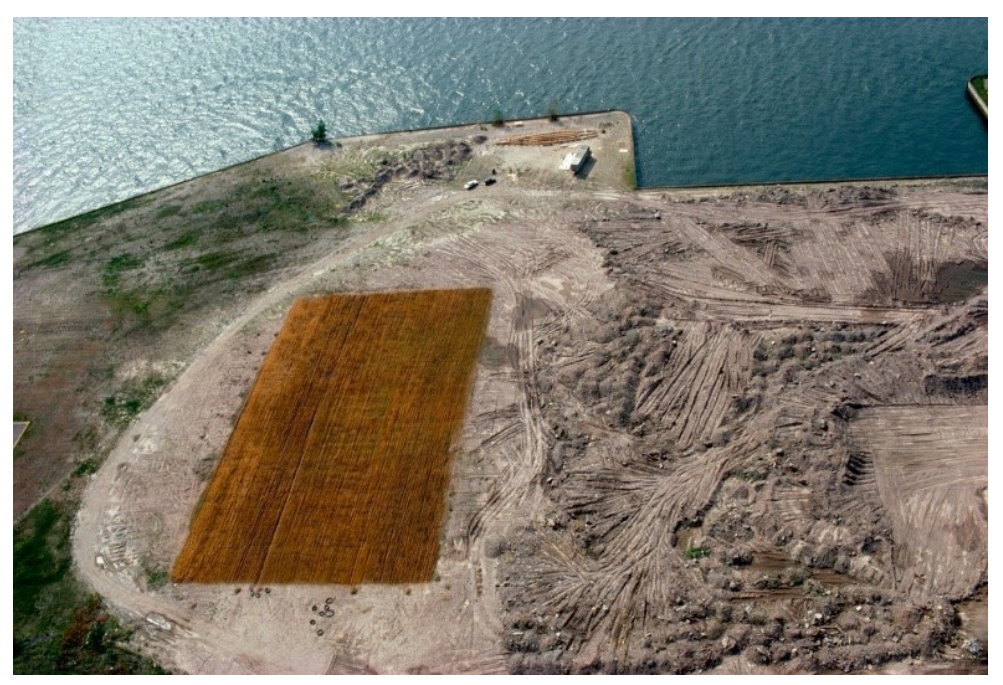

Imagen 38. Wheatfield - a Confrontation, Manhattan. Agnes Denes, 1982. Fuente: nytimes.com

Una de las obras más significativas de Denes es Wheatfield - a Confrontation, donde la artista eligió un vertedero de Manhattan, cerca de Wall Street, para plantar un campo de trigo dorado de dos acres (imagen 38). Para poder llevar a cabo la obra tuvo que realizar una previa negociación del espacio dado que pretendía cultivar en un lugar despoblado que se destinaba a acumular desperdicios. La artista fue documentando todo el proceso desde el inicio del cultivo. Una vez realizada la cosecha, el grano recogido recorrió "veintiocho ciudades alrededor del mundo en una exposición llamada La Muestra Internacional de Arte para el Fin del Hambre Mundial" (Brown, 2014: 14). 


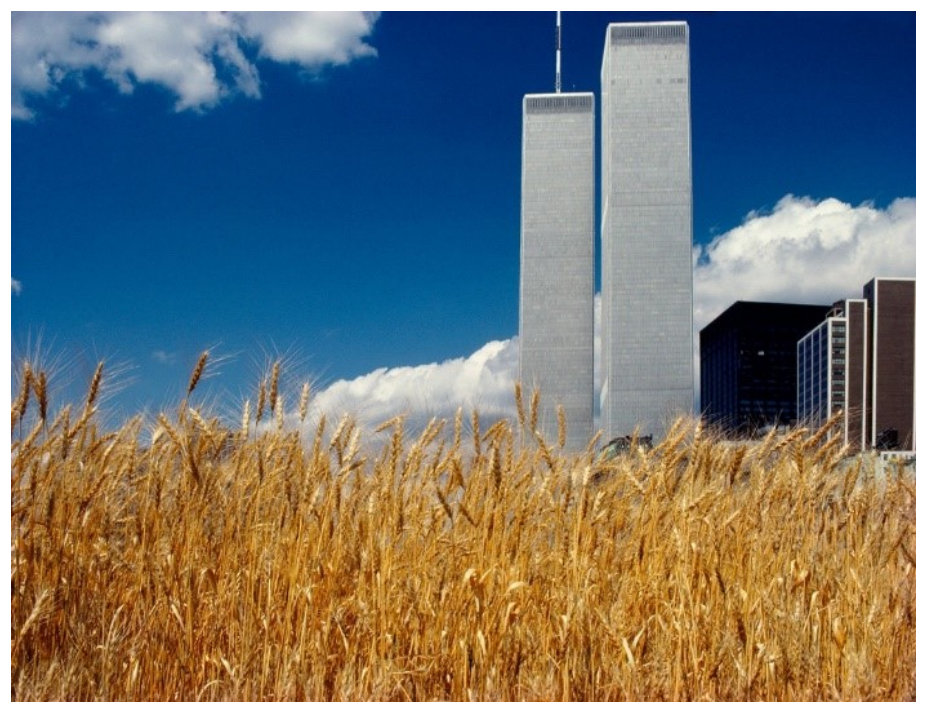

Imagen 39. Wheatfield - a Confrontation, Manhattan. Agnes Denes, 1982. Fuente: nytimes.com

Denes obtuvo ayuda de voluntarios para llevar a cabo la preparación de la tierra y la plantación. Esta obra fue pionera en las cuestiones de huertos urbanos que décadas después se empezarían a dar en medio de las urbes. En un artículo de The New York Times, Karrie Jacobs destaca,

"Wheatfield" es, en retrospectiva, visto como un momento decisivo en el arte público. Su corta existencia se documentó en fotografías, que han adquirido una resonancia adicional a medida que los espacios vacíos de la ciudad de Nueva York se llenan y se erradican paisajes familiares. Una pieza que alguna vez trataba sobre el contraste entre el entorno artificial y el natural ahora trata más sobre la vulnerabilidad de todo. Los dos rascacielos gigantes en el fondo de las fotos resultaron inesperadamente tan perecederos como la obra de arte en primer plano (Jacobs, 2018: 1).

Cabe señalar que la artista realizó la obra en un contexto donde el arte se enfocaba principalmente a las galerías y museos; además, en un entorno donde el perfil de la mujer artista era notorio por su ausencia.

Por otra parte, destacamos al artista alemán Joseph Beuys y su concepto de escultura social. Su arte abarcaba cuestiones sociales, económicas, 
ambientales, políticas y culturales, con una importante preocupación por el medio ambiente y las cuestiones ecológicas. De entre su extenso repertorio de creaciones, destacamos la obra titulada 7000 Oaks (7000 robles) y el proyecto Difensa della Natura.

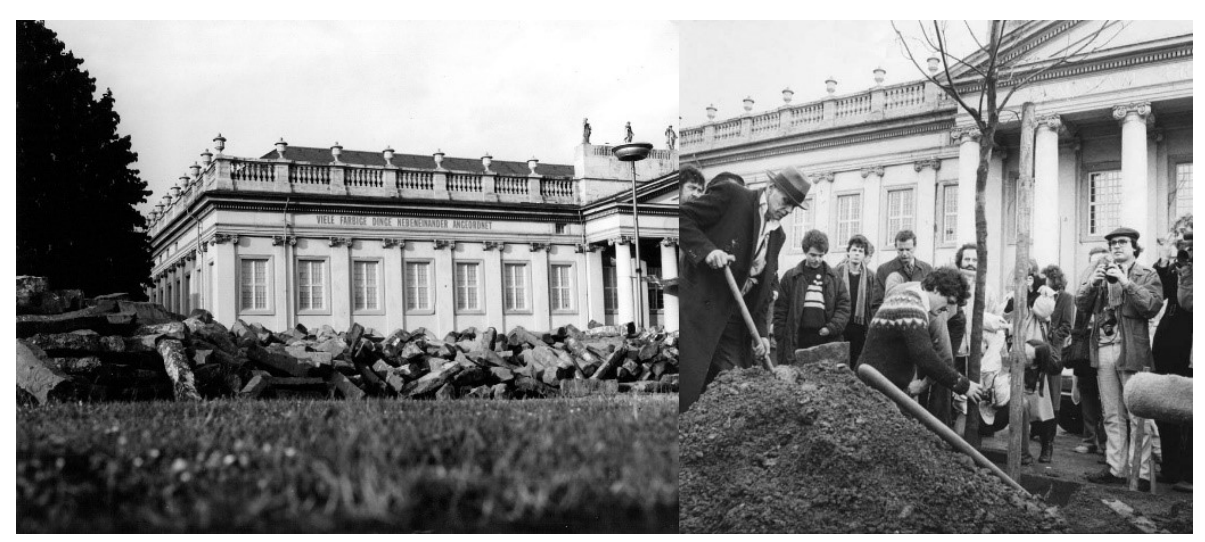

Imagen 40. 7000 Oaks, vista fachada museo Fridericianum. Joseph Beuys, 1982. Fuente: galiciagarden.com Imagen 41. 7000 Oaks, vista plantación primer árbol. Joseph Beuys, 1982. Fuente: galiciagarden.com

Beuys realizó la intervención de 7000 Oaks en el contexto de la muestra de arte contemporáneo de Documenta de Kassel (Alemania). Delante de la fachada del museo Fridericianum el artista dejó 7000 bloques de basalto (imagen 40), en el final de la acumulación de las piedras Beuys plantó el primer roble. La obra tuvo mucha controversia, pero fue una acción que consiguió cambiar el paisaje del lugar al mismo tiempo que movilizó y concienció a la población. Las condiciones de la acción fueron que las piedras solo se podían mover si se plantaba un árbol a su vera. A lo largo de cinco años la población y las instituciones fueron plantando los robles y movilizando los bloques, el cambio visual del espacio, la visión ecológica y social y el concepto de reforestación a través de la acción artística no tuvo precedentes. 
Dália Rosenthal en su investigación O elemento material na obra de Joseph Beuys, presentada para la obtención de su Maestría en Artes, concluye acerca de la obra de 7000 Oaks,

Expresa la convicción de Beuys de que los seres humanos fueron capaces de aprender a encontrar una nueva forma de vivir mejory apuntar al arte como una dirección posible y concreta. No el arte sólo dentro de los museos, galerías o circuitos de arte cerrados en general, sino el arte visto por el Concepto Expandido de Arte: abierto a ser aplicado en todas las direcciones que contribuyen a la formación de una sociedad más creativa. Todas sus teorías buscaban construir una base práctica y teórica para llegar a este camino, creando estímulos para elevar la conciencia del potencial interno de cada individuo como creador responsable del mundo en el que quiere vivir (Rosenthal, 2002: 118) .

Además, la acción fijaba una mirada más allá del lugar de su intervención, fue inspiración para un cambio social y ecológico en el mundo donde se empezó a movilizar y concienciar a la sociedad de la importancia de la continua plantación de árboles. Si bien la obra no está directamente vinculada con la producción agrícola, los valores que promueve en la sociedad y la dimensión de cambio social que alcanza con efectos positivos no tiene precedentes.

Beuys, entre 1980 y 1985, llevó a cabo la que sería su última propuesta, Operazione Difesa della Natura, un proyecto artístico con connotaciones ecológicas que, además, planteaba la defensa del ser humano y de sus valores. En el contexto de dicho proyecto llevo a cabo diversas actuaciones, destacamos Olivestone, 1984. Beuys trabajo con elementos del mundo agrícola, una antigua tina de decantación de aceite, piedra y aceite de oliva virgen. Colocó una piedra dentro de la tina de dimensiones mínimamente

\footnotetext{
3 expressa a convicção de Beuys de que os seres humanos eram capazes de aprender a encontrar um novo caminho para viver melhor e aponta para a arte como uma direção possivel e concreta. Nao a arte apenas interna a museus, galerias ou circuitos artísticos fechados em geral, mas sim a arte vista pelo Conceito ampliado de arte: aberta para ser aplicada em todas as direções que contribuam para a formação de uma sociedade mais criativa. Todas as suas teorias buscaram construir uma base prática e teórica para se alcançar este caminho; criando estimulos para a conscientização do potencial intemo de cada individuo como um criador responsável pelo mundo em que deseja viver. Traducción realizada con deepl.
} 
inferiores y volcó unos doscientos litros de aceite. La pequeña película de aceite que recubría la piedra reflejaba todo aquello que le rodeaba.

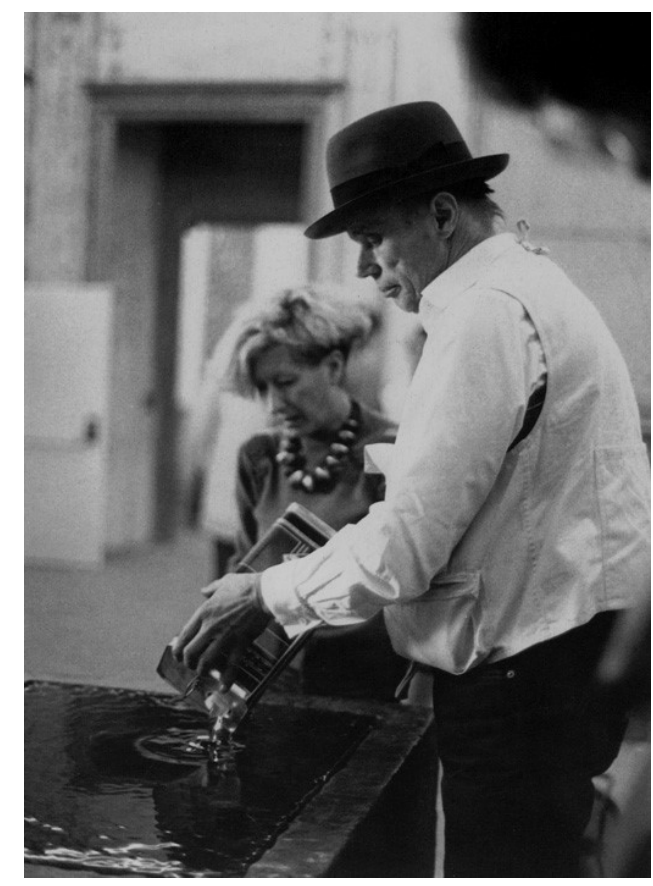

Imagen 42. Olivestone, tina, piedra y aceite. Joseph Beuys, 1984. Fuente: tesis Javier Garcerá, pp. 272

El artista generó un diálogo entre el espacio, el ser humano y elementos de la naturaleza de producción mineral y vegetal. La piedra que descansaba dentro de la tina era porosa e iba absorbiendo el aceite de tal forma que necesitaba una alimentación constante para no perder el efecto del reflejo. La pieza necesitaba de la atención y el vínculo con el artista para mantener su esencia. El doctor en Bellas Artes Javier Garcerá, en su tesis doctoral Visiones desde el exilio: Modernidad y posmodernidad frente a la escisión entre el hombre y el mundo señala que,

La propuesta de Olivestone estaba formulada mediante esa capacidad de integrar saltos temporales, materiales y espirituales. Sus elementos, 
proviniendo del mundo agrícola, asumían una catarsis significativa que los convertía en espejo de la vida, del tiempo y del espacio. No solamente se conseguía la superación escultórica mediante el concepto ampliado del arte, sino que, además, eran los conceptos tradicionalmente antagónicos los que perdían sus posiciones enfrentadas para relacionarse de forma dialéctica (Garcerá, 2005: 273).

Beuys trabajaba en sus obras cuestiones ambientales, territoriales, ecosistémicas y ecológicas donde incluía los valores y la historia del ser humano, generaba un vínculo entre el hombre/mujer y la naturaleza, con especial relevancia en los aspectos sociales. Los proyectos de arte que llevó a cabo con participaciones colectivas permitieron expandir el arte a una dimensión social y promovió valores de defensa de la naturaleza. La obra de Beuys se convirtió en un referente de los proyectos de arte ecológico y ambiental que se generaron en los años posteriores y se siguen creando en la actualidad; así como de los proyectos que vinculan el arte y la agricultura que se citarán en los próximos apartados y capítulos de esta investigación.

\subsection{El papel del arte español del siglo XXI visibilizando la agricultura}

En el contexto del arte contemporáneo en España y más concretamente en el vinculado al mundo rural, se ha producido un aumento de propuestas e iniciativas en este siglo XXI que se centran en preservar, elogiar y compartir las prácticas agrícolas tradicionales. De entre todas ellas podemos distinguir las organizaciones sin ánimo de lucro o fundaciones que se dedican a aspectos concretos, por ejemplo, la asociación de arte y agroecología Mandarina Borda en Palmera (Valencia); profundizamos en este proyecto en el quinto capítulo de esta investigación con los casos de estudio específicos.

También, destacamos La Fragua, una asociación sin ánimo de lucro que se sitúa en el Convento del siglo XV de Santa Clara de Belalcázar (Córdoba). La Fragua es un centro de arte y residencia que acoge artistas a nivel internacional. Sus objetivos se basan en desarrollar propuestas artísticas en el medio rural, se combina la investigación, el diálogo, la producción y la exposición de las obras. En ese contexto, nos resulta relevante el simposio que dirigieron en 2017 en colaboración con la Delegación de Cultura del 
Ayuntamiento de Córdoba. La convención titulada Simposio AABAS reflexionaba sobre el arte, la agricultura, la biodiversidad, la alimentación y la salud. En dicho certamen participaron tres artistas en residencia y el colectivo Culturhaza, este último es tratado como caso de estudio específico en esta investigación y se profundiza en su proyecto en el quinto capítulo. No obstante, resulta conveniente resaltar la intervención artística que realizaron en el contexto del Simposio AABAS.

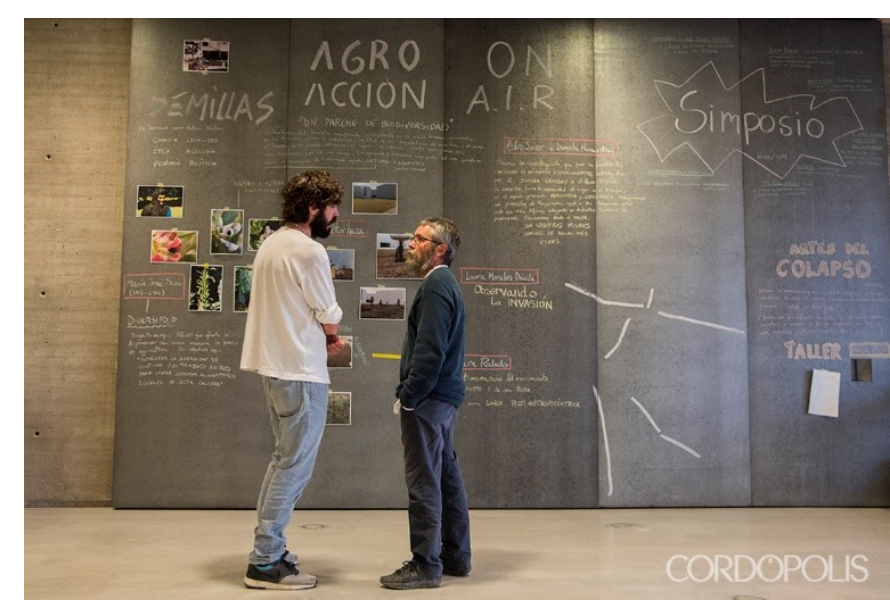

Imagen 43. Instalaciones del C3A en las que se desarrolla el Simposio Aabas, 2017. Fuente: Toni Blanco, cordopolis.es

Culturhaza, en su habitual defensa por las semillas autóctonas, por el papel del agricultor/a y por la biodiversidad, plantearon una acción titulada Parche de biodiversidad, dicha obra fue llevada a cabo en un pequeño terreno enfrente del edificio C3A donde tuvo lugar el simposio. La propuesta artística contaba con semillas de habas, altramuces, escanda y arvenses, estas últimas son las Ilamadas como "malas hierbas". Dichas semillas fueron facilitadas por la doctora María José Suso (IAS CSIC), la investigadora también realizó charlas sobre las semillas y los polinizadores en el transcurso de la acción Parche de biodiversidad. En el contexto de esa combinación de especies se trabajaron cuestiones de alimentación local, semillas autóctonas, nutrición de los 
suelos, la calidad de las cosechas, el papel del agricultor/a y el del consumidor/a.

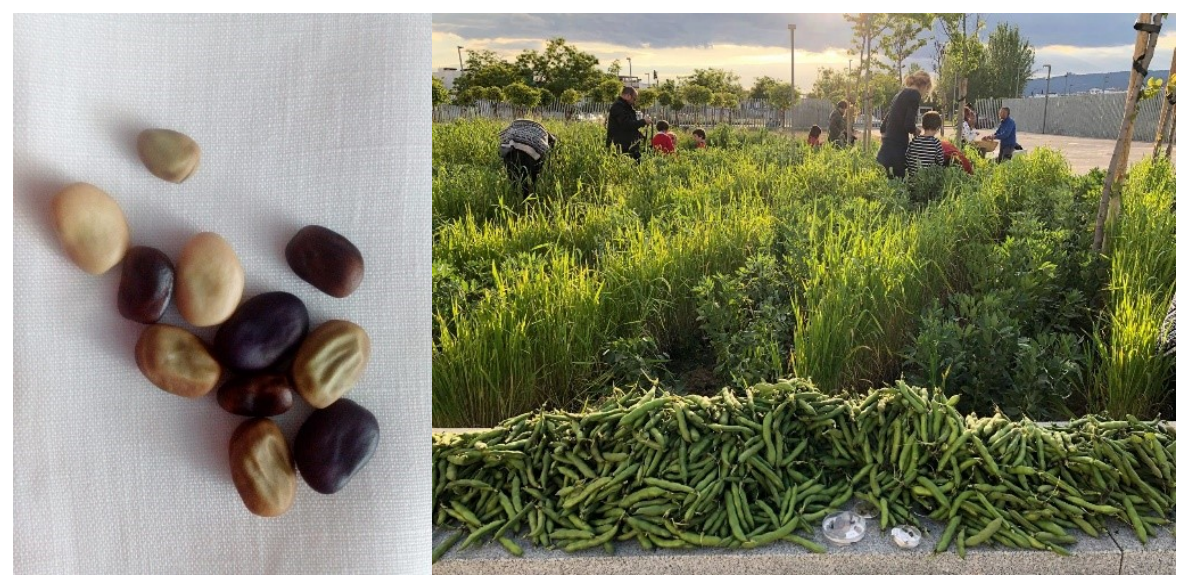

Imagen 44. Parche de biodiversidad, variedad de habas.

Simposio Abbas, Culturhaza, 2018. Fuente: La Fragua Imagen 45. Parche de biodiversidad, acción cosecha de las habas. Simposio Abbas, Culturhaza, 2018. Fuente: La Fragua

En el proceso de la acción intervino la comunidad, siendo partícipe de todo el proceso, desde la siembra hasta la cosecha. De tal forma tanto los artistas como los participantes entraron en un vínculo estrecho con el proceso de la obra, con las diferentes fases del proceso de cultivo y con la conciencia de una producción de alimentos sana, diversa y ecológica. La última de las fases fue la acción de recoger la escanda, el primer cereal que fue domesticado por el ser humano y que desde Culturhaza están recuperando. Antonio, director de Culturhaza, en una entrevista para el diario digital de Córdoba destacaba,

La gente ha de entender que lo que supuso la revolución verde con los químicos y los herbicidas es una estrategia puramente económica. Las últimas investigaciones agrícolas ya no buscan la superproducción, sino la producción de calidad capaz de regenerar la tierra y mantener el nivel de crecimiento del ser humano (Velasco, 2017: 1). 


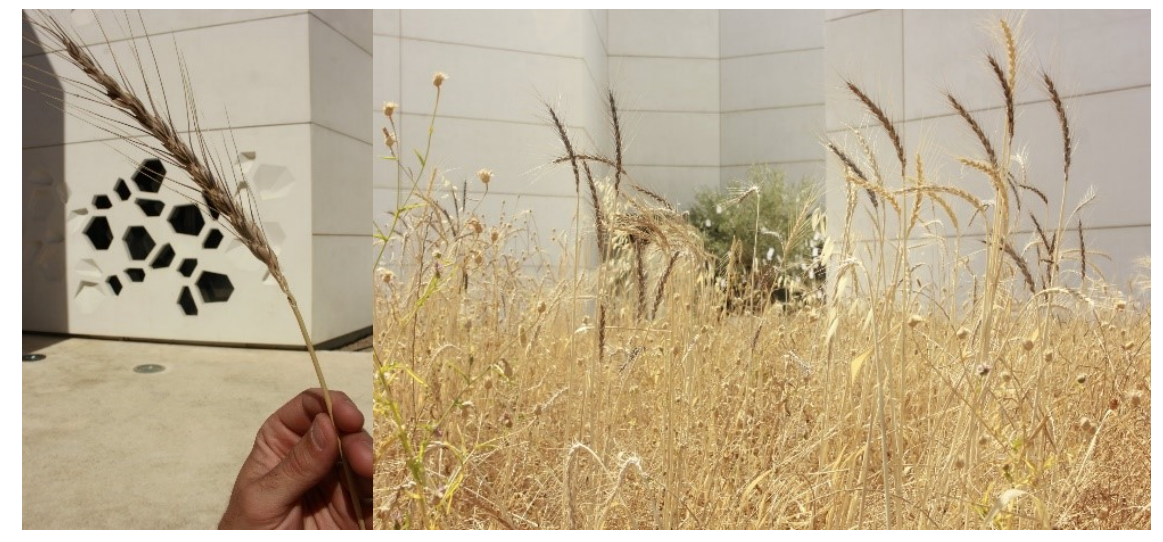

Imagen 46. Parche de biodiversidad, detalle de la escanda.

Simposio Abbas, Culturhaza, 2018. Fuente: La Fragua Imagen 47. Parche de biodiversidad, cosecha de la escanda.

Simposio Abbas, Culturhaza, 2018. Fuente: La Fragua

Antonio, como veremos en el último capítulo, dirige una producción agrícola ecológica de siete hectáreas donde está demostrando que se pueden producir unas cosechas sostenibles, diversas, ecológicas y con un alto valor nutritivo, simultáneamente realizan propuestas artísticas y difunden sus resultados.

Siguiendo en la línea de colectivos artísticos, destacamos proyectos como los impulsados por Fernando García Dory en Campo Adentro (Madrid), Inland o La escuela de pastores (Asturias), son iniciativas con la intención de recuperar y mantener en el tiempo prácticas y conocimientos que cada vez están más en desuso. Campo adentro se basa en los conceptos de arte, agricultura y territorio, realizan diversas propuestas y grupos de debate en diferentes zonas, tanto a nivel estatal como internacional. Se comparte el conocimiento, se abren discusiones y se generan resultados que son expuestos a través de publicaciones o propuestas artísticas que vehiculan las conclusiones y los pensamientos compartidos. Se inició en el contexto de un congreso internacional que tuvo lugar en el Museo Nacional Centro de Arte Reina Sofía de Madrid (España), marcando el inicio de nuevas iniciativas futuras. En cuanto a Inland, tuvo su primer encuentro de investigadores y creadores en 
una aldea de Cangas de Onís en julio del 2018. A lo largo de una semana se organizaron conferencias, charlas, salidas de campo, debates, tiempos para el trabajo creativo y presentación de propuestas artísticas. En el programa confluyeron diversos campos científicos (economía ecológica, sociología, agronomía, ingeniería sostenible, bioarquitectura, arte) con el fin de conectar con las comunidades locales y promover iniciativas para una transición hacia sociedades sostenibles.

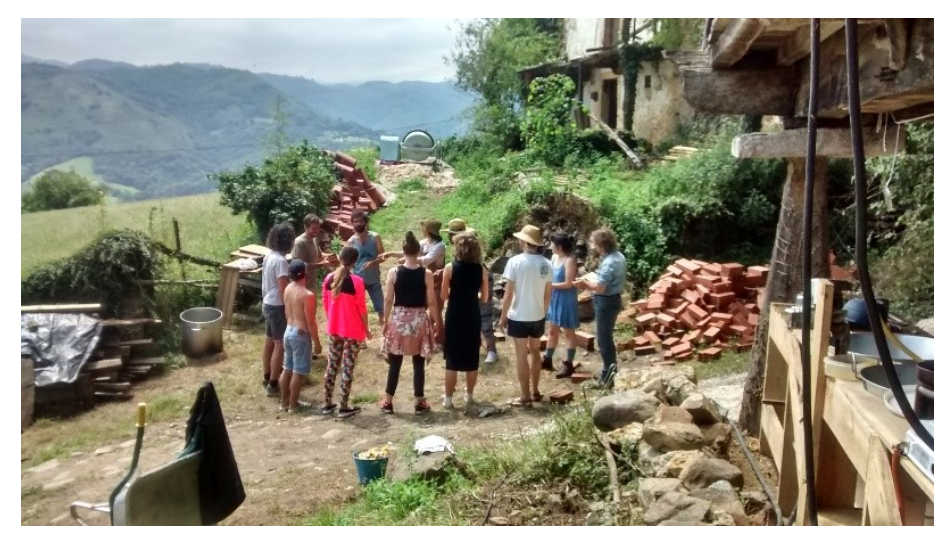

Imagen 48. Grupo de trabajo Inland. Cangas de Onís, 2018. Fuente: propia

En el encuentro de 2018, se reunieron estudiantes de diferentes disciplinas y países, donde pudieron compartir sus experiencias y conocimientos. Si bien, el programa de actividades y charlas era muy completo y diverso, se notaron carencias de tiempos más distendidos para la reflexión, el descanso y la exploración a nivel individual. Periodos que consideramos necesarios para el asentamiento de los conocimientos compartidos, para la observación y la meditación.

Así pues, en los tiempos de trabajo colectivo, se realizó una división por grupos temáticos donde se trabajaron la montaña, el bosque y la aldea por separado. Destacamos el colectivo que trabajó en el concepto de la montaña, donde se desplazaron varios días a la cima de un monte próximo a la aldea y 
experimentaron de primera mano la labor del pastoreo. Fueron acompañados de uno de los pocos pastores de ovejas que quedan en la zona y el cual también está implicado en la Escuela de pastores (grupo de transmisión del conocimiento del pastoreo a nuevas generaciones interesadas en dicho oficio). El pastor les compartió su experiencia y sus labores del día a día.

Tras pasar la semana y asistir a las actividades programadas, el grupo de trabajo de la montaña compuesto por Nel Cañedo, Carla Rangel, Juxhina Spahiu, Sébastien Tripod, Stéphane Vérlet-Bottéro y Chiara Sgaramella, presentó su proyecto artístico, titulado Digesting tensions. Dicha propuesta fue una acción performativa donde se invitó a todos los participantes del programa a entrar en la bodega que contenía la casa principal de la aldea. Dicho espacio fue preparado minuciosamente, al entrar se repartieron unos trozos de tela que contenían una frase escrita, cada persona leía su texto y se sentaba en círculo alrededor de una mesa donde descansaba un queso elaborado por el pastor en las montañas.

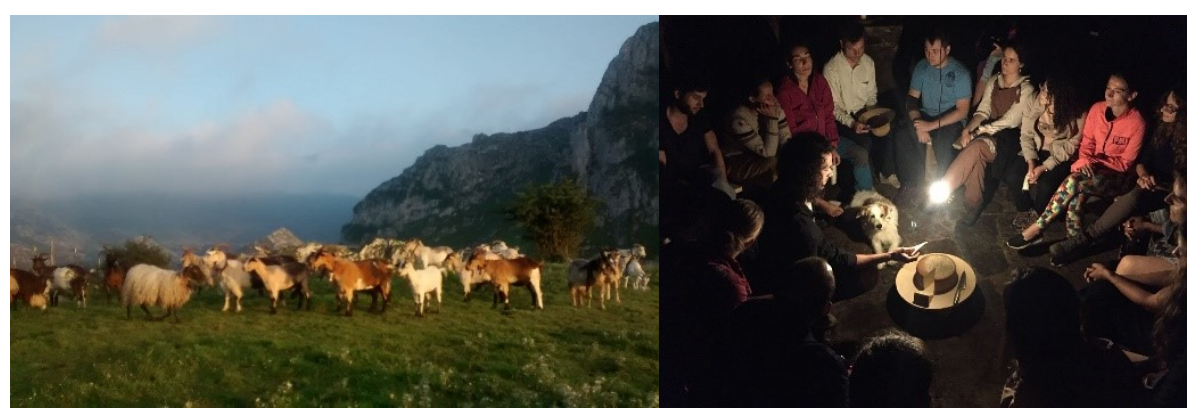

Imagen 49. Vista rebaño en el contexto de Inland. Asturias, 2018. Fuente: propia Imagen 50. Vista happening Digesting tensions. Inland, 2018. Fuente: Inland

En un ambiente frío, silencioso e iluminado con un único punto de luz, cada persona aleatoriamente iba cogiendo un trozo de queso y al mismo tiempo que lo saboreaba expresaba con palabras las sensaciones que le inspiraba la 
frase que le había tocado junto con la experiencia vivida a lo largo de la semana. Finalmente, se creó un ambiente emotivo donde a modo de ritual todos los componentes de Inland pudieron compartir sus impresiones, generando un diálogo entre los múltiples agentes que conforman el ecosistema de los Picos de Europa. Así pues, el programa facilitó las vivencias y el conocimiento de una aldea remota en el norte de España a universitarios, investigadores, creadores y profesionales que no suelen estar en contacto con estos modos de hacer y vivir, ofreciendo un acercamiento a lo rural.

Por otra parte, también consideramos relevante el perfil de artistas que han centrado su trabajo o parte de él en las cuestiones agrícolas, en este ámbito destacamos creadoras como Lucía Loren. Esta artista y activista medioambiental, Licenciada en Bellas Artes por la Universidad Complutense de Madrid, realiza un cuidadoso trabajo artístico en el cual interactúa con la relación del ser humano, su entorno y el paisaje. En sus intervenciones utiliza los propios elementos que encuentra en la naturaleza, les realiza pequeñas variaciones y reflexiona sobre el concepto de paisaje cultural. Entre su extenso repertorio de obras, destacamos las más vinculadas a la agricultura, Arqueología de una huerta sería una de ellas (imagen 51).

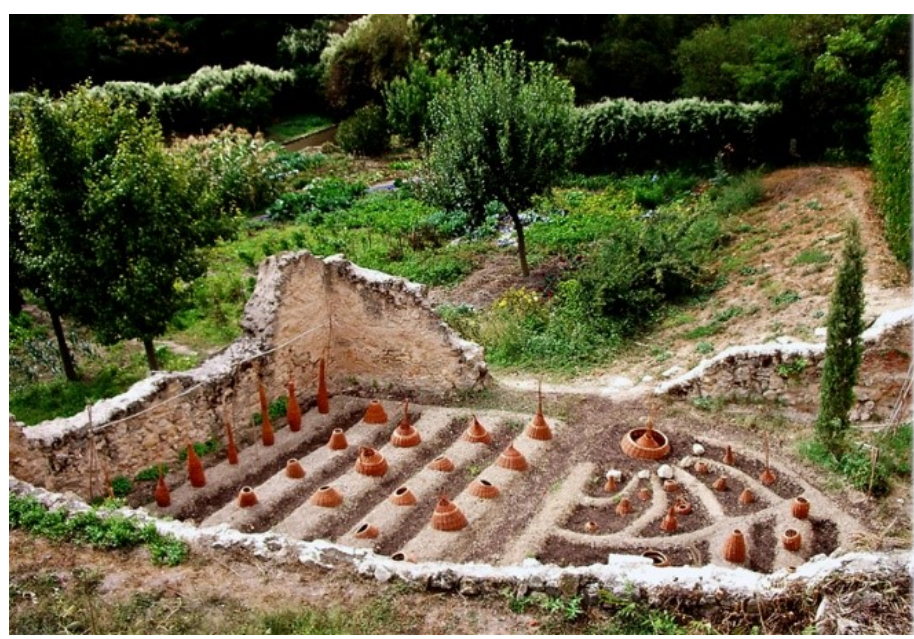

Imagen 51. Arqueología de una huerta. Ruinas, tierra y cestos de mimbre. Lucía Loren, 2008. Fuente: tramamimbre.com 
Esta obra fue realizada en el interior de unas ruinas localizadas en la Hontanilla, Valle del Clamores y Patio del Museo de Arte Contemporáneo Esteban Vicente de Segovia, dentro del marco de la exposición Naturalmente Artificial: el arte español y la naturaleza, 1968-2006. La intervención pretende recrear una huerta de una forma muy poética. Con la utilización de mimbre, tierra y ruinas simula la organización, las cosechas y la imagen de una huerta en pleno rendimiento. Loren visibiliza un espacio que podría estar en plena producción y ha sido engullido por la ciudad, genera un vínculo entre el lugar, el agricultor/a y la producción de alimentos cercana a través de esa imagen de huerta imaginaria. En una entrevista realizada por greenmuseum.org, Loren destaca que

Se trata de una huerta simbólica, donde los cestos se transforman en la huella fósil de una cosecha imaginaria. La huerta se visibilizaba desde diversos puntos de la ciudad, sirviendo de reclamo para que los paseantes recorrieran el espacio que conecta con este valle repleto de aljibes, regueras y huertas (Loren, 2012: 4).

La obra de esta artista también se genera en colectivo, en un estrecho vínculo con los habitantes de las zonas donde realiza sus intervenciones. Crea lazos que sirven de aprendizaje para ambas partes y les ofrece su propia visión tras la investigación, la observación y la interacción con el lugar y sus habitantes. Otra de las obras de Lucía Loren en relación con el espacio agrícola y su cosecha es Al hilo del paisaje (imagen 52 y 53).

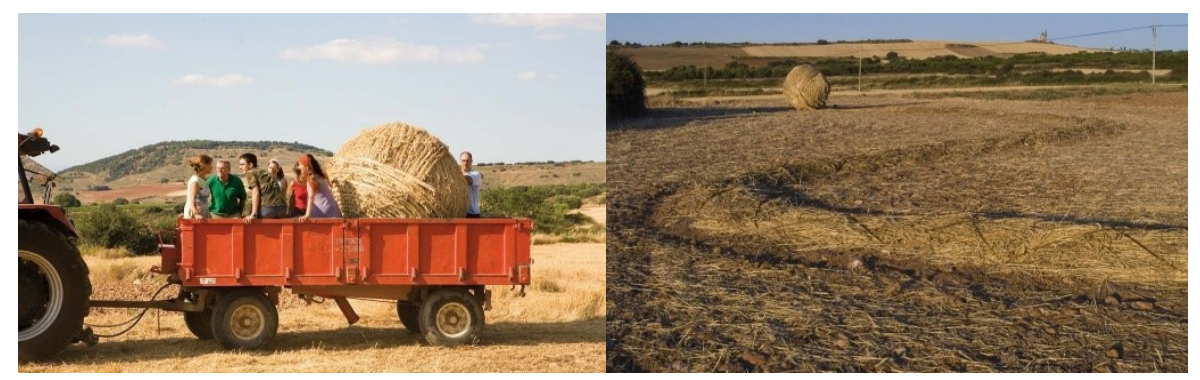

Imagen 52. Al hilo del paisaje, Santa Lucía de Ocón, La Rioja. Lucía Loren, 2007. Fuente: lucialoren.com Imagen 53. Al hilo del paisaje, Santa Lucía de Ocón, La Rioja. Lucía Loren, 2007. Fuente: Iucialoren.com 
Loren y los agentes que colaboraron con ella tejieron un gran ovillo de trigo (unos 3 metros de diámetro), de un modo muy simbólico cosieron la tierra con el trigo, reparándola y uniéndola con sus propias cosechas. Con los materiales que les ofrece el campo y con los recursos que disponen los agricultores y las agricultoras intervinieron el campo agrícola de una forma muy sutil a la vez que impactante visualmente, pero que se integra en el paisaje generando una nueva estampa poco usual.

Utilizar los propios materiales del paisaje, se convierte en una herramienta de investigación sobre la que trabajar para comprender el proceso cíclico de continuas transformaciones sobre el que se dibuja el paisaje. La artesanía ha sido una gran fuente de inspiración en mi proceso de trabajo con el paisaje. La figura del artesano, lo mismo que la del agricultor o la del pastor tradicional se señalan cómo referencia a seguir en relación con un modo de entender el desarrollo de una cultura material a partir de los propios recursos del territorio (Loren, 2012: 5)

Finalmente, en esa línea de ensalzar y elogiar el trabajo en el campo, citamos el proyecto \#HORTATTACK impulsado por el Ayuntamiento de Valencia en colaboración con Mercavalencia en 2017. El objetivo de la propuesta fue poner en valor el trabajo de los agricultores de la huerta de Valencia y promover una alimentación saludable y cercana. Para ello se realizaron unas frutas y verduras de tamaño monumental y se colocaron en diversos puntos estratégicos de la ciudad. Concretamente se materializaron un tomate, un limón, una naranja, una berenjena, una alcachofa y un pimiento, cultivos típicos de la huerta valenciana.

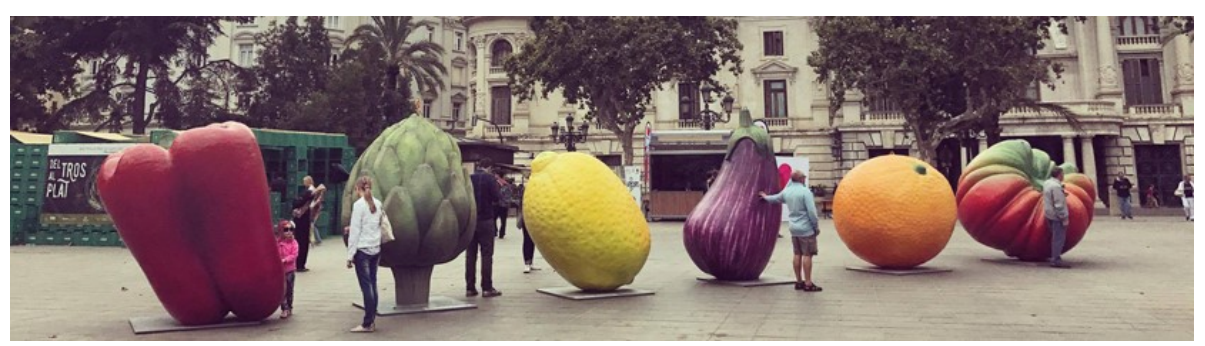


Además, junto a las obras esparcidas por la ciudad se lanzó una campaña por redes sociales con la etiqueta \#hortattack que incitaba a la población a fotografiar las piezas y subirlo a sus perfiles sociales con dicha etiqueta. La idea fue un éxito y muchas personas fueron las que utilizaron su propia creatividad para generar fotografías de las obras junto a otros elementos, frases o ellos/ellas mismas. De una forma dinámica se cautivó la atención de la población haciéndola partícipe de parte del proceso creativo. Asimismo, se generaron diversas actividades y certámenes durante el período expositivo donde se compartieron valores de alimentación de kilómetro cero y se elogió la huerta valenciana y sus agricultores/as. La propuesta también viajó por los municipios cercanos a Valencia en el contexto de eventos relacionados con la agroalimentación.

Finalmente, las obras volvieron a Valencia y se les quiso dar una segunda vida, esta vez bajo la etiqueta de\#HortaAttackReloaded. En esta propuesta, a modo de conclusión de la campaña, se realizó una colaboración con los artistas urbanos Julieta XLF, Vinz, Belén Segarra, Lolo, E1000 y AnimalitoLand, los cuales intervinieron las monumentales frutas y verduras generando otra visión creativa sobre cada alimento.

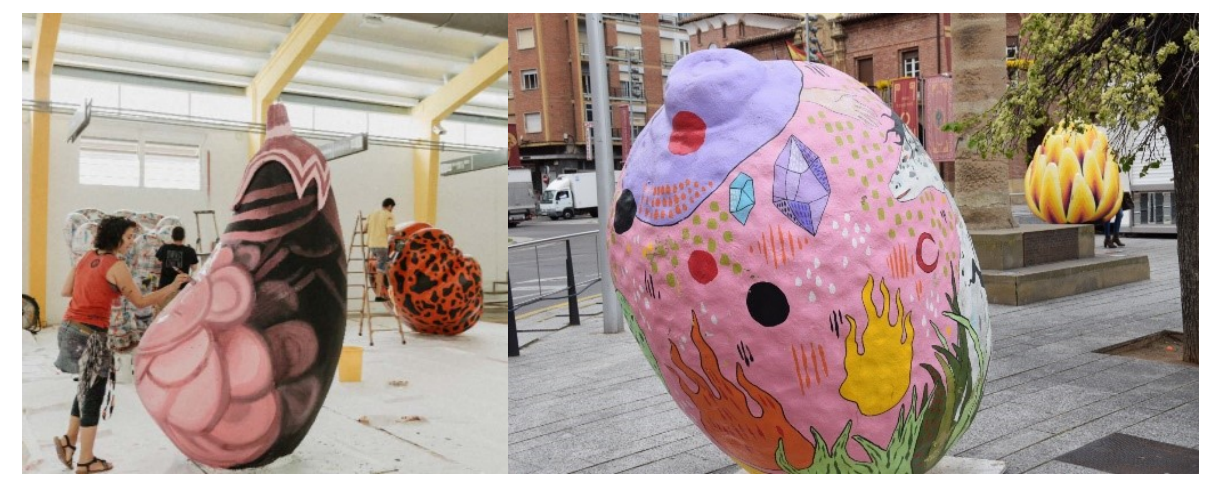

Imagen 55. \#HortaAttackReloaded, vista proceso elaboración. Valencia, 2017. Fuente: mercavalencia.es Imagen 56. \#HortaAttackReloaded, vista ubicación en la calle. Valencia, 2017. Fuente: mercavalencia.es 
Cada artista plasmó su propia visión creativa e imaginativa en el alimento elegido, dándoles un aspecto totalmente diferente. Con ello se volvió a vincular el arte con las cuestiones agroecológicas, haciendo partícipe a toda la población. De una forma muy dinámica y actual, arte, campo y redes sociales, se unieron poniendo en valor aspectos tan importantes como las labores en el campo, la producción local y la alimentación saludable.

\subsection{Conclusiones del capítulo}

El recorrido histórico de la relación representativa y simbólica entre agricultura y arte nos demuestra el grado de importancia que esta ha tenido en la conformación de las distintas culturas, siendo un factor esencial en la transición a sociedades asentadas en un territorio específico. Por lo tanto, la evolución y la creciente complejidad de las culturas no podría entenderse sin conocer sus avances en la técnica agrícola y la subsiguiente capacidad de almacenamiento de alimentos, que otorgaba estabilidad a la estructura social.

El valor de la agricultura en sus manifestaciones culturales se ha expresado principalmente a través de dos vías: la descriptiva, mostrando en entornos arquitectónicos sagrados y profanos las labores agrícolas como identidad de una cultura; y la simbólica, creando diosas y símbolos del agro, que generaban un vínculo entre el poder de la deidad y la abundancia de las cosechas. De tal forma la agricultura no se queda tan solo en la parte técnicoproductiva, sino que afecta a todos los aspectos de las culturas históricas, incluyendo la espiritualidad.

La estructura agrícola ha sido fundamental en la definición de las sociedades, así como en la jerarquización de estas, incluida la perspectiva de género. Es algo que hemos visto representado a través del arte, sobre todo en la Edad Moderna. Algunos autores relacionan el inicio de las sociedades sedentarias con el principio de la jerarquización social y el paso de sociedades matrifocales a sociedades patriarcales, introduciendo principios de poder más piramidal. 
Con la segunda revolución industrial y la revolución verde, la ciudad y la técnica, así como las innovaciones poéticas de las vanguardias históricas, sustituyen en gran medida a la agricultura como tema prioritario del arte en su capacidad de evocación y reflejo de la identidad social. Será solo en la segunda parte del siglo XX cuando se retomará el interés de la reflexión artística sobre la agricultura, pero ya desde la perspectiva crítica del deterioro socio ecológico que supone la agricultura intensiva de base agroquímica. A partir de aquí surgen caminos muy variados de reflexión artística sobre la necesidad de armonizar cultura y naturaleza, donde la agroecología será un tema de gran importancia en el arte, así como un nuevo fin cultural y estético en el ámbito de las humanidades ecológicas. 



\section{CAPÍTULO 2}

\section{AGRICULTURA INDUSTRIAL Y SU VISIÓN DESDE LAS PRÁCTICAS ARTÍSTICAS}

El objeto de estudio en este capítulo se centra en analizar la agricultura industrial a través de la práctica artística. Una vez contextualizada la situación de los monopolios agrícolas, veremos cómo el arte contribuye a la difusión y crítica de estas prácticas agresivas con la biosfera y sus habitantes. La proletarización del campesinado, la contaminación por el uso de agrotóxicos y la manipulación genética serán algunos de los puntos clave. Asimismo, el arte sirve de vehículo a activistas en sus campañas de crítica hacia estas prácticas abusivas. Cabe señalar que el artista tiene un papel clave a la hora de visibilizar las consecuencias de esta industria en los pobladores rurales, ya que la práctica artística contribuye desde diferentes ámbitos y lugares dando voz al campesinado que se encuentra amenazado y desprotegido. En este capítulo nos centramos en la situación agrícola industrializada, monopolizada y globalizada, así como en las propuestas artísticas que nacen para cuestionar estos modelos productivos abusivos, todo ello en el contexto del siglo XXI. Destacamos la situación que vive Argentina dada la libertad que se da en este país a la agricultura industrial y al uso abusivo de agrotóxicos (algunos incluso prohibidos en otros países). El doctor en Biología Fernando Barri y el Licenciado en Sociología Juan Wahren en su artículo sobre el 
modelo sojero de desarrollo en la Argentina, señalan la década de los 90 como el punto de partida de estos modelos de producción,

A partir de la década de 1990 comienzan a profundizarse en Argentina un modelo de desarrollo económico basado en la producción intensiva del monocultivo de la variedad de soja transgénica RR (Roundup Ready, porsu sigla en inglés) (Barri y Wahren, 2009: 1).

Asimismo, citaremos las interesantes iniciativas artísticas que han surgido en el país a lo largo del siglo XXI en protesta hacia tales situaciones. No obstante, dado que este modelo productivo se sitúa en un contexto globalizado, también se da en otros países como Estados Unidos, Brasil, Colombia o la India, por citar algunos. Por tanto, hemos incluido en el estudio proyectos y artistas de otras zonas geográficas que hemos considerado relevantes en la lucha y el cuestionamiento de estas prácticas agrícolas tan agresivas.

\subsection{Un modelo insostenible y destructor: la agricultura industrial y sus consecuencias}

\subsubsection{Los inicios}

El crecimiento de la población humana a lo largo de los siglos ha ocasionado la necesidad de elevar la producción de las cosechas para el consumo alimentario (humano y animal) y para la creación de otras materias como fibras o biocombustibles. Como hemos visto en el anterior capítulo, la Revolución Verde fue la que vendió, mediante los packs tecnológicos, esa idea de abundantes cosechas con la modificación genética y el uso de insumos. Pero, con los años, esa sobreexplotación a la tierra empezó a dar indicios de problemas de contaminación, pérdida de biodiversidad y desigualdad social. Además, esta tecnología pronto se desvió de intentar aportar soluciones a los problemas de desnutrición y carencias de alimentos de los países más desfavorecidos y pasó a fomentar el capitalismo. Por ejemplo, con la demanda de los biocombustibles y los incentivos que los gobiernos ofrecían a los agricultores, empezaron a destinar los cultivos a la producción de dichos insumos. El físico Alok Jha en su libro 50 maneras de destruir el mundo, destaca que 
De acuerdo con las cifras del Departamento de Agricultura de Estados Unidos, una cuarta parte del maíz y otros granos cultivados en el país en 2008 se utilizó para la producción de etanol. En lugar de ello, esos ciento siete millones de toneladas de cereales podrían haberse utilizado para alimentar trescientos treinta mil millones de personas durante un año, según el nivel de consumo medio mundial (Jha, 2012: 97).

El impulso por no depender de recursos fósiles como el petróleo produjo una desestabilidad alimentaria, de hecho, Jha recalca

Y un informe del Banco Mundial, de 2008, concluía que el impulso de los biocombustibles en Estados Unidos y Europa había hecho aumentar los precios de los alimentos en un 75 por 100. El pan se encarece en Inglaterra, las tortillas se hacen inasequibles en México. El aumento de los precios de los alimentos envió a las calles a miles de manifestantes en los países del Mediterráneo meridional y el norte de África (Jha, 2012: 98).

Todo esto nos lleva a plantearnos diversas cuestiones, si bien la Revolución Verde consiguió un gran aumento productivo de las cosechas, ¿se mantiene ese nivel de producción con el paso de los años? ¿Cómo afectan los intereses capitalistas a la producción de la alimentación? ¿Cuáles son las consecuencias sociales y ambientales de la contaminación de estos modos de producir? ¿Qué consecuencias sufre el pequeño y mediano agricultor/a? ¿Cómo afectará a la biosfera los organismos modificados genéticamente? ¿Qué papel tiene el arte en la difusión y comprensión de todas estas cuestiones? En los siguientes apartados vamos a ir desgranando estas cuestiones con la intención de acercarnos a sus posibles respuestas.

\subsubsection{La contaminación y el arte que la vislumbra}

La sociedad moderna con su afán capitalista, con sus modos de producir y consumir, ha provocado una gran contaminación planetaria. En el caso de la agricultura, empresas transnacionales motivadoras de la Revolución Verde crearon una serie de químicos y fertilizantes de síntesis que provocaron grandes impactos en la biosfera y sus habitantes. Algunos de estos químicos 
son el DDT, el Agente Naranja, el 245 T (componente principal del Agente Naranja), los PCB, el glifosato o la rBGH (también llamada hormona del crecimiento) $)^{4}$. El afán del ser humano por aumentar las cosechas, disminuir la mano de obra, controlar las plagas y mantener los campos libres de arvenses, sin importar cómo las técnicas utilizadas podían influir a corto y largo plazo en el planeta y sus habitantes, nos ha llevado a una situación insostenible. La humanidad se enfrenta a una cantidad de enfermedades derivadas de la utilización de estos químicos que no tiene precedentes, así como a una gran pérdida de biodiversidad.

Con el tiempo se han ido prohibiendo gran cantidad de los químicos antes mencionados, pero aún son muchos los que persisten y se utilizan en nuestro planeta. En primer lugar, el DDT y el Agente Naranja, han sido algunos de los químicos utilizados que más controversia y efectos secundarios ha ocasionado. El DDT fue introducido como plaguicida en la Segunda Guerra Mundial. Por otra parte, en la Guerra de Vietnam, el Agente Naranja fue utilizado como arma química para destruir las cosechas que alimentaban a las guerrillas y las malezas donde se escondían los vietnamitas. En la actualidad, Vietnam sigue sufriendo las consecuencias de aquella devastadora catástrofe ambiental, social, económica y sanitaria.

El DDT, un químico bioacumulable persistente que puede permanecer en el entorno por largos períodos de tiempo y no se descompone con facilidad. Este tipo de químicos se acumulan en los tejidos de los animales y pueden incorporarse a la cadena alimenticia o pasar a las nuevas generaciones a través de la placenta o durante la lactancia (Jha, 2012: 134).

\footnotetext{
4 DDT: compuesto organoclorado principal de los insecticidas, es incoloro, inodoro y prácticamente insoluble en agua, actualmente prohibido. Agente Naranja: mezcla de dos herbicidas hormonales 2,4-D y 2,4,5-T, actualmente prohibidos. PCB: policlorobifenilos creados por Monsanto que sirvieron como líquidos refrigerantes, solventes de síntesis de medicamentos, plásticos, colorantes y lubrificantes; se fabricaron principalmente en Anniston, actualmente una ciudad fantasma donde sus habitantes padecieron cáncer o chloroacnea actualmente prohibido. Glifosato: herbicida altamente contaminante utilizado a nivel mundial, actualmente prohibido en Austria. rBGH: hormona recombinante de crecimiento inyectada a las vacas para forzarlas a producir más lechey, por tanto, estas tienen más probabilidades de enfermar; prohibida en la Unión Europea, Australia, Nueva Zelanda y Canadá.
} 
El artista vietnamita Dinh Q. Lê, a través de su obra invita a reflexionar al público sobre las consecuencias que aún sufren los habitantes de Vietnam tras los ataques que sufrieron en los años 60 con el DDT. Lê crea pequeñas esculturas de hermanos siameses a los que les da un aspecto de deidad.

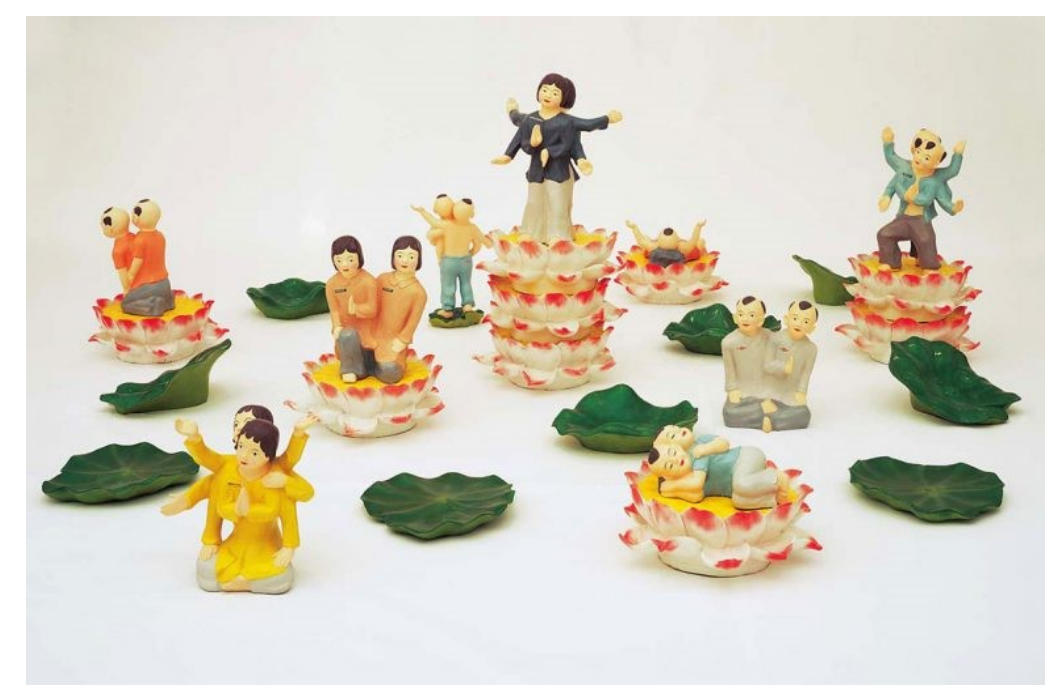

Imagen 57. Lotus land, fibra de vidrio, 27 piezas de polímero, pintura y madera. Dinh Q. Lê, 1999. Adquirido por Galería de Arte de Queensland, 2006. Fuente: aaa.org.hk

Además de incitar al cuestionamiento sobre los numerosos nacimientos de siameses como consecuencia de los tóxicos vertidos en la Guerra de Vietnam, hace una similitud con las mitologías y las deidades que son veneradas por sus habitantes, las cuales normalmente muestran una imagen con numerosas extremidades. Las piezas que componen la obra ostentan mucho color y formas amigables, dejando de lado la imagen impactante de las deformaciones y las consecuencias en la piel que ocasionó el Agente Naranja en los vietnamitas. El artista crea una nueva mirada para analizar estas situaciones desde esa relación entre las creencias y la realidad.

En 2018, Dinh Q. Lê realizó una exposición en el Tang Contemporany Art de Bangkok (Tailandia) comisariada por Loredana Pazzini-Paracciani donde 
siguió mostrando esa mirada contemporánea de los efectos del Agente Naranja en Vietnam, un tema que aún se considera tabú en la actualidad.

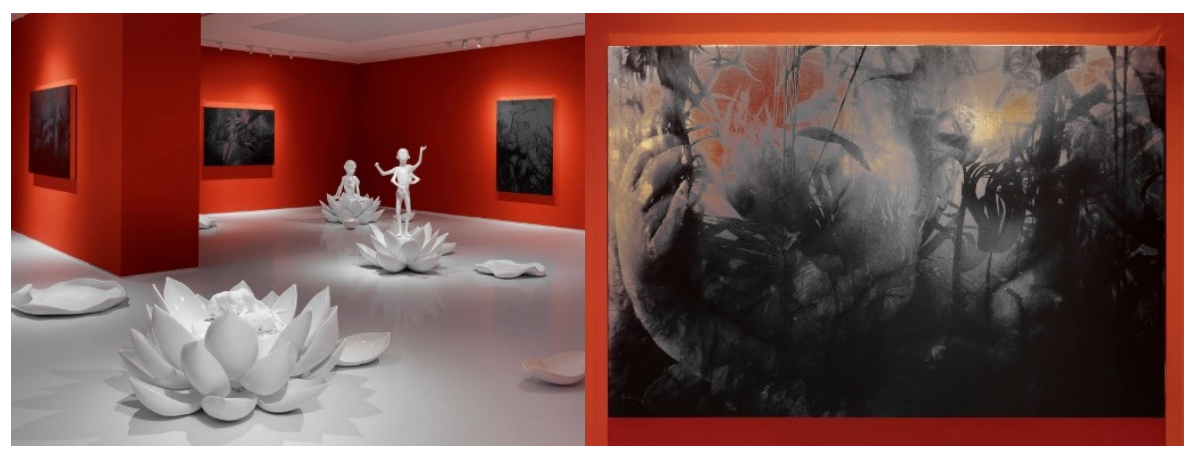

Imagen 58. Vista exposición Pure Land, Bangkok.

Dinh Q. Lê, 2018. Fuente: tangcontemporany.com Imagen 59. Untitled \#1, Light from darkness, truth always rises. Pure Land, Bangkok. Dinh Q. Lê, 2018. Fuente: tangcontemporany.com

En esta muestra de arte, Lê, optó por la neutralidad del blanco en sus esculturas, pero siguió haciendo alusión al simbolismo propio del budismo, generando esa relación entre la imagen de las creencias de los vietnamitas y la realidad de las consecuencias de este herbicida. También, se observan sutilmente las imágenes de niños deformes que se entreven entre trazados de malezas en sus impresiones UV sobre tela de vinilo plateado. Un aura de inocencia y pureza unida a las atrocidades de la guerra es el medio utilizado por el artista para cuestionar y hacer reflexionar sobre la actual situación de los habitantes de Vietnam.

Por otra parte, el DDT fue utilizado para combatir plagas con la intención de controlar y erradicar enfermedades como la malaria. Por ejemplo, en Costa Rica durante 35 años se estuvo rociando este químico en las casas familiares. Yendry Vargas Trejos en su artículo de la revista costarricense La Agroecóloga señala que, 
Se estima que entre 1950 y 1985, en Costa Rica se utilizaron alrededor de 1.400 toneladas de DDT en salud pública y se rociaron alrededor de 2 millones de viviendas. En 1981 se restringió el uso de este insecticida, y en 1998 se prohibió su importación y venta en el país (Vargas, 2018: 45).
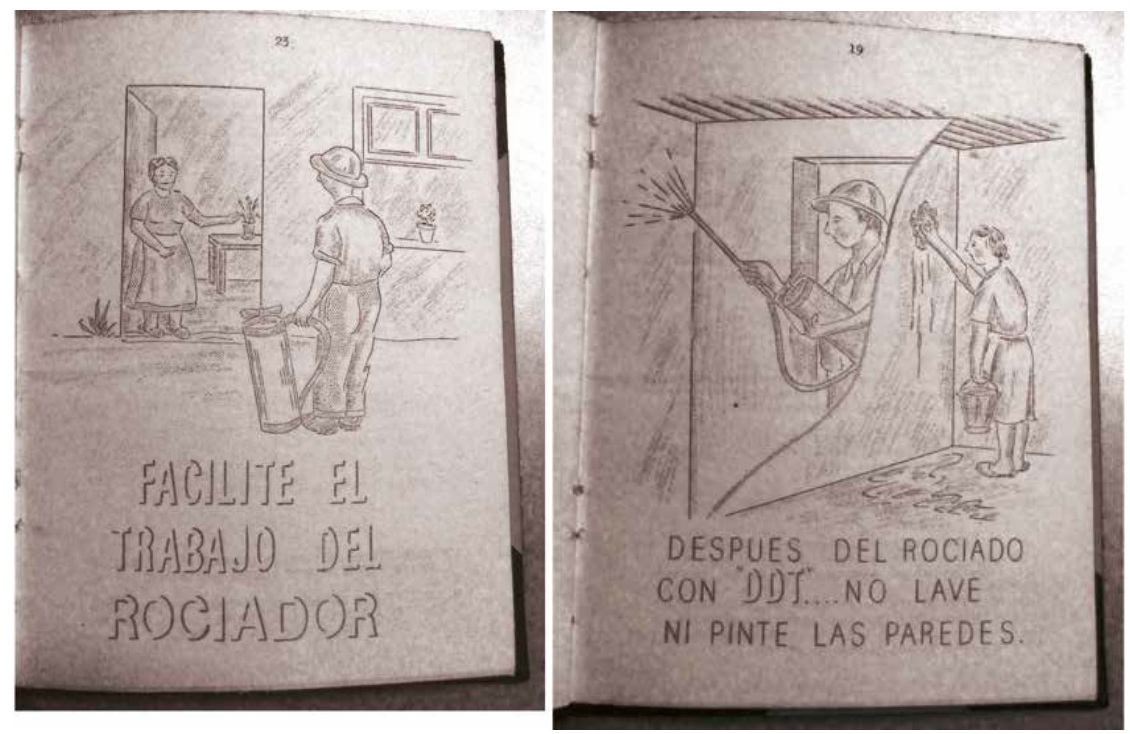

Imagen 60. Ministerio de Salubridad Pública, Departamento de Educación Sanitaria, Costa Rica, 1958. Fuente: La Agroecóloga

Las familias tenían que convivir con este químico, el Estado realizó campañas publicitarias para alentar a la población a colaborar en la fumigación del DDT (imagen 60). Sin embargo, la población no era consciente de la peligrosidad de este insecticida, siendo la publicación Primavera Silenciosa de Rachel Carson en 1962 la que marcó el inicio de la prohibición de estos químicos al evidenciar la alta toxicidad del DDT. No obstante, tras la prohibición del DDT se generaron conflictos morales y ecológicos, ya que unos defendían la salubridad del planeta y de sus habitantes y otros abogaban por el poder utilizar este químico para erradicar epidemias como la malaria. Además, la empresa Monsanto creadora del Agente Naranja, negando la peligrosidad del DDT pronto se puso a fabricar nuevos químicos como los PCB o el glifosato (Roundup como marca comercial). La periodista y documentalista Marie- 
Monique Robin en su libro El mundo según Monsanto señala cómo la empresa defendía sus productos y aseguraba que no provocaba efectos secundarios,

"Sentimos compasión por las personas que creen haber sido dañadas y comprendemos que traten de conocer la causa", declara en 2004 Jill Montgomery, uno de los portavoces de la empresa. "Pero todas las pruebas científicas dignas de credibilidad demuestran que el agente naranja no provoca efectos sanitarios a largo plazo"

Negarlo todo, por sistema. La misma negación que caracteriza hoy la postura de la empresa en relación al Roundup, el herbicida que lanzó al mercado en el mismo momento en que a mediados de los setenta se prohibía definitivamente en Estados Unidos el 2,4,5-T (y después en el resto del mundo) ... (Robin, 2008: 112).

Más adelante nos adentraremos en la problemática del Roundup, analizando el caso de Argentina. Todas estas prácticas tan abusivas han ocasionado que cada vez haya más colectivos que se movilicen en crítica hacia tal contaminación planetaria. En el ámbito del arte encontramos un aumento de propuestas artísticas centradas en cuestionar y hacer reflexionar al espectador sobre el pasado, presente y futuro de estas acciones y sus consecuencias. Por ejemplo, la exposición Contaminaciones contemporáneas: el ambiente natural como territorio del arte, realizada en Brasil en 2011 recoge una serie de obras de artistas preocupados por las problemáticas sociales, ambientales, económicas, políticas y sanitarias derivadas de la contaminación. Centrándonos en el caso que nos ocupa, destacamos la obra de Marcela Moraga titulada Protección de los sentidos mostrada en dicha exposición.

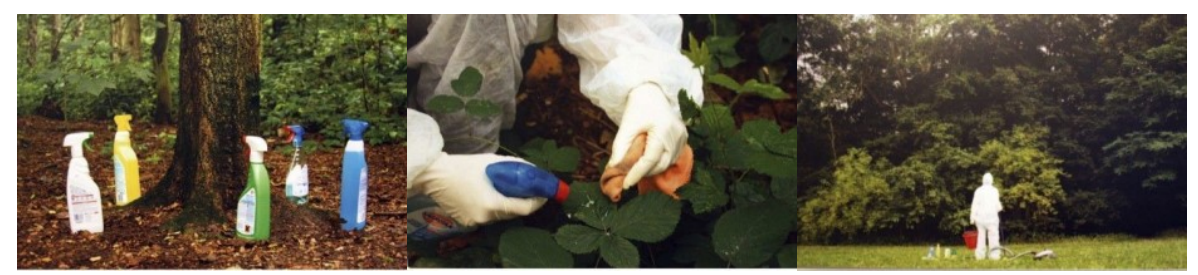

Imagen 61. Protección de los sentidos, fotografías y vídeo HVD. Marcela Moraga, 2010. Fuente: artishockrevista.com 
Moraga muestra una serie de fotografías y un vídeo de su performance donde aparece vestida con un equipo de protección y una serie de botes de limpieza y se predispone a limpiar una zona de bosque natural. La artista, con el uso de la ironía y la simulación de estar desinfectando el bosque (en realidad no lleva detergentes ni desinfectantes) apela al espectador a reflexionar acerca de ciertas prácticas abusivas que se realizan al entorno natural, ocasionando que cada vez queden menos espacios vírgenes.

Por otra parte, en la línea de la contaminación por pesticidas destacamos la obra de Suzan Shutan donde investiga la cantidad de nitratos derivados de los fertilizantes utilizados en la agricultura industrial y los herbicidas que llegan al agua. En su caso, realiza un estudio de los niveles de contaminación en los recursos hídricos del Estado de Nebraska. La artista destaca la alta contaminación del agua en algunas zonas por la atrazina, un herbicida muy utilizado en Estados Unidos en los campos de maíz. Los efectos tras la exposición a este químico pueden llegar a ser muy graves, interfiere en la actividad hormonal tanto de animales como de humanos. Científicos de México realizaron un estudio publicado en la Revista Internacional de Contaminación Ambiental, figurando como autora responsable Anne M. Hansen, donde destacaban que,

La exposición a la atrazina puede darse en el ambiente laboral, ya sea porvía inhalatoria o dérmica. Puede producir reacciones de irritación, así como alteraciones en las funciones de algunos órganos, problemas de reproducción y alteración en los niveles de hormonas; defectos de nacimiento en seres humanos (ATSDR 2003). La atrazina se considera ligeramente tóxica para la vida acuática (Graymore et al. 2001) y es un inductor de hermafroditismo en ranas, en concentraciones tan bajas como $0.1 \mu \mathrm{g} / \mathrm{L}$ (Hayes et al. 2002). Asimismo, la Agencia para la Protección Ambiental de los Estados Unidos (USEPA) determinó que existe evidencia de carcinogenicidad del herbicida en animales, más no en seres humanos (USEPA 2003) (Hansen, 2013: 67).

Aun así, este herbicida sigue utilizándose a nivel mundial, si bien hay países como Alemania, Suecia, Austria, Francia, Italia, Finlandia y Dinamarca que prohibieron su uso. Así pues, la artista Suzan Shutan, tras el análisis de los pozos en el Estado de Nebraska, plasmó el curso de los ríos con cinta azul 
sobre un muro blanco y fue colocando una serie de varillas metálicas que en su extremo sostenían una serie de pompones de algodón. Los diferentes colores de los pompones determinan si el nivel de contaminación de las aguas es mayor o menor según las zonas. De una forma muy simbólica, Shutan, mostró al público la dura realidad que viven en su Estado dada la alta contaminación por atrazina y nitratos.

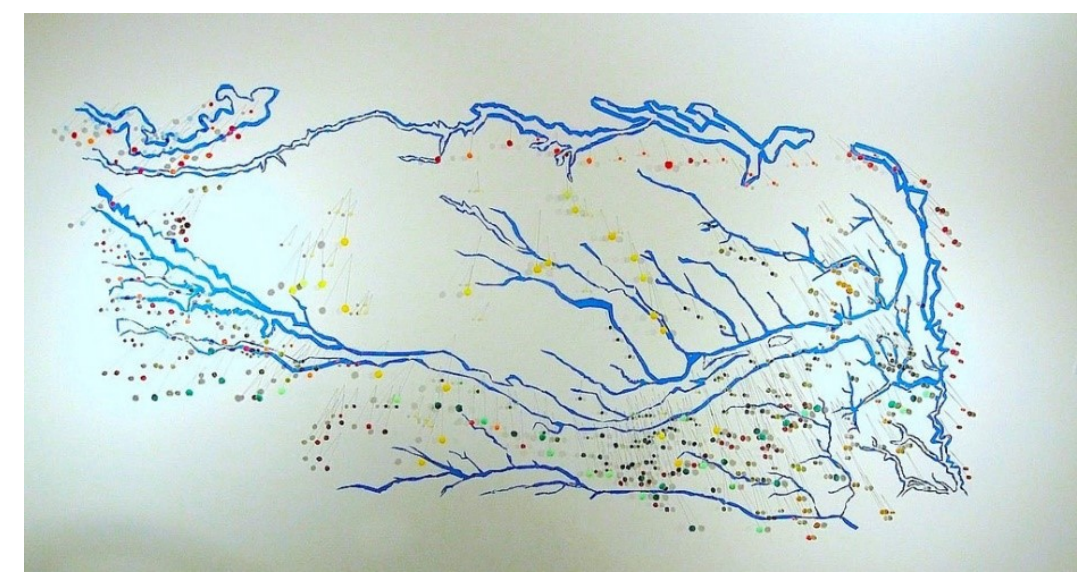

Imagen 62. Watered Down, cinta, alambre y pompones. Norfolk Art Center, NE. Suzan Shutan, 2016. Fuente: suzanshutan.com

\subsection{Agrotóxicos: el Roundup y el arte que lo cuestiona}

El Roundup es la marca comercial del herbicida glifosato, el más vendido a nivel mundial y producido por la empresa Monsanto. La salida al mercado de este producto vino marcada por la prohibición del DDT. De hecho, Monsanto, lo promocionó como un herbicida biodegradable. Marie-Monique Robin en su libro El mundo según Monsanto señala con qué frases se publicitaba dicho pesticida,

"Si, como Rex, usted detesta tener malas hierbas en su jardín, he aquí Roundup, el primer herbicida biodegradable. Destruye las malas hierbas desde el interior hasta sus raíces y no contamina ni la tierra ni el hueso de Rex. Roundup, jel herbicida que da ganas de utilizarlo!" Los amantes de los telediarios 
seguramente recuerdan este jovial anuncio de televisión en el que se ve a un perro pulverizar alegremente Roundup sobre las malas hierbas en medio del césped, antes de desenterrar el hueso que había escondido en el mismo lugar en el que el herbicida se había cargado las raíces de las plantas (Robin, 2008: 113).

Los agricultores lo utilizaban en masa para limpiar sus campos de arvenses antes de las plantaciones. También, Monsanto generó una variedad del Roundup con un enfoque hacia el mundo de la jardinería y del pequeño agricultor/a para eliminar sin esfuerzo esas hierbas no deseadas. Bajo la publicidad de que este producto no presentaba riesgos para el ser humano, animales y medio ambiente, se empezó a utilizar este herbicida en "todos los jardines de Francia y España, donde se utiliza abundantemente, sin protección alguna" (Robin, 2008: 116). En cambio, en 1996 y tras varias denuncias, se abrió una investigación sobre la toxicidad del Roundup. Se descubrió que la empresa había falsificado estudios con el fin de "ocultar una cantidad indefinida de muertes entre las ratas y ratones a los que se habían hecho las pruebas" (Robin, 2008: 118). Así pues, se decretó que la empresa transmitía mensajes engañosos y se

prohibe a Monsanto bajo pena de multa proclamar que su herbicida es "biodegradable, bueno para el medio ambiente, no tóxico, inofensivo y conocido por sus características medioambientales" (Robin, 2008: 120).

Aun así, tras la decisión de publicidad engañosa de los jueces estadounidenses, se sigue promocionando el Roundup por Europa. Sin embargo, en 2001 la Asociación de Aguas y Ríos de Bretaña llevó a juicio a la filial francesa de Monsanto después de verificar en varios estudios la presencia de glifosato en las aguas de los ríos bretones. Un juicio que consiguen alargar hasta 2007, año en que el tribunal resuelve que

La utilización combinada en las etiquetas y envases [de los herbicidas de la gama Roudup] de los términos y expresiones "biodegradable" y "deja el suelo limpio" [...] podían dejar creer falsamente al consumidor en la inocuidad total e inmediata de dichos productos a consecuencia de una degradación biológica rápida tras el uso, [...] cuando, por el contrario, pueden permanecer de forma 
duradera en el suelo e incluso extenderse a las aguas subterráneas (Robin, 2008: 122).

A pesar de que tras estas denuncias la empresa cambió su mensaje publicitario, se siguió vendiendo un producto altamente tóxico que es utilizado en grandes cantidades a nivel mundial. Las instituciones no destinan prácticamente financiación para la investigación sobre la toxicidad de estos productos, de hecho, que un científico/a se dedique a probar la toxicidad de los herbicidas puede acarrearle serios problemas en su carrera profesional.

Marie-Monique Robin nos expone el caso del profesor Robert Bellé, de la estación biológica de Roscoff, que depende del Centro Nacional de Investigación francesa y del Instituto Pierre y Marie Curie. El profesor Bellé realizó un estudio sobre los efectos de los pesticidas en los erizos de mar, ya que los efectos medidos en las células de estos animales son extrapolables al ser humano. En sus investigaciones se dieron cuenta de que los efectos que causaba el Roundup en las células era mucho más importante que los demás productos, es por ello por lo que se dedicaron a estudiar este herbicida. Los investigadores descubrieron que el Roundup afectaba a un punto clave del control de la división de las células, determinando que el Roundup podía inducir a las primeras etapas de cáncer. Las células afectadas podrían conducir al origen de cáncer treinta o cuarenta años después (Robin, 2008: 128-131). La concentración de Roundup utilizada en los estudios es muy inferior a la utilizada en agricultura y señala,

De hecho, una gotita basta para afectar al proceso de división celular. Esto quiere decir concretamente que para utilizar el herbicida sin restos no solo hace falta llevar un mono y una máscara, sino también asegurarse que no hay nadie en quinientos metros a la redonda... (Robin, 2008: 132).

Además, Bellé sostiene que realizaron los mismos estudios con el glifosato puro y pudieron observar que ahí no surgía ningún efecto. Por tanto, determinaron que los estudios que se ejecutaron previos a la homologación del Roundup se efectuaron con el glifosato puro sin los demás componentes que constituyen el Roundup. Dada la importancia de las investigaciones 
informaron inmediatamente a su institución y al propio Monsanto, incluso antes de hacer públicos los resultados. Sorprendentemente recibieron negativas un tanto agresivas por parte de la empresa Monsanto y peticiones expresas por parte de su institución para que no se hicieran públicos tales resultados (Robin, 2008: 132).

El capital movido por el uso de un herbicida tiene un gran peso a nivel mundial. Joseph Mendenselson en su artículo acerca del Roundup en la revista The ecologist, señala que "las ventas del glifosato alcanzan 1.200 millones de dólares USA al año" (Mendenselson, 1998: 23). Además, en el año 2000 se creó el Plan Colombia donde se destinaron ingentes cantidades de Roundup Ultra (una variedad que cuadruplica los efectos del Roundup) para erradicar las plantaciones de coca, vertiendo el herbicida desde avionetas indiscriminadamente, pasando por zonas habitadas. Una fuente de dinero para la empresa Monsanto a costa de la intoxicación de millares de personas.

En este contexto, en la imagen 63 podemos observar la contundente obra titulada Agua Dulce del artista argentino David Piero Ojeda, la cual sintetiza ese afán capitalista que se sitúa por encima del bienestar humano, animal y ambiental.

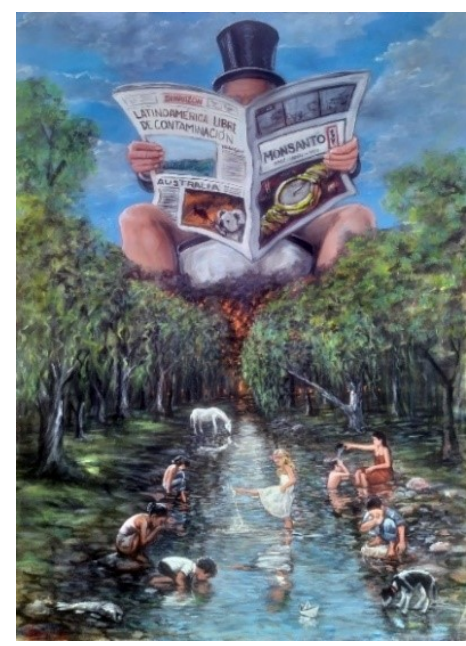

Imagen 63. Agua Dulce, acrílico. 


\subsubsection{Intoxicación por agrotóxicos, caso Argentina}

Argentina es un importante país productor agrícola, cosecha trigo, girasol o maíz, pero con los años ha ido tomando fuerza el cultivo de soja. Las cosechas producidas en Argentina, principalmente, son destinadas para la fabricación de piensos que alimentarán el ganado o para la elaboración de biodiesel. Fernando Barri, Doctor en Biología, y Juan Wahren, Licenciado en Sociología, en su artículo El modelo sojero de desarrollo en la Argentina: tensiones y conflictos en la era del neocolonialismo de los agronegocios y el cientificismotecnológico, señalan la década de 1990 como el comienzo de la producción intensa del monocultivo de la variedad de soja transgénica RR y puntualizan que se considera un

commoditie de alto valor en el mercado internacional (U\$ 900 la tonelada en la Bolsa de Chicago) (CME, 2010), orientada principalmente hacia la exportación. En efecto, la Argentina vende sólo a Europa alrededor de 2000 millones de dólares anuales en derivados de la soja. Otro actor importante del esquema de comercialización del monocultivo de soja es el mercado asiático (principalmente China), que, a partir de un aumento del consumo de carnes rojas en la dieta de su población, incrementó la demanda de soja como alimento para el ganado doméstico (son necesarios aproximadamente 5 kilos de soja para producir 1 kilo de carne) (Latarroca et al., 2004). En este sentido, cabe resaltar que las ganancias por las exportaciones de soja durante el año 2008 representaron 25.000 millones de dólares (La Nación, 2008a), aproximadamente un 10\% del PBI Nacional (INDEC 2009) (Barri y Wahren, 2010: 1).

La gran cantidad de capital y la demanda en el mercado de la soja produjo un aumento de las hectáreas destinadas a la cosecha de esta leguminosa. Además, con la introducción de la soja transgénica y su pack tecnológico asociado, las cantidades de Roundup vertidas en los campos aumentaron exponencialmente. De tal forma, dada la toxicidad de este producto, pronto aparecieron problemas sanitarios, ambientales, sociales y económicos en las zonas rurales de la Argentina.

El médico y docente Damián Verzeñassi, el cuál dirige el Instituto de Salud Socioambiental de la Facultad de Ciencias Médicas de la Universidad 
Nacional de Rosario, en su artículo Agroindustria, salud y soberanía. El modelo agrosojero y su impacto en nuestras vidas publicado en el libro La patria sojera, señala la cantidad de hectáreas de soja que se han llegado a cultivary los millones de litros de agrotóxicos vertidos.

Dieciocho millones de hectáreas que se anuncian como un logro y muestra del posicionamiento de privilegio de Argentina en el mundo por haber alcanzado los 100 millones de toneladas de granos, también dice en otras letras que, nada más en el último año, se han envenenado esos territorios con casi 300 millones de litros de químicos tóxicos para producir forrajes y combustibles, principalmente para la exportación. En estos territorios habitamos aproximadamente 12 millones de seres humanos (Verzeñassi, 2014: 43).

Las inmensas cantidades de agrotóxicos que se vierten en los campos, cerca de las zonas rurales habitadas, como escuelas y granjas, ha provocado un aumento en las enfermedades de las personas que viven en estos lugares. Existen diferentes tipos de intoxicación, estos pueden ser inmediatos o prolongarse en el tiempo y esto dificulta la asociación de la enfermedad al tóxico.

Los mecanismos de intoxicación pueden ser agudos o crónicos, dependiendo de la fuente de contaminación, el medio de ingreso del tóxico al organismo, el tiempo de exposición y la dosis absorbida, entre otros elementos (Verzañassi, 2014:35).

No obstante, cada vez son más numerosos los estudios que se centran en investigar y demostrar la relación del aumento de las enfermedades en los pobladores rurales con la exposición a estos tóxicos. Damian Verzañassi señala algunos en su artículo,

[...] existen trabajos que asocian la exposición crónica a agrotóxicos con enfermedad de Parkinson [...] trabajos científicos que mostraron aparición de Hipotiroidismo Subclínico (por aumento de la Hormona Tirotrofina) y supresión de la Hormona T3 en personas que manipulan agrotóxicos. [...] se correlacionan niveles de organoclorados con infertilidad femenina. [...] bajo peso al nacery/o menor tiempo de gestación, efectos cognitivos, retardo en el desarrollo psicomotor, vienen siendo constatados por los equipos de salud de las regiones fumigadas (Verzañassi, 2014: 36). 
Así como aumentan los estudios sobre la intoxicación de los agrotóxicos, también emergen asociaciones y trabajadores de diferentes ámbitos en defensa de la vida, en protección por la salud, por los derechos humanos, por el respeto a la naturaleza y en lucha por la prohibición de estas fumigaciones tan agresivas. El periodista argentino Patricio Eleisegui ha realizado un espectacular trabajo de difusión, visibilización y cuestionamiento de las prácticas realizadas en los cultivos de Argentina. Eleisegui publicó el libro Envenenados (2014), El fruto de la desgracia (2015) y Agrotóxico (2019), en cada uno de ellos va relatando a modo de denuncia las graves consecuencias sanitarias debidas a la utilización de agrotóxicos y transgénicos en el país. Sus libros dan voz a las personas afectadas por estos químicos que luchan día a día por sobrevivir, entre ellas, destacamos a Fabian Tomasi el cual se convirtió en un icono mundial en la lucha de los agrotóxicos. En 2017, el artista Facundo Roma pintó un mural en Rosario, provincia de Santa Fe (Argentina), con frases extraídas del libro Envenenados, honrando la lucha de Fabian Tomasi.

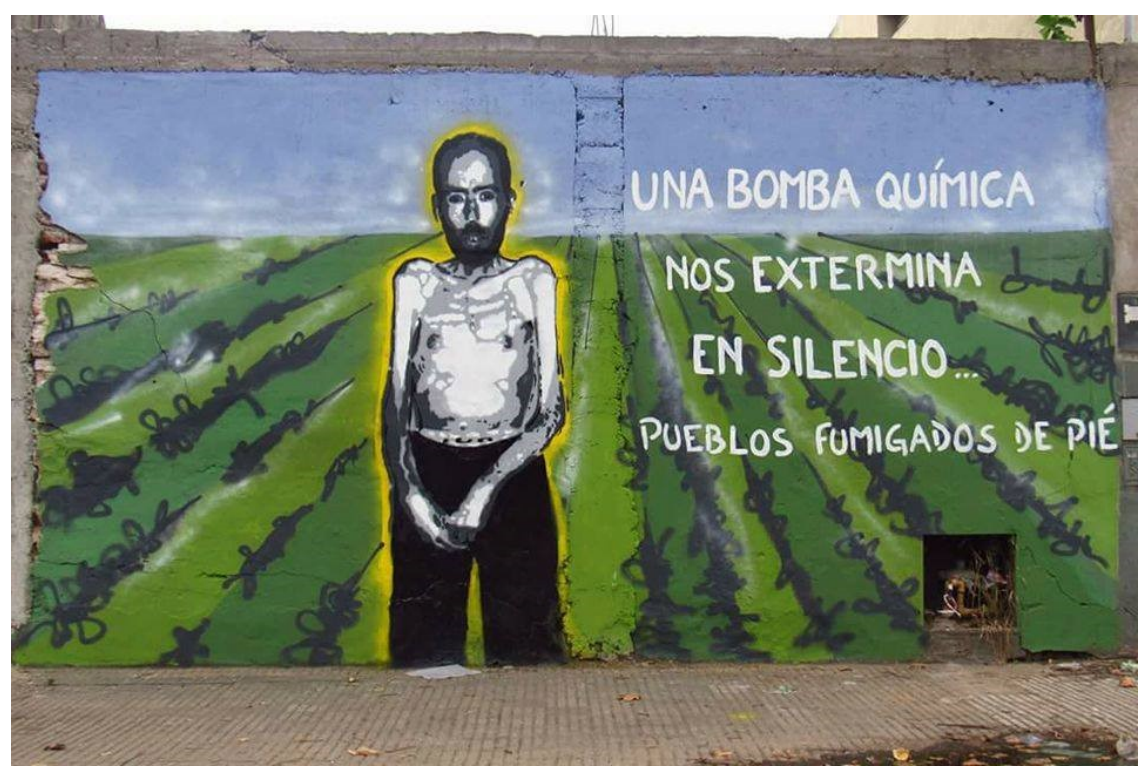

Imagen 64. Fabian Tomasi, una bomba química nos extermina en silencio, Rosario, provincia de Santa Fe. Facundo Roma, 2017.Fuente: @envenenados 


\subsubsection{La lucha de Fabian Tomasi y el arte emergente a partir de su historia}

Fabian Tomasi (1966 - 2018) era natural de Basavilbaso de la provincia Entre Ríos, Argentina. En 2006 empezó a trabajar en una empresa ubicada en su población llamada Molina \& Cia. SRL., su labor era trabajar como apoyo terrestre cargando los aviones fumigadores de las plantaciones de soja. Según las indicaciones de la empresa las labores se realizaban sin ningún tipo de protección, ya que los químicos con los que trabajaban decían no suponer un peligro para la salud. Los empleados estaban en contacto con miles de litros de químicos, no utilizaban equipos de protección, ni máscaras, ni guantes y se dedicaban a llenar los bidones para que las avionetas pudieran fumigar los campos. Tomasi, a los seis meses de estar trabajando en la empresa empezó a tener molestias en las manos, las cuales tenía que meter en agua caliente para poder calmar el dolor. Con el tiempo y tras mucha lucha le diagnosticaron polineuropatía tóxica metabólica severa. La empresa lo despidió sin compensación alguna y sin asumir ningún tipo de responsabilidad. Fabian Tomasi literalmente se estaba secando por dentro con pérdida de movilidad y trastornos en el aparato digestivo, entre otras dolencias. En el testimonio de Tomasi que alberga el libro de Envenenados, señala,

Nunca nos protegimos con nada y mucho menos cuando se empezó a usar el glifosato, ya que viene con una franja en el envase que dice que es levemente tóxico (Eleisegui, 2014: 194).

Además de todas las dolencias que tuvo que sufrir y que se fueron agravando en el tiempo, tuvo que luchar contra un sistema que no quería desvelar su enfermedad y el estrecho contacto que tuvo con los agroquímicos.

Tengo una rodilla operada de la que me sacaron más de un litro de líquido blanco. Cuando hicieron la biopsia en el hospital público de Basabilbaso, los resultados se perdieron y nunca supe qué fue eso. Me dijeron que nunca me voy a recuperar del todo. Y la primera vez que me revisaron completamente me dieron 6 meses de vida. La medicina no sabe a lo que se enfrenta (Eleisegui, 2014: 196). 
Tomasi dedicó sus últimos años de vida a visibilizar las atrocidades que se estaban realizando tanto al medio ambiente como a sus habitantes. Su enfermedad era muy visible físicamente, su imagen, sus discursos, su lucha y su sufrimiento se convirtieron en un hito mundial en contra de los agrotóxicos. Además, su lucha hizo emerger un movimiento social que lo acompañó; en ese contexto empezaron a aparecer artistas que con sus distintas formas de crear visibilizaron su historia. Por ejemplo, en 2016 empezaron a aparecer una serie de esténcil anónimos con la imagen de Tomasi y el título del libro Envenenados en diversos lugares de la provincia de Santa Fe, Argentina.
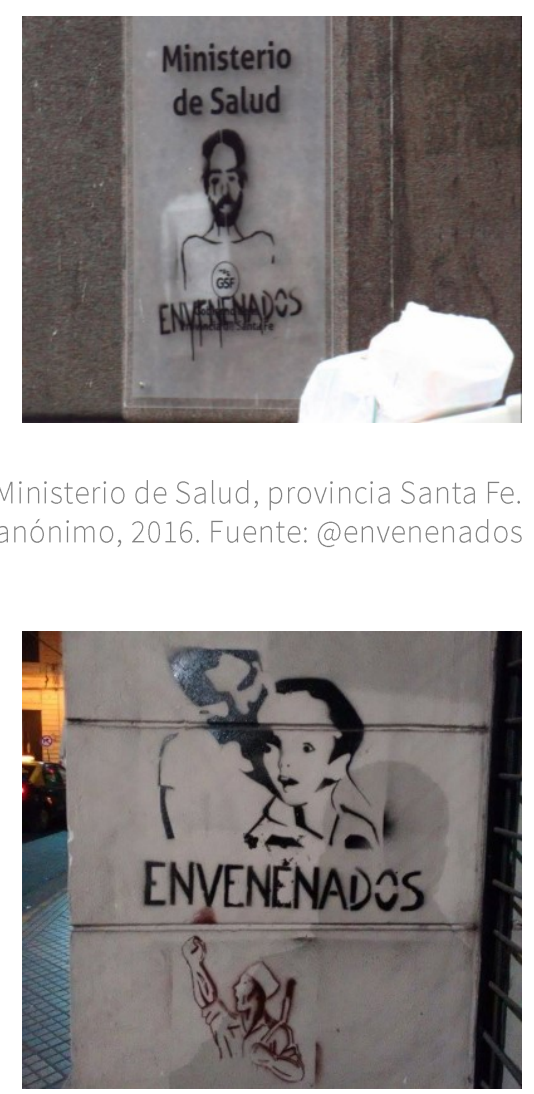

Imagen 66. Envenenados, Rosario, provincia Santa Fe. Esténcil anónimo, 2016. Fuente: @envenenados 
También se crearon murales con composiciones artísticas más complejas, en la imagen 67 podemos observar una llamativa pintura a color que abarca la situación de los agrotóxicos en el país desde un punto de vista más general, pero seguimos observando la figura de Fabian Tomasi en la parte central de la obra, como principal protagonista de la lucha contra los agrotóxicos.

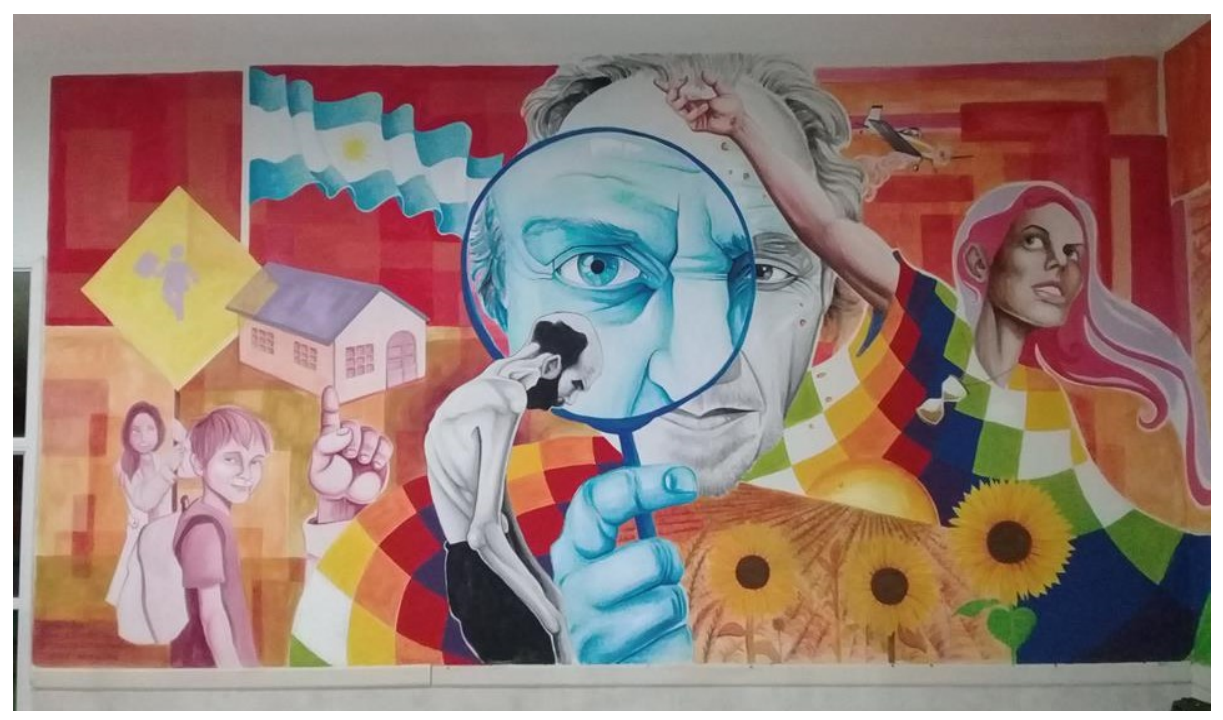

Imagen 67. Homenaje a Fabian Tomasi, nuestras maestras y niños fumigados, Trenque Lauquen, provincia de Buenos Aires. German Villamor, 2018. Fuente: @envenenados

Fabian Tomasi llevó a cabo una lucha en defensa de la vida, donde a pesar de su enfermedad, de los do lores que padecía y de los enemigos que se encontró en el camino, dedicó sus últimos años a investigar y divulgar material científico y médico en protesta ante el agronegocio que se lleva a cabo en la provincia de Argentina. Tomasi, falleció en septiembre de 2018 a los 52 años. En el Centro de Salud de Santa Clara, en Mar de plata (Argentina) realizaron un mural en homenaje a su persona. 


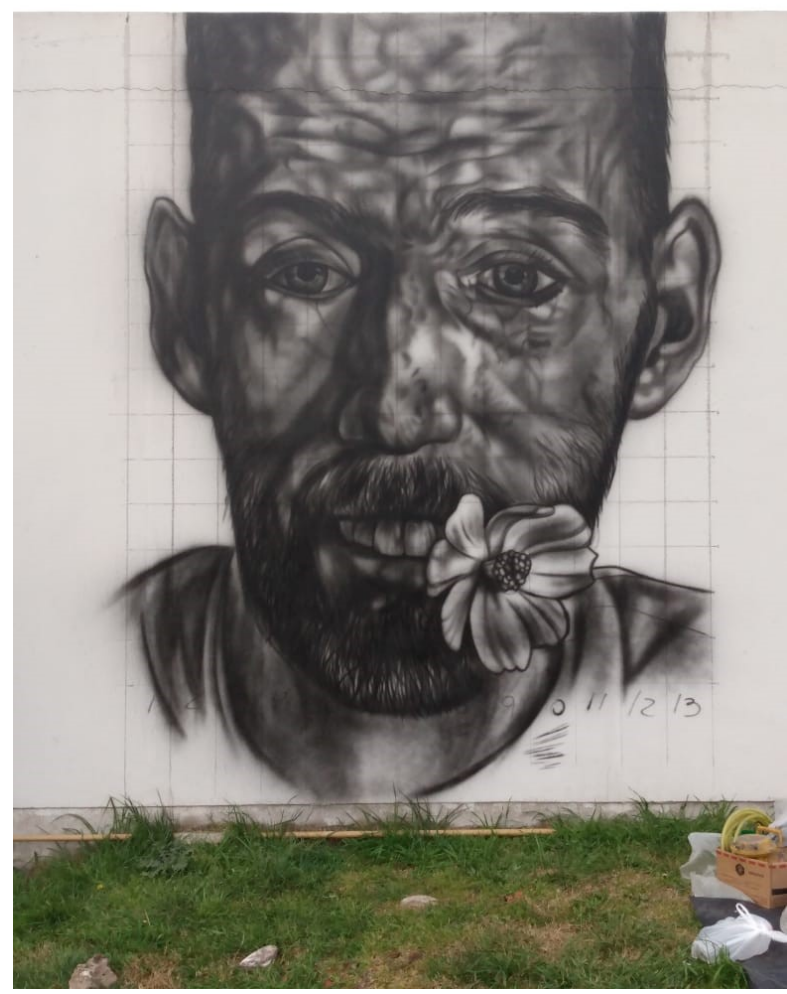

Imagen 68. Fabian Tomasi, Centro de Salud de Santa Clara, Mar del Plata. Chala y Sole, 2019. Fuente: Promotores Agroecológicos Mar del Plata

2.2.3. Los efectos de los agrotóxicos a través de la obra de Pablo Ernesto Piovano

Si bien la imagen más visible del efecto de los agrotóxicos en Argentina ha sido la de Fabian Tomasi, hay numerosas personas que padecen las consecuencias de las fumigaciones. A lo largo de 2014 y 2015 el fotógrafo argentino Pablo Ernesto Piovano recorrió las zonas rurales de las provincias argentinas de Entre Ríos, Chaco, Misiones, Córdoba y Santa Fe donde pudo observar las graves consecuencias sanitarias de las explotaciones con agrotóxicos. En ese tiempo dio fruto a su obra El costo humano de los agrotóxicos, el cual ya ha sido galardonado hasta con seis premios 
internacionales. La pieza se compone de una serie de fotografías que evidencian la triste realidad que viven los habitantes de estas zonas rurales.

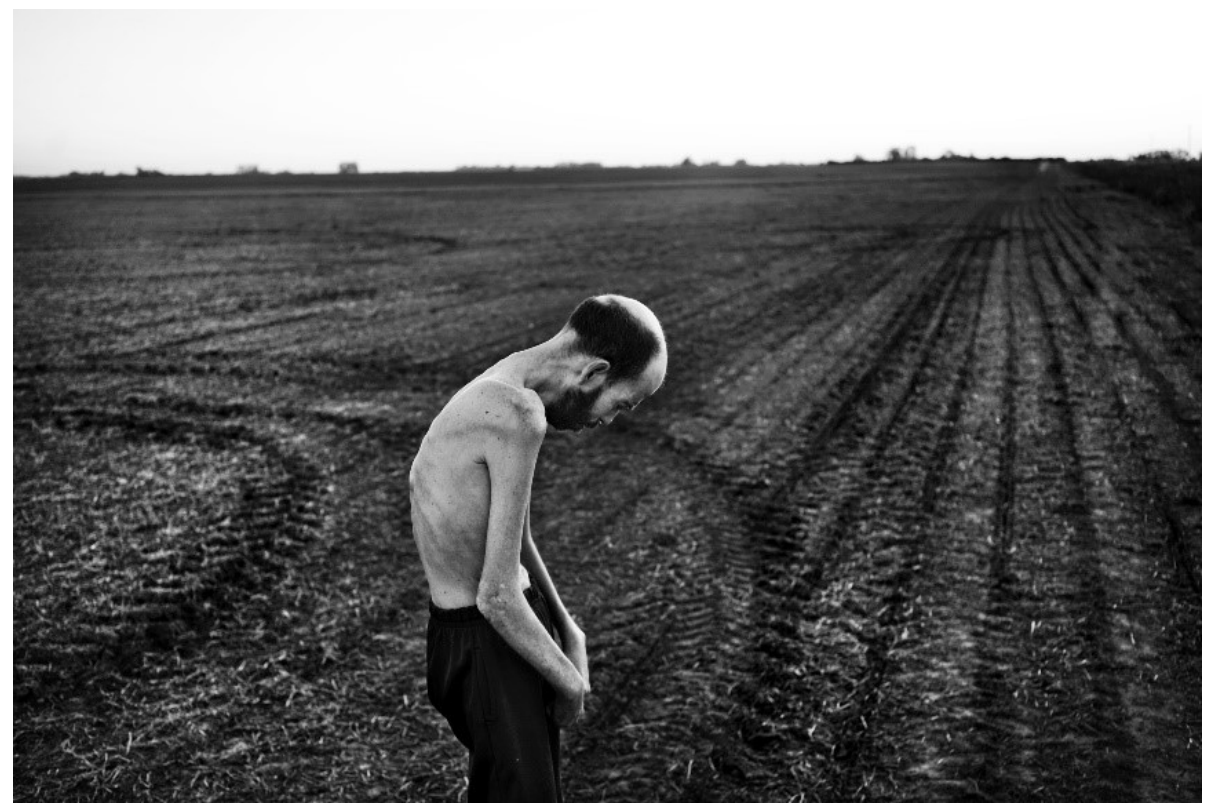

Imagen 69. Fabian Tomasi, El costo humano de los agrotóxicos, Argentina. Pablo Ernesto Piovano, 2014-2019. Fuente: pablopiovano.com

En su obra, Piovano, busca mostrar el cuerpo de las víctimas de los agrotóxicos, incitando al espectador a reflexionar sobre las atrocidades que están viviendo estas personas. Las constantes fumigaciones que sobrevuelan los campos de soja, principalmente, fumigan sin consideración, pasando por encima de escuelas, granjas y viviendas familiares. Los problemas sanitarios en estas poblaciones cada vez son más evidentes y numerosos, con casos de cáncer, problemas de piel, malformaciones, abortos y envenenamientos. Graciela P. Cacace y Jorge Osvaldo Morina del Grupo de Estudios sobre Geografía Economía y Comercio Internacional, en su artículo Agricultura industrial transgénica en Argentina. Agrotóxicos: consecuencia sociales y ambientales señalan que, 
De acuerdo a datos brindados por la Cámara de la Industria Argentina de Fertilizantes y Agroquímicos (CIAFA), en nuestro país durante el año 2017 se vendieron 3,8 millones de toneladas de agrotóxicos. La venta de herbicidas llegaría a 5 millones de toneladas en 2018. La Argentina se ha convertido en el país con mayor consumo de glifosato del mundo: mientras que en los Estados Unidos su uso es de 0,42 litros por habitante, en Francia el herbicida está completamente prohibido por las terribles consecuencias que genera en la salud de las personas, en nuestro país se utilizan 4,3 litros de este agroquímico por persona. En la Argentina es necesario modificar la legislación para que proteja a las personas y no a las corporaciones (Cacace y Osvaldo, 2018: 131).

Son abismales las cantidades de estos tóxicos vertidos al medio ambiente y en contacto con las personas, a pesar de que en la actualidad existen informes y evidencias de su peligrosidad.

En marzo de 2015, la OMS (Organización Mundial de la Salud) dio a conocer, a través de la Agencia Internacional para la Investigación sobre el Cáncer (IARC), un estudio que revela que el glifosato causó daño al ADN y los cromosomas en las células humanas analizadas (Cacace y Osvaldo, 2018: 130).

La continuidad de estos modos de producir alimentación, a pesar de los daños que causa, y el apoyo que reciben de políticos y empresas deja desamparados a los habitantes que viven cerca de estas plantaciones.

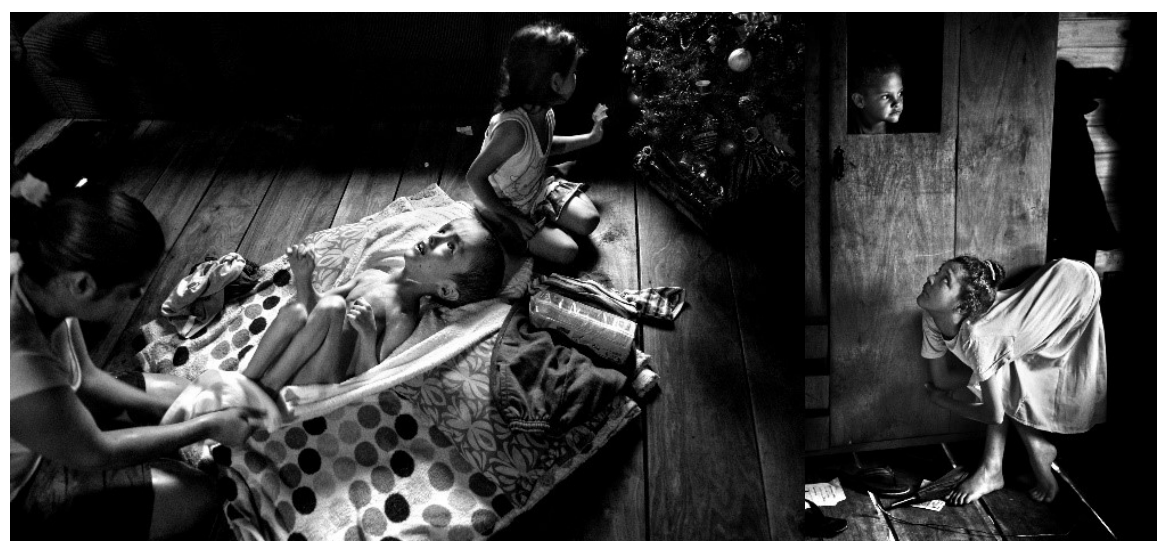

Imagen 70. El costo humano de los agrotóxicos, Argentina. Pablo Ernesto Piovano, 2014-2019. Fuente: pablopiovano.com 
Es por ello por lo que son tan importantes trabajos como los de Piovano. Su obra ha tenido una gran repercusión a nivel mundial y ha podido dar voz a aquellas personas que han de soportar estas indignas situaciones. En 2016, su trabajo también se expuso en el Collegi Major Rector Peset, Valencia (España), donde en una impactante exposición se pudo conocer muy de cerca su trabajo y la historia de cada una de las fotografías. En la imagen 71 podemos observar la imagen de un niño con graves problemas en la piel, según decía el pie de foto en la exposición,

Lucas Techeira tiene tres años y nació con Ictiosis, una afección que resquebraja la piel. Comúnmente se lo conoce como niño cristal. Su padre Arnoldo tuvo que abandonar su trabajo en las plantaciones de tabaco cuando nació su hijo. Su madre, Rosana Gaspar de 32 años, manipuló sin protección glifosato (Piovano, 2016)

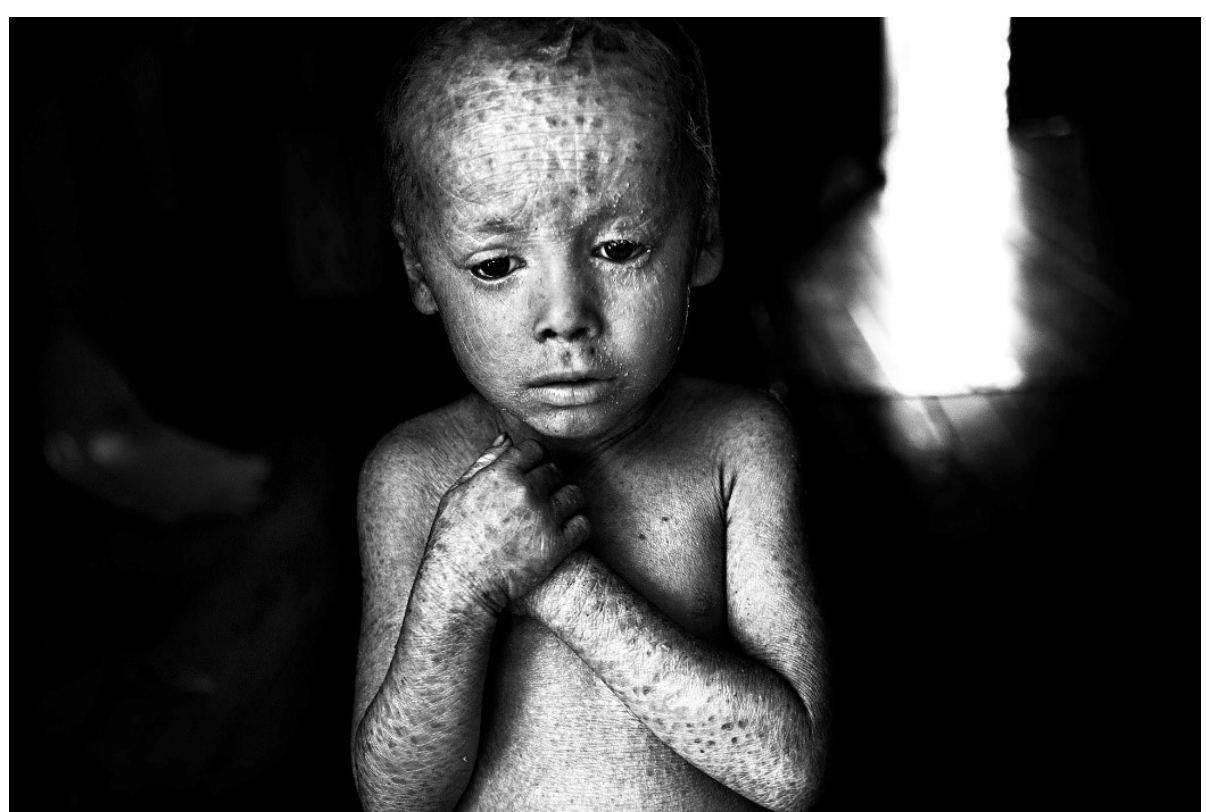

Imagen 71. Lucas Techeira, El costo humano de los agrotóxicos, Argentina. Pablo Ernesto Piovano, 2014-2019. Fuente: pablopiovano.com 


\subsection{Principal empresa transnacional de la agroquímica y el arte que la cuestiona}

Son varias las empresas transnacionales que se dedican a la producción y comercialización de agroquímicos y semillas, algunas de ellas MonsantoBayer, Syngenta, Dupont o Novartis. No obstante, nos vamos a centrar en Monsanto, la primera de las empresas que empezó a trabajar con el pack tecnológico para la agricultura y creó todos los agroquímicos que hemos nombrado en los apartados anteriores. Monsanto, primero fue una empresa química y, más tarde, se fundó como empresa agrícola en Missouri, 1901.

Actualmente, Monsanto, forma parte de la empresa farmacéutica y agrícola alemana Bayer. La empresa estadounidense fue adquirida por Bayer en 2018 por la ingente cantidad de 63.000 millones de dólares. A pesar de que ahora la marca Monsanto esté bajo la entidad corporativa de Bayer, siguen los juicios en Estados Unidos por los daños causados al medio ambiente y a las personas. Así como las polémicas por los organismos modificados genéticamente. En el anterior apartado hemos visto la contaminación que producen los agrotóxicos elaborados por esta empresa y las graves consecuencias sanitarias que han ocasionado, pero no son las únicas cuestiones por objetar en la praxis de las agroquímicas. Las patentes de las semillas y los organismos modificados genéticamente han llevado a la ruina a pequeños y medianos agricultores/as. Además, con estas tecnologías abarcan cada vez mayor control sobre la alimentación a nivel mundial.

La Doctora en Filosofía de la Ciencia, feminista y activista Vandana Shiva, entrevistada por Marie-Monique Robin señala claramente su punto de vista,

"No digo que la revolución verde no partiera de buenas intenciones, a saber, aumentar la producción alimentaria en los países del tercer mundo", me explica Vandana Shiva, "pero los efectos perversos del modelo agrícola industrial que la sustenta tuvieron unas consecuencias medioambientales y económicas dramáticas, en particular para los pequeños campesinos" (Robin, 2008: 454). 
En su entrevista Vandana Shiva marca dos Revoluciones Verdes, la primera dirigida por el sector público y la segunda por Monsanto. En la primera el control de las investigaciones y desarrollo agrícola estaba bajo la dirección de los gobiernos, había intenciones de aumentar las ventas de agroquímicos y maquinaria agrícola, pero había un objetivo marcado en incrementar las cosechas para alimentar a la población. En cambio, en la segunda, la única finalidad era enriquecer a la empresa Monsanto (Robin, 2008: 453). La agroquímica estadounidense implantó la ley Monsanto, el objetivo de esta empresa fue patentar la vida a través de la manipulación genética. Es decir, generan una semilla modificada genéticamente resistente a un herbicida como el glifosato, introducen la semilla en el mercado y la patentan, cualquier persona que cultive esa semilla tendrá que pagar a la empresa por ello. Además, las plantaciones que se hayan realizado con esas semillas necesitarán los productos, vendidos por la misma empresa, para poder obtener su alto rendimiento. Los agricultores terminan pidiendo préstamos para poder adquirir esta tecnología, pero cuando aparece una mala cosecha y hay pérdidas, terminan embargados.

Una vez haya impuesto como norma el derecho de propiedad de los granos modificados genéticamente podrá cobrar los royalities; dependeremos de ella para cada grano que sembremos y cada campo que cultivemos. Si controla las semillas, controla la alimentación; ella lo sabe, es su estrategia. Es más poderosa que las bombas, es más poderosa que las armas, es el mejor medio de controlar a las poblaciones de mundo (Robin, 2008: 454).

Del mismo modo que surgieron organizaciones en defensa de la biodiversidad y de la agroecología cuestionando las prácticas de las empresas transnacionales de la agroquímica, también surgieron artistas que generaron proyectos en crítica hacia la empresa Monsanto. Es curioso observar los artistas y las artistas visuales con un amplio marco de trabajo de diversidad temática, que han dedicado un período de su carrera creativa para analizar, investigar y generar propuestas artísticas que cuestionen e inviten a reflexionar sobre las prácticas de empresas como Monsanto. En este contexto, vamos a destacar una serie de artistas de diferentes países que han centrado su obra en Monsanto. 
En primer lugar, destacamos al artista estadounidense Steven Leyba (1966) y su controvertido arte. Leyba encuaderna hojas de lienzos pintados formando una serie de libros artesanales que pueden llegar a pesar hasta treinta quilogramos. En su obra utiliza el collage, fotografías, dibujo e, incluso, desechos humanos. A nivel conceptual suele trabajar temas sexuales vinculados al consumo, sus piezas tienen connotaciones ocultistas e incluso sadomasoquistas. Sin embargo, quiso dedicar una de sus obras a Monsanto. Entre 2011 y 2012, se dedicó a crear un libro de gran tamaño donde encuadernó con clavos una serie de lienzos repletos de dibujos, pinturas y collages un tanto extravagantes.

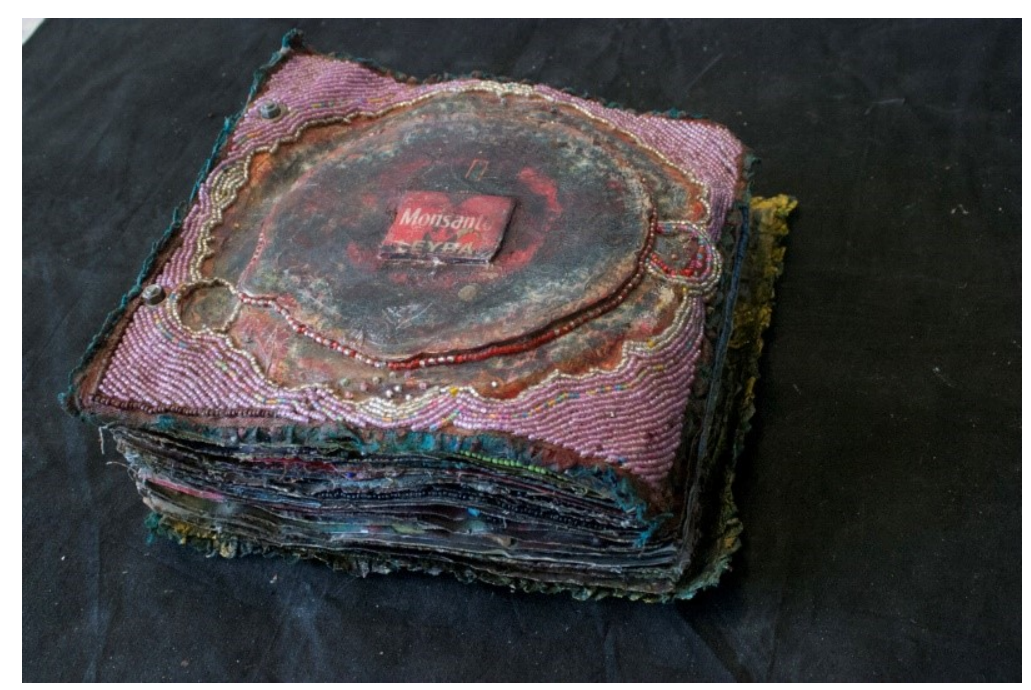

Imagen 72. Monsanto, libro de conjuros artesanal. Steven Leyba, 2010-2011. Fuente: organicauthority.com

El artista conmovido por la situación que tienen que vivir muchos habitantes del planeta debido a las prácticas contaminantes de la empresa Monsanto, así como por la gran cantidad de enfermedades y muertes que han ocasionado sus productos químicos, se sensibilizó con la población y creó un libro de conjuros para maldecir a Monsanto. Para ello, el artista realizó una investigación sobre los productos de la empresa, sus formas de proceder y 
sus dirigentes. Todo lo recopilado lo fusionó en una gran obra que recoge una serie de textos, dibujos e imágenes de personalidades relevantes de la empresa. Con una estética de libro procedente de magia negra, el artista literalmente enviaba una maldición a la empresa Monsanto.

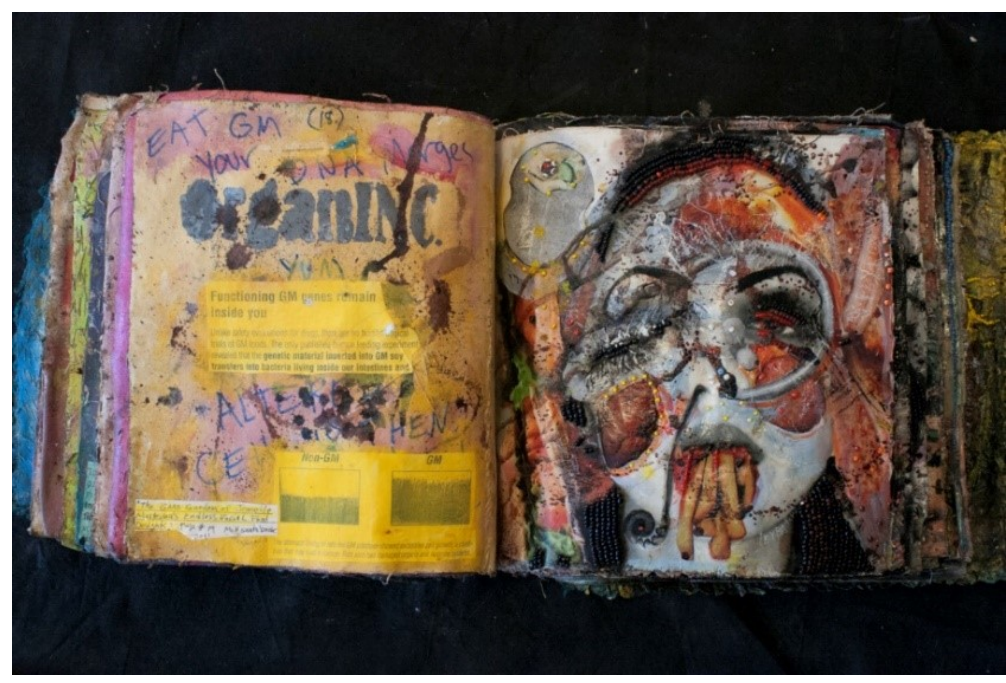

Imagen 73. Monsanto, vista interior libro de conjuros artesanal. Steven Leyba, 2010-2011. Fuente: organicauthority.com

Para el artista la obra significa una fuerza que contrarresta las maldades que provienen de Monsanto. Con esta propuesta pretende enviar pensamientos, energías y, literalmente, maldiciones que generen la suficiente fuerza para acabar con la empresa. A pesar del aspecto oscuro y macabro de su obra, Leyba guarda la esperanza de que la población recupere el poder de elegir una alimentación orgánica y, con ello, generar una fuerte lucha en contra de las directrices consumistas de estas empresas. Para ello, es muy importante la conservación de las semillas autóctonas, fomentando la biodiversidad. Vandana Shiva en su libro Biopiratería: El saqueo de la naturaleza y del conocimiento señala,

No hay mucho tiempo. Pero sí mucho que podemos hacer. Yen muchos rincones las comunidades han empezado ya a organizarse para resistir, para recuperar 
sus propias melodías. Es preciso hablar de ello. Que en todas partes se sepa que nos quieren arrebatar la música de la naturaleza y de los pueblos. Para que las gentes salgan a la calle, y digan iNO! Y es preciso cuidar y cultivar nuestras canciones, para que no se pierdan, y para que nuestra reserva de música nunca se agote. Recuperar nuestras semillas, nuestras variedades, nuestras tradiciones. Aquí y allá, en pequeñitas experiencias, ya se está haciendo también (Shiva, 2001: 17).

En ese contexto destacamos la obra de Carma Casulá, Monsanto no es santo de mi devoción. Casulá, artista, investigadora y docente española, realizó un proyecto personal titulado Al Natural_PRS, en el contexto del Parque Regional Sureste de la Comunidad de Madrid. En dicha propuesta analizó y contempló la variedad de paisajes que se entremezclan entre sí, las dinámicas urbanísticas, las zonas de ocio y la actividad agrícola. La artista, en el artículo sobre su proyecto señala,

Al Natural_PRS se centra en la calidad visual y calidad del suelo, y su visibilización; también, en poner en valor las apreciaciones de las personas que lo habitan y su arraigo con esta tierra (Casulá, 2018: 52).

La obra Monsanto no es santo de mi devoción forma parte de ese proyecto. Dicha pieza se centra en crear un banco de memoria, existen gran variedad de bancos de semillas, pero las intenciones de Casulá es recabar las connotaciones históricas, culturales, antropológicas y visuales de esas semillas. De tal forma, su obra se llena de poesía e historias.

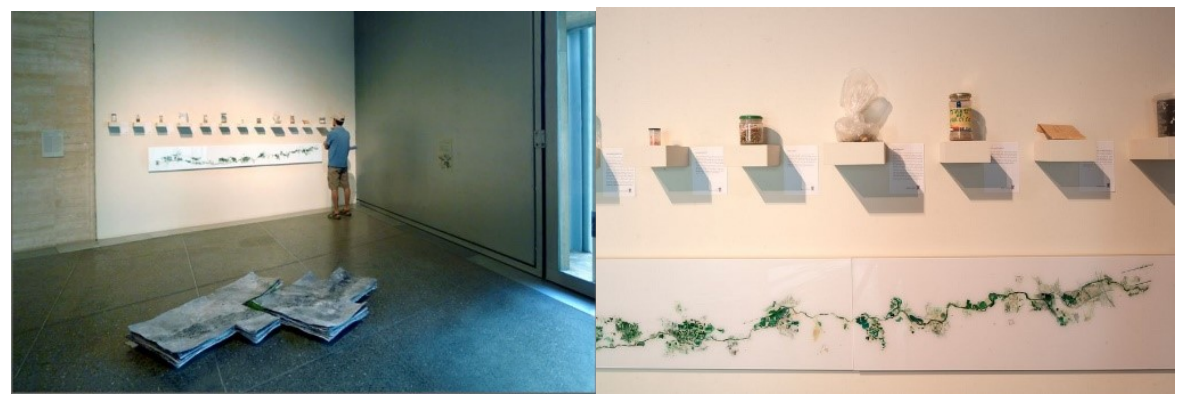

Imagen 74 e Imagen 75. Monsanto no es santo de mi devoción, exposición Hybris, MUSAC, España. Carma Casulá, 2017. Fuente: carmacasula.com 
La artista fue recabando la historia que le contaban los agricultores y las agricultoras de sus semillas, todo ello en el contexto de los paisajes analizados en su proyecto Al Natural_PRS. Posteriormente, de una forma muy sutil unió esas historias a las fotografías de dichas semillas, generando así el banco de memoria. Seleccionó trece variedades de semillas, con sus respectivas historias, haciendo alusión a "los trece meses lunares anuales por los que se rigen los agricultores" (Casulá, 2018: 75). En la imagen 74 y 75, podemos observar la obra en el contexto de la exposición Hybris, donde la artista opto por presentar directamente la semilla tal cual es guardada por cada uno de los agricultores/as junto a su historia.

\section{I S A N T O}
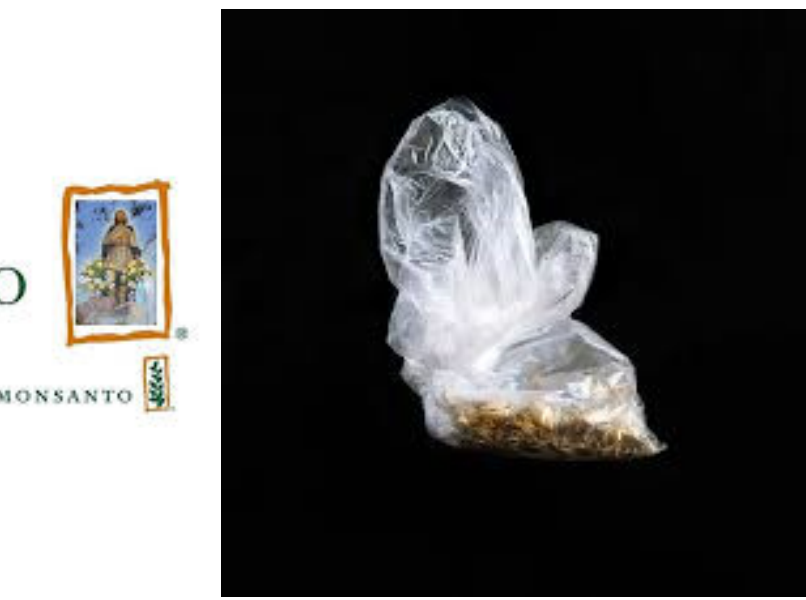

Imagen 76. Logo, Monsanto no es santo de mi devoción.

Carma Casulá, 2018. Fuente: carmacasula.com Imagen 77. Nieves_clavel moro, Monsanto no es santo de mi devoción.

Carma Casulá, 2018. Fuente: carmacasula.com

En la imagen 76 observamos el logo que elaboró Casulá para su proyecto, en dicha propuesta la artista vincula la devoción al santo de los agricultores, San Isidro, con la marca corporativa de Monsanto, marcando la importancia del cultivo tradicional y de la labor de los agricultores/as por su conservación. En la imagen 77 se muestra una de las trece semillas seleccionadas para la obra, en este caso la semilla de Nieves_clavel moro, y cuenta su historia, 
Nieves_clavel moro (46): "Hace muchos años que se perdió la simiente del clavel de moro, el nuestro. A mi padre le encantaba, siempre lo plantaba en su jardín. Creo que le recordaba a sus padres pues me acuerdo de la granja de mis abuelos con las flores naranjas en la puerta inundando de color. No sé si consiguió la primera simiente allí. jYa! En uno de sus viajes a Asturias en el jardincillo de una iglesia. Siempre andaba observando las plantas, y si alguna le gustaba intentaba hacerse son un esqueje o simiente. El murió hace unos años y no replantó claveles desde que se enfermó: hacía sólo lo necesario en el campo. El año pasado de la nada rebrotó una mata y fue un auténtico regalo, era como si rebrotara parte de mi pasado y la memoria de mi padre. Las he recopilado para plantarlas en la nueva temporada" (Casulá, 2018: 75).

La obra de Casulá siembra una semilla por la recuperación y la conservación de las tradiciones que sustentan la biodiversidad en nuestros campos. Además, pone en valor la importante labor que ha realizado el campesinado a lo largo de los siglos y plantea un cuestionamiento hacia las prácticas que generan empresas como Monsanto con la biopiratería. Silvia Ribeiro, en su artículo Biopiratería: la privatización de los ámbitos de la comunidad aclara el concepto de biopiratería que sostienen empresas como Monsanto.

Para las grandes empresas transnacionales que trabajan con biotecnología en farmacéutica y agricultura, y que son las principales interesadas y destinatarias comerciales de esos recursos biológicos, biopiratería es la utilización o reproducción sin autorización de sus innovaciones patentadas. Por ejemplo, cuando un agricultor utiliza sus semillas patentadas sin pagarle regalías, lo haga en forma consciente o no, como cuando el campo de un agricultor es contaminado por polen llevado por el viento desde otros campos que utilizan semillas patentadas (Ribeiro, 2015: 116).

Utilizando esa legislación Monsanto crea un equipo de detectives que se dedican a comprobar los campos de los agricultores para verificar si alguna de sus semillas ha sido plantada, sea intencional o accidentalmente, y no han pagado a la empresa por ello. En ese contexto,

Monsanto ya ha iniciado más de 460 juicios a agricultores en esos países, y en marzo de 2001 se condenó a un agricultor canadiense a pagar más de 75000 dólares por biopiratería porque su campo fue contaminado con semillas transgénicas patentadas por Monsanto El agricultor ni lo sabía ni lo quería, y además consideró que su campo se perjudicó por esta contaminación (Ribeiro, 2015: 116). 
Con ello, destacamos la obra del artista franco-venezolano Mathieu Asselin, un exhaustivo estudio de la actividad de Monsanto que queda retratada en un libro fotográfico que recoge paisajes, objetos, relatos, cartas personales, anuncios, archivos de la corte y textos. Su trabajo publicado en 2017, tanto en inglés como en francés, ha recibido relevantes premios como el Aperture Foundation First Book Award en 2017, el Dummy Book Award Kassel 2016, mención especial para el Luma Rencontres Dummy Book Award 2016 y su libro está preseleccionado para la Deutsche Börse Photography Foundation 2018.

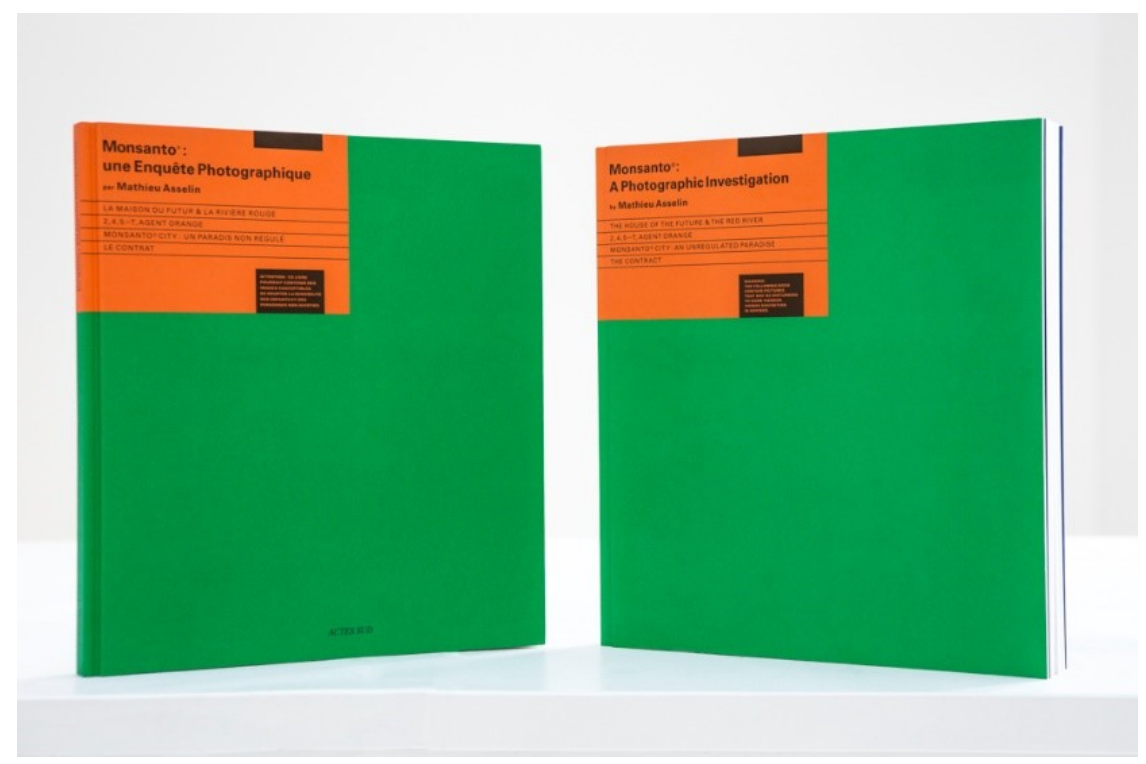

Imagen 78. Monsanto: una investigación fotográfica. Mathieu Asselin, 2017. Fuente: mathieuasselin.com

Sin menospreciar los méritos y galardones editoriales y fotográficos, en el caso que nos ocupa, consideramos relevante destacar las exposiciones artísticas que se generaron con los materiales que contiene el libro. Las exposiciones tuvieron lugar en Bélgica, Londres y Estrasburgo en 2018 y en Arles en 2017 y 2019. En dichas muestras se expusieron las fotografías en diferentes formatos y se hizo uso de diferentes recursos para crear armonía 
en el contexto de la sala generando un discurso claro del libro, pero en gran tamaño. Por ejemplo, las fotografías de los fetos deformados por el agente naranja llegaron a abarcar paredes enteras (imagen 79), así como las notas de prensa (imagen 80), todo ello intercalado con fotografías enmarcadas de diferentes tamaños y textos.

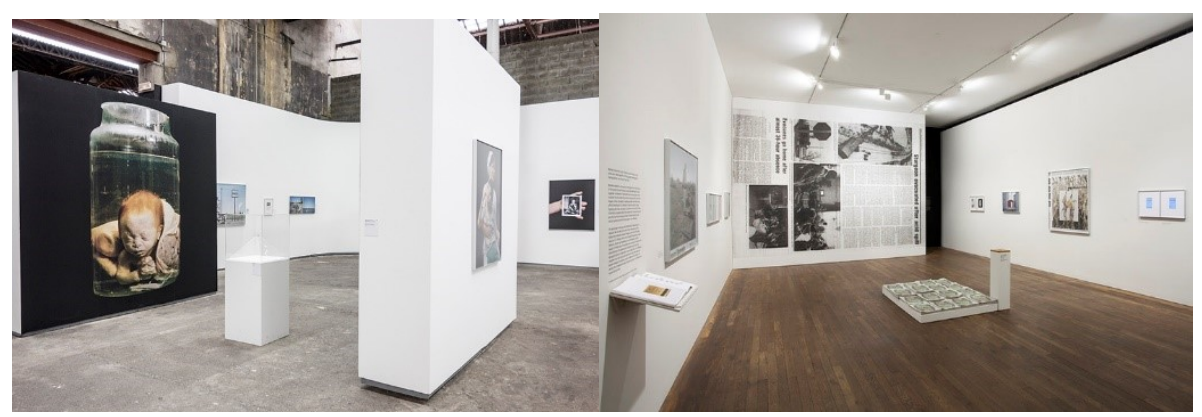

Imagen 79. Monsanto: una investigación periodística, exposición Rencontres d'Arles. Mathieu Asselin, 2017. Fuente: mathieuasselin.com Imagen 80. Monsanto: una investigación periodística, exposición Galería de fotógrafos de Londres. Mathieu Asselin, 2018. Fuente: mathieuasselin.com

Si bien el formato libro y su contenido muestra un meticuloso trabajo de investigación que vislumbra la actividad de Monsanto y el futuro que nos depara, si siguen ese tipo de prácticas. El hecho de trascender todo ese material a las dimensiones de una sala expositiva y jugar con diferentes composiciones y formatos, generando la misma narración que contiene el libro, causa un mayor impacto en el visitante, así como incrementa su interés en la obra. Por tanto, la proyección de la obra se multiplica, además, captando a sectores de la población que tal vez no hubieran accedido al proyecto si solo se hubiera quedado en el formato libro. Es por ello por lo que remarcamos la importancia de este tipo de muestras artísticas.

Asselin ha trabajado en su obra tanto la problemática vivida por los agricultores que han terminado quebrando por las prácticas abusivas de Monsanto, como las catástrofes sanitarias vividas en Vietnam con el Agente 
Naranja. Dimensiones diferentes, surgidas por la mala praxis de Monsanto, pero ambas cuestiones difíciles de afrontar. Además, el artista también ha utilizado los anuncios y las campañas publicitarias que utilizaba Monsanto para vender sus productos e intentar generarse una imagen de empresa comprometida en las labores del campo, la investigación y en el progreso de la agricultura, con el fin de dar visibilidad a las estrategias que son capaces de utilizar estas empresas con tal de sacar beneficio económico.

\subsection{Organismos genéticamente modificados y el arte que los cuestiona}

\subsubsection{Breve contexto social y estratégico de los organismos genéticamente modificados}

Los organismos modificados genéticamente (en adelante OGM) son una apuesta de las empresas transnacionales para la mejora del rendimiento de las cosechas, lo venden como el futuro de la agricultura para un mundo donde cada vez habitamos más personas. De hecho, algunos de los defensores de los OGM, dicen que son la solución para acabar con el hambre en el mundo. Sin embargo, vistas las situaciones que se han tratado en los apartados anteriores como el terrible caso de Argentina, nos lleva a cuestionarnos la veracidad de estas palabras. En relación con este asunto, el filósofo, matemático, ecologista y doctor en Ciencias Políticas Jorge Riechmann, en su libro Transgénicos el haz y el envés, señala que

Si realmente los cultivos transgénicos se destinasen a intentar paliar el hambre en el mundo, entonces deberían poseer alguna o varias de las siguientes características: (a) semillas capaces de crecer en suelos pobres, salinizados, contaminados, etc.; (b) cultivos con más proteínas y nutrientes, de alto rendimiento, sin necesidad de insumos caros (maquinaria, agroquímicos, biocidas, etc.); (c) pensados para los agricultores de subsistencia, no para los latifundios industrializados; (d) semillas baratas y fácilmente accesibles; (e) cultivos para alimentar personas, no ganado. De hecho, ninguno de los cultivos transgénicos que ya se comercializan tienen ninguna de las características mencionadas (Riechmann, 2004: 179).

Como hemos ido viendo los cultivos transgénicos se destinan a la alimentación del ganado de los países más industrializados y a la generación 
de biocombustibles, principalmente. Además, tienen una marcada función capitalista, incrementar la economía de las empresas que lo comercializan. como señala Riechmann,

La propaganda sobre "salvar al mundo del hambre" es por tanto una pantalla de humo. Los transgénicos, no en lo que se refiere a sus potencialidades abstractas sino en el contexto concreto del actual capitalismo de las multinacionales, incrementarán la desigualdad y con ella el hambre (Riechmann, 2004: 179).

Además, cabe destacar que el problema del hambre no viene dado por la cantidad de comida que se pueda llegar a producir sino por el acceso a ella.

A comienzos del siglo XXI, y según las cifras de la FAO y la ONU, más de 800 millones de personas padecen de hambre y desnutrición en un mundo donde el consumo de alimentos del 20 por ciento más rico de la población mundial es 16 veces mayor que el 20 por ciento más pobre. [...] la causa real del hambre en el mundo no es la escasez de comida, sino la escasez de equidad y democracia (Riechmann, 2004: 167).

Otro de los objetivos que se marca como defensor de los organismos genéticamente modificados, defiende que con los OGM el uso de herbicidas se disminuiría. Joseph Mendelson en su artículo acerca del Roundup en la revista The ecologist, 1998, señalaba que,

Un elemento central de la campaña de publicidad es la afirmación de que los alimentos modificados reducirán significativamente el uso de pesticidas y herbicidas. Como proclama la compañía "creemos que los alimentos deben cultivarse con menos pesticidas y herbicidas". En este bombardeo publicitario, Monsanto no menciona que son el mayor productor de productos químicos de la agricultura y que está usando la ingeniería genética para incrementar de manera espectacular, que no disminuir, el uso de herbicidas en los cultivos (Mendelson, 1998: 23).

En efecto, con los años se ha incrementado exponencialmente el uso de los agroquímicos vinculados a los OGM, como señalaba Cacace y Osvaldo anteriormente exponiendo el caso de Argentina. De hecho, las arvenses que crecen junto a los cultivos de OGM, como por ejemplo en las plantaciones de la variedad transgénica soja RR, se vuelven adictas al químico y cada vez se necesita verter más cantidad sobre ellas. Al fin y al cabo, la empresa busca 
aumentar su capital y para ello han de aumentar las ventas de sus productos. Todo ello, ocasiona graves consecuencias sanitarias, medioambientales y sociales, como hemos visto en los anteriores apartados de este capítulo.

Por otra parte, los agricultores que optan por utilizar este tipo de tecnologías se ven atrapados dentro de este modelo productivo que les hace desembolsar grandes cantidades de dinero para adquirir los packs tecnológicos y pagar las patentes. Sin embargo, esta tecnología no siempre es eficiente, se han dado casos en los que la naturaleza se ha vuelto resistente a los productos y ha ocasionado nuevas enfermedades o plagas en las plantas cultivadas. Cuando se dan este tipo de circunstancias el agricultor/a no obtiene abundantes cosechas y, por tanto, tampoco alcanza suficientes beneficios como para pagar a la empresa y poder sobrevivir, ocasionando una situación de endeudamiento. Un ejemplo abrumador lo tenemos en la India, cuando Monsanto introdujo la variedad transgénica de algodón BT.

En el año 2002 se introdujo la semilla de algodón BT vendida por Monsanto, los resultados fueron desastrosos para los agricultores que cultivaron la variedad transgénica. El cultivo de algodón transgénico padeció menos ataque de los gusanos cápsula, pero tuvo problemas con otras plagas como el pulgón. Finalmente, los agricultores que cultivaron esta variedad pagaron tres veces más por las semillas, gastaron lo mismo en insecticidas y obtuvieron una cosecha menor (Riechmann, 2004: 162). La Revolución Verde, no significaba sustentabilidad, muchos agricultores quedaron endeudados. Por ejemplo, como consecuencia de esos endeudamientos, en la India aumentaron drásticamente los suicidios de agricultores. Vandana Shiva, en su cometido de defender la biodiversidad, la libertad de las especies y para las especies fundó Navdanya. En una entrevista realizada por Sandra Baquedano en 2012, Shiva hablaba de las bases en las que se fundamentó su asociación y señalaba que,

Navdanya es una respuesta a la tragedia del suicidio de los granjeros. Suicidio que hemos tenido en los últimos quince años de agenda de globalización neoliberal, lo cual ha permitido que crezcan los monopolios de las semillas. 95\% de las semillas de algodón están ahora en manos de Monsanto. Produjeron un alza de precio del $8000 \%$. Una semilla de cinco rupias cuesta ahora cuatro mil rupias. Las semillas de cinco rupias se pueden guardar para siempre, las de 
cuatro mil tienen que ser compradas cada cuatro años. Esta es la receta para el endeudamiento. Una de las primeras cosas que Navdanya hizo fue crear bancos de semilla comunitarios (Baquedano, 2012: 380).

Consideramos imprescindibles asociaciones como la de Vandana Shiva que realizan una labor elogiable por la defensa y conservación de la biodiversidad, cultivando libremente las semillas autóctonas y aportando apoyo y soluciones a familias que se han visto inmersas en la ruina y la desesperación por ceder al engañoso mensaje de la Revolución Verde.

\subsubsection{El arte que cuestiona el maíz transgénico}

En el apartado anterior hemos abordado breves ejemplos de soja y algodón modificados genéticamente, pero también está bastante extendido el cultivo de maíz BT. Esta variedad transgénica se siembra en Norteamérica y Sudamérica y, a pesar de que la Unión Europea rechaza su cultivo, en España se han cultivado y se siguen cultivando miles de hectáreas de este OGM. El maíz BT ha sido modificado para albergar una toxina en su composición de tal forma que proteja la planta ante el ataque del taladro, sin embargo, no está siendo un sustituto de los demás pesticidas sino uno adicional. Aparte de los problemas derivados de las cantidades de insumos químicos vertidos en este cultivo, nos encontramos con las cuestiones de la biodiversidad. Estas empresas promueven el monocultivo, por ejemplo, en América Latina se cultivan más de doscientas variedades de maíz y las agroquímicas pretenden que se centren los cultivos en una sola variedad, concretamente en su variedad modificada. Todo ello conlleva pérdida de cultura, promoviendo que artistas, asociaciones y colectivos se movilicen para cuestionar dichas prácticas a través de sus creaciones artísticas.

Entre los diversos creadores, destacamos especialmente a Francisco Toledo (México, 1940) por su destacada labor como artista plástico y activista con una marcada lucha en el ámbito social y medioambiental. En 2010 empezó un relevante proyecto que encaja en el contexto de esta investigación, donde el artista se centró en generar una serie de acciones para combatir el maíz 
modificado genéticamente. Toledo, en colaboración con varias entidades, diseñó y produjo carteles donde se cuestionaba el maíz transgénico.
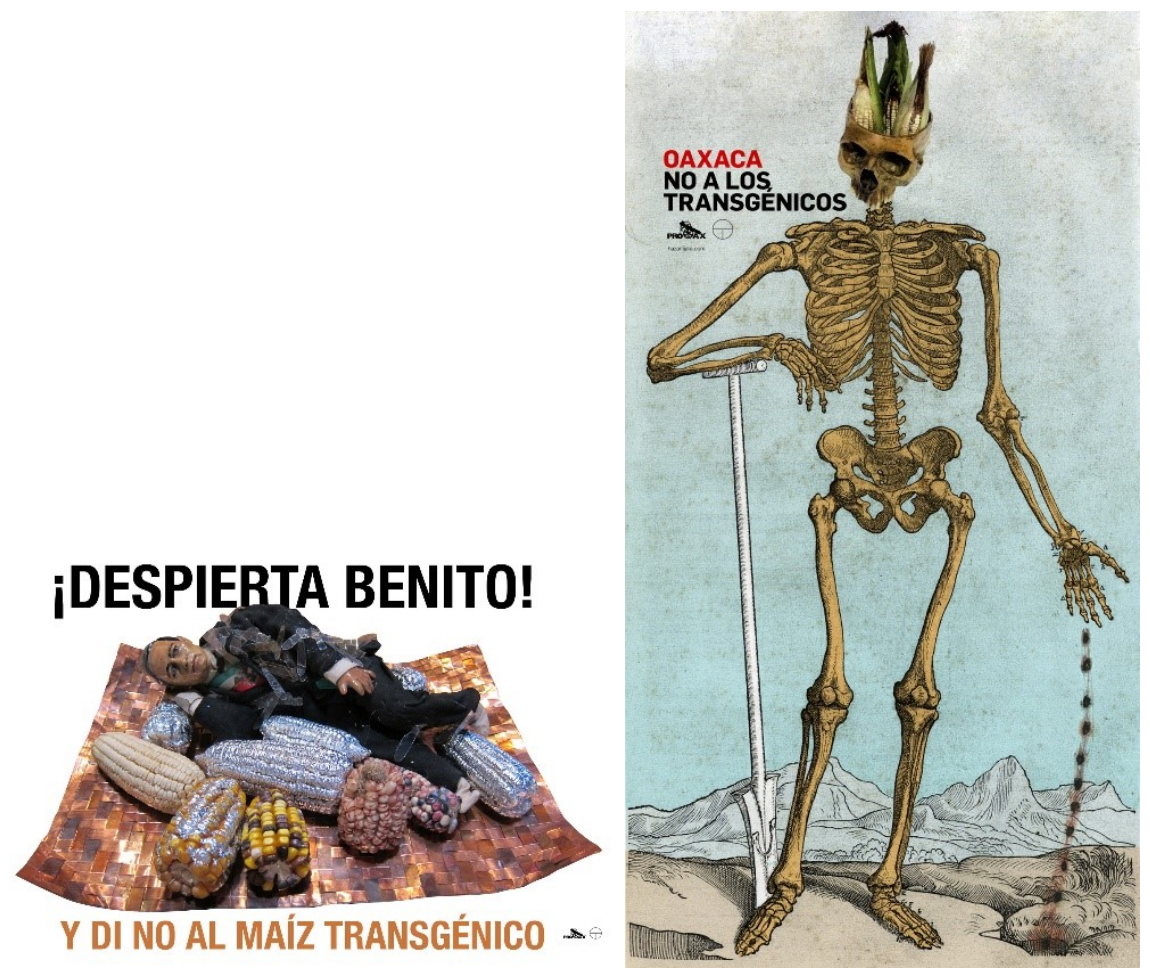

Imagen 81. Benito-transgénico, cartel. Oxaca, México. Francisco Toledo, 2010. Fuente: casa.oaxaca.gob.mx Imagen 82. Calavera del maíz, cartel. Oxaca, México. Francisco Toledo, 2010. Fuente: casa.oaxaca.gob.mx

En general, el diseño de los carteles que se expusieron ofrecía imágenes e ilustraciones tétricas que hacían alusión al maíz transgénico, relacionando la muerte y la enfermedad con este tipo de plantaciones. El mensaje de Toledo era claro y rotundo, descartando totalmente los OGM. Así pues, su trabajo no se quedó en algo puntual, sino que el proyecto de crítica hacia el maíz transgénico fue llevado a cabo hasta su fallecimiento en el 2019. Además de la realización de los carteles representando la negativa hacia el maíz 
modificado, también realizó pinturas, esculturas e instalaciones, así como exposiciones donde colaboró con artistas y entidades difundiendo la importancia de las variedades de maíz nativo. Por ejemplo, en 2014 realizó una exposición titulada Maíz nativo VS. Maíz transgénico, en el contexto de dicha muestra se realizaron diversas actividades como charlas para dar a conocer las variedades nativas de maíz, información sobre las consecuencias del maíz modificado, talleres para niños y recogida de firmas para prohibir la entrada de maíz transgénico en el país. Toledo, con la ayuda de asociaciones sin ánimo de lucro, artistas y algunas entidades, tenía como objetivo recabar un millón de firmas, pero carecía de apoyo gubernamental.

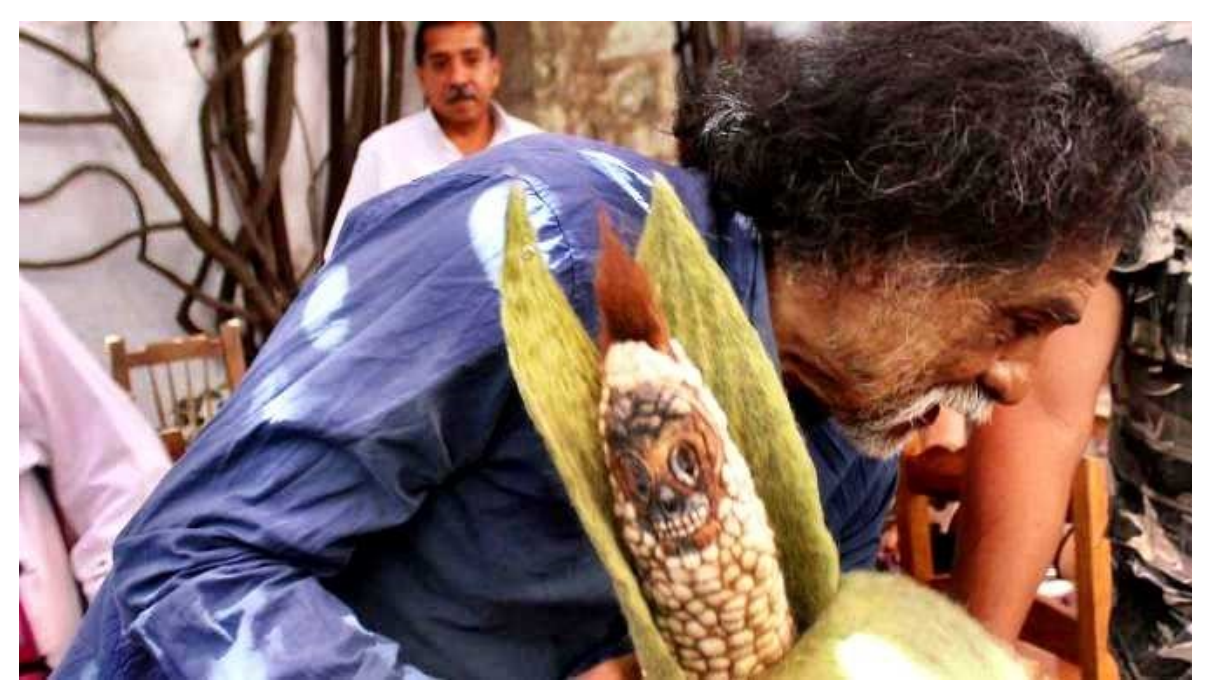

Imagen 83. Escultura de maíz junto al artista, Oxaca, México. Francisco Toledo, 2014. Fuente: regeneración.mx

En la imagen 83 podemos observar al artista con una de sus esculturas en una de las actividades de recogida de firmas. La pieza que sostiene relaciona el maíz con el dibujo de una calavera, ofreciendo una imagen lúgubre de lo que sería una mazorca transgénica. El artista a través de su obra y las diferentes acciones que se llevaron a cabo pretendió sensibilizar y dar a conocer a la sociedad la situación en la que podrían verse envueltos si se introduce el maíz 
transgénico y contamina al maíz nativo. Esta situación ya no tendría retroceso y perjudicaría a la mayoría del campesinado que cultiva las variedades nativas, dándose situaciones como las que hemos visto anteriormente en Argentina o la India.

En 2015, el artista realizó una exposición titulada Sin maíz no hay Toledo, las obras que se mostraron revivían la memoria ancestral de los pueblos y su maíz. El artista trabajó con imágenes en papel fotográfico y tapices de fieltro (imagen 84), también realizó piezas donde intervino con materiales como el cuero y el cobre (imagen 85).
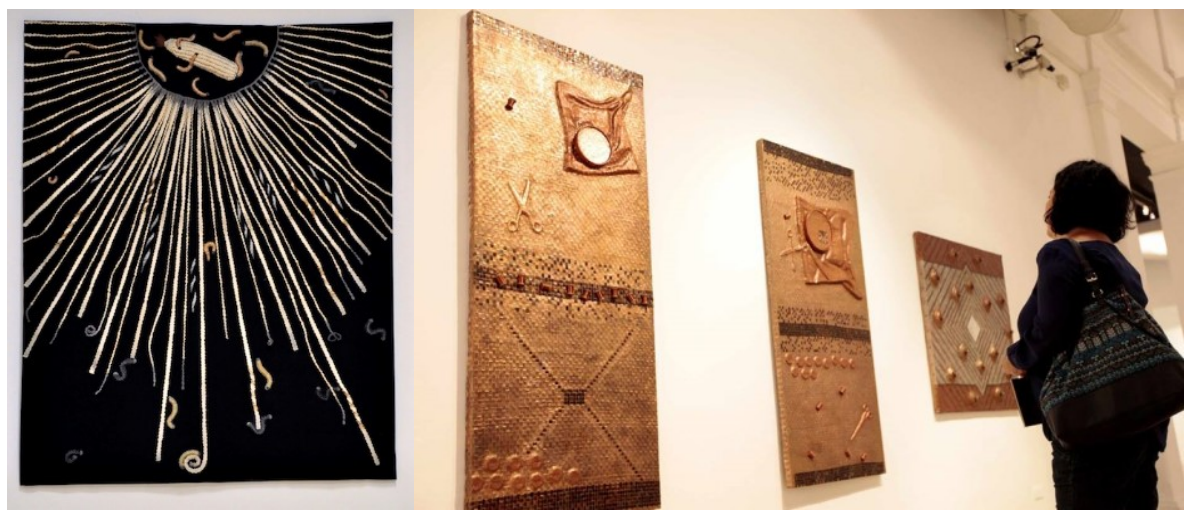

Imagen 84. Sin maíz no hay Toledo, Galería Polivalente de la Universidad de Guanajuato, México. Francisco Toledo, 2015. Fuente: oaxaca.media Imagen 85. Sin maíz no hay Toledo, Galería Polivalente de la Universidad de Guanajuato, México. Francisco Toledo, 2015. Fuente: eluniversal.com.mx

Como podemos observar en las diversas exposiciones que hemos señalado, la obra del artista es muy polifacética y va desde el diseño hasta la representación plástica a través de la pintura, imagen y escultura. Si bien, consideramos que la obra que realizó para la recién citada exposición Sin maíz no hay Toledo, tiene una mayor profundidad teórica al enlazarse con la memoria ancestral del pueblo mexicano. Asimismo, se observa una evolución en la resolución matérica de la obra, donde el acabado de sus piezas y la 
elección de los colores y materiales ofrecen armonía y composiciones muy trabajadas. Cabe resaltar que uno de los aspectos que motivó al artista a introducir la temática del maíz transgénico a lo largo de su obra, fue la empatía, el contacto que él recibió con el cereal en un pasado ligado a su familia y los terrenos de cultivo. Toledo, junto a su labor artística y activista en contra de los transgénicos fomentó la cultura popular y también ejerció de agente social, cultural y humanista. El artista invirtió sus ganancias en crear centros culturales y espacios donde los artistas emergentes pudieran mostrar sus talentos, también realizaba exposiciones donde invitaba a nuevos creadores a mostrar su obra junto a la suya. Su fallecimiento fue muy sentido en la población mexicana, sobre todo en su ciudad natal Oaxaca, realizándose distintos homenajes. Destacamos la última muestra del artista Toledo ve, en el Museo Nacional de Culturas Populares de México en el año de su fallecimiento 2019. Dicha exposición alberga 850 piezas del artista que muestran una visión panorámica de todo su recorrido profesional como homenaje a su labor artística, activista y social.

El trabajo encabezado por Toledo en colaboración con artistas, colectivos y entidades tuvo gran relevancia, su labor dejó huella en la población y la motivó a luchar por conservar su historia y cultura. Cabe destacar que la gran trascendencia de este artista también se debe a sus valores como persona y su coherencia en sus formas de pensar, actuar y vivir. En el mismo sentido destacamos la lucha que realizó el pueblo indígena de Guatemala en 2014 cuando Monsanto quiso implantar su llamada Ley Monsanto en el país. Dicha legislación pretendía aprobar una ley de protección de las variedades vegetales, para que Monsanto tuviera vía libre para introducir sus OGM en el país y, con ello, todo el pack tecnológico que las acompaña. La ley aprobada a espaldas de la opinión pública fue rechazada inmediatamente por la población guatemalteca, ya que amenazaba con la privatización de las semillas, por ejemplo, las del maíz criollo y sus variantes. De tal forma que se organizaron movilizaciones pacíficas en contra de dicha ley, indígenas, colectivos, asociaciones y la población en general se levantó en contra de la Ley Monsanto, consiguiendo su derogación días después de haber sido aprobada en el Congreso. Cabe señalar la importancia de la movilización 
social y las diversas acciones realizadas con el fin de preservar la identidad, la cultura y las semillas nativas de la población. En ese contexto, la artista guatemalteca Regina José Galindo, realizó un proyecto en conmemoración de dicha protesta. La instalación, titulada Mazorca, se componía de diversas piezas, esculturas de diferentes variedades de maíz, dibujos y, la obra más relevante, las fotografías y el vídeo de la performance que realizó en medio de un maizal en Totonicapán, Guatemala.

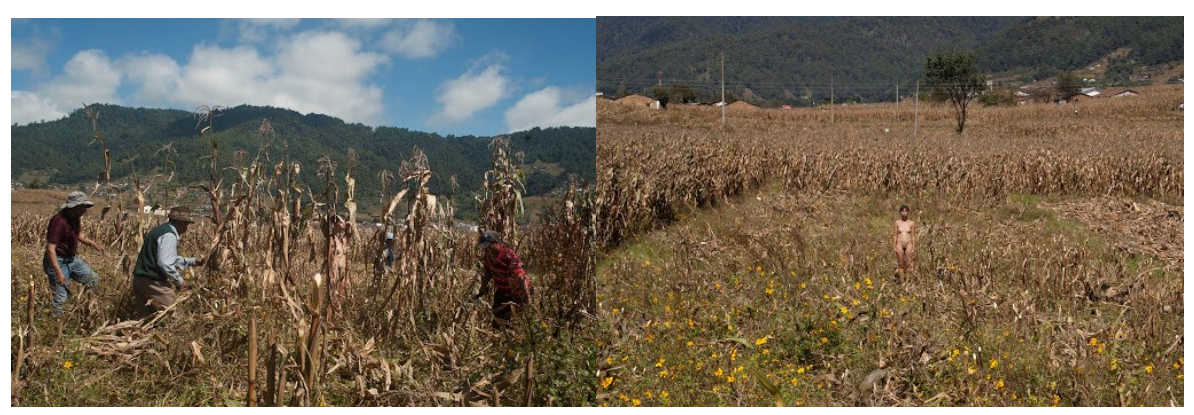

Imagen 86. Mazorca, performance, Totonicapán, Guatemala. Regina José Galindo, 2015. Fuente: reginajosegalindo.com Imagen 87. Mazorca, performance, Totonicapán, Guatemala. Regina José Galindo, 2015. Fuente: reginajosegalindo.com

La obra de Galindo muestra la relevancia que tiene el maíz en los guatemaltecos y guatemaltecas, siendo un cultivo que forma parte de su identidad y situándose como el principal sustento de la población. La artista también hace referencia a la guerra de Guatemala, donde se cortó y quemó el maíz como parte de la estrategia militar para acabar con las comunidades indígenas, pero el pueblo resistió y firmó la paz en 1996. Galindo, realiza una simbiosis con la resistencia del pueblo, en su performance se mantiene desnuda, firme y erguida en medio de un maizal mientras cuatro hombres cortan todo el maíz con machetes (imagen 86 y 87). Su trabajo elude a la fortaleza del pueblo indígena que a pesar de las debilidades que puedan tener frente al ejército o las leyes de las empresas, aguardan firmes, luchando por sus derechos, su historia y su cultura. La artista somete su cuerpo a 
situaciones extremas como reflejo de una realidad social dominada por el abuso y la injusticia.

\subsection{Lavado verde, la visión a través del arte documental y publicitario}

\subsubsection{Cuando la agroindustria se tiñe de verde}

Tras todas las cuestiones que se han ido viendo a lo largo de este capítulo y los movimientos que se han generado en contra de las grandes empresas de la agroindustria, cabe destacar el momento en que estas se adueñan de una estética más verde en sus campañas con tal de seguir vendiendo sus productos y calmar a las masas. Estas prácticas, llamadas greenwashing o lavado verde, son realizadas por dichas empresas con potentes campañas de marketing que resultan engañosas para la población. Empresas como Monsanto-Bayer, disponen de mucho capital y de gran visibilidad publicitaria. La artista Asunción Molinos en su proyecto WAM (Museo de Agricultura Mundial) muestra clara e irónicamente cómo dichas empresas tienen mayor visibilidad que el pequeño y mediano agricultor/a.

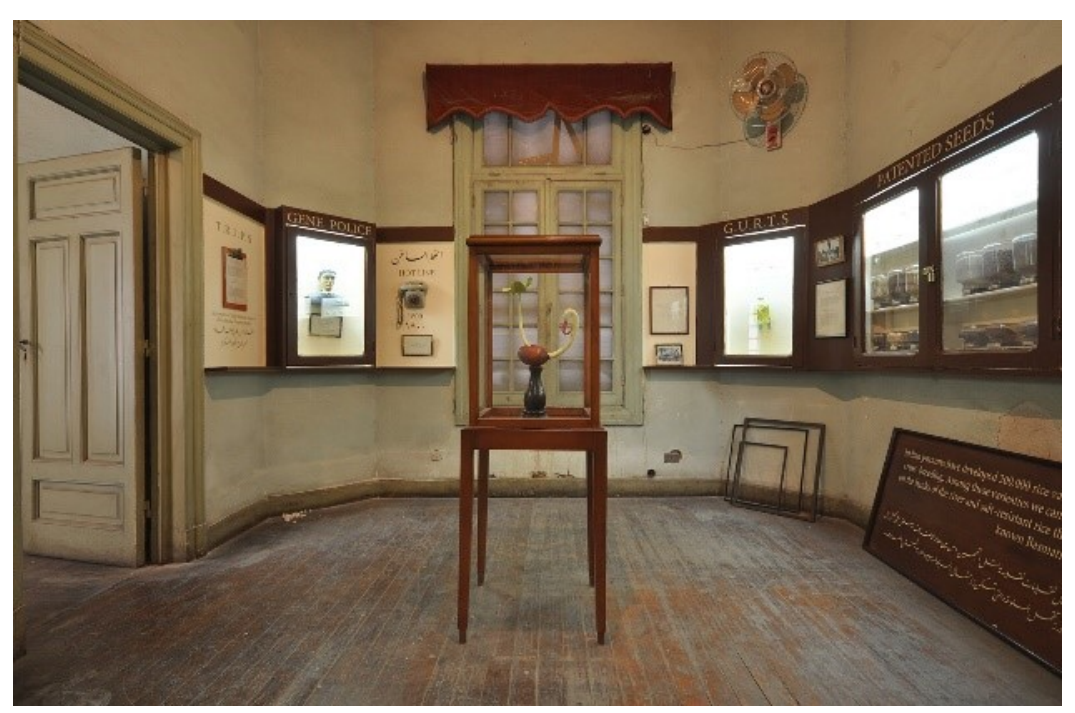

Imagen 88. WAM (Museo de Agricultura Mundial), vista instalación. El Cairo, Egipto. Asunción Molinos, 2010. Fuente: asuncionmolinos.com 
Molinos es Licenciada en Bellas Artes por la Universidad Complutense de Madrid (España), vive y trabaja entre Egipto, Omán y España. Realizó la citada instalación en el contexto del programa The Townhouse Gallery con motivo de la XXI Bienal de Arte Contemporáneo, contando con el apoyo de la Embajada de España en Egipto y Matadero Madrid. La propuesta de la artista versa principalmente sobre la introducción de la biotecnología en la producción de alimentos, tras un exhaustivo estudio de la situación agrícola Asunción Molinos creó una narrativa donde introdujo todo tipo de información proveniente de empresas agroquímicas, científicos, campesinado, organizaciones como la FAO y publicidad.

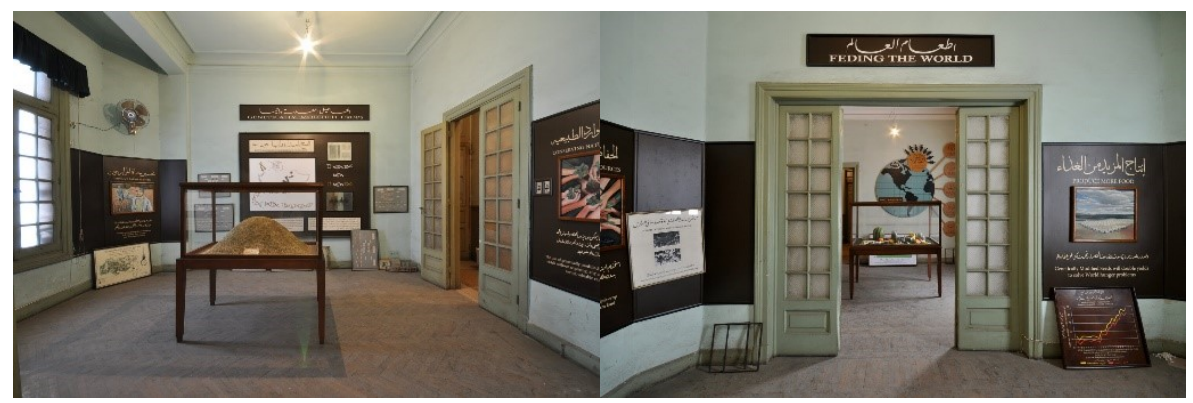

Imagen 89. WAM (Museo de Agricultura Mundial), vista instalación. El Cairo, Egipto. Asunción Molinos, 2010. Fuente: asuncionmolinos.com

La información, muy dispar entre sí, fue organizada con un cierto desorden premeditado a lo largo de seis habitaciones. En primer plano, en lugares privilegiados y con gran visibilidad se podía observar la información proveniente de las agroquímicas, su visión de prosperidad agrícola a través de las mejoras genéticas, el mensaje que le llega a la población. En cambio, en un segundo plano, en el suelo y apoyados sobre las paredes se disponía la situación del campesinado, las realidades del campo y el posible futuro que nos espera si se siguen con las patentes, los agroquímicos y, finalmente, con el modelo neocolonial agrícola. Molinos dispuso la información en concordancia con la visibilidad real de la misma. Además, generó un ambiente con una estética propia de un antiguo museo agrícola con carteles 
pintados a mano, dibujos a carboncillo y abundante madera. La disposición de los elementos, su vertiente pedagógica y la cantidad de información dispar entre sí, lleva al espectador a la realidad que se vive actualmente en el sector agrícola donde se presentan cuestiones contradictorias e incluso falsedades y publicidad engañosa. Es por ello por lo que la artista también hace uso de la ironía para tratar según que cuestiones como la de las patentes de semillas (imagen 90 y 91 ).

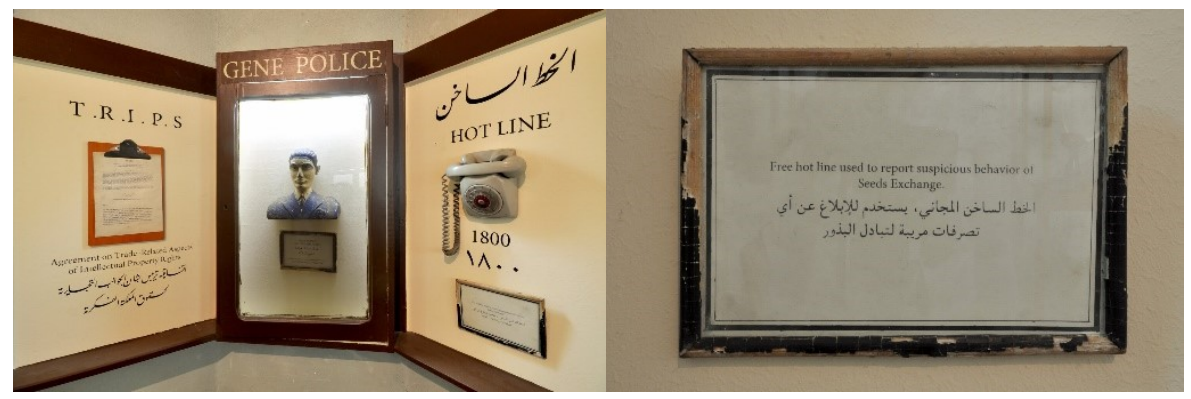

Imagen 90. WAM (Museo de Agricultura Mundial), vista obra de la instalación. El Cairo, Egipto. Asunción Molinos, 2010. Fuente: asuncionmolinos.com Imagen 91. WAM (Museo de Agricultura Mundial), detalle obra imagen 88. El Cairo, Egipto. Asunción Molinos, 2010. Fuente: asuncionmolinos.com

En estas imágenes podemos observar a modo de parodia la metodología utilizada por las empresas de las agroquímicas con sus patentes, donde sus propios empleados han de hacer de policías buscando las posibles semillas patentadas que se hayan sembrado en campos que no estén pagando los royalities. También, recrea la llamada que realizan estas empresas al propio campesinado para que avisen si sospechan de campos sembrados con las semillas patentadas que no hayan firmado contrato.

Finalmente, la obra de Asunción Molinos nos introduce en una realidad muy dispar, donde resulta complejo detectar la veracidad de la información. Tal y como se muestra en la instalación, las empresas agroquímicas se sitúan en un lugar privilegiado dentro del sector agrícola, invierten ingentes cantidades de dinero en sus campañas publicitarias y son capaces de persuadir a la 
población. Es por ello por lo que nos planteamos, ¿qué ocurre cuando las empresas agroquímicas nos venden sus productos con palabras como natural, verde, eco, orgánico o biodegradable? La población compra esos productos confiando en el mensaje que les ofrece la empresa, seguros de que adquieren productos que no serán dañinos para la biosfera.

En el segundo apartado de este capítulo vimos cómo Monsanto fue capaz de vender su producto a base de glifosato, el Roundup, como biodegradable, hasta que fue denunciado y obligado por la justicia a eliminar ese engañoso mensaje (apartado 2.2. Agrotóxicos: el Roundup y el arte que lo cuestiona). Pero, hasta entonces, ingentes cantidades de glifosato fueron vertidas al medio ambiente por personas que pensaban que adquirían un producto biodegradable. ¿Dónde queda la ética y la veracidad en la publicidad de estos productos? ¿Nos situamos en un punto en el que todo vale con tal de aumentar las ventas de un producto, aunque este sea extremadamente dañino y no se esté informando de ello?

\subsubsection{La propaganda corporativa a través de la obra de Kirsten} Stolle

La obra de la artista estadounidense Kirsten Stolle se basa en la investigación de la publicidad corporativa, la política alimentaria y la biotecnología. Trabaja el collage, el dibujo y la instalación para cuestionar la práctica de las empresas agroquímicas, sus productos y sus comunicaciones. La artista se centra en analizar cómo estas empresas publicitan su propia imagen y sus productos curándose de ocultar su pasado. Así pues, hace uso de la propia publicidad de empresas como Bayer-Monsanto y Dow Chemical para deconstruirla, detectando los mensajes engañosos y dando la oportunidad al espectador de tomar conciencia de las estrategias de estas empresas para embellecer y ecologizar sus productos. A través de las piezas de Stolle se observa el lavado verde persistente en la historia de las citadas agroquímicas, visibilizando cómo se apropian de una imagen verde, próspera, moderna y sostenible para seguir aumentando sus ventas y, por tanto, sus ingresos. 
Por lo tanto, entre su extenso repertorio de obras destacamos aquellas que se exhibieron en una de sus últimas exposiciones individuales realizada en Nome Gallery, Berlín, 2020. Dicha muestra abarcaba las obras de Stolle que se han centrado especialmente en analizar la imagen pública y la retórica de la empresa Bayer-Monsanto. Las piezas se centran en la estrategia publicitaria empleada por la agroquímica a lo largo de su historia. La artista analiza al detalle cada frase e imagen, así como las estrategias de marketing lanzadas por dicha empresa. En la imagen 92 podemos observar una de las obras que se mostró en la exposición, Pesticide pop, es una serie de diez impresiones de archivo pigmentadas y enmarcadas.

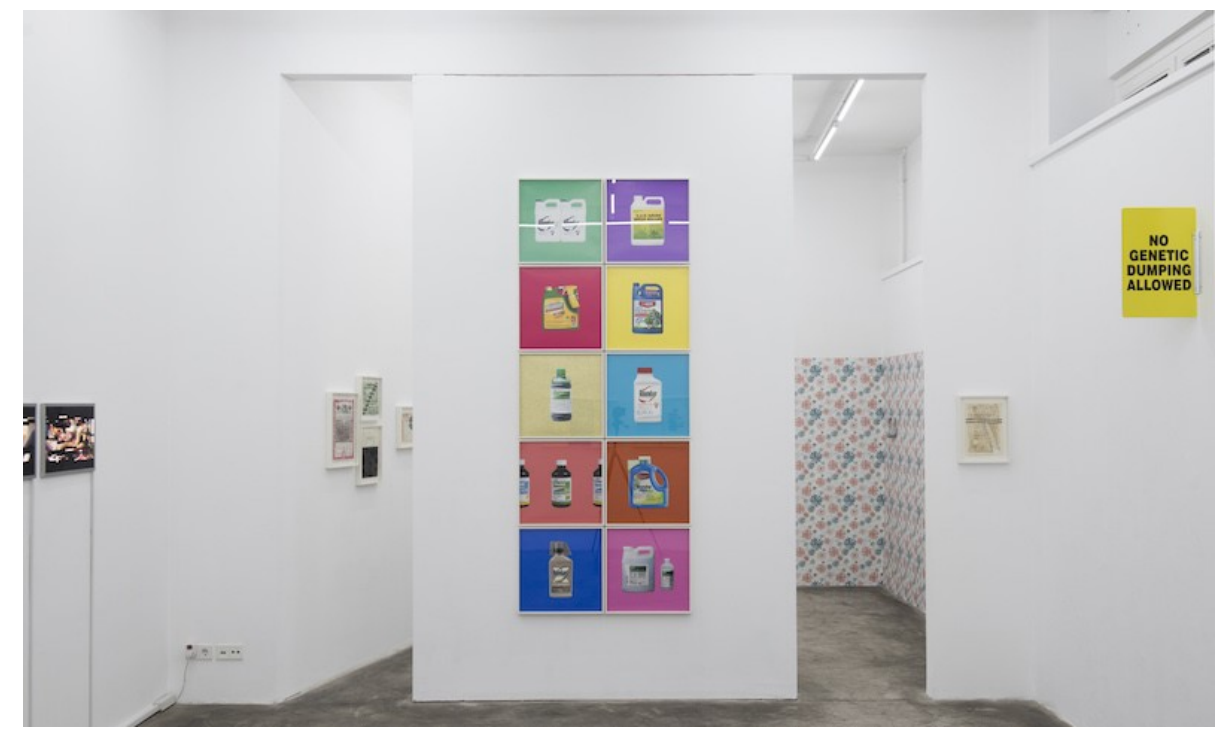

Imagen 92. Pesticide pop, vista obra en exposición. Gallery Nome, Berlín. Kirsten Stolle, 2020. Fuente: kirstenstolle.com

Stolle muestra los envases donde Bayer-Monsanto comercializa sus pesticidas como una muestra de obras de arte pop. Como si un juego de sátira y glorificación se tratara, la artista enmarca en estallidos de color los tóxicos comercializados por la agroquímica, llevándolo a lo absurdo. Como hemos visto en los anteriores apartados, productos como el glifosato han 
causado innumerables intoxicaciones, enfermedades y muertes; aun así, se sigue publicitando y vendiendo rodeado de llamativos colores y potentes letterings como si de un producto beneficioso y de progreso se tratara. Otra de las obras expuestas que cabe destacar es It's time (imagen 93 y 94).

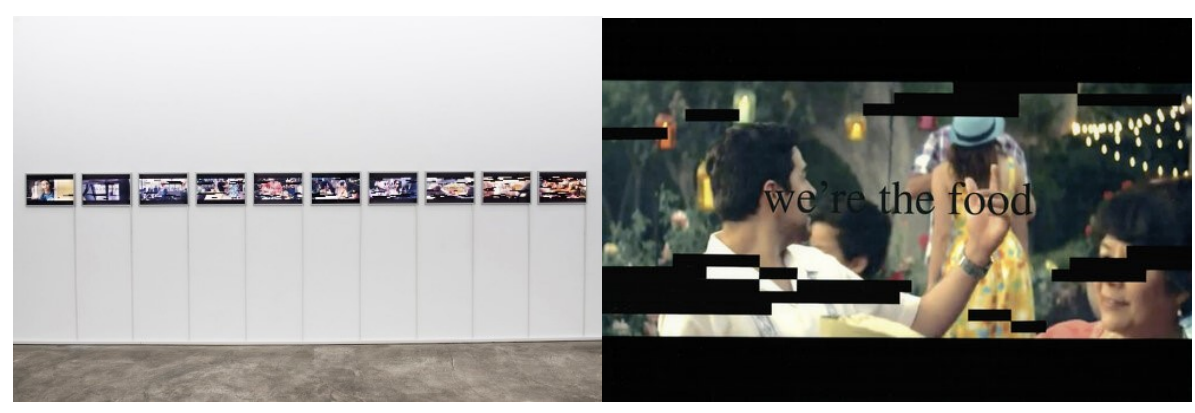

Imagen 93. It's time, vista obra en exposición Gallery Nome, Berlín. Kirsten Stolle, 2020. Fuente: kirstenstolle.com Imagen 94. It's time, detalle obra en exposición. Gallery Nome, Berlín. Kirsten Stolle, 2020. Fuente: kirstenstolle.com

En esta pieza la artista se centra en desgranar un anuncio que emitió Monsanto en el año 2014. En dicha publicidad la empresa mostraba escenas con abundante comida, sensaciones de felicidad, progreso y modernidad, en definitiva, una serie de arquetipos que buscan esconder la verdadera realidad de la producción de alimentos. Así pues, Stolle, realizó diez capturas de pantalla y las colocó en cajas de luz. Según avanza la secuencia seleccionada por la artista aparecen más zonas negras que hacen alusión a palabras y hechos censurados. Asimismo, cada captura muestra una serie de palabras extraídas del audio original del anuncio que al verlas fragmentadas generan una nueva narrativa, It's done - this is the best part-when we talk about what's going on - more and more - we are the food - at Monsanto - working everyone using more - it's time. Monsanto, en la publicidad lanza un mensaje de la necesidad de más comida para una población creciente y al mismo tiempo se muestra como una empresa que sigue trabajando y haciendo uso de los recursos naturales de una forma eficiente. Stolle, desmonta su anuncio plagado de arquetipos que lo posicionan en un claro lavado verde y ofrece el 
real objetivo de la empresa: más consumo, más mercantilización y más ganancias.

Siguiendo en la misma línea de investigación destacamos la pieza No Risk to Public Health (imagen 95), la artista se centró en analizar un anuncio publicado por Bayer en 2019 donde defendía el uso del glifosato remarcando que no había riegos en la salud.

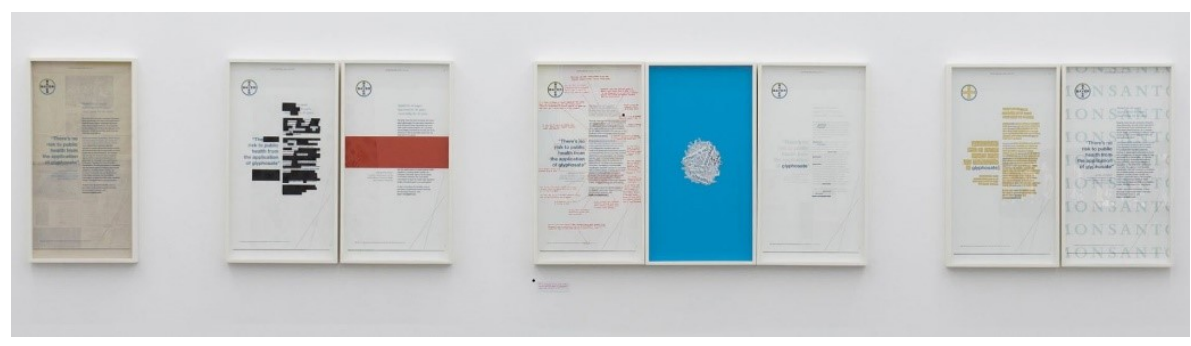

Imagen 95. No Risk to Public Health, vista obra en exposición. Gallery Nome, Berlín. Kirsten Stolle, 2020. Fuente: kirstenstolle.com

Stolle muestra el anuncio tal cual apareció publicado en el New York Times y seguidamente expone seis intervenciones que realizó sobre dicho anuncio. Bayer defiende el glifosato a pesar de las evidencias científicas de la toxicidad de dicho producto, es por ello por lo que la artista se dedica a suprimir palabras del texto dejando en evidencia frases como "el glifosato es cancerígeno", también cortando palabras y generando un collage o señalando anotaciones a modo de corrección del texto. En la misma línea se muestra la obra Revolutionary control corner, donde el espectador se coloca unos auriculares para poder escuchar unos audios que han sido previamente editados a partir de fragmentos de una publicidad sobre pesticidas emitida en la década de los 40 por el Departamento de Agricultura de Estados Unidos. En definitiva, Stolle pretende generar una nueva narrativa que revise el histórico de la empresa, resaltando las evidencias científicas y los casos de intoxicación que han producido productos cómo el glifosato. Con sus obras muestra las contradicciones que presentan las agroquímicas tanto en sus formas de proceder como en la imagen que pretenden ofrecer a la población. 
La línea de trabajo de Stolle desvela las estrategias que son capaces de utilizar estas empresas con el único fin de continuar su modelo productivo y aumentar su capital, evidenciando cómo la preocupación por la salud y el medio ambiente en empresas como Monsanto parece desaparecer.

\subsubsection{La lucha desde el activismo y la estética asociada}

Las grandes empresas agroquímicas se apropian de estrategias artísticas y de marketing para publicitar sus productos, potenciar las ventas y crear su imagen ante la población, pero también grupos activistas utilizan esas mismas estrategias con tal de informar de las prácticas nocivas de dichas empresas, luchando por proteger la Tierra y sus habitantes. Por ejemplo, se suele hacer uso de la framing theory (teoría del encuadre) donde, conscientes de que las personas creamos marcos de lenguaje o filtros emocionales que se vinculan al sentido que le damos a todo aquello que nos rodea y al cómo nos comunicamos, estudian cómo será presentada la información sobre la realidad que pretenden mostrar. La investigadora María Luisa Azpíroz en su artículo Maíz transgénico vs agricultura ecológica: un análisis del discurso de Greenpeace México en torno a la seguridad alimentaria, la soberanía alimentaria y el derecho a la alimentación (2007-2017), se basa en la teoría del framing para analizar el discurso de Greenpeace, en su caso concretamente en México. En el artículo destaca que,

Según Benford y Snow (1988), los frames de acción colectiva (en los que se situaría el discurso de Greenpeace) tratan de movilizar potenciales seguidores para obtener apoyo de los testigos y desmovilizar a antagonistas. Estos autores explican que el proceso de framing tiene tres funciones principales: diagnóstico, pronóstico y motivacional. La función diagnóstico incluye la descripción de la situación problemática actual, así como la atribución de culpa o causalidad. La función pronóstico incluye la descripción de qué debería hacerse. La función motivacional incluye una llamada a la acción o lógica para implicarse en una acción meliorativa o correctiva (Azpíroz, 2019: 7).

De tal forma, en primer lugar, se plantea el problema, en segundo lugar, la posible vía de actuación-solución y, en tercer lugar, el llamamiento a actuar. Siguiendo con la organización de Greenpeace destacamos su lucha en contra 
de los transgénicos, por ejemplo, con el maíz modificado genéticamente. El diagnostico nos plantearía la problemática de la introducción en los cultivos y el mercado de esta variedad modificada, así como las leyes y los mecanismos políticos que favorecerían esta situación. Pudimos ver en apartados anteriores la situación de lucha en México por la posible introducción de variedades de maíz transgénico que contaminarán las variedades nativas, encabezada por el artista Francisco Toledo. La función pronóstico nos informaría de las actuaciones realizadas como denuncias por la siembra de transgénicos, presentación de estudios e investigaciones que avalen la situación problemática presentada en el diagnóstico y muestra de caminos viables como el apoyo a la agricultura ecológica, campesina y el consumo de variedades nativas. Finalmente, la función motivacional, nos llevaría a la participación en la acción colectiva haciendo mayor fuerza con tal de conseguir las posibles soluciones.

En ese contexto de problemática, solución y actuación nos situamos en señalar las estrategias artísticas utilizadas por los activistas que les sirven de apoyo e imagen de sus discursos. Organizaciones como Greenpeace hacen uso de llamativas ilustraciones, imágenes y letterings, así como de performances colectivas para generar un fuerte impacto en la sociedad con sus discursos.

En la imagen 96 podemos observar una intervención realizada por Greenpeace en medio de un cultivo de maíz. La ejecución del símbolo en el maizal mexicano apoya su discurso en contra de los transgénicos. Asimismo, la realización de símbolos e ilustraciones en los campos de cultivo es una práctica muy utilizada por los colectivos artísticos, como podremos observar en el tercer capítulo de esta investigación. Por otra parte, en la imagen contigua se muestra la presentación de una pancarta colocada en la fachada de un edifico donde se puede observar la imagen de una mazorca de maíz unida a una bomba, siguiendo con la defensa del maíz nativo y con el rechazo al modificado genéticamente. Las actuaciones de Greenpeace buscan llegar al máximo público posible con un discurso claro y eficaz y, para ello, es necesario la utilización estratégica de símbolos e imágenes que capten la 
atención del espectador. Es por ello por lo que hemos querido resaltar la importancia de las estrategias artísticas en el discurso activista como potenciador del mismo.

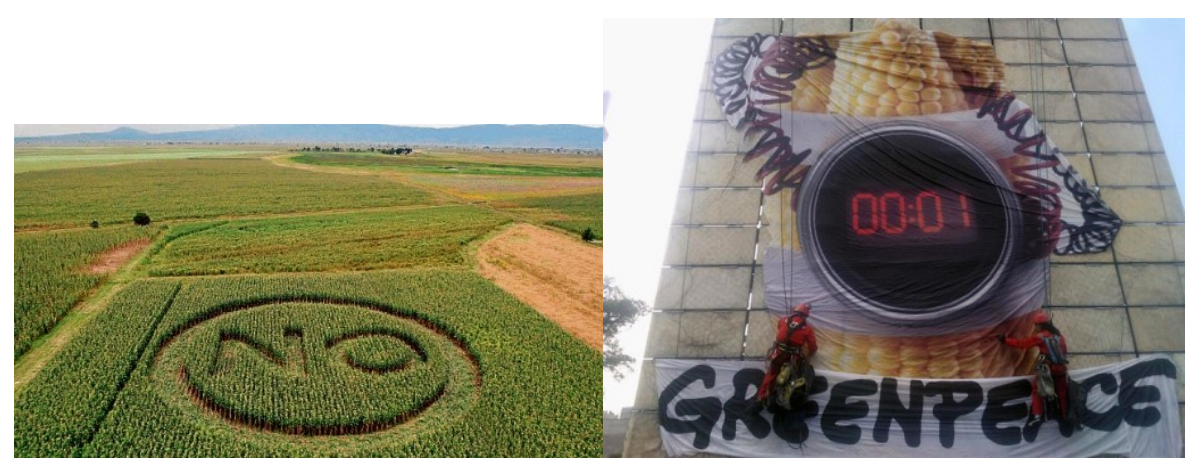

Imagen 96. NO, intervención de 60 metros de diámetro. Maizal transgénico, México. Greenpeace, 2007. Fuente: archivo-es.greenpeace.org Imagen 97. Manifestación en Estela de la Luz, México. Greenpeace, 2013. Fuente: ecoosfera.com

También cabe destacar las acciones realizadas en la vía pública con previo llamamiento a los activistas. Siguiendo prácticamente las mismas pautas de actuación realizan concentraciones con la intención de presionar, en el caso que nos ocupa, para que se haga efectiva la prohibición de los transgénicos. En las siguientes imágenes podemos observar dos acciones realizadas con el mismo fin, pero en países diferentes. En primer lugar, se observa la acción realizada enfrente del Ministerio de Agricultura de Madrid (España), donde un grupo de activistas vestidos con monos de un llamativo naranja presentan pacíficamente pancartas en contra de los transgénicos junto a una tonelada de maíz modificado genéticamente ensacado y con la imagen de una calavera. Además, los activistas escalan las vallas, cuelgan pancartas y se encadenan entre ellos. Todo está previamente calculado y coordinado entre ellos y ellas para hacer llegar su mensaje y presionar al ministerio, los llamativos colores, los letterings, los símbolos y sus posiciones. Finalmente, 
todo quedó retratado en imágenes y vídeos que sirvieron para seguir haciendo presión desde otros medios.

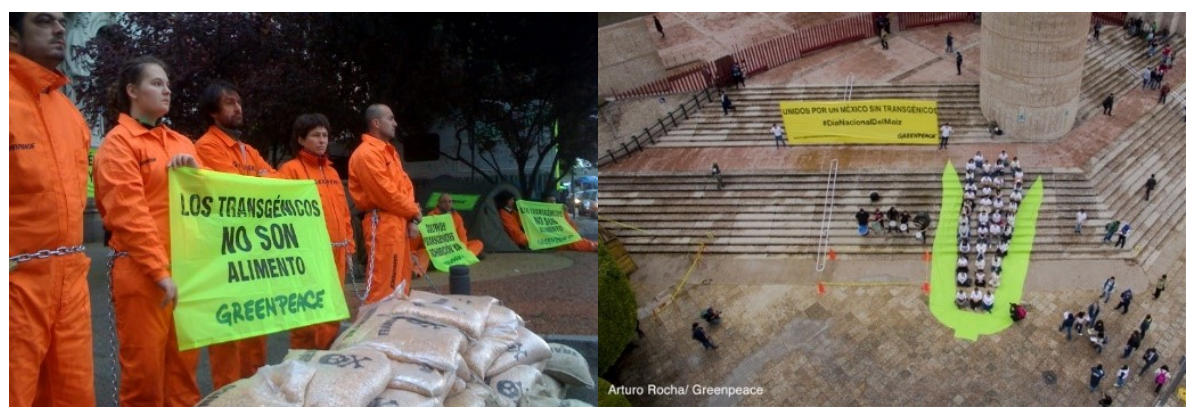

Imagen 98. Di no a los transgénicos, acción. Ministerio Agricultura, Madrid. Greenpeace, 2010. Fuente: greenpeaceblong.wordpress.com Imagen 99. Unidos por un México sin transgénicos, acción. Consejo de la Judicatura Federal, México. Greenpeace, 2015. Fuente: efe.com

En la imagen 99 podemos observar otra acción de Greenpeace en contra de los transgénicos, pero en México. Del mismo modo que en la acción recién comentada, utilizan el posicionamiento premeditado del personal participante, así como los colores y los textos con tal de crear escenas e imágenes potentes que transmitan fácilmente su mensaje. Si bien las acciones e intervenciones de Greenpeace no estarían consideradas ni pensadas como una pieza artística como tal, sino que más bien se apropian de las estrategias del arte contemporáneo para potenciar sus discursos, hemos considerado relevante destacar este tipo de actuaciones por la importancia que se le da a la creación de imágenes, acciones y símbolos como parte indispensable del mensaje. Con ello citamos la reflexión del docente e investigador José Albelda en su capítulo Arte y ecología. Aspectos caracterizadores en el contexto del diálogo arte-naturaleza del libro Arte y ecología,

Podríamos hablar simplemente de acciones creativas con una estética cercana a los posicionamientos artísticos, buscando complementar el mensaje ecologista directo que por redundancia puede llegar a perder interés. Es por ello 
que no tiene especial sentido tratar el arte de vocación ecologista independientemente de las demás acciones y colectivos que trabajan en dicha línea. Pero si procede destacar la utilidad de las sinergias con la creatividad artística por su capacidad simbólica, sus estrategias de alta empatía y su contribución a la concreción temática de las ideas que se pretenden comunicar (Albelda, 2015: 233).

Si bien consideramos que las sinergias creadas por los colectivos activistas con la creatividad artística y sus discursos han sido capaces de conseguir cambios importantes, como la suspensión de la siembra de maíz transgénico que se consiguió en 2013 como medida precautoria a raíz de la acción colectiva presentada. Además, cabe resaltar la gran labor colectiva donde se unen campesinos, abogados, científicos, artistas, intelectuales, agricultores, activistas y organizaciones civiles por un mismo objetivo, la defensa del maíz nativo.

\subsubsection{La visión de la agroindustria desde el documental/videoarte}

En este apartado hemos considerado relevante destacar el trabajo que se realiza desde el audiovisual proyectando discursos que cuestionan la agroindustria. Como señala la docente e investigadora Lorena Rodríguez en su capítulo Audiovisuales y discurso ecosocial: de la casa a la intemperie del libro Arte y ecología,

En una sociedad inundada de imágenes en el espacio público y privado -donde lo audiovisual ya no es una actividad exclusiva de las grandes empresas de la industria cultural, sino que forma parte de la vida cotidiana- se hace indispensable que los movimientos ecologistas tengan una vertiente audiovisual (Rodríguez, 2015: 165).

Así pues, el campo audiovisual es un importante medio para personas de diferentes ámbitos que pretenden hacer llegar cuestiones que no suelen ser tratadas por los medios de comunicación generales. Por ejemplo, en el caso que nos ocupa, las problemáticas ocasionadas por los transgénicos y los químicos que se utilizan en sus cultivos no suelen ser expuestas en noticieros o programas televisivos mediáticos. Por tanto, el uso del audiovisual para tratar estos temas puede ser un óptimo recurso de denuncia de las 
situaciones que se están viviendo en países como Argentina. El investigador y periodista Patricio Eleisegui, citado al principio de este capítulo, hizo uso de este recurso para lanzar el documental La Frutilla del Postre: el caso Arroyo Leyes, tratando la situación de Argentina. Eleisegui tras sus investigaciones, publicación de libros y denuncias de la situación con la soja transgénica denunció en 2019 otro cultivo que parece repetir los mismos patrones, la producción de fresas. En esta ocasión se eligió el formato audiovisual en abierto por internet, de este modo en poco tiempo consiguió hacer llegar su mensaje y denuncia a innumerables espectadores de diferentes países.

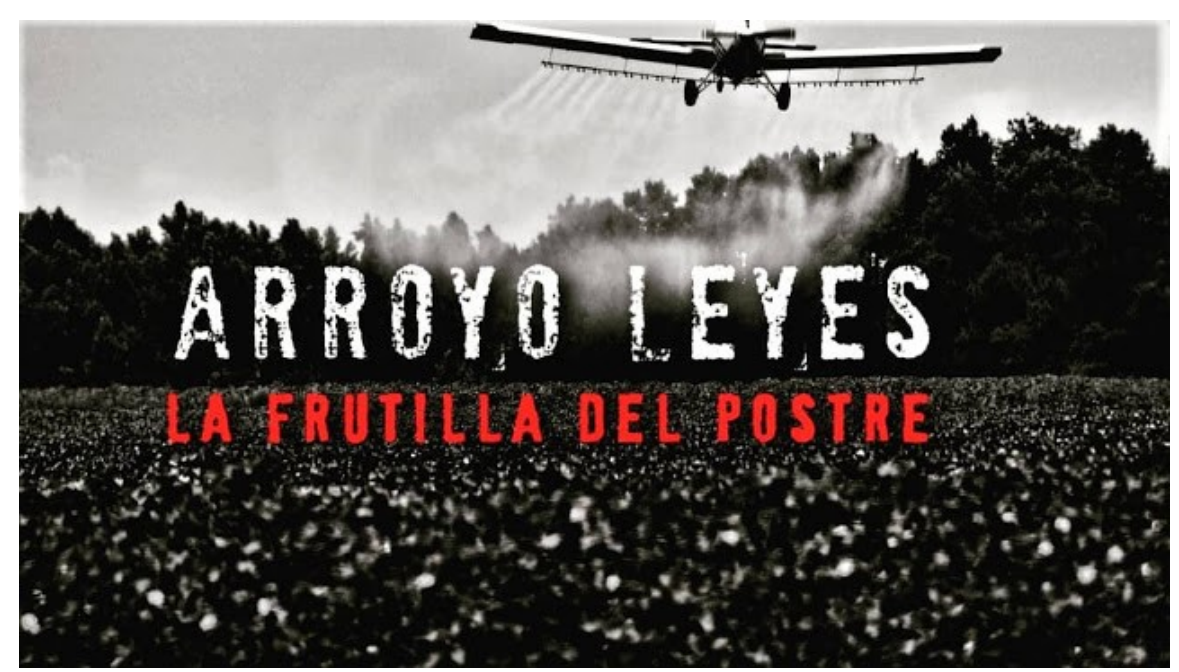

Imagen 100. La Frutilla del Postre: el caso Arroyo Leyes, portada del documental. Patricio Eleisegui, 2019. Fuente: laretaguardia.com

Del mismo modo, producciones audiovisuales que se pueden visionar en abierto en la red, Hambre de soja (2007) o El mundo según Monsanto (2008) facilitan el acceso a sucesos concretos de una forma clara, sencilla y empática. En Hambre de soja, el director Marcelo Viñas trata la problemática de la soja transgénica que hemos visto al principio del capítulo, los daños irreparables en la biodiversidad, la contaminación, el aumento de la desocupación, hambrunas, indigencia y problemas de salud son tratados a 
través de entrevistas y casos reales, donde las imágenes y los relatos impactan en el espectador y potencian su empatía. En El Mundo según Monsanto, la directora Marie Monique Robin realizó el documental tras la publicación de su libro bajo el mismo título, en dicho audiovisual Robin ofrece tramos de las entrevistas que realizó, llamadas, búsquedas en internet, artículos e información que encontró de la empresa Monsanto y sus productos. Robin llegó a mayor público difundiendo la misma información por dos vías distintas, el libro y el audiovisual.

Así pues, en todos los documentales que hemos citado, consideramos que la imagen unida al relato y a la experiencia de las personas participantes potencia el mensaje siendo un recurso eficaz de denuncia. Sin embargo, a veces, este tipo de documentales con imágenes y situaciones catastróficas suelen generar desaliento y tristeza en el espectador, ocasionando su nula actuación o rechazo ante tales circunstancias por el desánimo generado. Es por ello por lo que resulta importante destacar los audiovisuales que abarcan una mirada hacia posibles soluciones y no solo se centran en la situación problemática. En ese sentido, destacamos el documental A Farm for the Future (Una Granja para el futuro) producido por Rebecca Hosking en 2009. La directora y protagonista narra en primera persona su proyecto de vida en el que decide regresar a la granja familiar para hacerse cargo de ella, en Devon, Inglaterra. Hosking cuenta las problemáticas derivadas de la gran cantidad de combustibles fósiles que necesita para el mantenimiento de la granja, como la necesidad de cada vez mayores cantidades de energía, el encarecimiento de los recursos fósiles y la contaminación que producen. Tras varias investigaciones y asistencia a ponencias acerca del fin de los recursos fósiles, se plantea encontrar otros modos de producir que no se alimenten de tales cantidades de combustibles fósiles y conseguir una granja de bajo consumo energético que sea sustentable en el tiempo y futuro que nos esperan. Para ello, contacta con reconocidos investigadores y permacultores, los cuales le comparten sus experiencias, estudios y técnicas de cómo han conseguido tener una granja sustentable de baja energía y cómo es posible llegar a ello basándose en el estudio de los procesos de la propia naturaleza. El enfoque que toma el documental aportando casos reales de otros modos 
de producir que se pueden sustentar en el tiempo y son equilibrados con el entorno, da una luz de esperanza al espectador que está visionando el audiovisual y está tomando conciencia de las dificultades a las que nos estamos enfrentando y a las problemáticas que están ocasionando los modos de producir actuales, basados en el capitalismo y en el consumo exponencial de combustibles fósiles.

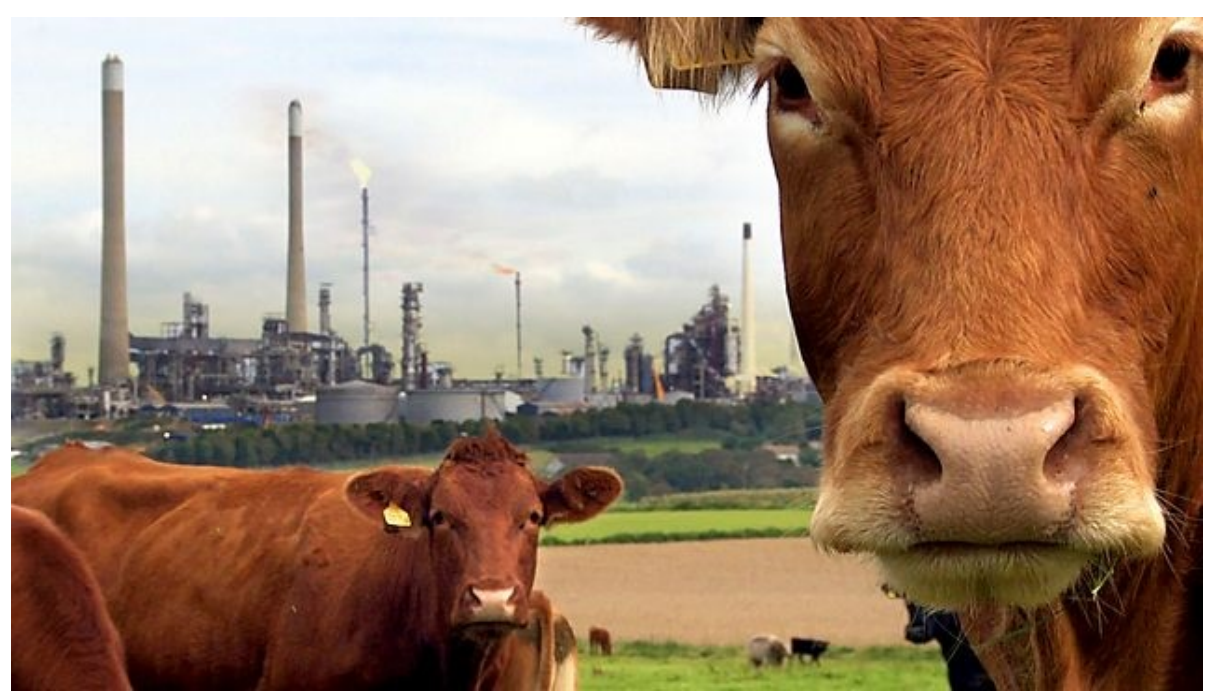

Imagen 101. A Farm for the Future, frame del documental. Rebecca Hosking, 2009. Fuente: bbc.co.uk

Del mismo modo que consideramos importantes las aportaciones positivas y que muestren posibles vías de actuación hacia una producción de la alimentación que se sitúe en equilibrio con la biosfera, también entendemos la relevancia de audiovisuales que muestren su visión desde la sátira o el humor. En un punto en el que nos invaden las imágenes y audiovisuales con temas catastróficos y apocalípticos, el espectador puede llegar a colapsar provocándole desazón e incluso optando por desviar la atención de dichas problemáticas, buscando una omisión del sufrimiento por desconocimiento. Es por ello por lo que destacamos audiovisuales como el realizado por los 
dibujantes, actores y cómicos españoles Carlos Areces y Joaquín Reyes. Dos tomates y dos destinos es un cortometraje que sensibiliza al espectador sobre la agricultura ecológica.

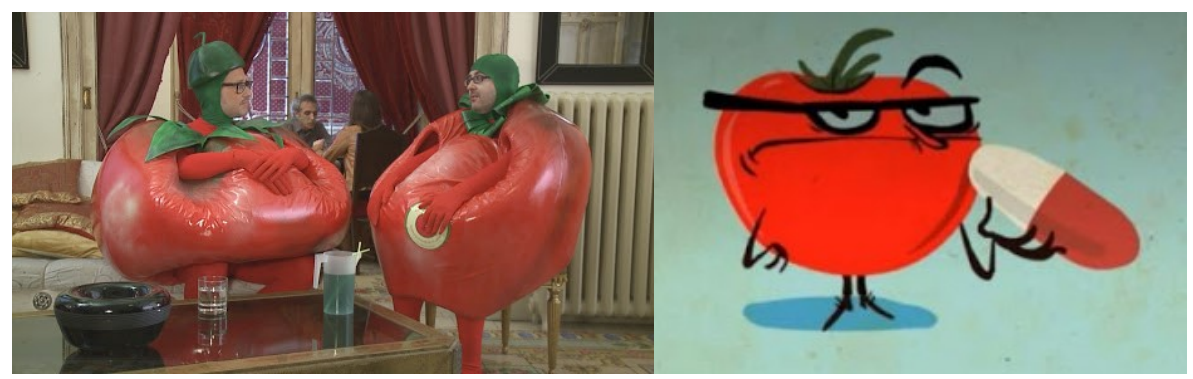

Imagen 102. Dos tomates y dos destinos, frame del cortometraje.

Carlos Areces y Joaquín Reyes, 2012. Fuente: youtube.com Imagen 103. Dos tomates y dos destinos, frame del cortometraje. Carlos Areces y Joaquín Reyes, 2012. Fuente: masteragroalimentario.es

El audiovisual lo protagonizan dos tomates que se citan en un bar tras haberse conocido por un chat en internet, uno de procedencia ecológica llamado Mauricio y otro de producción transgénica llamado K-44 (imagen 102). La escena transcurre en una cafetería donde dialogan dos tomates, visualizándose de una forma clara, sencilla y llamativa la forma tan diversa de la producción de cada uno. Para ello no solo se sirven de la ironía y el humor, sino también de cortas animaciones que aparecen en pantalla acompañando la historia de cada tomate (imagen 103). La combinación de la escenografía, la sátira y las coloridas animaciones resultan ser efectivas a la hora de captar rápidamente la atención del espectador. El cortometraje transmite una situación real, compleja y actual como es la diferencia de dos modelos de producción agrícola, los transgénicos y la producción ecológica, de una forma muy cómica. Además, al generar risa se libera dopamina, endorfina y oxitocina, que sitúan al espectador a analizar el planteamiento del audiovisual desde un estado neuroquímico cerebral placentero. 


\subsection{Conclusión capítulo}

A lo largo del capítulo se ha ido planteando la situación que ha provocado un sistema agrario basado en el capitalismo y el consumo exponencial. Se evidencia cómo, bajo el mantra de la Revolución Verde, las agroquímicas han vendido sus packs tecnológicos cambiando las formas de cultivar con el único afán de producir más, vender más y consumir más. Asimismo, se ha podido comprobar cómo el arte es un potente medio para cuestionar y visibilizar las prácticas de la agroindustria. Sobre todo, en las obras artísticas que sacan a la luz las consecuencias del agronegocio y dan voz a colectivos vulnerables que carecen de medios para comunicar y denunciar las situaciones en las que se encuentran.

De tal forma, a lo largo del estudio se ha detectado que los proyectos artísticos que proceden de artistas o colectivos que han tenido un previo contacto con la situación agrícola suelen ser más relevantes y continuados en el tiempo. Por ejemplo, los creadores o creadoras que mantienen un recuerdo de vivencias pasadas y/o presentes que se sitúan en un ambiente familiar y agrícola, como el artista mexicano Francisco Toledo que dedicó sus últimos nueve años de vida al trabajo de sus obras en contra de los transgénicos.

También resulta relevante destacar la gran variedad de técnicas, formatos, materiales y creaciones que se han mostrado para visibilizar la agroindustria y las atrocidades que ha llegado a causar. Abordando desde la contaminación que ha producido dicha industria a las consecuencias sanitarias, ambientales y sociales de las prácticas abusivas que han llevado a cabo, todo ello visto desde la escultura, la pintura, el mural, la intervención en el territorio, la performance, el audiovisual y la fotografía. Además, se han utilizado espacios tanto públicos como privados, interiores y exteriores con mayor o menor relevancia para la exposición de las obras. Toda esa diversidad creativa y expositiva es esencial para hacer llegar al mayor número de espectadores posibles las situaciones que se derivan de un modelo de 
producción agrícola basado en el incremento de beneficios de unas pocas empresas transnacionales.

Las obras son creadas por artistas o colectivos que empatizan con las situaciones que viven los pobladores rurales y utilizan sus recursos y experiencia artística para llevar estas problemáticas al mundo del arte. Por tanto, se han observado perfiles muy diversos, por una parte, artistas consagrados con gran trayectoria que reciben remuneración económica por su trabajo y pueden exponer en espacios de especial relevancia, llegando a un tipo de público que pueda estar alejado de estas circunstancias por habitar en grandes ciudades y desconocer la situación que se vive en las zonas rurales. Si bien, las obras expuestas en estos espacios pueden quedar como un suceso esporádico, ser visibilizadas por un sector reducido de la población y no trascender de una forma generalizada. Por otra parte, se han citado creaciones de artistas que pueden tener menor trascendencia en los círculos artísticos, pero suelen poseer una gran empatía por los sucesos de los que han tomado conciencia y sienten la necesidad de comunicarlo por el medio que mejor saben expresar, el arte. Utilizando espacios públicos, abiertos y zonas exteriores, buscando un impacto directo con la población, denunciando y visibilizando las situaciones provocadas por los agroquímicos y los transgénicos sin que la obra se conciba como un producto de mercado del arte. Además, en ocasiones realizan su trabajo de forma desinteresada o a cambio de una remuneración simbólica. Con ello también queremos destacar que, en ocasiones, la situación de precariedad que vive el artista empatiza con la situación también precaria del campesinado, siendo una vía de conexión para el trabajo colaborativo entre ambos.

Hemos demostrado, igualmente, que los documentales y videos son un medio de difusión pública muy importante gracias a su posible difusión viral en internet, y que su narrativa audiovisual genera un alto nivel de empatía, tanto en estructuras clásicas de narrativa documental, como en escenificaciones más creativas y/o irónicas de video-ficción. Asimismo, hemos ilustrado cómo las estrategias artísticas, sobre todo las vinculadas al land art, se han utilizado en el ámbito del ecologismo en ambiciosas 
campañas mediáticas como las de Greenpeace contra los transgénicos, a modo de ejemplo de la idea ampliada de arte público.

En el próximo capítulo se destacarán los principales modelos de producción agrícola sustentable y los proyectos artísticos que se han dedicado a ensalzarlos, visibilizarlos, elogiarlos y difundirlos. Ofreciendo los posibles caminos para un cambio en la producción alimentaria que se sitúe en equilibrio con la biosfera y sus habitantes. 




\section{CAPÍTULO 3}

AGRICULTURA SUSTENTABLE Y SU MANIFESTACIÓN A TRAVÉS DEL ARTE

A lo largo de este capítulo contemplaremos algunos tipos de agricultura sustentables desde el punto de vista artístico. Como hemos visto en el anterior capítulo, la agricultura industrializada con sus monocultivos, abonos de síntesis y pesticidas ha ganado mucho terreno en las últimas décadas, ocasionando graves consecuencias en la biosfera y sus habitantes. Dadas estas situaciones se dio la necesidad de acuñar el concepto de agricultura sustentable, una práctica agrícola que contemplase el ámbito económico, social y ambiental, satisfaciendo las necesidades humanas presentes y futuras. Según la Organización de las Naciones Unidas para la Alimentación y la Agricultura (en adelante FAO), el enfoque para equilibrar estos aspectos se basa en cinco puntos clave:

1. Aumentar la productividad, el empleo y el valor añadido en los sistemas de alimentación.

2. Protegere impulsar los recursos naturales.

3. Mejorar los medios de subsistencia y fomentar el crecimiento económico sostenible.

4. Potenciar la resiliencia de las personas, de las comunidades y de los ecosistemas. 
5. Adaptar la gobernanza a los nuevos retos (FAO, 2018: 8).

Si bien son objetivos muy ambiciosos dada la situación de encrucijada en la que nos encontramos, cada vez es más notable el eco de estos propósitos en cualquier ámbito de estudio.

A lo largo de este capítulo citaremos y desarrollaremos brevemente algunos tipos de agricultura que englobamos dentro del modelo sustentable. Analizaremos el papel que juega el arte en el apoyo, la difusión y el fomento de estos modos de cultivar. Nos interesa una convivencia en armonía del ser humano con el medio ambiente donde la contemplación, el respeto y la preservación del hábitat sean los puntos clave. Para ello comentaremos distintos tipos de agricultura: tradicional/familiar/local/indígena, biodinámica, orgánica/biológica/ecológica, natural de no intervención y permacultura. Se verán y analizarán tanto proyectos que potencian la belleza innata del paisaje agrícola, como cualquier tipo de manifestación artística que pueda estar relacionada con estas formas de cultivar.

Algunas de las características comunes que comparte la agricultura sustentable y nos interesan en estos modos de hacer son:

- Alimentos que se producen sin abonos de síntesis.

- Carencia de organismos modificados genéticamente.

- Km. 0: se tiene en consideración el kilometraje del viaje de estos alimentos hasta llegar al consumidor.

- La menor carga de plásticos utilizada tanto en su cultivo como en su distribución para venta.

Además, a este listado de características que tomamos en cuenta de las prácticas agrícolas más sustentables, nos interesa sumar los siguientes aspectos que puedan concurrir en proyectos que combinen el arte con la agricultura:

- Utilización de recursos artísticos como la composición, la geometría y/o el color, tanto en los cultivos como en la difusión de estos. 
- Generación de talleres donde el arte actúe como canalizador para ayudar a comprender situaciones políticas, económicas y ambientales relacionadas con la agricultura.

- Creación de obras artísticas de gran tamaño en el campo agrícola con fines lúdicos y educativos, así como enriquecedores para el propio proyecto de agricultura sustentable.

- La obra artística como muestra de la cultura agrícola en el espacio expositivo, dándole visibilidad desde otros contextos como el museo, la galería, los centros culturales o ferias.

Una vez contextualizadas las diferentes prácticas agrícolas sustentables en las que nos vamos a centrar, veremos proyectos donde se contemplen dichos aspectos artísticos. Cabe señalar que la permacultura también entra dentro de ese listado de agricultura sustentable. Pero, en este capítulo solamente la citaremos y ubicaremos en el contexto de las demás, ya que hemos querido hacer hincapié en esta filosofía destinándole un capítulo completo de la investigación. Nuestra intención es mostrar la importancia de tomar en consideración los principios de la permacultura dada la situación ecosistémica en la que nos encontramos actualmente.

\subsection{Aproximación a conceptos y modelos de cultivo agrícola sustentable}

\subsubsection{Agricultura tradicional, familiar, local o indígena}

Este apartado lo hemos querido dedicar a esa agricultura que lleva innumerables años desarrollándose en nuestras tierras a base de experimentación empírica y campesina. Existen diferentes estilos de trabajo agrícola, los cuales pueden variar según las condiciones climáticas, la ubicación, la época o la situación sociopolítica, entre otras cosas. Si bien las formas de cultivar tradicionales, familiares, indígenas o locales, según queramos ubicarlas y denominarlas, han aportado alimento a la humanidad a lo largo de décadas de una forma sustentable y garantizando las cosechas de las generaciones futuras. 
El conocimiento de la tierra se ha pasado de generación en generación, ha sido un aprendizaje constante. El agricultor o agricultora hacía del campo su vida, lo cuidaba con respeto, le proporcionaba nutrientes, trabajaba con sistemas cerrados y le daba descansos a la tierra.

Los sistemas de agricultura tradicional han surgido a través de siglos de evolución biológica y cultural, y representan experiencias acumuladas de interacción entre el ambiente y agricultores sin acceso a insumos externos, capital o conocimiento científico. Estas experiencias han guiado a los agricultores en muchas áreas del mundo en el desarrollo de agroecosistemas sustentables, manejados con recursos locales y con energía humana y animal (Altieri, 1991: 2).

Además, la larga trayectoria de la agricultura tradicional ha sido acompañada de rituales y creencias. Dependiendo de la zona geográfica, se utilizaban unos símbolos u otros, pero todo ello vinculado a la tierra, a su veneración, a los procesos de siembra, de riego, de recolecta o de descanso. Todos estos procesos culturales mantenían el equilibrio de los ecosistemas y fomentaban el respeto por la naturaleza.

La existencia de cultos y rituales agrícolas está documentada en muchas sociedades, incluso las de Europa Occidental. De hecho, estos cultos eran un foco de especial atención para la Inquisición Católica. Escritores sociales de la época medieval tales como Ginzburg (1983) han demostrado cómo las ceremonias rurales eran tildadas de brujería y cómo dichas actividades se convirtieron en focos de intensa persecución. Y no es sorprendente que cuando los exploradores españoles y portugueses de la post-inquisición emprendieron sus viajes y la conquista europea se extendió por el globo bajo el lema de «Dios, Oro y Gloria», como parte de un proyecto más amplio, existieran actividades evangelizadoras, las que a menudo alteraron las bases simbólicas y rituales de la agricultura en sociedades no occidentales. Estas modificaciones se transformaron, y a menudo interfirieron con la transferencia generacional y lateral del conocimiento agronómico local (Hecht, 1999: 16).

Según la geógrafa estadounidense Susanna B. Hecht, serían tres los procesos que ocasionaron la merma de los conocimientos agronómicos generados por grupos étnicos y sociedades no occidentales: 
(1) la destrucción de los medios de codificación, regulación y trasmisión de las prácticas agrícolas; (2) la dramática transformación de muchas sociedades indigenas no occidentales y los sistemas de producción en que se basaban como resultado de un colapso demográfico, de la esclavitud y del colonialismo y de procesos de mercado, y (3) el surgimiento de la ciencia positivista (Hecht, 1999: 15).

El avance de la ciencia, la tecnología y las sociedades de consumo, también restó importancia al conocimiento agrícola tradicional de las sociedades occidentales dando lugar a nuevas industrias agrícolas, así como al abandono de fincas tradicionales en plena producción. Sin embargo, cabe resaltar que llegaron otras prácticas agrícolas basadas en el estudio científico con la intención de fomentar una agricultura de enfoque sustentable, como la biodinámica o la ecológica. Si bien,

El «redescubrimiento» de la agroecología es un ejemplo poco común del impacto que tienen las tecnologías pre-existentes sobre las ciencias, donde, adelantos que tuvieron una importancia crítica en la comprensión de la naturaleza, fueron el resultado de una decisión de los científicos de estudiar lo que los campesinos ya habian aprendido a hacer (Kuhn 1979). Kuhn señala que, en muchos casos, los científicos lograron «meramente validar y explicitar, en ningún caso mejorar, las técnicas desarrolladas con anterioridad» (Hecht, 1999: 17).

Estos tipos de agricultura con menor recorrido pretendían y pretenden recuperar el conocimiento del campesinado, pero, además, surgen como una alternativa a una agricultura industrializada que cada vez cobra más fuerza.

\subsubsection{Agricultura biodinámica}

"El término biodinámico surgió a partir de ocho conferencias dadas por Rudoff Steiner en Pentecostés de 1924, en Koberwitz, Silesia" (Koepf, 2001: 3) Estas conferencias, fueron cursos sobre agricultura que se basaron en la antroposofía ${ }^{5}$, se contemplaban las leyes y fuerzas etéricas en la formación y

\footnotetext{
${ }^{5}$ Según la RAE: doctrina difundida por Rudolf Steiner a principios del siglo XX, según la cual el hombre pertenece a tres mundos, el del espíritu, el del alma y el del cuerpo, y tras la muerte el alma se une con el espíritu para reencarnarse en otras formas corporales.
} 
el crecimiento vegetal, así como las influencias cósmicas. Estos cursos iban dirigidos a campesinado experto, con la finalidad de complementar su conocimiento y que pudieran aplicarlo en sus campos.

Steiner concibe la granja como un organismo, donde tierra, vegetación, animales y humanos se unen generando un círculo cerrado. Además, para ser estructurada ha de ser sustentable, considerando como tal aquella que no necesite proveerse de abonos ni otras sustancias del exterior. Según Herbert Hans Koepf (1914-2007) director del Departamento Agrícola de la Sección de Ciencias del Goetheanum, Dornach (Suiza), Doctor en Agricultura y Doctor Honoris causa por la Universidad de Hohenheim, Alemania.

Se cuida la tierra, se abona con material orgánico, se alterna los cultivos, se observa cuidadosamente y se aplican tratamientos inocuos.

En realidad, el consejo de Rudolf Steiner estaba dirigido a situaciones definidas. Sugirió la idea de la necesidad de la autosuficiencia de las granjas para la zona templada y húmeda, donde desde tiempos antiguos la agricultura diversificada y con el ganado había sido la práctica habitual. La gran mayoría de ejemplos y la más amplia experiencia en el desarrollo de granjas biodinámicas han surgido en Europa y en las zonas templadas de otros continentes. Existe una rica variedad de tipos de granjas que se han desarrollado en el curso de varias décadas. A menudo surge la pregunta de si este método es adecuado también para otras zonas climáticas (Koepf, 2001: 11).

Además, en este tipo de agricultura se realizan una serie de preparados biodinámicos que "son distintos de los compuestos naturales y fisiológicamente activos [...] son sustancias en una condición que no se encuentra en la naturaleza" (Koepf, 2011: 6). Estas sustancias vegetales, animales y, en ocasiones, minerales se utilizan para el control de plagas o el crecimiento de las plantas, entre otras cosas. Sin embargo, es un estudio que no solo se basa en el retorno a los conocimientos ancestrales, sino que profundiza en la naturaleza para que las sustancias y las energías confluyan en la producción de alimentos de alto grado en nutrientes. Así pues, realizan una exhaustiva investigación de los elementos naturales con el fin de evolucionar las prácticas agrícolas tradicionales en nuevas formas de cultivar, 
concibiendo la granja como un organismo y mostrando atención a todas sus partes.

Así pues, uno de los métodos más conocidos de este tipo de agricultura es el Preparado 500, se realiza con estiércol de vaca procedente de granjas ecológicas y su elaboración nos acerca al ritual. Esta técnica consiste en rellenar cuernos de vaca con el estiércol y enterrarlos en una zona del cultivo para que maceren a lo largo del otoño e invierno. A finales de la primavera se desentierran y se esparce el contenido de los cuernos por las zonas de cultivo. Como resultado, se obtiene un suelo más vivo con el objetivo de que las plantas crezcan más sanas y con mayor vitalidad. La agricultura biodinámica está muy vinculada a la ecológica, siendo la finalidad de ambas trabajar la tierra de forma equilibrada, con productos orgánicos y evitando la utilización de fertilizantes de síntesis y pesticidas.

\subsubsection{Agricultura orgánica, biológica o ecológica}

Los sistemas de producción orgánica, biológica o ecológica parten de los mismos objetivos y características. Según la Unión Europea (Normativa Europea 834/2007), se establece que no hay diferencias entre estos tres conceptos. Simplemente son sinónimos, utilizados por diferentes zonas geográficas para denominar este tipo de agricultura, por ejemplo: el término orgánico en Reino Unido, el biológico en Francia y el ecológico en España o Alemania. Sin embargo, cabe señalar que, según la etimología, sí hay una diferencia entre la ecológica y las demás, aunque en la práctica no se matice. La biológica y orgánica hace referencia al cierra del círculo de la materia orgánica y la ausencia de abonos y plaguicidas de síntesis química, haciendo uso de métodos biológicos para el control de plagas y abonos orgánicos. En cambio, el concepto ecológico debería referirse además a la ausencia de plásticos agrícolas, a la gran disminución de la motorización de prácticas agrícolas con diésel, así como a la cadena de distribución de Km. 0. Es decir, calculando la huella ecológica de la producción. Así pues, una vez introducidos los conceptos señalamos que en este ensayo utilizaremos el término orgánico. 
Destacamos a Sir Albert Howard (1873-1947), nacido en Inglaterra y descendiente de una familia de agricultores, "se le considera el iniciador de la revolución de la agricultura orgánica y sus principales investigaciones se han realizado en la India" (Vanderlinde, 2018: 157). En 1943 publicó su libro titulado Un testamento agrícola, donde defendió el uso equilibrado de la tierra y la importancia del humus. En su investigación, Howard, estudio el trabajo agrícola de los campesinos y los consideró como sus profesores. Puso en valor la capacidad de los agricultores por conservar los nutrientes y la fertilidad del suelo mediante técnicas sencillas que garantizaban las cosechas de las generaciones futuras. En cambio, fue muy crítico con las praxis que provenían de investigaciones científicas con el uso de insumos químicos. Según el geógrafo e historiador Tarcísio Vanderlinde,

El hallazgo de Howard es que la investigación agricola ha convertido a los agricultores, no en productores de alimentos de mejor calidad, sino en hábiles saqueadores de los recursos naturales. La finitud del suelo y el uso depredador de los procedimientos "científicos" en la agricultura es un tema transversal en la obra del autor. Sin embargo, la investigación en la agricultura no se descarta por el autor, aunque defiende la antigua sabiduría campesina de tratar el medio ambiente en un procedimiento inteligente y sostenible. La investigación cualificada, basada en parámetros sostenibles, es aceptada y estimulada por el autor(Vanderlinde, 2018: 158)7.

La agricultura orgánica persigue y defiende la práctica agrícola que respeta los ciclos cerrados de la naturaleza, el compostaje, la calidad del humus, la asociación de cultivos y, en definitiva, la producción de alimentos sanos y nutritivos ahora y en el futuro. Howard, fue un precursor y defensor de la agricultura orgánica, sobre todo, tras su publicación de Testamento Agrícola,

\footnotetext{
${ }^{6}$ É considerado o iniciador da revolução da agricultura orgânica, sendo que as suas principais pesquisas se desenvolveram na Índia. Traducción realizada en DeepL.

${ }^{7}$ A constatação de Howard é a de que a pesquisa agrícola tem feito dos fazendeiros, não produtores de alimento de melhor qualidade, mas, sim, hábeis saqueadores dos recursos naturais. A finitude do solo e o uso predatório de procedimentos "científicos" na agricultura é uma temática transversal na obra do autor. A pesquisa na agricultura, contudo, não é descartada pelo autor, embora defenda a sabedoria milenar camponesa de trato com o ambiente num procedimento inteligente e sustentável. A pesquisa qualificada, fundamentada em parâmetros sustentáveis, é aceita e estimulada pelo autor. Traducción realizada en DeepL.
} 
pero han sido muchas personas las que también han defendido el uso equilibrado de la tierra desde diferentes puntos del planeta, bajo denominaciones distintas, en épocas distintas y enfoques diversos, pero todas con el mismo fin.

Desde Alemania, Hans Müller, María Müller y su amigo Hans Peter Rusch trabajaron en la agricultura orgánica bajo el término de organischbiologischer landba. En 1946 fundaron la primera cooperativa para la comercialización de alimentos orgánicos. Dada la situación de esos años, donde no importaba tanto la forma de cultivar sino la máxima producción para alimentar a una población que había sido devastada por la guerra, la aparición de nuevos movimientos preocupados por el medio ambiente y la ecología surgió a partir de los años 70.

Entre todas las asociaciones que contemplan la agricultura orgánica, queremos destacar la Federación Internacional de Movimientos de Agricultura Orgánica (IFOAM, por sus siglas en inglés). En 1972, cinco organizaciones de varias naciones reunidas en Versalles (Francia) fundaban esta federación en defensa de la alimentación orgánica. Un momento importante, donde diferentes naciones se organizaban por un bien común, defender la alimentación orgánica y sensibilizar sobre los peligros de la agricultura química.

IFOAM desafía el poder y la riqueza de las compañías de pesticidas y biotecnología. Es una disputa asimétrica y aunque los logros del sector orgánico hasta la fecha son grandes, la tarea que queda por delante es aún mayor (Paull, 2010: 100$)^{8}$.

8 IFOAM challenges the power and wealth of pesticide and biotech companies. It is an asymmetric contest and while the achievements of the organics sector to date are great, the task ahead is even greater. Traducción realizada en DeepL. 


\subsubsection{Agricultura natural de no intervención}

En los años 30, en Japón, empezaba la filosofía de Masanobu Fukuoka y su llamado Método Fukuoka. Sus formas de cultivar no tardaron en cruzar las fronteras y convertirse en referentes a nivel mundial tanto en la agricultura natural como en la permacultura. El señor Fukuoka estuvo trabajando durante años en su método de agricultura natural, escribió libros, artículos y fue entrevistado, pero en ese momento no se mostraba gran interés por su trabajo. La gran mayoría de agricultores japoneses se habían pasado a trabajar con el método de la industria química. Después de la Segunda Guerra Mundial los americanos introdujeron el pack de agricultura química en el mercado. Este método de cultivo fue bien acogido por la gran mayoría de los agricultores japoneses, pero el trabajo a través de abonos químicos de acción rápida acabó con el humus del suelo en una sola generación. "Para compensar la reducción en trabajo humano y animal, el nuevo sistema destruía las fértiles reservas del suelo" (Fukuoka, 1978: 6).

El trabajo en la agricultura natural, además de las tareas de siembra y cosecha, lleva una gran inversión de tiempo de observación y contemplación. Sus intenciones eran imitar a la naturaleza, acompañarla en sus procesos de vida y muerte, nutrir la tierra y realizar las mínimas tareas de intervención en los cultivos.

¿Qué tal si no se hace esto? ¿Qué tal si no se hace aquello? -ésta era mi manera de pensar-. Finalmente llegué a la conclusión de que no había necesidad de arar, ni de aplicar abono, ni de hacer compost ni de utilizar pesticidas. Cuando se profundiza en ello, pocas prácticas agrícolas son realmente necesarias (Fukuoka, 1978:12).

El hecho de trabajar la tierra observando los ciclos de la naturaleza y acompañando sus propios procesos, deja al ser humano en una posición de agente externo que se dedica a expandir semillas y cosechar. El agricultor o agricultora, es una persona pacífica que escucha la naturaleza para acompañarla en su desarrollo. Si bien, el propio medio natural ya está dotado de factores que potencian la fuerza de la vida, el crecimiento de las 
plantas, el control de las plagas, las cosechas sanas y la alimentación rica en nutrientes. Bajo la esencia de esta filosofía el agricultor o agricultora respeta los tiempos, fomenta la biodiversidad, es paciente y con un trabajo constante obtiene cosechas regulares, equilibradas y abundantes todos los años.

En el capítulo 2 hemos observado que la agricultura industrializada es todo lo contrario, busca la inmediatez y la mayor cosecha posible sin tener en cuenta la conservación del hábitat para las futuras cosechas. Se generan monocultivos que precisan de grandes inversiones de energía y químicos que empobrecen el suelo, pasando a ser más susceptibles de plagas y enfermedades, entre otros aspectos. Los campos de Fukuoka, situados en una pequeña aldea en la isla de Shikoku en el sur de Japón, no se han labrado en años y no se han utilizado ni pesticidas para el control de plagas ni abonos de síntesis. Aun así, las cosechas de Fukuoka son tan abundantes como en las explotaciones más productivas de Japón.

Para ello marcó cuatro principios de la agricultura natural:

1. No laboreo.

2. No utilizar abonos químicos ni compost preparado.

3. No desherbar mediante cultivo o herbicidas.

4. No dependencia de los productos químicos.

Según Fukuoka, estos principios "cumplen el orden natural y llevan al origen de la riqueza de la naturaleza” (Fukuoka, 1978: 20). Toda su investigación ha seguido estas líneas de pensamiento, "este es el núcleo de mi método de cultivo de hortalizas, cereales y cítricos” (Fukuoka, 1978: 20). En cambio, considera que la investigación moderna

divide a la naturaleza en pequeños pedazos y realiza experimentos que no se ajustan ni a las leyes naturales ni a la experiencia práctica. Los resultados se ordenan según la conveniencia del investigador, no de acuerdo con las necesidades del agricultor. Creer que estas conclusiones pueden utilizarse con éxito invariable en la parcela del agricultor es un gran error (Fukuoka, 1978: 31). 
Además, para Fukuoka es importante que las cuestiones de contaminación por productos químicos en la agricultura sean tratadas desde todos los ámbitos.

No es únicamente una cuestión que deban resolver los entomólogos. Filósofos, religiosos, artistas poetas deben también ayudar a decidir si es permisible o no el uso de productos químicos en la agricultura y cuáles pueden ser las consecuencias incluso de la utilización de abonos orgánicos (Fukuoka, 1978: 16).

\subsubsection{Permacultura}

Llamada también agricultura permanente, la Permacultura fue acuñada por Bill Mollison y David Holmgren a mediados de los 70 en Australia. Parten de unos principios éticos y de diseño para el manejo de la tierra, también se nutren del conocimiento de la agricultura biodinámica e incluso de la agricultura natural, pero la Permacultura va más allá conformando un sistema de diseño integral que abastece las necesidades humanas sin degradar los ecosistemas. Se contempla tanto el cuidado de la tierra como el cuidado de las personas y el compartir con equidad.

En sus comienzos Mollison y Holmgren en Permaculture One describieron la permacultura como un "sistema integral y evolutivo de especies de plantas perennes o perpetuas y de animales útiles al hombre" (Mollison y Holmgren, 1978: 7). Veinticuatro años después David Holmgren publicaba Permacultura, principios y senderos más allá de la Sustentabilidad donde proporcionaba

una definición más usual de la permacultura, que refleja la expansión del enfoque implícito en Permacultura Uno, es "diseño consciente de paisajes que imiten los patrones y relaciones encontradas en la naturaleza, mientras generan abundante comida, fibras y energía para satisfacer las necesidades locales." Las personas, sus construcciones y las maneras en que se organizan son de importancia central. Así, la visión de la permacultura como agricultura permanente o sustentable ha evolucionado a la de cultura permanente o sustentable (Holmgren, 2002: 45). 
Dada la importancia que consideramos que tiene esta filosofía al contemplar conocimientos ancestrales junto a la ciencia y sus avances, desde una perspectiva ética que fomenta la equidad y el cuidado de toda la biosfera y sus habitantes, hemos dedicado el siguiente capítulo de esta investigación a desarrollar más ampliamente este sistema de creación de asentamientos humanos sostenibles.

\subsection{Recursos artísticos en la difusión de la práctica agrícola sustentable}

En esta sección, el objeto de nuestra investigación se centra en la búsqueda de las estrategias artísticas que son utilizadas y contempladas, de forma intencionada o no, en la difusión de la agricultura sustentable.

Los aspectos artísticos han estado y están presente en la difusión de la agricultura, como hemos visto en el anterior capítulo las empresas transnacionales disponen de más recursos y, por ello, pueden tener personal dedicado únicamente al márquetin. Los proyectos que se fundamentan en una agricultura sustentable no suelen tener el tiempo o la economía suficiente para centrarse en estas cuestiones, por ello consideramos relevante el papel del artista en la creación de obras que promuevan estas prácticas. Así como, la importancia de trabajar en conjunto, agricultores/as y artistas.

Las obras que se han elegido en esta sección parten de esas líneas de pensamiento. Asimismo, están desarrolladas en diversas localidades de España y muestran un acercamiento a las zonas rurales. Nos hemos centrado en aquellas iniciativas que han surgido a lo largo del siglo XXI, que tienen un importante papel en la valoración de la práctica agrícola y en la difusión de la cultura rural de zonas en situación de despoblación.

\subsubsection{El arte urbano que ensalza la agricultura}

Los festivales que ofrecen la posibilidad de plasmar la creatividad de los artistas en grandes murales cada vez son más notables. En la población de Penelles, un municipio de España con poco más de 400 habitantes, se inició 
un certamen de arte urbano en 2016 que ha ido repitiéndose anualmente hasta la actualidad. El festival se titula Gargar, haciendo alusión al sonido que emite el pájaro Ganga Ortega que habita esas zonas y se encuentra en peligro de extinción. Sin embargo, la peculiaridad de este certamen anual versa en que todas las obras se centren en mostrar el mundo rural. De tal forma, el pueblo se sirve de la unión de la práctica artística y la vida rural para visibilizar su cultura y evitar caer en el olvido.

La población de Penelles, se está convirtiendo en un referente de arte urbano y rural. En cada edición se intervienen un total de 900 metros cuadrados de pared, llegando a alcanzar un total de cien murales en el año 2019. Además, su popularidad ha alcanzado un nivel internacional, atrayendo a artistas de países como Francia, Portugal, Inglaterra o Alemania. En la siguiente imagen podemos observar el mural realizado por el artista francés Harry James en la edición de 2018, mostrando una fusión entre la estética urbana y los animales que habitan en la zona.

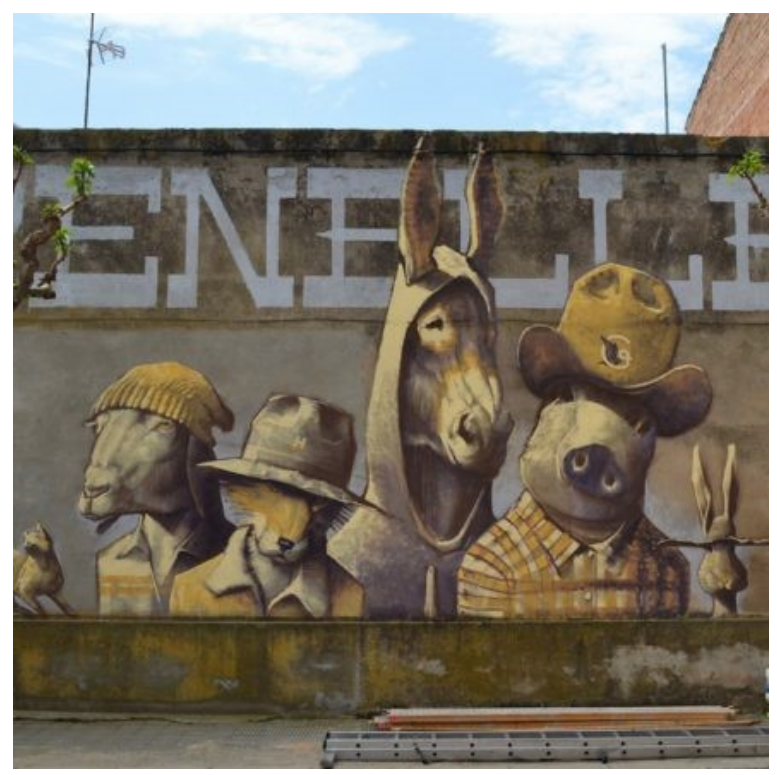

Imagen 104. Festival GarGaren Penelles, Harry James, 2018. Fuente: gargarfestival.com 
La organización del festival recoge fondos para el pago de los materiales, las grúas, el desplazamiento y la estancia de los participantes, en cambio no se contempla un pago en concepto del tiempo de trabajo del artista. Aun así, son numerosas las personas que se han presentado a las continuadas convocatorias con tal de mostrar su mirada de la cultura rural y aportar su semilla en la lucha contra la desaparición de las zonas agrícolas.

Para ilustrar, citamos al artista Miquel Wert, en cuyo mural se recrea una escena típica campestre con un toque de nostalgia, la obra fue pintada en escala de grises y se presentó en el certamen de 2017. La composición, el tratamiento de la luz y las sombras, así como las pinceladas nos recuerdan a las escenas captadas por cámaras fotográficas de los años cincuenta (imagen 105). Como exponen Cristóbal Gómez Benito y Emilio Luque Pulgar en el libro Imágenes de un mundo rural 1950-1980, "la España rural de los años cincuenta presentaba todavía todos los rasgos de una sociedad cuya actividad fundamental era la agricultura" (Gómez y Luque, 2006: 22).

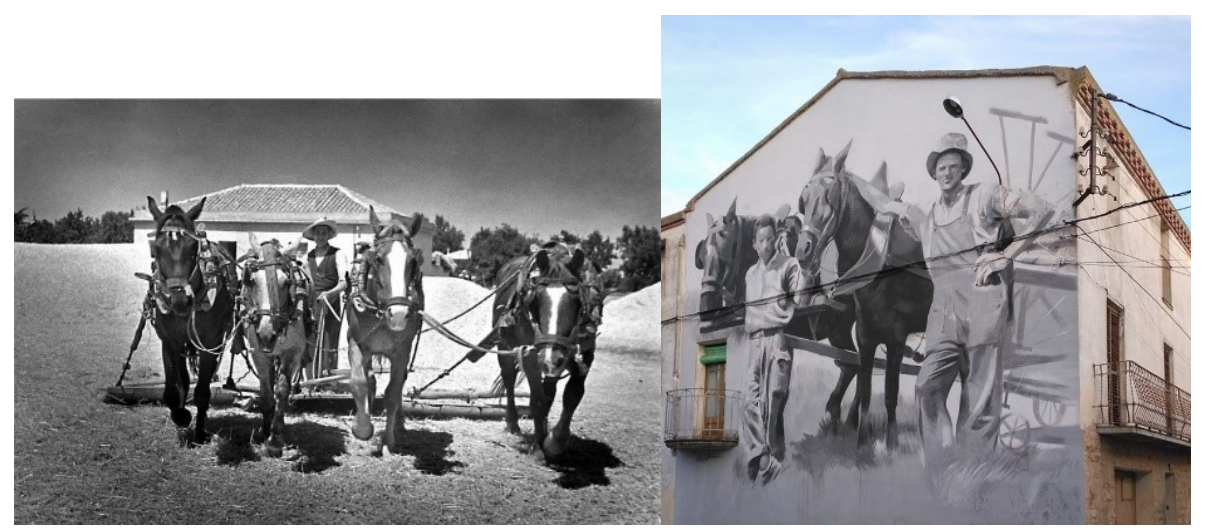

Imagen 105. Tracción animal, fotografía trillando en la era de Palencia, España. Felipe Sierra Calvo, 1954. Fuente: Imágenes de un mundo rural Imagen 106. Nostos, Festival GarGar en Penelles, España Miquel Wert, 2017. Fuente: miquelwert.com

Esta intervención junto a todas las que han ido cobrando vida en las paredes de la población han atraído la curiosidad de miles de personas, generando 
un nuevo motor social, cultural y económico en Penelles. En consecuencia, los festivales han ido albergando una envergadura mayor, realizándose otro tipo de dinámicas en el marco de dicho certamen. Además de la posibilidad de observar a los artistas en su proceso de creación, también se organizan actividades vinculadas a otras disciplinas artísticas como la música.

El éxito de estos festivales dio lugar a la primera residencia artística en la población, realizada por el artista francés Zeso WF. Este pintor participó en el Gargar de 2017, su trabajo junto a la experiencia como muralista en Nueva York le llevó a ser el primer artista en residencia de Penelles. Durante cuatro meses estuvo viviendo en la población para desarrollar quince obras que se expusieron en la Sala $B$, un espacio que se ha habilitado como sala de exposiciones. La muestra titulada New York Penelles dirigida por Binomic.cat en colaboración con PingPong Technologies, el Ayuntamiento de Penelles y la Diputación de Lérida, recrea una estética urbana y neoyorquina influenciada por los años que estuvo viviendo y pintando en la ciudad de Nueva York. En resumen, la implicación cultural de Penelles y su labor por difundir su tradición rural en los continuos festivales de Gargar, ha ocasionado un incremento en el interés por la práctica artística, contribuyendo a su difusión y generando nuevos motores económicos y sociales en la población.

Cabe destacar que la labor realizada por los habitantes de Penelles y su esfuerzo por potenciar la práctica artística y su cultura rural, también ha sido seguida por otras poblaciones del territorio español. Por ejemplo, en Cheste (Valencia) han imitado sus dinámicas generando el festival Graffitea, aunque en el caso de esta población no se centran en la temática rural, por ello no vamos a adentrarnos en dicha iniciativa.

Sin embargo, en la población de Fresnedillas de la Oliva, en la Comunidad Autónoma de Madrid, optaron de manera puntual por utilizar el arte urbano como vehículo para proyectar las historias del pueblo. En 2014 convocaron a artistas y creadores a presentar proyectos que dieran vida a las casas de piedra abandonadas de la población. La artista que resultó seleccionada fue Elena Parlange, realizó un mural en el centro del pueblo y ochenta y seis 
pinturas sobre tabla en ventanas y puertas de las casas en desuso. Las obras muestran la cultura y las tradiciones de la población, creándose una ruta llamada Casas con vida que guía al espectador en un recorrido por las distintas creaciones que la artista realizó en el pueblo.

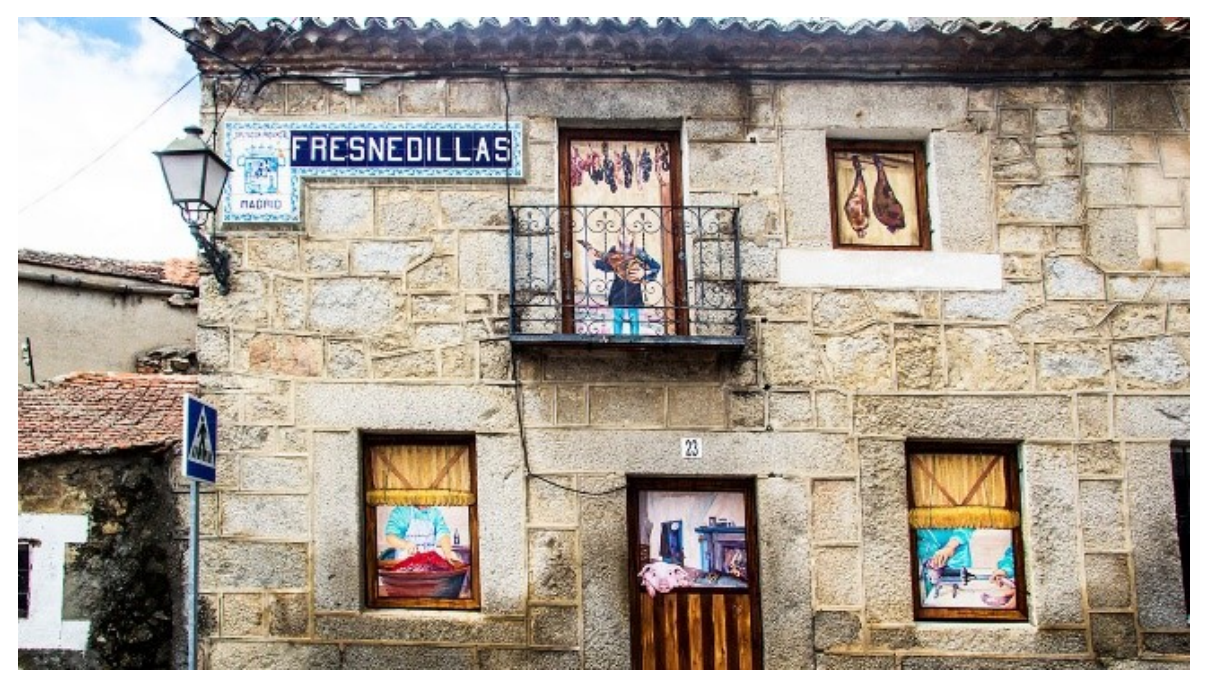

Imagen 107. Ruta Casas con Vida en Fresnedillas de la Oliva en Madrid, España. Elena Parlange, 2014. Fuente: elespanol.com

Con la misma idea de mostrar las tradiciones y la cultura rural, en 2016 emprendían proyectos de arte urbano en la población de Romangordo en Cáceres. Los artistas que trabajaron en esta localidad de apenas 300 habitantes lograron plasmar actividades diarias de los pueblerinos y, al mismo tiempo, revitalizaron fachadas, puertas y ventanas de edificios que se encontraban en un estado de conservación afectado por el paso del tiempo. Estas obras de arte han cautivado la mirada de miles de personas que se acercan a Romangordo con el fin de contemplarlas al mismo tiempo que recorren sus calles. 


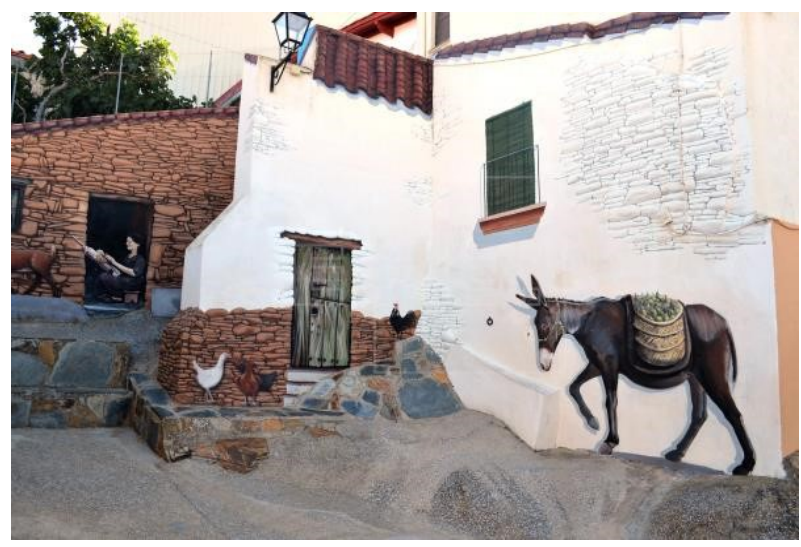

Imagen 108. Mural de Romangordo, imágenes que marcan la identidad de un pueblo, 2019. Fuente: efe.com

En síntesis, el trabajo del artista en estos proyectos resulta ser un potente motor de la actividad social y económica de las poblaciones rurales. Si bien estos lugares se encuentran afectados por el éxodo rural y su censo en bajada, estas obras recrean sus modos de cultivar y sus tradiciones haciéndolas perdurar en el tiempo. Además, son compartidas con el resto de la sociedad, se valora el trabajo del artista y el del campesinado. Sin embargo, se detecta que en ocasiones el trabajo del artista queda supeditado a una acción altruista o a cambio de algún galardón, siendo descompensado si se compara con la inversión de tiempo y trabajo del creador o creadora.

\subsubsection{Los murales de Joseba Murúzabal (España, 1984)}

En esta sección, siguiendo en la línea del mural, conviene enfatizar el trabajo del artista español Joseba Murúzabal debido a que sus obras se centran en el campesinado, concretamente en las mujeres que habitan las zonas rurales del norte de España. Este joven licenciado en Bellas Artes realizó una serie de pinturas tituladas Fenómenos do rural, unos lienzos donde el artista ensalza a la mujer campesina, la muestra como una heroína que ha hecho del trabajo en el campo su modo de vida. 
En la imagen 109 se observa una mujer de avanzada edad situada en equilibrio sobre el extremo de una azada. Así pues, el tratamiento del realismo de la pintura junto a la desproporcionalidad de la acción genera una escena impactante y llena de color. En 2016, tras presentar un proyecto en el contexto del festival Desordes Creativas en Ordes, A Coruña, Murúzabal cambió el lienzo por la pared, pintando su primer mural (imagen 110). A partir de ese momento el artista empezó a trabajar en murales de hasta quince metros en las zonas rurales de Galicia.

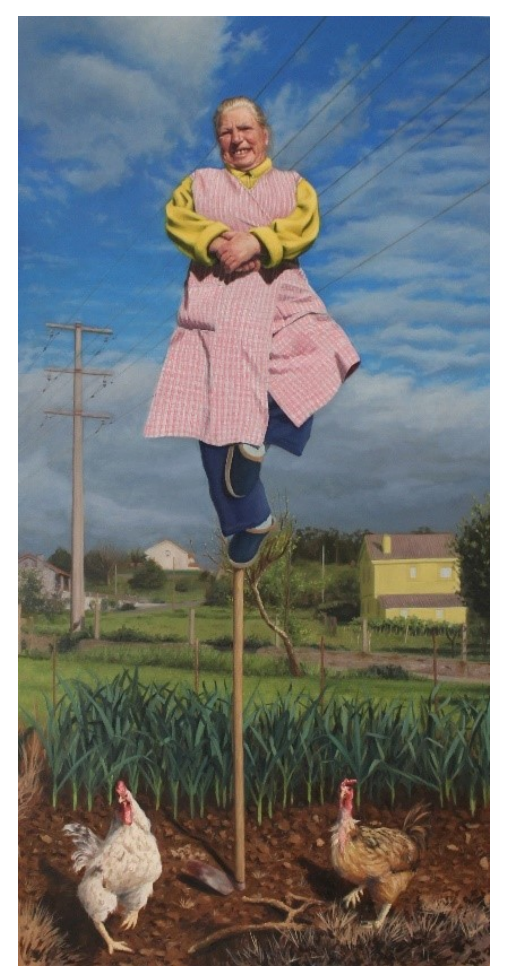

Imagen 109. Equilibrio na horta. Óleo sobre lienzo 240x110 cm, Murúzabal, 2016. Fuente: galeriametro.com

Cada una de sus obras lleva detrás una mujer real, Murúzabal entrevista a las mujeres campesinas que luego pintará, visita el lugar donde viven, invierte tiempo en estar con ellas y compartir historias. Tras la escucha de las 
experiencias y vida de las mujeres, el artista visualiza los poderes de cada una de ellas para mostrarlas como heroínas de ciencia ficción. En una entrevista del diario El Confidencial, el artista

enfatiza en el tema, en que la mujer rural no deja de trabajar, en que no se jubila de la azada y de la hoz porque su vida acostumbrada al trabajo no lo permite. "Nuestro rural está lleno de sexagenarias, septuagenarias y octogenarias con una energía y una fuerza fuera de lo normal" (Murúzabal, 2017: 2).

En la siguiente imagen podemos observar la obra de A greleira de 50 pies en Ordes, donde se muestra el super poder de Lola, una mujer de 91 años que sigue vendiendo sus grelos a la vera de la carretera cerca de Ordes en A Coruña.

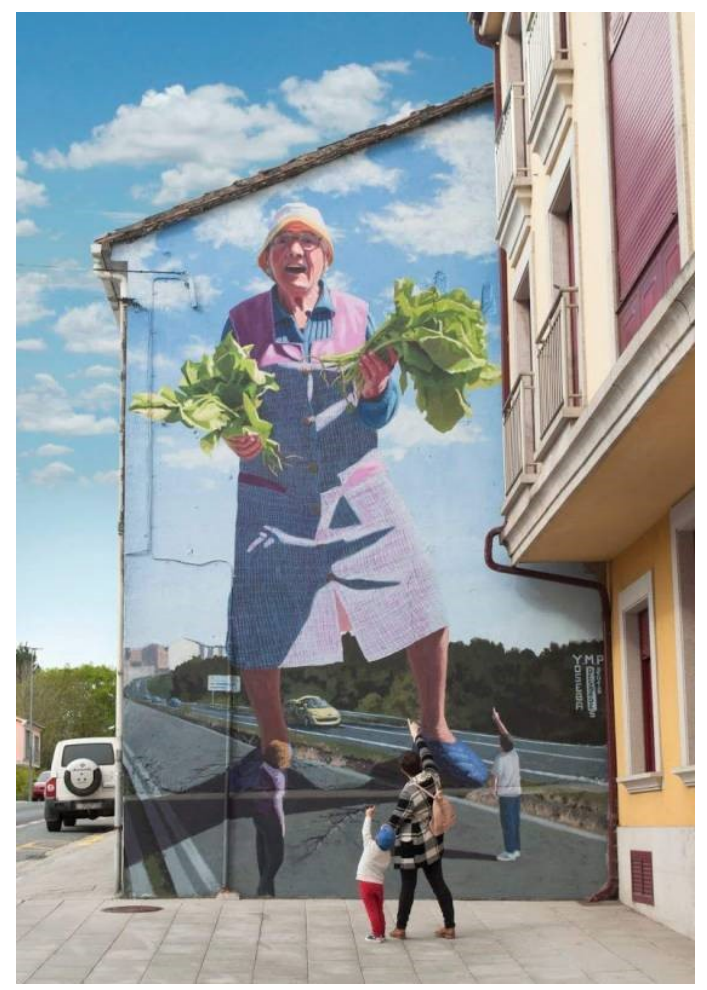


Las obras visibilizan unas mujeres reales, trabajadoras y luchadoras en una avanzada edad. La finalidad del artista es homenajear el trabajo y la energía inagotable de estas campesinas. Consideramos que el uso del humor unido al realismo de las pinturas y de las historias que albergan, generan una potente combinación para engrandecer el trabajo de las mujeres en el campo.

En una de sus obras de 2019, concretamente el mural ubicado en Santiago de Compostela, el artista hace un homenaje a una mujer que recientemente había fallecido. Se inspiró en la icónica escena de la película de Mary Poppins dirigida por Robert Stevenson y retrató a Soledad, una mujer muy conocida en el barrio de Sar. En suma, los murales realizados en estos contextos homenajean la labor del campesinado, resaltan las particularidades de cada cual y generan su propia identidad.

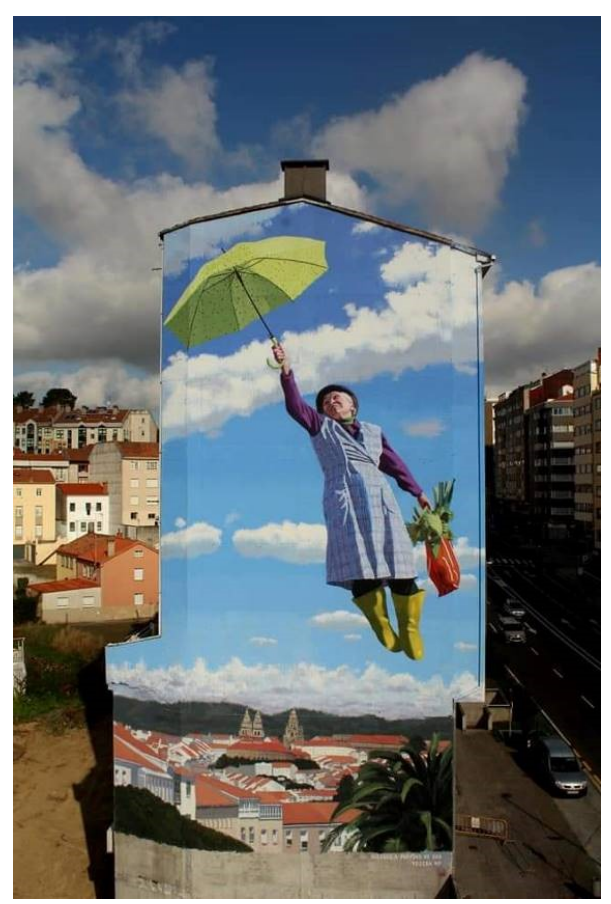




\subsection{Talleres artísticos en el contexto agrícola sustentable}

En esta sección, el objeto de investigación se centra en la búsqueda de artistas o colectivos que realicen talleres donde los recursos artísticos sean los vehículos para hacer llegar la cultura agrícola a la sociedad. Dentro del contexto de los diferentes modos de agricultura sustentable, la realización de talleres para contribuir en el aprendizaje de la comunidad es muy habitual.

Massanobu Fukuoka, en cada uno de los viajes que realizaba, compartía su conocimiento, sus técnicas de cultivo y su experiencia en la agricultura natural. El método más conocido es Nendo Dango, una vez recogidas, lavadas y secadas las semillas, explicaba cómo cubrirlas con la arcilla para hacer bolitas que posteriormente se esparcían por los campos. Fukuoka, en el documental Fukuoka's Natural Farm de abril de 1998, aparecía compartiendo dicho proceso con la comunidad. Primero secaban la arcilla y la molían hasta que fuera polvo, la pasaban por un tamiz para quitar los grumos y la materia orgánica. Luego mezclaban la arcilla con las semillas y echaban agua para ir amasando, hasta que desaparecían las burbujas y se generaba una masa. Las bolitas se hacían con las dos manos e iba quedando toda la semilla cubierta con una fina capa. Este proceso lo explicaba en su finca y en sus viajes, con el fin de compartir su técnica de siembra e ir sembrando nuevas semillas al mismo tiempo.

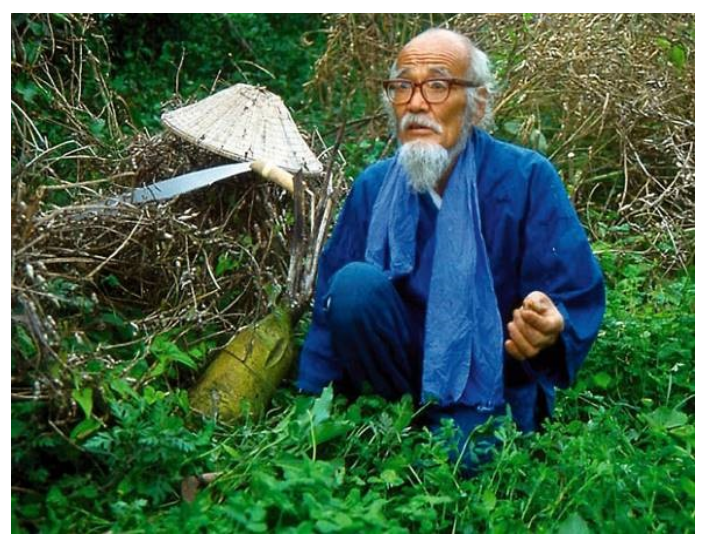

Imagen 112. Masanobu Fukuoka. Fuente: www.elpais.com 
Al recubrir las semillas con una fina capa de arcilla, ni los pájaros ni los insectos podían comérselas cuando se esparcían por el campo, quedando más segura la siembra. Las bolitas no se entierran, se esparcen y con las primeras lluvias empiezan a germinar de una forma más segura. Fukuoka fomentaba este proceso como un juego, jugando a ser niños, a tirar semillas.

Consideramos que las dinámicas que se generan con el fin de compartir técnicas, conocimiento e incluso las propias experiencias en la agricultura, son muy enriquecedoras para fomentar modos de cultivar más sustentables. El hecho de generar estos vínculos, utilizar recursos propios del arte para crear y transformar los discursos, puede captar la atención de un público más diverso, así como hacerlo partícipe. Según, el británico Jonathan Benthall,

Los artistas tienden cada vez con mayor frecuencia a considerar su trabajo desde el aspecto de una investigación, de una actividad no conclusiva que solo aspira a la fabricación de un objeto pero que sin embargo propone una definición precisa. La ciencia puede también ser considerada como una actividad no conclusiva que adelanta unas definiciones que se refieren a ciertos aspectos de la naturaleza más que establecer verdades últimas. Dentro de la reestructuración de nuestra cultura la ciencia puede unirse al arte en una más amplia búsqueda humana (Bentahall, 1972: 164).

En esta investigación buscamos esa unión, arte y ciencia, pero también el vínculo con la cultura campesina, con las experiencias en la práctica agrícola, con la contemplación y respeto de la biosfera. Los proyectos elegidos como ejemplo de materialización de estas ideas emergen en España, en el contexto del siglo XXI, contemplando la participación colectiva en el proceso de sus propuestas artísticas.

En los años 60, se inició un fenómeno de migración neorrural en Europa Occidental y en Norteamérica, principalmente. Este suceso marcó el principio de la creación de movimientos que trabajarían la cultura campesina desde otros puntos de vista. En España, ese éxodo rural fomentó el emprendiendo de proyectos en los que confluyen diferentes áreas del conocimiento. La Doctora en Bellas Artes Yigu Chen sintetiza en la siguiente cita un perfil de 
artista polifacético centrado en la creación de acciones artísticas que abarcan aspectos sociales, medioambientales, políticos y económicos:

Los artistas, en el contexto que investigamos, no se centran ya en crear obras físicas, sólidas y completas, sino que se convierten en acompañantes que inducen el proceso creativo: crean redes y diseñan paradigmas de modos de relacionarse; trabajan en temas prácticos, como la resolución de las cuestiones de logística o la recuperación de conocimientos tradicionales; adoptan el trabajo de animadores sociales; emplean técnicas de cuentacuentos; usan habilidades plásticas o musicales para conseguir un ambiente lúdico y participativo, etc. En definitiva, manejan lo intangible y lo relacional para motivar la sintonía entre los diferentes actores-participantes (Chen, 2016: 129).

De tal forma las iniciativas que se recogen en esta sección confluyen en ese vínculo de prácticas y pensamientos, fomentando la participación colectiva en el contexto de la difusión de la cultura agrícola sustentable.

\subsubsection{Vivens Hortis, Cartagena, España}

Al sureste de la península Ibérica, en Cartagena, se sitúa el proyecto de Vivens Hortis generado por Lorena Rosique. Esta joven ambientóloga de formación por la Universidad de Murcia y agroecóloga por la Universidad de Barcelona, fue galardonada como emprendedora social y ambiental del año 2018 de la Región de Murcia. En su proyecto ofrece un asesoramiento sobre el cultivo agroecológico, para ello genera dinámicas, talleres, charlas y acude a congresos. En su página web se muestra parte del trabajo que realiza, ofreciéndose como coordinadora de proyectos de huertos ecológicos en centros educativos, de huertos urbanos o incluso diseñando el cultivo de hortícolas en la terraza de un apartamento.

La sostenibilidad, la divulgación y la concienciación son los principales objetivos que persiguen sus proyectos. Rosique, colabora con Cultivando San Antón, una iniciativa para construir redes culturales en Cartagena. Se puede unir cualquiera que tenga interés en participar en la creación de un espacio

\footnotetext{
${ }^{9}$ Véase www.vivenshortis.es
} 
colectivo de cultivo tanto de alimentos como de relaciones humanas, generando una simbiosis intergeneracional. En las siguientes imágenes podemos observar al colectivo diseñando el huerto en asamblea.

Las estrategias que utilizan estos colectivos y que se fomentan y coordinan por investigadoras como Rosique, son un pulso para una sociedad que cada vez está más comprometida con las cuestiones medioambientales. Además, la conservación del patrimonio y de la cultura agrícola son aspectos esenciales para garantizar la alimentación de las generaciones futuras, ensalzando la importancia de la autogestión y la cooperación.

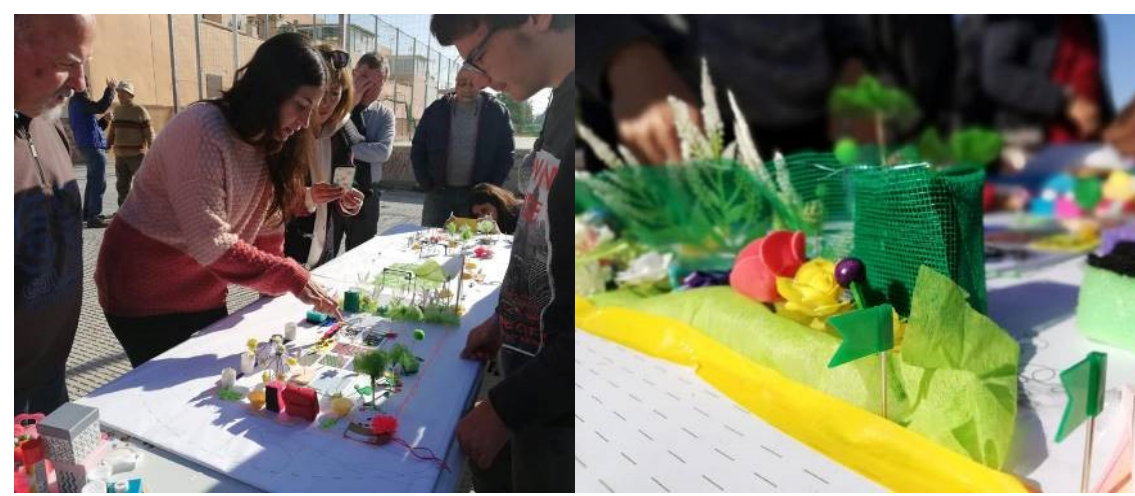

Imagen 113. Vista maqueta huerto, Cartagena, 2019. Fuente: @cultivandosananton Imagen 114. Detalle maqueta huerto, Cartagena, 2019.Fuente: @cultivandosananton

\subsubsection{Re.Colectivo, Asturias, España}

Si nos desplazamos hacia el norte de España, encontramos el proyecto La Revuelta al campo, impulsado para la difusión de aquellas iniciativas generadas por los jóvenes que toman la decisión de volver al pueblo y emprender actividades relacionadas con la agricultura. Gracias a esta plataforma de divulgación hemos conocido la existencia del proyecto Re.Colectivo que iniciaron cuatro jóvenes en una finca de Asturias. 
En 2012, Joaquín Vila, Regina Degiorgis, Laura Lara y Eduard Crespo, alquilaron una propiedad con tierras en la zona asturiana de Cabranes y empezaron la creación de un lugar de autoconsumo con cuatro vías de trabajo: la pedagogía crítica, el trabajo psicosocial, el arte y el diseño. La formación académica de los integrantes del proyecto es de artes, tal vez es por ello por lo que los cultivos en esta finca son únicamente para su propio abastecimiento. La inversión de la energía de este colectivo está más centrada en la creación de cursos, talleres, exposiciones y mercadillos de arte, compartiendo la visión de su modo de vivir a través de estas prácticas.

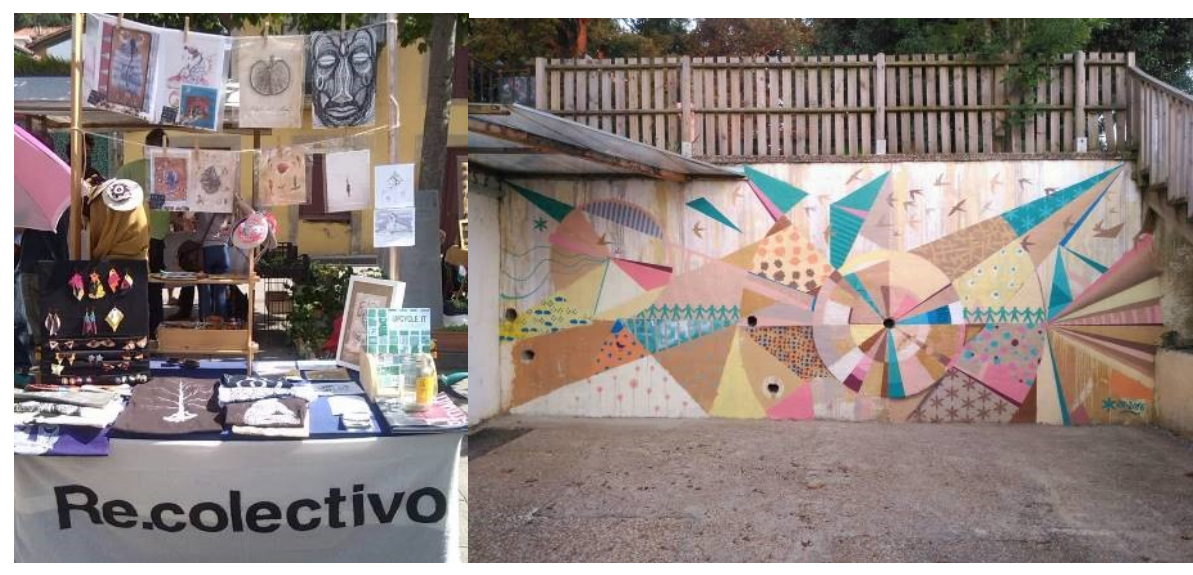

Imagen 115. Vista parada mercadillo arte, Re.Colectivo, 2014.Fuente: @recolectivo.rural Imagen 116. Vista mural en Colegio Andolina de Gijón, España. Re.Colectivo,2016.Fuente: @recolectivo.rural

En sus inicios generaron una actividad de puertas abiertas para generar vínculos con las fincas colindantes, donde la música, la expresión artística y la comida no pudo faltar. En la imagen 116 podemos observar el mural que realizaron para el Colegio Andolina de Gijón, en 2016, con la participación de quince niñas y niños entre tres y nueve años. Con este tipo de actividades, el grupo lleva hasta los centros educativos la visión de su modelo rural de vida, aportando conocimiento y experiencia a las generaciones futuras. 


\subsubsection{Viridian, Valencia, España}

Siguiendo con proyectos artísticos vinculados al aprendizaje de la cultura agroecológica en los centros educativos cabe citar al colectivo Viridian ${ }^{10}$ formado por las Doctoras en Bellas Artes, Estela de Frutos y Chiara Sgaramella. Estas artistas junto a la colaboración de organizaciones valencianas como Vorasenda, Justicia Alimentaria y Xarxa d'Escoles per l'Horta, han generado un proyecto titulado Banco de semillas. Dicha iniciativa se basa en potenciar la biodiversidad y la creatividad, defendiendo la variedad de cultivos, especies y pensamientos.

La propuesta consta de varias fases, donde tras potenciar el imaginario de cada uno de los participantes, los animan a inventar variedades hortícolas y dibujarlas en una serie de tablas que posteriormente serán colocadas en el huerto, ilustrando el organismo imaginado. Con este tipo de dinámicas, el colectivo Viridian, consigue que los intervinientes profundicen en aspectos agroecológicos y de soberanía alimentaria. En la siguiente imagen podemos observar una parte de la actividad llevada a cabo por las artistas junto a los asistentes de la V Trobada Vorasenda, Carpesa (Valencia).

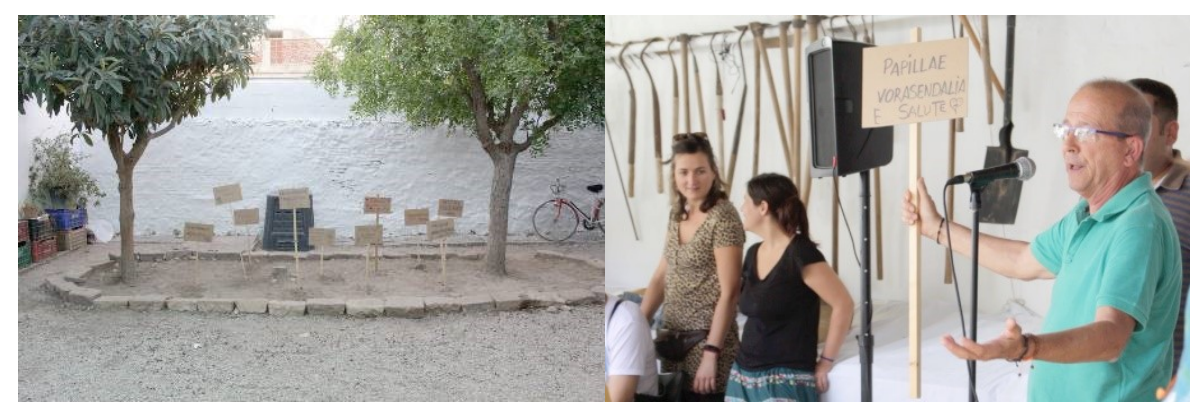

Imagen 117. Vista intervención Banco de semillas en V Trobada Vorasenda, Viridian, 2018. Fuente: Viridian Imagen 118. Vista Banco de semillas en V Trobada Vorasenda, Viridian, 2018. Fuente: Viridian

${ }^{10}$ Véase www.viridianecoart.com 
La segunda fase de su iniciativa tuvo lugar en 2019 en el contexto de la IV Marxa d'Escoles per L'Horta, en Castellar-Oliveral, (Valencia). Las artistas de Viridian, contemplan su proyecto como la construcción de

un "banco de semillas" creativas de las que puede crecer cualquier cosa imaginada. Se trata de unas semillas diferentes que germinan en un territorio simbólico: son plantas híbridas, divertidas y/o revolucionarias que constituyen un acercamiento lúdico a la agroecología y a la soberanía alimentaria generando espacios compartidos de reflexión y creatividad (Viridian, 2018).

Los participantes en la dinámica, en este caso el alumnado de las escuelas de primaria, a través de las pautas marcadas por el colectivo artístico, son libres de navegar en su imaginario con tal de crear especies hortícolas innovadoras. La acción les motiva a realizar una investigación previa de la cultura agrícola de la zona. De tal forma, el colectivo Viridian, fomenta el conocimiento de variedades hortícolas y de aspectos propios de los organismos vegetales. Además, potencia el pensamiento crítico en el alumnado, la acción participativa y la organización del trabajo en grupo. Les abre nuevas vías de expresión al materializar sus ideas a través del dibujo, de la puesta en común y de la propia acción en el huerto.

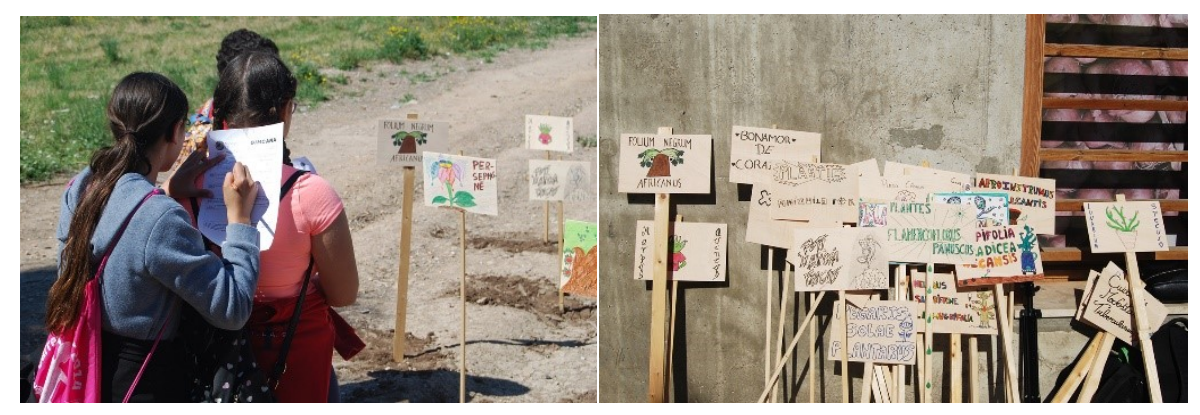

Imagen 119. Alumnas en Banco de semillas IV Marxa d'Escoles per L'Horta, Viridian, 2019. Fuente: Viridian Imagen 120. Vista Banco de semillas IV Marxa d'Escoles per L'Horta, Viridian, 2019. Fuente: Viridian 


\subsection{La obra artística en el campo agrícola}

Los proyectos que hemos ido viendo hasta ahora se centran en la utilización de recursos artísticos para la difusión de la cultura agrícola y/o en la creación de dinámicas de enfoque colectivo para compartir conocimiento y experiencias en el contexto de la agricultura sustentable. En esta sección nos vamos a centrar en las obras de arte que son generadas en el propio campo agrícola o en las inmediaciones. Asimismo, vamos a prestar atención al rol que adquiere el público en dichas obras.

En España, existen iniciativas como Culturhaza en Córdoba, donde se trabaja Land art en terreno agrícola. En esta investigación dicho proyecto se contempla como caso de estudio concreto con entrevista, por ello se tratará en el capítulo quinto de esta tesis. Por otro lado, cabe destacar la intervención realizada por la artista Lucía Loren en un campo de cultivo de la población de Carrícola en Valencia (España). Además, nuestra mirada ha cruzado fronteras y destacamos proyectos de relevancia global con una extensa trayectoria de creación artística en los cultivos. Concretamente, los laberintos de maíz ecológico en el proyecto de The Corn Maze In The Plains, en Virginia (E.U.A.) y, por otro lado, el proyecto de Arte Tanbo en Japón con una trayectoria de más de veinte años.

\subsubsection{Intervención en terreno agrícola, Lucía Loren (España, 1973)}

La artista Lucía Loren ha sido citada en el capítulo primero de esta investigación debido a su larga trayectoria en la práctica artística vinculada al paisaje, fundamentalmente en España. Pero, en esta sección abordamos la intervención que realizó en el contexto de Biodivers, una convocatoria artística que tiene lugar en la población de Carrícola. Loren, artista y docente Licenciada en Bellas Artes por la Universidad Complutense de Madrid, en sus intervenciones artísticas trata de "resolver problemas como la erosión y esterilidad del suelo, o la vulnerabilidad de los árboles producida por roturas en la corteza" (Parreño, 2015: 266). En el caso de la obra que nos atañe, Loren, en colaboración con los habitantes de Carrícola, dibujo un signo de 
interrogación en un campo de cultivo de la población. En las siguientes imágenes podemos observar la distribución de la paja y la quema posterior.

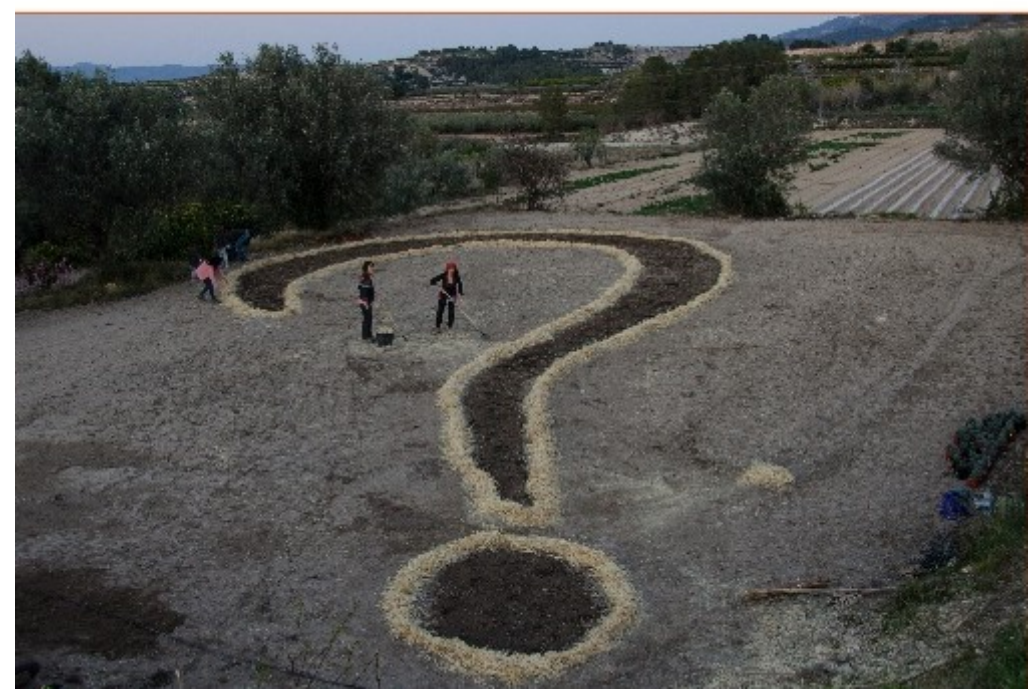

Imagen 121. Vista dibujo signo de interrogación, Carrícola, 2015. Fuente: biodivers2015.wordpress.com Imagen 122. Quema de la paja, Carrícola, 2015. Fuente: biodivers2015.wordpress.com

La intervención, marcada por la participación colectiva, fue un acto muy simbólico. La artista, utilizó el recurso del signo de interrogación visibilizando una realidad muy común en las zonas rurales, la falta de relevo generacional. Así pues, la falta de trabajadores en el campo ocasiona un abandono de las parcelas. Sin embargo, estos terrenos en otra época estuvieron en producción. Dicho abandono también viene condicionado por las escasas rentas que producen las cosechas en comparación con la inversión de tiempo, dinero y trabajo que precisan los cultivos. De tal forma, los herederos de las fincas, en ocasiones, optan por la venta o el abandono.

Loren, a través de su intervención regeneró la vitalidad del suelo con la quema de la paja y la plantación de las caléndulas y la lavanda. Además, las 
plantas sirvieron a los artesanos del pueblo para la elaboración de sus productos locales.

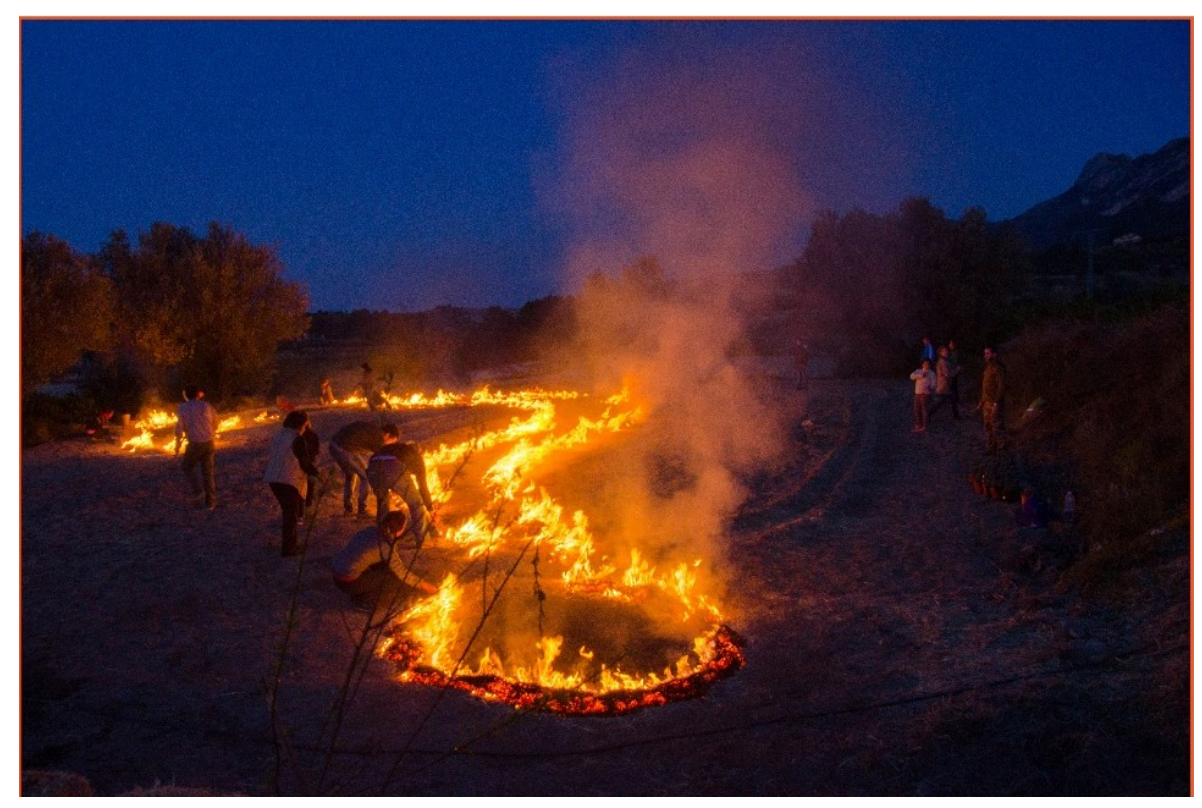

Imagen 123. Quema de la paja, Carrícola, 2015. Fuente: biodivers2015.wordpress.com

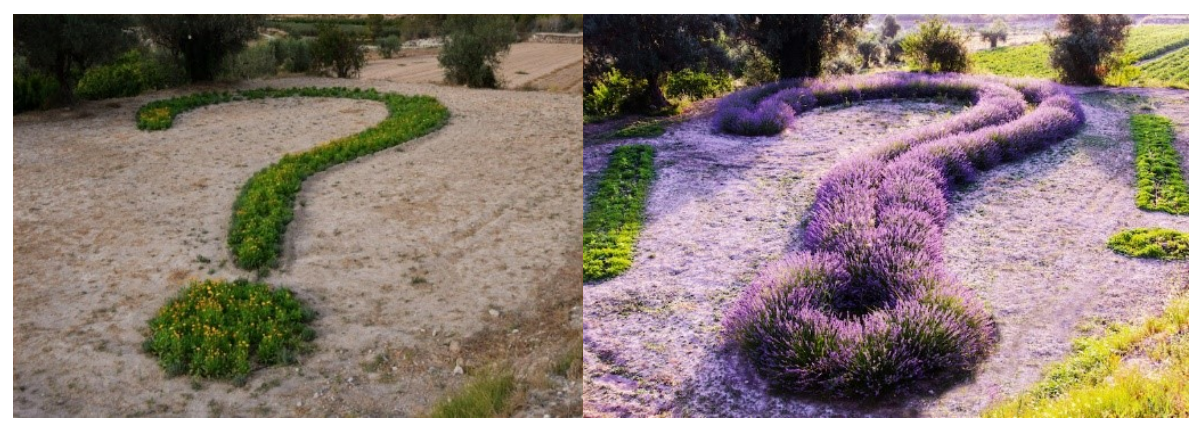

Imagen 124. Obra con caléndulas, Carrícola, 2015. Fuente: lucialoren.com Imagen 125. Obra con lavanda, Carrícola, 2016. Fuente: lucialoren.com 
Cabe mencionar la siguiente cita del Doctor en Biología y especialista en Restauración Ecológica, Luis Balaguer Núñez, en el libro de Arte y ecología, donde reflexiona que

el arte en el territorio puede constituirse en una valiosa herramienta con la capacidad de modificar conductas y hábitos sociales. Es por ello que, con frecuencia, es más importante el proceso de creación de la obra de arte, con la implicación social que conlleva, que el producto final, la obra de arte acabada. [...] combinando contenidos ecológicos, geográficos, filosóficos o históricos, pueden contribuir notablemente a profundizar en la compresión de las causas y en la implementación de soluciones de conflictos socio-ambientales subyacentes (Balaguer, 2015: 49).

En la intervención de Loren se contemplan los aspectos recién mencionados por Balaguer, es más, la obra de la artista estuvo en un continuo proceso de transformación. Contemplándose la regeneración del suelo, la historia del lugar, la participación de la comunidad y el posterior aprovechamiento de las plantas cultivadas, sirviendo de utilidad a los artesanos del pueblo para la elaboración de sus productos locales.

\subsubsection{El laberinto de maíz ecológico: The Corn Maze In The Plains} (E.U.A., 2000)

Siguiendo con las creaciones en los cultivos, destacamos los laberintos de maíz como una actividad lúdica que acerca a sus visitantes a un contexto agrícola. Estas creaciones tienen finalidades y aspectos diferentes según el contexto en que se generen. De hecho, en 2014, según el libro Guinness de los récords se certificó el laberinto temporal de maíz más grande del mundo de 60 acres (24, 28 hectáreas), fue realizado Cool Patch Pumpkins en Dixon, California (E.U.A.). Sin embargo, aunque sea una actividad de acercamiento a zonas rurales donde se contempla el uso de los recursos artísticos en su diseño, no se especifica que métodos de cultivo se utilizan para la construcción de estas enormes creaciones. Además, se marca la objetividad en la grandeza de la creación y en la cantidad de visitantes, dejando de lado los aspectos propios de la práctica agrícola sustentable. 


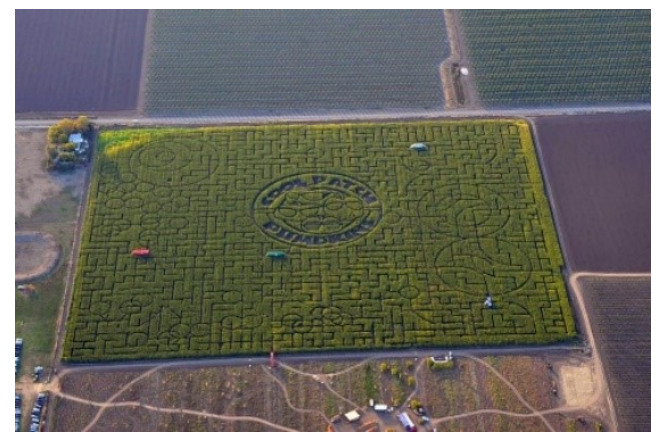

Imagen 126. Vista diseño Cool Patch Pumpkins en Dixon, California,2016.Fuente: @coolpatchpumkins

Si bien, cabe citar Casa Grande de Xanceda, en A Coruña, España, una granja familiar ecológica de 200 hectáreas de prado y bosque donde cuidan más de trescientas vacas. Principalmente se dedican a la venta de sus productos ecológicos, pero les caracteriza un fuerte compromiso social y medioambiental, generando iniciativas donde transmiten su visión de producción orgánica. En el año 2012, crearon un laberinto de maíz ecológico en su granja, una actividad lúdica y educativa que cautivó a los visitantes de la granja. En este caso si se contempla la producción orgánica y su difusión, pero la creación resultó ser un acontecimiento puntual. Además, el diseño se basó simplemente en generar una serie de calles y encrucijadas, sin contemplar un diseño específico con algún motivo ilustrado.

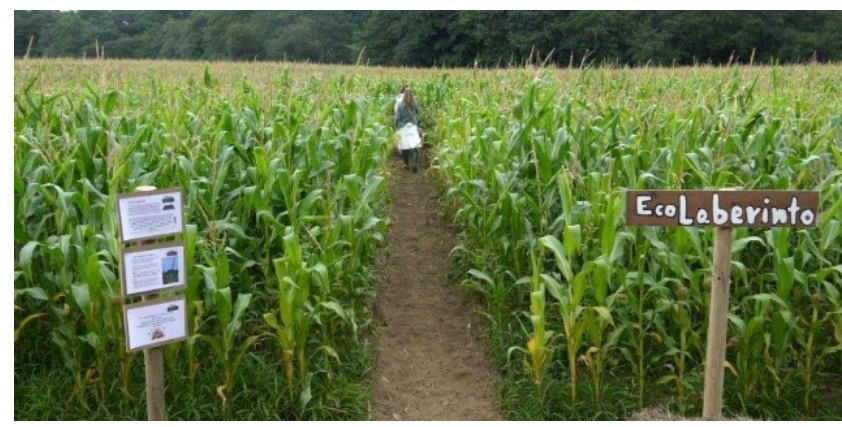

Imagen 127. Entrada EcoLaberinto, Casa Grande de Xanceda, 2012. Fuente: casagrandexanceda.com 
Por ende, el proyecto que citamos en esta sección, The Corn Maze In The Plains, en Virginia (E.U.A.) abarca el laberinto de maíz como un acontecimiento dentro del contexto de una granja de producción orgánica que fomenta valores de respeto y equidad, genera motivos ilustrados en los cultivos y cuentan con una experiencia de veinte años.

Kate y Hub Knott, son los dueños de esta fundación, donde en el año 2000 quisieron probar a dibujar un laberinto con el cultivo de maíz para poder disponer de un lugar donde la gente pudiera ir a su granja a divertirse y experimentar. Con los años este evento se ha convertido en una tradición, donde muchas familias esperan la crecida del maíz para poder ir a recorrer las líneas de las ilustraciones que esta pareja ha creado en su campo de 5 acres.

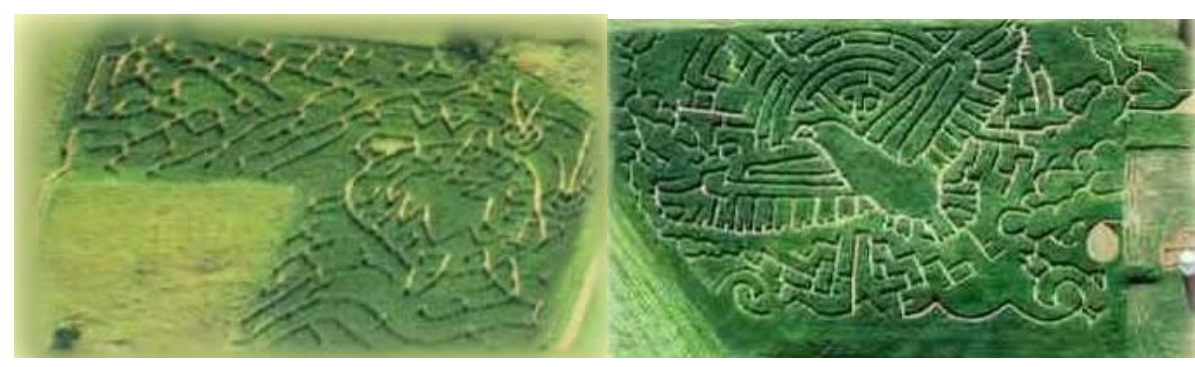

Imagen 128. Turtle Island, Virginia, 2000. Fuente: cornmazeintheplains.com Imagen 129. Fly with Freedom!, Virginia, 2003. Fuente: cornmazeintheplains.com

En las anteriores imágenes podemos observar la evolución del trazo en la ilustración, en solamente tres años, la mejora tanto en la composición como en las líneas es muy notable. La experiencia y el trabajo de tantos años ha generado interesantes y atractivos resultados como podemos observar en las composiciones de las siguientes imágenes. Sus diseños están inspirados en fomentar la alimentación saludable y la agricultura orgánica. 


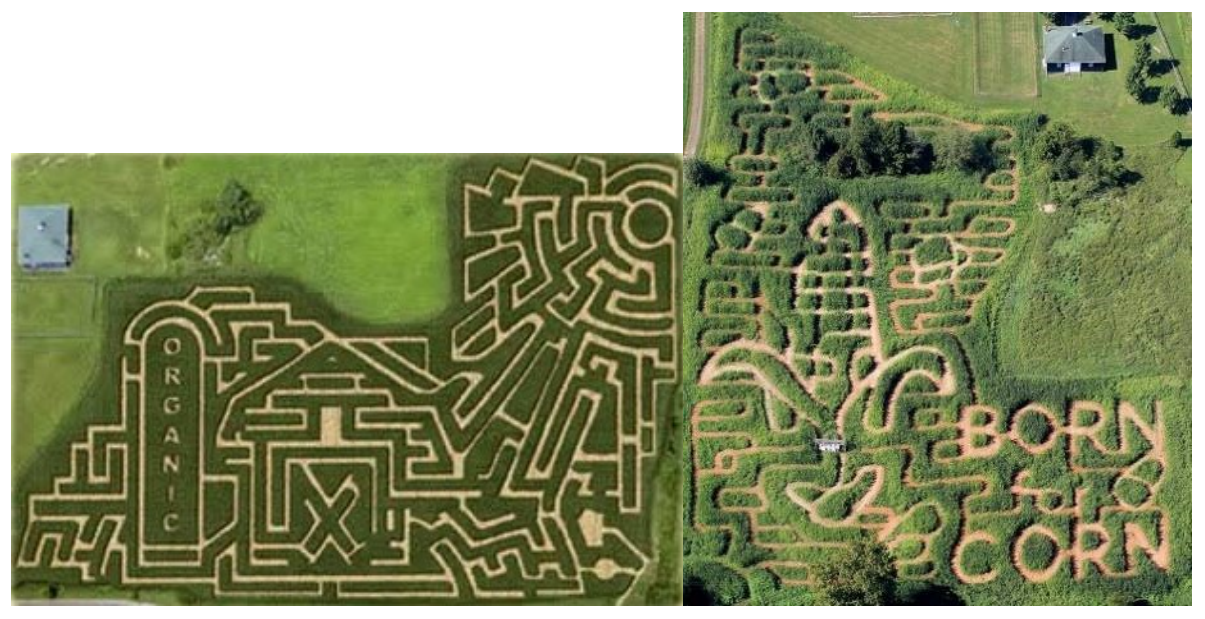

Imagen 130. Barn to be Wild, Virginia, 2005. Fuente: cornmazeintheplains.com Imagen 131. Born for Corn, Virginia, 2018. Fuente: cornmazeintheplains.com

The Corn Maze In The Plains, ha sido nombrado el mejor laberinto de maíz del norte de Virginia. Además, Kate y Hube Knott junto a sus dos hijas, se dedican al cultivo de semillas hortícolas y florales, al cuidado de los animales, a la venta de sus cosechas y a la creación de dinámicas en su granja. Organizan eventos lúdicos, donde las familias pueden ir a disfrutar del espacio que han generado, aprovechan todos los recursos que les ofrece el campo y todos los medios que disponen para el cultivo de la tierra.

En las temporadas altas de trabajo contratan a personal para que les ayuden en las labores de la granja, con todo ello consiguen abarcar un abanico de posibilidades muy amplio y pueden seguir financiando su proyecto. Organizan fiestas, mini laberintos, lanzamientos de calabazas, toboganes gigantes y carreras de obstáculos agrícolas, entre otros. Por otro lado, disponen de una pequeña tienda donde poder vender sus cosechas y elaboraciones artesanales. Si bien, todo su proyecto luce una estética campestre muy singular. 


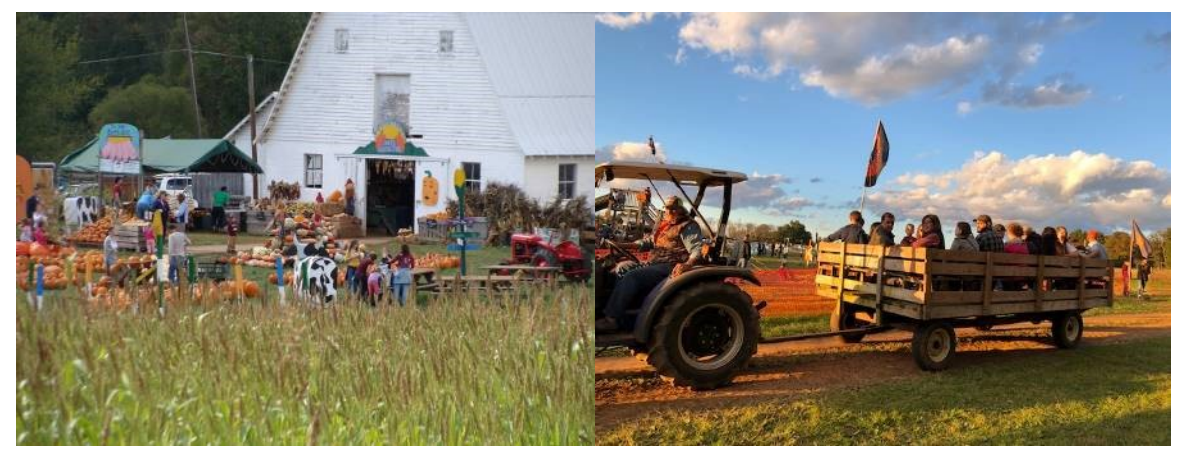

Imagen 132. Granja The Corn Maze In The Plains, Virginia, 2010. Fuente: cornmazeintheplains.com Imagen 133. Paseo en remolque tractor Virginia,2019. Fuente: @cornmazeintheplains

Si bien los laberintos de maíz desde los años 90 se convirtieron en una actividad muy habitual en los Estados Unidos, también hay otros países que se han unido a realizar estos diseños en los cultivos, como Francia, Reino Unido, Alemania o España. Como hemos introducido al principio de esta sección, hemos elegido The Corn Maze In The Plains de Virginia, porque no se concibe el laberinto de maíz únicamente como una obra de fin comercial, sino que se contemplan aspectos de fomento de la agricultura orgánica, de soberanía alimentaria, de cooperación y de economía circular.

\subsubsection{Arte Tanbo: arte de campo de arroz (Japón, 1993)}

En 1993, en Inakadate cerca de Hirosaki, se iniciaba la primera siembra de arroz contemplando el campo como si de un lienzo se tratara. La ilustración Iwakiyama fue el inicio de un acontecimiento que se iría repitiendo anualmente. Los habitantes de esta población llevaron el arte a sus campos, difundiendo a su vez las variedades autóctonas de arroz y su cultura agrícola. En la siguiente imagen podemos observar ese primer diseño, el monte Iwaki, el cual se realizó con tres tipos de arroz. Este monte sirvió como inspiración para la realización de las ilustraciones que se realizaron los siguientes años en ese arrozal. 


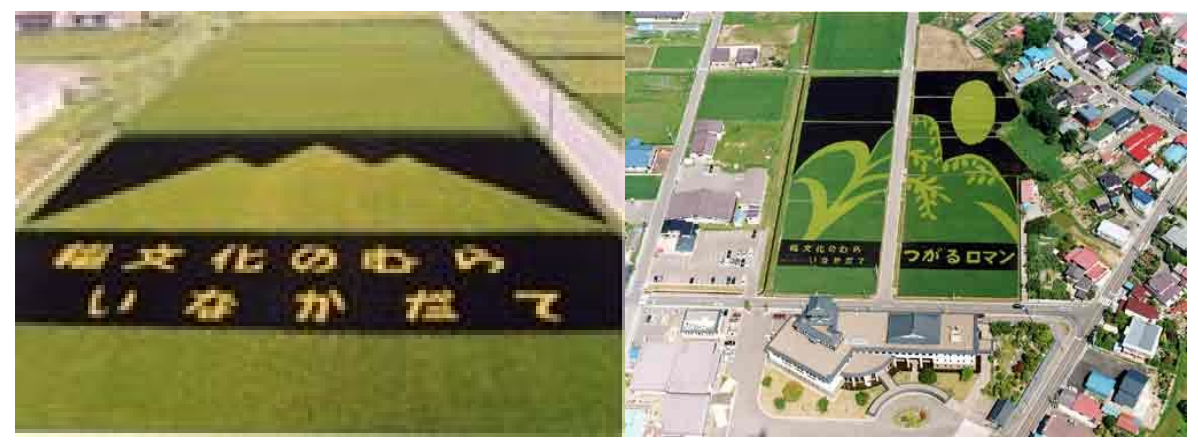

Imagen 134. Ilustración Iwakiyama, Inakadate, 1993. Fuente: vill.inakadate.lg.jp Imagen 135. Ilustración Gira de siembra y cosecha de arroz, Inakadate, 2002. Fuente: vill.inakadate.lg.jp

En 2002, celebrando su décimo certamen bajo el título de Gira de siembra y cosecha de arroz, ampliaron el diseño del monte Iwaki a los tres arrozales colindantes (imagen 135). Con los años la popularidad de estas fue aumentando, cada vez recibían más visitantes tanto locales como extranjeros. Cada nueva edición de este certamen iba ganando aceptación y renombre, con lo cual las ilustraciones que se generaban resultaban más complejas e interesantes, incluso añadieron otro campo más, generando dos obras por edición. Asimismo, se fueron inspirando en obras maestras de pintores, en escenas de películas o en su propia cultura e historia. De tal forma, esta localidad, ha potenciado una vía creativa donde se contemplan sus aspectos culturales, económicos y sociales.

En 2019 tuvo lugar la vigesimoséptima edición y se lanzó como la Gira de experiencia en la siembra de arroz donde se hizo un llamamiento para participar en el proceso de la creación de la obra. Colaboraron 1.300 personas que a lo largo de una jornada sembraron ocho variedades de arroz en un lienzo de 15.000 metros cuadrados. El evento con previa inscripción gratuita contemplaba la explicación del proceso de siembra y diseño, finalizando con una gran comida de arroz y caldo de carne. 
Esas intervenciones culturales se han realizado a menudo en respuesta a la participación creativa de un sentido de "lugar" o "bienestar" de la comunidad en la sociedad (Rao, 2014: 90). ${ }^{11}$

En las siguientes imágenes se puede observar el proceso de la creación de esta obra, titulada Oshin, desde el primer día hasta la cosecha.

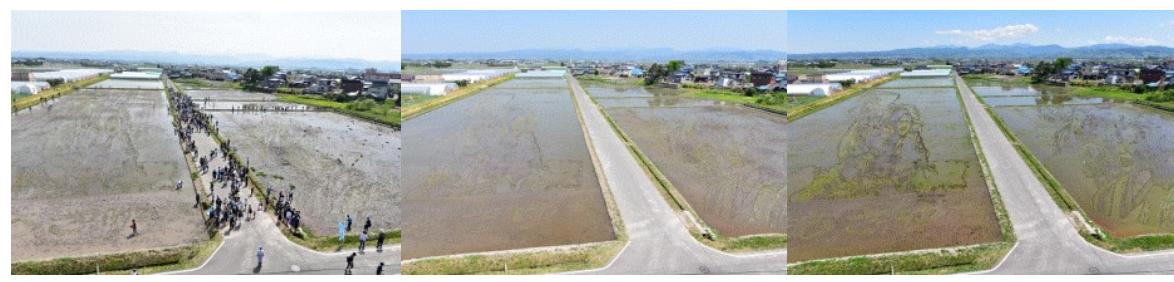

Imagen 136. Siembra y primeras vistas Oshin, Inakadate, 2019. Fuente: vill.inakadate.lg.jp

En las siguientes capturas empiezan a salir los colores de las diferentes variedades de arroz, apareciendo distintas tonalidades verdosas, moradas, amarillas, rojizas y negras.

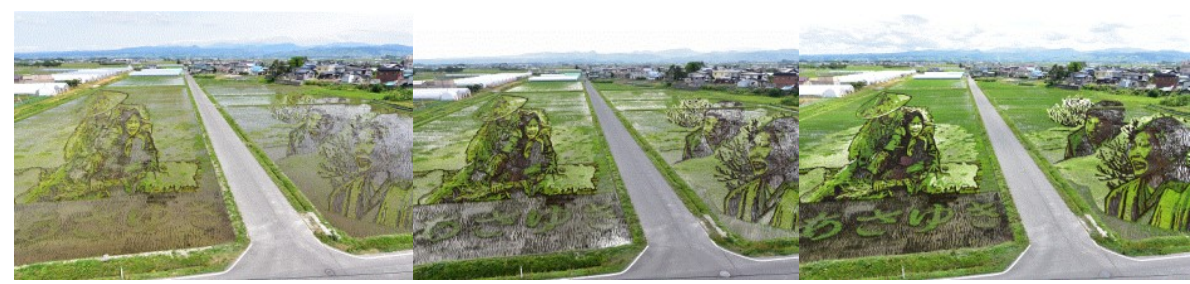

Imagen 137. Vistas Oshin, Inakadate, junio 2019. Fuente: vill.inakadate.Ig.jp

\footnotetext{
${ }^{11}$ Such cultural interventions have often been realized in response to creatively engaging a community's sense of 'place' or 'well-being' in society. Traducción realizada por T. Thompson.
} 


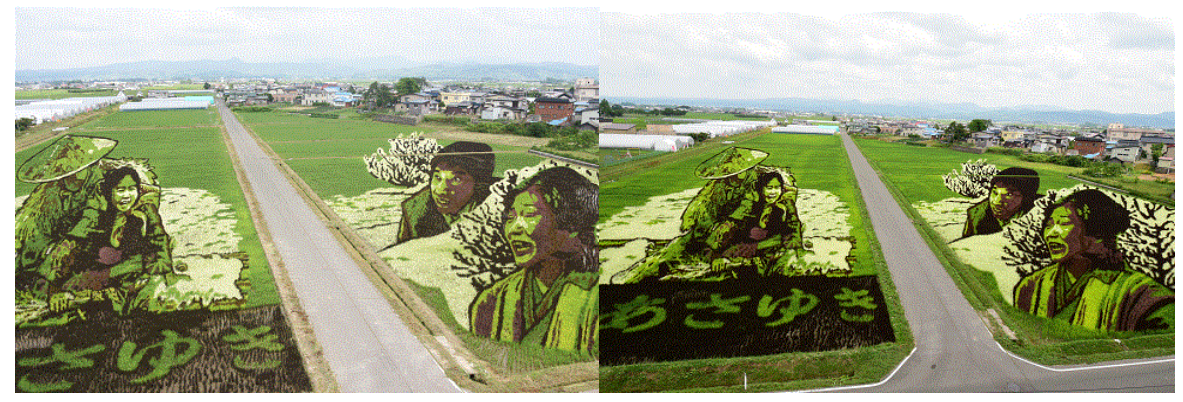

Imagen 138. Vistas Oshin, Inakadate, julio 2019. Fuente: vill.inakadate.lg.jp

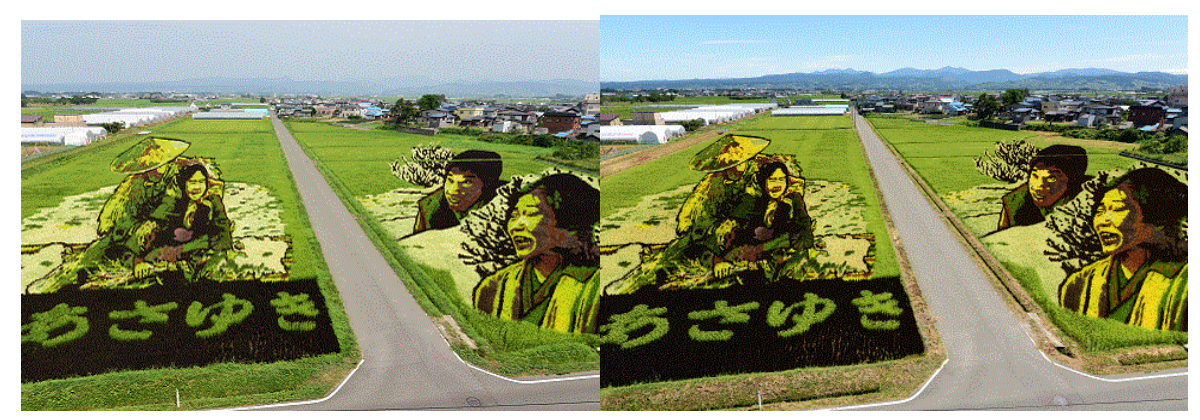

Imagen 139. Vistas Oshin, Inakadate, agosto 2019. Fuente: vill.inakadate.lg.jp

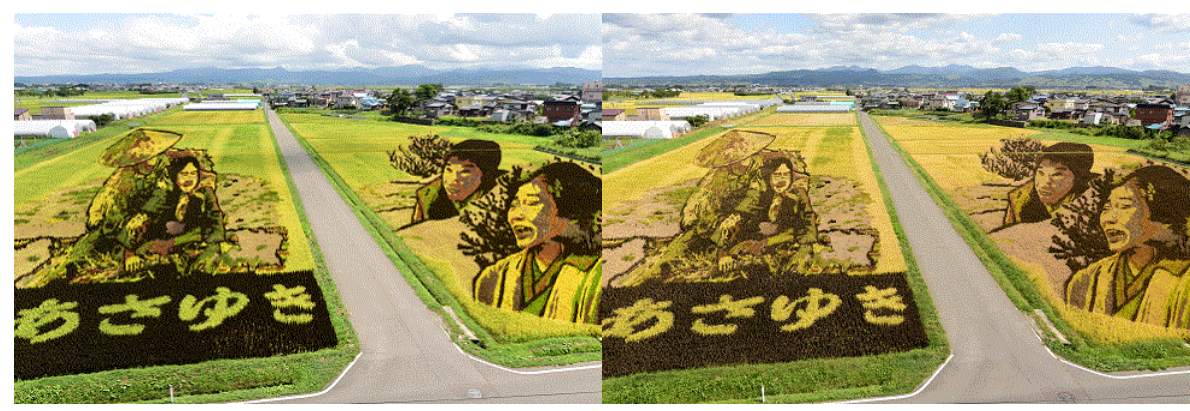

Imagen 140. Vistas Oshin, Inakadate, septiembre 2019. Fuente: vill.inakadate.lg.jp 
En octubre de 2019 la obra llega a la cúspide, el cultivo está listo para la recogida y las 1.300 personas que participaron en la siembra son convocadas para participar en la cosecha del arroz, finalizando con una celebración colectiva. La recogida de la variedad de arroz que cubría el fondo del dibujo ocasiona una perspectiva tridimensional no vista hasta el momento.

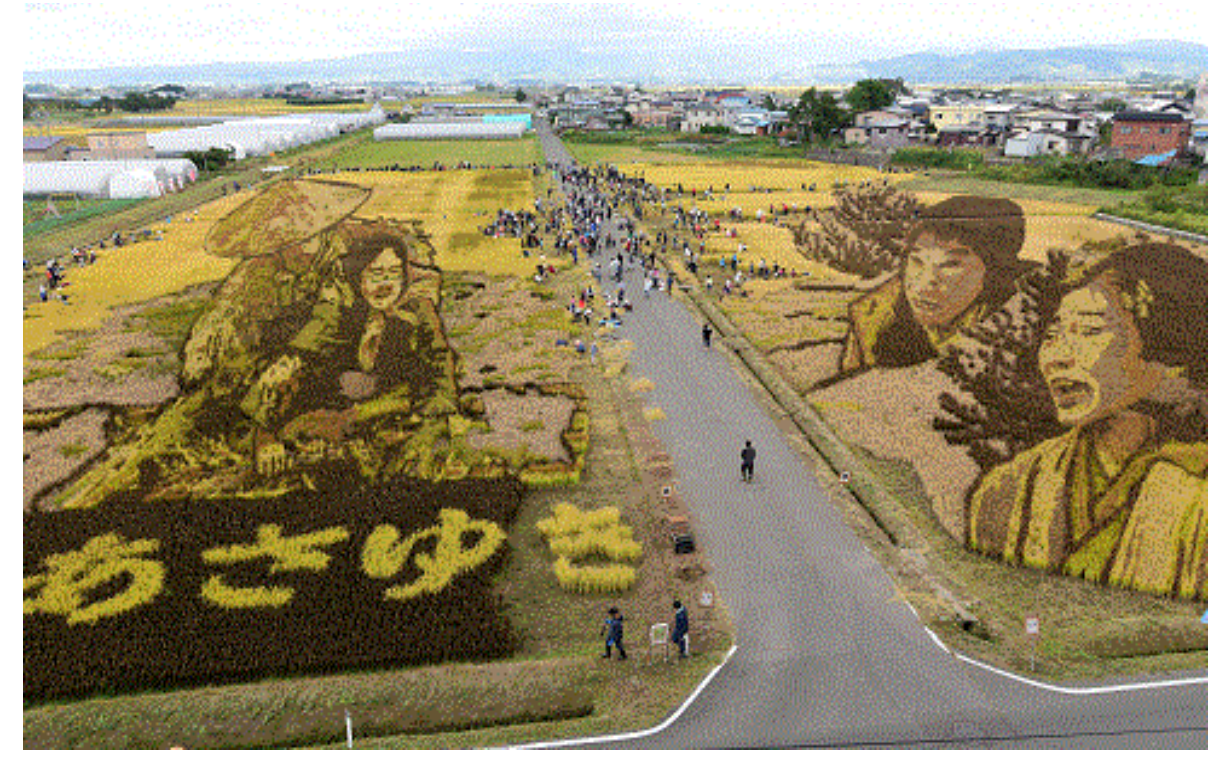

Imagen 141. La cosecha de Oshin, Inakadate, octubre 2019. Fuente: vill.inakadate.lg.jp

Cabe destacar la interesante conversión de un trabajo agrícola tradicional en un proceso artístico capaz de transmitir y difundir su cultura a nivel local y mundial. Fomentando la conservación de las variedades autóctonas de arroz y generando experiencias en la comunidad. Además, durante los meses de proceso natural de la obra, enfrente de los campos se sitúa un edificio con un mirador, los visitantes pagan una entrada, siendo una forma de poder seguir financiando las obras año tras año. Si bien el habilitar expresamente un lugar para la observación de los campos dibujados, facilita el placer de la contemplación. 
Desde tiempos remotos, en las diversas manifestaciones de la cultura japonesa existe un sentimiento interiorizado que se expresa en el respeto y la admiración reverencial hacia la naturaleza (Zambrano, 2017: 154).

Consideramos que en estos proyectos está presente el respeto hacia la naturaleza propio de la cultura japonesa, unido a una increíble coordinación de los participantes en todo el proceso de la obra.

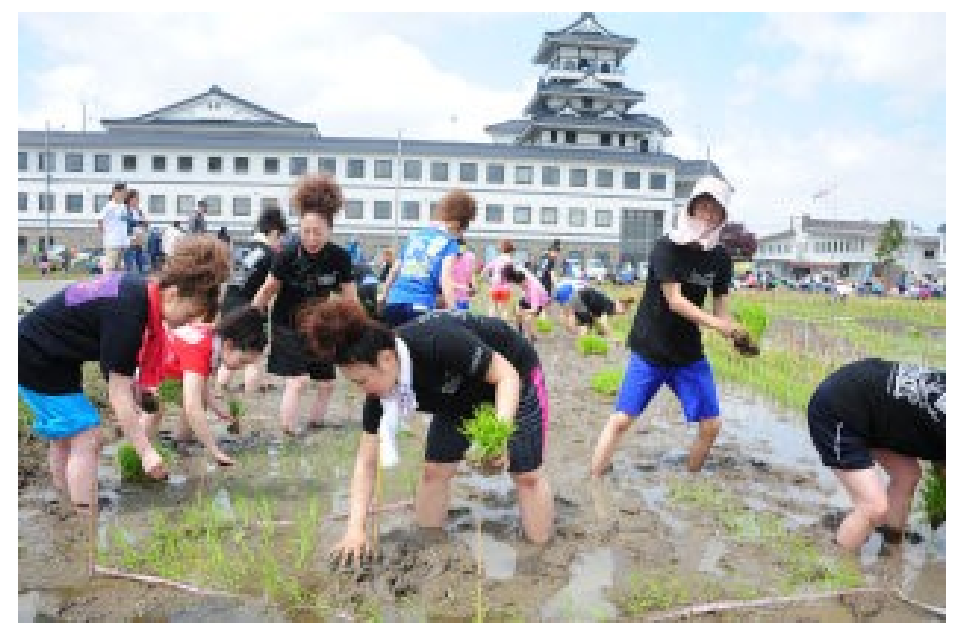

Imagen 142. Vista edificio-mirador desde campo de arroz, Inakadate, 2019. Fuente: vill.inakadate.lg.jp

\subsection{Del campo agrícola al espacio expositivo}

Seguimos en la búsqueda de las confluencias entre el arte y la agricultura sustentable, pero en esta ocasión nos centramos en las obras que se muestran desde otros contextos, fuera del campo y sus inmediaciones. Seleccionamos a artistas que visibilizan la realidad del campo a través de sus obras expuestas en salas expositivas, centros culturales, galerías, museos o ferias. Al hacer llegar estos relatos a estas ubicaciones, se amplía el abanico de difusión y fomento de las prácticas agrícolas sustentables. Se abre la posibilidad a los sectores de la población que puedan estar más alejados de 
las realidades del campo a experimentar un acercamiento. Además, se ensalza y homenajea la figura del agricultor y agricultora.

Dado que entre los objetivos de esta investigación se contempla la indagación en los aspectos agrícolas y artísticos de zonas sudamericanas, se ha dedicado esta sección a mostrar el trabajo creativo de artistas de este subcontinente. Como hemos citado en el capítulo anterior, la situación de América del Sur con los monocultivos está arrasando con su cultura rural e indígena. Por consiguiente, surge mayor actividad por parte de artistas, que utilizan su creatividad para mantener viva la cultura agrícola del lugar y trasladarla a las salas expositivas.

\subsubsection{Las pinturas de José Cruz García Albarado (México, 1974)}

Este artista es un ejemplo en el estudio de la agricultura junto a la cultura del campesinado y las variedades vegetales exóticas, todo fusionado en la pintura. José Cruz García es un pintor mexicano e Ingeniero Agrónomo con Maestría en Ciencias en Fruticultura y Doctorado en Filosofía en estudios de Arquitectura de Paisaje. Actualmente, es profesor investigador en Maestría de Paisaje y Turismo Rural en el Colegio de Postgraduados Campus Córdoba (México), en la línea de generación del conocimiento de los recursos naturales con potencial turístico y su aprovechamiento sustentable. Además, lleva veinte años de experiencia en las artes plásticas con un interés por unir arte y ciencia en sus obras. Su trabajo es principalmente pictórico.

Bajo el titulo Expresarte de la Tierra, realizó una muestra de acuarelas en el Museo del Centro Cultural Mexiquense Bicentenario en 2013. Esta muestra fue un tributo a los cultivos nativos de México. El artista expuso una serie de acuarelas con llamativos colores donde interpretó cuarenta y cinco cultivos distintos. Su trabajo se acerca a las láminas de botánica y así se puede contemplar en el libro ExpresArte de la Tierra. Tributo a los cultivos nativos de México que publicó en colaboración con el Sistema Nacional de Recursos Fitogenéticos para la Alimentación y la Agricultura (SINAREFI) y con el Servicio Nacional de Inspección y Certificación de Semillas (SNICS), entre otros. En la 
siguiente imagen podemos observar el cartel anunciador de la exposición donde aparecen algunas de las acuarelas de la muestra.

\section{Exposición pictórica}
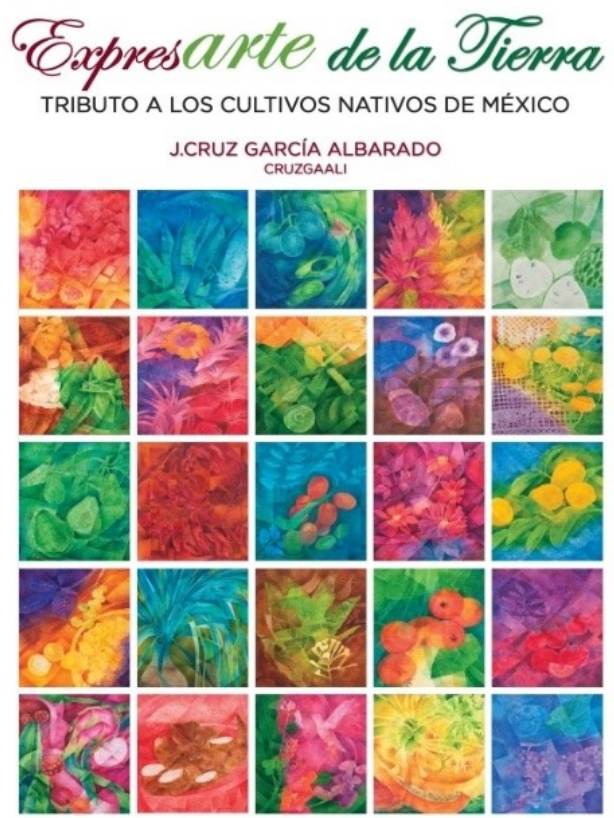

Museo del Centro Cultural Mexiquense Bicentenario

Inauguración 16 de mayo, 2013 17:00 horas.

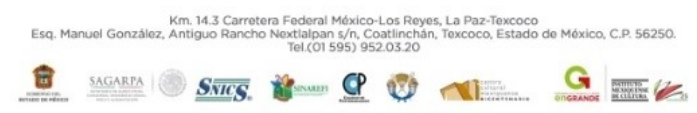

Imagen 143. Cartel Expresarte de la Tierra, Jose Cruz García, México, 2013. Fuente: cuexcomate.com

Las acuarelas de Jose Cruz García, también Ilamado Cruzgaali, son el fruto del trabajo realizado con las redes de SINAREFI, donde confluyen investigadores de diferentes disciplinas e instituciones, asociaciones civiles, organizaciones no gubernamentales, productores y sociedad en general. En la publicación cada acuarela lleva su ficha técnica y un breve texto de inspiración del artista. 
El promedio del libro lo escribió Adolfo Rodríguez Cantó, Doctor en Ciencias Agrarias por la Universidad Autónoma de Chapingo (México), exponiendo que

La ciencia es arte, trabajo creativo; la creación artística es ciencia aplicada. En ambas se genera conocimiento y ambas son medios para la difusión del conocimiento. Cruzgaali es apasionado de la relación entre ciencia y arte, y encontró en el paisaje el elemento unificador (Rodríguez, 2012: 14).

En ese vínculo, el artista busca la valoración de la agrobiodiversidad existente en su país, sus obras pictóricas la ensalzan y la publicación del libro en versión bilingüe ofrece la posibilidad de que se expanda el conocimiento. Su labor es un homenaje tanto a los cultivos como a las personas que siguen trabajando en su conservación, sembrando semillas y ofreciéndonos alimento. Enlazamos esa unión de arte y ciencia con la reflexión de María Novo en el libro Arte y ecología,

El camino compartido, el dialogo sereno y la vocación de restaurar los lazos rotos, resultan ya indispensables para afrontar y reconvertir la depredación ecológica y la inequidad social que caracterizan a nuestro tiempo histórico. Emplazados a esa tarea, científicos y artistas aprendemos a caminar juntos, a cogernos de la mano para mirar con asombro y respeto la vida, imaginar mundos posibles y comprometernos a la hora de dejar un planeta digno a las generaciones futuras (Nova, 2015: 34).

En ese imaginario, Jose Cruz García, crea sus paisajes de la cultura agrícola sustentable, llenos de simbolismo y esperanza. En 2017, en el marco de la celebración de la XIX Junta Interamericana de Agricultura (JIA) en la sede central del Instituto Interamericano de Cooperación para la Agricultura (IICA), el pintor realizó otra exposición artística bajo el título Semblanza de la Agricultura de las Américas en San José (Costa Rica). El artista expuso un total de veinte pinturas inéditas de $60 \times 60 \mathrm{~cm}$ que unidas formaban un gran mural. Sus obras juegan con el color, las formas orgánicas, sinuosas y los elementos propios de la cultura agrícola del país. En esta pieza se trabajan aspectos como: la innovación agrícola, la inclusión y los territorios rurales, el agro ecoturismo, el cambio climático, el valor agregado y la agricultura familiar. 


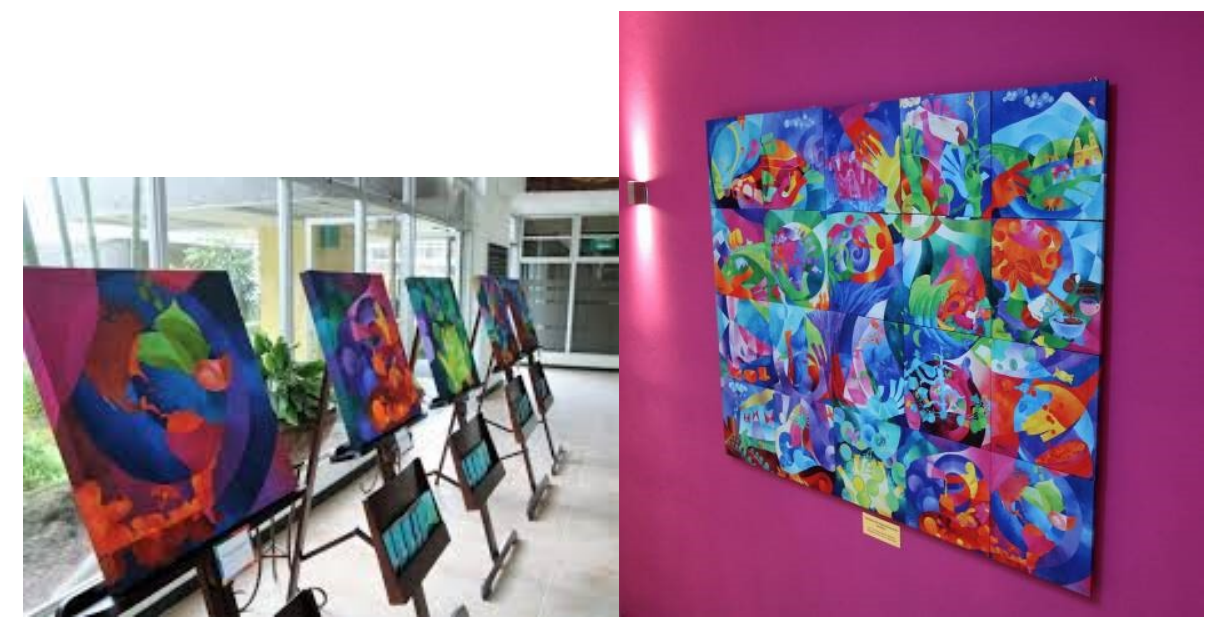

Imagen 144. Vista exposición Semblanza de la Agricultura de las Américas,

Cruzgaali, 2017. Fuente: iica.int Imagen 145. Vista mural Semblanza de la Agricultura de las Américas,

Cruzgaali, 2017. Fuente: iica.int

Esta obra también se concibe como un proyecto artístico-educativo, estimulando la reflexión sobre los acontecimientos presentes y futuros de la agricultura. Tras la presentación del proyecto, realizado en colaboración con el Colegio de Postgraduados Campus Córdoba y el Instituto Interamericano de Cooperación para la Agricultura (IICA), se generó una publicación donde las veinte obras acompañan textos de especialistas miembros de IICA.

3.5.2. La cultura de la alimentación chilena a través de la obra de Natascha de Cortillas Diego (Chile, 1967)

Licenciada en Educación con Mención Artes Plásticas de la Universidad de la Concepción de Chile, con Maestría en Artes Visuales por la Universidad Autónoma de México y docente en el Departamento de Artes Plásticas de la Universidad de la Concepción, esta artista visual trabaja aspectos del campesinado utilizando el arte como canalizador. Natascha de Cortillas lleva más de diez años investigando la cultura de la alimentación en las localidades de la Región del Biobío en Chile. 
En 2019, muestra su proyecto Cosecha, siembra y resistencia en la Galería Gabriela Mistral de Santiago, Chile. Su obra ensalza la labor de cuatro mujeres campesinas que trabajan para el autoabastecimiento suyo y de la comunidad. Pone en valor la agricultura de subsistencia de María Silva, Norma Arriagada, Ximena y Felicinda Martínez. Al mismo tiempo sitúa la labor de estas mujeres en el contexto del monocultivo de pinos y eucaliptos que sufren en su zona por la industria forestal. En la exposición muestra vídeoentrevistas de las campesinas, fotografías, documentos de archivo, una vídeo performance y productos orgánicos cosechados por las agricultoras. La artista, ubicó dos espacios, uno con plantones y el otro con hortalizas cosechadas por las agricultoras. Asimismo, el público podía llevarse los vegetales ya que se iban reponiendo.

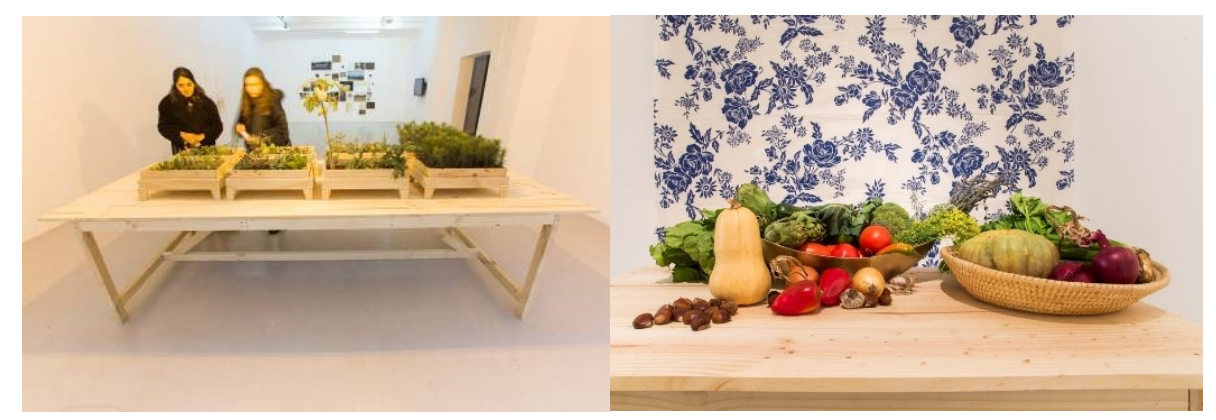

Imagen 146. Cosecha, Natascha de Cortillas, 2019. Fuente: arteinformado.com Imagen 147. Cosecha_Naturaleza Mueta, Natascha de Cortillas, 2019. Fuente: arteinformado.com

En esta muestra, la artista también expuso una vídeo performance donde cuestionaba los monocultivos de pino y eucalipto. En su obra realiza una comparación donde por un lado se observa la labor de resistencia y lucha de las mujeres campesinas y por otro el monocultivo lineal, patriarcal y capitalista propio de la industria. Se da a conocer la realidad que viven estas agricultoras, una lucha por la conservación de su cultura, por su autoabastecimiento y por generar redes con la comunidad. 


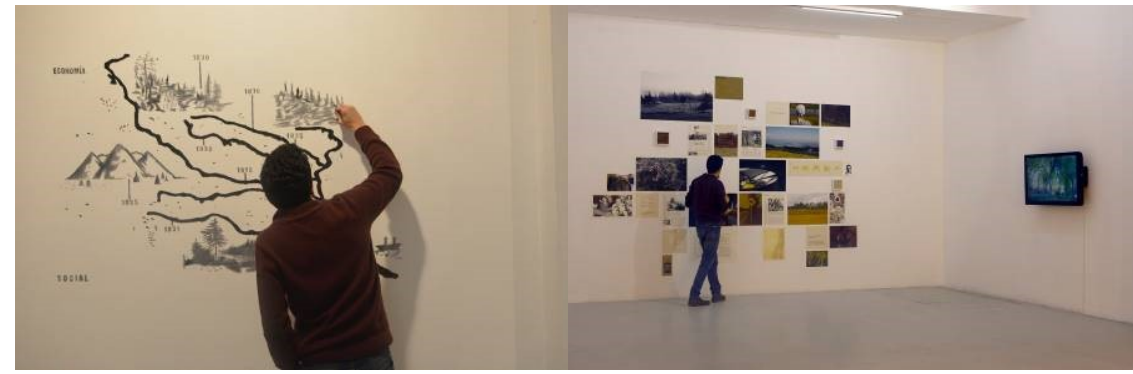

Imagen 148. Levantamiento iconográfico del territorio del rio Bio-bío y del avance de las plantaciones forestales, Natasha de Cortillas, 2019. Fuente: terremoto.mx Imagen 149. Vista instalación Cosecha: siembra y resistencia, Natasha de Cortillas, 2019. Fuente: terremoto.mx

El trabajo de Natasha de Cortillas es muy cercano al día a día de estas mujeres, la artista se implica concienzudamente, comparte tiempo con ellas, las entrevista, las contempla, las escucha y las entiende. Toda esa investigación le sirve para llevárselo al campo artístico, donde culmina con intervenciones y performance que hacen adentrarse al espectador en el modo de vivir de estas campesinas. Consideramos que el trabajo de esta artista irrumpe en la galería como un concepto de obra lejano al habitual en un mercado de arte marcado por el capitalismo. Obras que se disponen como ofrendas al espectador, vídeos que proyectan experiencias y cuestionan aspectos propios de la industria forestal. Un proyecto experiencial con el objetivo de generar conciencia sobre la cultura agrícola del lugar. Según el artículo de La Auraucanía, publicado por el Ministerio de las Culturas, las Artes y el Patrimonio del gobierno de Chile, la artista explica que

Mostrar el trabajo desde las campesinas es una forma de reclamary dar cuenta de las contingencias sociales y políticas que hay respecto a la disparidad en las formas de trabajar la tierra y sus recursos naturales (Cortillas, 2019).

En honor a cada una de las cuatro mujeres campesinas entrevistadas, la artista produjo cuatro delantales con ilustraciones bordadas. Cada pieza sintetiza la vivencia de cada una de ellas, campesinas y cocineras, pero cada una con su propia historia. 

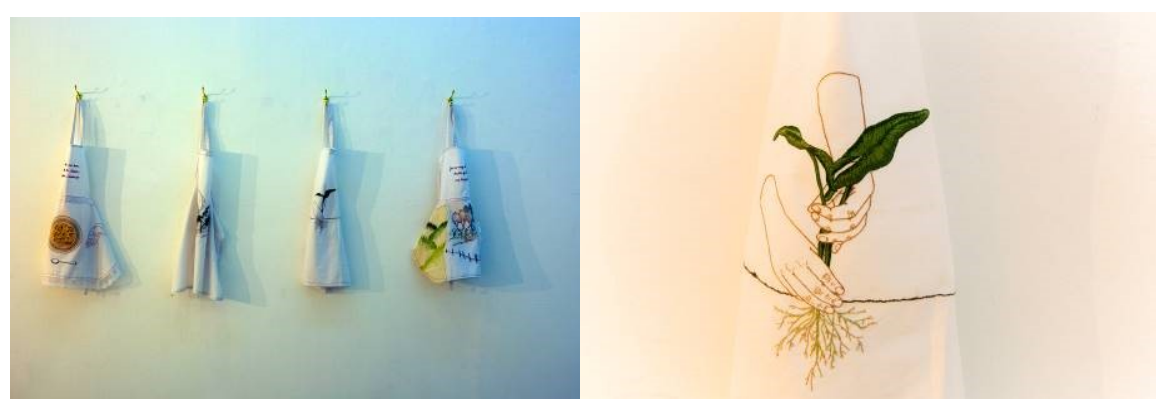

Imagen 150. Cuatro delantales colgados Cosecha, Natasha de Cortillas, 2019. Fuente: terremoto.mx Imagen 151. Delantal Cosecha, Natasha de Cortillas, 2019. Fuente: arteinformado.com

El proyecto Cosecha: siembra y resistencia de Cortillas, ha sido una muestra itinerante que ha realizado la artista para la colección de la Galería de Arte Contemporáneo Gabriela Mistral de Santiago, Chile. Sin embargo, Natasha de Cortillas lleva un largo recorrido en el estudio de la alimentación y la cultura campesina, proyectos como Desterritorialidades Culinarias y Chile amasa su pan han sido expuestos en distintos territorios chilenos. Su trabajo se proyecta en múltiples representaciones, según la artista

estos ejercicios se movilizan a través de intervenciones culinarias, donde la visualidad instalada hace referencia a ciertos hitos del arte clásico, pero que se vincula en esencia a decires locales y particulares que embargan la percepción del artista en el intercambio cultural con otras realidades locales de la región latinoamericana (De Cortillas, 2010: 1).

Sus performances se inspiran en hitos del arte clásico, por ejemplo, las escenas pictóricas de Friederich referencian a la obra de la artista Chile amasa su Pan. Sin embargo, se vincula con la esencia de la cultura rural, con las peculiaridades de las localidades de la región latinoamericana y con las realidades del lugar. 


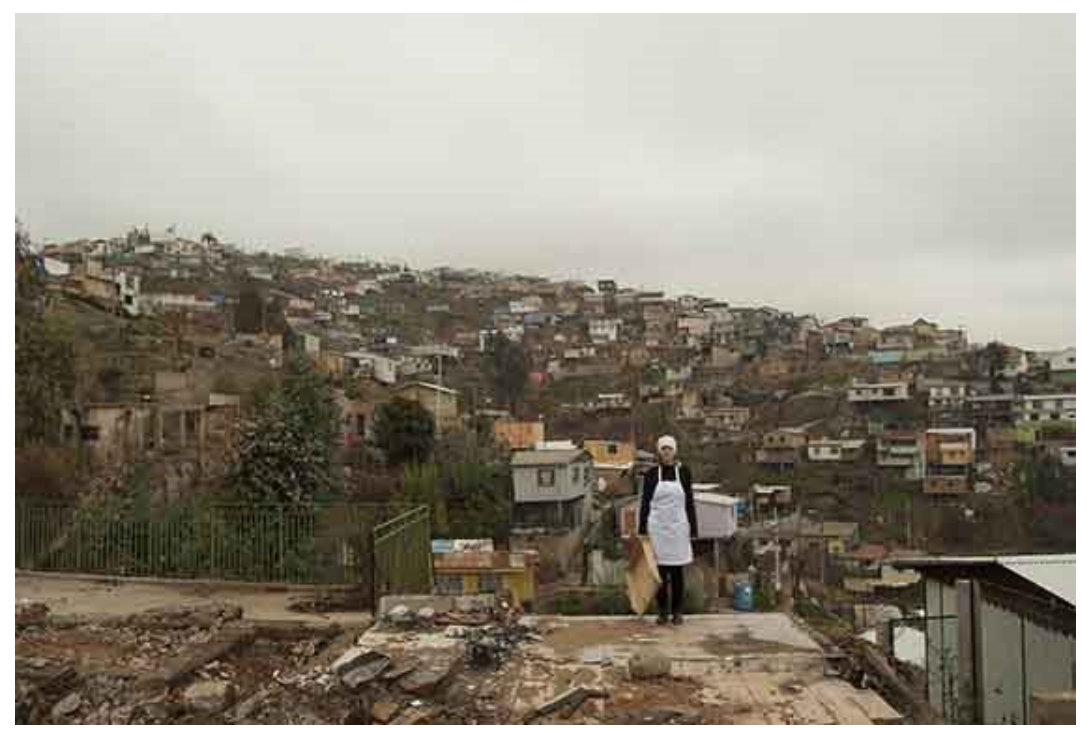

Imagen 152. Pan para hoy hambre para mañana de la serie Chile amasa su Pan, Natasha de Cortillas, 2014. Fuente: nataschadecortillas.cl

\subsubsection{Los dibujos de Jose Ismael Manco Parra (Colombia, 1982)}

Artista visual y agricultor, docente en el proyecto pedagógico El Valiadero artístico y en la Universidad de Distral Francisco José de Caldas, Colombia. Desde hace diez años lleva a cabo un proceso creativo bajo el nombre Intercambio de Semilla y Pensamiento, situando a la agricultura como una obra de arte. Sus piezas proponen una reflexión sobre las prácticas agrícolas, sobre el territorio y las situaciones sociopolíticas, económicas y ambientales del lugar. Parte de su propia experiencia y de la herencia de sus antepasados, para trabajar hacia el respeto y la valoración de la cultura agrícola que lo ha visto nacer.

Su práctica artística es diversa: dibujo, performance, instalación o escultura. Presenta su obra en casas de campesinos y campesinas, en escuelas, en centros culturales y salas expositivas, su intención es generar espacios reflexivos y de discusión donde se contemple la práctica agrícola tradicional. 


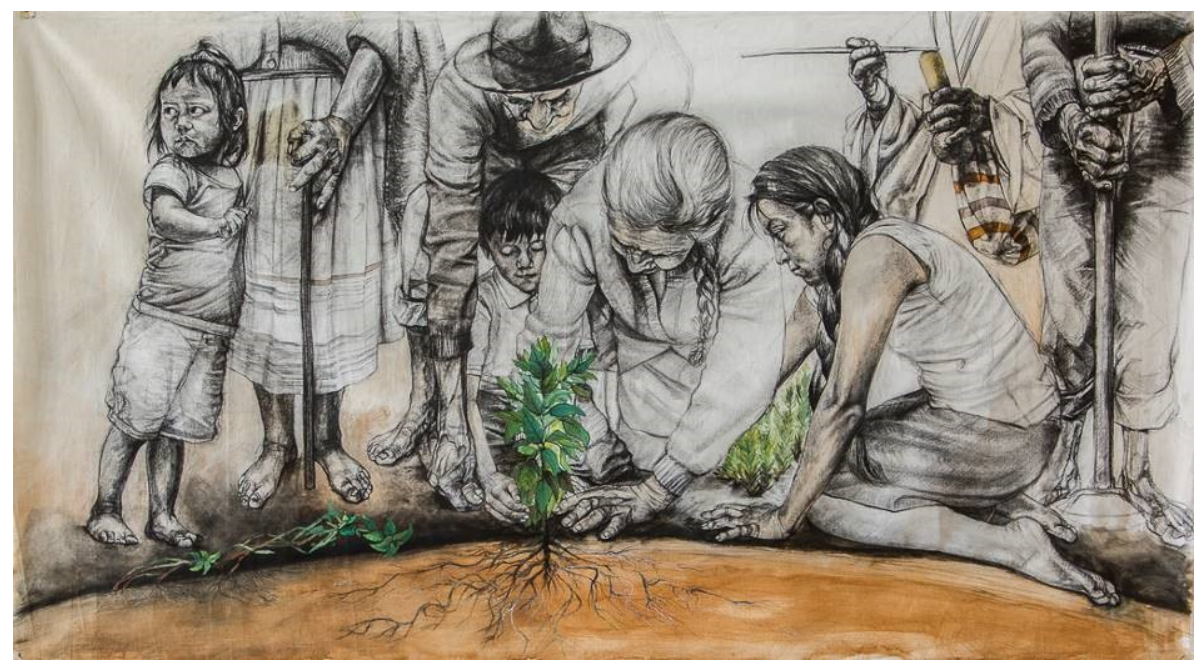

Imagen 153. Intercambio de semillas y pensamiento, Jose Ismael Manco, 2014. Fuente: efimero.org

Nosotros somos campesinos, agricultores y poseedores de una de las regiones en términos ambientales más importantes del mundo. Cerca del 50\% de los páramos del planeta está en Colombia. Boyacá es el departamento del país con mayor área de páramo, y las políticas extractivistas están poniendo en riesgo estos ecosistemas y, de paso, las culturas ancestrales campesindias. Por eso comparto e intercambio semillas con personas (campesinos y no campesinos) comprometidas con procesos ambientales y con la defensa de las semillas nativas. Una semilla puede ser una palabra o un pensamiento; puede ser muchas cosas, y bueno, lo importante es sembrarla (Manco, 2016: 184).

Ante el imperialismo del capital con sus dinámicas extractivistas y sus monopolios, el artista lucha sembrando semillas, compartiendo conocimiento y difundiendo el legado de sus antepasados. Utiliza el arte como canalizador de su experiencia y legado agrícola.

Su trabajo ha recorrido países como Colombia, México y Argentina. Sin embargo, en 2019, en el contexto del Otoño Cultural Iberoamericano cruzó fronteras y viajo a España. Su obra se expuso en el Centro de Recepción y Documentación del Puerto de Huelvay, posteriormente, en el Real Círculo de Labradores de Sevilla. Las muestras recogieron una serie de dibujos de gran formato realizados únicamente con carbón y tintes vegetales. Sin embargo, 
su obra reúne una dimensión más amplia, la cual favorece el diálogo de la cultura agrícola entre los observadores.

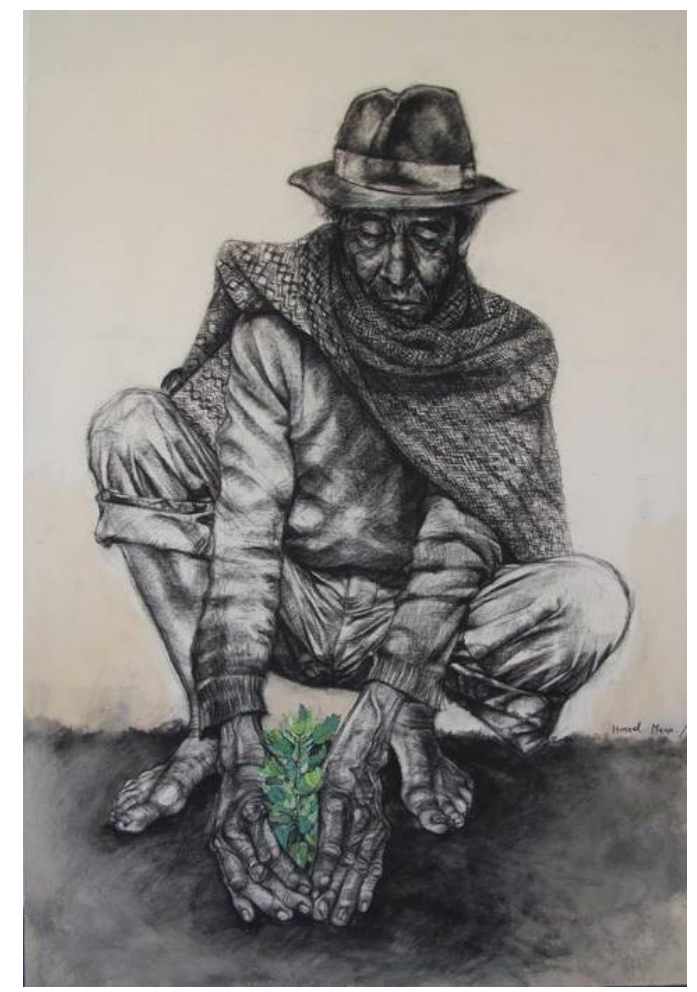

Imagen 154. Sembrador, Jose Ismael Manco, 2014. Fuente: huelva24.com

\subsection{Conclusiones capítulo}

Las intervenciones artísticas que contemplan aspectos de la agricultura sustentable son cada vez más notables. Las aportaciones por parte de los artistas al cuestionamiento de la cultura agrícola han aumentado en el contexto del siglo XXI. La monopolización de los cultivos y la utilización de grandes cantidades de agrotóxicos por parte de la agricultura más industrializada ha favorecido la aparición de agentes que muestran su punto de vista desde otros contextos como el arte. Las obras que se han citado en 
este capítulo versan sobre la necesidad de conservar el conocimiento ancestral, haciendo visible la posible interacción de la cultura agrícola tradicional con los actuales avances desde la sustentabilidad.

En primer lugar, se ha comprobado con las diversas obras citadas en el apartado 3.2., que el uso de recursos artísticos facilita la difusión y la comprensión de la cultura rural. A través de las creaciones de arte urbano se ha visibilizado la praxis de zonas rurales en situación de despoblación. Además, las diversas creaciones artísticas y las actividades que se organizan en su contexto han sido un motor cultural, social y económico en las poblaciones.

En segundo lugar, cabe remarcar la importancia del taller artístico, el cual sive para profundizar en el conocimiento de la cultura agrícola sustentable de forma colectiva, fomentando el dialogo y el pensamiento. El papel del artista en los centros educativos resulta clave en la formación del alumnado hacia una participación crítica y creativa.

En tercer lugar, la creatividad, la belleza y la técnica se han fundido en el campo agrícola y sus inmediaciones. La obra de Lucía Loren muestra un proceso de regeneración de la tierra desde la participación colectiva, trazando diferentes fases coherentes con las situación social, medioambiental y económica de la población. Por otra parte, con los laberintos de maíz de Virginia o los campos de arroz de Japón se ha visibilizado la constante creatividad que han plasmado durante años en sus cultivos, abordando sus tradiciones desde el arte. Además, cabe destacar la capacidad del ser humano en cuanto a organización, en la Gira de experiencia en la siembra de arroz se coordinó el trabajo de 1.300 voluntarios en 15.000 metros cuadrados de campo para realizar la ilustración y su posterior cosecha.

En cuarto lugar, se ha considerado relevante la recreación de la cultura agrícola e indígena en las obras que han sido llevadas a la sala expositiva por los diferentes artistas sudamericanos que se han abordado. Como se ha citado en dicha sección, la opresión por parte de los monopolios de la 
industria agrícola ha generado la necesidad por parte de artistas de expresar a través del arte la importancia de sus tradiciones. De este modo se han expuesto obras en galerías, salas expositivas, centros culturales o educativos, fomentando el acercamiento de la agricultura sustentable a lugares donde habitualmente no está presente.

Consideramos que el arte en menor o mayor medida puede contribuir en la conservación de la cultura agrícola. La práctica artística funciona como un canalizador que crea discursos que contemplan un abanico de emociones y sentimientos más amplio. Sin embargo, en ocasiones, el trabajo del artista es altruista, la situación de precariedad laboral es compartida entre el sector artístico y el agrícola. Por ello, es complejo que abunden los proyectos que vinculen ambos oficios. Aun así, la implicación de artistas en la recuperación de la cultura agrícola persiste y continúa generando nuevas iniciativas. En el siguiente capítulo se contemplan proyectos bajo los principios de la permacultura, se visualiza como el arte aborda esta filosofía y cuál es su papel en la transición hacia la sustentabilidad. 



\section{CAPÍTULO 4}

\section{ARTE Y PERMACULTURA}

En este apartado nos adentramos en la permacultura para entender su filosofía y analizar su vinculación con la cultura contemporánea. Una vez captada la esencia de esta práctica veremos sus vinculaciones con el arte y cómo se nutren entre sí. La permacultura se origina y fundamenta en Australia, pero es un movimiento global con cientos de proyectos en todos los países. Se establece en una serie de principios éticos, sostenibles y ecológicos que abarca a toda la biosfera y sus habitantes. Se caracteriza por basarse en los saberes ancestrales de uso y cuidado de la tierra combinados con la ciencia moderna, pero siempre teniendo en cuenta el bienestar de todos los seres vivos, trabajando con la naturaleza y no contra ella. Si bien Bill Mollison es su creador, David Holmgren ${ }^{12}$ y Rosemary Morrow ${ }^{13}$ también han contribuido a su difusión. A lo largo del ensayo desarrollaremos sus principales características y principios, para llegar a comprender un poco más el concepto de permacultura. Asimismo, analizaremos cómo el arte

\footnotetext{
${ }^{12}$ David Holmgren es ecólogo, ingeniero de diseño ecológico y escritor. Cocreador del concepto de permacultura.

${ }^{13}$ Rosemary Morrow cuenta con titulaciones en agricultura, horticultura, sociología rural y educación para personas adultas. Lleva más de 20 años practicando y enseñando la permacultura en Australia y otros países.
} 
puede colaborar dentro de esta filosofía para fortalecerla, ayudar en su difusión y, finalmente, mejorar la vida de todos los habitantes del planeta reduciendo nuestra huella ecológica y haciéndonos más autosuficientes.

\subsection{Principios de la permacultura}

David Holmgren nos plantea doce principios de diseño permacultural en su libro Principios y senderos más allá de la sustentabilidad:

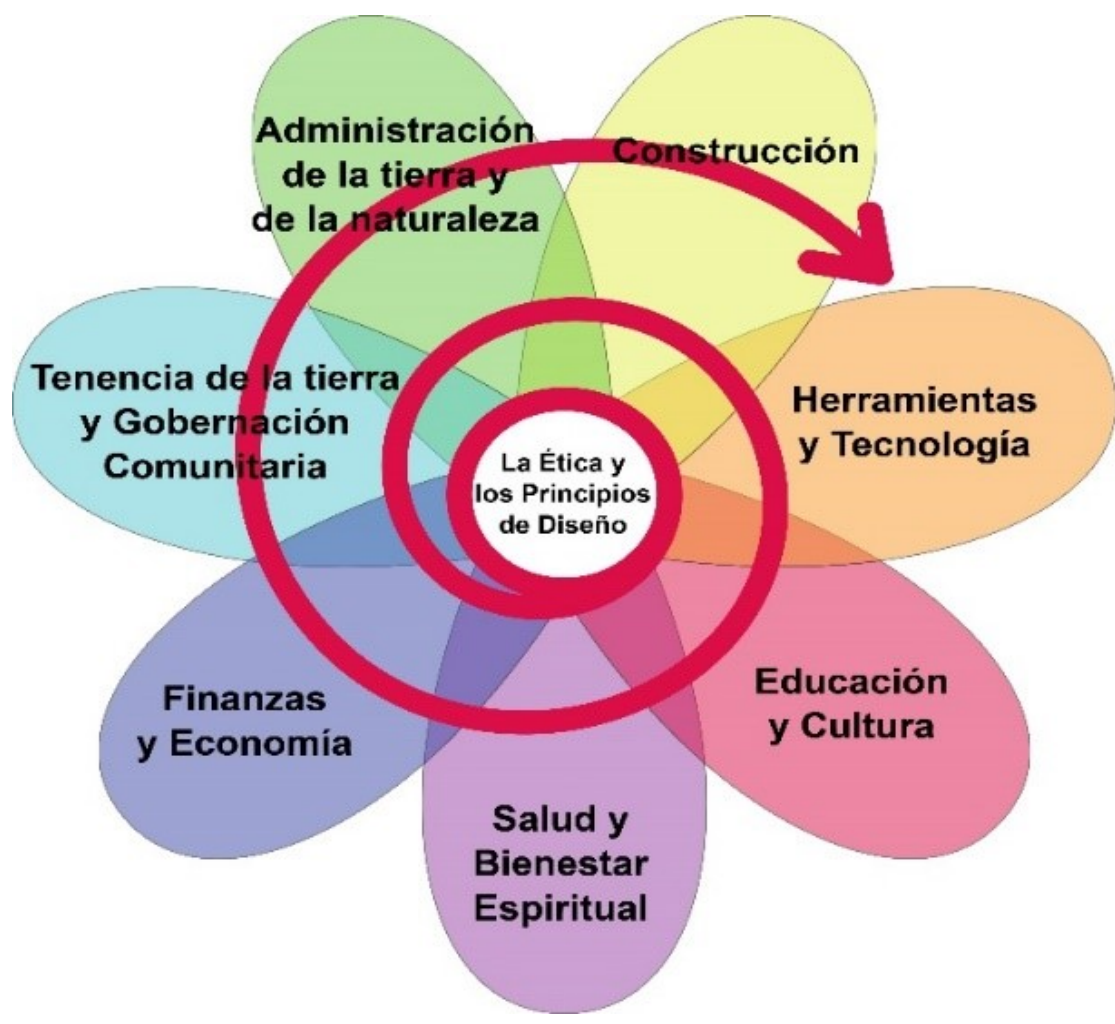

Imagen 155. Flor de Permacultura, 2015 Fuente: VARGUX

I. Observar e interactuar. Resulta imprescindible prestar atención a la naturaleza, la interacción entre todos los elementos que la forman es un punto clave para el desarrollo del diseño permacultural. La 
agricultura tradicional suponía una ardua labor, con gran esfuerzo de animales y personas para el trabajo. La agricultura industrial supone una gran inversión de energía fósil. En cambio, la permacultura propone una gran inversión de información y diseño.

II. Capturar y almacenar energía. Vivimos en la era del declive de los recursos fósiles, es por ello por lo que es muy importante generar nuestra propia energía renovable, ya sea solar o hidráulica. Además de almacenar y compartir el excedente.

III. Obtener un rendimiento. No hemos de olvidar que necesitamos obtener recompensas ya sea en alimento o energía para poder mantener y seguir con nuestro proyecto permacultural.

IV. Aplicar la autorregulación y aceptar la retroalimentación. Nutrimos y controlamos la naturaleza para beneficiarnos de sus propios ciclos naturales.

V. Usar y valorar los recursos y servicios renovables. Obtener energía de las plantas, la tierra, los animales, el sol o el agua sin que ellos se consuman.

VI. No producir basura. Este es un principio básico de cierre de ciclo, evitando generar basura, reciclando la mayoría de los elementos que desechamos y generando compost con los desechos biológicos, devolvemos a la tierra energía y alimento.

VII. Diseñar desde los patrones a los detalles. Hemos de tender a diseñar nuestros patrones desde una observación general, empezando a una gran escala para terminar centrándonos en los detalles.

VIII. Integrar más que segregar. Hemos de pensar en la correcta integración de los diferentes elementos que vayamos a colocar en nuestro diseño para que se beneficien entre ellos.

IX. Usar soluciones pequeñas y lentas. Tender a la autosuficiencia en todos los sentidos, aunque ello nos genere un proceso más lento.

X. Usar y valorar la diversidad. Beneficiarse de la diversidad de elementos para crear un equilibrio, controlar las plagas y la producción.

$X I$. Usar los bordes y valorar lo marginal. Beneficiarse de la gran diversidad de los ecotonos, bordes entre dos biorregiones donde se 
superponen las especies de ambas regiones, generando una mayor biodiversidad que la de las regiones respectivas.

XII. Usar y responder creativamente al cambio. Tener una visión para la posibilidad de cambio, mirada hacia el futuro con una perspectiva de sistemas a mayor escala y cooperativos (Holmgren, 2013: 23).

Posteriormente, debido a una constante necesidad de actualización de la información y remodelación de los conocimientos, estos doce principios que acabamos de resumir brevemente son reformulados y divididos en los siguientes tres grupos por la escritora Rosemary Morrow: principios de diseño, principios estratégicos y principios de actitud. Los principios de diseño se fundamentan en la ecología, en preservar y aumentar la biodiversidad, conservar y ampliar las fuentes de agua garantizando su pureza. Los principios de estrategia sirven para realizar el diseño de nuestro proyecto, pensando en los patrones de la naturaleza y beneficiándose de las asociaciones de los diferentes elementos que la componen. Los principios actitudinales se basan en un comportamiento ético donde se prime el trabajo unido a la naturaleza y nunca contra ella, junto a una buena administración y reparto de los recursos que se obtienen. Consideramos que la actualización de los principios de la permacultura que realiza Rosemary Morrow queda mejor clarificada al dividirse en estos tres grupos, organiza y sintetiza la información ayudando al lector en el entendimiento de los diferentes principios.

Esta autora ha realizado diferentes proyectos permaculturales en distintos países y climas, dicha experiencia queda recogida en el libro Guía de Permacultura para el uso de la Tierra, (Rosemary Morrow, 2018: 24).

En esta completa guía, de muy fácil lectura, el lector puede apreciar y tomar conciencia de que los pequeños cambios están en nuestras manos, y que éstos pueden suponer grandes aportaciones para un futuro. Siendo el arte de la permacultura la fusión de mucha información y conocimiento con la práctica, tal y como dice Erich Fromm en El arte de amar: 
El proceso de aprender un arte puede dividirse en dos partes: una, el dominio de la teoría; la otra, el dominio de la práctica [...] Solo llegaré a dominarlo después de mucha práctica, hasta que eventualmente los resultados de mi conocimiento teórico y los de mi práctica se fundan en uno, mi intuición, que es la esencia del dominio de cualquier arte (Fromm, 1988: 6).

Con esto queremos decir que no hay una pauta que se tenga que seguir literalmente para crear nuestro proyecto de permacultura, sino que partiendo de unos conocimientos y principios básicos cada uno va diseñando su propio proyecto permacultural, adaptándose a las inclemencias del tiempo, de cada lugar, a las necesidades de cada ser y aprendiendo sobre la práctica, aprendiendo in situ. También, van a ser necesarias nociones de diferentes áreas del conocimiento como las ciencias sociales, ambientales, la filosofía y el arte. Una fusión de todas las áreas del conocimiento nos ayudará en el diseño permacultural, aprovechando al máximo los recursos y cerrando el ciclo sin generar residuos.

Podemos decir que la permacultura se convertirá en nuestra filosofía de vida, muy necesaria para los tiempos de crisis ecosistémica que estamos viviendo y que se va a ir acrecentando con los años; como decía Albert Einstein: Nuestra tarea debe ser vivir libres, ampliando nuestro círculo de compasión para abarcar a todas las criaturas vivientes y la totalidad de la naturaleza y su belleza. Estamos en un momento donde, más que nunca, serán imprescindibles tomar estilos de vida más resilientes para poder llevar una vida buena sin acabar con todos los recursos que nos ofrece la madre tierra.

Retomamos los principios de la permacultura actualizados por Rosemary Morrow, que hemos citado anteriormente, y recordamos sus principios de actitud: cuidar de las personas, cuidar de la tierra y redistribuir los excedentes. Cabe destacar este apartado y darle mucha importancia, ya que es nuestra actitud la que nos llevará a sentir, crear y mantener nuestro proyecto permacultural, la que nos conectará con la tierra, las personas y los animales. La actitud positiva será nuestro motor, como dice el escritor y comunicador Víctor Küppers ${ }^{14}$, la suma del conocimiento y la habilidad se multiplican con

\footnotetext{
${ }^{14}$ Véase www.kuppers.com
} 
la actitud. Podemos adquirir muchos conocimientos y habilidades para trabajar nuestro proyecto, pero solo con una actitud realmente positiva se acrecentarán esos saberes. A pesar de que estas hipótesis funcionan para cualquier ámbito, consideramos que en la permacultura encajan perfectamente debido al enfoque holístico de la misma.

Tabla de principios de actitud en Guía de permacultura para el uso de la tierra, (Rosemary Morrow, 2018: 24):

\section{PRINCIPIOS DE ACTITUD}

\begin{tabular}{|c|c|}
\hline POSTURA BÁSICA & RESULTADOS \\
\hline $\begin{array}{l}\text { Trabajar con la naturaleza, no contra } \\
\text { ella. }\end{array}$ & $\begin{array}{l}\text { Da como resultado un impacto negativo } \\
\text { mínimo y sostenibilidad a largo plazo. }\end{array}$ \\
\hline $\begin{array}{l}\text { Valorar los bordes, lo marginal y } 10 \\
\text { pequeño. }\end{array}$ & $\begin{array}{l}\text { Lo que es pequeño y diverso puede ser } \\
\text { vital. }\end{array}$ \\
\hline $\begin{array}{l}\text { Ver las soluciones implícitas en los } \\
\text { problemas. }\end{array}$ & $\begin{array}{l}\text { Nos ayuda a superar bloqueos desde el } \\
\text { diseño a la implementación. }\end{array}$ \\
\hline o generar residuos. & $\begin{array}{l}\text { Avanzar hacia un ecosistema de ciclo } \\
\text { cerrado. }\end{array}$ \\
\hline $\begin{array}{l}\text { alorar a la gente, sus conocimientos y } \\
\text { u trabajo. }\end{array}$ & $\begin{array}{l}\text { Atrae a la gente y les aporta autoestima } \\
\text { y apoyo. }\end{array}$ \\
\hline espetar toda forma de vida. & $\begin{array}{l}\text { Se valoran las maravillas que aporta la } \\
\text { diversidad naturaly cultural. }\end{array}$ \\
\hline $\begin{array}{l}\text { Utilizar el transporte público y } \\
\text { combustibles renovables. }\end{array}$ & $\begin{array}{l}\text { - Avanzar hacia una planificación } \\
\text { urbanística a escala humana y } \\
\text { sostenible que genere espacios más }\end{array}$ \\
\hline $\begin{array}{l}\text { Tener en cuenta la distancia que } \\
\text { recorren los alimentos. }\end{array}$ & $\begin{array}{l}\text { agradables y menos contaminación. } \\
\text { - Apoyar a la agricultura local, los } \\
\text { productos de la biorregión, reducir los } \\
\text { costes de la alimentación y liberar las } \\
\text { carreteras de camiones. }\end{array}$ \\
\hline Reducir nuestra huella ecológica. & $\begin{array}{l}\text { - Aceptar la responsabilidad, simplificar } \\
\text { nuestras vidas y conseguir una mayor } \\
\text { autosuficiencia. } \\
\text { - Recordar el futuro y ahorrar recursos. }\end{array}$ \\
\hline
\end{tabular}


Dentro de estos principios de actitud, entra el cuidado a las personas, permacultura es cuidado y es respeto, empezando por cuidarnos a nosotros mismos para así poder cuidar a nuestra familia, nuestra comunidad y nuestro entorno. Viviendo en equilibrio y en armonía, actuando con responsabilidad comunitaria, entendiendo que lo que nos afecta a nosotros afecta a nuestro entorno y viceversa. Llevando una actitud donde prevalezca el cuidado y una sostenibilidad a largo plazo, evitando pensar únicamente en los resultados inmediatos. Además, también consideramos importante trabajar disciplinas que abarquen en su totalidad el cuerpo, el espíritu y la mente, en busca de un equilibrio, como diríamos en latín clásico Mens sana in corpore sano ${ }^{15}$ (sátira X: 356). Para ello, podemos fomentar prácticas como el yoga, el TAI CHI o la meditación (entre otras), centrándonos en una salud preventiva y preocupándonos de nuestro bienestar espiritual.

Los principios de diseño se basan en el agua, la energía y el suelo, elementos esenciales para los procesos de vida. Rosemary Morrow en la explicación de éstos, detalla la necesidad de conservar y ampliar las fuentes y reservas de agua; captar y almacenar la energía utilizando medios de bajo impacto ecosistémico y renovables; preservar y aumentar la biodiversidad. Pero, sobre todo, proteger y mantener los bellos paisajes naturales y tradicionales.

Tabla de principios de diseño en Guía de permacultura para el uso de la tierra, (Rosemary Morrow, 2018: 25):

PRINCIPIOS DE DISEÑO

Preservar, regenerar y ampliar todos los paisajes permanentes naturales y tradicionales.

Agua: conservar y ampliar todas las fuentes y reservas de agua y mantener y garantizar la pureza de ésta.
LUGARDE APLICACIÓN

Cuencas hidrológicas, valles, márgenes de carreteras, restos de bosques, crestasy pendientes pronunciadas y nuestras parcelas.

Cuencas, afluentes, humedales, ríos, lagos, acuíferos, manantiales y estuarios, incluyendo los sistemas de provisión de agua tradicionales, como por ejemplo los

15 La cita completa es Orandum est ut sit mens sāna in corpore sānō. Su sentido original es el de la necesidad de orar para disponer de un espíritu equilibrado en un cuerpo equilibrado. 
campos de arroz en terrazas de Bali o tuberías enterradas y los canales de agua de deshielo de Oriente Próximo. Cuidar de la salud de los sistemas marinos.

Energía: captar y almacenar energía de Buscar las fuentes solares, eólicas, de las todos los medios no contaminantes y olas y geotérmicas. Captar energía renovables. mediante vegetación. Transformar los monocultivos extensivos en sistemas diversificados permanentes, agua y biomasa (plantas y animales) de todo tipo.

Utilizar el diseño y la tecnología solares pasivos.

Utilizar la fuerza del viento y de las olas para generar energía.

Biodiversidad: preservar y aumentar la De bosquestropicales a desiertos.

biodiversidad de todo tipo.

De invisible a gigante.

En nichos, hábitats, semillas, asentamientos humanos, religiones, conocimientos, habilidades y actitudes.

Los principios estratégicos, se basan en una serie de conocimientos que nos ayudarán a ser más eficaces y minimizarán el impacto ambiental ocasionado por los posibles errores de diseño, haciendo un uso más adecuado de los recursos. Creando desde los patrones a los detalles, pero empezando pequeño, aprendiendo de los cambios y del propio camino.

Tabla de principios estratégicos en Guía de permacultura para el uso de la tierra, (Rosemary Morrow, 2018: 26):

PRINCIPIO ESTRATÉGICO

Centrarse en la sostenibilidad a largo Reflexión atenta.

plazo.

Cooperar, no competir.

Diseñar de los patrones a los detalles.
Compartir los mejores conocimientos y prácticas.

Ver primero el cuadro completo. 


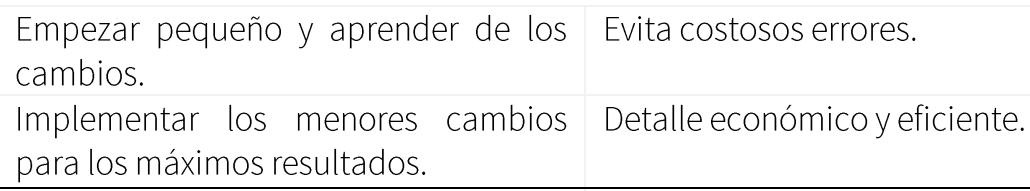

Convertir los recursos y los servicios Establece una retroalimentación que renovables en prioritarios. nos conduce hacia la sostenibilidad a largo plazo.

Devolver a las ciudades la producción Potencia la seguridad alimentaria y de alimentos. evita riesgos.

Consideramos la permacultura como un paradigma holístico, vemos y experimentamos la realidad como un todo en constante evolución, donde tenemos en cuenta el pasado, el presente y el futuro con todas sus posibilidades de ser. Lo que nos lleva a valorar la necesidad de destacar la huella ecológica de cada habitante del planeta y de cada país, ya que nos servirá como reflexión para tomar conciencia del impacto que ocasionamos al medio ambiente. Actualmente, existen páginas web ${ }^{16}$ que nos ayudan a medir nuestra huella ecológica, lo cual nos sirve para empezar a tomar conciencia del gran impacto que ocasionamos y ocasionaremos en la biosfera si seguimos con el mismo ritmo de creciente consumo. Si analizamos nuestra huella ecológica con nuestro modelo de vida actual y volvemos a analizarla con un estilo de vida permacultural, veremos el gran descenso numérico que se produce.

Rosemary Morrow, nos pone el ejemplo de una niña en Malasia donde apenas tiene huella ecológica y, por el contrario, un habitante de Australia tiene una huella de siete hectáreas. Con este ejemplo, si generalizamos, necesitaríamos disponer de tres planetas para seguir con ese nivel de vida. Partiendo de que este modelo de habitar es insostenible y hay que empezar a generar cambios en la sociedad, consideramos que el estilo de vida basado en la permacultura es de los más adaptados y resilientes. Estos estilos de vida normalmente son

\footnotetext{
${ }^{16}$ Véase: www.tuhuellaecologica.org
} 
aplicados a pequeña escala, hogares, fincas y pequeñas comunidades, pero cada vez son más los colectivos que se interesan por cuidar su hábitat.

Un ejemplo lo tenemos con la Fundación Los Madroños ${ }^{17}$, la cual se basa en un modelo holístico donde los principios básicos de la permacultura están bien integrados, además de llevar una gran labor en la difusión de los saberes de la permacultura, a través de la editorial Kaicron ${ }^{18}$. Un pilar fundamental, ya que es trabajo de todos difundir el conocimiento y educar a las nuevas generaciones para que crezcan sabiendo valorar la tierra y los recursos que nos ofrece. Se realizaron prácticas ${ }^{19}$ en esta fundación para profundizar en el concepto de permacultura. La Fundación Los Madroños es una Casa de Reposo donde se apuesta por una salud integral, se considera igual de importante la salud física como la mental y emocional, factor importante dentro de la permacultura como comentábamos anteriormente.

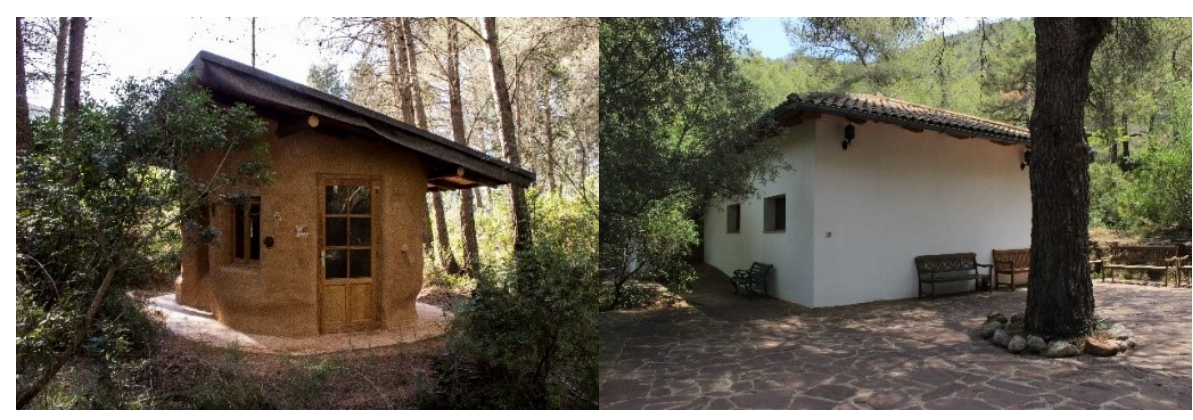

Imagen 156. Vista casa de barro. Fundación Los Madroños, 2018. Fuente: propia Imagen 157. Vista patio y edificio habitaciones. Fundación Los Madroños, 2018. Fuente: propia

\footnotetext{
${ }_{17}$ Un espacio creado para que puedas experimentar un estilo de vida en armonía con las leyes naturales, tomar contacto contigo mismo y tu realidad actual, situado en el Parque Natural del Desierto de las Palmas, Castellón. Véase www.casadereposo.com

${ }^{18}$ Editorial y distribuidora española, lugar de reflexión e investigación donde sus valores y filosofías van marcados por albergar ecología, educación, economía, cultura, sabiduría y salud. ${ }^{19}$ Prácticas realizadas en el contexto del Diploma de Especialización en Sostenibilidad, Ética Ecológica y Educación Ambiental ofertado en la Universitat Politècnica de València. Véase www.ecoeducacion.webs.upv.es
} 
Es un lugar para reconectar con la naturaleza, con el ser interior, para meditar, descansar y desintoxicarse. Durante la estancia en la casa, se pudo conocer de primera mano la esencia del lugar, la estética, el funcionamiento interno y la evolución de los alojados durante su estancia, así como nutrirse de las bases de la permacultura. Se pudo trabajar en las huertas, recuperando las más dañadas y aprendiendo nuevos conocimientos a la hora de trabajar la tierra.

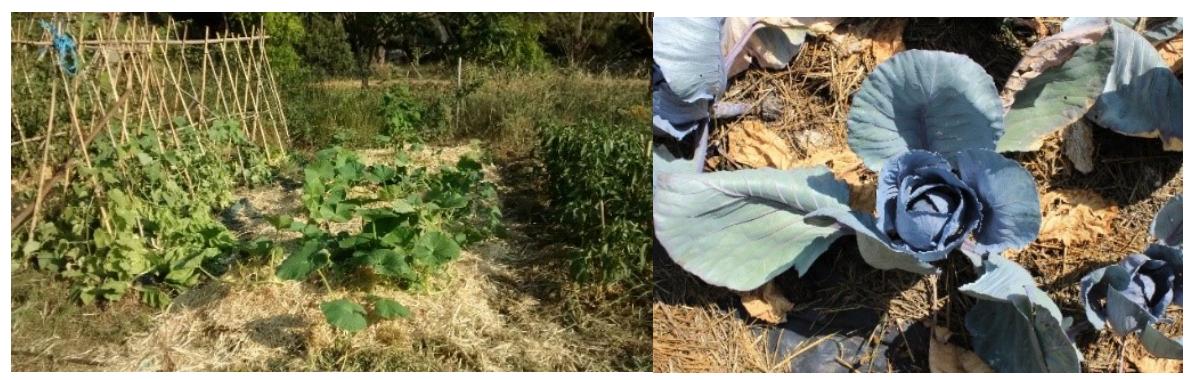

Imagen 158. Vista de una de las huertas. Fundación Los Madroños, 2018. Fuente: propia Imagen 159. Detalle de una de las huertas. Fundación Los Madroños, 2018. Fuente: propia

La Fundación dispone de cinco espacios de huerta permacultural y un invernadero. Se utilizan energías renovables y agua de los pozos para mantener tanto los cultivos como las casas. Una de las principales problemáticas que se detectan, es la carencia de agua. En pleno parque natural del Desierto de las Palmas, un enclave único, pero con gran falta de agua y lluvias, es una zona de monte mediterráneo pero muy seco. Deben controlar mucho el agua y se lo hacen saber bien a todos los alojados en la casa. También disponen de una depuradora donde consiguen filtrar el agua y utilizarla para regar algunas zonas de vegetación. Asimismo, utilizan depósitos para almacenar el agua que sacan de los pozos con la ayuda de una bomba eléctrica alimentada por energía solar. Es un espacio que genera el mínimo impacto ecosistémico, vive, crece y se desarrolla en sintonía con el propio lugar. Un enclave único, donde apreciar la naturaleza, valorando los 
recursos que nos ofrece, así como sus limitaciones, observando la estética tanto de las propias huertas como de las energías que se generan por el vínculo de la comunidad y su conexión con el lugar.

La permacultura es una herramienta que nos puede ayudar en el proceso de empoderamiento para recordar nuestro lugar dentro de la naturaleza. Siendo necesario generar alternativas, invirtiendo nuestra energía de una forma responsable y consciente. Además, son necesarias técnicas diferentes para abarcar los problemas sociales y medioambientales que estamos viviendo y que van a ir acrecentándose. Cada vez son más las organizaciones que se preparan en permacultura, fomentando y difundiendo sus conocimientos a través de cursos, talleres y publicaciones. Consideramos que la permacultura abarca herramientas para afrontar un declive energético como el que la sociedad irá viviendo, incrementándose con el paso de los años.

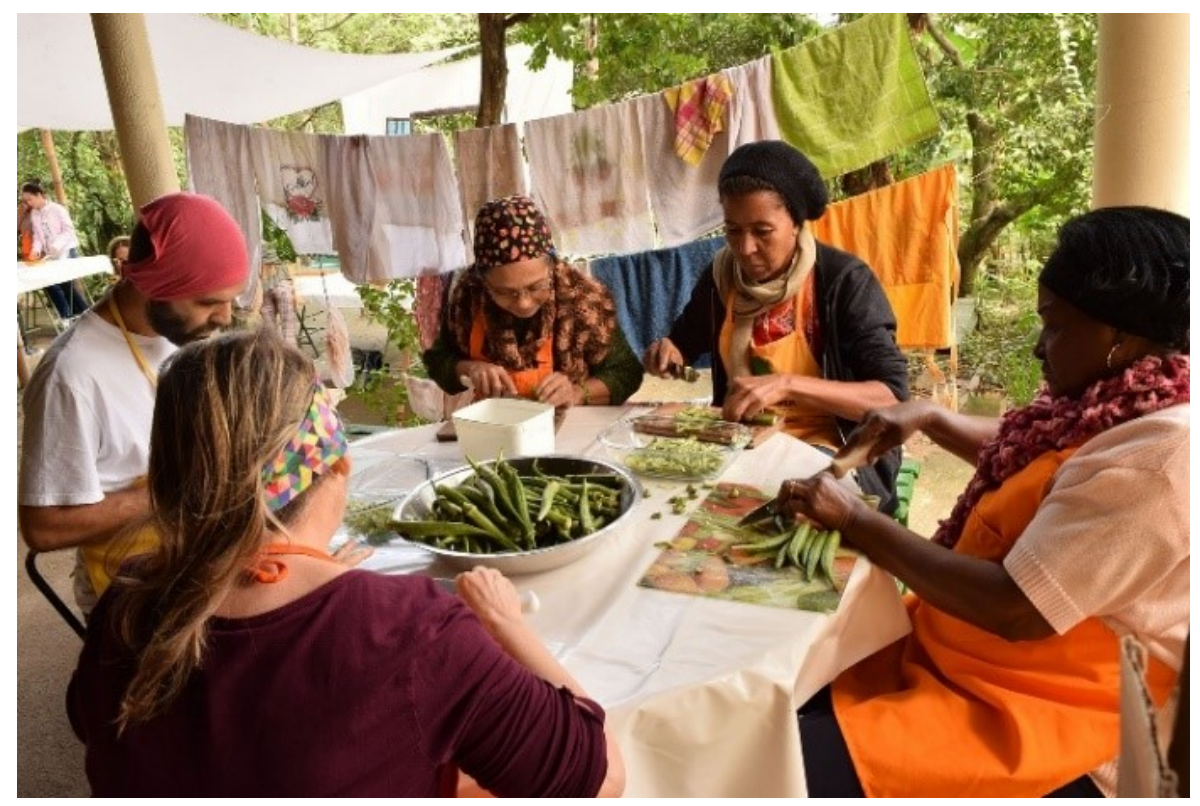

Imagen 160. Grupo comunidad Fuente: Creative Commons, s.f. 
De modo que observamos el papel del arte en la difusión de estos saberes como una potente herramienta, tanto para la difusión de éstos como para potenciar la sensibilidad de éstos en la sociedad. Cabe destacar las capacidades empatizadoras del arte con la finalidad de crear grupo/comunidad, por la fascinación asociada a la creación del diseño de los propios cultivos o a la conservación del paisaje por la simple contemplación de su belleza. Como ejemplo, podemos observar la imagen que acompaña al texto, contemplando la hermosura de un campo de manzanos.

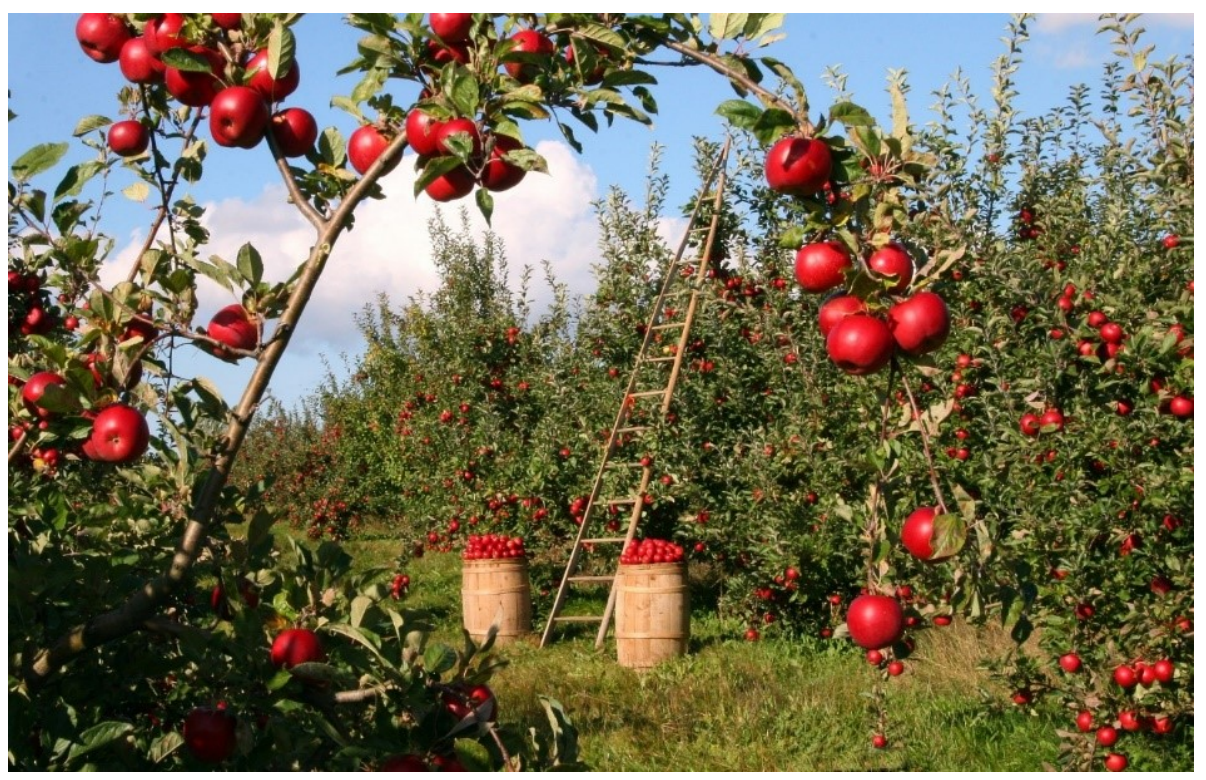

Ilustración 161. Campo de manzanos. Fuente: Creative Commons, s. f.

En el quinto capítulo de esta investigación, junto a los casos de estudio, se analizan los aspectos artísticos vinculados a los diferentes proyectos agroecológicos.

\subsection{Conexión del cuerpo con la tierra}

El vínculo que se genera con la tierra, con el espacio y con la propia naturaleza es esencial para poder vivir como un elemento más integrado en el propio 
diseño permacultural. Todos los elementos de la naturaleza están interconectados, como dice Jorge Riechmann en su libro Un buen encaje de los ecosistemas, somos seres ecodependientes e interdependientes. Por ello, las pautas y el conocimiento que nos ofrece la filosofía permacultural resulta útil para el aprendizaje en la gestión de los recursos que nos ofrece la biosfera. Asimismo, esa administración se contempla desde el equilibrio y los cuidados, recordando un estilo de habitar más conectado con la naturaleza. Sin embargo, la permacultura, también se sirve de los avances tecnológicos y científicos para adaptarlos a esa visión de sustentabilidad, viendo cuáles son las comodidades de las que disfrutamos actualmente y podemos introducir en un modelo de vida más equilibrado y respetuoso con nuestro entorno donde se puedan cubrir las necesidades básicas.

Nos situamos en una época en la que la tecnología se instaura para ofrecernos una vida tan cómoda, que llegamos a gastar más energía en un aparato electrónico que la que gastaríamos nosotros mismos con nuestro propio cuerpo para generar la misma acción. Un ejemplo muy claro lo tenemos con la secadora de la ropa, a no ser que vivamos en una ciudad donde llueva 365 días al año y no veamos el sol, lo más sencillo y ahorrador sería secar la ropa al calor del astro. Tomar conciencia para optimizar la energía en una época de declive energético será de gran importancia, sabiendo gestionar mejor los recursos y generando excedentes que podamos compartir.

El arte, la espiritualidad y los conocimientos ancestrales, están vinculados al concepto de permacultura. En un momento en el que el ser humano cada vez está más desconectado de sus raíces, de su conexión con la tierra, con el entorno natural y con el concepto de colectividad, sentimos la necesidad de recuperar, valorar y difundir todos los saberes ancestrales que tanto necesitamos en estos tiempos.

El proyecto de $B$ collective ${ }^{20}$ es un ejemplo de fusión del arte con los principios de la permacultura donde crear una cultura saludable y sostenible. Su

${ }^{20}$ Véase www.bcollective.org 
fundadora Nala Walla lleva veinte años trabajando con la sanación del cuerpo, con la ecología y con la comunidad. Reside en Port Townsend ciudad ubicada en el condado de Jefferson, Washington (EUA), donde tiene la oportunidad de aplicar la filosofía ecosomática práctica en su granja permacultural junto a su familia. Tiene publicados artículos donde investiga sobre el cuerpo, las relaciones con los principios naturales, la sanación, la permacultura y el activismo. Además, trabaja en educación, en medicina y nutrición ancestral. Un proyecto muy amplio al que dedica su vida y su tiempo en cultivarse para poder compartir con la comunidad.

En su obra artística, trabaja principalmente con el cuerpo, la zona cero en permacultura, defiende la necesidad de sanar nuestro cuerpo, de llegar a un equilibrio y una paz interior para poder conectar con la tierra y cuidar los aspectos externos a nosotros. Sanar el interior para ayudar en el exterior. En las siguientes imágenes podemos observar unas capturas de la performance que realizó en colaboración con la artista Tamara Ashley de Reino Unido, un site-specific titulado De-composition realizado en Fort Worden, en Port Townsend, Washington (EUA). El lugar elegido muestra una base militar en descomposición donde han podido explorar temas como el anacronismo, el aislamiento y la decadencia.

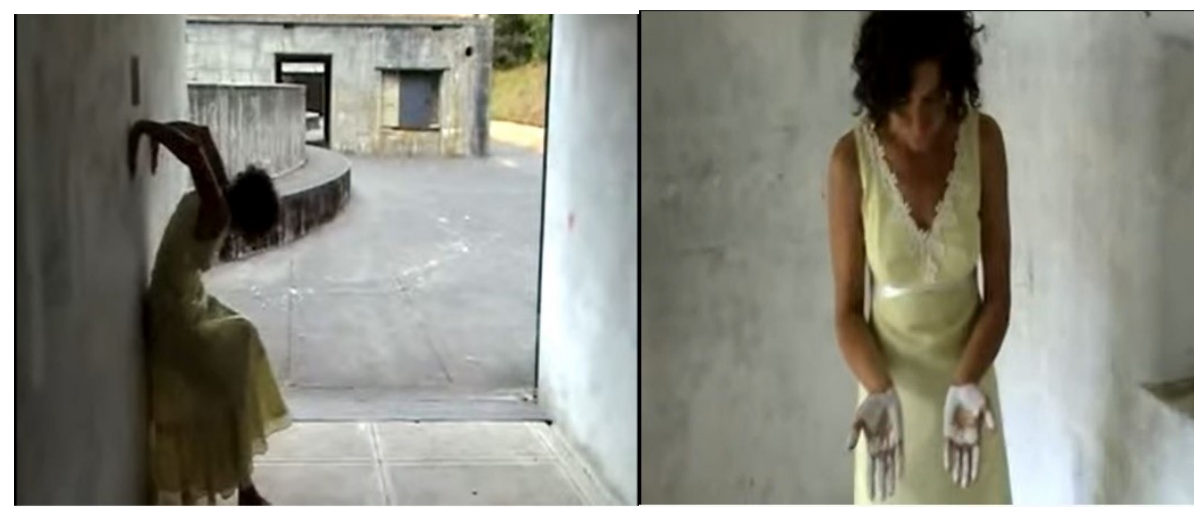

Imagen 162. De-Composition, performance. Nala Walla y Tamara Ashley, 2009. Fuente: bcollective.org Imagen 163. De-Composition, performance. Nala Walla y Tamara Ashley, 2009. Fuente: bcollective.org 


\subsubsection{Salud y bienestar}

Partiendo de las capacidades sanadoras de la permacultura tanto por su conexión/relación con la tierra como por su concepto de integración y generador del grupo comunidad, encontramos proyectos muy interesantes como el producido por la Universidad de la Laguna. Un proyecto originado en la Finca del Manto Tinto para el desarrollo de la permacultura, donde trabajan está filosofía como terapia para personas con problemas de salud mental.

La permacultura ayuda a la integración sociolaboral a través de sus principios, de una forma sustentable y en contacto directo con la tierra. Los objetivos que trabajan y han ido consiguiendo satisfactoriamente en el proyecto son, desde el desarrollo de habilidades sociales para facilitar la comunicación, el trabajo en equipo y la creación de hábitos básicos en el trabajo, hasta la mejora de las capacidades cognitivas básicas como la atención, la concentración y la comprensión. Además, las expectativas de futuro y la evolución positiva, tanto en el alumnado como en su familia es un factor de gran impacto a nivel emocional.

Con el objetivo de observar si este proyecto se podía aplicar en un ámbito europeo, para que no quedara en algo puntual como experiencia de la citada finca, lanzaron cinco proyectos piloto en Suecia, Eslovenia, Grecia y España. Así pues, crearon la guía PERMIND ${ }^{21}$, unas pautas generadas en base a sus experiencias en la finca donde se resaltan los aspectos sanadores de la permacultura. La prioridad del proyecto no es el trabajo del campo, la tierra y el agua, sino el cultivo de las relaciones humanas al mismo tiempo que se reconecta con la naturaleza. Esta guía está a libre disposición una vez finalizado el proyecto.

Es por ello por lo que nos preguntamos, si a todos estos objetivos y planteamientos que utiliza la filosofía permacultural para la mejora en la salud de ciertas personas con diversidad funcional, le añadimos la vertiente

\footnotetext{
${ }^{21}$ PERMIND: Permacultura aplicada en la recuperación de personas con enfermedad mental. Programa de ayudas erasmus plus de dos años que finaliza en septiembre de 2019.
} 
artística ipodremos potenciar tanto los objetivos como los resultados a través de la belleza y las potencialidades del arte? Cabe decir que la permacultura ya está muy vinculada con nociones artísticas y, por tanto, ya se trabajan. Pero, nosotros vamos más allá, para potenciar el papel del arte en los proyectos vinculados al trabajo permacultural. A través de la imagen y el diseño atraemos mayor público y, por tanto, mayor difusión de nuestro proyecto y de todos los saberes vinculados a él.

Podemos destacar el proyecto Pyramid ${ }^{22}$ con sede en Leeds (Inglaterra), por su trabajo fomentando la integración de personas con o sin dificultades de aprendizaje a través de las artes creativas. Realizan una gran labor para enseñar y ayudar a desarrollar las habilidades artísticas de las personas con diversidad funcional. A través de grupos de arte colaborativos les dan apoyo, reconocimiento y oportunidades para desarrollarse profesionalmente. Es un buen ejemplo de comunidad integrada con altas aptitudes de respeto, tolerancia, compañerismo y humildad, que utilizando la práctica artística ensalzan su autoestima, su lugar en el mundo y ese sentimiento de sentirse útil y realizado. Ofrecen tanto la formación como el seguimiento de la creación artística, así como la exposición de las obras y su posible venta. Trabajan por proyectos, en los cuales se demoran el tiempo que sea necesario para llegar a desarrollar las habilidades, comprender y nutrir cada etapa del proceso de trabajo.

\subsubsection{El arte de la toma de conciencia}

Consideramos que para poder llegar a potenciar la belleza y el alma de la permacultura plenamente a través del arte, primero es necesario trabajar una conexión con la tierra, con la naturaleza, un aprendizaje y una comprensión del lugar que habitamos que se unirá a nuestros propios procesos de vida.

La toma de conciencia es la clave, observar nuestros hábitos, nuestra forma de relacionarnos tanto con la naturaleza como con las personas que nos rodean. Siendo fundamental el respeto a nosotros mismos para así poder

${ }^{22}$ Véase www.pyramid-of-arts.org.uk 
estimar nuestro entorno, nuestro planeta. "La Permacultura se orienta hacia el crear medioambientes humanos autosustentables" (Meacham, 2010: 3) y para ello hemos de conseguir un equilibrio en nuestras emociones, en nuestro ser, un equilibrio interior que proyecte un trato equitativo tanto en las relaciones humanas como en las relaciones con el medio natural.

Si partimos de la base en la que actualmente estamos, en un planeta desequilibrado y desestructurado donde una parte de los habitantes de la Tierra acumulan y retienen riquezas, mientras la otra parte se muere de hambre en una sociedad que se rige por el capital, promover sociedades más sostenibles y respetuosas se convierte en nuestra prioridad.

Estimaciones sobre la magnitud de esta desigualdad indican que la mitad más pobre de la población mundial -aproximadamente 3.500 millones de personassólo genera alrededor del 10\% del total de las emisiones mundiales atribuidas al consumo individual, y sin embargo viven mayoritariamente en los países más vulnerables ante el cambio climático.

En cambio, aproximadamente el 50\% de estas emisiones puede atribuirse al $10 \%$ más rico de la población mundial, cuya huella de carbono media es hasta once veces superior a la de la mitad más pobre de la población, y 60 veces superior a la del 10\% más pobre. La huella de carbono media del $1 \%$ más rico de la población mundial podría multiplicar por 175 a la del 10\% más pobre (Oxfam, 2015: 1).

Tras leer este fragmento del informe emitido por Oxfam, vemos las claras evidencias de la desigualdad que estamos viviendo, así como la falta de respeto, de valoración, de compartir, de asumir responsabilidades y de actuar por parte de ese $10 \%$ más rico de la población mundial. Es por ello por lo que defendemos la filosofía permacultural dado que piensa en soluciones, en formas de vivir más equitativas donde el respeto y la valoración son primordiales. Cultivando una base de fuertes valores emocionales, donde el centro del universo no sea ni el ser humano ni el capital, sino una consideración por todo en cuanto nos rodea, por lo que se nos ofrece y ofrecemos desde la equidad. 


\subsubsection{El pensamiento positivo}

Nuestras formas de actuar, pensar, decidir y compartir van conformado nuestro entorno y nuestra huella en el planeta. El hecho de crecer en entornos donde se nos acompañe a opinar, a ser libres pensadores, a compartir las emociones, a seguir nuestros propios estímulos e intentar ser la mejor proyección de nuestro ser interior, ¿puede llegar a sonar un poco utópico o es que nos han hecho creer que lo contrario era lo correcto y esto algo novelesco?

Recordamos que estamos marcados por una sociedad donde el capital es el centro del universo y lo importante es consumir, no se facilita el camino a que la sociedad pueda abrir su mente, proyectar sus pensamientos, generar sus propios proyectos, sus propias formas de ser y compartir fuera de esa burbuja. La permacultura defiende esas formas de ser y de vivir vetadas por el capitalismo, buscando continuamente soluciones a las adversidades que nos vienen y nos van a ir viniendo con el paso de los años.

La permacultura como disciplina curativa. El factor más importante en el diseño para la curación es la intención de uno. Lo que pensamos y decimos tiene un profundo efecto en el mundo físico real. Investigación fascinante por el científico japonés Masaru Emoto sugiere que, simplemente dirigiendo pensamientos positivos hacia el agua almacenada, uno puede mejorar su calidad. Por consiguiente, el diseñador/a en permacultura habla y piensa en soluciones en lugar de problemas (Michael, 2001: 4)23.

La permacultora Patricia Michael hace una hermosa comparación de la filosofía permacultural con el trabajo de investigación del científico Masaru Emoto, donde se potencia y se pone en valor el poder de los pensamientos

\footnotetext{
${ }^{23}$ Permaculture as a Healing Discipline The most important factor in design for healing is one's intention. What we think and say has a profound effect on the actual physical world. Fascinating research by the Japanese scientist Masaru Emoto suggests that merely by directing positive thoughts toward stored water one can improve its quality. Accordingly, the Permaculture designer talks and thinks about solutions rather than problems. In our reports and the language we use with the clients, we stay as positive as possible. Traducción realizada porT. Thompson.
} 
positivos, resaltando la inmensa fuerza que puede llegar a tener nuestra mente y nuestros pensamientos.
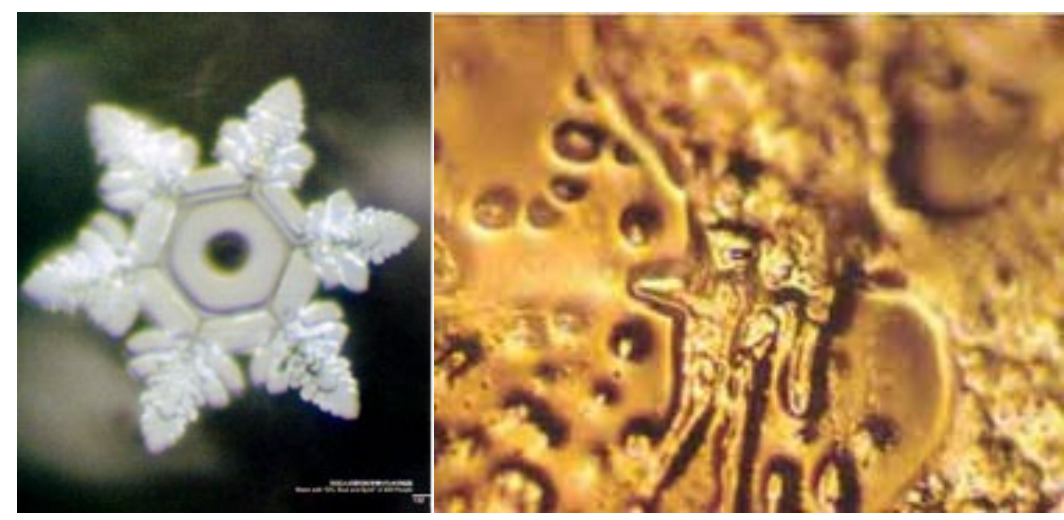

Imagen 164. Mensaje de amor de 500 personas.

Masaru Emoto, 2002. Fuente: oshogulaab.com Imagen 165. Mensaje de "me enfermas, jte voy a matar!" Masaru Emoto, 2002. Fuente: oshogulaab.com

Emoto ha llevado a cabo experimentos donde estudia el efecto de las ideas, las palabras y la música sobre las moléculas de agua. Su estudio consiste en captar fotográficamente la forma de la molécula de agua que ha recibido esa palabra, música o idea. En ellas se puede observar cómo la recepción de un mensaje positivo y agradable genera una composición en la molécula estructurada, a la vez que bella y agradable a la vista. En cambio, cuando el mensaje es negativo se visualiza una imagen desorganizada y difusa. Cabe destacar el gran valor estético de su trabajo, donde a través de su investigación genera una serie de fotografías con una composición tanto de color y forma muy potentes y atractivas.

Si partimos de que el planeta se compone de un 70\% de agua y el cuerpo humano aproximadamente también, según la investigación de Emoto podemos llegar a tener una gran influencia según nuestros pensamientos con las moléculas de agua que forman nuestro cuerpo y el planeta que habitamos. 
A pesar de lo controvertida que pueda haber llegado a ser su investigación, para nosotros es otra evidencia más que nos mueve a proyectar pensamientos positivos para un mejor habitar. Además de seguir resaltando su fuerte vínculo con la forma, con la imagen, con el color, con la luz y, en definitiva, con el arte.

\subsection{La belleza asociada al diseño de huertas permaculturales}

El diseño de nuevos modelos de alimentación va a ser imprescindible en un planeta con cada vez menos recursos, es por ello por lo que apostamos por el diseño de huertas permaculturales. Estos diseños son capaces de optimizar al máximo los recursos, generando gran variedad de alimentos en espacios más reducidos. Pero nosotros nos vamos a centrar en la vinculación del arte con la agricultura en este contexto.

La propia belleza producida por la naturaleza unida a las composiciones y diseños generados por el ser humano desembocan en preciosas estampas. Este hecho lo podemos observar en el diseño de los huertos permaculturales.

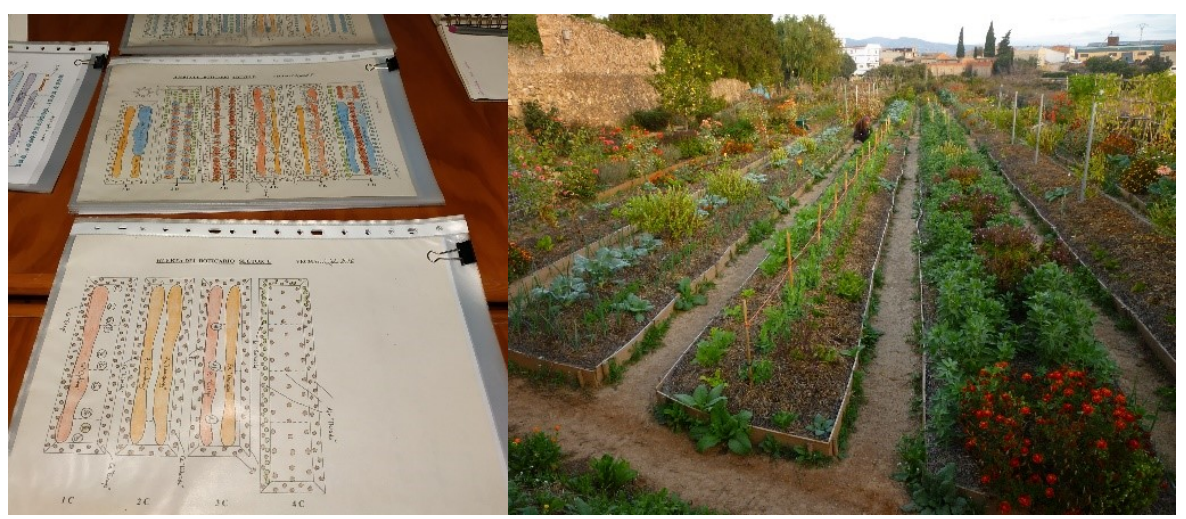

Imagen 166. Bocetos en papel Huerta del Boticario, 2019.

Fuente: propia Imagen 167. Vista Huerta del Boticario, 2017. Fuente: Carlos García Dolz 
El agricultor o agricultora a través de la búsqueda del equilibrio natural es capaz de generar un ecosistema vivo con las diferentes asociaciones de cultivo. Estas composiciones son creadas como un artista pinta un cuadro o un escultor construye su escultura. Primero se realiza una tarea de estudio donde se analiza el espacio, los diferentes elementos que formarán parte de él, la composición, la finalidad de la obra y se genera el bocetaje. En la imagen anterior podemos observar los bocetos de la parcela de La Huerta del Boticario $^{24}$, mostrados por el agricultor en el curso que imparte de Diseño de huertas en permacultura. Huerto natural-sinérgico, en Macastre, Valencia (España). La fotografía contigua muestra el diseño de las parcelas in situ, donde podemos observar cómo se han adaptado al lugar y cómo han dispuesto todos los elementos basándose en los principios de la permacultura.

Tras estudiar y conocer las asociaciones de los cultivos, los beneficios de las plantas aromáticas y medicinales, así como de los insectos y demás seres vivos que conforman su ecosistema, prepararon el espacio para llevar a cabo el diseño permacultural que previamente elaboraron en papel.
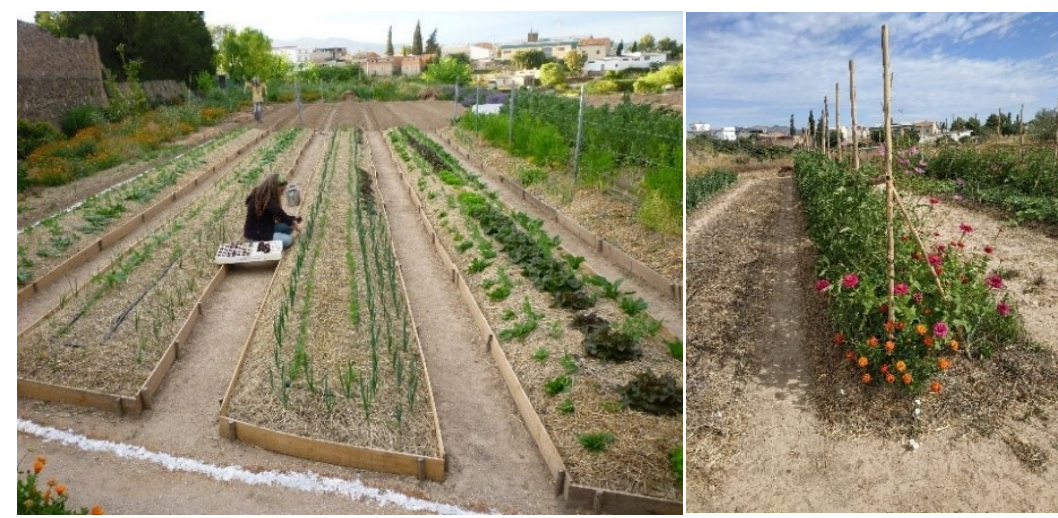

Imagen 168. Vistas primera parcela, Huerta del Boticario.

Macastre, Valencia, 2015. Fuente: Carlos García Dolz Imagen 169. Vistas segunda parcela, Huerta del Boticario. Macastre, Valencia, 2019. Fuente: propia

${ }^{24}$ Véase www.huertadelboticario.org 
La huerta permacultural la podemos visualizar como una obra procesual, la cual está viva. La dedicación y el cariño del agricultor/a junto a todos los seres vivos que interactuarán en ese mismo espacio dará lugar al transcurso de todas sus fases, desde el nacimiento a la muerte. Contemplamos la muerte como un punto y seguido, como un momento de descanso donde la tierra se nutre de los restos para volver a renacer en otros cultivos, un circuito cerrado en el cual todo vuelve a la tierra. Se recogen las semillas, se realizan los plantones y se empieza un nuevo diseño según las rotaciones de cultivo que se vayan destinando a cada parcela, según la climatología y la influencia lunar.

Es un proceso de estudio y trabajo, de prueba y error, de investigación, de juego, de contemplación, de generador de vida y de creación de arte. "La agricultura es la profesión propia del sabio, la más adecuada al sencillo y la ocupación más digna para todo hombre libre" (Cicerón, 106-43 a. C.).

Tras todo el tiempo y trabajo invertido podemos observar preciosas estampas con el florecer de las aromáticas y medicinales, con la aparición de bellos insectos y con la contemplación de todo el conjunto.

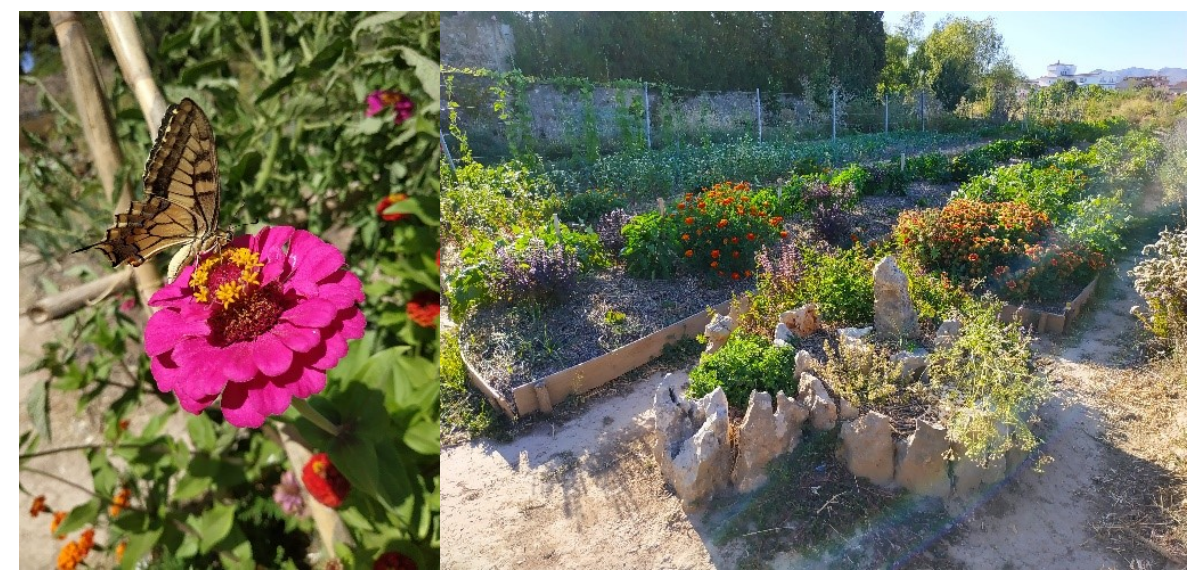

Imagen 170. Detalle flor, Huerta del Boticario. Macastre, Valencia, 2019. Fuente: propia Imagen 171. Huerta del Boticario. Macastre, Valencia, 2019. Fuente: propia 
Valoramos especialmente la estética del conjunto, las composiciones creadas por todas y cada una de las plantas organizadas junto a los diferentes elementos que componen finalmente el diseño permacultural. En esa totalidad contemplamos lo bello en equilibrio con lo real, con la fealdad que pueda conllevar.

Además, hemos de resaltar el uso de la geometría en el diseño de las huertas, la forma en espiral es la más característica de todas, ya que la solemos observar en casi todos los proyectos permaculturales. En la medida de lo posible y según el espacio del que se dispone, se suelen diseñar las huertas con curvas, formas sinuosas o redondeadas.

La espiral es un símbolo que puede ser observado en diferentes elementos de la naturaleza, se relaciona con la idea de crecimiento y evolución, podemos observar esta geometría en animales como caracoles o conchas, en vegetales como la piña y en formas más espaciadas como huracanes o galaxias. En permacultura se suelen construir espirales con cultivos de aromáticas y medicinales, con un pequeño estanque de agua donde se genera una interacción entre un ecosistema de tierra y uno de agua, produciendo la creación de un ecotono (Pérez, 2004: 2). Estas espirales van en ascenso, se generan sombras y en un espacio muy reducido se pueden cultivar una gran variedad de plantas diferentes.

Las materializaciones de las espirales son muy diversas tanto a nivel formal como estético. En la anterior imagen podemos observar la espiral de aromáticas y medicinales de la Huerta del Boticario, en este caso, realizada con piedras y sin estanque de agua. Estas espirales además de ser bellas por su propia composición atraen a gran cantidad de insectos beneficiosos para la huerta y nos proporcionan condimentos para utilizar en cocina. Estos diseños tienden a abarcar todos los aspectos que puedan intervenir en él, siempre pensando en generar un círculo cerrado.

En este apartado, cabe mencionar las chacras (palabra de origen kichwa, que significa espacio para el cultivo) que se trabajaban en zonas de Sudamérica. Del mismo modo que los diseños de los huertos permaculturales, estos 
plantíos también tienen una belleza muy peculiar. Sus elementos geométricos en relación con las diferentes plantaciones crean hermosas estampas.

Las chacras andinas trascienden la noción del huerto productivo que impulsa la economía familiar y asegura la seguridad y soberanía alimentaria de las familias que las cultivan. Estos espacios resguardan un entramado de creencias, conocimientos y prácticas que les otorgan un valor cultural y espiritual de vital relevancia dentro de la cosmovisión kichwa (Moncada, Aranguren y Almeida, 2018: 30).

Además, se generan potentes imágenes con la interacción de los distintos cultivos, el equilibrio entre las diferentes especies y el juego de las formas y colores de los alimentos.

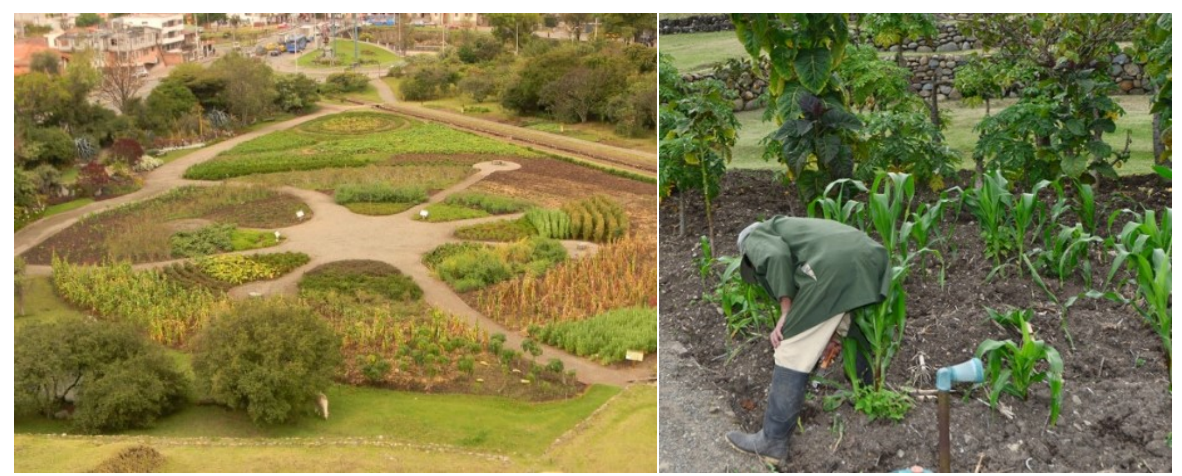

Imagen 172. Chacra de origen kichwa.

Fuente: Museo y Parque Ancestral Pumapungo

Imagen 173. Cuidador de la chakra

Fuente: La chakra y el mundo andino, Miguel Arévalo, EL TIEMPO

Así pues, parámetros muy similares han sido trabajados por diferentes artistas en sus obras paisajísticas, donde la composición y la asociación de plantas se convierten en el objetivo principal, con el fin de potenciar el propio esplendor de la naturaleza. En las siguientes imágenes observamos diseños como el que realizó el artista Michael Singer en el Museo de Isabella Stewart Garden de Boston, el cuál revolucionó el concepto de los diseños de jardín 
exterior (Grande, 2005: 140), o bien, su obra en la Planta de reciclaje de Phoenix (1993), donde se visualiza claramente el fuerte potencial que tiene la naturaleza y como este artista lo ensalza. En los diseños permaculturales también se trabaja desde esa visión estética y de conjunto.

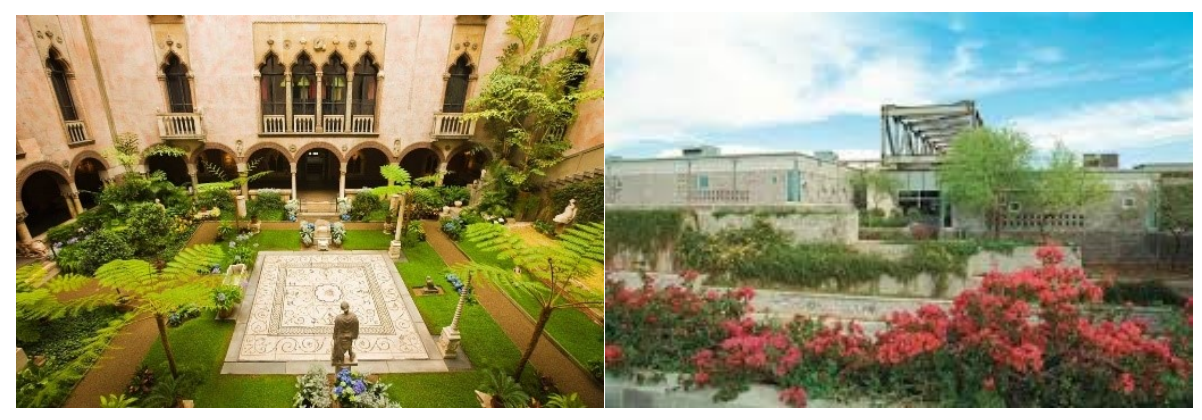

Imagen 174. Museo Isabella Stewart Gardner, jardines interiores.

Fuente: traveler.es

Imagen 175. Phoenix Recycling Plant.

M. Singer y L. Glatt, 1993. Fuente: Michael Singer

Cabe destacar que los diseños de cualquier tipo de proyecto analizados y pensados desde diferentes puntos de vista y perfiles tienden a ser más eficientes y completos. El intercambio de los diferentes conocimientos aportados por el grupo/comunidad unidos a una buena comunicación y potenciando la parte creativa pueden ser las claves para generar un buen diseño.

"El proceso creativo de los artistas es muy especial y difiere del de cualquier otro profesional" (Grande, 2005: 149), dando lugar a puntos de vista desde otra perspectiva que pueden aportar y confluir perfectamente con un conocimiento más técnico. Con el fin de conseguir un equilibrio a través de la observación y del cuestionamiento que nos lleve a potenciar el respeto por la naturaleza y nuestro entorno.

El arte pasa a ser entendido como un proceso que confluye entre diversas técnicas y conocimientos, con tal de potenciarlos, convirtiéndose en un ente 
procesual y perenne. La única finalidad ya no es estética y exhibitiva. Con ello hacemos hincapié en la necesidad de generar dinámicas holísticas e interdisciplinares donde confluyan diferentes temáticas y conocimientos, integrando aspectos técnicos, gráficos, estéticos, sociales, humanísticos, matemáticos, tecnológicos y ecológicos.

La obra Food Forest, creada por el colectivo de artistas Artist as Family ${ }^{25}$, reúne los aspectos que hemos ido comentando en este subapartado. Es una intervención de arte público que se integra en la exposición In the Balance: Art for a Changing World, en el Museo de Arte Contemporáneo de Sidney, Australia. Food Forest funciona como un jardín comunitario situado en el césped de la iglesia anglicana de San Miguel en Surry Hills, Sidney. Es un jardín comestible que se basa en los principios de la permacultura, donde confluye el arte con el abastecimiento de comida, las labores comunitarias, la economía local, la alimentación orgánica y la biodiversidad, entre otros.
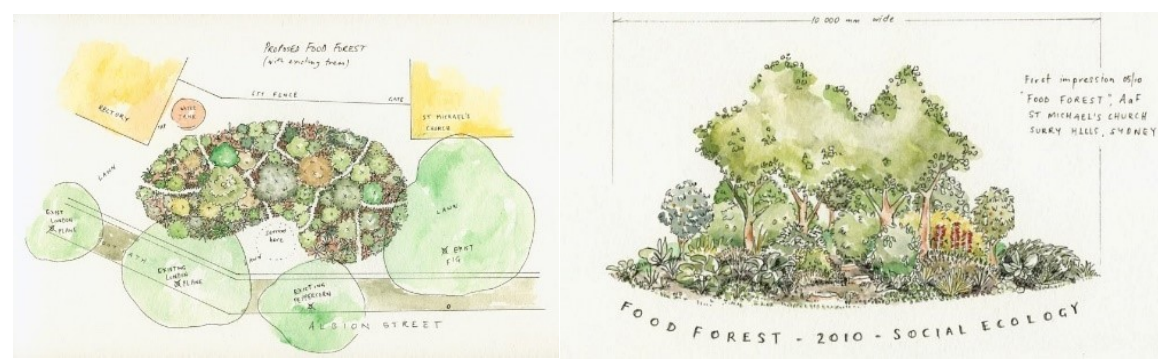

Imagen 176. Ilustraciones proyecto Food Forest. Artist as Family, 2010 Fuente: theartistasfamily.blogspot.com

El bosque de alimentos imita los ecosistemas y patrones que es encuentran en la naturaleza, normalmente estos jardines comestibles se basan en ocho capas (piso superior, sotobosque, capa de arbustos, capa herbácea, capa de raíces, capa de cobertura de suelo, capa de vid y capa micelial). Al tener en cuenta todas estas capas en el diseño se puede aprovechar mejor el espacio,

${ }^{25}$ Véase: www.theartistasfamily.blogspot.com 
colocar más plantas, dar sombra al suelo suprimiendo las malezas y crear un suelo más nutritivo con plantas que fijan nitrógeno y acumulan nutrientes sin necesidad de aplicar fertilizantes. Además, la variedad de plantas genera un entorno equilibrado atrayendo polinizadores y evitando plagas.

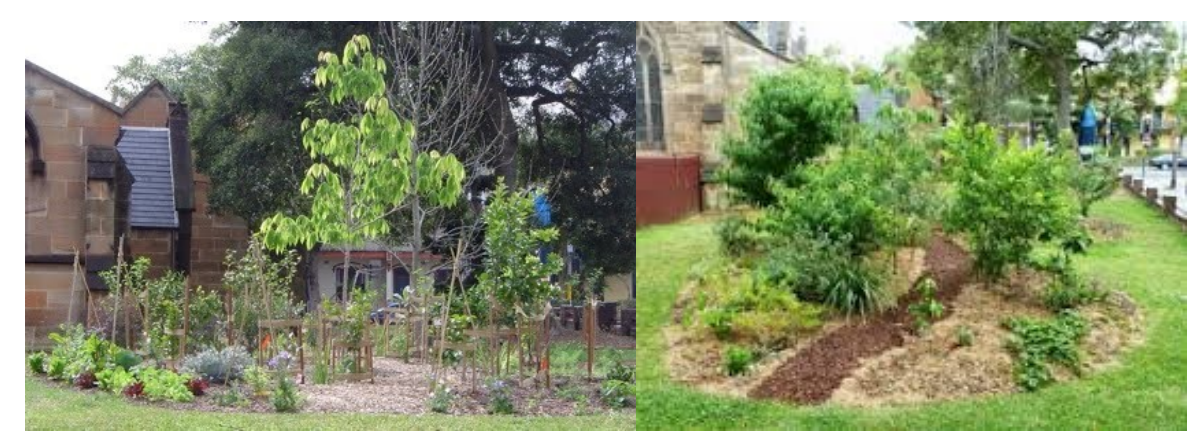

Ilustración 177. Vistas crecimiento proyecto Food Forest. Artist as Family, 2010 Fuente: theartistasfamily.blogspot.com Imagen 178. Finalización proyecto Food Forest. Artist as Family, 2010 Fuente: theartistasfamily.blogspot.com

Según los artistas, el trabajo 'defiende la biodiversidad y demuestra que el arte puede ser generativo; que puede ser un recurso, en lugar de solo un extractoro explotador de recursos... Este trabajo intenta desdibujar la línea entre el arte y la naturaleza. Food Forest es un sistema biológico que es en parte autosuficiente. Utiliza una combinación de ecología aplicada (imitando un sistema forestal) y lo que Artist as Family llama 'calentamiento social' (arte que hace relaciones)' (Brown, 2014: 242)26.

El proyecto se concibe con y para la comunidad, los artistas presentan ilustraciones, diseños, ideas y conocimientos, pero se abren a los demás para que puedan expresar sus propias necesidades, sus hábitos, experiencia y saberes. En ese compartir la comunidad les informa de las hierbas

\footnotetext{
${ }^{26}$ According to the artists, the work 'champions biodiversity and demostrates that art can be generative; that it can be a resource, rather than just an extractor or exploiter of resources... This work attemps to blur the line between art and nature. Food Forest is a biological system that is in part self-maintaining. It utilizes a combination of applied ecology (mimicking a forest system) and what Artist as Family call 'social warming' (art that makes relationships).' Traducido por T. Thompson.
} 
medicinales que más utilizan, los frutos, plantas, recaban las variedades autóctonas y se ofrecen como voluntarios en el mantenimiento del lugar. El bosque abastece de alimentos orgánicos a los residentes locales y al comedor comunitario de la iglesia, es un lugar de paz y creación donde se colabora entre todos para la obtención de alimentos sanos, promoviendo la comida pública.

Además, cabe destacar que Artist as Family, lleva un estilo de vida acorde a sus formas de pensar, difundir y crear. En su hogar fomentan un modelo de vida sustentable, imparten cursos de permacultura, se autoabastecen de los alimentos que producen o de los que compran en la cooperativa, fomentan economía social y local, así como positividad, esperanza y soluciones.

\subsection{Arte como visibilizador de la permacultura}

Las artes plásticas, como el arte poético, deben expresar pensamientos del espiritu o conceptos cuyo origen es el alma, pero no mediante el lenguaje, sino como la callada naturaleza: mediante la figura, mediante la forma, mediante obras sensibles e independientes de ella. Así pues, las artes plásticas funcionan manifiestamente como un vínculo activo entre el alma y la naturaleza y solo pueden ser entendidas y captadas en el contexto de ese vivo medio entre ambas (Schelling, 1807: 116).

La unión entre el arte y la naturaleza la podemos observar al contemplar en proyecto del artista londinense Nils Norman, Edible Park ${ }^{27}$ (2010) comisariado por Stroom Den Haag como parte de su amplio programa Foodprint. Un paisaje comestible, una obra que crece y prospera y produce deliciosas verduras es lo que el artista concibió para Haya en Los Países Bajos. Además de ser un espacio para el cultivo, es un lugar de reunión, donde confluyen personas de distintos ámbitos, donde se comparten saberes, tiempo y trabajo.

Este huerto-jardín de unos 40 × 20 metros se ha construido basándose en los principios de la permacultura, teniendo en cuenta el lugar y sus habitantes para ser lo más resilientes posibles. Si bien su diseño ha sido fruto de la

${ }^{27}$ Véase: www.stroom.typepad.com/photos/eetbaar park/index.html 
colaboración con el curso de diseño de permacultura local, Permacultuur Centrum Den Haag. "Se basa en una serie de círculos con un árbol frutal o de nueces en cada centro, desde el cual otras plantas irradian en una variedad de gremios y alturas" (Nils Norman, 2012).

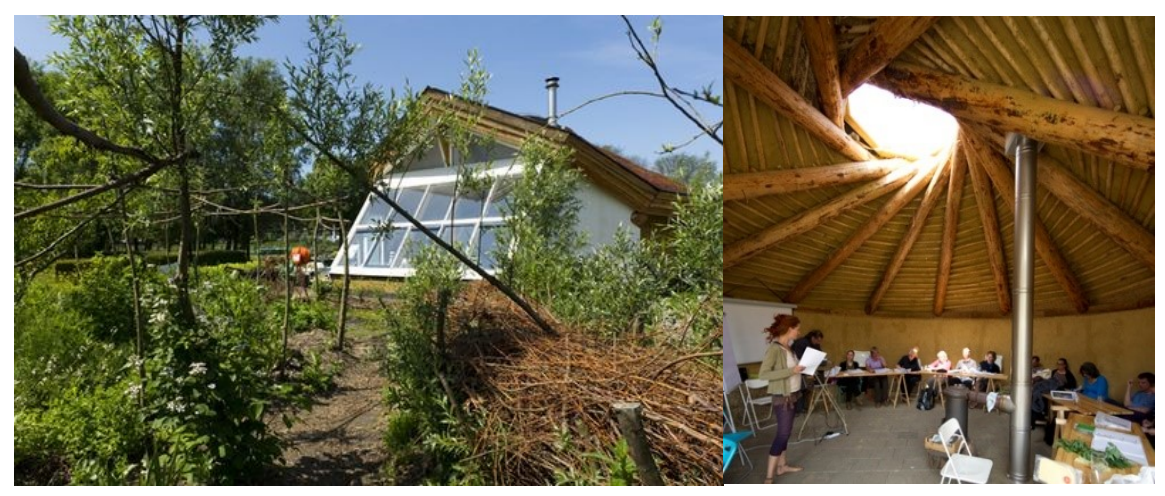

Imagen 179. Vista exterior. Edible Park, 2011. Fuente: Eric de Vries Imagen 180. Vista interior del pabellón. Edible Park, 2011. Fuente: Eric de Vries

En el centro del paisaje comestible podemos contemplar un pabellón realizado en bioconstrucción donde utilizaron madera, balas de paja y materiales reciclados. Se decidió colaborar con varios arquitectos para la realización de esta edificación donde la comunidad pudiera realizar talleres y workshops, siendo un punto de unión y conexión para los habitantes de Haya.

El día de la inauguración de la obra, en un gesto lleno de simbolismo, el artista le hizo entrega de las llaves del pabellón a una asociación local de jardinería, Gezonde Gronden (Agnieszka Gratza, 2011). El proyecto ha ido evolucionando con el tiempo, la comunidad ha velado por su mantenimiento y se ha convertido en un área de aprendizaje de los principios de la permacultura. El artista ha sido capaz de generar un espacio natural en medio de una ciudad donde sus habitantes han colaborado en su construcción y mantenimiento y, 
además, sirviendo dicho lugar de experimentación y aprendizaje permacultural.

Estas obras de arte parten con la ilusión, dedicación y compromiso del artista, convirtiéndose finalmente en un proceso de unión con la comunidad, de experimentación e investigación in situ. Se trabaja a través de las herramientas y potencialidades del arte para crear espacios más sustentables y respetuosos con el medio. Estos lugares, a su vez, sirven como un continuo proceso de aprendizaje tanto de las personas que habitan en Haya como de todas aquellas que mostrarán interés en el proyecto, en su mantenimiento o en participar en sus actividades. Si bien nos ayuda a visualizar que el arte puede llegar a ser un gran medio de expresión social y cultural, donde se pueden potenciar unas formas de vivir más sustentables, ayudando a comprender y apreciar el lugar donde vivimos.

Otro artista que también contempla en sus obras los estilos de vida permaculturales es Fritz Haeg, concretamente en la obra Integridades domésticas (2012), un interesante proyecto pensado para interactuar con el público, para fomentar la relación con la naturaleza y nuestro entorno cotidiano. Este proyecto se forma de varias partes $^{28}$, una primera parte fue la realización de un jardín orgánico circular de hierbas comestibles, medicinales, aromáticas y plantas, que se instaló en el Jardín de Esculturas Abby Aldrich Rockefeller del MoMA. Este jardín fue creciendo durante el verano y el otoño y sirvió para recolectar los elementos necesarios que se utilizaron en la siguiente instalación.

El artista realizó una alfombra con retales que fueron donados, esa alfombra fue pasando por diferentes países antes de llegar al MoMA y a su paso fue creciendo. En el museo se generó un espacio donde los diferentes elementos cosechados en el jardín se disponían estratégicamente sobre la alfombra, creando un espacio abierto al público, un lugar de interacción, de

\footnotetext{
${ }^{28}$ Véase: www.fritzhaeg.com/domestic-integrities/main.html
} 
acercamiento a los diferentes elementos que encontramos en el exterior y hacemos nuestros.

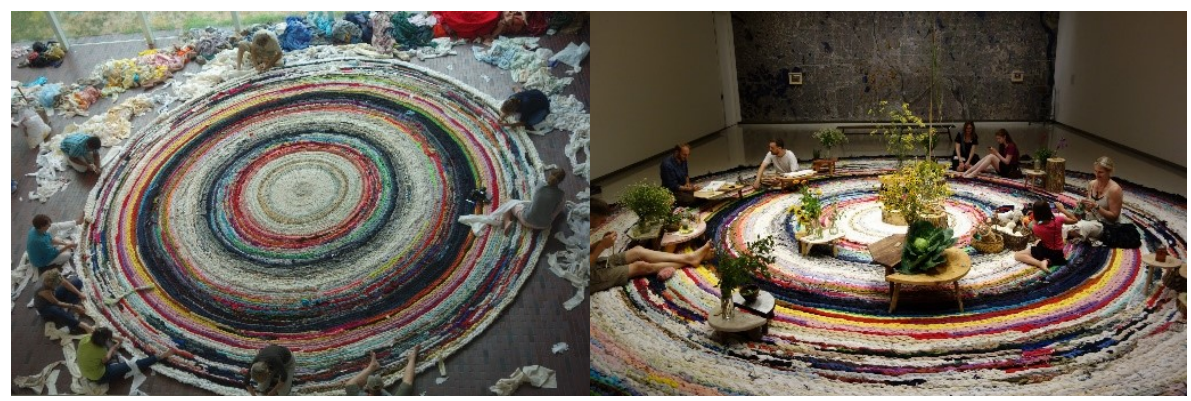

Imagen 181. Tejiendo la alfombra.

Fritz Haeg, 2013. Fuente: fritzhaeg.com Imagen 182. Domestic Integrities Part A05: Minneapolis, Minnesota.

Fritz Haeg, 2013. Fuente: fritzhaeg.com

Este proyecto viajó por varios países y en cada uno se fueron generando discursos únicos, tras la presentación en el MoMA en Nueva York, también se expuso en el Broad Museum of art en Michigan, en The Hammer Museum en Los Ángeles, en el Cordeva Museum en Lincoln y en la ciudad de Minneapolis, entre otros. En cada lugar se generaron diversos conocimientos, presentaciones y actuaciones sobre la alfombra, un acercamiento a la cultura, la gastronomía y los cultivos de cada país.

El museo se utiliza como medio para acercar los conocimientos, la admiración y el respeto por todos aquellos recursos naturales que cosechamos y nos llevamos a nuestros hogares. Un compartir de todos esas prácticas y saberes que hemos heredado de nuestros ancestros. Esta obra es un buen ejemplo de cómo un proyecto individual es llevado y trabajado en colectivo, siendo de vital importancia la interacción del propio público para integrar todos los aspectos propuestos previamente, generándose un discurso, un sentir y una observación del espectador con los diferentes elementos cosechados. Además, el propio acto de tejer genera en el grupo una conexión. Desde el principio, se genera un compartir con la experiencia 
de cada cual, así como un momento de meditación y concentración individual que puede llegar a producir paz y tranquilidad interior.

En la línea de muestras de arte-permacultura en salas expositivas, observamos la propuesta de la artista Xin Cheng ${ }^{29}$ para la exposición colectiva Freedom Farmers: New Zealand Artists Growing Ideas, en Auckland Art Gallery (Nueva Zelanda) comisariada por la curadora Natasha Conland. La obra, titulada Propositions for Freedom Farmers, se enmarca en los conceptos de sostenibilidad y libertad artística.

Cheng, realiza un trabajo de acercamiento a construcciones improvisadas y entornos comunitarios, expuestos a modo de escaparate en la sala. Para ello, utiliza elementos reciclados y plantas nativas generando una narración que parte de la experiencia y el aprendizaje obtenido tras sus viajes e investigaciones. El objeto se convierte en un transmisor de conocimiento y aprendizaje permacultural, donde el público puede hacerlos suyos y aplicarlos en sus hogares.

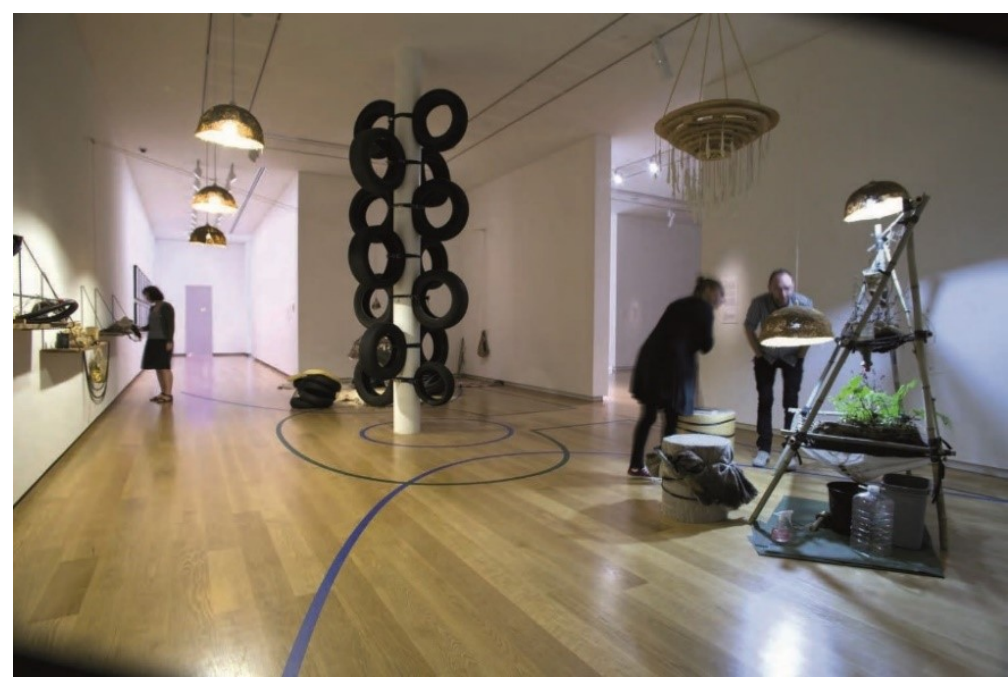

Imagen 183. Propositions for Freedom Farmers, instalación con materiales reciclados y plantas nativas comestibles. Xin Cheng, 2013-2014. Fuente: xin-cheng. info

29 Véase: www.xin-cheng.info 
El trabajo de la artista Xing Cheng es una fusión de la investigación con la experiencia y la práctica. Se entreve su base de estudios en biología y psicología utilizando su posterior aprendizaje en arte para generar su propio discurso, donde incluye talleres, prácticas colaborativas, el propio caminar, la investigación y la vida.

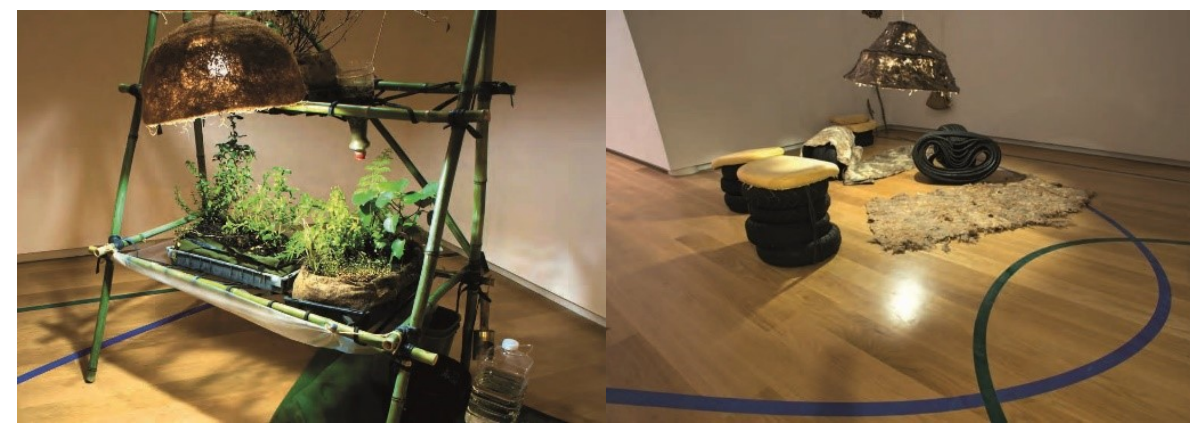

Imagen 184. Vista detalle Propositions for Freedom Farmers. Xin Cheng, 2013-2014. Fuente: xin-cheng.info Imagen 185. Vista detalle Propositions for Freedom Farmers. Xin Cheng, 2013-2014. Fuente: xin-cheng.info

Por otra parte, encontramos el Programa de Arte Urbano del Departamento de transporte de la Ciudad de Nueva York (DOT). Este programa artístico se forma de tres líneas de trabajo: PARTners, Site to Site y Arterventions, donde se les da la oportunidad de proponer nuevas formas de ver la ciudad, a través de la intervención de calles, plazas y aceras, a los colectivos artísticos, a la comunidad, a las organizaciones sin ánimo de lucro y a toda aquella persona que muestre interés.

Dentro del apartado pARTners destacamos la obra Maize Field, creada por la artista Christina Kelly junto a la Asociación Boreum Hill. Esta intervención se sitúa en las calles Bergen y Smith en Brooklyn, Nueva York, y está formada por un cultivo de maíz. La artista tras un estudio de mapas antiguos descubrió senderos que llevaban a los campos donde los indios Lepale tenían sus cultivos, a los que nombraban Las tres hermanas. Estos cultivos se formaban 
por el maíz, el frijol que trepaba por su tallo y la calabaza que servía de acolchado por abajo para frenar la aparición de las hierbas no deseadas.

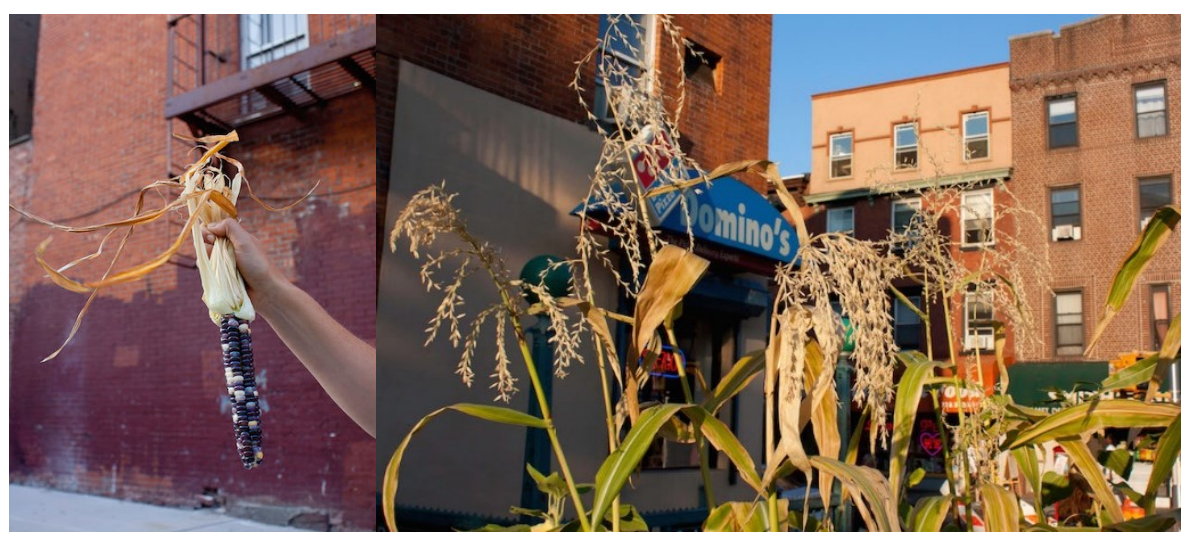

Imagen 186. Vista detalle Maize Field, en la esquina de Bergen y Smith. Marie Viljoen, 2010. Fuente: ediblebrooklyn.com Imagen 187. Maize Field, en la esquina de Bergen y Smith. Marie Viljoen, 2010. Fuente: ediblebrooklyn.com

Kelly, en un deseo de rememorar y dar visibilidad a esos cultivos que cubrían todas las calles ahora repletas de alquitrán, consiguió semillas nativas y realizó una pequeña plantación de maíz azul Gigi Hill, Hannah Beans y calabaza nativa White Bush Scallop. El cultivo lo realizó justo enfrente de una pizzeria de Domino's, el maíz creció con hermosos tallos y el cartel de la pizzería se podía entrever entre sus hermosas espigas. En cambio, con el calor del verano y la sequía el cultivo de frijoles y de calabaza sufrió mucho y no consiguió sobrevivir.

En la pieza, la artista no solo ha dado visibilidad a los cultivos de nuestros ancestros, sino que ha puesto en valor la importancia de recuperar y mantener las semillas y la biodiversidad, así como evidenciar la problemática de la sequía y el cambio climático en los cultivos. Además, Kelly consiguió las semillas de maíz en base a un intercambio, comprometiéndose a hacer entrega de seis espigas de la cosecha a la persona que le facilitó dichas semillas. Con ello se fomenta el trueque, la expansión de las semillas y la 
conservación. Todos estos aspectos son contemplados desde la permacultura y, en este caso, se hace uso de la intervención artística para ponerlos en valor.

\subsection{El arte del aprovechamiento de los recursos}

La permacultura tal y como hemos ido desarrollando es una filosofía de vida de las más sostenibles y equilibradas con nuestro entorno. A través de todos los proyectos que hemos ido visitando tanto de permacultura, como de huertas ecológicas, sinérgicas o tradicionales, observamos que el aprovechamiento de los recursos y el reciclaje es un punto clave en todas ellas.

Además, es muy habitual que utilicen elementos que fueron construidos para otro fin en el diseño de la huerta o en la construcción de herramientas, consiguiendo generar interesantes poemas visuales. Muchas de las composiciones que hemos ido fotografiando o recabando de artistas o agricultores/as, nos acercarían a una especie de arte povera, donde se utilizan elementos carentes de valor o desechos, pero que a la vez pueden encontrar en ellos una gran utilidad para otro fin.

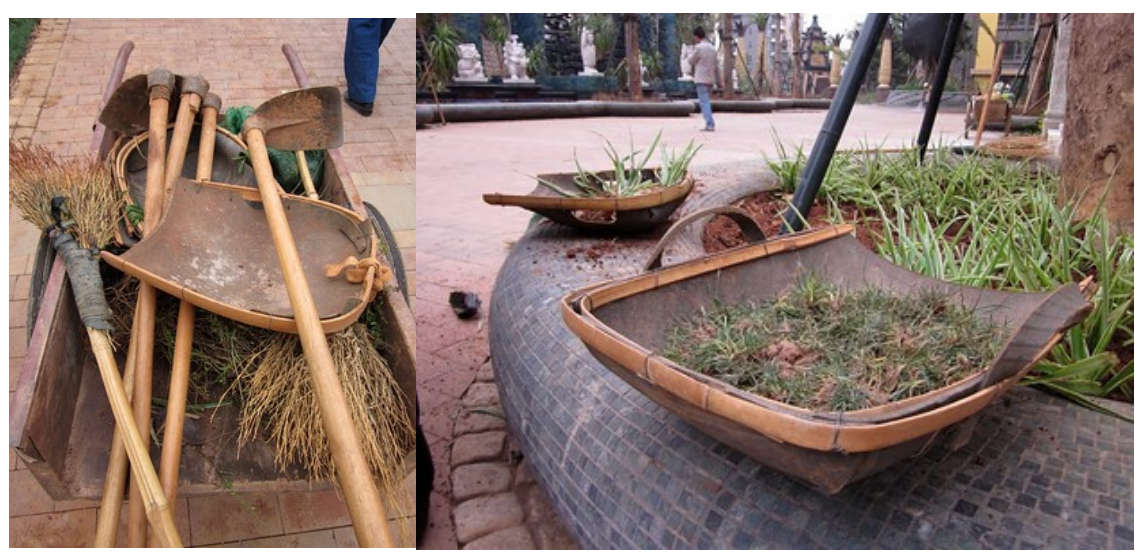

Imagen 188. China. Xin Cheng, 2007. Fuente: xin-cheng.info Imagen 189. China. Xin Cheng, 2007. Fuente: xin-cheng.info 
Al hilo de estos comentarios encontramos el proyecto en curso de la artista anteriormente citada, Xin Cheng, donde retrata todas aquellas construcciones que han sido elaboradas con elementos destinados a otro fin. La artista aprovecha sus viajes para documentar esas creaciones únicas, sostenibles y adaptadas al espacio y luego publicarlas en su web. Estas creaciones son diseñadas por personas que habitan esos lugares, aprovechando los recursos de los que disponen, no son objetos realizados por un especialista en marketing o diseñador de producto. Al detenerse y observar estos objetos se visualiza la reutilización y el aprovechamiento de recursos en la creación de piezas únicas, se destaca la belleza de la simplicidad de los elementos al mismo tiempo que la autenticidad.

En la siguiente imagen, izquierda, podemos observar una huerta que utiliza para sostener sus plantas palos de escoba. Reutilizan el objeto, le dan otro uso totalmente distinto al que fue creado, al mismo tiempo, generan una composición jugando con la repetición de un mismo elemento en un espacio determinado. En la foto de la derecha, observamos que han utilizado el mismo recurso, pero con botellas de vidrio para marcar las líneas sinuosas de la parcela donde van a cultivar.

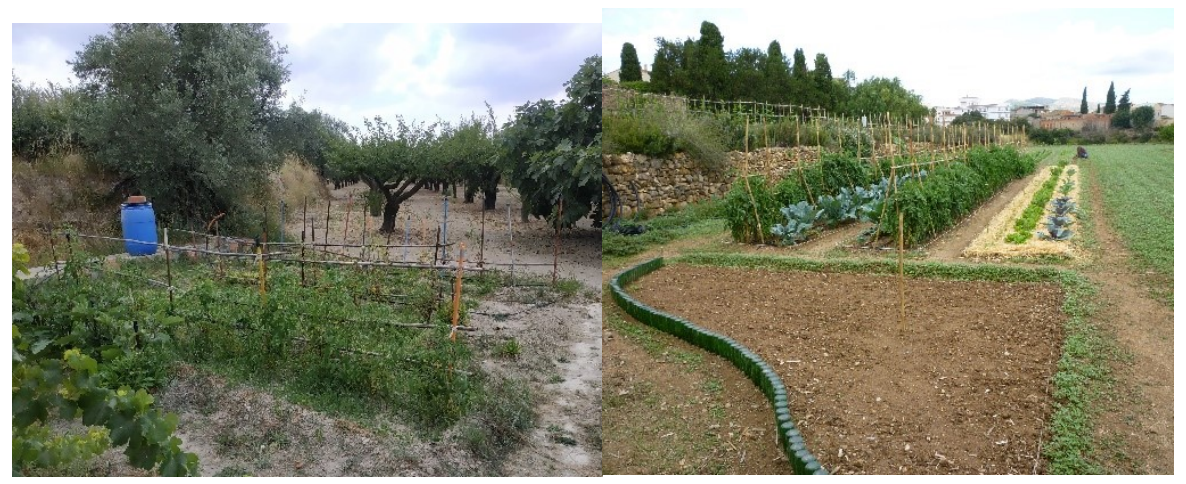

Imagen 190. Vista huerta con palos de escoba.

Bocairent, 2019. Fuente: propia Imagen 191. Vista Huerta del Boticario. Macastre, Valencia, 2017. Fuente: Carlos García Dolz 
La utilización de estos objetos, además de solventar el problema que pueda tener el agricultor/a en ese momento, generan una mayor atracción visual hacia el lugar. Trabajan con el color, la repetición y la disposición de los elementos en el campo como si de un lienzo se tratara.

Asimismo, observamos otros ejemplos en las siguientes imágenes, como la composición que se genera al colgar las calabazas en mallas reutilizadas, al ser un alimento de largo almacenaje se colocan elevadas para evitar que los ratones puedan morderlas, consiguiéndose una masa informe que se completa con las potentes tonalidades de las calabazas.

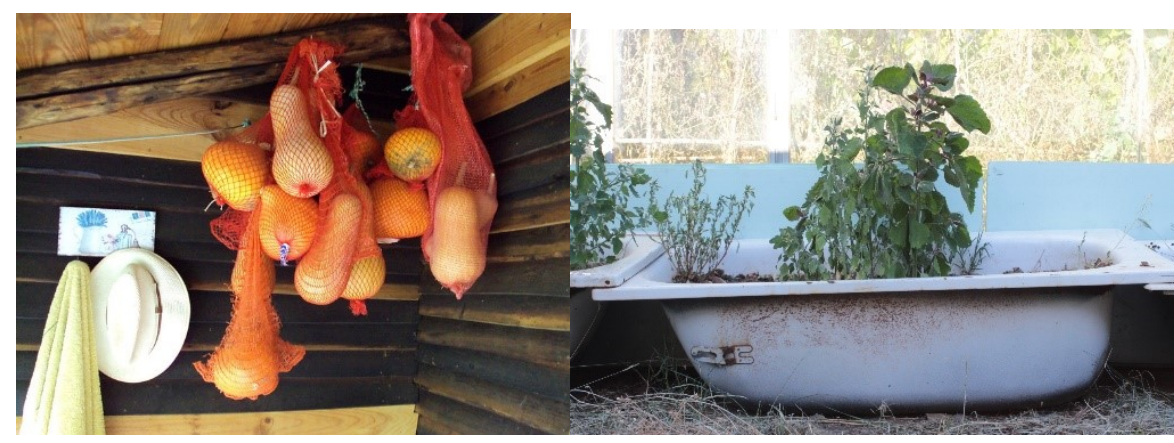

Imagen 192. Finca la Castilla, 2019.

Fuente: Trini

Imagen 193. Bañera para plantel. Fundación Los Madroños, 2018. Fuente: propia

En la imagen de la derecha se ha reutilizado una antigua bañera para realizar los planteles, también se suelen utilizar para la elaboración de pequeñas charcas o para cultivar plantas acuáticas. La composición que se genera con la bañera y el plantel nos puede llevar a recordar a las obras de redy-made. Se han utilizado un objeto ya existente que no se considera normalmente artístico y se ha quitado de su contexto original, adecuándolo en otro lugary dándole otra función. Faltaría que su creador quisiera elevarlo a la categoría de arte y etiquetarlo como tal. Consideramos que el agricultor/a tiene grandes capacidades para trabajar y manejarse en el campo y, estás, unidas 
al aprovechamiento que hace de los recursos que dispone y a su propia creatividad, le permite generar poemas visuales (voluntaria o involuntariamente), que potencian la belleza de sus espacios y terrenos agrícolas.

Dentro del Programa de Arte Urbano de DOT (Nueva York), el cual comentábamos en el subapartado anterior, cabe destacar el proyecto artístico Artfarm realizado en 2010, una instalación para mejorar la apariencia de una calle de paso en 180 E. 165th Street y Carroll Place en el Bronx, es un proyecto artístico donde consideramos que se recogen muchos de los aspectos que hemos estado comentado en este subapartado. La pieza de arte urbano está realizada por los arquitectos Valeria Bianco, Christian Gonsalves, Shagun Singh y Justin Taylor, en asociación con Architecture for Humanity (AfH ny STUDIO) y en colaboración con el Bronx Museum of the Arts. Es una obra que se forma de cincuenta y nueve maceteros realizados con elementos reciclados, colocados estratégicamente en una calle de paso donde forman una llamativa composición con los diferentes elementos, en este caso el lienzo es la propia calle.

Curiosamente, para la realización de la obra, AfH ny STUDIO se inspiró en el mercado de agricultores cercano. Realizaron la composición con los diferentes maceteros construidos con puertas o cajas de madera recicladas y dieron color, luz, alegría y dinamismo a una simple calle de paso. Además, se generaron talleres donde participó el alumnado de las escuelas locales y la propia comunidad, dándoles la oportunidad de poner su granito de creatividad y haciéndoles partícipes del cambio. En el mismo proceso de creación de la obra, los voluntarios aprovecharon para reparar las grietas, las barandillas, los escalones y los desperfectos que pudiera haber en la calle.

En las siguientes imágenes, podemos observar el boceto previo y la composición final de la obra, una creación que no solo ha generado una llamativa calle en el Bronx, sino que ha unido a una comunidad, inspirándose en los agricultores, reutilizando elementos que fueron creados en su momento para otro fin, creando grupo y utilizando las estrategias artísticas para generar una atractiva composición y ensalzar un lugar de paso. 


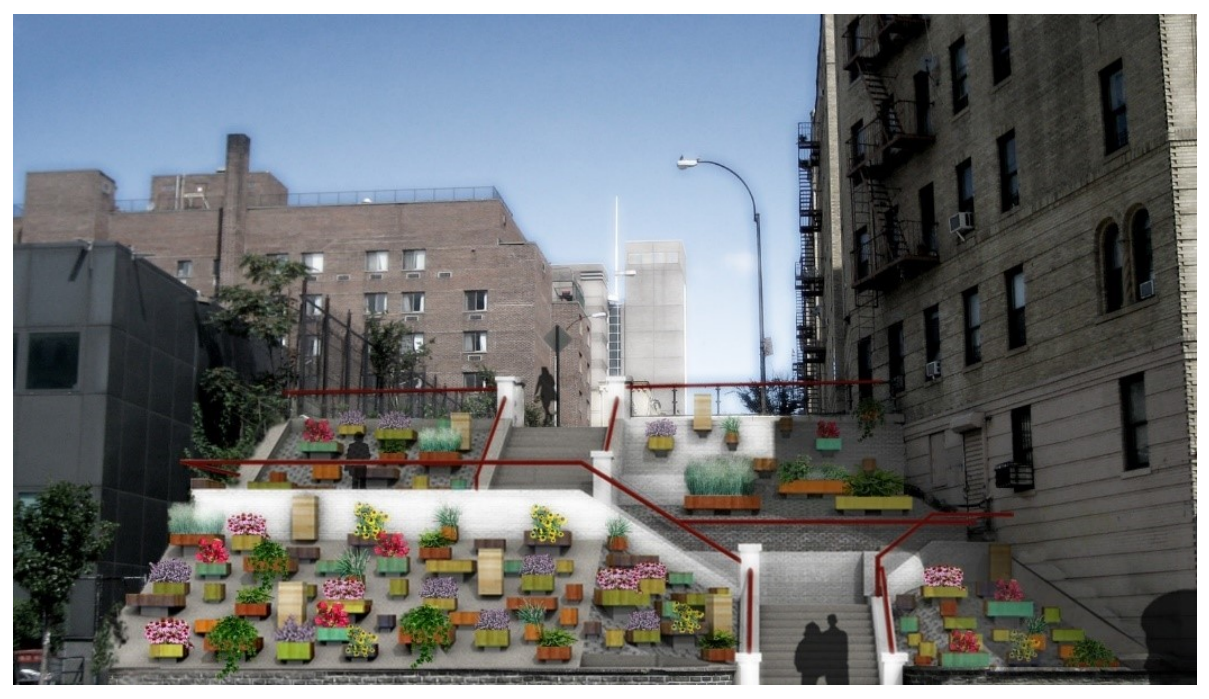

Imagen 194. Boceto intervención ARTfarm, 2010. Fuente: AFHny Studio

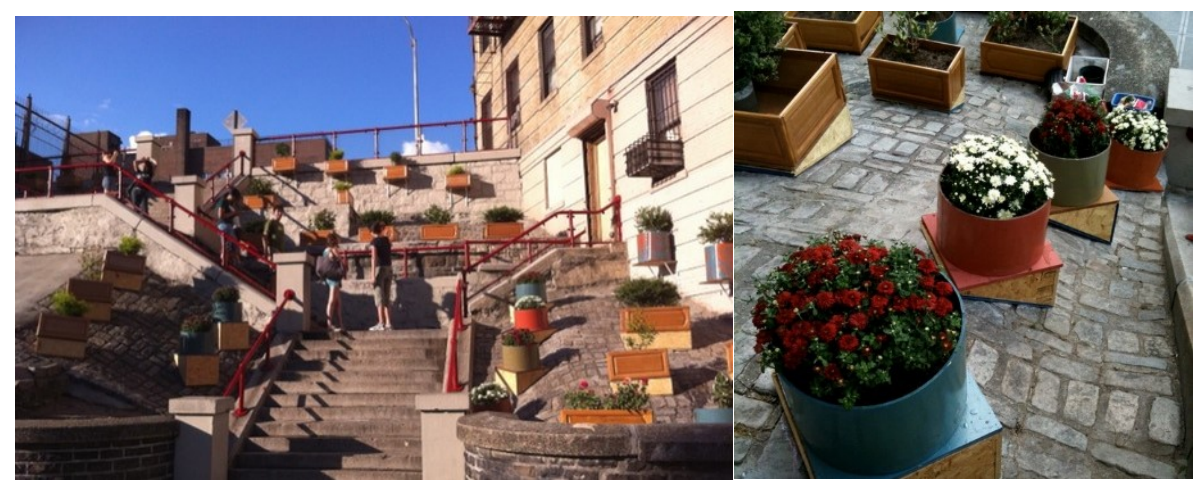

Imagen 195. Intervención ARTfarm, 2010

Fuente: AFHny Studio Imagen 196. Detalle Intervención ARTfarm, 2010. Fuente: AFHny Studio

4.6. El arte y la permacultura como creador del grupo/comunidad

A lo largo de los diferentes apartados de este capítulo, hemos ido viendo el nexo entre la permacultura y el arte. Si bien nos centrábamos especialmente 
en el área de aplicación a la agricultura, debido al tema que nos atañe, la filosofía permacultural abarca muchos más aspectos cómo hemos descrito en el apartado de los principios de la permacultura. Entre ellos, cabe destacar en esta sección, la importancia del trabajo colectivo para adaptarse al cambio climático al que se enfrenta la humanidad y sus consecuencias.

La filosofía que se sigue es en esencia la de trabajar con la naturaleza y no contra ella, diseñando los hábitats y las organizaciones humanas de maneras que buscan deliberadamente emular las características que contribuyen a la resiliencia, la sostenibilidad y la productividad de los sistemas naturales (Henfrey y Penha-Lopes, 2018: 23).

Cabe destacar que la difusión del conocimiento permacultural es posible gracias a la participación de diferentes colectivos a nivel global, entre ellos podemos destacar la británica Permaculture Association ${ }^{30}$. El propósito de dicha organización se basa en generar una red de pensadores con el poder de crear culturas y ecosistemas saludables. A través de su web dan información de cursos, publicaciones, eventos y soluciones prácticas, facilitan toda clase de material e informan de los participantes activos en permacultura, tanto a nivel práctico como teórico en cualquiera de sus principios.

Nuestro interés se fija especialmente en la parte cultural, en los procesos del arte vinculados al cuidado de la tierra, de las personas y del reparto equitativo. La práctica artística tiene la capacidad de generar empatía con el otro, creando lazos afectivos en el grupo y contribuyendo a potenciar las actividades colectivas. Un aspecto que considerar dada la necesidad de paz, equidad, compañerismo y humildad en la comunidad para poder trabajar y colaborar en armonía.

La alta tasa de fracaso en estas comunidades, de agotamiento y asimilación de la corriente principal, no es causada por la falta de habilidad o capacidad. En pocas palabras, estas comunidades fallan una y otra vez porque la gente no puede llevarse bien. Es la falta de infraestructura social saludable lo que ha causado y continúa causando la mayor parte de la dificultad. Yes precisamente dentro de esta área de salud social que las artes benefician más a una

\footnotetext{
${ }^{30}$ Véase: www.permaculture.org.uk
} 
comunidad y a las personas que comprenden esa comunidad. Las prácticas artísticas comunitarias son bastante indispensables si queremos cumplir el principio principal de la permacultura "CUIDADO DE LAS PERSONAS" (Walla, 2005: 2$)^{31}$.

Si bien, La Comunidad Hare ${ }^{\beta 2}$, un colectivo de personas que vive en una aldea temporal en el Consejo Regional de Eshkol, es un ejemplo de grupo que convive en armonía, con una gran preocupación y respeto por el medio ambiente y el cuidado de las personas. Junto al lema Vive la vida que amas y ama la vida que vives, conforman una vida comunitaria hermosa y significativa cuidándose los unos a los otros, fomentando la generosidad. Velan por la tierra que habitamos, al igual que potencian el crecimiento y el desarrollo personal. Uno de sus objetivos es construir una nueva aldea en el desierto de Negev, en Israel.

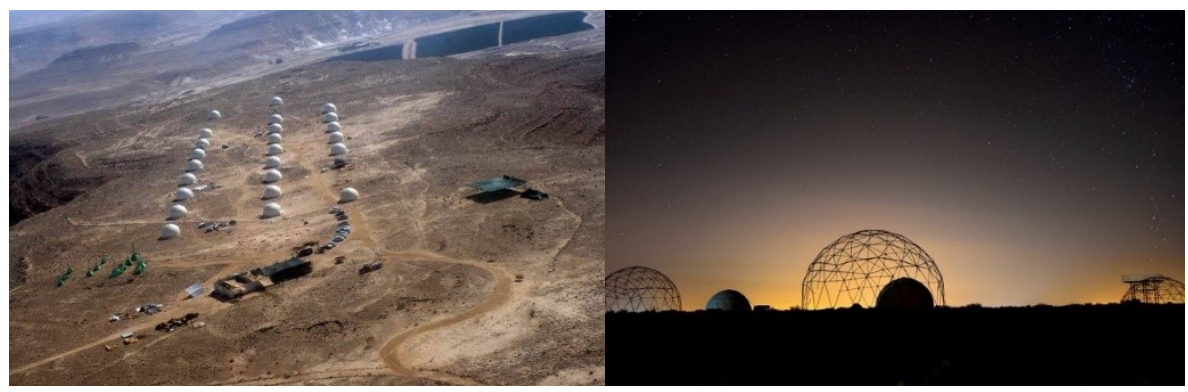

Imagen 197. Vista aérea asentamiento Negev, 2016.

Fuente: Dafna Nudelman

Imagen 198. Vista anochecer en asentamiento Negev, 2016.

Fuente: Dafna Nudelman

\begin{abstract}
31 The high rate of failure in these communities, of burnout and reassimilation into the mainstream, is not caused by lack of skill or capability. Simply put, these communities fail over and over again because people cannot get along. It is the lack of healthy social infrastructure which has caused and continues to cause most of the difficulty. And it is precisely within this arena of social health that the arts most benefit a community, and the individuals that comprise that community. Community arts practices are quite indispensable if we want to fulfill the main permaculture tenet "CARE FOR PEOPLE.". Traducción realizada por T. Thompson.

32 Una comunidad de 80 adultos, familias, parejas, solteros y 30 niños que conviven desde hace unos 10 años. Véase www.harel-negev.co.il/en/
\end{abstract}


Para ello, ya hicieron a modo de happening una puesta en marcha de la aldea. A lo largo de seis semanas desplegaron toda la infraestructura necesaria para vivir en medio del desierto (domos geodésicos ${ }^{33}$, tanques de agua, paneles solares, entre otros), basándose en la filosofía de la permacultura.

Generaron un bello paisaje en medio del desierto, donde Dafna Nudelman ${ }^{34}$ tuvo la oportunidad de participar como voluntaria. Dado que no tenían permisos para asentar una comunidad en el desierto de Neveg, a los tres meses tuvieron que recoger y despedirse del emplazamiento. Curiosamente, si se observa la fotografía del lugar, una vez se marcharon no queda rastro alguno de que una comunidad de tal tamaño hubiera pasado por ahí. Su objetivo sigue siendo construir una nueva aldea en esa ubicación, donde vivir todos juntos en comunidad, manteniendo los valores de respeto mutuo y respeto al medio ambiente.
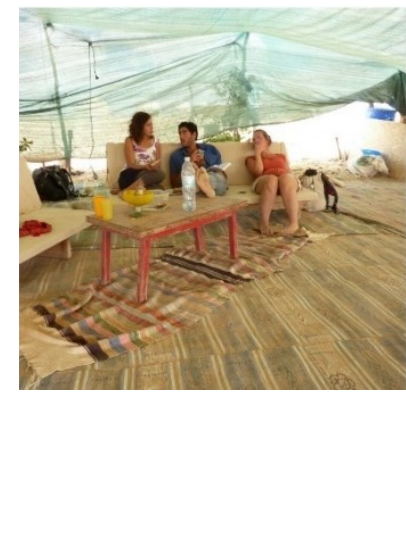

Imagen 201. Vista territorio tras la retirada del asentamiento Negev, 2016

Fuente: Dafna Nudelman

\footnotetext{
${ }^{33}$ Parte de una esfera geodésica, un poliedro generado a partir de un icosaedro o un dodecaedro, las caras de una cúpula geodésica pueden ser triángulos, hexágonos o cualquier otro polígono.

${ }^{34}$ Autora de fotos realizadas a la intervención de la comunidad en el desierto, artículo publicado en: https://medium.com/dafnu-notas/arte-y-permacultura-en-el-desierto-miexperiencia-en-gareen-harel-23d6217b5929
} 
No obstante, tras intentar ponerse en contacto con la comunidad y no recibir respuesta por parte de esta, quedarían cuestiones por responder y aspectos por ampliar, como:

- El nivel de consenso en la toma de decisiones a través de las asambleas.

- Sustento económico de la comunidad.

- Procedencia de la comida, medicamentos y atención médica.

- Métodos educativos, sobre todo en los niños.

- Actividades culturales, proyectos artísticos.

Todos estos apartados son importantes para consolidar una comunidad, así como para que aquellas personas ajenas a la comunidad puedan llegar a un mejor entendimiento del funcionamiento interno y del modo de vivir.

Al hilo de este contexto, encontramos una comunidad de unas doscientas personas en Portugal con el proyecto Tamera ${ }^{35}$. Comenzaron en 1978, siendo un pequeño grupo de personas, trabajando de una forma más autónoma, caminando hacia un mundo post-capitalista. En la actualidad, conforman un fuerte asentamiento donde su misión se basa en empoderar a las personas para construir culturas regenerativas basadas en la no-violencia. Para ello, realizan investigación en fundamentos éticos, sociales, sexuales, ecológicos, tecnológicos y económicos con la intención de generar un modelo adaptable a su comunidad. Además, su visión es generar biotopos curativos en diferentes lugares del planeta, de tal forma que haya comunidades autónomas pero interconectadas, basadas en los principios de la permacultura.

Entre todos los apartados de investigación que trabajan, destacamos Tamera art, dirigido por su cofundador Dieter Duhm. Esta comunidad ha dado especial relevancia a las capacidades del arte para generar felicidad, alegría y humor, así como para fomentar la creatividad en los habitantes de la

${ }^{35}$ Véase: www.tamera.org 
comunidad. El arte les sirve para concentrarse, compartir, construir juntos y desarrollar habilidades artísticas. Además, el momento de creación puede llegar a ser muy meditativo, relajante y estimulante.

Trabajan su parte más creativa en un centro de creación cultural donde su objetivo es revivir el arte; además, imparten cursos para la comunidad, los visitantes y estudiantes. Experimentan con diferentes expresiones artísticas y organizan exposiciones con las creaciones resultantes. Podemos observar desde pinturas, como en las siguientes imágenes, muy expresionistas, con carga matérica y potentes colores, a intervenciones en el espacio público.

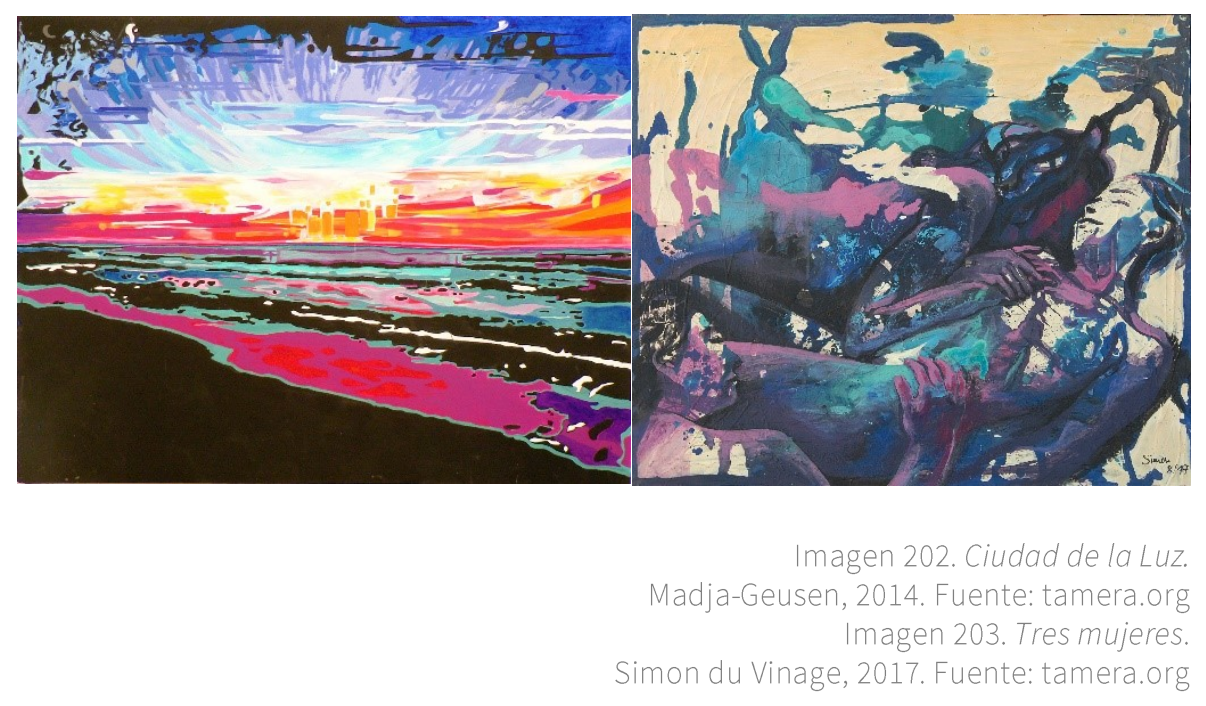

En la siguiente imagen podemos observar la vista aérea de un mensaje que se formó con la participación de mil personas de cuarenta países, el diseño de la imagen humana aérea fue realizado por John Quigley de Spectral Q (defensor ambiental estadunidense) y el vídeo por Ludwig Schramm y el equipo de Tamera. 


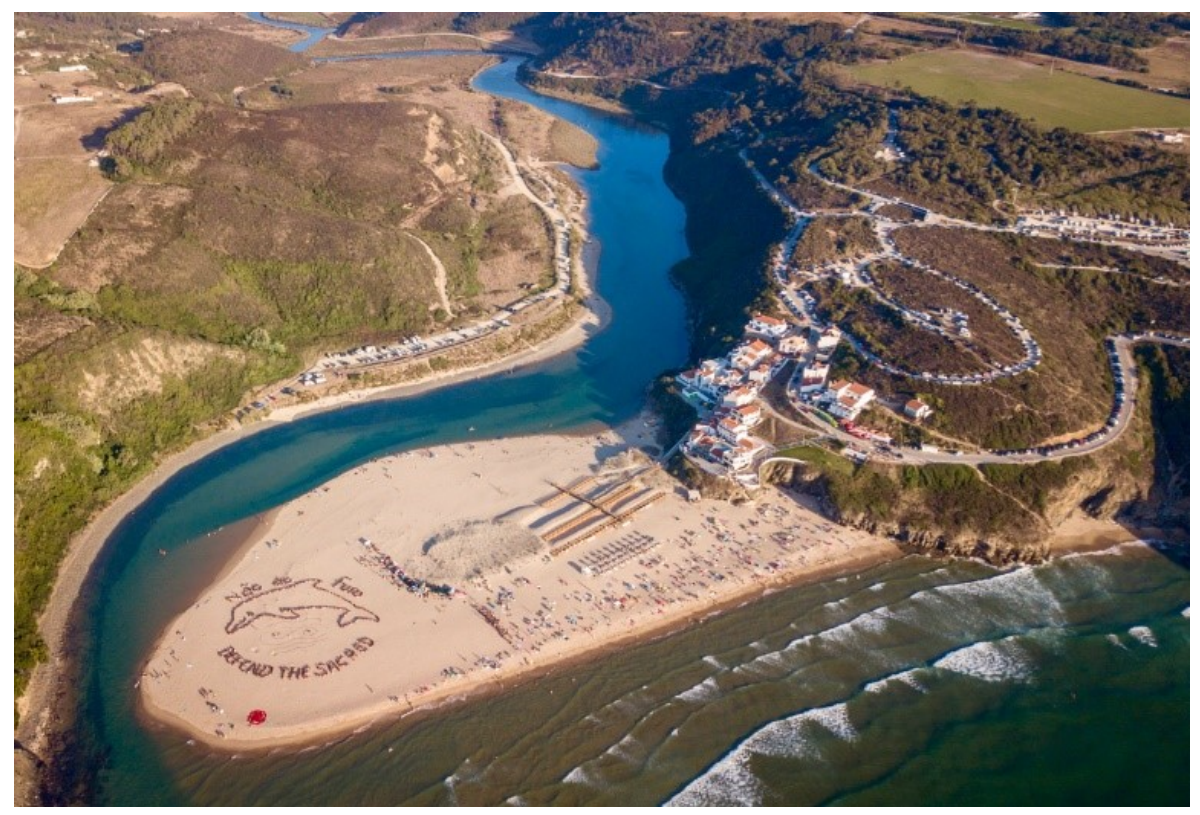

Imagen 204. Não ao Furo! Sim ao Futuro. L. Schramm, K. Delacasa, S. Vinage, Y. Kovo, Spectral Q, 2017. Fuente: tamera.org

Esta intervención artística fue inspirada por el movimiento de Protectores de agua, el principal objetivo de la acción fue detener los planes de las perforaciones de petróleo en alta mar en Portugal, fue parte del evento de Defiende lo sagrado: imagina una alternativa global, organizado por Tamera.

En este contexto, los encuentros se han estado realizando desde 2017 hasta la actualidad, movilizando a activistas, voluntarios, simpatizantes, artistas y toda aquella persona que tuviera interés, se han organizado charlas, reuniones y acciones. Todo ello se ha realizado desde la defensa de lo más sagrado, combinando acción política con arte y oración, una ceremonia por el agua y el fuego. Cabe destacar la gran coordinación y organización para poder llevar a cabo una acción artística de estas características con un número tan elevado de participantes. 


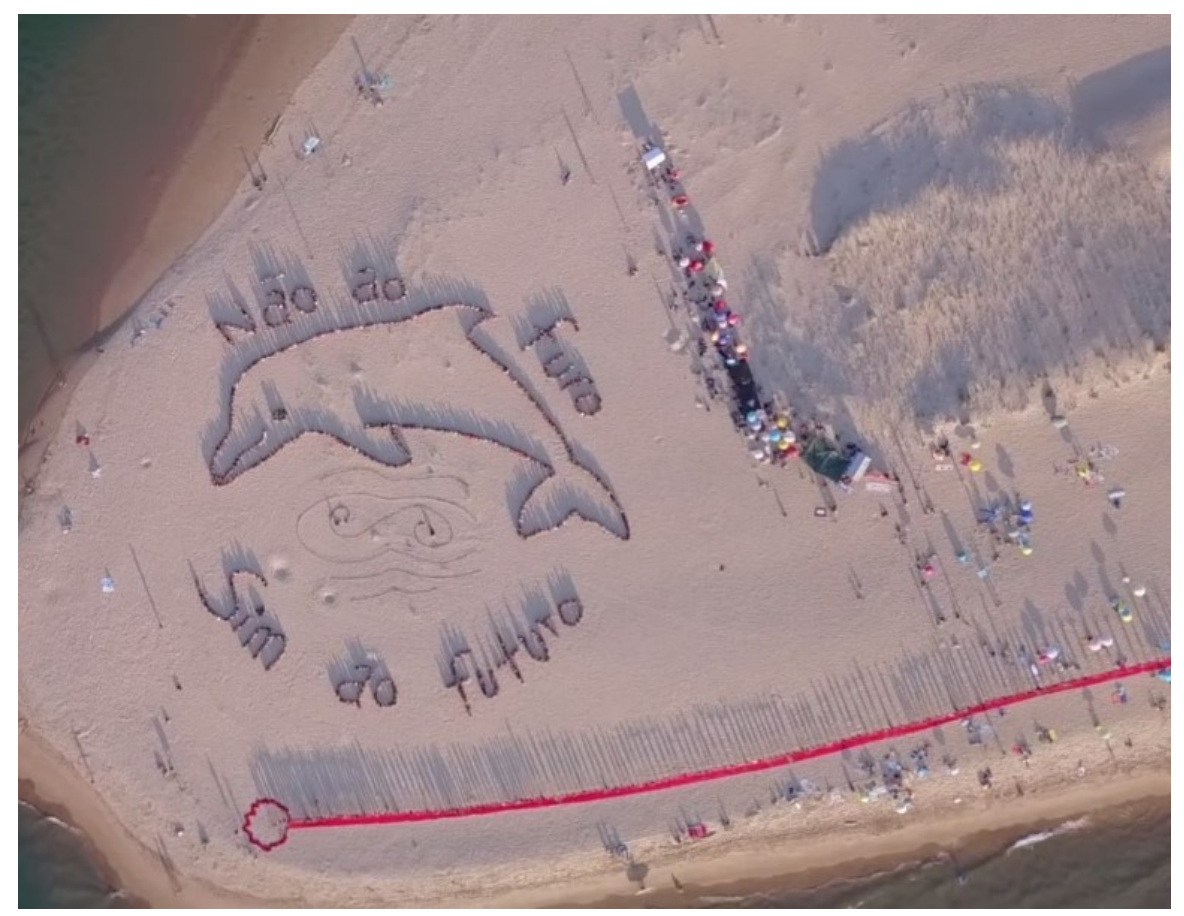

Imagen 205. Detalle acción, Não ao Furo! Sim ao Futuro. L. Schramm, K. Delacasa, S. Vinage, Y. Kovo, Spectral Q, 2017. Fuente: tamera.org

\subsection{Conclusiones capítulo}

Tras detallar los principios de la permacultura, hemos podido comprender mejor su filosofía y su finalidad. El trabajo de varios autores como David Holmgren y Rosemary Morrow citados en este capítulo, nos han ayudado a visualizar la esencia de la permacultura. Con ello hemos podido pasar a investigar, analizar y observar cómo se trabaja esta filosofía desde diferentes manifestaciones artísticas y desde diferentes autores. Si bien también hemos hecho hincapié en la vinculación tan directa que tiene el arte con la permacultura y la salud, donde se da importancia a la necesidad de equilibrio emocional en las personas, así como de sus cuidados.

A lo largo del capítulo hemos visibilizado los artistas y colectivos que se preocupan por difundir la permacultura desde otras narraciones. Además, 
hemos considerado importante destacar la parte más creativa del agricultor/a. Tal y como hemos comentado anteriormente, el agricultor/a trabaja con el campo como si de un lienzo se tratara, realiza sus bocetos, estudios, estructuras, sus diseños y composiciones para crear sus cultivos y, al mismo tiempo, hace uso de estrategias artísticas (voluntaria o involuntariamente) consiguiendo generar espacios de contemplación componiendo con la naturaleza.

Todo ello también lo hemos podido visualizar desde obras generadas por artistas que han sido ubicadas en museos o galerías, un contexto totalmente diferente pero que nos sirve para llevar el mensaje de la permacultura a todas las ubicaciones posibles. Las obras han sido generadas teniendo en cuenta los materiales, con el menor impacto posible, reutilizando en la medida de lo posible y, sobre todo, dando un mensaje coherente con los principios de la permacultura.

Asimismo, también hemos podido observar muchos proyectos que parten de la visión de trabajo colectivo, donde se involucra a la comunidad. Muchas de las obras que hemos investigado se han realizado en colectivo y en el espacio público. Proyectos procesuales con gran impacto social, tanto en el proceso de construcción de la obra como en su culminación y posterior difusión en los medios.

Consideramos que cada vez hay más colectivos sensibilizados con la filosofía de la permacultura y motivados por difundir sus principios por medio de diferentes estrategias artísticas. Así pues, hemos podido comprobar a través de la lectura, el estudio y la observación de los proyectos que hemos descrito, que es mayor el interés del público cuando se trabajan aspectos artísticos. Comparamos estas obras con sutiles semillas que se van sembrando desde diferentes puntos del planeta donde poco a poco irán dando sus frutos. 




\section{CAPÍTULO 5}

\section{ESTUDIO DE CASOS ESPECÍFICOS}

Los proyectos elegidos para el presente estudio confluyen en el mismo hilo conductor: potenciar la agricultura, dándole el valor y la importancia que merece, a través de las prácticas artísticas. El arte se convierte en una herramienta, en un medio, para la difusión de la agricultura, para compartir su conocimiento y su belleza. Pero, también la propia agricultura, según y como, se convierte en arte en sí misma, y en arte crítico y activista. Ambos se unen con el fin de reconectar a las personas con el origen de la procedencia de los alimentos, con la tierra, con el conocimiento, con la autonomía de decidir dónde adquirir sus alimentos, con la oportunidad de exigir alimentos sanos y libres de tóxicos, con la posibilidad de aprender a generar sus propios alimentos y con el respeto hacia las personas que cultivan en equilibrio con el medio en el que trabajan.

Todo ello se transmite a través de potenciar la belleza de la propia práctica agrícola, sus cultivos y el encanto intrínseco de la naturaleza, así como, al generar nuevos espacios de conocimiento donde dialogar, valorar, cuestionar y crear. Si bien, se produce trabajando con otra visión, cultivando desde la mirada artística, uniendo diversos campos del conocimiento, abriendo nuestras mentes a nuevas formas de ver y crear. 
Observamos proyectos teóricos, más enfocados a la difusión del conocimiento donde la práctica artística es más puntual y, por otra parte, percibimos movimientos con un potencial activista muy marcado. Aun así, en todos ellos, se generan espacios donde dialogar entre diferentes agentes, uniendo conocimientos y miradas muy diversas con el objetivo de mejorar la situación del sector agroalimentario.

\subsection{Kultivator: arte y agricultura en Öland, Suecia}

Los artistas Mathieu Vrijman, Malin Lindmark Vrijman y Marelene Lindmark junto a los agricultores Henric Stigeborn y Maria Lindmark fundaron en 2005 Kultivator, una cooperación experimental donde fusionan la agricultura orgánica con las prácticas artísticas. Tienen una residencia que a la vez es un lugar de exposición y una granja en la isla de Öland, Suecia, donde invitan a toda aquella persona que pueda estar interesada en realizar una residencia artística, un proyecto, una conferencia o, simplemente, una visita.

En sus inicios producían en la granja suficiente alimento como para abastecerse a ellos mismos y organizaban eventos para vender los excedentes. Tenían una tienda en la propia granja donde vendían desde tomates a la carne de sus ovejas. Actualmente, la tienda no está en funcionamiento, aunque tienen intenciones de volver a ponerla en marcha.

En estos momentos los coordinadores artísticos son Mathieu Vrijman y Malin Lindmark Vrijman y el gerente de la granja es Henric Stigeborn. Si bien, según el proyecto con el que estén trabajando colaboran con otros agentes. A su vez, tienen habilitados diferentes espacios para los animales y disponen de vacas lecheras y caballos, entre otros. Uno de sus proyectos con los caballos, coordinado por Malin Lindmark Vrijman, es realizado con refugiadas sirias a las que están ayudando tanto a aprender a montar a caballo como a llevar a cabo los cuidados de estos animales. Cabe destacar que en Siria no está bien visto que una mujer monte a caballo, solo los hombres más fuertes son los que suelen hacerlo. El hecho de haber realizado estas reuniones con las refugiadas sirias durante medio año, todas las semanas, produjo un cambio 
de actitud y autoestima en estas mujeres. Además, se observó un empoderamiento y un aumento de su alegría.

En la granja tienen dispuestos varios espacios para alojar a los residentes, si bien experimentan realizando nuevas construcciones de arcilla, paja y abono de caballo. Además, en 2011, para el proyecto Campamento, compraron un autobús que convirtieron en otro espacio de residencia para artistas. En este caso, se inauguró con la presencia de un grupo de artistas procedentes de Suecia, Líbano, Egipto, Dinamarca, Turquía, Noruega, España y Jordania. Este taller intercultural se propuso como una fábrica de ideas, con puestas en común, charlas y diversas actividades en el contexto de Kultivator que culminó en una exposición colectiva.

El autobús, que alberga nueve camas y una cocina, finalmente se quedó en Kultivator como un espacio más para nuevas residencias artísticas. Los estudiantes y voluntarios que se quedan en el lugar están organizando el espacio, construyendo un baño y trabajando con elementos reciclados.

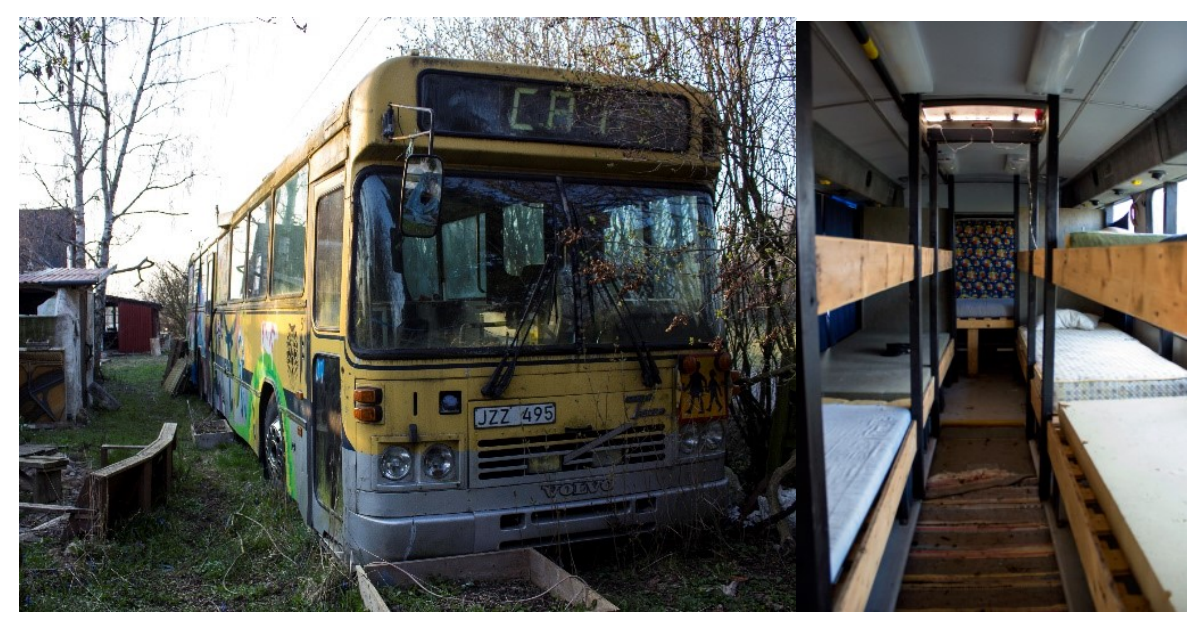

Imagen 206. Autobús-residencia artística, Kultivator, 2019. Fuente: propia Imagen 207. Vista interior Autobús-residencia artística, Kultivator, 2019. Fuente: propia 
En Kultivator son muy libres, están abiertos a realizar cualquier tipo de iniciativa, muchas de las propuestas que se han realizado en Kultivator son proyectos piloto o experimentos. Se construyó un edificio con tejado verde de forma experimental con la intención de ubicarlo en las ciudades para guardar las bicicletas. Esta propuesta no fue muy funcional allí, aunque lo utilizan como hábitat para las gallinas, sin embargo, el espacio que les cedió Kultivator les sirvió para llevar a cabo el prototipo del proyecto y experimentar.

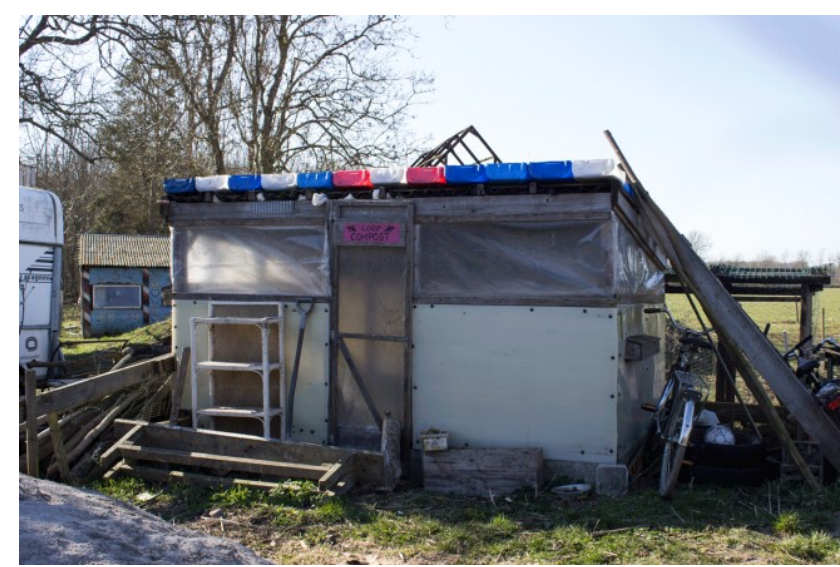

Imagen 208. Prototipo edificio tejado verde. Kultivator, 2019. Fuente: propia

\subsubsection{Las intervenciones artísticas en Kultivator}

En el contexto de Kultivator se han realizado intervenciones de diversas temáticas y técnicas. Además de trabajar con la tierra y cuidar de los animales, es un lugar de experimentación, de encuentro y de diálogo. De entre todas las piezas realizadas, vamos a destacar aquellas intervenciones que están situadas en el territorio de Kultivator.

En Kultivator se da mucha importancia al cuidado de los caballos, les sirven de ayuda en tareas del campo como sacar troncos del bosque o con los cuales realizan talleres como los que hemos comentado al principio con las refugiadas de Siria. Así pues, las colaboraciones con los refugiados se dan en 
muchas ocasiones en el contexto de Kultivator, es por ello por lo que también surgen oportunidades de crear piezas artísticas en el territorio del proyecto, como la que podemos observar en la imagen 209. Dicha obra, fue realizada por uno de los refugiados que estuvo trabajando en Kultivator, el cual quiso realizar un mural en una de las paredes de la finca. La pieza hace alusión a un poema árabe, el cual utiliza para realizar una metáfora con la danza de los caballos y las mujeres. Para ello, hizo uso de los caligramas islámicos, sintetizando en una frase si quieres saber cómo me siento, pregunta a mi caballo.

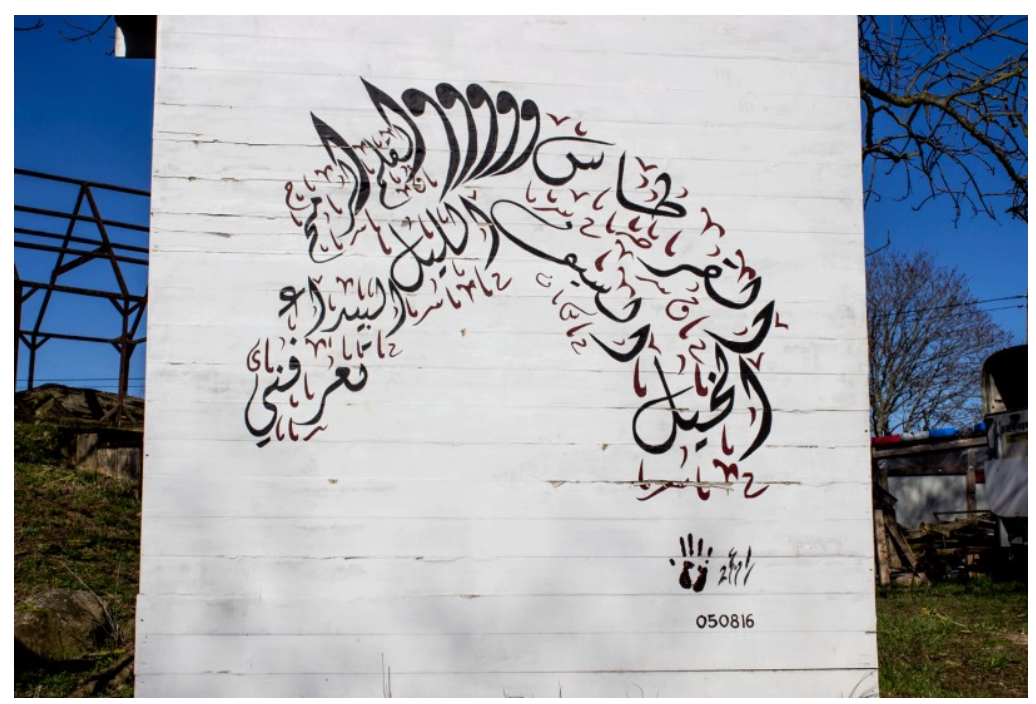

Imagen 209. Si quieres saber cómo me siento pregunta a mi caballo, Kultivator. Suecia, 2019. Fuente: propia

Siguiendo con la misma línea de los caballos, se generó otra pieza que iba a funcionar como un refugio para dichos animales. La pieza estaba formada por una edificación de madera a modo de refugio (como podemos observar en la imagen 210), la cual contenía un carro de caballos. Era un lugar muy bonito donde los artistas que acudían a Kultivator se podían sentar a dibujar y, al mismo tiempo, estar junto a los animales. Actualmente, solo queda la estructura exterior ya que los caballos se comieron el carro. 


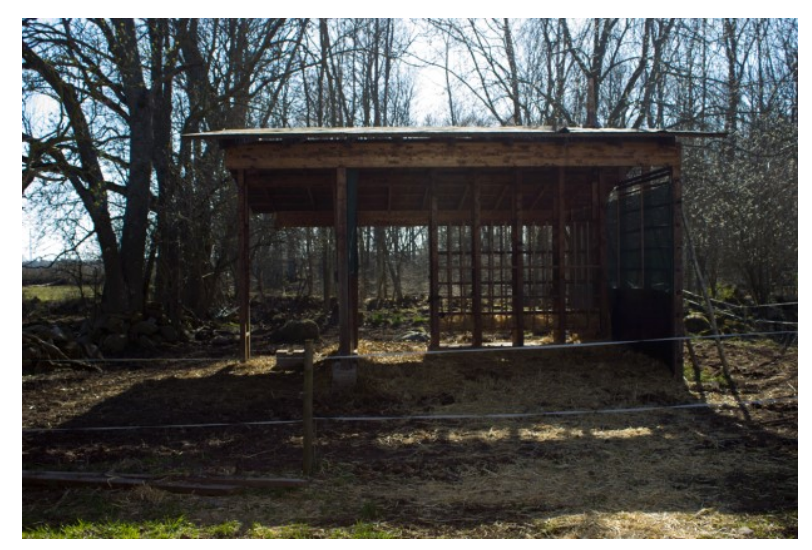

Imagen 210. Refugio caballos, Kultivator. Suecia, 2019. Fuente: propia

Por otra parte, en 2010, Mathieu Vrijman y Malin Vrijman empezaron a realizar una pequeña construcción que sirviera como refugio colectivo e internacional para el arte y la agricultura. Su idea era construir un espacio donde pudieran trabajar en colectivo con muchos artistas y asociaciones de otras zonas del mundo, creando un lugar de diversas confluencias que abocaran al mismo fin, el arte y la agricultura. Es por ello por lo que decidieron realizar una boda en la que casaron el arte con la agricultura, esta especie de happening fue un acontecimiento que, además, sirvió para inaugurar el lugar.

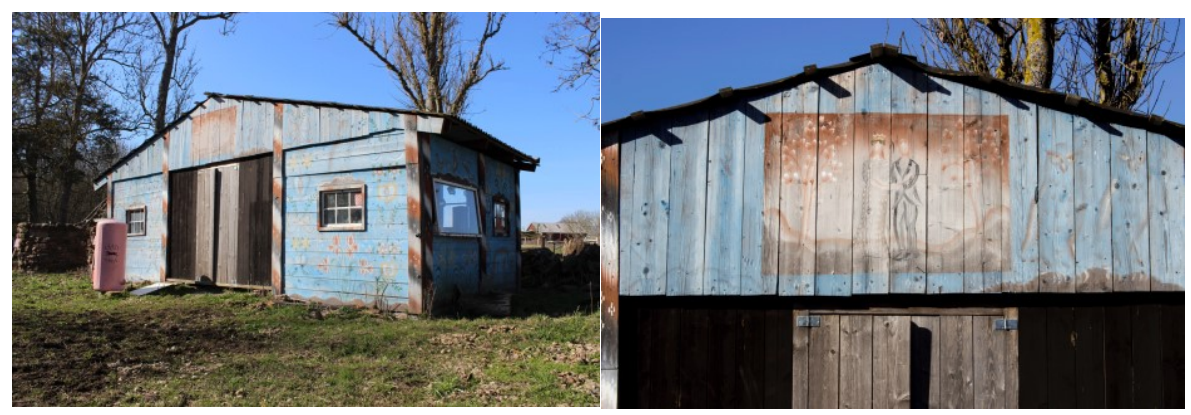

Imagen 211. Refugio Arte y agricultura, Kultivator. Suecia, 2019. Fuente: propia Imagen 212. Detalle refugio Arte y agricultura, Kultivator. Suecia, 2019. Fuente: propia 
En la imagen 211 podemos observar la construcción del refugio y en la imagen 212 podemos ver la pintura que realizó un artista holandés para conmemorar esa unión del arte y la agricultura. El lugar ha ido mejorándose y actualizándose, actualmente, es una cocina para elaborar pan internacional. Además, han empezado un proyecto en el cual tienen tres tipos diferentes de horno y producen diversos tipos de pan y pizzas. Así pues, invitan a personas de diferentes culturas para que puedan aprender y degustar las variedades de panes, el lugar se convierte de nuevo en un espacio de encuentro, dialogo y multiculturalidad. En las siguientes imágenes podemos observar el interior del refugio, con una vista de los hornos y la mesa central (imagen 213) y los espacios para colgar poemas, dibujos y fotografías (imagen 214). Además, podemos observar técnicas de la cultura siria para repeler a las moscas, como son las bolsas de plástico con agua que hay colgadas del techo, las moscas se reflejan en el agua, se asustan y se van.
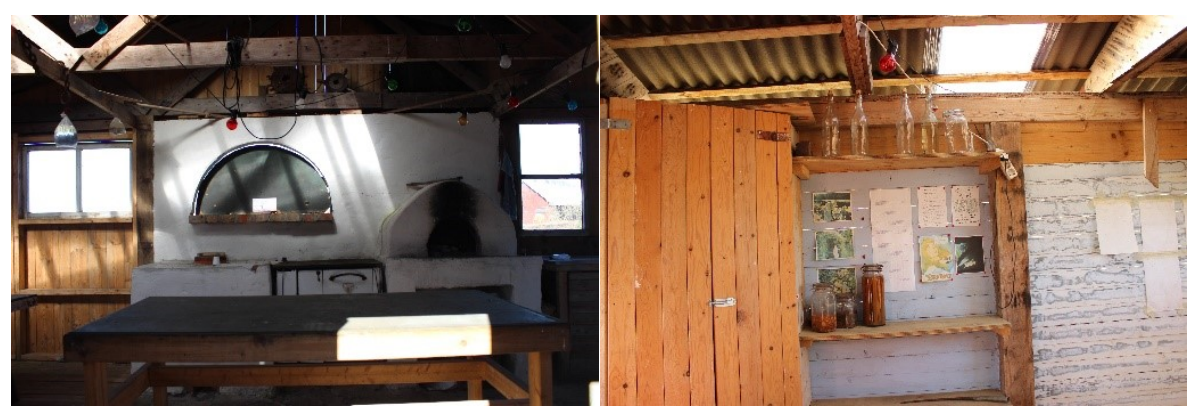

Imagen 213. Vista hornos refugio Arte y agricultura, Kultivator. Suecia, 2019. Fuente: propia Imagen 214. Vista interior refugio Arte y agricultura, Kultivator. Suecia, 2019. Fuente: propia

Asimismo, al trabajar con refugiados sirios y generar proyectos a raíz de su cultura, fueron surgiendo nuevas propuestas en las que trabajar. En el siguiente caso, uno de los refugiados colaboró con Mathieu y Malin Vrijman en la creación de una pieza en la que se necesitaba invertir mucha energía. Así pues, se planteó realizar una intervención donde pudieran hacer una prueba de filtro verde para el agua. Cerca de la granja hay un pequeño río y 
toda el agua de la isla se está yendo al mar, además, los purines de las granjas, fertilizantes y agrotóxicos que se utilizan en las fincas de la isla acaban contaminando el agua. Por tanto, excavaron un gran agujero, trajeron más agua del embalse y del río y realizaron una especie de filtro de agua con diferentes vegetales. La pieza sirve como pequeño experimento para luego poderlo trasladar a embalses y ríos más grandes, donde puedan filtrar más cantidad de agua con la misma técnica. Además, construyeron una especie de puente encima de la zona de filtrado que permite observar más de cerca el espacio generado. El trabajador sirio que estuvo con ellos mostró mucho interés en la construcción de dicho puente, su ayuda fue de mucha utilidad para la creación de la pieza, además, el hecho de estar con ellos trabajando en este proyecto, sintiéndose útil e invirtiendo mucha energía en su construcción, contribuyó a mejorar su estado anímico.

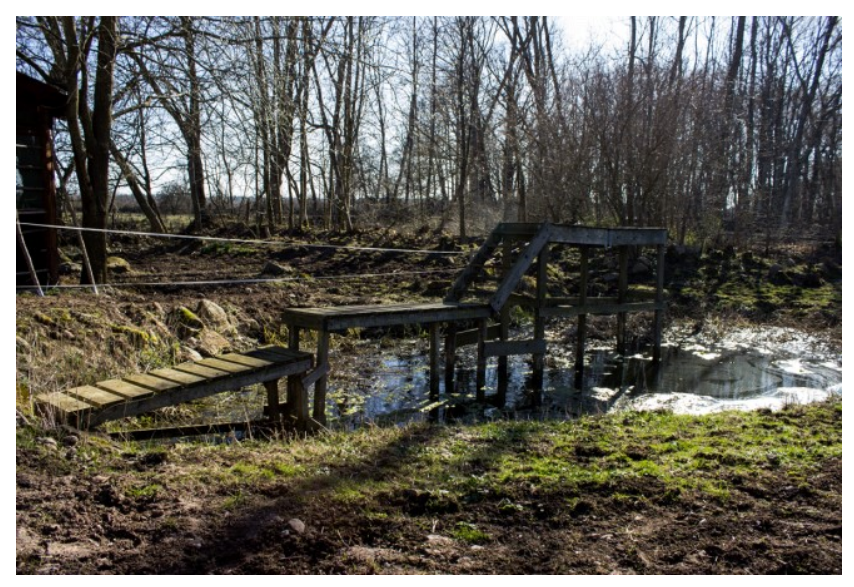

Imagen 215. Filtro verde, Kultivator. Suecia, 2019. Fuente: propia

Finalmente, en el contexto de Kultivator encontramos otras piezas más aisladas que completan el recorrido de intervenciones situadas en su territorio. Encontramos una bioconstrucción en forma del símbolo de infinito que sirve como un baño seco ecológico para los asistentes a los diferentes encuentros que se realizan en Kultivator (imagen 216). 
También, en la imagen 217, podemos observar una obra que realizó Mathieu, en la cual quiso fusionar un carrito de la compra del supermercado con un cultivador. La pieza pretende incitar al espectador a reflexionar y tomar conciencia sobre la procedencia de la comida. Actualmente, la sociedad tiene tan fácil acceso a los alimentos en los supermercados que, en ocasiones, se pierde el conocimiento de su punto de origen y de cómo se cultivan esos productos básicos necesarios para nuestra alimentación y para la vida. Esta toma de conciencia es necesaria para poder valorar tanto la importancia de la tierra como de las personas que la cuidan y trabajan.

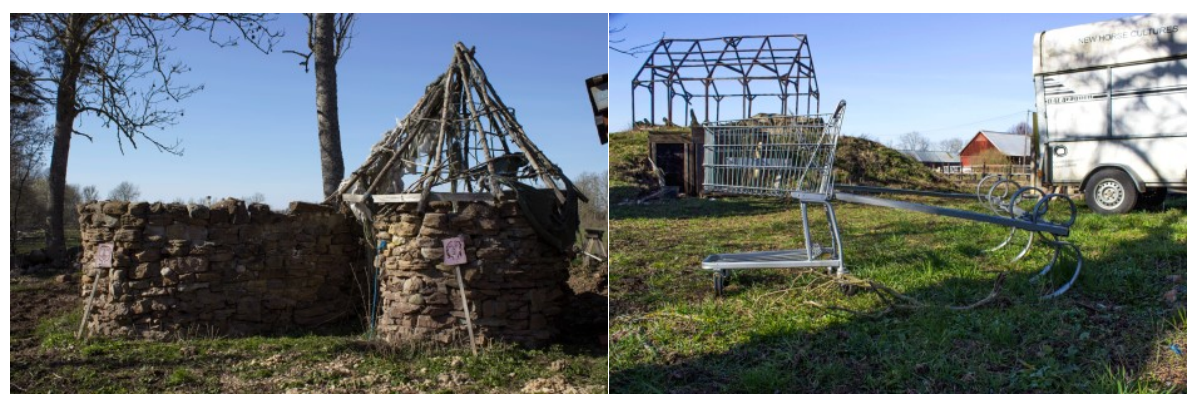

Imagen 216. Bioconstrucción aseo seco, Kultivator. Suecia, 2019. Fuente: propia Imagen 217. Carrito con cultivador, Kultivator. Suecia, 2019. Fuente: propia

\subsubsection{La escuela Ölands Folkhögskola}

Tanto Mathieu Vrijman como Malin Lindmark Vrijman son activistas de largo recorrido, además de los proyectos que se realizan en Kultivator también realizan encargos o propuestas en otros lugares. Mathieu Vrijman combina su trabajo artístico con la docencia en la escuela Ölands Folkhögskola donde inspira y guía a su alumnado a través de la creación de proyectos, de puestas en común y diversas actividades. Entre ellas, la creación de un horno en los alrededores de la escuela, utilizando barro y abono de caballo. 


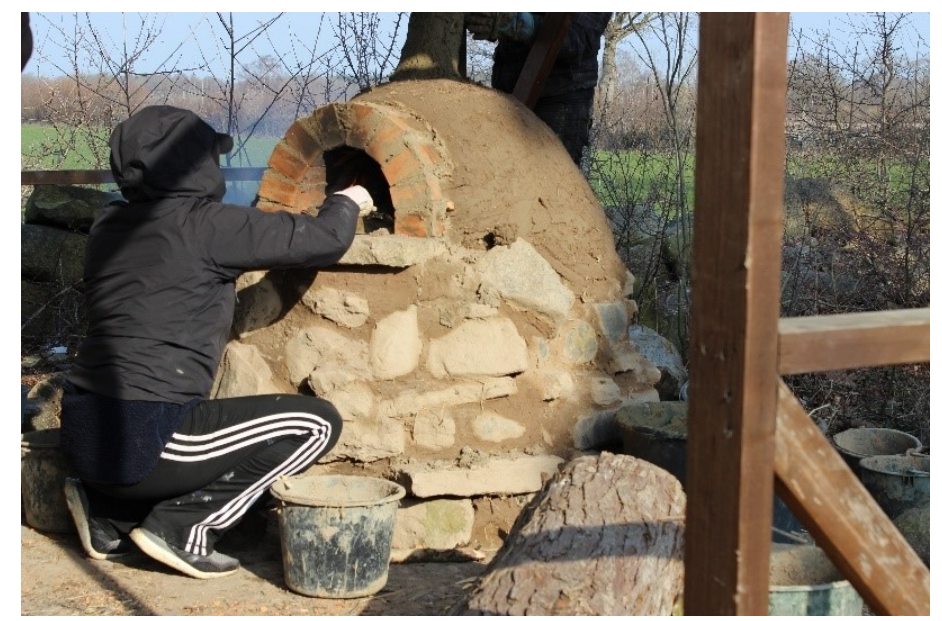

Imagen 218. Alumna construyendo el horno. Ölands Folkhögskola 2019. Fuente: propia

La escuela Ölands Folkhögskola es un lugar de estudio e investigación donde el alumnado tiene la posibilidad de acceder a gran diversidad de conocimiento. Está enfocado para personas que no han alcanzado la educación secundaria y quieren especializarse en algún área en concreto o prepararse para el acceso a la universidad. La escuela les ayuda a sacar su creatividad, así como experimentar y compartir conocimiento con profesionales artistas, cineastas, escritores y músicos. Además, las instalaciones de la escuela ofrecen muchas posibilidades, en el interior del edificio se encuentran salas dedicadas a diferentes áreas creativas como escultura, pintura, grabado o cine.

Por otra parte, en los exteriores cuentan con grandes jardines en los que pueden llevar a cabo diversos proyectos, como el horno que recién hemos comentado, también un gallinero y un huerto. Mathieu Vrijman intenta potenciar las capacidades creativas de su alumnado combinando tanto la práctica con creaciones de proyectos en los exteriores de la escuela, como manteniendo discusiones y puestas en común, potenciando sus capacidades críticas y la participación colectiva. 


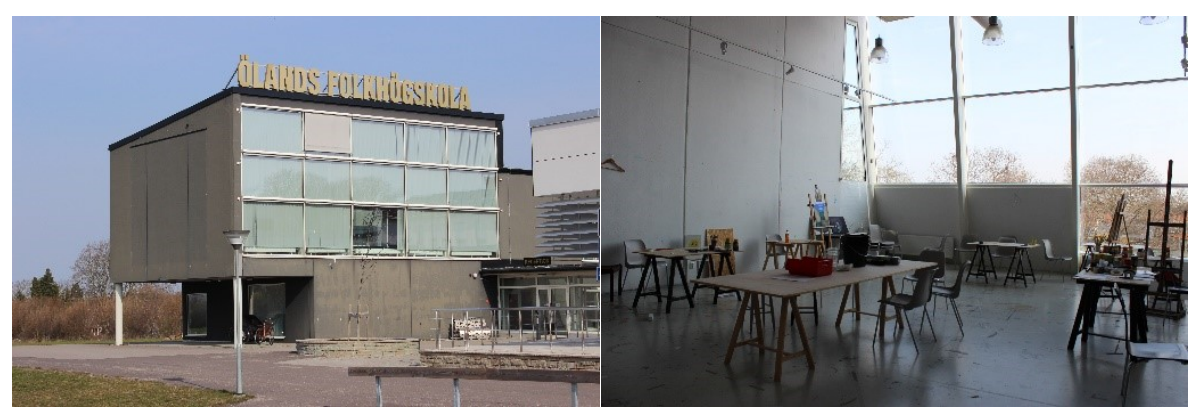

Imagen 219. Escuela Ölands Folkhögskola.

Öland, Suecia, 2019. Fuente: propia Imagen 220. Vista aula arte Ölands Folkhögskola.

Öland, Suecia, 2019. Fuente: propia

\subsubsection{Conclusión}

En el proyecto Kultivator encontramos diferentes vías de trabajo; en primer lugar, su trabajo y colaboración con la granja colindante; en segundo lugar, los proyectos que emprenden con los refugiados sirios; por otra parte, los encuentros y residencias artísticas que se realizan en el contexto de Kultivator; también, las piezas y proyectos que realizan Mathieu y Malin tanto fuera como dentro de Kultivator y, finalmente, la docencia que imparte Mathieu en la escuela Ölands Folkhögskola. Sin embargo, todas esas vías de trabajo están muy unidas y en todas ellas se trabaja desde el conocimiento y la vinculación del arte y la agricultura. Por tanto, consideramos que Kultivator es un proyecto muy completo y activo, el cual está abierto a todo tipo de propuestas, trabajando con personas, independientemente de su cultura o procedencia, generando vínculos y acercamientos al territorio a través de las estrategias artísticas.

Si bien, consideramos que mantener este tipo de proyectos económicamente resulta complejo sin tener apoyos, es por ello por lo que es necesario una inversión de tiempo y esfuerzo considerable para poder conseguir financiación, bien sea a través de la presentación de proyectos a convocatorias, a través de encargos o a través de la impartición de docencia. Asimismo, desde las instituciones es difícil encontrar apoyos o financiación que se prolongue en el tiempo y pueda ofrecer estabilidad a los proyectos de 
estas características, siendo apoyos muy puntuales y, normalmente, a través de previas convocatorias públicas. Así pues, consideramos admirable el trabajo y la dedicación de Mathieu Vrijman y Malin Lindmark Vrijman y del gerente de la granja Henric Stigeborn.

Finalmente, gracias a la colaboración de Mathieu y Malin con Henric, ha habido un mayor acercamiento e interés, por parte de los participantes y asistentes a Kultivator, hacia el trabajo que se realiza en la granja y su valoración. Un trabajo indispensable para la obtención de la alimentación básica de nuestra dieta diaria. Además, insistimos en la importancia de este tipo de vínculos y colaboraciones con los agricultores y granjeros para evidenciar el aumento de la pérdida de estos trabajos del sector primario, ya sea por cuestiones económicas o por falta de relevo generacional. Henric Stigeborn nos comentaba las pocas granjas que quedaban en la zona de Öland (Suecia) y como poco a poco estaban cerrando todas por llegar a situaciones insostenibles.

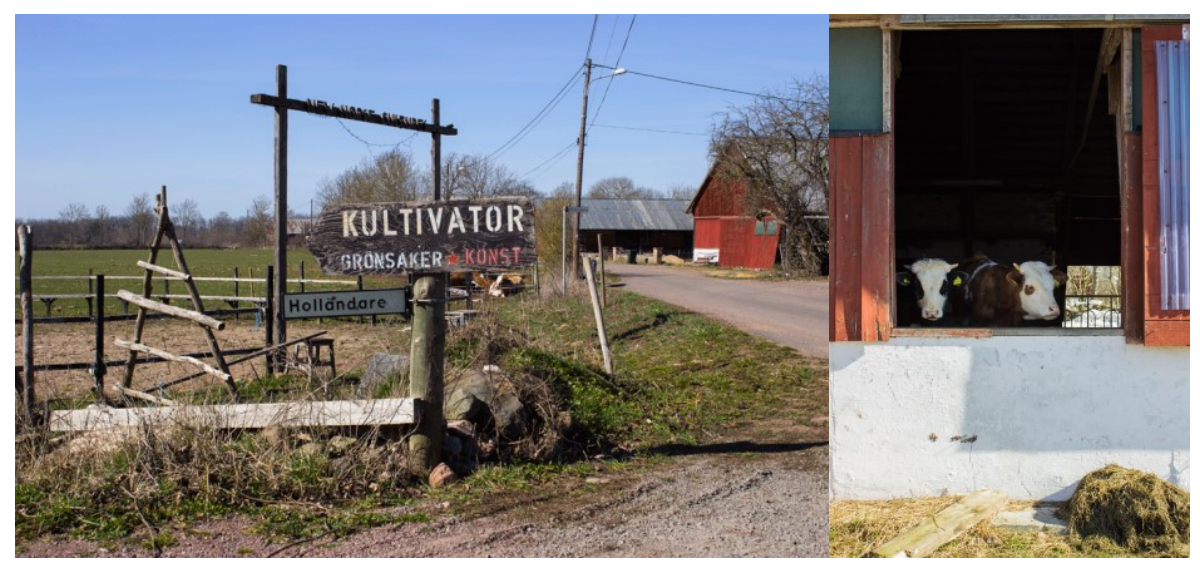

Imagen 221. Entrada a Kultivator, Kultivator. Suecia, 2019. Fuente: propia Imagen 222. Vacas en granja de Henric Stigeborn, Kultivator. Suecia, 2019. Fuente: propia 


\subsection{Enriqueta Rocher y su asociación Mandarina Borda}

\subsubsection{Introducción}

El trabajo artístico de la creadora y docente Enriqueta Rocher (Valencia, 1968) abarca diferentes aspectos, pero todos ellos se vinculan con el paisaje. En 2012, fundó la asociación sin ánimo de lucro Mandarina Borda donde, movida por su intuición, empezó a trabajar el paisaje a través de la geometría como punto de unión con la naturaleza, a trabajar aspectos como la permacultura, el territorio y sus recursos, a impartir talleres y la creación de obras de foodart. Su inspiración se fomenta tras la observación de los procesos naturales, llevándola a crear en consonancia con la naturaleza.

Algunas de sus creaciones se pueden observar en su huerto situado en Palmera (Valencia), donde cultiva en mándala, cuida de sus naranjos y mandarinos y recoge todos aquellos elementos naturales que le sirven para investigar y crear. Algunos de sus referentes se remontan a los años 70 - 80 con el movimiento artístico Land Art, como Agnes Denes y su obra Wheatfield - Confrotation.

Enriqueta Rocher además de invertir en su vocación artística y docente, también se siente sensibilizada con el medio ambiente, con un marcado interés en la investigación de las pieles y la pulpa de la naranja para la realización de utensilios desechables totalmente orgánicos. La artista, a pesar de ser consciente de las dificultades que puede llevar el trabajo en colectivo, apuesta por compartir, crear e investigar con colectivos y artistas afines a su línea de estudio. En 2013, organizó el I Encuentro de arte y agroecología y, dado el gran acogimiento que tuvo, ha seguido organizando encuentros bajo el título de Trastellaor.

\subsubsection{El nacimiento de Trastellaor}

En las zonas de huerta de la comarca de la Safor, en la Comunidad Valenciana (España), encontramos el uso del término trastellaor, comúnmente utilizado en estas tierras para denominar al elemento que sirve de tapa para cerrar las acequias, pudiendo guiar y controlar el agua de riego hacia sus campos. El 
uso de esta palabra fue dado por el propio agricultor y agricultora al resultarle una molestia tener esta pieza de cierre por el campo y la acequia, convirtiéndose en un trasto para él/ella. En la imagen 223 podemos observar la fotografía de la artista Pau López, seleccionada en Trastellaor 2019, donde se muestra un almacén que fabricaba trastellaors.

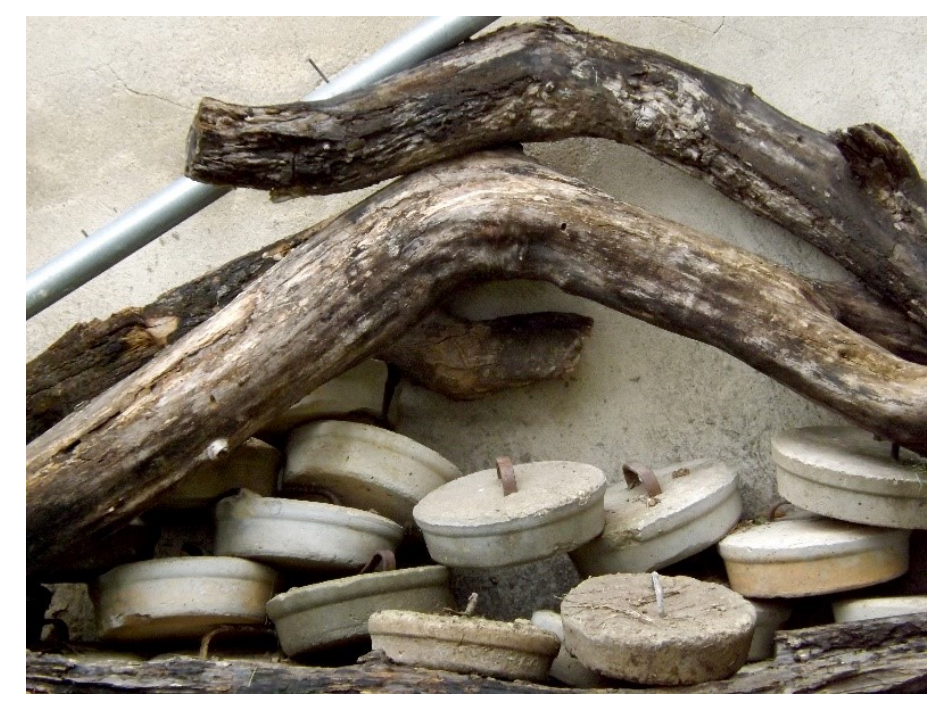

Imagen 223. Trastellaors. Pau López Anquela, 2019. Fuente: cesión del artista

Este nombre, Trastellaor, ha encabezado las tres últimas convocatorias de arte y agroecología que ha lanzado Rocher desde su asociación cultural Mandarina Borda. Este lugar de creación está ubicado en la población de Palmera, Valencia (España), ubicación donde permanecen los artistas seleccionados en cada edición de Trastellaor para la realización de las obras. Es interesante observar la diversidad de obras presentadas en cada uno de los encuentros, trabajándose diferentes conceptos, pero con una clara vinculación al paisaje y más concretamente a la agroecología.

En el primer encuentro se trabajó el concepto de ecosistema, un término amplio que abarcó obras de happening, intervención en el territorio, 
escultura y food-art. Además, se organizaron mesas redondas y momentos de picnic más distendidos para seguir compartiendo conocimiento. El segundo de los encuentros tuvo lugar en 2016 y se convocó a creadores que quisieran presentar proyectos donde primara la utilización de los recursos naturales que nos ofrece la huerta, generando un vínculo entre el ser humano y el territorio. Uno de los elementos que se repitió en cada una de las obras seleccionadas en esa edición fue la caña.

La tercera convocatoria se produjo en 2018 centrando la atención en la Tierra como planeta y como elemento, bajo la premisa de utilizar materiales orgánicos en la creación de las obras. La más reciente de las convocatorias tuvo lugar en 2019 bajo el concepto de agua, siguiendo con los parámetros de utilizar materiales orgánicos, pero con libertad de técnica y creación. Todas las ediciones de Trastellaor han mantenido un vínculo de respeto, admiración y contemplación hacia la naturaleza el cuál consideramos que se puede recoger en siguiente fragmento de Schelling:

Las artes plásticas, como el arte poético, deben expresar pensamientos del espiritu o conceptos cuyo origen es el alma, pero no mediante el lenguaje, sino como la callada naturaleza: mediante la figura, mediante la forma, mediante obras sensibles e independientes de ella. Así pues, las artes plásticas funcionan manifiestamente como un vínculo activo entre el alma y la naturaleza y solo pueden ser entendidas y captadas en el contexto de ese vivo medio entre ambas (Leyte y Cortés, 2004: 116).

\subsubsection{Los creadores en Trastellaor}

Hemos realizado una selección de obras de creadores y creadoras que han dejado su semilla en Trastellaor, incluidas también las piezas de la artista y fundadora Enriqueta Rocher. Dado que el objetivo de las diferentes convocatorias es generar un vínculo entre el arte y la agroecología, la elección de obras a desarrollar ha sido pensada con la intención de crear una narración con diferentes procesos agroecológicos. 


\subsubsection{Cápsula I}

Iniciamos este primer subapartado con la obra de Darío Escriche de la edición 2019, titulada Cápsula I. Esta pieza es una escultura interactiva donde el artista, utilizando materiales como la caña y el hilo de cáñamo, ha creado una semilla gigante que al mismo tiempo sirve de banco de semillas. La obra pretende poner en valor la importancia de la conservación de las variedades autóctonas y favorecer mediante ese espacio el intercambio de las semillas entre los agricultores y agricultoras, así como con los visitantes.

Nos situamos en un momento importante de pérdida de biodiversidad, dado por el aumento exponencial de los monocultivos en el sector agrícola, entre otros. La pieza de Escriche ofrece la semilla para facilitar la recuperación, la conservación y la variedad de especies, poniendo en valor nuestro patrimonio natural, cultural e histórico. Semillas de unos cultivos que durante siglos se han ido adaptando a las inclemencias del lugar, adquiriendo gran fortaleza y adaptación al medio.

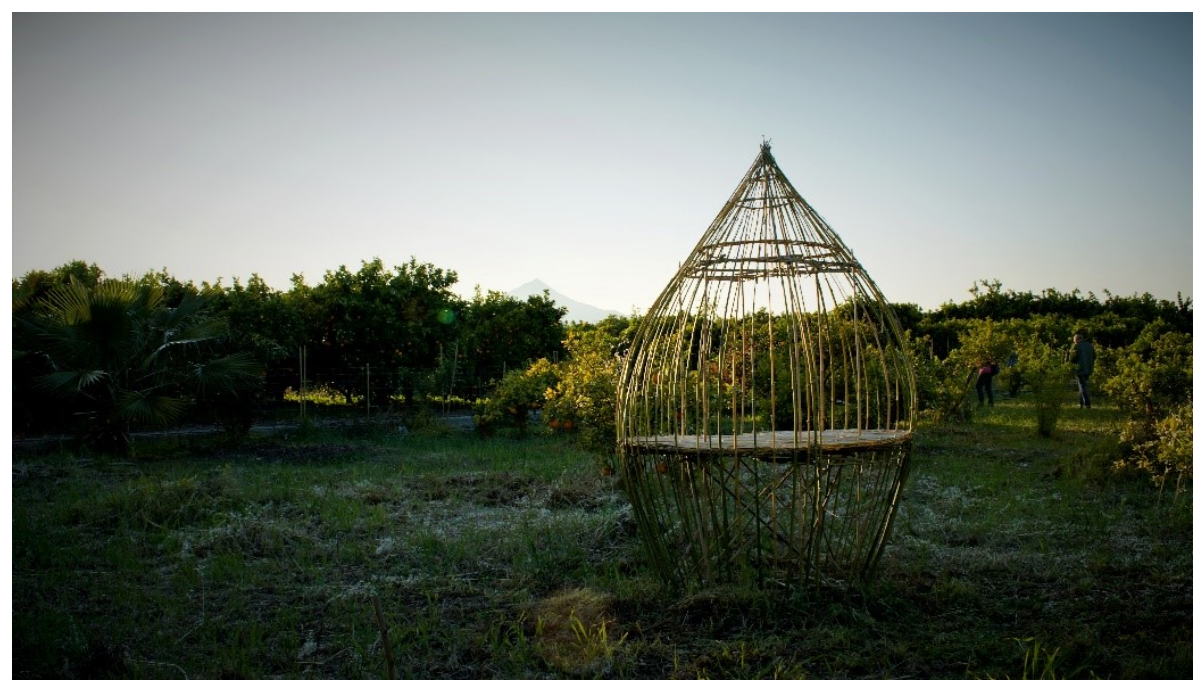

Imagen 224. Cápsula I, Darío Escriche, 2019. Fuente: cesión del artista 


\subsubsection{La Naranja Borde}

Siguiendo con procesos agroecológicos, pasamos a la etapa de crecimiento y maduración del cultivo, donde nos detenemos a observar e investigar la naranja y la mandarina borde. La artista, Miriam Martínez Guirao seleccionada en el Trastellaor 2019, fue la que abarcó estos aspectos en su obra. Configuró una serie de sutiles y bellas ilustraciones que muestran la naranja borde y sus partes, las cuales podemos observar en la imagen 225.

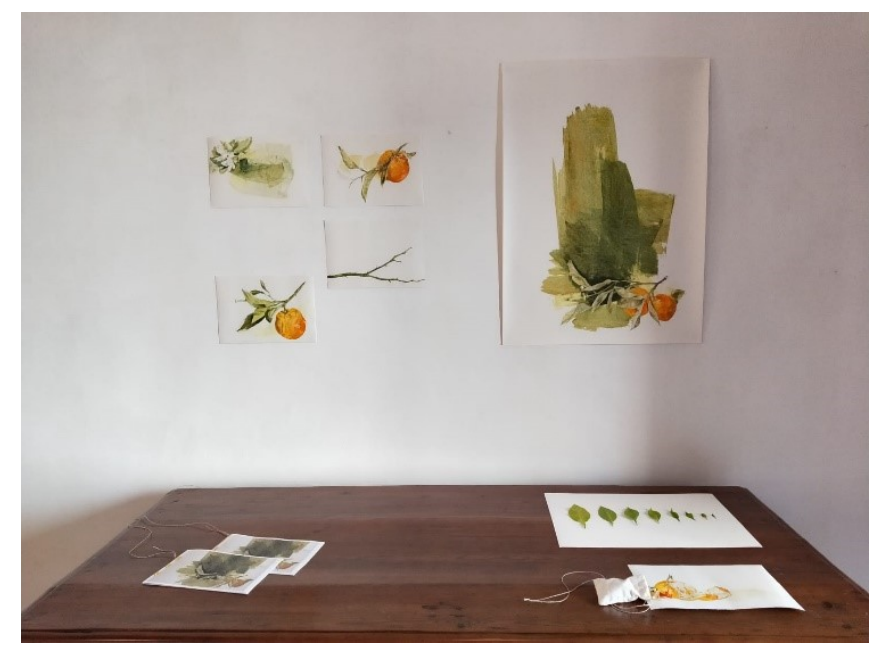

Imagen 225. La naranja borde, Miriam Martínez Guirao, 2019 Fuente: cesión del artista

La artista estuvo alojada en la residencia que ofrece Rocher a los seleccionados y durante los quince días que permaneció allí, pudo observar el lugar, los árboles, el fruto y las hojas con detenimiento. Además, su inspiración la llevó a experimentar y realizar saquitos relajantes con las flores de azahar, crema facial, suero calmante para la piel e infusiones con las hojas de la naranja borde. Todas estas propuestas naturales y orgánicas las reflejó en el catálogo que se editó posteriormente, donde también se presentaron las ilustraciones. Si bien consideramos el trabajo de esta artista una fuente de 
inspiración y conocimiento en el aprovechamiento de los recursos de este amargo fruto.

\subsubsection{Recetario hecho con amor borde}

En este apartado hemos escogido la obra presentada por Enriqueta Rocher en la edición de Trastellaor 2019. Bajo el título que ampara esta sección, la artista presentó una obra de food-art contribuyendo a generar una conexión con las obras presentadas por el resto de los y las artistas en esa convocatoria. Cada una de las recetas fue meticulosamente estudiada, posteriormente se publicaron en el catálogo para su conocimiento y difusión. La naranja borde fue el ingrediente que inspiró a Rocher para la creación de cada una de las piezas.

En la imagen 226 podemos observar la obra de food-art presentada por la artista el día de la inauguración de la convocatoria en abril de 2019, fue la pieza que culminó el encuentro. Tras una detallada explicación por parte de Rocher, los visitantes pudieron experimentar tanto por la vista como por medio de las papilas gustativas todo el conjunto propuesto en el encuentro, pudieron saborear el amargor de la naranja borde combinado con el dulzor de frutos y vegetales de la huerta.

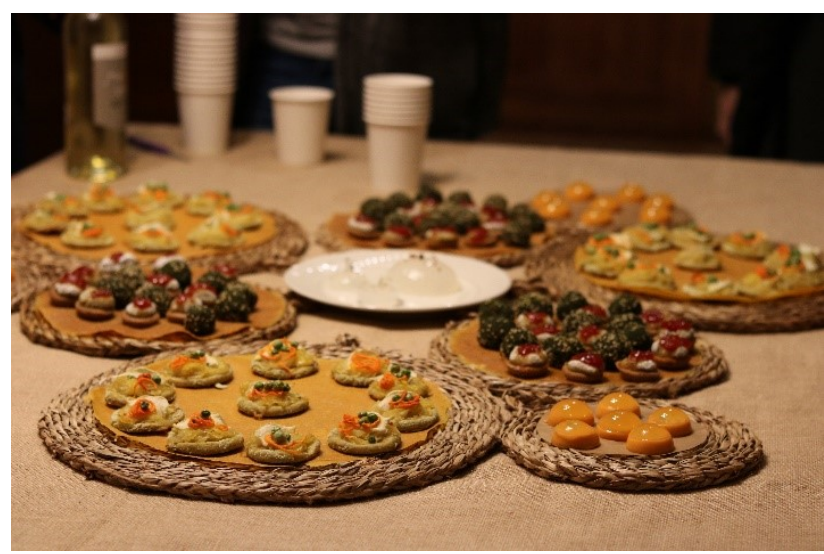

Imagen 226. Recetario hecho con amor borde. Enriqueta Rocher, 2019. Fuente: cesión del artista 


\subsubsection{Ad infinitum}

Hemos elegido la obra de la artista Chiara Sgaramella, seleccionada en la edición de Trastellaor 2016 bajo el título de Ad infinitum, como muestra de la etapa de compostaje, regeneración y aprovechamiento de los residuos orgánicos. La artista generó una relación entre el concepto de infinito, utilizando su representación gráfica ( $\infty)$, y los ciclos cerrados del compostaje de la materia. De una forma muy poética, Sgaramella creó una pieza escultórica que al mismo tiempo tiene la funcionalidad de generar abono orgánico, contribuyendo a difundir las buenas prácticas agroecológicas.

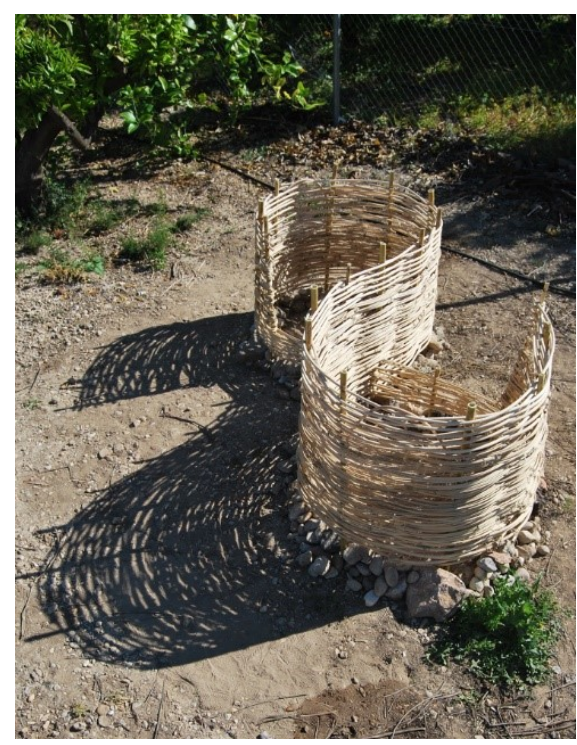

Imagen 227. Ad Infinitum. Chiara Sgaramella, 2016. Fuente: cesión del artista

Cabe señalar que en la construcción de la pieza utilizó únicamente los recursos que pudo encontrar en la misma huerta, realizando una estratégica estructura con cañas apoyadas sobre una cama de piedras. Sgaramella consiguió con esta propuesta integrar con sutileza un elemento artístico y funcional en el paisaje, sin dañar el entorno de la huerta. 


\subsubsection{Conclusión}

El trabajo de la artista Enriqueta Rocher con la asociación Mandarina Borda y, más concretamente con el proyecto Trastellaor, ha dado la oportunidad de encuentro a artistas sensibilizados con el medio ambiente. Gracias a su dedicación, se ha dado la posibilidad a creadores de cualquier edad, ámbito y nacionalidad de generar proyectos que inspiren y promuevan prácticas más sostenibles vinculadas a la agroecología. Se ha lanzado un mensaje de cuidado, valoración y respeto por el paisaje agrícola y su entorno. La cantidad de propuestas presentadas en las diferentes ediciones son una prueba del nivel de sensibilización cada vez más elevado de la sociedad en mantener la biodiversidad, favoreciendo a la conservación de tradiciones y de las semillas autóctonas. Es de agradecer que se promuevan proyectos donde se nos acerque a la naturaleza como fuente de vida, "en la naturaleza hay vida y muerte y la naturaleza está llena de gozo. En la sociedad humana hay vida y muerte, y la gente vive en la tristeza" (Fukukoa, 1978: 60).

\subsection{Culturhaza: arte y agroecología en Córdoba (España)}

Culturhaza es un proyecto agrícola y artístico que Agripino (Antonio José Ruano Ruano) y Protasia (Nazaret García Cuadrado) iniciaron en 2005. Sitúan el punto de partida en un taller de Land Art que realizaron en la I Bienal de Arte de Almería (España), donde Agripino hizo una intervención en el paisaje titulada Deceso y Protasia una acción agro-poética, la trilla de un verso, titulada Comienzo.

Agripino se licenció en Geografía e Historia, especialidad Historia Contemporánea de España, y Protasia es veterinaria, especialista en parasitología. Antes de Culturhaza, Agripino hacía cerámica, collage y escultura con materiales reciclados, naturales o no, y Protasia escribía, fundamentalmente poesía. Juntos conocieron el movimiento artístico Fluxus y la performance en el Museo Vostell-Malpartida (Cáceres, España) y asistieron a talleres de vídeo-acción, vídeo-creación y de sonido. Actualmente, practican el Agrolandart y la performance en Culturhaza, apoyándose en la fotografía y el vídeo para documentar sus trabajos. 
También hacen instalaciones empleando escultura y escritura y, a veces, sonido y vídeo-creación. Forman parte de la red de espacios de arte en el campo Cubo Verde ${ }^{36}$.

Culturhaza está situada en Villarrubia, a 5, 5 kilómetros de Córdoba capital, entre Sierra Morena y la Campiña. Son las siete hectáreas y media de tierra que los abuelos de Agripino compraron en los años 30 del pasado siglo cuando emigraron desde Jaén atraídos por la oportunidad que ofrecía la zona regable del Pantano del Guadalmellato. Construyeron una casa, establos y pajar (hubo vacas) y, más tarde, el secadero de tabaco. construcciones que se fueron reformando y adecuando a nuevas funcionalidades. Formalmente, Culturhaza es una explotación agrícola con frutales, huerta y cultivo de cereal y leguminosas. Agripino es la tercera generación de la familia que se ocupa de esta tierra, es agricultor a título principal (ATP) y está certificado como productor ecológico. Él reside en la casa que construyeron sus abuelos. En cambio, Protasia trabaja en Extremadura y se desplaza con frecuencia a Córdoba, también proviene de familia de agricultores-ganaderos y conoce el trabajo del campo, sobre ella recae la mayor parte del trabajo burocrático. Pero, consensuan todas las decisiones, agrícolas y artísticas.

Desde Culturhaza consideran que el hecho de que Agripino sea ATP es parte del proyecto artístico, pues significa hablar con conocimiento de causa de una realidad profesional castigada en todo el mundo, la del pequeño agricultor, al que le cuesta más sobrellevar la carga burocrática y las trabas administrativas que trabajar a la intemperie sin horas ni días y con poca o nula retribución dineraria. El trabajo del campo es una actividad sin reconocimiento social, siendo importantísima para mantener la vida en la Tierra. Es por ello por lo que la conciencia ecológica y el conocimiento de la realidad social del agricultor, víctima de la desconsideración y de la

\footnotetext{
${ }^{36}$ El Cubo Verde es una red informal que alberga las iniciativas que relacionan el artey el campo, ayudan a difundir los proyectos y a promocionar las actividades, talleres, residencias artísticas... que se realizan en su contexto, www.elcuboverde.org
} 
burocracia, les condujo al artivismo, que ellos vinculan al Agrolandart. La técnica fundamental para hacer Agrolandart es el manejo agroecológico de la tierra y los cultivos. Es decir, la agricultura ecológica ha determinado el propósito de su actividad artística y su modo de hacer arte. Así pues, Agripino también se dio de alta en el Impuesto de Actividades Económicas (IAE) como artista.

En Culturhaza, emplean el arte para defender la agroecología en una sociedad que, con el éxodo rural que comenzó el siglo pasado, olvidó por completo la cultura agrícola, además, la Administración Pública promueve el crecimiento de la agroindustria a costa de la desaparición de las pequeñas explotaciones familiares. Mediante el arte quieren difundir conocimiento sobre agricultura, alimentación y biodiversidad, visibilizar el entorno social agrícola y urbano, concienciar a la gente del momento histórico que viven, apelando a la responsabilidad individual para con el planeta y para con los seres humanos.

A lo largo de los más de quince años que llevan al frente del proyecto agrícola, han tenido problemas administrativos suficientes como para comprender que agricultores con menos preparación o más edad hayan tirado la toalla. Parte de las dificultades surgen de que lo normal no es hacer agroecología, lo normal es tener un solo cultivo, es más sencillo tanto agrícola como burocráticamente. Por ejemplo, en Culturhaza, la huerta familiar de toda la vida desapareció del Sistema de Información Geográfica para la Política Agraria Común (SIGPAC) porque son solo 300 metros cuadrados y está entre árboles, cuando hicieron la correspondiente alegación al SIGPAC el gestor les comentó que no merecía la pena, pero les pidieron un informe de un agrónomo y unas fotos, y eso remitieron. A los dos años denegaron la petición por no aportar un certificado del colegio oficial de agrónomos y fotos georreferenciadas. Consideraron sembrar árboles para adecuarse al SIGPAC, pero el lugar de su ubicación sería en Huerta Chica, una de las piezas de continuidad de Culturhaza, un espacio para la experimentación artística y para evitar la hibridación de algunas hortícolas, de modo que como la Política Agrícola Común (PAC) no subvenciona ni los frutales ni la huerta y el asunto 
no tiene trascendencia económica para Europa, decidieron mantener Huerta chica como espacio agro-artístico virtualmente inexistente.

La certificación ecológica es otra fuente de problemas, los inspectores no siempre tienen suficiente experiencia y conocimiento. Desde que uno de ellos se desdijo de lo hablado, Agripino graba las inspecciones, que duran hasta cuatro horas. La inspección de condicionalidad de la PAC supuso presentar los papeles de tres años (2017-2019), incluyendo los que están en poder de la Administración y un libro de tratamientos fitosanitarios y de fertilización que ni el inspector sabía rellenar. En Culturhaza no se usan fitosanitarios y se abona con humus de lombriz y estiércol de caballo. La finalidad de estos controles es evitar la nitrificación del suelo y las aguas, pero no parece el sistema más adecuado cuando en fincas cercanas se puede ver a agricultores convencionales tratando intensivamente, a veces sin equipo de protección, o con las bolitas de urea sobre la tierra. Los inspectores de la Línea Verde solo actúan si hay denuncia. A los controles de la PAC y de la certificación ecológica se suman los derivados de la autorización para hacer venta directa. No les parece que se ejerza la misma presión sobre los agricultores convencionales.

Además, todas las cuestiones recién comentadas son meramente burocráticas, consumen mucho tiempo, tienen plazos y, cuando coinciden con tareas del campo que no se puede posponer, resulta desalentador y agotador. Asimismo, todo esto tratándose de una actividad que no genera recompensa económica pues los precios de la alimentación son artificiales en todo el mundo, están intervenidos por los gobiernos y por industrias que practican el dumping sin control, así han tumbado los precios del aceite, de la almendra y de la naranja, por ejemplo. Así pues, los precios de los cereales son los mismos de hace cuarenta años, los de muchas frutas no pagan la recogida, las patatas es un monopolio y parece que no hay modo de solucionarlo. Hay organizaciones que se ocupan o deberían ocupar de estos temas, pero no se ven resultados. 


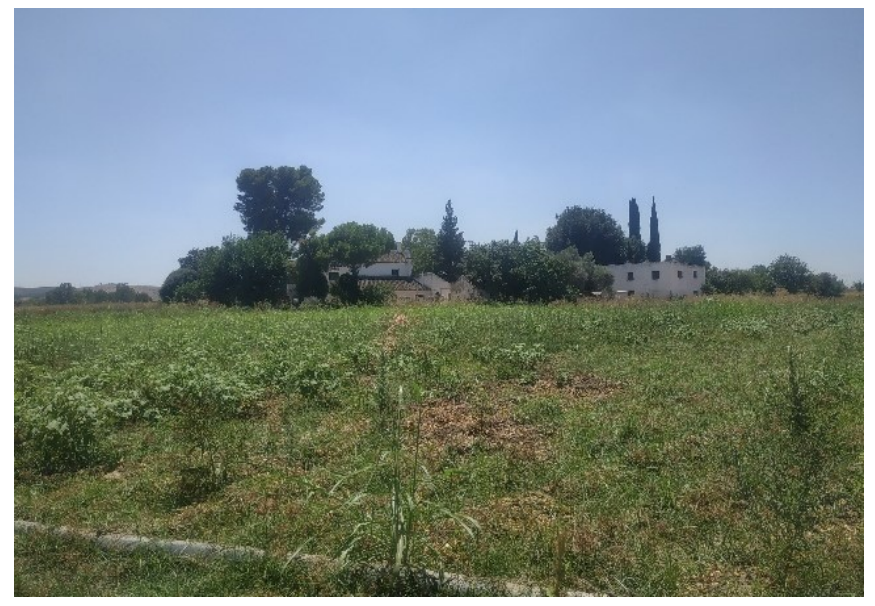

Imagen 228. Vista huerta y casa Culturhaza. Córdoba, 2020. Fuente: propia

\subsubsection{El Agrolandart de Culturhaza}

Desde un principio, el proyecto Culturhaza se definió como 50\% arte y 50\% agricultura, o a la inversa. El trabajo artístico de Agripino y Protasia parte de los fundamentos del movimiento artístico Fluxus. Comenzaron haciendo instalaciones con los cultivos, en ocasiones insertaban esculturas u objetos y hacían performances participativas. Lo llamaron Agrolandart para diferenciarlo del Land Art que no siempre tiene en cuenta la ecología ni suele incluir la finalidad de producir alimentos.

En 2012 pusieron en marcha la pieza de arte social Mucho Cucho, una huerta que genera alimentos, conversación e ingresos. Los productos que ofrece este espacio se envían por email los lunes a la gente interesada para que puedan hacer su pedido antes del jueves y recogerlo el viernes, cuando la gente va a recoger sus encargos suele haber tiempo para ver cómo va la huerta y hablar. Para Agripino, la conversación es otra forma de hacer arte, de enseñar a mirar, de transformar, además, insiste en la importancia de que frutas y hortalizas estén en el grado óptimo de maduración, de que vayan directamente de la huerta a la cocina. Los clientes y amigos de Culturhaza que 
participan en las performances y en las labores de las piezas de Agrolandart se llaman a ellos mismos Los Cuchos, de ahí el nombre de la pieza.

Mucho Cucho ha generado también un espacio físico, El Edén, así lo llamó una de las voluntarias de la Asociación La Cibera ${ }^{37}$. Entre árboles colocaron lo necesario para preparar los pedidos, una mesa, una pila para lavar las raíces y una instalación para los cubos que en verano mantienen frescas las hortalizas. También, pusieron dos cocinas de gas, fregaderos, cestillos escurridores y, al fondo, una escultórica mesa amapola, pues en ocasiones, se cocina y se come en El Edén.

En 2013 hicieron otra pieza de continuidad, El huerto-poema de los días, diseñado por Holga Méndez, artista y profesora de la Universidad de Zaragoza. Esta pieza se compone de un espacio con frutales para que pasten el burro y las gallinas y un lugar donde desarrollar performances y otras actividades, también tiene una pared pantalla, una era y una torre. Otra pieza de continuidad es La alberca, una antigua piscina que hace las funciones de charca, en ella prosperan las lentejas de agua, los insectos, las ranas, es el territorio de caza del ave Martín pescador y el lugar donde se mantienen fresquitas durante el verano las planteras de la huerta de invierno. Anteriormente, ya mencionamos Huerta Chica, allí Agripino instaló un pequeño invernadero, Ñeru, para las planteras de la huerta de verano.

Por otra parte, más lejos de la casa, está la higuera del pozo en la linde sur, allí Isabel Moreno, artista y profesora de la Universidad de Jaén, construyó con piedra y barro el Poyete de la Higuera, inspirado en la hoja del árbol para desarrollar un proyecto audiovisual de recuperación de saberes. Es un punto alto, pues se eleva sobre una noria cegada, ideal para observar. En el resto de tierra arable cultivan escanda asturiana en rotación con una leguminosa, veza o guisante. Fue la escanda, cereal con el que mantienen una especial relación sentimental, el que les hizo pensar que los propios cultivos, hechos de forma agroecológica, son piezas artísticas capaces de emocionar por su

37 Una organización para apoyar y difundir la agroecología en relación con el arte y la educación y para dar cobertura legal al voluntariado que participa en labores agrícolas y artísticas y en otras acciones de carácter social. 
belleza agrícola, que abarca su biodiversidad y su funcionalidad. El cultivo de escanda también es una pieza de continuidad, Fisga. Comenzaron a recuperar y a adaptar la semilla en su primera obra de Agrolandart, la sembraron en otoño de 2005 y la cosecharon en julio de 2006, con una performance participativa que llamaron Pan.

Así pues, llegados a este punto, pensaron que, consecuentemente, los alimentos que obtienen también deberían de ser arte, pues son producto del trabajo de Agripino, que dice sentirse verdaderamente artista cuando cultiva. En concreto, el final del ciclo de la pieza procesual Fisga, que se mantiene en pie durante 8 meses, es la harina de escanda, resultado de nocturnas performances de molienda de Agripino (para aprovechar la tarifa valle de la luz), donde además obtiene material de vídeo y grabaciones sonoras para vídeo-creaciones experimentales. La harina es verdaderamente excepcional, en textura y sabor, pero no puede ser comercializada porque para obtener el Registro Sanitario tendría que cumplir las mismas normas que una industria que muele en un día más que él en todo el año. Así pues, como acto reivindicativo se proponen vender la harina vía on-line como arte de escanda, una pieza seriada person-specific, pues se hace por encargo.

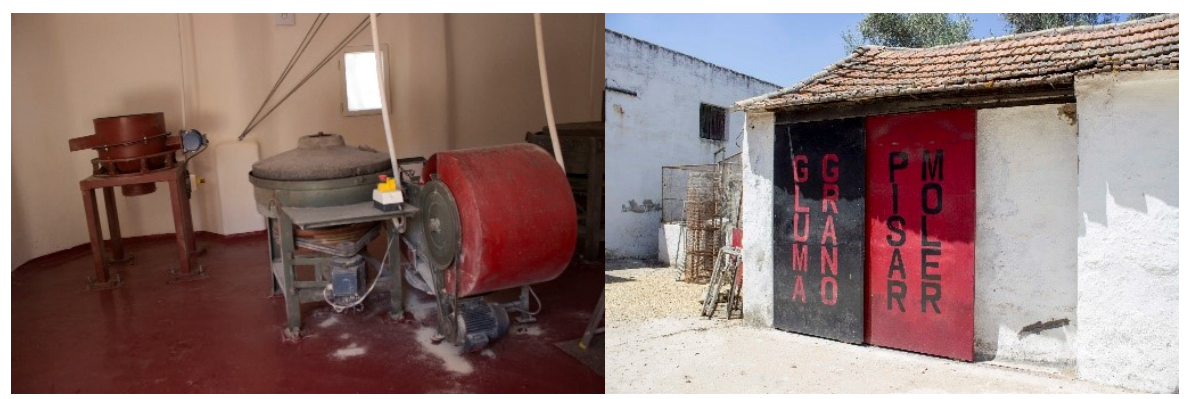

Imagen 229. Molino de harina, Culturhaza.

Córdoba, 2020. Fuente: propia Imagen 230. Vista entrada habitación molienda, Culturhaza. Córdoba, 2020. Fuente: propia 
Otro ejemplo de obra de Agrolandart es la pieza Vinilo, realizada en Huerta Chica por dos personas, Isabel y Jacobo, sin experiencia agrícola y con mucho talento musical. La propuesta fue la elección de una planta cada uno y el acuerdo de cómo disponerlas. Isabel eligió la albahaca, en recuerdo de su hermano recientemente fallecido, que era músico. La elección de esta planta vino dada por la situación que se dio al venir de Italia unos amigos de su hermano, querían hacer una comida homenaje y le pidieron albahaca fresca, no la encontró en toda Córdoba, luego pasó por Culturhaza a recoger su pedido y en casa encontró entre las verduras un ramito de albahaca que Agripino puso, por sorpresa, de regalo, eso la emocionó mucho y quiso hacer una pieza con la albahaca. Por otra parte, Jacobo eligió cultivar algodón para su zanfona. Así pues, decidieron llamar a la pieza Vinilo. Dibujaron un círculo, donde sembraron el algodón, y una espiral áurica, donde plantaron la albahaca. Tanto Isabel como Jacobo, trabajaron juntos en la siembra, el riego y los escardes. Cuando las plantas estaban más hermosas hicieron una performance participativa, hubo palabras, música en directo y poesía. Protasia escribió Soneto para Vinilo y, mientras tomaban algo y hablaban, sonaron los vinilos que Isabel solía escuchar con su hermano. Agripino documentó y editó un vídeo con las labores y la performance que proyectaron en otra reunión. La obra terminó con la recogida de las semillas.

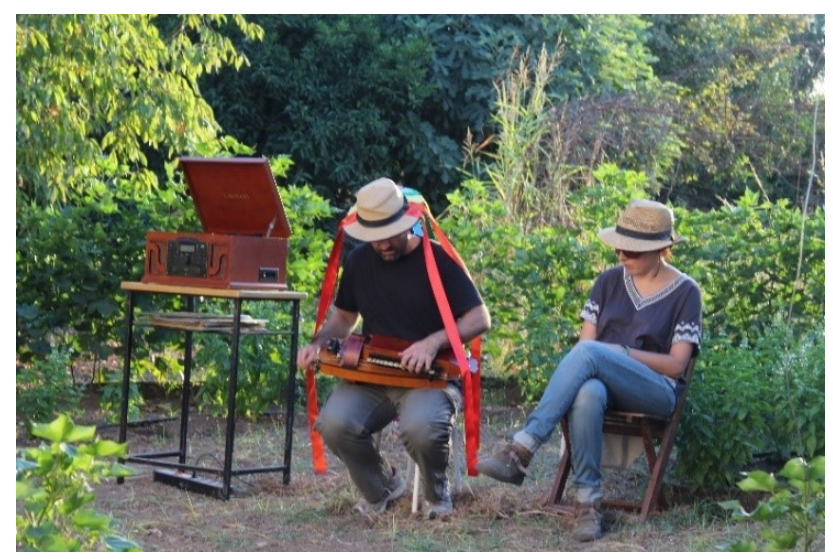

Imagen 231. Pieza Vinilo, Jacobo con su zanfona e Isabel. Culturhaza, 2016. Fuente: Culturhaza 
Otro ejemplo de performance fue la que realizaron jóvenes acogidos por la Asociación para la Defensa Social de Adolescentes y Menores (ADSAM) de Córdoba. Participaron en una obra de Agrolandart de Beatriz Quintana y Marta Linaza, Canto a Villarrubia, donde pisaron soja en la era del Huertopoema. Los jóvenes saltaron sobre las vainas hasta desgranarlas, hubo descansos y conversación, las monitoras se sorprendieron de lo tranquilos que estuvieron y la buena actitud que tuvieron.

Finalmente, en el primer capítulo de esta investigación ya citamos la pieza realizada por Culturhaza en el C3A de Córdoba, titulada Un parche de biodiversidad, en la cual realizaron una hermosa pieza de Agrolandart con habas, escanda y arvenses en un parterre a la entrada del centro. A lo largo de ocho meses se sucedieron performances en torno a las labores de cultivo, en las que intervino gente del barrio, artistas en residencia en el centro y visitantes ocasionales. Sin embargo, la pieza no fue plenamente entendida por la propia institución del C3A, que no la publicitó en la programación. A Protasia y Agripino no les extraña, pues al lado de su pieza se encontraba El árbol de los deseos de Yoko Ono, en versión olivo centenario en maceta, lo que les parece una crueldad vegetal y una mala interpretación de la obra.

\subsubsection{Las colaboraciones con Culturhaza}

En Culturhaza se han desarrollado parte de tres proyectos de investigación agronómica europeos, NASTEC, DIVERSIFOOD y SOLIBAN. También, Culturhaza fue una de las fincas experimentales que la agrónoma belga Lola Richelle eligió para el estudio de su tesis, donde comparó los suelos de la sierra, la vega y la campiña. Por otra parte, en 2020 un alumno de Kalø Organic Agriculture College de Dinamarca, permaneció siete meses realizando prácticas en Culturhaza. En varias ocasiones, Protasia y Agripino han colaborado con el Instituto de Villarrubia para las prácticas de sus alumnos. También han colaborado en la realización de Trabajos Fin de Máster de agricultura y de arte. 
Culturhaza participa junto a otras tres personas que también realizan huerta en el Proyecto Alimentando Córdoba del Instituto de Agricultura Sostenible (IAS) de la Universidad de Córdoba. Se trata de proporcionar hortalizas y verduras ecológicas a familias desfavorecidas. Hace año y medio solicitaron a Mercacórdoba una cámara frigorífica y un espacio para montar los pedidos, porque deben tener registro sanitario, pero siguen esperando.

En el ámbito social han colaborado para dar trabajo a una mujer migrante, Omoyemwen. De acuerdo con la Asociación La Cibera, aumentaron la huerta a tres hectáreas y organizaron un crowdfunding para sufragar el sueldo de Omoyemwem durante los meses en que hay trabajo y no hay producción. La huerta comenzó a producir durante el confinamiento, mientras llevaron los pedidos a domicilio fue bastante bien, pero al terminar el confinamiento los clientes dejaron de hacer pedidos. Donaron a los bancos de alimentos muchos kilos de calabacín y alficoz. En verano tuvieron ingresos gracias al tomate rosado que sus abuelos trajeron de Jaén y cuya semilla conservaron año tras año, ellos, su padre y ahora él. Asimismo, el contrato de Omoyemwen se mantiene con las aportaciones propias y de miembros de la Asociación La Cibera. De la experiencia han aprendido que se pueden cultivar tres hectáreas de huerta agroecológicamente porque hay equilibrio biológico. Así pues, están en contacto con la Asociación Mujeres en Zona de Conflicto (MZC) que trabaja con mujeres inmigrantes, supervivientes de malos tratos o de trata, con quien están buscando una salida laboral para Omoyemwen.

En el plano artístico han colaborado y colaboran con artistas, entre ellos Holga Méndez, Sandra Revuelto, Beatriz Quintana, Marta Linaza, Lucía Loren e Isabel Moreno. Por otra parte, participan como docentes desde 2014 en el Máster de Investigación y Educación Estética: Artes, Música y Diseño de la Universidad de Jaén (AMUDI). Los alumnos se desplazan a Culturhaza, participan en performances, conversan sobre arte, agricultura, alimentación, ecología y, antes de la COVID-19, comían en comunidad. En 2021 han empezado a impartir una sesión en el contexto del Diploma de Sostenibilidad, Ética Ecológica y Educación Ambiental de la Universitat Politècnica de València, donde han tenido la oportunidad de compartir todo 
su conocimiento y su trabajo, así como ese vínculo del arte con la agroecología, con alumnado procedente tanto de España como de Sudamérica, principalmente.

En cuanto a previsiones de futuro, para el próximo año se plantean cultivar más leguminosas (garbanzo negro, habichuela pinta, judía mungo verde y lenteja negra) con intención de venderlas online para ampliar el abanico de posibles compradores. También, en un futuro no muy lejano, esperan pasar el testigo a sus sobrinos y que ellos sigan construyendo Culturhaza.

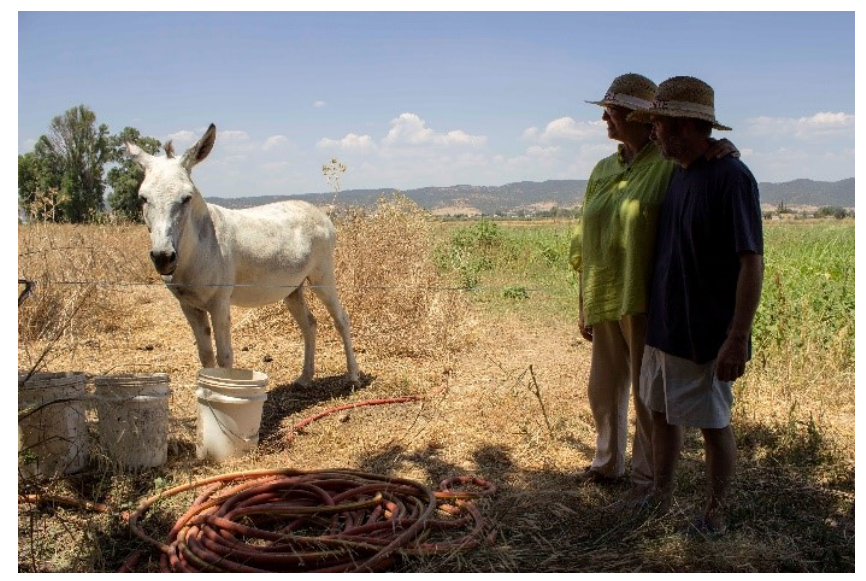

Imagen 232. Antonio, Nazaret y su burro, Culturhaza. Córdoba, 2020. Fuente: propia

\subsubsection{Conclusión}

Culturhaza ocupa una finca de siete hectáreas y media donde llegaron a vivir tres familias con muchos hijos en la década de los 30 - 40 del pasado siglo, mientras que actualmente el proyecto lucha por sacar el sueldo de la mujer ayudante, Omoyemwen. La competencia de la agricultura industrial, que abarata los precios de los alimentos a costa de la calidad y del medio ambiente aplicando técnicas de publicidad y marketing, hace que los pequeños y medianos agricultores tengan muchas dificultades para 
mantener su trabajo, pues en la decisión de compra de la gente pesa más el precio que la calidad o la huella ecológica de los alimentos. Es por ello por lo que resulta admirable el trabajo de proyectos como el de Culturhaza, que sin apoyo institucional lleva quince años difundiendo la agroecología con estrategias artísticas, promoviendo que tanto artistas como no artistas intervengan en happenings y performances, o que hagan en Culturhaza piezas de Agrolandart, con la única condición de que éstas cumplan los ciclos de los cultivos y las premisas de la agroecología.

Si bien hemos detectado que el arte contemporáneo es capaz de generar en el público un acercamiento hacia el conocimiento agrícola, es importante que ese acercamiento se mantenga y que aumente la valoración de los alimentos obtenidos con métodos agroecológicos, que en Culturhaza no dudan en calificar como obras de arte. Consideramos necesario que desde el ámbito de la cultura se fomente la creación, apoyo y difusión de proyectos como Culturhaza, que ofrecen prácticas artísticas intermedia en espacios naturales de gran biodiversidad, cultivada y arvense, donde fluye la posibilidad de expandir conciencia agroecológica.

\subsection{Kultivarte: arte y permacultura en el Algarve, Portugal}

Kultivarte es un proyecto que está ubicado en el pueblo de Barão de São João en Lagos, Algarve (Portugal) para promover medios de vida basados en la permacultura y las artes. Este proyecto holístico fue inaugurado en junio de 2018 por Sandra Peixoto con la ayuda económica de su socio, un americano residente en Portugal que quería invertir en un proyecto que promulgara formas de vivir sustentables en equilibrio con la naturaleza, una iniciativa que fuera ejemplo de la existencia de otros modelos de vivir que no estuvieran marcados por el consumismo exponencial propio de una sociedad capitalista.

El proyecto se basa en los principios éticos de la permacultura, cuidar a la tierra, cuidar a la gente y compartir de manera justa. Pero, esta iniciativa no se centra únicamente en la permacultura en sí, es un espacio abierto a todo tipo de público que desee aprender, compartir, cooperar, participar, observar 
y crear desde el respeto a la naturaleza y las personas. Kultivarte nace y crece en un espacio de eco-aldea que alquilaron en el pueblo de Barão de São João. En este lugar se encuentra una tienda, un restaurante, un patio y varias zonas para la realización de diversas actividades. Además, disponen de un terreno adicional de unas dos hectáreas donde se cultivan cereales y vegetales. Cultivan trigo corazón, negrito y otras variedades ancestrales, únicamente para la producción de pan. El trigo es sembrado, cultivado, recogido y molido de forma biológica, se amasa el pan y se cuece en un horno de leña, posteriormente se vende en la tienda y en el restaurante de Kultivarte. Los vegetales cosechados en el huerto de 400 metros cuadrados también son utilizados para la preparación de comida vegetariana, vegana y crudívora que se ofrece en el restaurante.

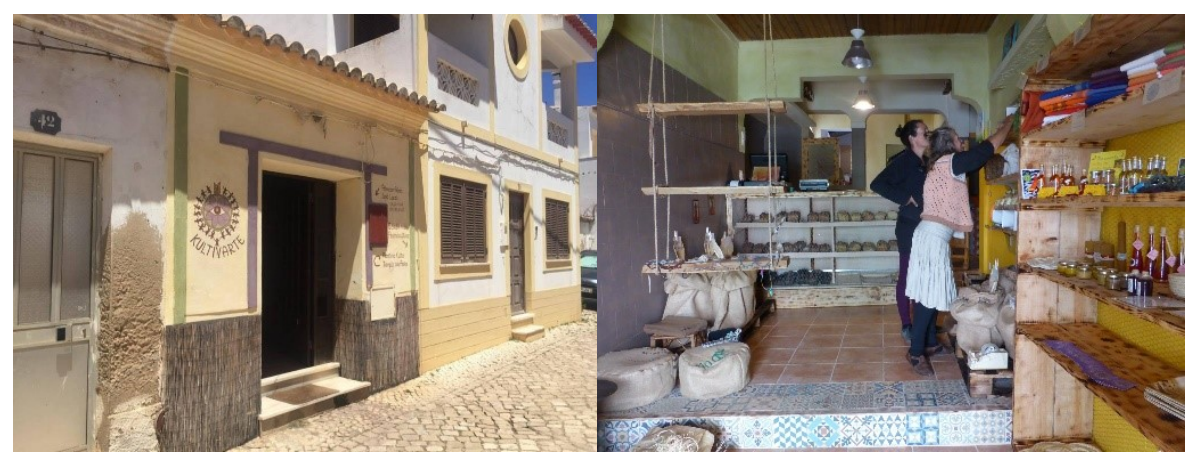

Imagen 233. Vista entrada Kultivarte, Barão de São João, Portugal, 2020. Fuente: cesión de Kultivarte Imagen 234. Vista tienda Kultivarte, Barão de São João, Portugal, 2020. Fuente: cesión de Kultivarte

La intención de Sandra es traer a Kultivarte formas de alimentarnos más respetuosas con el medio ambiente, menos dependientes del consumo animal y de la mercantilización con todo los envases y plásticos que conlleva. Tomar conciencia de las diversas formas de alimentación como la macrobiótica, fomentando una alimentación orgánica, saludable y no animal. Si bien, si necesitan algún producto que no pueden obtener de sus 
propias cosechas buscan proveedores locales que trabajen con productos orgánicos.

Junto a toda la labor de producción y elaboración de alimentos, Kultivarte funciona como un espacio de encuentro donde se promueven las artes. El objetivo de la iniciativa es crear una economía circular, es por ello por lo que todos los residentes del pueblo y cualquier persona interesada puede colaborar en el proyecto ofreciendo sus servicios con clases de arte, conciertos, exposiciones, danza, teatro, meditación. Por ejemplo, durante los conciertos se preparan pizzas en el horno de leña con la harina y los vegetales del huerto, que serán consumidos por los asistentes al concierto, generando una producción y economía local y circular. Los colaboradores, participantes y asistentes en Kultivarte suelen ser los residentes del pueblo, portugueses y extranjeros. En la zona del Algarve encontramos una multiculturalidad muy marcada, una parte de la población está formada por extranjeros que se instalan en este lugar en busca de una mayor conexión con la naturaleza y de una educación para sus hijos más cercana, en un entorno natural. Por lo que respecta a la parte más conservadora de la población, en un principio, eran un poco reacios al proyecto, por desconocimiento y novedad, pero poco a poco se ha normalizado e incluso han llegado a asistir a algunas de sus actividades.

\subsubsection{Las artes en Kultivarte}

Como hemos comentado anteriormente son muchas las actividades que se realizan en el contexto de dicho proyecto con el fin de promover las artes. Para Sandra, la fundadora de la iniciativa, el arte es algo que va intrínseco en las personas, es por ello por lo que el espacio de Kultivarte no se limita únicamente a artistas profesionales, sino que se abre a cualquier tipo de manifestación artística promovida por personas que sientan la necesidad de expresar y compartir sus formas de crear con los demás. En ese contexto se han realizado residencias artísticas de danza y música africana, donde ha asistido un profesor de Burkina Faso que vive en Bélgica, donde los asistentes han tenido la oportunidad de aprender sobre estas artes. 


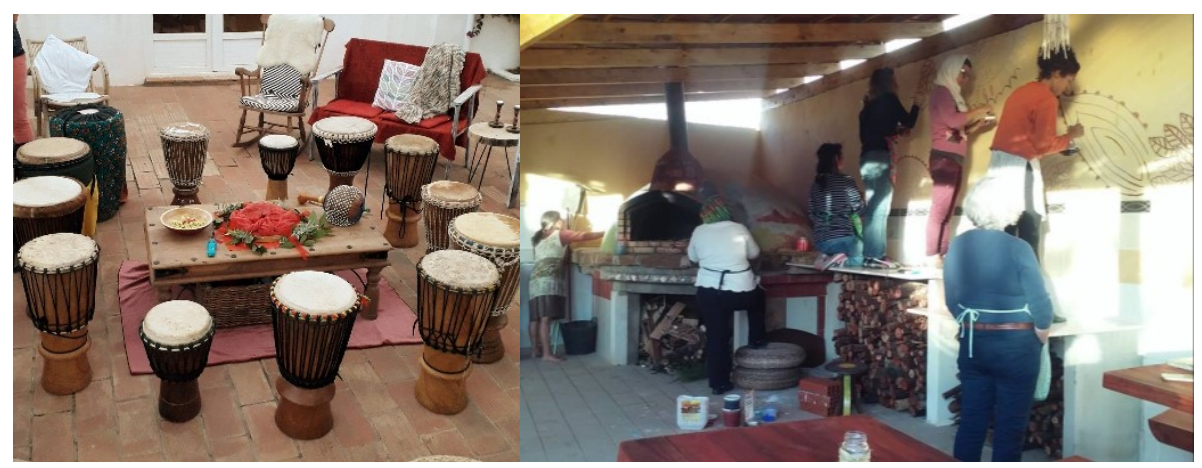

Imagen 235. Vista African Drum class, en Kultivarte, Barão de São João, Portugal, 2019. Fuente: cesión de Kultivarte Imagen 236. Vista creación mural en Kultivarte, Barão de São João, Portugal, 2018. Fuente: cesión de Kultivarte

También, observamos la creación de un mural de forma colectiva en la imagen 236. Las actividades y los acontecimientos que transcurren en el día a día de Kultivarte siempre llevan intrínsecos aspectos del arte, los cuales generan unión en la comunidad. Del mismo modo se tiene muy presente los aspectos del bienestar, es por ello por lo que también se organizan sesiones enfocadas en sanar cuerpo y mente, por ejemplo, a través de la meditación o el yoga. Si bien, debido a la situación originada por la epidemia del COVID-19 el proyecto tuvo que cerrar temporalmente y no pudimos asistir presencialmente a realizar un estudio de campo en Kultivarte. En el cual hubiéramos podido indagar más profundamente en los aspectos artísticos del mismo. No obstante, con el estudio que hemos podido realizar telemáticamente, no nos cabe duda de que el arte, de una forma generalizada, accesible a cualquier persona y no mercantilizada, está presente en la iniciativa.

\subsubsection{La escasez de agua}

Sandra, la fundadora de Kultivarte, nos compartió las problemáticas derivadas de la escasez de agua. Si bien nos comentó que la zona del Algarve es una zona bastante seca de por sí, con el cambio climático y los monocultivos, cada vez hay mayores problemas de agua. Los campos de 
Kultivarte se riegan con el agua de un pozo cercano, a mediados de agosto del 2019 el pozo secó ocasionándole pérdidas del 40\% de la cosecha. La grave situación llevó a la comunidad a reunirse para tratar la problemática en la que se veían envueltos, de ahí surgió la asociación Regenerart. Esta asociación, de la cual Sandra es una de las cofundadoras, trata por medios legales y junto a abogados la situación de la escasez de agua derivada de los monocultivos circundantes.

Cerca del proyecto Kultivarte se encuentran más de cien hectáreas de monocultivo de aguacate, el cual, según nos comenta Sandra, necesita cerca de quince litros de agua por cada árbol al día. Este tipo de producción agrícola aumenta con los años ocasionado por la gran demanda y el alto valor de este fruto en el mercado. Las consecuencias de cultivar grandes extensiones de monocultivo son desastrosas para el medio ambiente, como vimos en anteriores capítulos, la pérdida de biodiversidad, las carencias nutritivas del suelo y las técnicas agresivas y químicas que utilizan para el control de plagas y enfermedades, son las principales secuelas. Estas situaciones que ocasionan la contaminación del entorno, unidas a la escasez del agua, afectan directamente a las fincas circundantes que optan por llevar una vida en equilibrio con la naturaleza, cultivando con técnicas biológicas y sin agotar los recursos naturales.

Hemos querido señalar estos sucesos con el fin de recalcar la importancia de proyectos como el de Kultivarte, donde en esa zona de unión de saberes y artes, ha sido posible tratar cuestiones que atañen a toda la población, fuera de la zona del proyecto en sí. Kultivarte ha servido de nexo para ser la búsqueda de soluciones a problemáticas que atañen a todo tipo de personas, independientemente de sus formas de ser y pensar.

\subsubsection{Apoyos e ideas futuras de proyecto}

La iniciativa de Kultivarte fue originada por Sandra y únicamente ha tenido el apoyo financiero de su socio americano. Por parte de las instituciones y entidades de la población o ciudades circundantes únicamente ha recibido información acerca de las legalidades que debía cumplir en su proyecto, pero 
en ningún caso ha recibido ningún tipo de apoyo económico ni se han llegado a generar colaboraciones. Es por ello por lo que este tipo de proyectos emergen con dificultades económicas, las cuales acarrean muchas veces gran labor desinteresada por parte de sus fundadores. Estos sucesos son indicativos de que las personas que emprenden este tipo de proyectos tienen muy interiorizados los principios en los que quieren emprender sus formas de vivir y compartir con la comunidad. Poseen notables valores de respeto hacia las personas y la naturaleza, con una gran toma de conciencia sobre las problemáticas en las que se encuentra la vida en la biosfera actualmente.

Kultivarte se vio en la situación de tener que cerrar provisionalmente a causa del COVID-19, como hemos mencionado con anterioridad, pero también por la carencia de recursos económicos. No obstante, esto ha sido un momento de pausa para repensar el proyecto e idear como potenciarlo. Para ello, Sandra, ha estado organizando encuentros en busca de personas que quieran formar parte de una cooperativa dentro de Kultivarte. De esta forma, cada persona integrante de la cooperativa podrá coordinar su micronegocio pudiéndole dedicar mayor tiempo y, entre todas las micro iniciativas originadas, potenciar la esencia de Kultivarte. Esta nueva visión que pretendía salir a la luz a finales del pasado año 2020, es una evolución de la idea principal del proyecto, con una mayor cooperación, creación y difusión de la permacultura y las artes, en un entorno que sea equilibrado y rentable.

\subsubsection{Conclusión}

En este concepto de proyecto observamos cómo las artes forman parte del día a día de las personas que conforman Kultivarte. El arte no se limita a ser un producto material de consumo propio del mercado del arte, sino que de una forma intrínseca nace en cada uno de los participantes del proyecto, manifestándose de diversas formas. Por una parte, la siembra y cosecha del trigo biológico, la molturación para conseguir la harina y la propia elaboración del pan artesanal es un proceso de creación artística y así lo siente la panadera, Sandra, considerando toda una sucesión de acciones en sintonía con sus principios ecológicos que recuperan formas de producción artesanales que hoy en día se encuentran en desuso. Sandra, al trabajar 
desde ese punto de vista, tratando cada pan como una pieza artística, pone en valor el trabajo manual, el respeto a los tiempos, al entorno y a la dedicación de un oficio esencial para la alimentación mundial. Asimismo, cabe destacar que junto al alimento que se vende se le acompaña la información del proceso, la capacidad nutritiva, se generan charlas, debates y se comparten opiniones, todo ello contribuye a la consolidación de valores como el respeto hacia la importancia de los trabajos primarios realizados artesanalmente.

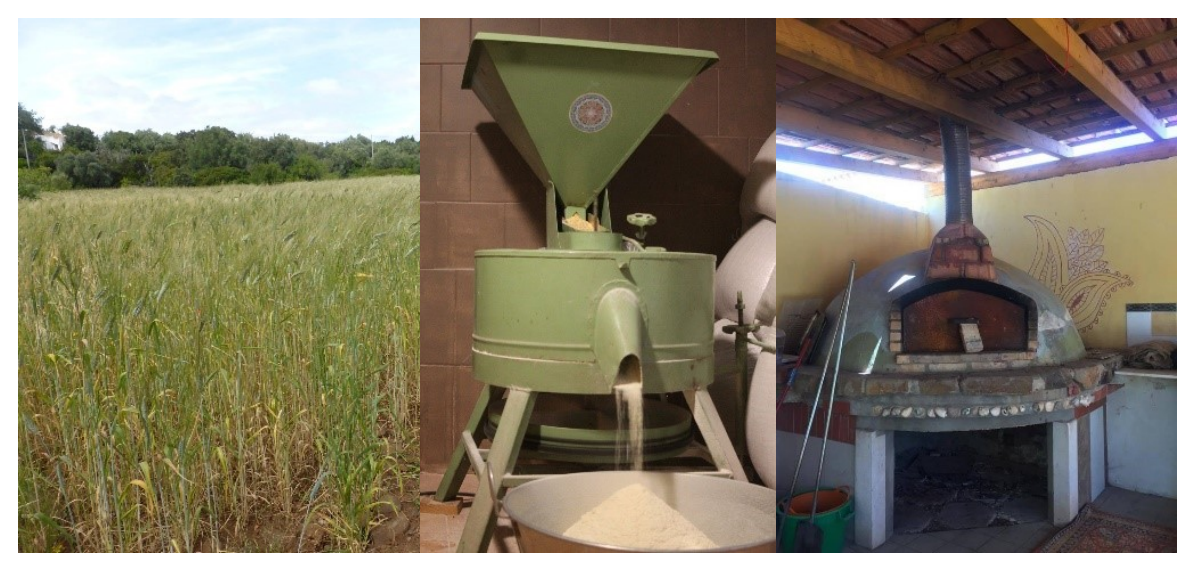

Imagen 237. Vista campo cereal en Kultivarte, Barão de São João, Portugal, 2019. Fuente: cesión de Kultivarte Imagen 238. Vista molino en Kultivarte, Barão de São João,

Portugal, 2019. Fuente: cesión de Kultivarte Imagen 239. Vista horno en Kultivarte, Barão de São João,

Portugal, 2019. Fuente: cesión de Kultivarte

Por otra parte, encontramos toda una serie de actividades que están generadas para la creación y difusión de todo tipo de arte, desde las más matéricas como la pintura y la escultura, hasta las más espirituales y performativas como la danza, el teatro, la poesía o la música. Cabe destacar la importancia que se le da al arte en el proyecto, siendo un pilar fundamental en el mismo, el cual sirve de conexión entre organizadores, colaboradores y asistentes. Todo ello se concibe desde el trabajo y respeto comunitario, además, se tienen muy en cuenta los cuidados tanto en las personas como 
en el medio ambiente. Si bien, para que este tipo de proyectos holísticos funcionen se necesita de gran capacidad organizativa. En este caso, Sandra es la encargada de gestionar prácticamente todo lo que ocurre en Kultivarte, desde los cultivos, a la elaboración de la comida y las actividades que promueven el arte. Es por ello por lo que se necesita de un gran esfuerzo y capacidad para poder gestionar un proyecto de estas características y al mismo tiempo que funcione. Sin embargo, con la nueva visión de la cooperativa se podrán generar micronegocios dentro del proyecto, los cuales tendrán su propio coordinador, de esta forma se descarga trabajo a la actual organizadora, se potencian cada una de las distintas áreas y el proyecto crece desde una cooperación más acentuada.

\subsection{Quinta Das Relvas, Branca, Portugal}

Quinta Das Relvas es una asociación ubicada en una antigua granja familiar situada en la población de Branca, Portugal. El proyecto fue fundado por Beatriz y Antonio hace cuatro años, en 2016. La granja de unas dimensiones considerables y con las mínimas condiciones de habitabilidad fue el lugar elegido por esta pareja para crear un proyecto de artey sostenibilidad. Beatriz con formación en Bellas Artes, Maestrado en Anatomía Artística y cursando actualmente estudios de Doctorado en Arte, es la encargada de coordinar la parte artística del proyecto. En cambio, su pareja, Antonio, es el encargado de todos los aspectos relacionados con la sostenibilidad. No obstante, ambas áreas están siempre muy vinculadas en las actividades que se realizan en el contexto de Quinta Das Relvas, el proyecto nace y crece a partir de esa unión de arte y sostenibilidad.

En el contexto del proyecto se realiza agricultura sustentable siguiendo los principios de la permacultura y la agroecología, esa práctica agrícola les sirve como proceso de aprendizaje a los visitantes, asistentes y colaboradores de Quinta Das Relvas. Se realizan actividades y residencias en el contexto del trabajo agrícola, para ellos es muy importante el proceso, la experimentación y el contacto directo con la tierra y sus ciclos vitales. Si bien la cosecha que recogen de las plantaciones sirve para un consumo interno, no comercializan el producto, únicamente sirve de autoabastecimiento. 
Las actividades y proyectos que se coordinan desde Quinta Das Relvas, no fusionan directa y conscientemente el arte y la agricultura, sino que terminan por vincularse debido al tipo de actividades y al contexto en el que se realizan. Por ejemplo, la realización de actividades para la identificación de formas orgánicas a través de la fotografía nocturna, en esa iniciativa voluntaria o involuntariamente termina por unirse el arte y la agricultura.

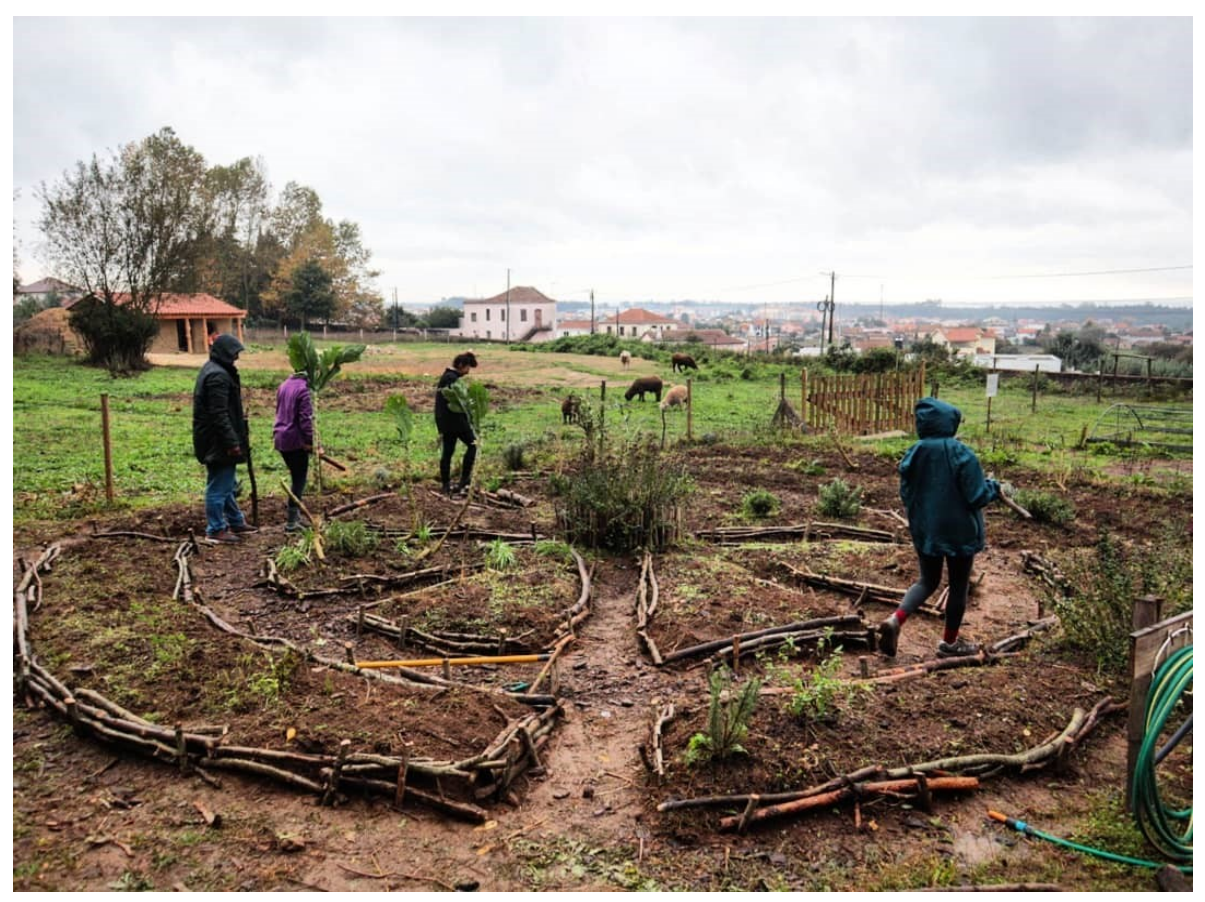

Imagen 240. Huerto mándala en Quinta Das Relvas. Branca, Portugal, 2020. Fuente: @quintadasrelvas

\subsubsection{Residencias artísticas, cursos y workshops}

En el contexto de Quinta Das Relvas se realizan residencias artísticas, workshops, conferencias, intercambios, etc. Todas las propuestas que tienen lugar en la finca se unen en el camino del arte y la sostenibilidad. Destacamos las residencias, festivales y actividades programadas para que los asistentes puedan alojarse unos días en Quinta Das Relvas, de esa manera el vínculo con 
el espacio es mayor y se facilita la inmersión en las actividades del día a día de la finca. Beatriz y Antonio, tras la experiencia de trabajo en la finca decidieron reducir el número de actividades y empezar a crear proyectos de mayor envergadura que fueran anuales, de tal forma los asistentes disponen de un tiempo mayor para la investigación, el estudio y la creación. La primera residencia artística que realizaron fue dedicada a la temática del Land Art, participaron diez alumnos/as de la Escuela de Bellas Artes de Lisboa y todas las piezas fueron creadas en el contexto de Quinta. Los estudiantes con plena libertad de creación estuvieron diez días en Quinta Das Relvas conociendo el lugar, experimentando con los materiales, observando la naturaleza e inspirándose de ella para la creación de las piezas que conformaron la exposición pública al final del período de residencia. Las piezas fueron muy variadas, se trabajó con fotografía, vídeo, escultura o pintura.

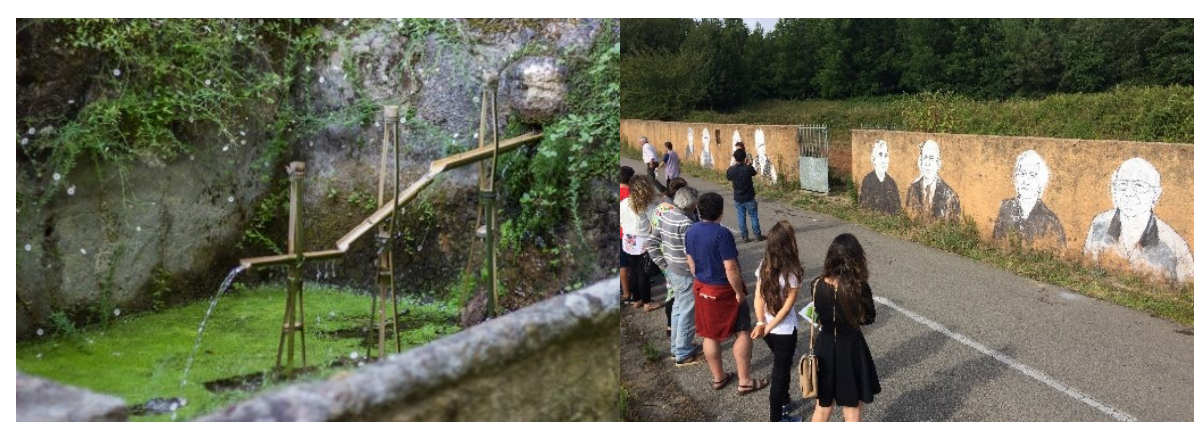

Imagen 241. Intervención en residencia Land Art, Quinta Das Relvas. Branca, Portugal, 2017.Fuente: @quintadasrelvas Imagen 242. Intervención en residencia Land Art, Quinta Das Relvas. Branca, Portugal, 2017. Fuente: @quintadasrelvas

Anualmente han seguido realizando residencias artísticas bajo el nombre de Um Grão na asa, en ellas, los y las artistas han podido experimentar en un espacio alejado de la ciudad, en plena naturaleza y con materiales lo más sostenibles posible. En las siguientes imágenes podemos observar el proceso de algunas de las piezas que se realizaron en el contexto de la residencia Grão de 2020 . 


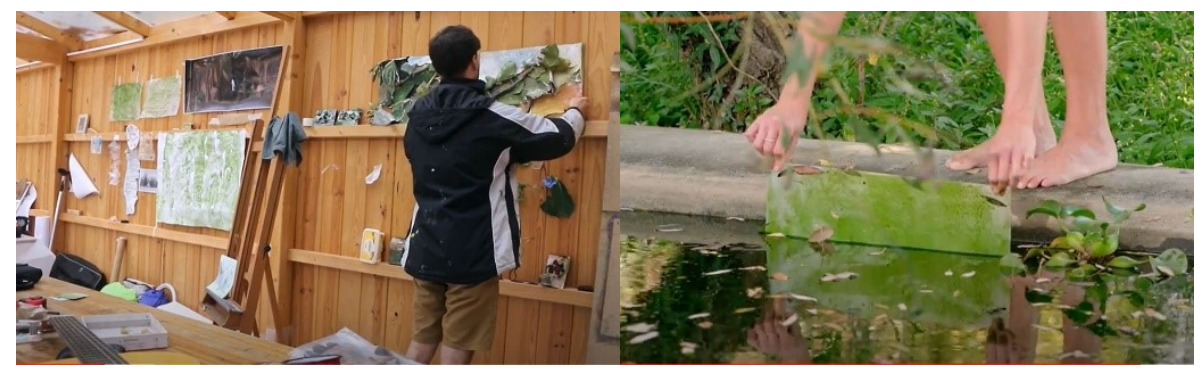

Imagen 243. Proceso obra, residencia Um Grão na asa, Quinta Das Relvas. Branca, Portugal, 2020. Fuente: @quintadasrelvas Imagen 244. Proceso obra, residencia Um Grão na asa, Quinta Das Relvas. Branca, Portugal, 2020.Fuente: @quintadasrelvas

Fueron siete los y las artistas que participaron en la residencia Um Grão na asa del 2020. Las obras realizadas fueron expuestas en la Biblioteca Municipal de Albergaria-a-Velha de Portugal con el objetivo de ser vistas y compartidas con las poblaciones colindantes a Quinta Das Relvas. Para los fundadores de Quinta es muy importante el trabajo con la comunidad, es por ello por lo que en la medida de lo posible ofrecen facilidades para que los habitantes cercanos puedan participar o asistir a las actividades que se realizan. No obstante, resulta complejo acercar a los sectores más conservadores de la población a este tipo de proyectos. No es usual encontrar iniciativas donde se trabaje el arte y la sostenibilidad en espacios tan alejados de la ciudad, siendo proyectos muy novedosos para según qué parte de la población, ese desconocimiento muchas veces ocasiona temor y falta de interés en las actividades que se organizan en dichos proyectos.

Además de las residencias artísticas que hemos mencionado, en Quinta Das Relvas también se han organizado encuentros internacionales de ilustración, el YETI-Youth Education Through Illustration, cursos de diseño de permacultura certificados y cursos de bioconstrucción, entre otras actividades. La variedad de las temáticas ofrece muchas posibilidades al participante, ya que hay artistas que asisten a Quinta para realizar un proyecto o residencia y terminan interesándose por la permacultura o, a la 
inversa, asistentes a cursos de permacultura que terminan realizando alguna obra artística o colaborando en las bioconstrucciones.

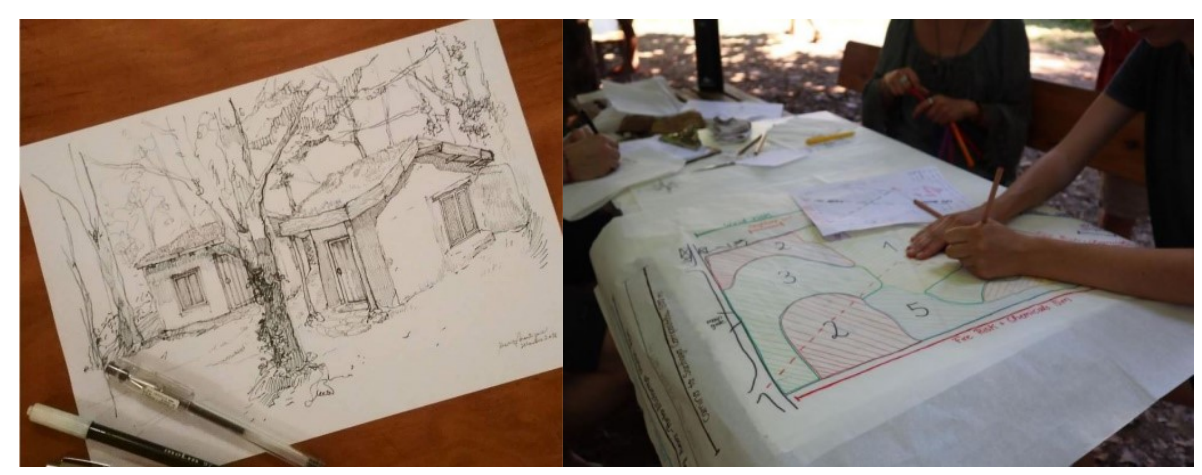

Imagen 245. Boceto proyecto bioconstrucción, Quinta Das Relvas. Branca, Portugal, 2018. Fuente: @quintadasrelvas Imagen 246. Proceso diseño permacultura, Quinta Das Relvas. Branca, Portugal, 2019.Fuente: @quintadasrelvas

La diversidad de actividades, la libertad a la hora de crear proyectos y de sumergirse en el día a día de Quinta Da Relvas, trabajando desde ese punto del arte y la sostenibilidad en un entorno natural, son las claves fuertes del proyecto y las más valoradas por los participantes. Además, también realizan intercambios con Erasmus+, con la Escuela de Bellas Artes de Lisboa y de Oporto, no son estrictos con la forma y procedencia de los asistentes. Para los fundadores de Quinta Das Relvas es muy importante que cualquier actividad que se realice sea sustentable en tres vertientes, a nivel ecológico, a nivel emocional y a nivel económico. Las propuestas presentadas han de tener un inicio y un fin y ser autosustentables de alguna manera, así como estar en equilibrio con los principios de Quinta Das Relvas, tanto Beatriz como Antonio ofrecen toda ayuda posible en dicho proceso.

\subsubsection{Colaboraciones y financiación}

Como hemos mencionado con anterioridad, Quinta Das Relvas colabora con la Escuela de Bellas Artes de Lisboa y Oporto y con Erasmus+, pero también trabajan con asociaciones locales, escuelas, con la Ecoaldea Duval en Sintra 
y con la Junta Municipal, aunque con esta última el vínculo no es tan fuerte como les gustaría. Además, actualmente están llevando una colaboración con una asociación más dedicada a la música. Y, desde el 2019, empezaron a trabajar en proyectos con América Central y Asia. Todas las colaboraciones siempre van en la línea del arte y la sostenibilidad.

Sin embargo, emprender un proyecto de la envergadura de Quinta Das Relvas, es un gran reto, sobre todo a nivel económico. Debido a la escasa financiación de este tipo de proyectos, se necesita de un constante esfuerzo por mantener la sustentabilidad de la iniciativa. El mantenimiento de la granja, los animales, la luz, el agua, etc., todo ello conlleva una serie de gastos que han de ser cubiertos para poder asegurar la continuidad del proyecto. Desde Quinta Das Relvas intentan minimizar el coste a los participantes, con tal de fomentar las colaboraciones y facilitar el acceso a este tipo de aprendizajes. Algunas de las actividades que realizan conllevan un pago de tasas para cubrir los gastos básicos, en cambio, otras propuestas como la convocatoria de residencia artística Grão no conlleva ningún pago para el artista residente. Un gran porcentaje de los participantes en las actividades de Quinta Das Relvas suelen ser jóvenes en formación y, normalmente, con mayores dificultades económicas, es por ello por lo que desde Quinta intentan dar facilidades en este aspecto. No obstante, si una persona presenta un proyecto esporádico para realizarlo en las instalaciones de la finca, entonces, sí conlleva un pago establecido. De tal forma, los ingresos por la parte de actividades en concepto de pago de tasas son mínimos.

Por otra parte, las colaboraciones con la Cámara y Junta Municipal son muy escasas, desde Quinta están abiertos a fomentar esa colaboración, pero no siempre es fácil. Si reciben alguna ayuda del ayuntamiento es de forma muy esporádica, una vez al año y, por ejemplo, la cantidad de la ayuda no llega ni a sufragar los gastos de luz que puedan acarrear las actividades realizadas. En cambio, sí colaboran a la hora de ceder espacios municipales para exponer los resultados de las residencias artísticas, suelen realizarse muestras en la biblioteca municipal dando acceso libre a toda la comunidad, de tal forma se abren las puertas del proyecto a toda la población, 
compartiendo el conocimiento y la experiencia. Además, los habitantes locales suelen tener un descuento en las actividades que conllevan un pago de tasas. No obstante, el gran porcentaje de los participantes de Quinta procede de otras ciudades y países.

Así pues, las colaboraciones que mantiene Quinta Das Relvas con todas las asociaciones y entidades que hemos ido nombrando funcionan en mayor medida como un intercambio de contactos, de servicios e información. Si bien, desde Bellas Artes de Oporto y Lisboa contribuyen con apoyos económicos a la hora de financiar los materiales y viajes de las residencias artísticas. Por tanto, los fundadores de Quinta Das Relvas tuvieron que buscar otras vías de financiación para poder sustentar su proyecto de arte y sostenibilidad. Es por ello por lo que crearon un eco-hostal en la granja, siendo su principal fuente de financiación. Las personas que se alojan en su eco-hostal suelen estar interesadas en las áreas que se trabajan en Quinta, no van de una forma aislada, sino que quieren participar y experimentar que es lo que ocurre en ese lugar. En este momento disponen de cuatro casitas en bioconstrucción, pensadas para dos personas o matrimonio con hijo/a y ocho tiendas con capacidad para tres personas en cada una. Aun así, solo trabajan en el eco-hostal al 100\% en verano, durante el invierno es de forma puntual. Es por ello por lo que siempre necesitan prever un financiamiento, sea a través de proyectos, de pago de tasas, del eco-hostal, de apoyos externos, etc. Es una lucha constante por mantener la sustentabilidad económica del proyecto.

\subsubsection{Conclusión}

Como hemos podido ir observando, el proyecto de Quinta Das Relvas es una iniciativa que lucha por ir creciendo en la línea del arte y la sostenibilidad en medio de un paraje natural. Sus fundadores, con una gran predisposición a la colaboración, abiertos a todo tipo de propuestas que se encuentren en sintonía con la Quinta y con su amor por las artes y la naturaleza, trabajan por mantener la sustentabilidad del proyecto y seguir aportando su granito de arena a la concienciación ecológica a través de las estrategias artísticas. 
La programación de actividades en sintonía con la emblemática ubicación del lugar ofrece a los participantes experiencias únicas y así lo comparten en los vídeos depositados en las redes sociales de Quinta Das Relvas. Si bien no se centran exclusivamente en el vínculo del arte y la agricultura o permacultura, sí hemos encontrado que esa unión se da de forma imprevisible en el desarrollo de proyectos o durante la estancia en Quinta. Se ofrece un abanico muy amplio de trabajo dentro de Quinta pero siempre bajo los dos pilares fundamentales del proyecto, el arte y la sostenibilidad. También, hemos detectado que las personas que suelen participar en proyectos como Quinta, ya vienen con cierta sensibilidad hacia estos temas, es complejo que personas ajenas a temas relacionados con el arte y la ecología se interesen por dicho proyecto. Consideramos que esa falta de interés puede darse por falta de comprensión sobre la finalidad de relacionar el arte y la sostenibilidad y por falta de información sobre las potencialidades del arte a la hora de fomentar formas de vivir más sustentables. Además, los sectores más conservadores de la población suelen considerar la cultura y, más aún, el arte vinculado a la sostenibilidad, como algo secundario, complementario y no imprescindible, lo que fomenta el desinterés.

Finalmente, hemos tomado conciencia de la gran labor, en muchas ocasiones desinteresada, que necesitan este tipo de proyectos, con una constante búsqueda de apoyos y financiación. Lamentablemente, el arte y la sostenibilidad siguen siendo temas de menor interés para según que entidades a la hora de dar ayudas y fomentar el trabajo en esta línea. Además, como se suelen dar muchas facilidades económicas a los participantes con la finalidad de fomentar el conocimiento y la participación, es difícil encontrar una continuidad en la autofinanciación del proyecto. Es por ello por lo que en Quinta Das Relvas optaron por poner en marcha el eco-hostal, siendo la mayor fuente de financiación del proyecto actualmente.

\subsection{Conclusiones conjuntas}

A lo largo del capítulo hemos descrito y analizado cinco proyectos completamente distintos, pero todos ellos con un claro vínculo del arte y la agricultura. La elección de dichos proyectos fue pensada como ejemplo de 
iniciativas que contaran con una trayectoria de al menos unos años y que unieran el arte y la agricultura desde diferentes líneas de trabajo e investigación. Como hemos podido observar, todos los proyectos tienen finalidades muy similares, si bien según que iniciativa se centra más en los aspectos de producción y valoración del agricultor/a o en la creación de proyectos artísticos y residencias. Así pues, consideramos que independientemente de la ubicación geográfica, los proyectos comparten sensibilidades hacia la situación agrícola actual, la cual está poco valorada y con falta de relevo generacional. Asimismo, también los aspectos culturales son a considerar, ya que las iniciativas citadas luchan por darles la relevancia que tienen en la sociedad, en el caso que nos ocupa, utilizando las estrategias artísticas para la difusión de conocimiento agrícola, para informar de la situación agroalimentaria actual, para fomentar la importancia de la biodiversidad y/o para compartir los principios de la permacultura. También, en todas las iniciativas se fomenta el trabajo en colectivo, las colaboraciones con otras entidades $u$ organizaciones están muy presentes sea para compartir conocimiento, difusión o favores.

Por otra parte, cabe destacar la importancia que se le da a la parte pedagógica en todos los proyectos, de una forma u otra todos se involucran en organizar cursos, talleres, charlas o directamente imparten docencia en instituciones educativas. La inversión de energía en este ámbito fomenta la transmisión de conocimiento y la concienciación, además, en algunos de los casos es una ayuda económica para la sostenibilidad del proyecto. También, las residencias artísticas que se generan en el contexto de los proyectos son fuente de difusión de conocimiento, aprendizaje y creación. Si bien, en proyectos como Kultivator, Mandarina Borda o Quinta Das Relvas son más inmersivas, al tener la opción de alojarse durante varios días en dichos lugares. Así pues, cabe señalar que las obras realizadas en el contexto de los proyectos estudiados no tienen una pura finalidad mercantilista, más bien es el fruto de procesos de aprendizaje y concienciación que se convierten en piezas que sirven para difundir el conocimiento, para compartir y/o para alimentarnos. 
Otro aspecto que considerar es el punto de vista de la agroecología que se repite en todas las iniciativas, siendo esta ya de por sí una postura creativa. En este sentido, la relación del arte y la agricultura se ha estado basando en una forma de cultivar orgánica y sustentable, respetando el equilibrio de la biosfera. Así pues, las creaciones artísticas también se sitúan en estos parámetros. Si bien, en proyectos como Culturhaza con sus cultivos o en Kultivarte con la elaboración del pan, muestran sus producciones, sus campos, sus cosechas y sus comunicaciones como sus resultados artísticos, una idea de artisticidad permeable que contempla aspectos del arte más allá de las intervenciones en el campo de cultivo.

Finalmente, cabe destacar las dificultades económicas a las que se ven sometidos estos proyectos. Como hemos comentado en cada uno de los apartados, se da la coincidencia de falta de financiación en todas las iniciativas. El apoyo institucional suele ser muy escaso y puntual, resulta muy complejo tener un sustento económico fijo y continuado. Cada uno de los proyectos nos compartió el esfuerzo y la inversión de energía que necesitan a diario para estudiar estrategias y buscar posibles ingresos que puedan seguir sustentando el proyecto. Dado que las convocatorias artísticas o proyectos lanzados por las instituciones se dan en ocasiones muy puntuales y, además, no tienen la seguridad de conseguirlo ya que suelen ser por concurrencia competitiva, es necesario buscar otras formas de financiación. Es por ello por lo que la vía de la educación y el compartir sus saberes y experiencia a través de cursos, talleres o residencias puede ser un camino de posibles ingresos. También, si se dan las condiciones de habitabilidad en el lugar del proyecto se puede alojar a los participantes e interesados siendo otro sustento económico, como en Quinta Das Relvas que pudieron montar el eco-hostal siendo su principal fuente de ingresos durante los meses más cálidos. 



\section{CONCLUSIONES}

A lo largo del presente estudio hemos ido describiendo y analizando las vinculaciones entre el arte y la agricultura que se han ido dando desde los inicios, con la finalidad de encontrar aquellos puntos de unión que pudieran favorecer prácticas agrícolas más sustentables. Para ello hemos partido de los objetivos que nos marcamos al principio de la investigación y que detallamos de nuevo con los respectivos comentarios de los resultados alcanzados:

1. Entender y profundizar en la crisis ecológico-social que vivimos actualmente y cómo la producción de alimentos intensiva, industrializada y monopolizada contribuye a su aceleración.

El grado de cumplimiento de este objetivo se ha alcanzado siguiendo la lectura de libros y artículos propuestos en la biografía, así como con la información obtenida al cursar y coordinar el Diploma en Sostenibilidad, Ética Ecológica y Educación Ambiental de la Universitat Politècnica de València. También, a través de lo aprendido durante la estancia de investigación en Composing knowledge: art, agroecology and new ruralities (INLAND), Asturias. Todo ello nos ha llevado a situarnos en un mejor entendimiento de la compleja situación agroalimentaria actual, para poder abordar desde el punto de vista 
artístico sus posibles vías de transformación hacia modelos más sustentables. Como hemos visto a lo largo del estudio la proletarización del campesinado, la contaminación por el uso de agrotóxicos y la manipulación genética han sido los puntos más cuestionados por sus consecuencias para los pobladores rurales, para el pequeño/mediano agricultor/a y, en definitiva, para la biosfera y sus habitantes.

2. Localizar y estudiar a artistas que trabajen en su obra cuestiones de labores en el campo, principalmente en la parte agrícola.

Los resultados alcanzados en este objetivo han venido dados por la búsqueda bibliográfica, el visionado de documentales y la impartición de docencia en la asignatura de Arte y Naturaleza del Grado en Bellas Artes de la Universitat Politècnica de València. También, pudimos colaborar en la organización de un seminario de artistas y ecología, donde intervinieron Clive Adams, Betsy Damon y Amy Sharrocks, y pudimos tener acceso a la información de artistas que trabajan la línea de arte y campo.

Así pues, entre todos los artistas que hemos ido citando a lo largo del estudio destacamos, por una parte, a Pablo Ernesto Piovano, Kirsten Stolle y Francisco Toledo, por su lucha en contra de los agrotóxicos, de la empresa Monsanto y de los transgénicos. Por otra parte, los artistas que ponen en valor las prácticas agrícolas sustentables como Lucía Loren, José Cruz García Albarado, Natascha de Cortillas Diego y José Ismael Manco Parra, así como los proyectos de Vivens Hortis, Re. Colectivo, Viridian, The Corn Maze In The Plains y Arte Tanbo.

3. Explorar la capacidad del arte para crear empatía con la situación que tiene que vivir una parte de la población mundial debido a las producciones de alimentos transgénicos.

La lectura de artículos del médico y docente Damián Verzeñasi, así como de los libros Envenenados (Patricio Eleisegui, 2014), Fruto de la 
desgracia (Patricio Eleisegui, 2015), Agrotóxico (Patricio Eleisegui, 2019), El mundo según Monsanto (Marie-Monic Robin, 2018) y Transgénicos el haz y el envés (Jorge Riechmann, 2004) han sido claves a la hora de analizar y comprender la situación que viven según qué sectores de la población mundial con los transgénicos. De esta forma hemos podido explorar cómo las estrategias artísticas han realizado un papel fundamental en la difusión de estas situaciones, generando en el público sensibilidades hacia los afectados por los transgénicos.

4. Analizar, a través de la obra artística, cómo afecta la producción de alimentos a gran escala tanto en el continente europeo como en el sudamericano.

A través de la lectura de la bibliografía propuesta, la asistencia a seminarios, congresos y talleres en el ámbito del proyecto $1+d+i$ Humanidades Ambientales. Estrategias para la empatía ecológica y la transición hacia sociedades sostenibles, así como con la realización de cursos de agroecología y la impartición de la asignatura de Agroecología y alimentación del Diploma de Especialización en Sostenibilidad, Ética Ecológica y Educación Ambiental de la Universitat Politècnica de València, se ha profundizado en la situación agroalimentaria y en cómo los artistas a través de los recursos artísticos han visibilizado las situaciones que se dan en ambos continentes. Partiendo de una situación de sobreexplotación de los terrenos en Sudamérica con grandes extensiones de monocultivos y producción transgénica y señalando las restricciones de estas prácticas en la mayoría de los países europeos.

5. Observar los elementos estéticos y métodos compositivos en prácticas de cultivo más sustentables, como la permacultura.

Los resultados alcanzados en este objetivo se han conseguido a través de las prácticas realizadas en el contexto del Diploma de Especialización en Sostenibilidad, Ética Ecológica y Educación Ambiental las cuales se realizaron en la Fundación los Madroños, 
donde aparte de la práctica que se realizó en los huertos se tuvo acceso a gran número de libros especializados en permacultura de la editorial Kaicron. También, se amplió el aprendizaje de la permacultura con la realización de los cursos de Sistemas de producción de materia vegetal en agricultura ecológica. Producción de semillas y plantones y Diseño de huertas en Permacultura. Huerto Natural-Sinérgico. Todo ello nos llevó a poder analizar y realizar estudios de campo donde pudimos observar la belleza intrínseca de los propios huertos permaculturales, de sus diseños, sus cosechas y los elementos que utilizan en su construcción.

Por otra parte, cabe destacar la estancia de investigación que se realizó en el Centro de Investigación y Estudios en Bellas Artes (CIEBA) en Lisboa (Portugal), donde pudimos contactar con los proyectos de Kultivarte y Quinta Das Relvas analizando sus vías de trabajo de permacultura en relación con las artes.

Así pues, para llevar a cabo los objetivos generales, planteamos los siguientes objetivos específicos:

1. Realizar una investigación detallada de proyectos colectivos donde se relaciona el arte y la agroecología, mediante el estudio de casos.

Este objetivo se ha alcanzado con la realización de trabajo de campo y entrevistas a los cinco proyectos que vinculan el arte y la agricultura que hemos descrito en el quinto capítulo de esta investigación. Esta búsqueda de iniciativas y estudio de las mismas nos ha llevado a tomar conciencia de la existente sensibilización hacia la situación agroecológica actual. Además, hemos observado cómo desde las prácticas artísticas se pueden abordar puntos de investigación muy diferentes con finalidades similares.

2. Analizar el impacto en la sociedad de las obras de los artistas que trabajen con estos temas. 
Este objetivo ha sido más complejo de abordar, ya que analizar el impacto en el público de las propuestas artísticas que se han ido citando a lo largo de la tesis resulta difícil dado que las obras pueden tener diversas interpretaciones según quien las observe. Además, no existe un registro por parte de los artistas o colectivos estudiados que puedan facilitar las impresiones que han ocasionado sus obras. Si bien, en las entrevistas nos han dado indicios del impacto de sus proyectos en el público, siendo constante en todos ellos las sensaciones de extrañeza y desconocimiento hacia el trabajo que realizan. Las personas que suelen participar en las iniciativas ya traen consigo una cierta sensibilización hacia las temáticas previamente tratadas por los proyectos, siendo los sectores conservadores los más reacios a participar, informarse o colaborar en las propuestas.

3. Creación de obra artística propia para experimentar en la práctica aspectos teóricos enunciados en la tesis.

A lo largo de la investigación se ha ido experimentando en la práctica artística propia y se ha tenido la oportunidad de difundir resultados en exposiciones artísticas colectivas propuestas por el Centro de Investigación Arte y Entorno (CIAE) de la Universitat Politècnica de València:

- Semilla Gráfica en el Aula Magna Gianpietro Ballatore de la Facultad de Scienze forestali e ambientali de Palermo, Sicilia (2018).

- La ciudad a través de la ventana. The city from the window, Proyecto OFAA \& CIAE (2018).

- Biotopo gráfico, IV Jornadas Internacionales de Paisajismo y Arboricultura, Valencia (2019).

- Diálogos culturales, Feria Internacional de arte Centre Polivalent d'Oliva, Proyecto OFAA \& CIAE (2019). 
Sin embargo, las obras más relevantes, como fruto del estudio, han sido Por la Soberanía Alimentaria (2017) seleccionada en la convocatoria A les Balconades (Ruzafa, Valencia, España) y Espiral de la vida (2019) seleccionada en la convocatoria Trastellaor (Palmera, Valencia, España). Estas obras, que podremos observar en el Anexo de obra propia situado al final de esta investigación, han analizado y cuestionado la situación agroalimentaria, principalmente de la huerta valenciana, y han dado paso a poder compartir aprendizajes del estudio, a crear discusiones y a generar acercamientos hacia la situación agrícola actual.

Así pues, partiendo de los objetivos recién citados y comentados, retomamos la hipótesis planteada al inicio del estudio:

$>$ El arte como medio de comunicación y educación, es una buena herramienta para plasmar tanto la gran problemática que vivimos en la actualidad con una producción de alimentos excesivamente industrializada y monopolizada, como para plantear sus posibles soluciones (agricultura ecológica, permacultura, huertos urbanos...).

Tras el estudio, llegamos a la deducción de que efectivamente el arte ha tenido una función principalmente comunicativa y educativa a lo largo de todas las propuestas artísticas y proyectos que se han citado y analizado en el transcurso de la investigación. Como hemos podido comprobar en los diferentes capítulos, el arte ha sido una herramienta esencial tanto para visibilizar las problemáticas ocasionadas por los monocultivos, agrotóxicos y transgénicos, como para vislumbrar prácticas agrícolas más sustentables y viables. Tanto los lienzos como las esculturas o las propuestas colectivas llevan consigo aspectos formativos en tanto que se ensalza la práctica agrícola desde diferentes técnicas. Por una parte, las pinturas han sido ventanas a nuestro pasado agrícola, las cuales nos incitan a valorar la gran labor que realizaban los campesinos y las campesinas en cada época, también, las esculturas nos han mostrado la simbología que utilizaban nuestros ancestros en relación con la tierra, los cultivos y sus deidades. Por 
otra parte, a través del arte contemporáneo hemos podido tomar conciencia de la situación agrícola actual y de la voluntad comunitaria por crear proyectos innovadores que fusionen arte y agricultura hacia la sustentabilidad. Con todo ello llegamos a las siguientes conclusiones generales:

1. Tras el recorrido histórico realizado en el primer capítulo de esta investigación se ha percibido la importancia de la representación plástica y simbólica de la cultura agrícola y todos sus avances. Evidenciando estos hechos como indispensables para la evolución de la sociedad en el conocimiento de las técnicas agrícolas. Se han visto representadas tanto las partes más técnicas y productivas como las más espirituales ligadas a deidades. También hemos visto representado el cambio de sociedades matrifocales con estructuras horizontales donde se elogiaban deidades que aludían a la mujer gestante, a la fertilidad y a la abundancia de alimento, a sociedades patriarcales de estructura piramidal donde la representación se centraba en elogiar el poder, las ganancias y los triunfos de guerra.

2. Con la segunda revolución industrial, la revolución verde, la ciudad y las vanguardias históricas, la agricultura pasó a un segundo plano en la representación plástica y simbólica. Siendo a partir del siglo XX cuando se retomó el interés en la agricultura, pero desde un punto de vista más crítico por el deterioro ocasionado debido a su industrialización.

3. Se ha comprobado cómo el arte ha servido de potente herramienta para favorecer la visibilidad de las prácticas de la agroindustria, ayudando a dar voz a colectivos más vulnerables y con menos recursos comunicativos a la hora de dar a conocer las situaciones a las que se ven sometidos por los abusos de los agrotóxicos en los cultivos, los monocultivos y los transgénicos.

4. Consideramos importante mencionar la variedad de artistas y colectivos involucrados en difundir la situación agroalimentaria actual 
a través de su práctica artística. Nos encontramos tanto con artistas de larga trayectoria que han expuesto en salas de gran relevancia como con artistas emergentes que realizan intervenciones o piezas que exponen cerca de su entorno vital y, en muchas ocasiones, sin remuneración alguna. Asimismo, la variedad de técnicas utilizada es muy diversa en ambos casos, pero cabe destacar que se da la coincidencia de que los artistas o colectivos que han tenido un contacto previamente con el mundo agrícola o han vivido en un entorno familiar agrícola, suelen estar más sensibilizados en la difusión de la situación agrícola a través de su práctica artística y suelen ser proyectos más continuados en el tiempo.

5. Se ha demostrado la importancia de los documentales y vídeos como medio de difusión pública, con la posibilidad de hacerse virales en internet y alcanzar un gran número de visualizaciones. Además, pueden llegar a generar un alto nivel de empatía, ya sean de narrativa documental como creativa, irónica o ficticia.

6. También se han citado ejemplos de campañas mediáticas como las de Greenpeace donde se vislumbra cómo utilizan las estrategias artísticas para hacer llegar sus mensajes al espectador, hablamos de una idea de arte público ampliado.

7. En el estudio se ha detectado que las intervenciones artísticas que contemplan aspectos de la agricultura sustentable cada vez son más notables, ya que las consecuencias de la agricultura industrializada han ocasionado que más agentes dediquen su tiempo a cuestionarlas a través del arte. Así pues, se han podido citar numerosas obras que se centran en conservar el conocimiento agrícola ancestral, así como los avances que se han dado en la práctica agrícola sustentable. No obstante, consideramos que es complejo que abunden proyectos o iniciativas que vinculen el arte y la agricultura y que cuenten con una larga trayectoria, dada la precariedad que se suele dar en ambos oficios. Es por ello por lo que ha resultado difícil acotar el territorio para la búsqueda de proyectos. 
8. Cabe destacar que tanto el arte urbano como los talleres artísticos que se realizan en el contexto educativo o en las poblaciones rurales han dado mucha visibilidad a zonas en situación de despoblación y han fomentado la formación del alumnado hacia una participación crítica y creativa.

9. Se han podido observar diversas técnicas y creaciones sobre el campo agrícola, desde laberintos hasta ilustraciones muy elaboradas como las de los campos de arroz en Japón. Además, cabe destacar la participación colectiva en todas estas intervenciones y la sensibilización con el cultivo orgánico.

10. Tras leer y comentar los principios de la permacultura citando a autores como D. Holmgren y R. Morrow, hemos podido comprender mejor la finalidad de la permacultura y profundizar en los aspectos artísticos de la misma. Por tanto, se ha vislumbrado la belleza intrínseca de los cultivos, el vínculo con artistas tratando la permacultura desde los espacios expositivos, la creatividad del permacultor/a en el diseño de sus huertas, el trabajo en comunidad y la importancia de la salud y los cuidados. Así pues, sostenemos que el arte puede servir de puente para acercar a la gente a la filosofía permacultural.

11. El trabajo de campo y las entrevistas a proyectos específicos de arte y agricultura nos han servido para entender la situación a la que se enfrentan estas iniciativas en la actualidad. Si bien hay mucho interés y predisposición en la continuidad de los proyectos vinculando el arte con prácticas agrícolas sustentables, las dificultades económicas y la falta de apoyo son notables, generando desgaste energético en los mismos.

12. Otro aspecto que contemplar es la parte pedagógica, la cual está muy presente en todos los proyectos entrevistados siendo esencial para la transmisión de conocimiento y el aprendizaje de la cultura agrícola. Asimismo, el trabajo en colectivo también se da en todas las iniciativas 
sea a través de las residencias artísticas, de talleres, cursos como de convocatorias específicas. Así pues, resaltamos el punto de vista de la sustentabilidad que está presente en todos los proyectos, la agroecología ya de por sí tiene una marcada postura creativa y, en estas iniciativas, hemos observado cómo la potencian a través de la práctica artística. Además, no dudan en exhibir sus cosechas y sus cultivos como piezas artísticas, mostrando una idea de artisticidad permeable que contempla aspectos del arte más allá de las intervenciones en el campo de cultivo.

Llegados a este punto, cabe señalar que la presente investigación nos ha ofrecido un recorrido de propuestas artísticas centradas en la valoración de la agricultura, demostrando la existente vinculación del arte y la agricultura desde sus inicios. Además, todas las iniciativas citadas se basan en la sustentabilidad, donde defienden a través del arte el cuidado y respeto por el equilibrio de la biosfera. Es por ello por lo que podemos afirmar que efectivamente existe una vía artística dedicada a valorar, respetar y recordar las prácticas agrícolas sustentables. Sin embargo, consideramos que queda mucho recorrido en esta línea de investigación, siendo un tema tan importante como la alimentación del ser humano son escasos los proyectos, con larga trayectoria, que defienden las prácticas agrícolas sustentables desde el arte. Así pues, encontramos necesario que se pongan en valor, se visibilicen y se apoyen este tipo de iniciativas dada la importancia de los temas que trabajan y defienden, luchando por dar voz al sector agrícola y a la producción de alimentos libre de tóxicos.

Finalmente, la presente investigación nos ha ofrecido desde un punto de vista general las vinculaciones del arte y la agricultura hasta concretar en el análisis de proyectos actuales y específicos en esta línea de trabajo. Sin embargo, este estudio abre nuevos caminos de investigación donde se podrían considerar análisis más específicos y profundos acotando territorios de otros países, comparando las diferencias de cada lugar, no solo en cuanto a la práctica artística sino también a las situaciones climatológicas de cada sitio. Asimismo, también se podrían contemplar análisis de los posibles límites de 
los modelos agroecológicos en su extrapolación hacia una escala mayor, pasando de lo local a lo global, y la formulación de estrategias viables. Otra vía de investigación se podría centrar en recabar las impresiones y consecuencias en el público tras observar y/o participar en propuestas artísticas vinculadas a la agricultura, analizando si ocasionan algún impacto en sus modos de vivir y consumir. Para concluir, a nivel personal, consideramos interesante centrarnos en la práctica, llevando al campo todo lo recopilado en este estudio con tal de experimentar y seguir ensalzando la gran labor del agricultor y agricultora a través de las estrategias artísticas, compartiéndolo con el mayor número de personas posible. 



\section{CONCLUSIONS}

Throughout this study the relationship between art and agriculture from the Neolithic Age until the present has been described, with the aim of finding those points of union that could favour more sustainable agricultural practices. In order to do so, a set of general objectives was defined at the beginning of the research. Both the objectives and the results of this study are presented as follows:

1. To examine and deepen our understanding of the current ecological-social crisis and how intensive, industrialised and monopolised food production contributes to its acceleration.

The degree of fulfilment of this objective has been achieved by following the reading of books and articles proposed in the bibliography, as well as with the information obtained by studying and coordinating the Diploma in Sustainability, Ecological Ethics and Environmental Education of the Universitat Politècnica de València and through a research stay at Composing knowledge: art, agroecology and new ruralities (INLAND), Asturias. All of this has led to a better understanding of the current complex agri-food situation, in order to 
be able to approach, from an artistic point of view, its possible ways of transformation towards more sustainable models. As shown throughout the study, the proletarianisation of the peasantry, contamination through the use of agrochemicals and genetic manipulation of crops have been the most questioned points due to their consequences for the rural population, for the small/medium farmer and, in short, for the biosphere and its inhabitants.

2. To identify and study artists whose practice deals with issues related to the rural world, mainly on the agricultural side.

The results achieved in relation to this objective have come from the bibliographic search, the viewing of documentaries and the teaching of the subject Art and Nature in the Fine Arts Degree at Universitat Politècnica de València. The collaboration in the organisation of a seminar on artists and ecology, in which Clive Adams, Betsy Damon and Amy Sharrocks took part, provided relevant information on artists working in the field of art and the rural world.

Thus, among all the artists we have mentioned throughout the study, the work of Pablo Ernesto Piovano, Kirsten Stolle and Francisco Toledo was particularly important, for their struggle against agro-toxins, the Monsanto company and GMOs. On the other hand, of special relevance was the research of artists working with sustainable agricultural practices such as Lucía Loren, José Cruz García Albarado, Natascha de Cortillas Diego and José Ismael Manco Parra, as well as the projects of Vivens Hortis, Re. Colectivo, Viridian, The Corn Maze In The Plains and Arte Tanbo.

3. To explore the capacity of art to create empathy with the situation that a part of the world's population has to endure due to the production of genetically modified crops. 
The study of articles by the doctor and teacher Damián Verzeñasi, as well as the books Envenenados (Patricio Eleisegui, 2014), Fruto de la desgracia (Patricio Eleisegui, 2015), Agrotóxico (Patricio Eleisegui, 2019), El mundo según Monsanto (Marie-Monic Robin, 2018) and Transgénicos el haz y el envés (Jorge Riechmann, 2004) have been key to analysing and understanding the situation that some sectors of the world's population are experiencing with GMOs. In this way, the relevance of artistic strategies in the dissemination of these issues, generating public awareness of those affected by GMOs, has been assessed.

4. To analyse, through artistic work, how large-scale food production affects both the European and South American continents.

Through reading the proposed bibliography, attending seminars, conferences and workshops within the scope of the project $1+d+i$ Environmental Humanities. Strategies for ecological empathy and the transition towards sustainable societies, as well as attending courses on agroecology and teaching the subject Agroecology and Food in the Specialisation Diploma in Sustainability, Ecological Ethics and Environmental Education at the Universitat Politècnica de València, the agro-food situation has been studied in Depth. Moreover, an examination was carried out of the ways in which artists, through aesthetic resources, have made the situations that occur on both continents visible. Starting from a situation of overexploitation of the land in South America with large extensions of monocultures and transgenic production and pointing out the restrictions on these practices in most European countries.

5. To observe the aesthetic elements and compositional methods in more sustainable cultivation practices, such as permaculture.

The results achieved in this objective have been obtained through the practices carried out in the context of the Diploma of Specialisation in 
Sustainability, Ecological Ethics and Environmental Education which were carried out in the Los Madroños Foundation, where apart from the practice in the gardens, access was gained to a large number of specialised books on permaculture from the Kaicron publishing house. Also, a deeper understanding of permaculture was achieved through the courses of Systems of production of vegetable matter in ecological agriculture. Seed and seedling production and Permaculture garden design. Natural-Synergic Garden. All this knowledge enriched the field studies where the intrinsic beauty of the permaculture gardens themselves, their designs, their crops and the elements used in their construction was observed and appreciated.

On the other hand, it is worth mentioning the research stay at the Centre for Research and Studies in Fine Arts (CIEBA) in Lisbon (Portugal), where an in-depth study of the Kultivarte and Quinta Das Relvas projects was carried out, analysing their permaculture work methods in relation to the arts.

In addition to the general objectives, the following specific objectives were established:

1. to carry out a detailed investigation of collective projects where art and agroecology are related, through case studies.

This objective was achieved by conducting fieldwork and interviews about the five projects linking art and agriculture described in the fifth chapter of this research. This search for and study of initiatives has led us to become aware of the existing awareness of the current agro-ecological situation. Furthermore, we have observed how artistic practices can address very different points of research with similar aims.

2. To analyse the impact on society of the works of artists working on these issues. 
This objective has been more complex to tackle, as analysing the impact on the public of the artistic proposals that have been mentioned throughout the thesis is difficult, given that the works can have different interpretations depending on who observes them. In addition, there is no record kept by the artists or collectives studied that could facilitate the impressions that their works have had on the public. However, in the interviews, they have provided indications of the impact of their projects on the public, with a constant feeling of strangeness and unfamiliarity with the work they do. The people who tend to participate in the initiatives already bring with them a certain awareness of the themes previously dealt with by the projects, with the conservative sectors being the most reluctant to participate, be informed or collaborate in the proposals.

3. Creation of personal artistic work in order to experiment in practice with the theoretical aspects explored in the thesis.

A parallel research, has been carried out in my own artistic practice and whose results were disseminated in the following collective art exhibitions proposed by the Centro de Investigación Arte y Entorno (CIAE) of the Universitat Politècnica de València:

- Semilla Gráfica at the Aula Magna Gianpietro Ballatore of the Faculty of Forestry and Environmental Sciences of Palermo, Sicily (2018).

- The city through the window. The city from the window, OFAA \& CIAE Project (2018).

- Biotopo gráfico, IV Jornadas Internacionales de Paisajismo y Arboricultura, Valencia (2019).

- Diálogos culturales, International Art Fair, Centre Polivalent d'Oliva, OFAA \& CIAE Project (2019). 
However, the most relevant works, as a result of the study, have been Por la Soberanía Alimentaria (2017) selected in the call A les Balconades (Ruzafa, Valencia, Spain) and Espiral de la vida (2019) selected in the call Trastellaor (Palmera, Valencia, Spain). These works, which can be seen in the Annexes of the thesis at the end of this research, have analysed and questioned the agri-food situation, mainly in the Valencian-huerta, and have led to the sharing of lessons learned from the study, to create discussions and to generate other approaches to the current agricultural situation. Thus, based on the mentioned objectives, we return to the hypothesis put forward at the beginning of the study:

$>$ Art, as a means of communication and education, is a relevant tool for capturing both the great problems we are currently experiencing with an excessively industrialised and monopolised food production, and for proposing possible solutions (ecological agriculture, permaculture, urban gardens...).

After the study, the conclusion that art has indeed had a mainly communicative and educational function throughout all the artistic proposals and projects that have been mentioned and analysed in the course of the research. As seen in the different chapters, arthas been an essential tool both for making the problems caused by monocultures, pesticides and GMOs visible, and for envisioning more sustainable and viable agricultural practices. Both the canvases and the sculptures or the collective proposals carry with them formative aspects insofar as the agricultural practice is extolled from different techniques. On the one hand, the paintings have been windows to our agricultural past, which encourage us to value the great work carried out by the peasants in each period; also, the sculptures have shown us the symbolism used by our ancestors in relation to the land, the crops and their deities. On the other hand, through contemporary art we have been able to become aware of the current agricultural situation and the community's will to create innovative projects that merge art and agriculture towards sustainability. Therefore, the following general conclusions are reached: 
1. After the historical analysis carried out in the first chapter of this research, the importance of the artistic and symbolic representation of agricultural culture and all its advances has been perceived. These facts have been shown to be indispensable for the evolution of society in the knowledge of agricultural techniques. Both the more technical and productive aspects and the more spiritual dimensions linked to deities have been represented. A change was observed from the representation of matrifocal societies with horizontal structures where deities that alluded to the pregnant woman, fertility and the abundance of food were praised, to patriarchal societies with a pyramidal structure where the representation was centred on praising power, profits and war triumphs.

2. With the second industrial revolution, the green revolution, the city and the historical avant-garde, agriculture took a back seat in artistic and symbolic representation. It was not until the 20th century that interest in agriculture resumed, but from a more critical point of view due to the deterioration caused by its industrialisation.

3. It has been shown how art has served as a powerful tool to favour the visibility of agro-industrial practices, helping to give a voice to more vulnerable groups with fewer communicative resources when it comes to expose the situations to which they are subjected due to the abuse of agro-toxins in crops, monocultures and transgenic crops.

4. It is important to mention the variety of artists and collectives involved in disseminating the current agri-food situation through their artistic practice. Both long-established artists who have exhibited in major galleries and emerging artists who make interventions or pieces that are exhibited close to their living environment and, on many occasions, without any remuneration whatsoever, have tackles these important issues. Likewise, the variety of techniques used is very diverse in both cases, but it is worth noting that the artists or collectives that have had previous contact with the 
agricultural world or have lived in an agricultural family environment tend to be more aware of the agricultural situation through their artistic practice and their projects tend to have a long-term approach.

5. The importance of documentaries and videos as a means of public dissemination has been demonstrated, with the possibility of going viral on the internet and reaching a large number of views. In addition, they can generate a high level of empathy, whether they are documentary or creative, ironic or fictional narratives.

6. Examples of media campaigns have also been cited, such as those of Greenpeace, where we can see how artistic strategies are employed to get their messages across to the spectator, creating an idea of expanded public art.

7. The study has detected that artistic interventions contemplating aspects of sustainable agriculture are becoming more and more notable, as the consequences of industrialised agriculture have caused more agents to dedicate their time to questioning them through art. Thus, numerous works that focus on preserving ancestral agricultural knowledge, as well as the advances that have been made in sustainable agricultural practice were analysed in this thesis. However, it was difficult to find an abundance of projects or initiatives that link art and agriculture and that have a long trajectory, given the precariousness that often exists in both economic spheres. This is why it has been difficult to narrow down the territory for the selection of projects.

8. It should be noted that both urban art and artistic workshops in the educational context or in rural populations have given much visibility to areas in a situation of depopulation and have encouraged the training of students towards critical and creative participation. 
9. Various techniques and creations on the agricultural field have been observed, from labyrinths to very elaborate illustrations such as those of the rice fields in Japan. In addition, the collective participation in all these interventions and the awareness of organic farming should be highlighted.

10. After reading and commenting on the principles of permaculture formulated by authors such as D. Holmgren and R. Morrow, better understanding of the purpose and the artistic aspects of permaculture was reached. Therefore, the intrinsic beauty of the crops was analysed together with, the link with artists dealing with permaculture from the exhibition spaces, the creativity of the permaculturist in the design of their gardens, the work in community and the importance of health and care. Thus, it was shown that art can serve as a bridge to bring people closer to the permaculture philosophy.

11. Fieldwork and interviews with specific art and agriculture projects have provided a deeper understanding of the situation these initiatives are currently facing. Although there is a lot of interest and willingness to continue the projects linking art with sustainable agricultural practices, the economic difficulties and lack of support are notable, generating energy drain.

12. Another aspect to consider is the pedagogical dimension, which is very present in all the examined projects, being essential for the transmission of knowledge and the learning of agricultural culture. Likewise, collective work is also present in all the initiatives, whether through artistic residencies, workshops, courses or specific calls for proposals. Thus, the notion of sustainability is present in all the projects, agroecology already has a marked creative stance and, in these initiatives, we have observed how it is enhanced it through artistic practice. Moreover, harvests and crops are exhibited as artistic 
pieces, showing an idea of permeable artisticity that contemplates aspects of art beyond the interventions in the field.

At this point, it should be noted that the present research has offered an overview of artistic proposals centred on agriculture, demonstrating the existing link between art and agriculture since the Neolithic age. Furthermore, all the mentioned initiatives are based on sustainability, art, care and respect for the balance of the biosphere. This is why it can affirmed that there is indeed an artistic path dedicated to valuing, respecting and remembering sustainable agricultural practices. However, this line of research is still not fully explored, as there are few projects with a long trajectory that defend sustainable agricultural practices through art, even though the subject is as important as human nutrition. Therefore, it is necessary to highlight, make visible and support this type of initiatives given the importance of the issues they work on and defend, fighting to give a voice to the agricultural sector and the production of toxic-free food.

Finally, this research has provided a general understanding of the relation between art and agriculture through the analysis of current and specific projects. However, this study opens up new lines of research where more specific and in-depth analyses could be considered, delimiting territories in other countries, comparing the differences in each place, not only in terms of artistic practice but also in terms of the climatological situations of each site. Analyses of the possible limits of agroecological models in their extrapolation to a larger scale, moving from the local to the global, and the formulation of viable strategies, could also be envisaged. Another line of research could focus on gathering the impressions and consequences of the public after observing and/or participating in artistic proposals linked to agriculture, analysing whether these art forms have any impact on their ways of living and consuming. To conclude, on a personal level, I consider it interesting to focus on art practice in the future, taking all the knowledge developed in this study to the field in order to experiment and continue extolling the great work of the farmer through artistic strategies and, sharing it with as many people as possible. 




\section{BIBLIOGRAFÍA}

Albelda, J. (2015) "Arte y ecología. Aspectos caracterizadores en el contexto del diálogo arte-naturaleza”. En T. Raquejo y J. M. Parreño (eds.) Arte yecología. Madrid: UNED.

Albelda, J. y Saborit, J. (1997) La construcción de la naturaleza. Valencia: Direcció General de Promoció Cultural, Museus i Belles Arts Consellería de Cultura, Educació i Ciència.

Albelda, J. y Sgaramella, C. (2015) “Arte, empatía y sostenibilidad. Capacidad empática y conciencia ambiental en las prácticas contemporáneas de arte ecológico". Revista Ecozon@, Vol. 6, No. 2. ISSN 2171-9594 [consult. 2019/06/08]. Disponible en: https://ecozona.eu/article/view/662

Albelda, J., Parreño, J. M. y Marrero Henríquez, J.M. (coords.) (2018) Humanidades ambientales. Pensamiento, arte y relatos para el siglo de la gran prueba. Madrid: Los libros de la Catarata. 
Altieri, M. (1999) AGROECOLOGÍA. Bases científicas para una agricultura sustentable. Montevideo: Editorial Nordan-Comunidad [consult. 2020/05/02]. Disponible en:

https:/www.icia.es/icia/download/Agroecolog\%C3\%ADa/Material/ Agricultura_sustentablell.pdf

Larach, M. A. (2001) El comercio de los productos transgénicos: el estado del debate internacional. Santiago de Chile: Naciones Unidas.

Ardit, M. (2007) "La historia rural de la España oriental durante la Edad Moderna: un estado de la cuestión". Ediciones Universidad de Salamanca, 29. ISSN: 0213-2079 [consult. 2020/04/04]. Disponible en: https://www.researchgate.net/publication/41206602_La historia ru ral_de_la_Espana_oriental_durante_la_Edad_Moderna_un_estado _de_la_cuestion

Ariza, S. (2021) "De la práctica a la investigación en el arte contemporáneo, producir conocimiento desde la creación". Revista Arte, Individuo y Sociedad, Vol. 33, No. 2. ISSN: 1131-5598 [consult. 2020/07/09]. Disponible en:

https://revistas.ucm.es/index.php/ARIS/article/view/68916

Arribas, F. (2007) "La idea de desarrollo sostenible". Universidad Rey Juan Carlos, Sistema, 196 [consult. 2020/02/12]. Disponible en: https://www.academia.edu/15643900/La_idea_de_desarrollo_soste nible

Arribas, F. (2015) "Arte, naturaleza y ecología”. En T. Raquejo y J. M. Parreño (eds.) Arte y ecología. Madrid: UNED.

Azpíroz, M. L. (2019) “Maíz transgénico vs agricultura ecológica: un análisis del discurso de Greenpeace México en torno a la seguridad alimentaria, la soberanía alimentaria y el derecho a la alimentación (2007-2017)". Revista de Alimentación Contemporánea y Desarrollo Regional, Vol. 29, No. 54, México. ISSN: 2395-9169. 
Bakers, M. (2019) Agricultura en la Edad Media. Cambridge Stanford Books [consult. 2020/07/15]. Disponible en:

https://es.scribd.com/read/437235213/Agricultura-en-la-EdadMedia

Bakers, M. (2019) Agricultura: de la antigua Roma al intercambio colombino. Cambridge Stanford Books [consult. 2020/06/10]. Disponible en: https://play.google.com/books/reader?id=7B7NDWAAQBAJ\&hl=bn\& $\mathrm{pg}=\mathrm{GBS} . \mathrm{PP} 1$

Baquedano, S. (2012) "Entrevista a Vandana Shiva en Dehradun, India 2012". DILEMATA Vol. 4, No. 10. ISSN 1989-7022 [consult. 2020/09/20]. Disponible en:

https://www.dilemata.net/revista/index.php/dilemata/article/view/ 176

Barri, F. y Wahren, J. (2010) "El modelo sojero de desarrollo en la Argentina: tensiones y conflictos en la era del neocolonialismo de los agronegocios y el cientificismo-tecnológico". Centro de Ecología y Recursos Naturales Renovables, UNC y Grupo de Estudios Rurales, Instituto de Investigaciones Gino Germani, UBA. [consult. 2020/09/20]. Disponible en:

https://www.academia.edu/11574824/El_modelo_sojero_de_desarr ollo_en_la_Argentina_tensiones_y_conflictos_en_la_era_del_neoc olonialismo_de_los_agronegocios_y_el_cientificismo_tecnol\%c3\% B3gico

Barros, C. (2019) "Comer como un egipcio". Egiptología 2.0, No. 12 [consult. 2020/06/11]. Disponible en:

https://www.researchgate.net/publication/334645649

Barruti, S. (2013) Malcomidos, cómo la industria alimentaria Argentina nos está matando. Editor digital Faldegort [consult. 2020/09/15]. Disponible en: 
http://files.geotareas.webnode.com.ar/200000264-

78512794ef/Malcomidos\%20\%20Soledad\%20Barruti.pdf

Behar Rivero, D. S. (2008) Metodología de la investigación. Lima: Editorial Shalom [consult. 2020/02/10]. Disponible en:

https://es.calameo.com/read/004416166f1d9df980e62

Benítez Jamchen, J. (2015) Estética de la indeterminabilidad. Madrid: Editorial Bubok [consult. 2020/06/10]. Disponible en:

https://www.bubok.es/libros/240417/Estetica-de-laindeterminabilidad

Bernat, C. (2010) War-Era Food Posters. [consult. 2020/08/20]. Disponible en: http://www.goodpotato.com/beans are bullets/chapter7/ch7gallery5.html

Boff, L. (1996) Ecología: grito de la Tierra, grito de los pobres. Madrid: Editorial Trotta.

Bolaños, J. I. (2003) "El Valle del Nilo: de la Geografía al mito". Cuadernos Geográficos, No. 33. ISSN: 0210-5462 [consult. 2020/06/11]. Disponible en: https://www.redalyc.org/articulo.oa?id=171/17103305

Borgdorff, H. (2016) "El debate sobre la investigación en las artes" Revista de ciencias de la danza, No 13, 2010. ISSN 1135-9137 [consult. 2020/06/11]. Disponible en:

https://docplayer.es/3707041-El-debate-sobre-la-investigacion-enlas-artes-henk-borgdorff-amsterdam-school-of-the-arts.html

Brown, A. (2014) Art \& ecology now. United Kingdom: Thames \& Hudson.

Burnett, G. (2017) El Libro Vegano de la Permacultura. Castellón: Kaicron S.L.

Cacace, G. P. y Osvaldo, J. (2018) "Agricultura industrial transgénica en argentina. Agrotóxicos: consecuencias sociales y ambientales". Universidad Nacional de Luján, Instituto de Investigaciones Geográficas, Grupo de Estudios sobre Geografía Económica y 
Comercio Internacional. Anuario de la División de Geografía, No. 12. ISSN 1851-7897 [consult. 2020/06/11]. Disponible en:

http://ri.unlu.edu.ar/xmlui/handle/rediunlu/622

Casulá, C. (2018) "Al Natural_PRS. Parque Regional Sureste de la Comunidad de Madrid”. Revista SOBRE, Vol. 4. ISSN 2387-1733 / E-ISSN 2444-3484 [consult. 2020/10/16]. Disponible en: https://doi.org/10.30827/7369

Chae-Suk, L. (2016) "A Study on the Landmark for Regional Revitalization". Journal of the Korea Academia-Industrial cooperation Society, Vol. 17, No. 3. ISSN 1975-4701 [consult. 2020/05/06]. Disponible en: https://www.koreascience.or.kr/article/JAKO201613360957212.pdf

Chrino, M. y Stevens, M. (2001) Artey botánica. Madrid: Editorial Lunwerg-Caja Madrid.

Ciancaglini, F. (2018) "Naturaleza Viva, granja agroecológica-biodinámica". Revista MU, No. 121. Caba: Cooperativa de Trabajo Gráfica Patricios. [consult. 2020/06/20]. Disponible en:

https://www.lavaca.org/mu/mu-121-generacion-verde/

Cirlot, L. y Manonelles L. (coords.) (2011) Procesos creativos y trastornos psíquicos. Barcelona: Universitat de Barcelona.

Cortillas Diego, N. (2010) "Amasijo y desterritorialización acercamiento al entendimiento de obra como acontecimiento del espacio local". Revista Alzaprima, Universidad De Concepción [consult. 2020/05/15]. Disponible en:

http://www.nataschadecortillas.cl/wpcontent/uploads/2015/05/Armasijo-y-desterritorializaci\%C3\%B3n2010.pdf

Critical Art Ensemble (2002) The Molecular Invasion. New York: Autonomedia.

Cruz García, J. (2012) Expresarte de la Tierra. Tributo a los cultivos nativos de México. Texcoco: Colegio de Postgraduados. 
Eisler, R. (2005) El cáliz y la espada. Nuestra historia, nuestro futuro. Santiago de Chile: Editorial Cuatro vientos.

Eleisegui, P. (2015) Fruto de la Desgracia. Concordia, Entre Ríos: Editorial PV.

Eleisegui, P. (2017) Envenenados. Una bomba química nos extermina en silencio. Ciudad Autónoma de Buenos Aires: Gárgola.

Faba, N. (2015) La alimentación actual desde la práctica artística: Evolución en el uso de los aditivos alimentarios. Trabajo Fin de Máster. Universidad Politécnica de Valencia, Valencia [consult. 2020/10/15]. Disponible en: https://riunet.upv.es/handle/10251/60950

FAO (2018) Transformar la alimentación y la agricultura para alcanzar los ods. 20 acciones interconectadas para guiar a los encargados de adoptar decisiones. Roma: Organización de las Naciones Unidas para la alimentación y la agricultura [consult. 2020/05/02]. Disponible en: http://www.fao.org/publications/transforming-food-agriculture-toachieve-sdg/es/

Fontcuberta, J. (1998) Ciencia y fricción. Fotografía, naturaleza, artificio. Murcia: Mestizo.

Fromm, E. (1988) El arte de amar. Barcelona: Ediciones Paidós.

Fukukoa, M. (1978) La revolución de una brizna de paja. Cornudella de Montsant: Instituto Permacultura Monsant [consult. 2019-12-28] Disponible en: https://base.socioeco.org/docs/la-revolucic3b3n-deuna-brizna-de-paja2.pdf

Gaignard, R. (1989) La pampa argentina. Ocupación-poblamiento-explotación. De la Conquista a la crisis mundial (1550-1930). Buenos Aires: Ediciones Solar.

Gallego, J. (2004) "La agricultura en la Grecia antigua. Los labradores y el despegue de la pólis”. Historia agraria, No. 32 [consult. 2020/06/26]. Disponible en: 
http://repositori.uji.es/xmlui/bitstream/handle/10234/159669/2004 \%2c\%2032\%2c\%2015-35.pdf? sequence=1\&isAllowed=y

Garcerá, J. (2005) Visiones desde el exilio: Modernidad y posmodernidad frente a la escisión entre el hombre y el mundo. Tesis Doctoral, Universidad Complutense de Madrid. [consult. 2020/02/03]. Disponible en: https://eprints.ucm.es/id/eprint/7205/1/T28717.pdf

García, R. (2017) "La invención de la retícula urbana: escuadra y arado. Una cuestión geométrica y agrícola”. EGA Revista de Expresión Gráfica Arquitectónica, No. 22 [consult. 2020/03/05]. Disponible en: https://www.researchgate.net/publication/315989750 La_invencion de la reticula_urbana escuadra_y arado Una cuestion geomet rica_y_agricola

Gimbutas, M. (2014) Diosas y dioses de la Vieja Europa (7000-3500 a. C.). Madrid: Ediciones Siruela.

Gisclard, M., Allaire, G. y Cittadini, R. (2015) "Proceso de institucionalización de la agricultura familiar y nuevo referencial para el desarrollo rural en la Argentina”. Mundo Agrario, Vol. 16, No. 31 [consult. 2019/02/08]. Disponible en:

https://www.redalyc.org/articulo.oa?id=845/84539280003

Gómez, C. y Luque, B. (2006) Imágenes de un mundo rural 1955-1980. Madrid: Ministerio de Agricultura, Pesca y Alimentación.

González, M. (2015) Prácticas artísticas híbridas contemporáneas en el ámbito rural. Paraisurrural. Tesis Doctoral, Universitat Politècnica de València [consult. 2020/05/03]. Disponible en: https://riunet.upv.es/handle/10251/61461

Grande, J. K. (2005) Diálogos Arte Naturaleza. Lanzarote: Fundación César Manrique [consult. 2020/02/01]. Disponible en: http://www.fcmanrique.org/recursos/publicacion/dialogosartenatur aleza.pdf 
Hansen, A. M. (2013) "Atrazina: un herbicida polémico". Revista Internacional de Contaminación Ambiental, Vol. 29, número especial sobre plaguicidas [consult. 2020/09/18]. Disponible en: https://www.revistascca.unam.mx/rica/index.php/rica/article/view/ $41420 / 38390$

Haskell, B. (2020) América: Muralismo mexicano y el arte en los Estados Unidos, 1925-1945. Whitney Museum of American Art [consult. 2020/09/16]. Disponible en:

https://whitneymedia.org/assets/generic_file/1374/20_Vida_Essay_ PDF.pdf

Henfrey, T. y Penha-Lopes, G. (2018) Permacultura y adaptación al cambio climático. Castellón: Kaicron S.L.

Heredia, D. (2018) Arte y ecología. Límites para la recuperación de espacios degradados. Trabajo Fin de Grado, Universitat Politècnica de València [consult. 2020/04/16]. Disponible en:

https://riunet.upv.es/handle/10251/110742

Hernández Zubizarreta, J. y Carrión, J. (2013) “Las empresas transnacionales y los derechos humanos”. En B. Román y G. de Castro (eds.) Cambio social y cooperación en el siglo XXI, Vol.2 [consult. 2020/10/23]. Disponible en:

http://biblio3.url.edu.gt/Publied/Cambiosyc/8HernandezCarrion.pdf

Hillison, J. y Tech, V. (1998) "Agriculture in the classroom: early 1900s style". Journal of Agricultural Education, Vol. 39, No. 2 [consult. 2020/10/14]. Disponible en: https://www.jae-online.org/attachments/article/510/39-02-11.pdf

Holmgren, D. (2013) Permacultura. Principios y senderos más allá de la Sustentabilidad. Castellón: Kaicron S. L. 
Jacobs, K. (2018) "La mujer que cosechó un campo de trigo en Wall Street". The New York Times Style Magazine, 14 de junio de 2018 [consult. 2020/09/03]. Disponible en:

\section{https://www.nytimes.com/2018/06/14/t-magazine/agnes-denes- art.html}

Jha, A. (2012) 50 Maneras de destruir el mundo. Barcelona: Editorial Planeta.

Kastner, J. (2005) Land Art y arte medioambiental. Londres: Phaidon.

Koepf, H. (2001) ¿Qué es la agricultura biodinámica? Madrid: Editorial Rudolf Steiner.

Latorre, J. (2012) "Fotografía y Arte: Encuentros y Desencuentros". Revista de Comunicación, Vol. 11 [consult. 2020/09/16]. Disponible en:

https://www.academia.edu/35030185/Fotograf\%C3\%ADa_y Arte_E ncuentros y Desencuentros Encounters and evades_between_ar t and photography

Leyte, A. y Cortés, H. (Ed.) (2004) Schelling, F.J.K El "Discurso de la academia" Sobre la relación de las Artes Plásticas con la Naturaleza (1807). Madrid: Biblioteca Nueva S. L.

López, G. (2006) "Sarcófago bajo-imperial del museo de Arles con escena agrícola”. Espacio y tiempo en la percepción de la Antigüedad Tardía, Vol. XXIII, CSIC España HUM2004-01056 [consult. 2020/07/10]. Disponible en:

https://revistas.um.es/ayc/article/view/49631/47501

Loren, L. (2012) Arte y territorio. Intervención artística para la reconstrucción del medio natural y cultural. Entrevista realizada por Yolanda Zuloaga para greenmuseum.org. Aportaciones desde la periferia. Jaén: COLBAA [consult. 2020/09/05]. Disponible en:

http://www.educacionartistica.es/aportaciones/3_propuestas/inter vencion_reconstruccion/309_lucialoren_entrevista_greenmuseum. $\mathrm{pdf}$ 
Maderuelo, J. (1997) El jardín como arte. Actas Arte y Naturaleza. Huesca: Diputación Provincial de Huesca.

Maderuelo, J. (2001) Arte público: naturaleza y ciudad. Lanzarote: Fundación César Manrique.

Marín, C. (2014) "Arte medioambiental y ecología: Elementos para una reflexión crítica”. Arte y políticas de identidad, Vol. 10-11 [consult. 2020/03/05]. Disponible en:

https://revistas.um.es/reapi/article/view/219161/171651

Maroto, J. V. (2014) Historia de la agronomía. Una visión de la evolución histórica de las ciencias y técnicas agrarias. Madrid: Ediciones MundiPrensa.

Meacham, B. (2010) "La Ética de la Permacultura y la Cadena de Beneficios". Permaculture Activist magazine, No. 75 [consult. 2019/04/10]. Disponible en:

https://www.bmeacham.com/whatswhat/PDF/Permacultura\%c3\% 89tica.pdf

Mendelson, J. (1998) Roundup: el herbicida más vendido del mundo. Revista The ecologist, Vol. 28. No. 5 [consult. 2020/10/10]. Disponible en: https://archivo.ecologistasenaccion.org/uploads/r/null/0/c/b/0cbd3 54333d41ab9998b7621eb324d72826b028da6530ef0ded7415513d57 41d/1998_GAIA_15.pdf

Mestre, A. C. (2011) El culto a la Madre Tierra: Mujer, Naturaleza y Espiritualidad. Trabajo Fin de Carrera, Universitat Politècnica de València [consult. 2020/02/15]. Disponible en:

https://riunet.upv.es/bitstream/handle/10251/15099/proyecto_final _de_carrera.pdf

Michael, P. (2001) Permaculture as a Design Modality for Healing and Regeneration: Design with a Deeper Agenda. Aveiro: Fourth European Academy of Design Conference. 
Migliorini, P., Gkisakis, V., Gonzalvez, V., Raigón, M. D. and Bàrberi, P. (2018) "Agroecology in Mediterranean Europe: Genesis, State and Perspectives”. Sustainability, Vol. 10 [consult. 2020/11/05]. Disponible en: https://www.mdpi.com/2071-1050/10/8/2724

Mollison, B. y Holmgren, D. (1978) Permaculture ONE, una agricultura permanente para asentamientos humanos. Tasmania: Tagari.

Moncada, J. A., Aranguren, J. y Lugo, C. (2018) "Una aproximación al conocimiento de la diversidad y multifuncionalidad de las chacras andinas". En Aranguren, J. R. y Moncada, J. A. (coord.) Sembrando vida y cultura. Las chacras como espacios multifuncionales en comunidades indígenas andinas. Caso: Fakcha Llakta, Otavalo, Ecuador. Ibarra: Editorial UTN [consult. 2020/05/11]. Disponible en: https://issuu.com/utnuniversity/docs/ebook_las_chacras_como_es pacios_mul

Monserrat, V. J. (2012) "Los artrópodos en la mitología, la ciencia y el arte de Mesopotamia”. Boletín de la Sociedad Entomológica Aragonesa (S.E.A.), No. 51 [consult. 2020/04/12]. Disponible en:

https://www.researchgate.net/publication/290433536_LOS_ARTRO PODOS_EN_LA_MITOLOGIA_LA_CIENCIA_Y_EL_ARTE_DE_MESOPOT AMIA

Monserrate Ruiz, S. (2015) "De la agricultura arcaica al agronegocio y los modelos asociativos. Su impacto social". Journal of Agriculture and Environmental Sciences, Vol. 4, No. 2. ISSN: 2334-2404 [consult. 2020/03/10]. Disponible en:

http://jaesnet.com/vol-4-no-2-december-2015-abstract-16-jaes

Morrow, R. (2018) Guía de Permacultura para uso de la tierra. Castellón: Kaicron S. L.

Nogué, J. (ed.) (2008) El paisaje en la cultura contemporánea. Madrid: Biblioteca Nueva. 
Oszvald, T. (2017) Adaptation of the Design Philosophy and Methods of Permaculture in Community Engaged Art Projects. Tasmanian College of the Arts, University of Tasmania [consult. 2020/05/11]. Disponible en: https://eprints.utas.edu.au/23889/1/Oszvald whole thesis.pdf

OXFAM (2015) La desigualdad extrema de las emisiones de carbono. [consult. 2020/03/08]. Disponible en: https://www-cdn.oxfam.org/s3fspublic/file_attachments/mb-extreme-carbon-inequality-021215es.pdf

Paull, J. (2020) "The Koberwitzers: Those Who Attended Rudolf Steiner's Agriculture Course at Koberwitz in 1924, World's Foundational Organic Agriculture Course". International Journal of Environmental Planning and Management, Vol. 6, No. 2. ISSN: 2381-7240 [consult. 2020/07/20]. Disponible en:

https://www.researchgate.net/publication/342551908_The_Koberwi tzers_Those_Who_Attended_Rudolf_Steiner\%27s_Agriculture_Cour se_at_Koberwitz_in_1924_World\%27s_Foundational_Organic_Agric ulture_Course

Pereira, C. A. (2013) "Participación y acción colectiva en los movimientos globales de ecoaldeas y permacultura". Revista Latinoamericana de Psicología, Vol. 45, No. 3. ISSN: 0120-0534 [consult. 2020/04/24]. Disponible en:

https://www.redalyc.org/pdf/805/80529820006.pdf

Poza, M. (2019) "Las labores de los meses en el Románico". Revista Digital de Iconografía Medieval, Vol. I, No. 1. e-ISSN: 2254-853X [consult. 2020/07/15]. Disponible en:

https://www.ucm.es/data/cont/docs/621-2013-11-13-

LaboresMeses.pdf

Rafols, J.F. (2001) Historia del arte. Barcelona: Editorial Óptima S. L. 
Raigón, M. D. (2010) La industria ecológica relacionada con la producción vegetal de transformación de alimentos. Valencia: Sociedad Española de Agricultura Ecológica

Rajshekhar Rao, Ar. (2014) In Search of Aat in Landscape Design. 1st International Congress on Environmental, Biotechnology and Chemistry Engineering. IPCBEE, Vol. 64 [consult. 2020/07/15]. Disponible en:

http://www.ipcbee.com/vol64/017-ICCUE2014-2-005.pdf

Raquejo, T. (1998) Land Art. Donostia, San Sebastián: Editorial Nerea, S. A.

Raquejo, T. y Parreño, J. M. (eds.) (2015) Arte y ecología. Madrid: Universidad Nacional de Educación a Distancia.

Ribeiro, S. (2015) "Biopiratería: la privatización de los ámbitos de la comunidad". En Acosta A. y Martínez E. (eds.) Biopiratería La biodiversidad y los conocimientos ancestrales en la mira del capital. Quito: Abya Yala.

Ridner, E., Gamberale, M.C., Burachik, M., Lema, M., Levitus, G. y Rubinstein, C. (2008) Alimentos Transgénicos: mitos y realidades. Buenos Aires: Editorial Nutrición y Salud.

Riechmann, J. (2003) Cuidar la T(t)ierra Políticas agrarias y alimentarias sostenibles para entrar en el siglo XXI. Barcelona: Editorial Icaria.

Riechmann, J. (2004) Transgénicos: el haz y el envés. Una perspectiva crítica Madrid: Los libros de la Catarata.

Riechmann, J. (2006) Biomímesis: Ensayos sobre imitación de la naturaleza, ecosocialismo y autocontención. Madrid: Los libros de la Catarata.

Riechmann, J. (2011) ¿Cómo vivir? Acerca de la vida buena. Madrid: Los libros de la Catarata. 
Robin, M. M. (2018) El mundo según Monsanto. Barcelona: Ediciones Península.

Rocher, E. (Ed.) (2019) IV Trastellaor 2019. Valencia: Mandarina Borda.

Rosenthal, D. (2002) O elemento material na obra de Joseph Beuys. Mestrado em Artes, Universidade Estadual de Campinas, Instituto de Artes [consult. 2020/11/12]. Disponible en:

http://repositorio.unicamp.br/bitstream/REPOSIP/285092/1/Rosent

hal_Dalia_M.pdf

Ross y Mars, J. (2017) Permacultura paso a paso. Castellón: Kaicron S. L.

Santos, J. J. (2019) ¿Para que sirve hoy la crítica de arte? Madrid: Ministerio de Cultura y Deporte.

Segura, P. (2012) Estudio del sistema permacultural en el marco de la Comunidad Valenciana. Trabajo Fin de Carrera, Universitat Politècnica de València [consult. 2019/12/12]. Disponible en: https://bahvalladolid.files.wordpress.com/2014/11/estudio-delsistema-permacultural-en-la-comunidad-valenciana-upv.pdf

Shawn Manoley, R. y Paolisso, M. (2006) "The Art of Farming: Exploring the Link between Farm Culture and Maryland's Nutrient Management Policies". Culture \& Agriculture, Vol. 28, No. 2. ISSN 1048-4876 [consult. 2020/03/25]. Disponible en: https://www.researchgate.net/publication/227698145 The Art of Farming_Exploring_the_Link_between_Farm_Culture_and_Marylan d's_Nutrient_Management_Policies

Shiva, V. (2001) Biopiratería: El saqueo de la naturaleza y del conocimiento. Barcelona: Icaria editorial, S. A.

Shiva, V. (2003) Cosecha robada: el secuestro del suministro mundial de alimentos. Barcelona: editorial Paidós. 
Soto, P. (2017) Arte, ecología y consciencia. Propuestas artísticas en los márgenes de la política, el género y la naturaleza. Tesis Doctoral, Universidad de Granada [consult. 2020/05/20]. Disponible en: https://dialnet.unirioja.es/servlet/tesis?.codigo $=122331$

Tauger, M. B. (2010) Agriculture in World History. Londres: Editorial Routledge.

Tello, A. (2006) Historia breve de Argentina, claves de una impotencia. Madrid: Editorial Sílex.

Torres, N. (2014) La regeneración de sitios degradados a través de la intervención ambiental. Tesis Doctoral, Universitat Politècnica de València [consult. 2020/09/10]. Disponible en: https://dialnet.unirioja.es/servlet/tesis?codigo $=87356$

Valles, M. (1997) Técnicas cualitativas de investigación social. Reflexión metodológica y práctica profesional. Madrid: Editorial Síntesis.

Vargas, Y (2018) "DDT: El veneno "salva vidas" que invadió el hogar". Revista La Agroecologa. Costa Rica: Cuatricromía S. A. ISSN: 2215-4965

Velasco, J. (2017) Semillas frente al colapso: arte y agricultura contra la "Biopiratería". Diario digital de Córdoba. [consult. 2020/09/05]. Disponible en: https://cordopolis.es/2017/11/16/semillas-frente-alcolapso-arte-y-agricultura-frente-a-la-biopirateria/

Verzeñassi, D. (2014) “Agroindustria, salud y soberanía. El modelo agrosojero y su impacto en nuestras vidas”. En Melón D. (coord.) La patria sojera. El modelo agrosojero en el Cono Sur. Buenos Aires: Editorial El Colectivo [consult. 2020/09/20]. Disponible en:

https://www.researchgate.net/publication/324039955_La_Patria_So jera

Vivas, E. (2014) El negocio de la comida ¿Quién controla nuestra alimentación? Madrid: Editorial Icaria. 
Whiston Spirn, A. (2006) Ser uno con la naturaleza: paisaje, lenguaje, empatía e imaginación [consult. 2020/06/15]. Disponible en:

http://habitat.aq.upm.es/boletin/n38/aaspi.html 


\section{VIDEOGRAFÍA}

Abbott, J., Achbar, M., y Bakan, J. (2003) La corporación. [Película]. Disponible en: https://www.youtube.com/watch?v=Bkr-paaAYJ8

Albelda, J., Sgaramella, C. y La Cosecha (2018) Carrícola, pueblo en transición. [Documental]. Disponible en: https://vimeo.com/325305402

Benenson, B. y Rosow, G. (2009) Dirt! [Película]. Disponible en: https://www.youtube.com/watch?v=71svxsE9FT8

Dion, C. y Laurent, M. (2015) Mañana. [Película].

Dopico, J. (2012) Agronautas. [Vídeo]. Disponible en: https://www.youtube.com/watch?v=0lwK-odnN1k

Eleisegui, P. (2019) La Frutilla del Postre: el caso Arroyo Leyes. [Documental\}. Disponible en: https://www.youtube.com/watch?v=b711g_wff6w\&t=828s

Felber, C. (2010) La Economía del Bien Común. [Vídeo]. Disponible en: www.youtube.com/watch?v=U4tL4eS--XM24 
González, A. y Ordóñez, B. (2014) Stop rodando el cambio. [Vídeo]. Disponible en: http://vimeo.com/67996097

González, M., Ramiro, P. y Jiménez, I. (2005) Gran superficie. [Película]. Disponible en: https://vimeo.com/2484977

Goude, E. (2009) In transition 1.0. [Vídeo]. Disponible en: https:/www.youtube.com/watch?v=HU3EihPIbB|

Goude, E. (2012) In transition 2.0. [Vídeo]. Disponible en: https://www.youtube.com/watch?v=FFQFBmq7X84

Green, T. y Hosting, R. (2009) Una granja para el futuro. [Película]. Disponible en: https://www.youtube.com/watch?v=PpZU86y4M7g

Grieco, G. (2019) Respira. [Película].

Jaud, J. P. (2008) Nuestros hijos nos acusarán. [Película]. Disponible en: https://www.youtube.com/watch?v=loEBePBfwVA

Kenner, R. (2008) Food Inc. [Película]. Disponible en: https:/www.youtube.com/watch?v=sx6K3E6nTro

Kogan, M. y Carpman, E. (2012) El cuento de la buena soja. [Vídeo]. Disponible en: https://www.youtube.com/watch?v=XVGfPrCVbmE

Robin, M. M. (2008) El mundo según Monsanto. [Película]. Disponible en: https://www.youtube.com/watch?v=PwxCEKotnbg

Picazo, L. M. (2015) Decrecimiento, del Mito de la Abundancia a la Simplicidad Voluntaria. [Película]. Disponible en: documentaldecrecimiento.com

Pons, C. (2012) La voz del viento. [Vídeo]. Disponible en: https://vimeo.com/59138479

Reyes, J. y Areces, C. (2012) Dos tomates y dos destinos. VSF Castilla y La Mancha. [Vídeo]. Disponible en:

https://www.youtube.com/watch?v=OLWE3aiJ2FI 
Spurlock, M. (2004) Super size me. [Película]. Disponible en: http://www.veoh.com/watch/v14139914cdZf59Dh

Vidor, K. (1934) El pan nuestro de cada día. [Película]. Disponible en: https://www.youtube.com/watch?v=yLfDkaogbc8

Viñas, M. (2004) Hambre de soja. [Película]. Disponible en: https://www.youtube.com/watch?v=gsEiZkcZksU

Wagenhofer, E. (2005) Nosotros alimentamos el mundo. [Película]. Disponible en:

http://asambleademajaras.com/videos/detalle video.php?idvideo= $\underline{255}$ 



\section{ANEXO I}

\section{KULTIVATOR}

\section{ENTREVISTA PRESENCIAL 02/04/2019}

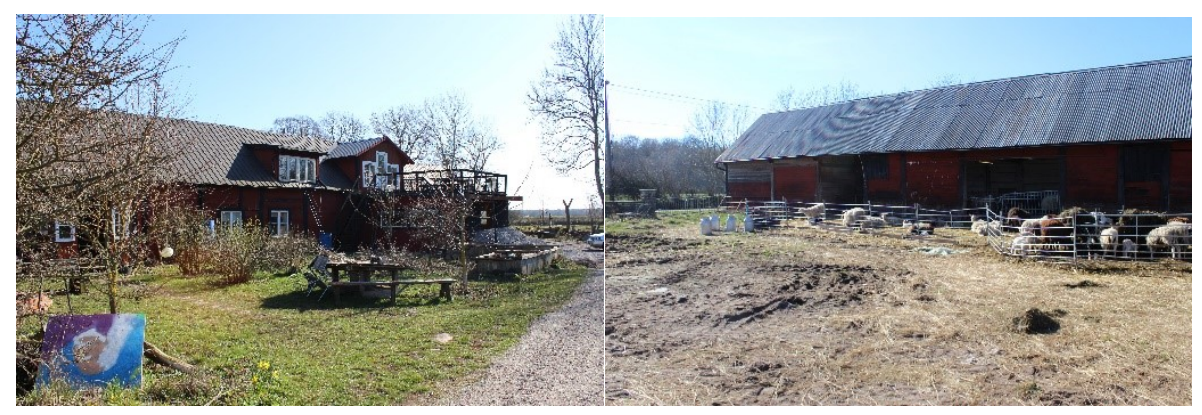

Imagen 247. Vista casa Kultivator,

Suecia, 2019. Fuente: propia Imagen 248. Granja de Henric Stigeborn, Kultivator. Suecia, 2019. Fuente: propia

El proyecto de Kultivator ${ }^{38}$ está situado en el pueblo rural de Dyestad, en la isla Öland, en la costa sureste de Suecia. Los artistas Mathieu Vrijman, Malin Lindmark Vrijman y Marelene Lindmark junto a los agricultores Henric

\footnotetext{
${ }^{38}$ www.kultivator.org
} 
Stigeborn y Maria Lindmark, crearon esta iniciativa donde proporcionan un espacio de encuentro y trabajo que busca puntos de unión entre la agricultura y el arte. En la isla de Öland se sitúa la residencia, el espacio expositivo y la granja lechera.

\section{1. ¿Cuántos años llevan en Kultivator? ¿Cuál es su papel en Kultivator?}

En 2005, yo, Mathieu Vrijman con Malin Vrijman y Marlene Lindmark junto a los agricultores Henric Stigeborn y Maria Lindmark, fundamos Kultivator, una cooperación experimental donde fusionamos la agricultura orgánica con las prácticas artísticas.

Actualmente, los coordinadores artísticos somos, yo, Mathieu Vrjman junto a Malin Lindmark y el gerente de la granja, Henric Stigeborn. Pero, según con el proyecto que estemos trabajando colaboramos con otros agentes.

\section{2. ¿Cuáles considera que son los puntos fuertes de unión entre el arte y la agricultura?}

Puede ser una respuesta muy larga, lo vemos como las dos cosas más esenciales para la vida y las personas, tener arte y agricultura. Practicar con los materiales, con las necesidades corporales, y también teniendo otros tipos de cultura en la memoria. El cuerpo y la mente unido es como el arte y la agricultura, los trabajos son paralelos en la agricultura y en el arte, porque estás trabajando con tu alrededor y tomas conciencia de tu alrededor, y estas produciendo comida para los animales o autoabastecimiento. En nuestro caso nos salió mal en el aspecto económico, pero el arte y la ecología favorecieron a la granja como una empresa.

Hay otras similitudes entre los dos, el arte y la agricultura en Europa ha sido como un interés de estado y el grupo europeo ha apoyado con subvenciones a granjeros, es una cosa cultural y están apoyando el arte y la cultura. Nosotros, estamos intentando buscar subvenciones y proyectos en los que nos puedan ayudar a seguir con el funcionamiento de la granja, que sea un interés en común para ellos y el estado. 
Un punto fuerte, cuando empezamos no había ningún artista contemporáneo en el campo, todos están en las ciudades. Nos mudamos por la enfermedad de la vaca loca, como la que tenían en Inglaterra, matando todas las vacas por la enfermedad. Normalmente, cuando un país tiene un trauma como la guerra de Vietnam, el arte ayuda a reflejarlo. Cuando preguntas a un granjero qué es lo bueno de trabajar con los artistas, dicen que les dan visibilidad. Enseñas a los pueblos y ciudades como trabaja un granjero, si no, solo se refleja la vida en las ciudades. Y eso creo que también es muy importante, porque está muy escondido y también tienen una idea muy antigua de que es un granjero, piensan que es un iletrado que está haciendo vueltas en el campo, pero no es así, están muy avanzados en tecnología y maquinaria, es una empresa con industria.

Muchas veces hablas con la gente y les dices que no es nuevo, como Vicent Van Gogh que iba al campo a pintar y luego vendía los cuadros en la ciudad, en cierta manera, no es tan diferente, aunque las granjas ya no son tan bonitas como antes.

\section{3. ¿Cómo cree que puede fortalecer y favorecer el arte a la agricultura? ¿Y concretamente hacia una agricultura más sostenible?}

Hay muchas granjas en esta isla pequeña y los granjeros aprovechan el abono de vaca por el campo, en esta manera está muy bien. Hay muchos campos también que hay abono artificial. Mañana podremos ver en la escuela como mis alumnos plantan un jardín-bosque (forest garden). Una cosa que hace el arte es mirar la belleza, mucha gente de la agricultura no le ve esa belleza y una cosa que creo, es que ahora los granjeros se están enterando. Nosotros también decimos que tenemos que capturar esa belleza, no solo de forma funcional, queremos animales salvajes por ahí para que las parcelas no estén vacías, no es bonito. 
4. ¿Cómo es la reacción del público al conocer su proyecto? ¿Y la implicación en los posibles proyectos colectivos?

Es muy diferente cada granjero, pero Henric que está trabajando con nosotros, él entiende que es importante. Yo creo que él está contento porque están pasando cosas bonitas, viniendo buena gente, ayudando en la granja y practicando con cosas. Pero, si es arte bueno o malo da igual, él está interesando en contar su historia, quiere decir su situación de granjero para que se enteren en las ciudades, le gusta que suene su voz.

Hay otros granjeros que preguntaban si Henric estaba bien de la cabeza por estar metido en el tema del arte y la agricultura, pero poco a poco están convenciendo a los demás granjeros. También, desde que nuestros hijos van al colegio y conocen otros hijos de granjeros, hay más dialogo entre todos por el tema de los niños y ya no nos ven como algo sospechoso. Nuestra casa siempre está abierta para que puedan venir a visitar nuestro trabajo, porque la gente nos ve trabajando mucho pero no saben qué hacemos, así pueden ver cómo hacemos una pieza de arte.

5. ¿Tiene algún tipo de subvención del estado para la financiación de los proyectos? ¿En caso negativo, como financian las acciones, exposiciones...?

Nosotros ganamos dinero por los proyectos que hacemos, pero no es algo constante, no tenemos apoyo continuado. Mucho de esto también funciona por el intercambio de favores, intercambio de comida y otras cosas. Pero, en principio, una fundación de arte del estado nos estaba ayudando para defender el campo, pero no tenemos sueldo permanente. Y, ahora, estamos desbordados porque nuestro nombre es bueno y vienen muchos artistas, hasta están pagando ellos mismos para venir. Ahora acabamos de existir, por ejemplo, tú estás aquí. 


\section{6. ¿Tiene referencias o conoce otros proyectos similares, donde se relacione el arte con la agricultura?}

Sí, tenemos tres páginas de web, pero una de Mathieu la han robado. La Boda del arte y la agricultura es el proyecto que está en la página web, para ver quién está en el pasado y quién está avanzando. My villages, es una página de una organización holandesa e inglesa, vienen de aldeas pequeñas y trabajan con el arte y la agricultura. También, Croasdaile art, Lake District New England, Fernando García Dory, Superflex, Future Farmers America... Depende también, hay mucha gente que trabaja con el campo en la ciudad, eso entonces no es tan granjero, es muy diferente, cuando hicimos la boda, el año después, en la Segunda Conferencia Internacional en España que organizó Fernando García Dory, el Ministro de Cultura vino y volvió a escribir un manifiesto nuevo y ahora tenemos que dejar el manifiesto para la gente y la agricultura. Y, My Villages, dijo que ellos no, no estaban de acuerdo, podemos trabajar en el mismo campo, pero somos diferentes, hay granjeros que son más prácticos, otros más documentados, somos más como fusión, hasta que somos lo mismo, pero somos muy diferentes. Sentimos que es un campo que está creciendo. Hasta hay gente empezando en Bielorrusia, no sé si habrán empezado ya, pero quieren empezar, también querían usar el mismo nombre que nosotros, y les dijimos vale, pues hacedlo. Hay mucha gente que tiene interés en buscar sobre el arte y la agricultura, tenemos gente llamándonos todo el rato, de Sudáfrica, de Australia, gente joven está yendo al campo porque les da una buena sensación. Laura Fisher, también ha venido desde Australia, con una organización que está empezando ahora mismo, que tiene que ver con esto. También una mujer de Colombia nos estaba escribiendo, que hace algo parecido a esto, pero no sabemos si ha empezado.

\section{7. ¿Suelen tener muchos artistas en residencia? ¿Cuántos anualmente, más o menos?}

Cada año es diferente, algunos vienen espontáneamente y lo pagan ellos mismos, normalmente una pareja al año, a veces dos o tres personas, vienen por su propia cuenta, ahora cinco por año más o menos. No somos residencia 
oficial, es que pasa y ya está, la gente viene, nosotros no pedimos nada y ellos no nos piden nada.

8. Desde el punto de vista del arte, ¿cuáles son las formas de expresión más utilizadas en sus proyectos? ¿Acciones colectivas o individuales? ¿Escultura, pintura, instalación, acciones performativas?

Cambia mucho, no sé si alguna es la dominante, muchas veces tenemos interacción, por ejemplo, escuelas, refugios, granjas... No hacemos mucha pintura, no lo negamos, pero puede ser parte de trabajo en un taller. La gente viene aquí por placer, hacemos trabajos de instalación, proyectos para empezar a construir películas, dibujos, hasta construir casas...

Ahora estamos metidos en trabajos más fijos, haciendo arte público, otro proyecto grande que estamos haciendo es limpiando el agua del río desde la ciudad. Yo deseo tener más trabajos fijos, porque exposiciones y proyectos pequeños dan poco dinero y yo ya estoy cansado de eso. Espero que podamos empezar a hacer trabajos fijos, pero seguimos haciendo proyectos pequeños.

\section{9. ¿Cuál es la principal finalidad de sus acciones/obras?}

Mejorar el mundo.

Hay mucho para decir, cosas importantes como la sustentabilidad, la democracia y la justicia social, son todos en general, todos son importantes.

10. ¿Les interesa la propia estética asociada a los cultivos, como por ejemplo los permaculturales como otra vía de expresión artística?

Sí, definitivamente sí, yo creo que el arte se cambia mucho mirando los granjeros porque el arte es como nuevo, nuevo, y las granjas piensan en ciclos cerrados y en tiempos largos. En nuestras piezas de arte hemos empezado a trabajar más lentamente. También lo que pienso que pasa aquí, es como el urinario de Marcel Duchamp, que lo puso en una galería y dijo que eso era arte y así la gente empezó a mirar el urinario con otros ojos. Tenemos muchas 
cosas de arte, mucha gente viene y nos dice: ¿eso es arte? y yo les dije que no, que es un pimentón. Ay que bonito es el pimentón... ahora lo miran con otros ojos. Es un cambio de mente, les haces ver con otros ojos.

Estamos muy interesados en los bosques, los campos de cultivo inundados y los pastizales y nuestra vida, y cómo podemos hacerla para que sea una vida productiva, una zona casi salvaje, tener peces en los campos inundados... También podemos tenerlo medio salvaje, medio domesticado. Para avanzar en el proceso de las granjas sin ser cuadriculado, poder ampliar las cosas y mejorarlas, tener una zona más amplia. Un problema de Suecia, también, es que no hay ningún bosque natural, todo está plantado. Es un bosque industrial.

\section{1. ¿Qué tipo de cultivos tienen en la granja? ¿Y animales?}

Es una granja lechera, tenemos cien vacas, aquí la granja es pequeña en comparación con las granjas de la zona. Tenemos casi cien ovejas, esos son los animales comerciales que tenemos aquí en la granja. También tenemos los caballos, que están trabajando aquí en los bosques y con nosotros. También tenemos jel gatito!

Tuvimos pollos con gallinas, pero este invierno pasado vino un zorro y los mató, entonces tuvimos que comprar más porque son importantes. Y el cultivo que tenemos en el campo, el más grande que tenemos, es para dar de comer a las vacas. Es una granja orgánica, debemos tener una función en todo para que sea un círculo cerrado, esa es una de las mejores maneras de hacer funcionar la granja. Y todo lo demás que cultivamos es para nosotros y no tenemos intenciones de venderlo.

\section{2. ¿Realizan algún tipo de actividad con centros educativos cercanos?} ¿En caso afirmativo, qué tipo de actividades y qué edades tiene el alumnado?

Sí, en la escuela Ölands Folkhögskola, mañana lo verás, es muy grande y tenemos proyectos para todas las edades. En otros países, Dinamarca, hicimos una pieza de arte público con niños de nueve años en un colegio. 
Hace unos años que estamos trabajando en una cosa muy sueca que se llama Full high school, es para estudiantes más mayores. Unos son socialistas, que quieren ayudar a los granjeros para que puedan aprender por ellos mismos. Pero aquí en la isla, lo vas a ver mañana en el high school, el arte es diseñado por el alumnado, tenemos cursos generales. También tenemos mucha integración de extranjeros, trabajamos mucho con ellos, siempre que hacemos un proyecto estamos con ellos, siempre hay gente ayudando, están fusionados y ahora estamos más unidos con ellos. Mañana cuando vengas a la escuela va a parecer una escuela normal, hasta que vengas a la parte de detrás, allí verás la parte de Kultivator. Construimos, tenemos gallinas, intentamos cambiar y mejorar la escuela. Es divertido vas a verlo mañana. 


\section{ANEXO II}

\section{MANDARINA BORDA}

\section{ENTREVISTA PRESENCIAL 21/04/2019}

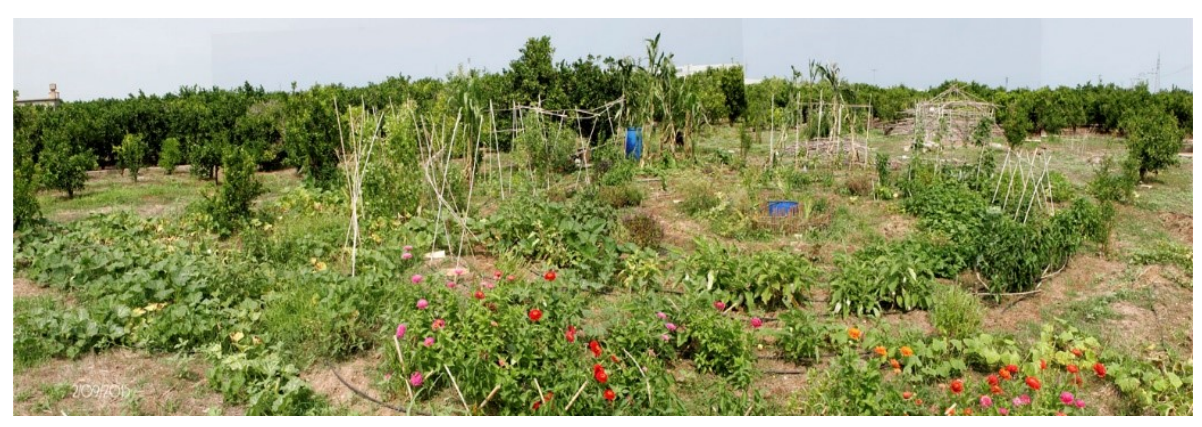

Imagen 249. Vista huerto mándala, Mandarina Borda. Palmera, Valencia, 2019. Fuente: Enriqueta Rocher

La asociación sin ánimo de lucro Mandarina Borda ${ }^{39}$ fue fundada por Enriqueta Rocher en 2012, está ubicada en la población valenciana de Palmera (España). Esta iniciativa nace como un espacio de creación e investigación donde confluyen varias líneas de trabajo, pero todas ellas

${ }^{39}$ www.mandarinaborda.org 
vinculadas a la naturaleza (huerto mándala, food-art, mapa corporal y creaciones con restos orgánico, entre otros). Así pues, dispone de una residencia para artistas y, anualmente, lanza la convocatoria artística Trastellaor, abierta a cualquier creador o creadora que tenga interés en las citadas líneas de trabajo, independientemente de su edad o nacionalidad.

\section{1. ¿Cuántos años lleva con el proyecto Mandarina Borda?}

Desde el 2012, siete años llevo.

\section{2. ¿Qué le llevó a relacionar el arte con la agricultura?}

Fue a través de la geometría, yo llevaba un tiempo trabajando el paisaje del cuerpo con la fotografía, instalación... y al estar aquí y ver el huerto abandonado, sentí que debía regenerarlo, luego me di cuenta de que estaba recorriendo el sentido inverso, con la fotografía y la instalación había trabajado desde el cuerpo para llegar al paisaje, ahora se trataba de trabajar el paisaje para llegar al cuerpo. Lo vi como una materialización de las ideas planteadas con la fotografía y la instalación.

Por otro lado, estaba interesada en plantear un proyecto de arte y naturaleza, si mi territorio era agrícola, tenía que hablar de agricultura.

\section{3. ¿Cuáles considera que son los puntos fuertes de unión entre ambos mundos?}

La vinculación más primaria del hombre con el territorio se da a través del alimento. Somos lo que comemos, el territorio nos nutre. La forma en que un fruto está cultivado va a determinar la forma en la que un cuerpo se construye, no sólo a nivel material, sino también energético.

La geometría, como manifestación energética, me sirvió de puente que enlazaba al hombre con la naturaleza, que establecía un elemento común entre todos los seres vivos y los definía. Al utilizar la geometría para crear el huerto mándala como modelo ecosistémico equilibrado, descubrí un orden natural de creación y es a partir de ese orden que se da el proceso creativo, 
esto nos conduce al espacio, el color, la forma, la incidencia de la luz... y la gestación de esos patrones geométricos... del aprovechamiento de los materiales desde el punto de vista agroecológico y de crear con esos materiales objetos de uso cuotidiano. Los cestos que se realizaban antes, el ver una caña y decir podríamos poner aquí las semillas, hacer cestas para poner la comida, para conservar...

\section{4. ¿Cómo cree que puede fortalecer y favorecer el arte a la agricultura? ¿Y concretamente hacia una agricultura más sostenible?}

Cuando empecé con el huerto y construí el huerto mándala, quería observar el proceso creativo de la naturaleza para aplicarlo al arte. No generar sistemas e imágenes que las creamos nosotros desde nuestra mente y, claro, es mejor ver cómo funciona el universo y engancharnos a esa manera de funcionar. En ese sentido, crear como crea ese universo te da otra visión de qué es el arte y quién es el artista. Por lo menos a mí me la dio. Y, ahí, por ejemplo, creo que está muy bien recuperar el artista como chamán, como visionario, como ser sensible que percibe un poco más allá porque observa a través de los sentidos...

Cultivar de este modo genera cosechas más abundantes, menor uso de agua, todo se reutiliza y se regenera. Con todos los restos que se derivan del huerto, en vez de realizar una quema, realizamos obras de arte, le damos otros usos, hablamos de esos procesos naturales y, entonces, digamos que ahí el arte está favoreciendo también a la agricultura.

5. Ya nos ha comentado de su interés en los cultivos geométricos, ¿cuáles son sus referentes o en que autores se basa para inspirarse en este tipo de labranza?

Me dijeron que en Latinoamérica la gente cultivaba en mándala, son los chakanas, cuya tradición proviene de los incas. Buscando, lo que más me llamó la atención fue el Complejo Moray en Machu Picchu, eso es lo que más me impactó. Porque claro, vi que en esas alturas se producía gran cantidad de cultivos de diferentes climas y que se producían en un cono invertido. 
Dependiendo del lugar donde vivas tienes que aprovechar la orografía para ir hacia abajo o hacia arriba, generando esos círculos...

Investigando encontré en las líneas de Nazca la figura del Chakana, que está grabada en la tierra, muchos de los círculos de cosechas que realizan en Sudamérica están basados en esta figura.

Revisé artistas del Land Art como Robert Morris, Richard Long... artistas de los '70 que trabajaron el territorio y la geometría, bien para hablar del lugar, bien para regenerarlo. Agnes Denes, fue para mí un gran referente, ya no hablaba solo de regeneración, sino que introducía la participación ciudadana y la agricultura. Me pareció que ellos habían abierto un camino, vi el arte como un proceso en el que cada época aporta algo nuevo a la anterior.

6. ¿Cómo es la reacción del público al conocer su proyecto? ¿Y la implicación en los posibles proyectos colectivos que organiza como Trastellaor?

Hay un poco de todo, está la gente que le parece una broma que te dediques a esto y, luego, está la gente que le parece muy innovador y que le encanta, y que me pregunta ¿cómo se te ha ocurrido esto?, es que esto es genial.

A la gente le cuesta llegar al huerto y tocar la tierra con sus manos. El proyecto les parece atractivo, pero implicarse es otra cosa, es un compromiso que muy pocos quieren adquirir. Aunque la participación es mayor en el caso del Trastellaor. El hecho de conocer a artistas y trabajar con ellos es más atractivo.

\section{7. ¿Está colaborando con algún otro proyecto o asociación?}

En un principio formaba parte del grupo de agricultores locales y de grupos alternativos de autoconsumo, en aquel momento pensaba que el proyecto debía realizarse en huertos ecológicos que ya estaban en activo, como forma de dar visibilidad al agricultor y poner en valor los procesos agroecológicos, pero la visión del agricultor es económica y la del artista es cultural, por lo que 
al final no funcionó, aunque las relaciones con algunos de ellos siguen siendo buenas.

Ahora estoy con el colectivo Obertament, que es un colectivo de salud mental, ellos llevan quince años trabajando. Es un colectivo independiente del hospital, ellos están ubicados en la Casa de la Natura desde hace unos años, en Gandía. Pero, evidentemente, trabajan con el equipo médico del Hospital de Gandía. Ellos trabajan arte y salud, y como conozco a una de las personas que trabaja allí, me contactaron para ver si podíamos exportar la idea de Trastellaor allí. Ellos están en un entorno natural en el río y quieren trabajar allí, en ese entorno, para generar arte. Finalmente, el ayuntamiento no ha contestado aún, pero se hará.

Yo estoy ilusionada con el colectivo Obertament, vamos a ver cómo transcurre, porque cada uno también lleva su idea. Pero al ser un colectivo de gente que tiene una enfermedad mental, que están por decirlo de alguna manera, desubicados, todo este proceso que yo he trabajado aquí personalmente y, después, a través de la agricultura, esto es lo que me hace ilusión a mí, el poder transportarlo a otra gente, porque considero que es muy saludable. Siempre está la pregunta de hasta qué punto esta gente tiene una enfermedad mental o hasta qué punto es una gente que esta tan conectada consigo misma, que se ha desconectado del estilo de vida de la sociedad, y ese crac es lo que le ha producido lo que hoy se llama enfermedad mental.

\section{8. ¿Tiene o ha tenido algún tipo de subvención del ayuntamiento para la financiación de los proyectos? ¿En caso negativo, cómo financian las acciones, exposiciones...?}

Solo tuve subvención en la segunda edición del Trastellaor, en el ayuntamiento hubo una batalla por estirar la iniciativa y que fuera un proyecto que nacía del ayuntamiento y pues a mí eso, como esto no tiene un fin económico, no me interesaba. Primero porque dentro del ayuntamiento no hay nadie interesado en la ecología. Entonces, por lo que he visto en otros sitios, cuando tú lo metes dentro del ayuntamiento para que ellos te financien y el proyecto se haga a lo grande (que ellos estaban dispuestos a poner el 
dinero o buscar apoyos, o al menos eso decían) como no hay un equipo que esté formado, ni que tenga por lo menos el interés, esto se desvirtúa y se convierte en otra cosa, que es en realidad lo que ha pasado. El ayuntamiento cogió el proyecto, fue a la diputación, allí les encantó la propuesta, les pareció fantástico, les dieron el dinero y a mí me dieron una propina, y ellos han montado otro proyecto con otra ideología. Tiene otro nombre, ya no tiene que ver con el arte y la agroecología, entonces eso es lo que ha pasado. Yo seguí yendo para ver si colaborábamos, entonces ellos me dijeron que porque no lo traía al pueblo y yo les dije que allí no había huertos, esto se tenía que hacer en el huerto. En el primer Trastellaor, les propuse que hiciéramos unas jornadas de formación, en el Centro Social yo estaba dispuesta a hacerles una charla sobre el Land Art, para que la gente viera que esto no es una cosa que se me hubiera ocurrido a mí, sino que viene de muchos años atrás. Entonces, si ellos hubieran cedido a hacer estos talleres u otros que les propuse, se hubiera podido realizar un acercamiento a la gente. La función educativa es muy importante, pero no están interesados.

También me fui a la escuela y les propuse que participaran en el Trastellaor, que vinieran e hiciéramos una visita, que les explicáramos, que hiciéramos una visita in situ... también estoy esperando a que alguien me diga algo. No hay interés.

\section{9. ¿Suele tener muchos artistas en residencia? ¿Cuántos anualmente, más o menos? ¿Suelen contactarle o vienen a través de convocatorias?}

Pocos, este año han venido los del Trastellaor y luego un par más. Me suelen contactar, la gente tiene interés en venir, pero quieren venir gratuitamente, y no podemos sostener los gastos que se derivan de las residencias. En el Trastellaor, es diferente, la gente viene preseleccionada con un objetivo, es una convocatoria donde la gente presenta un proyecto y yo cedo todo esto, pero porque enriquece el proyecto, hay un intercambio. 
10. Desde el punto de vista del arte, ¿cuáles son las formas de expresión más utilizadas en sus proyectos? ¿Acciones colectivas o individuales? ¿Escultura, pintura, instalación, acciones performativas?

La instalación, porque es la instalación la que genera más discurso con el territorio.

11. ¿Considera que las obras/proyectos que realizan los artistas en Mandarina Borda tienen repercusión fuera de aquí y siguen investigando y difundiendo los resultados? ¿O por el contrario se quedan en una intervención puntual in situ?

Hasta el momento se había quedado aquí, pero a partir de esta edición, que ya son cuatro ediciones, ahora esto hay que expandirlo. Estoy pensando en cómo articularlo bien con los artistas de este año o bien con todos los artistas de todas las ediciones.

Como mínimo me gustaría realizar un catálogo que recoja las 5 ediciones, un documento con el que se pueda presentar y difundir el trabajo de los artistas, que pueda ir acompañada de una exposición documentada de los proyectos realizados.

Por otro lado, sería conveniente proponer visitas participativas a los centros educativos de la comarca, aunque de momento no contamos con infraestructura suficiente para hacerlo.

12. ¿Hay algún aspecto que quisiera mencionar o comentar especialmente? ¿Hay algo que le parece importante y todavía no ha sido mencionado?

Por ejemplo, con el tema específico de arte y agricultura, yo creo que el arte una de las cosas que puede aportar a la agricultura es otra visión menos pesada y de menos carga de la agricultura. Hoy en día tenemos conocimientos de permacultura, de tecnología, la cual se puede aplicar a la agricultura, siempre desde el respeto y el equilibrio. Y el arte puede convertir trabajos que son pesados en trabajos lúdicos y otras maneras de pasar el 
domingo con tus hijos o tus amigos, por decir algo, con tiempos de ocio. Y a mí eso me parece muy importante porque es volver a la naturaleza con una actitud de juego, a mí esta relación lúdica es la que me ha marcado para volver aquí, cuando era pequeña jugaba mucho con la naturaleza, veníamos aquí en verano. Es algo que nos sigue vinculando y manteniendo en contacto con la naturaleza, pero ese vínculo de cuando eres pequeño que no sea solo de ir a hacer actividades a la naturaleza, sino que sean cosas espontáneas. A mí una imagen que se me quedó muy grabada fue un día que iba con mi padre y me dijo hoy vas a ver un nido, yo era pequeñita y estaba super emocionada y luego lo vi y me emocioné un montón, hoy en día me sigo emocionando. Todo eso también es agroecología, aunque no se le da tanta importancia. Yo en ese sentido, hay muchas cosas que defiendo que ya sé que son las super básicas, pero hay que recordar que esto es super importante, aunque te parezca que sea super básico. Por ejemplo, sabes cómo funcionan los cinco elementos y cuáles son las fases, entonces puedes solucionar cantidad de cosas. 


\section{ANEXO III \\ CULTURHAZA}

ENTREVISTA PRESENCIAL 24/07/2020

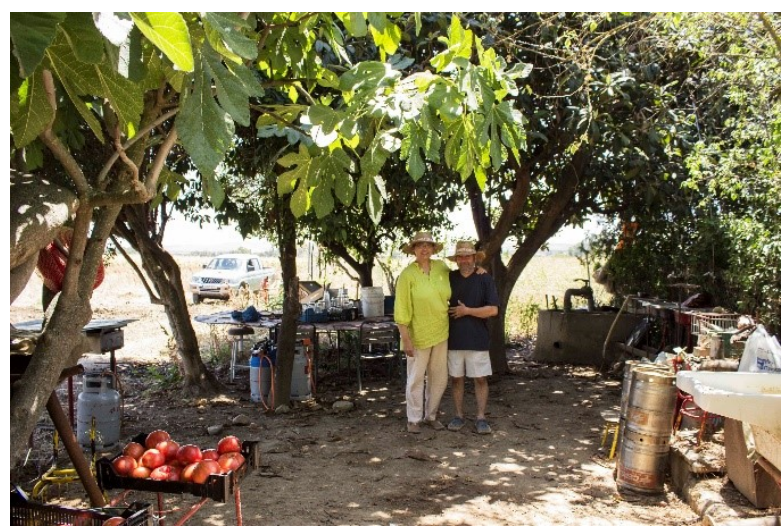

Imagen 250. Protasia y Agripino en Culturhaza. Córdoba, 2020. Fuente: propia

El proyecto Culturhazato es una iniciativa agrícola y artística situada en Villarrubia, a cinco kilómetros y medio de la ciudad de Córdoba (España). Fue

${ }^{40}$ www.culturhaza.blogspot.com 
fundada en el 2005 por Agripino y Protasia, se trata de un proyecto creativo donde vida, pensamiento, obra y agricultura se dan en la cotidianidad de sus días, bajo la denominación de Agrolandart.

\section{1. ¿Cuántos años llevan con el proyecto Culturhaza? ¿Cuál es su formación académica?}

Agripino y yo, Protasia, empezamos en el año 2005, Agripino se curó de una hepatitis y para celebrarlo nos fuimos a una Bienal de arte que hubo en Almería y creo que no se repitió más, hicimos un taller de Land Art y estuvo muy bonito, él hizo una obra que se llamaba Deceso y yo hice otra que se llamaba Comienzo.

Protasia es Licenciada en Veterinaria, especialista en parasitología y yo, Agripino, soy Licenciado en Geografía e Historia, con la especialidad de Historia Contemporánea de España.

\section{2. ¿Cuál es su papel en Culturhaza? ¿Cómo es la vida diaria en Culturhaza?}

Nosotros cuando empezamos el proyecto decidimos que yo, Agripino, estuviera como autónomo agrícola, como un agricultor más de la zona, para estar en las mismas circunstancias que están los agricultores, que es penosa. Porque es que, si no es imposible, si yo estoy en una asociación o fundación teniendo una cobertura, no me hubiera enterado de lo que es, aunque yo lo supiese por mi abuelo, mi padre, pero no es lo mismo que estando desde dentro. Yo tengo que luchar con bancos, con casas de semillas... todo eso lo he vivido de cerca. Entonces, todo eso es muy importante para poder definir el proyecto, el camino que está tomando, es un proyecto vivo... Además, tenemos la certificación ecológica, porque si no, no podemos guardar semillas, todos los años vienen y nos hacen los análisis y yo los grabo. Porque, hubo un año, que como meten gente que no tiene mucha idea, a veces hijos de latifundistas sin preparación de ningún tipo, nosotros de legislación tenemos que estar más o menos al día, yo le decía esto es cumpliendo la normativa de la ley de Coordinación de Actividades Empresariales (CAE) y me decía que no, me hizo modificar, que firmara un papel sino, no me sellaba la 
inspección y a los tres meses me vino una sanción, yo alegué y alegué, por supuesto es su palabra contra la mía porque no tengo ninguna documentación que diga lo que él me dijo, porque él lo negaba todo. Por supuesto, no pagué la sanción, estuve alegando y alegando, por eso al final dije, a partir del año que viene cada inspección la grabo en imágenes y sonido y cuando vienen se lo digo, os grabo porque no me fio de vosotros.

Este año, 2020, nos ha llegado un inspector de la Política Agrícola Común (PAC) y antes de saludar, literalmente me dijo, "vengo a demostrar que está engañando a la administración" y le dije, pues mira cógete el coche, te vas hacia Sevilla y me sancionas porque yo te voy a denunciar. Primero porque él no puede llegar a una persona que está trabajando, sea verdad o sea mentira, no puede llegar así a casa de nadie y, segundo, porque fue un maleducado. Él piensa que por regla general los agricultores son todos unos imbéciles, culturalmente el agricultor siempre ha recibido todos los palos y el problema es que la administración lo fomenta, porque lo primero que tienen que venir es con educación y si saben que no tienen preparación con más respeto deberían de tratarlos. Por eso, yo le dije, o te disculpas o aquí no entras. Nosotros cumplimos la norma europea, pero como no lo hace nadie, no se fiaban. Entonces, al final se disculpó, porque dijo sabía que la norma europea es así, pero al menos en Andalucía nadie la cumple y nos dio la enhorabuena.

Pero, no son formas de venir en un primer momento de la forma que vino. Estuve 3 horas con él, pregunta que me hacía, le respondía y le demostraba sobre la tierra y le mostré todo, yo no tengo que esconder nada. $Y$ todo esto retrasó el pago nuestro de la PAC. Y, luego, los vecinos de ahí al lado han hecho un drenaje, que yo lo he denunciado, y están tirando toda la porquería a los acuíferos, que a los vecinos de aquí hacia allá no pueden beber de sus pozos, que también es de un antiguo aljibe árabe y se lo han cargado, y, sin embargo, ahí no pasa nada. Ese hombre tiene 37 trabajadores, ninguno asegurado, con productos fitosanitarios permanentemente echándolos y, los de la línea verde de la diputación del ayuntamiento, pasan todos los días, y no pasa nada. Y, nosotros, que somos los únicos que estamos haciendo esto 
en Andalucía, en lugar de decir vamos a ayudarles, pues nos sancionan, nos ponen trabas...

Por eso te digo que esto es un proyecto de reivindicación social porque esto es maltrato a una institución que es el sector primario, y eso el común de la población lo tiene asimilado, las palabras gañán, la palabra burro... toda esa nomenclatura... y no saben lo que es un gañán, un gañán debía tener un conocimiento del territorio y de los animales, que más de uno quisieran tener, por muchos títulos que tengan. Y, a mí, ese sentido peyorativo de un montón de términos que están usándose todavía, políticos, periodistas... a mí me agreden mucho, lo que pasa que yo ya si puedo no me callo.

\section{3. ¿Qué los llevó a relacionar el arte con la agricultura?}

Protasia escribía poesía, colabora con su hermana que es artista y su hermano fotógrafo y, yo, Agripino, trabajaba con la escultura con materiales reciclados. Y venimos de tercera generación, de su padre ganadero y el mío agricultor.

Mi abuelo migró aquí a Córdoba, yo heredé estas tierras. La situación económica del mundo agrario está muy mal, supongo que con la tesis te habrás dado cuenta cómo está, es por ello por lo que llegó un momento que me di cuenta de que el sistema de trabajo de mi padre había quedado obsoleto con la realidad socioeconómica que había. Entonces, nosotros nos planteamos, vamos a iniciar un proyecto que tenga que ver con lo que a nosotros nos gusta del arte contemporáneo y la agroecología. Para un poco encauzar la conversación, queremos remarcar que diferenciamos entre la ecología y la agroecología, siempre vamos a hablar del concepto de agroecología en el que el ser humano está también ahí metido.

Entonces, decidimos dar el paso, en un principio habíamos pensado montar esculturas, pero poco a poco nos dimos cuenta de que lo importante era recuperar el conocimiento agrícola. Entonces, nos ha derivado por formación y por todo, a ese camino de hecho, ahora mismo nuestras piezas son piezas agrícolas, el paisaje agrario para nosotros es muy importante. Me estoy 
derivando, pero Protasia es veterinaria, está trabajando en un Centro de Investigación de Extremadura, ella no vive aquí y, yo, pues estoy aquí permanentemente sacando el proyecto adelante. Hemos realizado la conversión, hemos recuperado todas las semillas, todas las semillas que hay aquí son nuestras, estamos incorporando plantas nuevas, por ejemplo, aquí nunca se ha hecho lenteja y este año hemos conseguido cultivarla. Nosotros vamos intentando, todo el conocimiento que hemos recibido de nuestros antepasados que lo hemos recibido con la práctica, integrarlo en el proyecto de agroecología a través de las nuevas tecnologías.

\section{4. ¿Cuál consideran que tiene más relevancia en su proyecto, el arte o la agricultura?}

Nosotros siempre hemos dicho 50\% arte - 50\% agricultura, pero nos estamos dando cuenta que poco a poco el concepto de la biodiversidad dentro de los cultivos, esto son siete hectáreas y media, tiene la suficiente fuerza como para que sean piezas de arte. Ahora, dentro de eso, nosotros hacemos performances, hacemos música... y trabajamos con artistas o con gente en general, porque otra de las cosas que nosotros queremos dejar claro, esto es un proyecto de activismo social, eso lo tenemos muy claro. Porque lo que está pasando con la agricultura a nivel mundial es una vergüenza y reivindicamos el reconocimiento del sector primario como un sector fundamental y el de la cultura, porque cultivo viene de cultura, cultura viene de cultivo, las palabras no son gratuitas. En el mundo entero y, especialmente en este país, el reconocimiento social que hay del agricultor es nulo, por eso siguen manteniendo precios de hace 40 años, por eso las tierras se están perdiendo, se están salinizando, nitrificando...

Nuestro proyecto creativo más importante, ahora mismo, es demostrar que se puede hacer agroecología sin utilizar ningún producto, incorporando el manejo de las arvenses al cultivo agrícola, a las plantas domésticas y está funcionando maravillosamente. Hasta hace relativamente poco tiempo nos podían decir, bueno, pero eso cuando lo pases a unas dimensiones más grandes, no se puede hacer, pero ahora no nos puede decir nadie eso. Nosotros hemos recuperado la escanda, es el primer cereal que se cultivó en 
el neolítico, con el que empezó la agricultura, cultivo que tiene 11.500 años datado con la cultura del algar en Almería. Protasia es asturiana y, allí, fuimos buscando escanda antigua. En su pueblo encontramos medio kilo, con ese medio kilo hemos ido adaptándolo, se nos caía, hemos ido viendo las técnicas agrícolas, año a año, prueba y error y hemos conseguido una planta maravillosa, que estéticamente es preciosa.

Entonces, al final, lo que estamos haciendo es reconducir la situación con los artistas y con la gente que quiera hacer sus piezas aquí a la adaptación total al ciclo agrícola, no al revés, no que el artista llega y se adapta el ciclo a él. Teniendo respeto por las plantas, el medio... los detalles los cuidamos mucho en ese sentido. La cuestión es que poco a poco se ha ido definiendo el proyecto, a través del conocimiento que vamos adquiriendo más con la experiencia de todos los procesos agroecológicos, tierra, semillas, manejo... En el plan artístico estamos muy influenciados por el movimiento Fluxus, en lo que todos somos artistas.

\section{5. ¿Cómo es la reacción del público al conocer su proyecto? ¿Y la implicación en los posibles proyectos colectivos que han organizado?}

Nosotros trabajamos el boca a boca, aquí viene la gente y parte de nuestro trabajo artístico es sentarnos y explicarles, mira tenemos sandía, esta sandía viene de... El diálogo es una acción artística contemporánea para nosotros. Nuestro proceso de trabajo ha sido que la gente venga a la huerta a recoger sus pedidos, nosotros no nos desplazamos. A lo largo de la semana nos hacen el pedido que quieren y los viernes se dedican a venir a recogerlo, nosotros nos encargamos de recogerlo media hora antes, siempre maduro, siempre maduro, siempre maduro, porque eso voy a hacer mucho hincapié y se lo llevan siempre fresco para la semana, para que lo consuman siempre con máxima calidad. El hecho de que venimos trabajando con familias ya casi 15 años, niños que venían aquí, a este espacio, como una cosa lúdica se han ido con la conversación, con el juego, se han ido quedando con tal, comen verdura, saben mucho de plantas... y ese es nuestro bagaje como pieza artística global. Entonces, no es tanto, la incorporación de piezas, que, si hay que hacer una pieza de adobe, una escultura en mitad del terreno... se hace 
porque viene a colación de lo que cualquier artista nos quiera proponer. Pero, cada vez nos interesa más trabajar con gente que no es del mundo del arte.

La pieza Vinilo, para nosotros es una pieza emblemática, se lo propusimos a uno de nuestros clientes, Jacobo, que es músico autodidacta, pero es increíble, él nunca había realizado una pieza performativa, había que animarlo. Se dio la circunstancia que Isabel, una mujer que también nos compra, tuvo un hermano que recientemente falleció de cáncer muy joven y era músico, tenía un grupo de música, ella le enseñó mucho conocimiento de la música y luego ya era él el que le enseñaba a ella. Entonces, él se murió y, una vez pasaron unos meses, otro músico italiano vino a hacer una comida de pasta, la que le gustaba a él e iba buscando albahaca ecológica y no encontró por toda Córdoba. Nosotros normalmente no tenemos albahaca, pero justo ese viernes puse a todo el mundo un ramito de albahaca. Entonces, cuando desmontó el pedido y encontró la albahaca se emocionó muchísimo.

A raíz de eso, yo le propuse a Isabel, bueno Jacobo quiere producir algodón para su zanfona y tú con la albahaca, porque no planteáis una pieza juntos. Entre ellos empezaron a hablar, Jacobo también es ilustrador, salió el tema de lo del hermano de Isabel y llegamos al acuerdo de hacer un círculo y dentro una espiral áurica con el algodón, alrededor un círculo imitando un vinilo, entonces le pusieron el nombre de Vinilo. La pieza consistió en llevar los dos cultivos a término, desde la siembra, el deshierbe, el riego...y mientras tanto se hicieron algunas intervenciones, una de ellas fue que Isabel se trajo su tocadiscos con los discos que escuchaba con su hermano, nos sentamos allí en una comida, en el mismo entorno de la pieza mientras iba hablando iba poniendo los discos, fue precioso. Era vinilo porque un fin de año, el hermano de Isabel le pidió la colección de vinilos y se los robaron, ella se enfadó mucho, pero luego quiso darle un homenaje tras su muerte con ese vínculo de la música que tenían ambos. Fueron muchas circunstancias emocionales las que se dieron a lo largo del año, ellos se sembraron todo, lo hicieron todo ellos y sin saber nada.

Resultó una pieza muy hermosa, cuando ya montamos el vídeo, quedamos con todos sus amigos y toda la gente cercana y lo proyectamos junto con la 
celebración de otra cena para finalizar la pieza. Entonces, en este concepto de trabajar con la gente, ahí nos dio tiempo de hablar de las plantas, de la tierra, de los polinizadores... es un proyecto muy completo, ese es nuestro ideal de trabajar con la gente. Luego, si vienen artistas y se incorporan a esa forma de trabajo, perfecto.

\section{6. ¿Cómo creen que puede fortalecer y favorecer el arte a la agricultura? ¿Y concretamente hacia una agricultura más sostenible?}

El arte es como un ariete en todos los aspectos, entonces para la agricultura también puede servir, para abrir puertas, horizontes... por ejemplo, nosotros tenemos un molino de harina porque hacemos el ciclo completo de la escanda, con molienda a demanda una vez al mes. Para nosotros esto es una pieza de arte, lo máximo que molemos son 200 kilos al mes, según la normativa europea nosotros no debemos tener ni registro sanitario, pero como cada país puede adecuar cada normativa y, luego, el estado les ha dado la potestad a las autonomías, pues nosotros hemos intentado legalizarlo porque estamos alegal, y viene la inspectora y nos dice debes tener una habitación para cambiarte, un servicio y un grifo de agua, pero mi casa está a tres metros.

Lo que ellos plantean es para la gran industria que hacen moliendas de miles de kilos al día, pues no hay manera. Nosotros no mojamos el trigo, nosotros lo hacemos puro, porque es un trigo vestido, que está a oscuras que no tiene contaminación de ningún tipo, lo pelamos, lo molemos y se lo damos al cliente. No hay ningún peligro de nada, por lo tanto, lo que hemos pensado es que me voy a dar de alta como artista y todos los meses vamos a hacer una exposición, hemos consultado a una abogada, vamos a poner no apto para el consumo humano, total, los clientes ya los tenemos. Es una pieza de arte que yo hago todos los meses y las vendo, me pueden crujir, pero estamos dispuestos a hacerlo porque es una forma de reivindicar que no se puede tratar a una industria artesanal como a una gran industria. Es un riesgo, pero yo es que quiero seguir produciendo esta variedad, no quiero perderla, porque encima la variedad de Asturias se ha hibridado con la alemana y ya 
no es la escanda antigua, así que somos de los pocos que tenemos la escanda antigua.

Entonces, ¿cómo vamos a perder esta especie? yo no puedo mantenerla si no la comercializo porque forma parte del proyecto artístico. Entonces yo ahora estaba en módulos y me voy a pasar a estimación directa, porque en módulos no puedo ser autónomo agrícola y artista, entonces me paso y lo vamos a hacer, como acto de reivindicación. Porque si nos tenemos que atener a la administración, perdemos la especie y nos costó mucho recuperarla.

Nosotros, parte del trabajo y parte de lo que ahora mostramos como trabajo artístico es demostrar que se puede hacer agroecología rodeado de convencional, tenemos infinidad de polinizadores, insectívoros, sapos... nosotros lo que hemos hecho ha sido recuperar el ecosistema, luego ellos han venido solos.

Tenemos un pozo, que era un antiguo aljibe árabe, que mi abuelo para no tener conflictos hereditarios con el vecino, lo medió, el vecino lo enterró y él dejó el pozo, está registrado. Y, luego, tenemos agua de confederación, del pantano. Hemos conseguido poner en ecológico a la vecina de al lado. Tenemos una anécdota con las abejas, había girasol convencional en el cultivo de la parcela del vecino y las abejas se estaban llevando el polen del maíz, el maíz no tiene néctar, es un polen seco y no les gusta a las abejas, pero preferían llevarse el polen del maíz ecológico antes que el del girasol convencional que es el que les gusta. Tuvimos un 25\% más de producción de maíz, toda la vida aquí sembrando con mi padre y nunca había visto a las abejas llevarse el polen del maíz, jamás. Tenemos grabaciones porque aquello fue algo inaudito. Entonces, lo importante del proyecto nuestro, para nosotros, es ver como en 20 años se pueden hacer las cosas de otra manera y es falso que no haya buena producción... la Revolución Verde fue una gran mentira. 


\section{7. ¿Están colaborando con algún otro proyecto o asociación?}

Estos dos años estamos intentando ayudar a Omoyemwen a tener sus papeles, que es una chica con 26 años que ha cruzado el Mediterráneo con patera, que ha sufrido lo peor que pueda sufrir una mujer. Estamos intentando ayudarla y hemos cambiado nuestro chip totalmente, incluso la parte creativa, para hacer una huerta más grande para sacar su sueldo, con muchísimas dificultades, pero es que la huerta Mucho Cucho, que es como se llama, para nosotros es una pieza de Agrolandart, nuestra pieza más social porque nos ha servido a día de hoy para identificar un tipo de sociedad como es la cordobesa, retrógrada, cateta, latifundista... yo ahora mismo tengo totalmente asimilado el tipo de sociedad en la que estoy viviendo. El latifundismo ahora mismo, ni en la época de la Segunda República ni en Primo de Rivera, ahora es más que nunca, tu piensa que seis familias nobles de España se llevan casi el 75\% de las subvenciones de la Unión Europea. Nosotros reivindicamos que la alimentación no puede ser para una elite, nuestros productos tienen un precio que no son los que están en Mercadona porque eso es una vergüenza. Un tomate que solo tenemos nosotros de una semilla de hace 120 años, el tomate rosado, que lo están trayendo de Navarra, de Sevilla que lo están vendiendo como de un pueblo de aquí que tiene fama y ninguno se hace aquí, todo viene de fuera y lo están vendiendo a $6 €$ el kilo y nosotros a 2'40 €, encima ellos lo recogen verde. Para nosotros ese tomate es emblemático porque lo que nos ha ayudado a llegar hasta septiembre con el sueldo de esta chica, ha sido el tomate, el valor que para nosotros tiene no solo agrícola sino socioeconómico esa planta.

Nos pusimos en contacto con una asociación de mujeres en zona de conflicto, que están trabajando con mujeres inmigrantes, de malos tratos, supervivientes de trata de personas... Omoyemwen está viviendo con nosotros, hemos intentado por todos los medios mantener su sueldo, pero no ha respondido la ciudad y no ha respondido gente que tenía que responder por el proyecto. Nosotros no buscamos el proyecto, nos buscaron a nosotros y luego todo el mundo en el momento que significa cambiar mi ritmo de vida, la gente no quiere. Nosotros hemos intentado sacarlo para 
adelante, durante el confinamiento muy bien, vendimos muchísimo, pero cuando se acabó el confinamiento bajó la demanda.

Estamos también en otro proyecto que se llama Alimentando Córdoba y hay cuatro agricultores de aquí que están absorbidos por una cooperativa que tiene más fuerza, que es de un poco más al sur y están haciendo comida ecológica para la gente más desfavorecida, que yo decía mira que bonito. Pero, ya se acabó y la cuestión es que es un proyecto que siguen vendiendo como si funcionara y yo no les llevo ningún producto a ese sitio.

Cuatro personas que estamos haciendo huerta hemos conseguido que Merca Córdoba nos ceda un espacio, que nos monte una cámara frigorífica, para tener un espacio porque claro debemos tener el registro sanitario para poder manipular... si somos cuatro agricultores, yo he estado en Alemania y Francia en mercados y esto no sucede... además, aquí llevamos un año y aún no han empezado la obra y es montar una cámara frigorífica y levantar un poco el techo. Entonces, con este bagaje y conocimiento de la sociedad cordobesa, nosotros no vamos a cejar en hacer las cosas como las estamos haciendo, pero vamos a reinventarnos y tirar hacia la legumbre, hemos recuperado un garbanzo negro, una habichuela pinta, una judía mungo verde y este año hemos empezado con las lentejas. Vamos a hacer venta directa online, porque son productos que al ser semilla antigua hasta ahora no le ataca ningún bicho, sin utilizar conservantes, los sistemas de transportes ya han hecho una línea de trabajo para poder trabajar con agricultores así, con esto del confinamiento todavía están dando más dinero para eso. Y esperamos que se amplíe el abanico de posibles compradores.

\section{8. ¿Realizan algún tipo de actividad con centros educativos cercanos? ¿En caso afirmativo, que tipo de actividades y que edades tiene el alumnado?}

Sí, tuve a un chico hace seis meses y este año iban a ser quince. También hemos realizado una performance con un centro de los antiguos correccionales, aquella fue una historia muy bonita, conocimos a una de las monitoras y todos encantados, la performance consistía en que tenían que trillar el guisante en una era de piedra que hicimos y había que hacer ejercicio, 
saltar y demás y estuvieron como una seda. Las monitoras dijeron que jamás habían visto algo igual, no habían tenido que darles pastillas para tranquilizarlos, fumaron la mitad, estuvieron colaborando, nos preguntaron que a nadie les preguntan, se solían poner violentos y aquí nada. Es otra de las cosas que nosotros hemos observado, el tiempo más largo de la vida del homo sapiens ha sido el agricultor y lo tenemos todos en el ADN, por eso en el momento que tú sabes crear el contexto adecuado eso sale, intuitivamente. Por esa vía creo que es muy interesante también llegar a la gente, pero para eso ha de ser con un contacto directo, eso no puede ser a través de un vídeo...

También participamos con un máster en Jaén, antes venían aquí, que yo quiero que sigan viniendo, preparábamos una performance participativa, pues desde abonado con estiércol, siembra de garbanzos, recogida de lo que sea... para el grupo del máster, este año han sido 40 alumnos/as y aprovechamos para hablar de todas estas cosas.

9. Desde el punto de vista del arte, ¿cuáles son las formas de expresión más utilizadas en vuestros proyectos? ¿Acciones colectivas o individuales? ¿Escultura, pintura, instalación, acciones performativas?

Nosotros hicimos una pieza hace ya 3 años, en el C3A, el Centro de Arte Contemporáneo de aquí, con habas, con escanda y con arvenses, pues bueno, la institución del C3A, como aquello le pareció tan extraño, tan raro, no nos incluyó en el catálogo, ni en la guía del museo. Resultó una pieza maravillosa, porque todo el proceso fue muy bien y, al lado de nuestra pieza, había un olivo en una maceta, era la pieza de Yoko Ono, que si ella supiera que sacaron un olivo para ponerlo en una maceta seguramente protestaría, porque su pieza de los años 60 era con un olivo vivo, no en una maceta, que han tergiversado también. Nosotros integramos hasta el barrio, vinieron a preguntar, a la cosecha... fue una preciosidad de pieza, pues a la institución como tal la pieza no le entró por el ojo.

El problema de esto es que es una cultura que se pierde y, es la verdadera cultura. Como nuestros antepasados que solo con mirar sabían qué pasaba, 
no les hacía falta ni un dron ni nada, esa cultura es la que se pierde. Aquí vinieron con un proyecto de una empresa con la beca Madame Curie, tres agrónomos, una americana, un español y un inglés que pretendían poner la semilla en el suelo así de duro, eran unas máquinas en laboratorio e investigación, pero no tenían conocimiento del territorio, cero conocimientos, y yo les dije yo no estoy aquí para hacervuestro trabajo, hablé con el director y tuvimos nuestros problemas porque yo era colaborar no hacer su trabajo. Entonces, lo que me demuestra, es que se sigue haciendo huella en que el sector primario no importa.

Nuestra idea del proyecto Culturhaza, es poder pasar el testigo a nuestros sobrinos, nosotros hemos armado la base y ellos seguirán construyendo el proyecto, para que no se pierda el conocimiento. Que nunca se sabe lo que pueda pasar, pero por lo menos ya hay ese traspaso de conocimiento y eso da mucha energía para continuar. Para nosotros ahora mismo lo más importante del arte contemporáneo es la conversación, contar, enseñar... eso en realidad es lo que va a dar pie a que puedan entender algo más de todos los procesos económicos del sector primario y valorarlo. Es muy difícil, yo no voy a cambiar el mundo, pero por lo menos en la parcela que tenemos, intentarlo. Aquí tenemos siete hectáreas y media, con la casa, los frutales y todo. De esta tierra vivían tres familias, en los años 30-40, con muchos hijos, hoy en día aquí tres familias, imposible. Lo peor de todo es que nuestro proyecto tiene ya un reconocimiento de todo el mundo, somos un ejemplo, pues como mínimo facilitarnos las cosas, no estamos pidiendo dinero, pero menos trabas, que nos tienen con investigaciones cada seis meses.

\section{0. ¿Cuál es la principal finalidad de las acciones/obras que se producen o se han producido en Culturhaza?}

Yo siempre entiendo el mundo del arte como un paso más del convencionalismo social y tiene que arriesgarse, no se puede hacer arte como en el siglo XIX, el arte tradicionalmente y en su sentido más bello es el que detectaba los problemas reales de la sociedad y el problema ahora real es la alimentación, porque ahora interesa la tierra, el agua y la semilla. Porque lo que se está barajando aquí es que John Deere, el fabricante de maquinaria 
agrícola americano se va a quedar con todo, el pack entero, las tres casas de semillas que han quedado en el mundo las va a absorber y va a crear un pack productivo en el que el agricultor simplemente tenga que hacer lo que ellos digan, ahora tienes que echar este producto, ahora tienes que hacer esto... eso es lo que nos viene, eso es real. Hace poco han probado en Dinamarca un tractor que siembra 800 hectáreas en una mañana, esto conlleva que solo se siembra una variedad y que la semilla sea exactamente igual porque si no, no vale, con lo cual pierdes toda la biodiversidad. En Bélgica, por ejemplo, no tienen biodiversidad agrícola, todo monocultivo.

Hemos conocido un chico que trabajaba en Francia en un proyecto ecológico pero comercial y sembraban tres cosechas en un año, en ecológico sobre la misma tierra, es una multinacional de agroecología y lo que hace es echar mucho estiércol y al final él se fue porque hicieron un ensayo de cómo estaba el terreno por tanto estiércol y tenían más problemas de nitrificación que con el abono químico. Y, en lugar de decir vamos a poner remedio, lo escondieron y tiraron hacia adelante porque estaban ganando mucho dinero. Es que es por todos lados, ahora la agroecología es industrial también, por eso hay que ser más radical que nunca porque la situación es muy comprometida.

\section{1. ¿Tienen referencias o conocen otros proyectos similares, donde se relacione el arte con la agricultura?}

La semana pasada encontré a una chica en Hong Kong que es fotógrafa y se puso a trabajar en una huerta y ella dice, "si no conoces la agricultura no puedes apreciar esto". Y eso es lo que decimos nosotros también, y la idea de respetar los ciclos agrícolas, los tiempos, la persona que intervine, al final cuando termina el proceso, de pronto cuando se para a pensar ve que está de otra manera, todo eso para mí tiene que ver mucho con el concepto de arte contemporáneo, reivindicativo, de arte social que nosotros tenemos. Porque al final, lo que nosotros queremos es que haya un reconocimiento de la figura del agricultor. 


\section{2. ¿Hay algún aspecto que quisiera mencionar o comentar especialmente? ¿Hay algo que le parece importante y todavía no ha sido mencionado?}

Nosotros hemos estado trabajando durante seis años con una investigadora, con Ma José Suso, del Consejo Superior de Investigaciones Científicas (CSIC), muy interesante, es una de las máximas especialistas del mundo en habas, en leguminosas y está llegando a las mismas conclusiones, a través de las investigaciones científicas, que nosotros. Ella es la única, por ejemplo, en el centro de investigación que hay aquí, que es partidaria de los bancos de semillas, que todos los años se recupere semillas, ella nos ha dado un haba de flor de color roja que es preciosa que llevaba 100 años sin activarse. El primer año que la activamos fue el año pasado, la semilla este año ya ha sido más homogénea, pero todavía con defectos. Qué pasa, que eso a nivel productivo para salvar a una población de hambruna o tal, no es efectivo, entonces esa situación es muy complicada. Nosotros abogábamos por eso, por la recuperación de las semillas, pero estamos prácticamente solos, porque la gente que está realizando cultivo ecológico está comprando los plantones a Holanda.

Otra anécdota, teníamos una bandada de palomas que vivían en el cortijo que hay ahí abandonado y nos poníamos a espantarlas cuando sembrábamos, carreras para espantarlas, una faena. Desde que ha venido el aguilucho cenizo ya no tenemos problemas con las palomas, el aguilucho cenizo (una especie en peligro de extinción) hace su nido en el suelo de los trigales, como el trigo híbrido es de un ciclo super corto no le da tiempo a acabar la anidada, nosotros empezamos a cultivar la escanda que es de ciclo de 3-4 meses más largo y el aguilucho cenizo ha venido porque le da tiempo a anidar, así que ya no tenemos problemas con las palomas, todo esto ha pasado solo. Claro que nosotros hemos ido leyendo e informándonos de cómo ir recuperando el ecosistema, por ejemplo, en vez de plantar caléndula para atraer polinizadores poner las plantas arvenses. Nosotros a la escanda no le quitamos nada de hierba, convive con la hierba, lo que hemos hecho es durante unos años regular la que predominaba más y hemos ido dejando el 
melilotus, que es un tipo de trébol que nos hace de regulador general de las arvenses, entonces no hay ninguna plaga de ningún tipo de arvense.

Este año hemos cultivado lenteja, que aquí no se cultiva, no tiene polinizador y ha cuajado toda la flor y es una flor minúscula, probé porque me empeñé yo y ha cuajado toda la flor, es un síntoma buenísimo de biodiversidad. Entonces, todo esto que para nosotros tiene el plano agrícola puro y duro, el hecho de ver la diferenciación que hay en la forma de gestionar los cultivos agrícolas y manifestarlo a la sociedad nos da la suficiente fuerza para decir que en realidad es una reivindicación a través del arte contemporáneo. De hecho, empezamos llamándolo Agrolandart, yo creo que por el taller ese que hemos comentado al principio de la entrevista y veíamos que no había proyectos semejantes, pero no había simplemente porque no hay artistas agricultores o agricultores artistas. 


\section{ANEXO IV KULTIVARTE}

ENTREVISTA POR VIDEOCONFERENCIA 19/10/2020

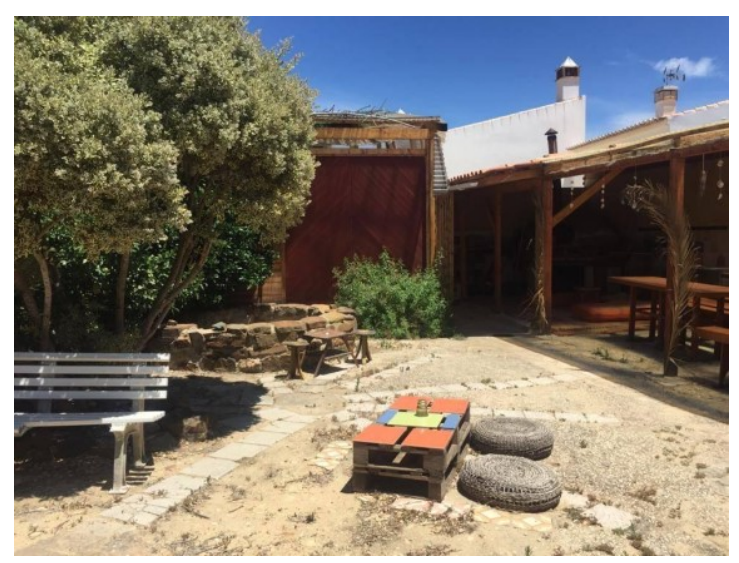

Imagen 251. Vista patio Kultivarte, Barão de São João, Portugal, 2019. Fuente: cesión de Kultivarte

El proyecto de Kultivarte ${ }^{41}$ fue fundado por Sandra Peixoto en el 2018 con la ayuda económica de su socio americano. La iniciativa, ubicada en el pueblo

${ }^{41}$ Sito en: R. Dr. António Guerreiro Tello 40, 8600-013 Barão de São João, Portugal 
de Barão de São João en Lagos, Algarve (Portugal), promueve medios de vida basados en los principios de la permacultura y en las artes.

\section{1. ¿Cuántos años lleva con el proyecto Kultivarte? ¿Cuál es su formación académica? ¿Cuál es su papel/desempeño en Kultivarte?}

Estudié Antropología en la Universidad Autónoma de Barcelona, fue donde tomé conciencia de la situación capitalista, la globalización... junto a muchos grupos activistas de Barcelona, empecé a conocer proyectos de eco-aldeas y permacultura. Luego volví a Portugal, hace unos ocho años, y colaboré con un proyecto de permacultura durante tres años donde aprendí y desarrollé mucho la permacultura. Luego, cuando salí de este proyecto, empecé mi proyecto de venta de pan en el mercado local, donde yo cultivaba el trigo biológico, lo molía, amasaba el pan, lo cocía a horno de leña y lo vendía, era un círculo cerrado. Posteriormente, fui invitada por mi socio, el cual quiso invertir en un proyecto con principios de sostenibilidad, le presenté el proyecto de Kultivarte y aceptó. En noviembre de 2017 alquilamos un espacio en la aldea de Barão de São João (400 metros cuadrados), lo renovamos y creamos una tienda biológica de productos alimentarios a granel, pequeña panadería artesanal con molino y horno, cocina para hacer comidas vegetarianas y en el espacio exterior hemos construido una sala de madera de $32 \mathrm{~m} 2$ donde realizamos actividades culturales, artísticas y de bienestar (yoga, danza, conciertos, meditación...) En junio de 2018 inauguramos el proyecto de Kultivarte.

\section{2. ¿Realiza agricultura sostenible en el contexto de Kultivarte? ¿Qué tipo de cultivos?}

Aparte del espacio que alquilamos para Kultivarte, yo tenía un terreno cedido para crecer los cereales y también empezamos a cultivar nuestros vegetables biológicos con la técnica de la agricultura ecológica y la permacultura. Durante estos dos años en el proyecto, hasta el COVID, hemos estado funcionando para promover la permacultura y las artes. Hemos trabajado con voluntarios y con personas cualificadas, colaboradores del proyecto, creciendo vegetales y cereales. También, vendiendo las cosechas en la tienda 
y elaborando la comida vegetariana para el restaurante, hacíamos pizzas en el horno de leña para vender en los conciertos que organizábamos. Intentamos crear una economía circular, todos los productores, agricultores, artesanos y artistas de la localidad estaban invitados a participar, desde comer los productos o a realizar sus servicios, conciertos, etc.

\section{3. ¿Colabora con algún otro proyecto, asociación o artistas? En caso afirmativo, ¿las colaboraciones son con organizaciones o personas a un nivel comunitario, local, nacional o internacional?}

Aquí donde vivimos, tenemos una comunidad multicultural, por diferentes razones, muchos extranjeros vienen a esta parte del Algarve porque buscan terreno para vivir más cerca de la naturaleza, de una forma más sostenible y, por lo tanto, también buscan aplicar la permacultura. Luego también vienen porque quieren que sus hijos sean criados en el contexto de la permacultura. Por lo tanto, tenemos una mezcla de los portugueses tradicionales que viven aquí y extranjeros que buscan formas de vida alternativas fuera de la ciudad y más creativas, muchas de estas personas también son artistas o artesanos, entonces tuve una gran variedad de personas que querían hacer aquí sus workshops de terapia, terapias alternativas, artes, danza, teatro, meditación, osho... muchas cosas. Por lo tanto, este espacio también estaba pendiente de este proyecto cultural, en este caso, multicultural, siendo un espacio de encuentro para la comunidad.

También hemos hecho momentos de reflexión para solucionar cuestiones transversales que nos afectan a los que vivimos aquí, por ejemplo, el Algarve se está quedando con problemas de agua muy fuertes, mi terreno el año pasado se quedó sin agua, a mediados de agosto del año pasado (2019) me quedé sin agua y perdí 40\% de mi cosecha (el terreno tiene cerca de dos hectáreas). Yo cultivaba una hectárea de cereales y teníamos un huerto de 400 metros cuadrados, el agua venía del pozo. El pozo secó, nosotros tenemos aquí, muy cerca de nuestra aldea, grandes monocultivos de aguacate. Muy cerca de mi terreno donde yo estaba creciendo mis cereales y mis vegetales, hay como más de 100 hectáreas de aguacate, es un monocultivo que necesita mucha agua, creo que son cerca de quince litros 
por día por árbol. También, las técnicas que usan son químicas, no son biológicas, por lo tanto, es una cuestión de salud pública que nos está afectando a todos y mucho más en esta zona que es bastante seca y ya tiene problemas de agua. Es por ello por lo que nos hemos juntado diferentes personas de la comunidad (portugueses y extranjeros) para intentar hacer algo para solucionar esta situación y, de ahí, se ha creado una asociación que se llama Regenerarte. Esta asociación también ha contratado un abogado y están trabajando de forma legal para impedir la continuación de estos crímenes ecológicos. Yo también fui una de las cofundadoras de esta asociación.

4. ¿Tiene o ha tenido algún tipo de subvención del ayuntamiento o de alguna institución u organización para la financiación de Kultivarte o los proyectos que nacen en su contexto? ¿En caso negativo, como se financian?

Mi proyecto, ha sido realizado autónomamente con el dinero de mi socio. Mi socio es americano y tiene una hija portuguesa con una mujer portuguesa, y quería invertir en un proyecto que fuera bonito para el mundo. Un ejemplo de que pudiéramos hacer las cosas de forma diferente, yo también tenía esta voluntad, ya estaba haciendo con el proyecto del pan un pequeño ejemplo de permacultura y con Kultivarte era un ejemplo para encontrar formas alternativas al sistema capitalista que está institucionalizado y para traer resiliencia y soberanía alimentaria a la población local. Para empezar, también, a través de este proyecto, a difundir cómo producir sus alimentos, cómo hacer permacultura y también arte.

5. ¿Qué le llevó a relacionar el arte con la permacultura? ¿Cómo cree que puede fortalecer y favorecer el arte al concepto de permacultura?

¿Por qué juntar el arte y la permacultura? porque la permacultura es simplemente una plataforma, en mi punto de vista, de buscar los conocimientos tradicionales y promocionados por la humanidad durante miles de años para su supervivencia con los conocimientos actuales. Y, de ahí, conseguimos volver a saber sobrevivir. Pero, para volver a saber sobrevivir sin 
ser únicamente con dinero porque nuestra sociedad aprende a ganar dinero y puede sobrevivir, tener comida, tener ropa, todo lo que necesitas, pero la humanidad siempre ha sabido sobrevivir sin dinero, ha sabido mirar a la naturaleza y aprender y colaborar con ella para tener sus necesidades cubiertas.

La permacultura es una filosofía de vida que, en mi punto de vista, tenemos que rebuscar para poder tener un futuro más sostenible, más pacífico, menos destructivo, menos explotador, menos damnificador. Por eso las técnicas de la permacultura son: cuidar de la tierra, cuidar de las personas y el compartir justo. Por eso, para mí la permacultura es como yo quiero vivir y creo que es también una forma donde podemos ganar una nueva conciencia de cómo crear nuestras sociedades, porque la permacultura va a la educación, a la economía, a la agricultura, a la alimentación. Por lo tanto, está en diversas áreas y aquí en este pequeño proyecto que intentamos promover esa posibilidad también ha sido esencial que las personas se pudieran encontrar y, luego, el arte es intrínseco al ser humano, no hay separación, todos los seres humanos tenemos algo de artistas.

Entonces, al haber un espacio, no solo para artistas profesionales, sino también para las personas de la comunidad se pudieran juntar, compartir, aprender y desarrollar también las formas de expresión. Para mí esto es la forma holística, como yo quiero vivir mi vida, porque también me gusta bailar, música, teatro, escribir poesía... Por lo tanto, también podemos desarrollar nuestra expresión artística y estar conectados con la naturaleza, con nuestra alimentación, con cómo producir nuestra alimentación, con lo que damos y devolvemos a la tierra, con plantar árboles para tener nuestra agua. Después de tantos años que estamos haciendo destrucción, tomamos medidas que son para buscar injusticias y desigualdad, pues entonces ya tenemos los conocimientos necesarios para poder hacerlo de forma diferente. Es un poco utópico y por eso también es difícil este tipo de proyecto.

Yo tuve mucho apoyo de mucha gente, pero también muchas dificultades de lograr tener un proyecto como este sostenible. No he tenido apoyo de ninguna entidad gubernamental, no he tenido apoyo financiero de ninguna 
entidad. Y, por lo tanto, ha sido un proyecto financiado por mi socio y mi propia voluntad de trabajar también muchas veces voluntariamente.

\section{6. ¿Cómo es la reacción del público al conocer su proyecto? ¿Y la implicación en los posibles proyectos colectivos que organiza?}

El proyecto se sitúa en el pueblo Barão de São João, es un pueblo cerca de Lagos, de la ciudad, y luego tiene Aljezur que es otra ciudad, hay una especie de triangulo. El proyecto ha tenido buena aceptación principalmente por la comunidad extranjera y también por los portugueses que están buscando alternativas de vidas, permacultores, artistas... todos han tenido resonancia con este proyecto. La comunidad más conservadora, más tradicional, le hacía un poco de confusión, no entendían muy bien, pero con el tiempo creo que cada vez más estos conceptos se están quedando normales, por decirlo de alguna manera.

Por parte de las instituciones, ayuntamientos, concejalías de cultura, nada. Lo único que tuve de las entidades legales, fue la información de la legalidad, de lo que es obligatorio, de lo que podía hacer, de lo que no...

Este proyecto ha cerrado por el virus COVID y por falta de dinero también, en este momento yo no puedo reabrir el proyecto porque también perdí la licencia por complicaciones con el arquitecto y, por lo tanto, tampoco hay incentivos o ayudas. La única solución que está en este momento encima de la mesa, que estamos trabajando para que acontezca, es crear una cooperativa. Por lo tanto, Kultivarte será una cooperativa para promover la permacultura y las artes. Tenemos un grupo de personas que están dispuestas a invertir para que tengamos un grupo de trabajo y dinero para volver a tener la licencia y poder reabrir.

\section{7. ¿Qué tipo de actividades se realizan en el contexto de Kultivarte?}

En Kultivarte, explicábamos todo lo que hacíamos, tenía un equipo de ocho voluntarios que iba cambiando cada tres semanas o un mes, íbamos al huerto a producir los vegetales, hablar de la tierra... Luego subíamos y había clases de yoga o de pintura o de danza, entonces, es una experiencia muy 
interesante de que volvemos a entender que vivir es simple. Es la conexión con la naturaleza con la alimentación y con nuestro cuerpo y nuestra expresión artística y espiritual. Esto un poco estábamos intentando producir, pero yo estaba sola gestionando todo el proyecto y tampoco pretendo seguir porque es un proyecto muy grande, había mucho trabajo, mucha tensión y presión para tomar decisiones y estar en todos los frentes. Por eso, ahora, estamos intentando la posibilidad de hacer un grupo de personas en la forma colaborativa/cooperativa donde cada uno se ocupe de su micronegocio y sea coordinador de su proyecto. Y, entonces, creo que podremos encontrar este proyecto en su potencial pleno, que todavía no ha estado.

\section{8. ¿Los productos que vende en Kultivarte son fruto de su producción agrícola?}

Yo estaba produciendo cereales, pero solamente trigo y las variedades ancestrales, estaba produciendo trigo corazón, negrito y otras variedades antiguas, eso era para el pan. Luego los vegetales los usábamos para la comida. Pero, hay otras cosas que teníamos que comprar, intentábamos comprar lo más local posible y orgánico, también, estar soportando la economía local, pero sí teníamos otros proveedores. La comida, totalmente vegetariana, vegana y crudívora.

También intentaba traer, a veces, conciencia sobre lo que comemos, información, hice fermentados con alguna producción extra del huerto, hacíamos chucrute, kombucha, babaganoush, vegetales deshidratados, pesto, etc. Por lo tanto, intentábamos que en este espacio además de lo que estábamos vendiendo de alimentación, hubiera información de la macrobiótica, de diferentes formas de alimentarnos, de hacer postres crudivoros... una alimentación más orgánica, más saludable y no animal. Esto es una de las cuestiones del consumismo y, por eso, también he intentado traer otras formas de alimentación y la conciencia de cómo están siendo utilizados los animales para ser comida del ser humano. 
9. ¿Habéis tenido alguna propuesta de arte y agricultura en Kultivarte? ¿Y algún tipo de exposición artística? Desde el punto devista del arte, ¿cuáles son las formas de expresión más utilizadas en sus proyectos? ¿Acciones colectivas o individuales? ¿Escultura, pintura, instalación, acciones performativas, música?

Hemos tenido esculturas de una amiga que es artista plástica, también cuadros, también he realizado una residencia artística de danza y música africana, ha venido un profesor de Burkina Faso y otro de Bélgica y he realizado una residencia artística de danza Contacto Improvisación con un profesor alemán. También, una asociación de aquí de Algarve realiza un festival que se llama Walk and Art Fest y hemos participado con una performance. También, ha venido una chica a enseñar a realizar cestos de palma y diferentes artesanías, muchas cosas hemos realizado. La gente sigue preguntando cuándo vuelve a abrir el proyecto porque es un sitio de encuentro y participación interesante.

10. ¿Tiene referencias o conoce otros proyectos similares, donde se relacione el arte con la permacultura y/o agricultura?

No conozco ningún proyecto como el que yo estoy intentando desarrollar promocionando el arte con la permacultura juntas. Pero hay proyectos aquí en la zona de personas que quieren hacer permacultura y también son artistas, lo que pasa es que mi proyecto no es el típico proyecto de permacultura que se sitúa en el terreno y están todos ahí construyendo y viviendo juntos. Kultivarte es un proyecto de un modelo económico y social que tiene obligaciones con la ecología, pero que está abierto a diferente público, a todo el público. Es un modelo diferente, es traer la panadería, la comida, la tierra y el cuerpo un poco juntos, pero no en un formato comunitario que estemos todos viviendo en el mismo terreno. Estamos en un entorno natural y este proyecto es un puente para que puedan nacer otros proyectos ecológicos y proyectos relacionados con el espacio que tenemos, que se puedan desarrollar aquí. 


\section{1. ¿Hay algún aspecto que quisiera mencionar o comentar especialmente? ¿Hay algo que le parece importante y todavía no ha sido mencionado?}

Me atreví a entrar en esta aventuray, es posible. Creo que también es la forma de lograr que se pueda expandir, reproducirse... hay la opción de querer vivir de una forma totalmente alternativa, en la naturaleza tienen su terreno y luego ahí hacen permacultura y arte y lo que sea. Pero, mi proyecto trae más la posibilidad de acercar los comercios tradicionales que necesitamos, que pasen a ser de otra conciencia, con producto local, con productos artesanales. La posibilidad de que entre las personas que se puedan juntar para ser productores y crear una red de economía circular, para compartir información, para crecernos intelectualmente y de consciencia. Que pueda haber un punto en que todos sean neorrurales, alternativos, tradicionales, con dinero, sin dinero, negro, blanco, portugués, extranjero... Un sitio transversal en el que es posible compartir un consumir de una forma más consciente, es muy interesante y bonito.

Luego, en su materialización es un camino para desgranar, construir, explorar, abrir... es necesario también deconstruir las estructuras mentales, legales y políticas por las que hemos estado viniendo a ser regidos. Porque la transformación que necesitamos urgentemente y con este virus, es que las medidas políticas sean ecológicas y en equilibrio con la naturaleza y que las personas puedan también crear otras formas de interrelacionarse con su trabajo, otras formas de ganar dinero. Entonces, esto es una pequeña semilla que me fue dada la oportunidad de criar y estoy agradecida por esa oportunidad, pero ahora también estoy rezando para que haya ayudas para que ella pueda volverse flor. Y, gracias a dios, hay gente, autónomos, que también ven que este es el camino para seguir y que se quieren juntar y crear la cooperativa y, si dios quiere, lo lograremos, así que esto es una pequeña semilla para un mundo mejor. 



\section{ANEXO V}

\section{QUINTA DAS RELVAS}

ENTREVISTA POR VIDEOCONFERENCIA 5/11/2020

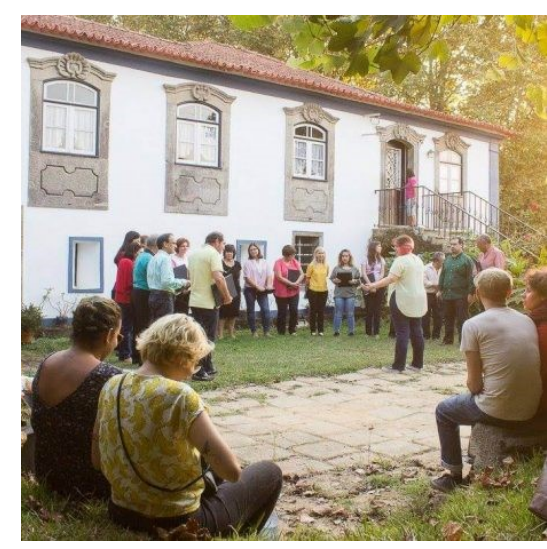

Imagen 252. Vista Quinta Das Relvas, Branca,

Portugal, 2019.Fuente: @quintadasrelvas

El proyecto de Quinta Das Relvas ${ }^{42}$ está ubicado en la aldea de Branca (Portugal), fue fundado por Beatriz y Antonio en 2016. La iniciativa nace en

${ }^{42}$ www.quintadasrelvas.pt 
una antigua granja familiar y, desde un inicio, todas sus actividades siempre están vinculadas al arte y la sostenibilidad.

1. ¿Cuántos años lleva con el proyecto Quinta Das Relvas? ¿Cuál es su papel en Quinta Das Relvas?

Nosotros aquí en Quinta Das Relvas somos una asociación y trabajamos desde un inicio dos áreas que siempre están vinculadas en todas las actividades, que son el arte y la sostenibilidad. Yo, Beatriz, coordino la parte de arte y mi compañero Antonio coordina la parte de sustentabilidad. Llevamos cuatro años con el proyecto, la granja era de mi familia y no estaba siendo utilizada, era una granja ya con una gran dimensión y con condiciones de habitabilidad mínimas. Lo que hicimos fue venir de la ciudad y crear esta asociación para trabajar en las áreas que nos interesaban, por tanto, el proyecto surge de un interés de los dos, yo en área de las artes y él más ligado a los aspectos de sostenibilidad, permacultura, etc. Por tanto, el proyecto en su base siempre tiene los dos componentes, además, lo que fuimos sintiendo fue que la unión entre las dos áreas podía ser muy lógica, en el caso de la permacultura que el arte forma parte de ella, luego, tenemos áreas artísticas, por ejemplo, el Land Art.

\section{2. ¿Cuál es su formación académica?}

Estudié pintura, tengo Licenciatura en Bellas Artes que estudié en Lisboa, luego tengo Maestrado en Anatomía Artística y actualmente estudio Doctorado en Bellas Artes. Durante la licenciatura realicé residencias artísticas, erasmus en la Universitat Politècnica de València, también estudié en Oporto, la formación fue en pintura y diseño.

3. ¿Realiza agricultura sostenible en el contexto de Quinta Das Relvas? ¿Qué tipo de cultivos? En caso afirmativo, ¿venden los alimentos cosechados o son para autoabastecimiento?

Nosotros realizamos agricultura sustentable aquí siguiendo los principios de la permacultura y agroecología, pero para consumo interno y con fines lúdicos. El consumo interno incluye nuestros voluntarios, nuestro equipo y 
participantes de actividades, por tanto, se queda en algo interno, no para venta. $Y$, respecto a los fines lúdicos, para tener ese contacto con la producción ecológica, su funcionamiento, o en el contexto de actividad para que puedan experimentar cómo hacer agricultura sustentable, donde la producción termina por no ser tan importante, lo que más nos interesa es el proceso.

\section{4. ¿Diría que en su proyecto hay un vínculo entre el arte y la agricultura y/o entre el arte y la permacultura? En caso afirmativo, ¿qué les motivo a relacionar ambos aspectos?}

Sí, estamos fusionados, en los cuatro años de actividad que llevamos nuestra manera de abordar estas temáticas está en evolución. Por ejemplo, en un inicio nosotros teníamos muchas actividades semanales, dirigidas a la población local en estas dos áreas, intentábamos constantemente encontrar un contacto, que no tuviera una predisposición directa por estos temas. Por ejemplo, actividades de identificación de formas orgánicas, entonces ahí intentabas juntar las dos áreas, por otra parte, fotografía nocturna, ahí también juntábamos las dos áreas. Temáticas donde los participantes pudieran tener interés en estos aspectos. Con el paso del tiempo comprendemos que era más provechoso para nosotros y para los participantes, hacer menos actividades y que estas tuvieran un mayor tiempo de dedicación.

Por eso, actualmente, nosotros realizamos residencias artísticas, conferencias, workshops, intercambios... son siempre propuestas en que los participantes se quedan en Quinta Das Relvas unos días. Esto lo que permite es que, en las actividades más dedicadas al arte, artes plásticas o performativas, los participantes tengan también la opción de ser inmersos en el día a día de lo que sucede en la finca, siendo incluidos en las actividades diarias. El 80-90\% de las veces se termina por influenciar el trabajo del propio artista con lo que acontece en el lugar, los materiales, la presentación de los trabajos... esa unión del arte con la sostenibilidad se termina dando de una forma muy natural. 
Pero, también tenemos mucha gente que viene en busca de ampliar sus conocimientos en permacultura y agroecología, igual no tienen oportunidad de hacer una pieza artística pero siempre es propenso en la actividad de la permacultura a crear cualquier cosa, por ejemplo, con la bioconstrucción es muy notorio, experimentando con materiales, formas... no es algo estricto lo que tienes que conseguir. Y, luego, pues pueden estar realizando una actividad de bioconstrucción y terminar participando en una actividad de Land Art o viendo las exposiciones de otros participantes. Por tanto, esa simbiosis va aconteciendo y, después, también están los participantes que vienen por una actividad de arte y luego se quedan más tiempo por participar en las actividades de la permacultura. No consideramos la necesidad de que haya un programa que obligue a las dos áreas a funcionar en conjunto, no quiere decir que no haya interés por nuestra parte.

Llevamos cuatro años trabajando y también es poco tiempo, es una cosa que va a seguir siendo trabajada. Por ejemplo, nosotros intentamos que los participantes que van a trabajar en arte utilicen materiales sostenibles en la medida de lo posible, ya los participantes suelen utilizar tintes naturales, procesos naturales, menos invasivos, etc. Pero no es una realidad que consigamos realizar en la totalidad, yo he de ser honesta. Nosotros intentamos hacer lo mejor posible dentro de nuestras posibilidades, el objetivo siempre es mejorar y ser más sustentables.

\section{5. ¿Qué tipo de actividades se realizan en el contexto de Quinta Das Relvas?}

A parte de las que ya hemos comentado, residencias artísticas, workshops, intercambios, etc. En ese contexto tenemos muchas variantes, hacemos ilustración anualmente, cuando digo intercambios tenemos uno de formación y otro joven, hacemos formación certificada en permacultura, también recibimos voluntarios con un componente formativo, las exposiciones que realizamos con los resultados de las residencias artísticas. . . El año pasado tuvimos un proyecto de artes performativas aquí en la Quinta y a partir de ahí fueron realizadas performance para la comunidad. También, 
en este momento tenemos clases de Yoga, una profesora local que imparte las clases aquí.

6. ¿Cómo funcionan las residencias artísticas en su proyecto? ¿Por convocatoria o los artistas se ponen en contacto con ustedes?

Empezamos a disminuir el número de actividades y empezamos a crear proyectos anualmente. De estos proyectos, tenemos una residencia de artes plásticas, donde los participantes son seleccionados por los proyectos que presentan. También, realizamos un festival de ilustración, YETI -Youth Education Through Illustration, donde invitamos artistas ya con algún conocimiento y cualquier persona se puede inscribir para participar en las conferencias y los workshops programados en el festival de ilustración. Estos dos proyectos son los más grandes que organizamos dentro del área de artes plásticas. También, realizamos intercambios internacionales que pueden ser dedicados a artes plásticas o performativas, también realizamos los intercambios con Erasmus +, también con Bellas Artes de Lisboa y de Oporto, no somos estrictos en la manera de cómo vienen los participantes. Una regla que nosotros tenemos aquí, en referencia al financiamiento, es que cualquier actividad que se realice en la Quinta tiene que ser sustentable en tres vertientes: a nivel ecológico, a nivel emocional y a nivel económico. Nosotros estamos abiertos a propuestas que vengan del exterior, pero los proyectos tienen que ser pensados con un inicio y un fin, además, tiene que ser autosustentables de alguna manera, nosotros ayudamos en ese proceso. Un proyecto que cumple esas tres características y se encuentre en equilibrio con nuestros objetivos podrá realizarse en la Quinta.

7. ¿Cuánto tiempo suelen estar en residencia los artistas? ¿Se alojan en Quinta Das Relvas, han de abonar algún importe o realizan tareas a cambio de la estancia, alimentación...?

Sí, los artistas se alojan en Quinta Das Relvas. En todas las actividades que duran varios días los participantes se alojan en la Quinta, por ser actividades inmersivas, tanto en el área de arte como de sustentabilidad. Muchos participantes son jóvenes, en formación y normalmente con mayores 
dificultades económicas, entonces nosotros intentamos minimizar los costes al máximo para el participante, la actividad se paga, pero intentamos disminuir los costes. Por ejemplo, si algún artista va a participar en alguna actividad nuestra programada podrá haber un pagamento de entrada, pero no siempre, como en las residencias artísticas donde no hay un pago por participar. Pero, si un artista quiere realizar una candidatura esporádica y utilizar el espacio de Quinta para realizar un proyecto suyo, sí que habría un pago por la utilización de las instalaciones. Entonces tendríamos dos vertientes, una con las actividades que nosotros realizamos más accesibles y económicas. Y, otra, los proyectos esporádicos que aceptamos sin estar programados en la actividad de la Quinta.

\section{8. ¿Los artistas han generado alguna propuesta donde se vincule concretamente el arte/permacultura-arte/agricultura en el contexto de Quinta Das Relvas?}

Muchos proyectos que fueron realizados aquí sí tuvieron una relación muy clara, pero no diría que fue de manera voluntaria, sino que fueron proyectos artísticos que se influenciaron por el contexto. Por ejemplo, nuestra primera residencia artística fue con el tema del Land Art y todas las piezas fueron creadas en el contexto de Quinta, algunas hacían una simbología con el agua, otras trabajaban con las formas de los árboles... la relación con el entorno va siempre surgiendo, pero los proyectos artísticos no procuran necesariamente regentar algo con la parte de la agricultura o la permacultura con un perfil de obra de arte, hay una contaminación fructífera, la relación se da de una manera muy natural. Los artistas se influencian con el entorno de la Quinta, con la agricultura, con la permacultura, con la sustentabilidad... hay situaciones puntuales en que esa relación crece y se expande a algo mayor, pero yo no diría que los artistas son centrados directamente en esto a un nivel profundo de investigación en las dos áreas. 
9. ¿Realizáis exposiciones artísticas abiertas al público con las obras fruto de las residencias?

Sí, desde el inicio siempre hemos querido trabajar con la comunidad local lo más posible, pero no siempre es fácil que los locales se sientan atraídos por nuestras actividades porque es algo muy específico y estamos en una zona muy poco cuidada en aspectos de arte y sostenibilidad. Pero siempre que hay resultados, esos resultados son expuestos de manera que los locales pueden acceder a esa información y, normalmente, en vez de abrir las puertas de Quinta, utilizamos espacios municipales. En este momento tenemos una exposición del fruto de una residencia en la biblioteca municipal, donde los locales van habitualmente y así pueden ver los resultados.

10. Desde el punto de vista del arte, ¿cuáles son las formas de expresión más utilizadas por los artistas residentes? ¿Acciones colectivas o individuales? ¿Escultura, pintura, instalación, acciones performativas, música?

Estamos abiertos a toda forma de expresión artística. Nosotros hemos trabajado las áreas que más nos han interesado, pero hemos tenido otros colaboradores en Quinta que han llegado a explorar otras ramificaciones, por ejemplo, Andrés, de una asociación local que hizo artes performativas en Quinta y su participación hizo que dedicáramos más tiempo en esta área. Por tanto, estamos abiertos a cualquier manifestación artística.

11. ¿Considera que el arte forma un pilar especialmente relevante en su proyecto o se sitúa como un aspecto complementario?

Sí, totalmente. El proyecto solo tiene sentido si los dos pilares principales, el arte y la sostenibilidad, se mantienen fuertes, todo lo que sucede en la Quinta está dentro de estas dos áreas. Somos una asociación de creaciones educativas. 
12. ¿Cómo es la reacción del público al conocer su proyecto? ¿Y la implicación en los posibles proyectos colectivos que organizan?

En un inicio fue muy difícil porque nosotros no éramos de aquí, no conocíamos mucha gente, trabajar arte y sustentabilidad aquí era un poco extraño para la gente. Pienso que, pasados estos cuatro años de nuestro trabajo, comienzan a valorar el trabajo que realizamos, pero no siempre comprenden exactamente qué hacemos. Nosotros intentamos mostrar los resultados y la importancia de lo que hacemos, pero no es fácil integrar a las personas locales y que participen. En las actividades que realizamos en el primer año, las pusimos gratuitas o con un descuento para los habitantes locales y era muy raro encontrar personas locales inscritas, venía gente desde Lisboa, desde Oporto y, en cambio, a nivel local era muy complicado. Hay mucha desconfianza de que es lo que podemos estar realizando aquí. No es nada fácil.

13. ¿Colabora con algún otro proyecto, asociación o artistas? En caso afirmativo, ¿las colaboraciones son con organizaciones o personas a un nivel comunitario, local, nacional o internacional?

Trabajamos con el cine y el teatro local, con la cámara municipal, trabajamos con algunas asociaciones locales, escuelas etc. Intentamos crear relaciones a nivel local y que puedan estar informados de los acontecimientos y resultados de Quinta Das Relvas. La relación con la cámara y junta municipal no es tan fuerte como nos gustaría, pero la tenemos.

Sí tenemos relaciones muy fuertes a nivel nacional con entidades como Bellas Artes de Lisboa u Oporto, asociaciones que trabajan con sustentabilidad y artes de otra forma, por ejemplo, con Ecoaldea Duval en Sintra. También, ahora tenemos un proyecto con una asociación más dedicada a artes como la música. Y a nivel internacional, con Erasmus +, enviamos y recibimos muchos grupos que trabajan principalmente las dos áreas, arte y sostenibilidad, a nivel europeo. Y, desde el año pasado, hemos trabajado también fuera de Europa, con proyectos en América Central y Asia. 
14. ¿Tiene o ha tenido algún tipo de subvención del ayuntamiento o de alguna institución u organización para la financiación de Quinta Das Relvas o los proyectos que nacen en su contexto? ¿En caso negativo, como se financian?

No, las colaboraciones que tenemos con las diferentes asociaciones son muy amigables, reciprocas, funciona como un intercambio de contactos de servicios. A nivel local, el arte y la sostenibilidad no es una prioridad, por tanto, nosotros tenemos un apoyo mínimo, es algo muy residual, por ejemplo, el apoyo que pueda recibir por parte de la cámara y junta municipal no llega ni para poder pagar la luz que utilizamos al realizar las actividades en Quinta Das Relvas y utilizamos el mínimo. Otro ejemplo, tenemos una residencia artística que no tiene costo para los participantes, gratuita para lo locales, se muestran los resultados para la población local, etc. Todo a costo cero para el municipio, pero yo preciso algo de apoyo económico para los gastos, la cámara podría llegar a estar dispuesta a ofrecer un mínimo apoyo, pero una vez por año, es siempre muy difícil y con mínimos que no cubren los gastos. No podemos realizar actividades contando con esos apoyos, no se sustentan.

Por otro lado, hay instituciones en Portugal que consiguen dar apoyos mayores, pero normalmente los apoyos son proyecto a proyecto, por tanto, cada proyecto está pendiente de candidaturas que pueden ser aprobadas o no. Y, nosotros cuando sacamos un proyecto ya necesitamos saber cómo se va a financiar, ya que te comprometes con los participantes, artistas, etc. Es muy difícil.

Bellas Artes de Oporto y Lisboa ya contribuyeron con apoyos, conseguimos reducir los costes de manera significativa, con materiales o pagos de viajes.

Nuestra fuente de financiación sería el eco-hostal, donde se alojan personas que tiene interés en las áreas que se trabajan en Quinta Das Relvas, no vienen de una forma aislada, quieren very participar en lo que ocurre aquí. Es nuestra mayor fuente de rendimiento para que el proyecto pueda continuar funcionando y sea sustentable económicamente. De cualquier manera, 
necesitamos prever un financiamiento sea a través del eco-hostal, de apoyos, a través de inscripciones de participantes, etc. Mantener la finca, la agroecología, los animales, la infraestructura, organizar las actividades... todo eso conlleva un gasto muy elevado, no podemos decir que la asociación está en riesgo de acabar su actividad, pero es una lucha constante.

En este momento tenemos cuatro casitas realizadas en bioconstrucción, pensadas para dos personas o matrimonio con hijo/a, y tenemos ocho tiendas con capacidad para tres personas cada una, pero solo funcionamos al $100 \%$ en el verano, entre abril y octubre. Luego durante el invierno solamente de forma puntual. 


\section{ANEXO VI \\ OBRA PROPIA}

INTERVENCIONES REALIZADAS EN EL CONTEXTO DE LA TESIS

\section{Por la soberanía alimentaria, Ruzafa, Valencia (España), 2017}

La obra Por la soberanía alimentaria fue realizada en colaboración con la Doctora en Bellas Artes Nuria Sánchez León y con la Plataforma per la Soberanía Alimentaria. Dicha intervención fue seleccionada en la convocatoria A les Balconades, lanzada por la asociación Jarit de Ruzafa, en Valencia (España). El objetivo principal de la pieza se basa en fomentar la concienciación del público a la hora de adoptar hábitos de consumo responsable. Pero, más específicamente, tratamos de:

- Informar al público del recorrido de los productos de consumo alimenticios desde su origen hasta su hogar y sus consecuencias en el cambio climático.

- Tomar conciencia de la situación de la agricultura local.

- Despertar el interés del público para que se cuestione sobre los alimentos que consume.

- Facilitar al público el contacto con productores locales, mercados agroecológicos y grupos de consumo. 
- Utilizar técnicas y materiales lo más coherentes posibles con el contenido conceptual de la obra.

La obra parte de nuestro interés por utilizar materiales acordes con el discurso que representen los intereses de la Plataforma per la Soberanía Alimentaria. En este sentido, las cajas de madera típicas de la recolección de manzanas simbolizan un mundo rural en el que aún pervive el contacto directo del agricultor con el producto. Estas cajas llegan a ser incluso un elemento nostálgico, que se acostumbraba a reutilizar, acumulando historias de usos pasados en su madera. Sin embargo, hoy en día gran parte de los productores suelen desecharlas acortando su ciclo de vida a un solo uso o en todo caso, reutilizándolas como decoración.

Nuestros ritmos de vida acomodados vinculados a sistemas de producción desmesurados y acelerados, han facilitado un distanciamiento físico y cognitivo entre el productor y el consumidor, así como la desconexión con la agricultura local. La figura del agricultor se difumina, se desconoce e incluso se desconfía, ocasionando la ruina de los pequeños campesinos. Al mismo tiempo el origen de los productos se aleja y, paradójicamente, disminuye el precio de mercado a costa del petróleo barato, del medio ambiente y de la ruina de tantas personas.

Desde la soberanía alimentaria se defiende justo lo opuesto a este modelo de producción convencional: el derecho de los pueblos a alimentos nutritivos y culturalmente adecuados, accesibles, producidos de forma sostenible y ecológica y también su derecho a decidir su propio sistema alimentario y productivo.

Nuestra intención con esta obra es reflejar estas dos caras del consumo. Por un lado, reflejamos a modo de gráfico de barras los kilómetros recorridos por los alimentos desde sus lejanos orígenes hasta nuestros hogares en Valencia. Así pues, las consecuencias ambientales de estos trayectos son comentadas en unos folletos situados junto a la pieza que el espectador puede coger y llevarse. 
Por otro lado, ofrecemos al espectador información práctica de los productores, mercados agroecológicos y grupos de consumo del área metropolitana de Valencia. El objetivo es acercarles la información para incitarles a pensar en el origen de los alimentos que consumen y facilitarles un cambio en sus hábitos de consumo.

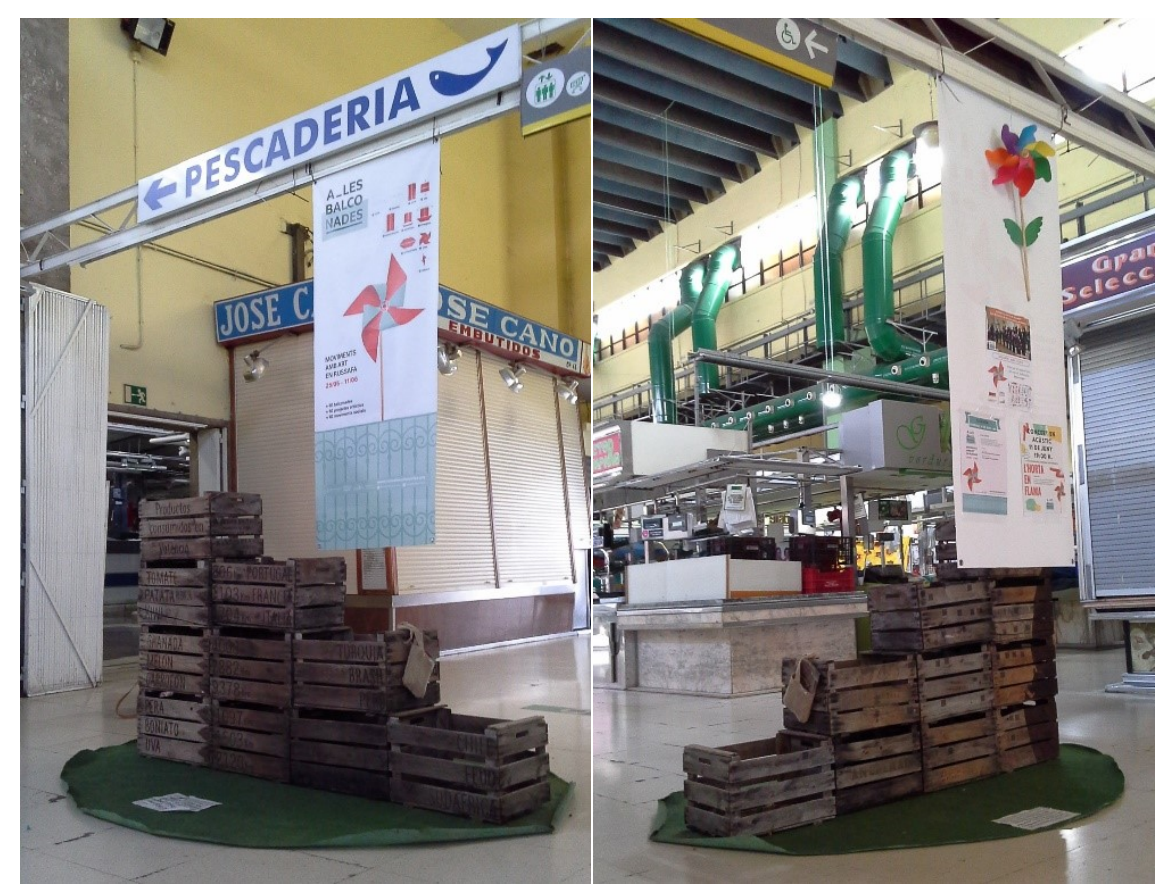

Imagen 253. Vista delantera, Por la soberanía alimentaria. A les Balconades, Mercado de Ruzafa, Valencia, 2017. Fuente: propia Imagen 254. Vista trasera, Por la soberanía alimentaria. A les Balconades, Mercado de Ruzafa, Valencia, 2017. Fuente: propia

En la imagen 253 y 254, podemos observar la obra sita en el Mercado de Ruzafa en Valencia, España. La pieza estuvo expuesta en ese lugar durante mayo y junio del 2017, en el contexto de la convocatoria de A les Balconades, en ese período se aprovechó para realizar actividades alrededor de la obra junto a integrantes de la Plataforma per la Soberanía Alimentaria. Así pues, se dialogó con la gente que acudía al mercado, con los propios vendedores y se 
realizaron actividades dirigidas a los niños/as para ayudarles a tomar conciencia de la procedencia de los alimentos que toman cada día.

Cabe destacar que los artistas Newton y Helen Harrison, pioneros del arte ecológico, defienden que el arte no debe aspirar a transformar actitudes o presentar soluciones sino a incitar cuestiones y nuevos puntos de vista. En nuestro caso, hemos considerado que en esta obra ligada a un movimiento social concreto se hace necesaria esta literalidad, en favor de una mayor legibilidad y comprensión del mensaje. A petición de la Plataforma per la Soberanía Alimentaria la pieza se acompañó de folletos informativos.

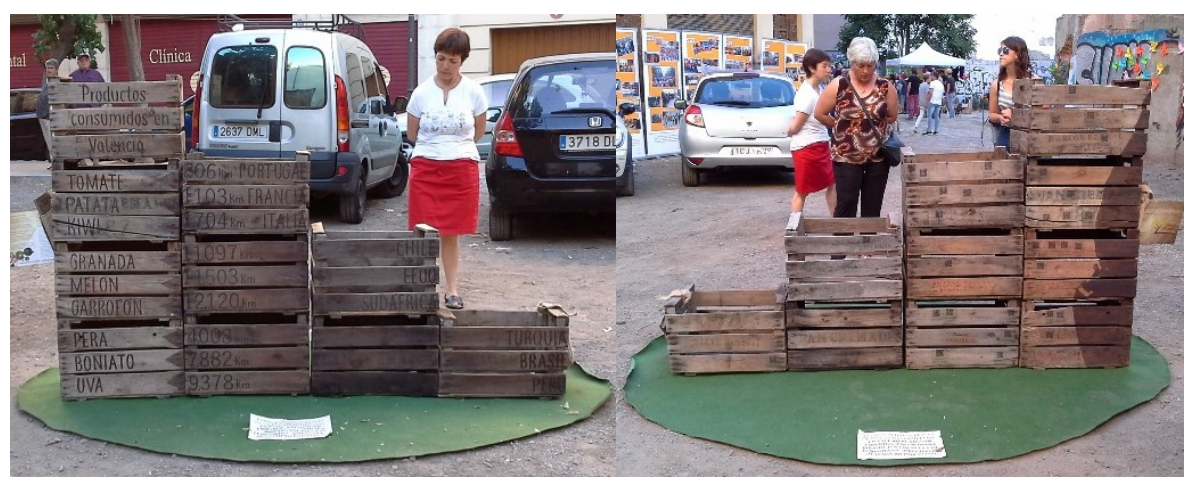

Imagen 255. Vista delantera, Por la soberanía alimentaria. Clausura A les Balconades, barrio de Ruzafa, Valencia, 2017. Fuente: propia Imagen 256. Vista trasera, Por la soberanía alimentaria. Clausura A les Balconades, barrio de Ruzafa, Valencia, 2017. Fuente: propia

Finalmente, podemos observar la obra nuevamente en las imágenes 255 y 256, la pieza fue seleccionada para ser colocada en el barrio de Ruzafa, Valencia, en el contexto del evento de clausura de la convocatoria A les Balconades. Cabe señalar, que tras esa exposición y el interés que mostró la gente en dicha propuesta, se nos solicitó mostrar la pieza en la sede de Podemos en Ruzafa, Valencia, lugar donde fue robada por unas personas que suplantaron nuestra identidad. 


\section{Espiral de la vida, Trastellaor, Palmera, Valencia (España), 2019}

La intervención titulada Espiral de la vida fue seleccionada en la convocatoria Trastellaor del 2019 y fue realizada durante la estancia de investigación en la residencia de la asociación sin ánimo de lucro Mandarina Borda, en Palmera, Valencia (España). Así pues, en la intervención, se hace uso de la espiral áurea para simbolizary dar valor a los cultivos autóctonos de las tierras valencianas.

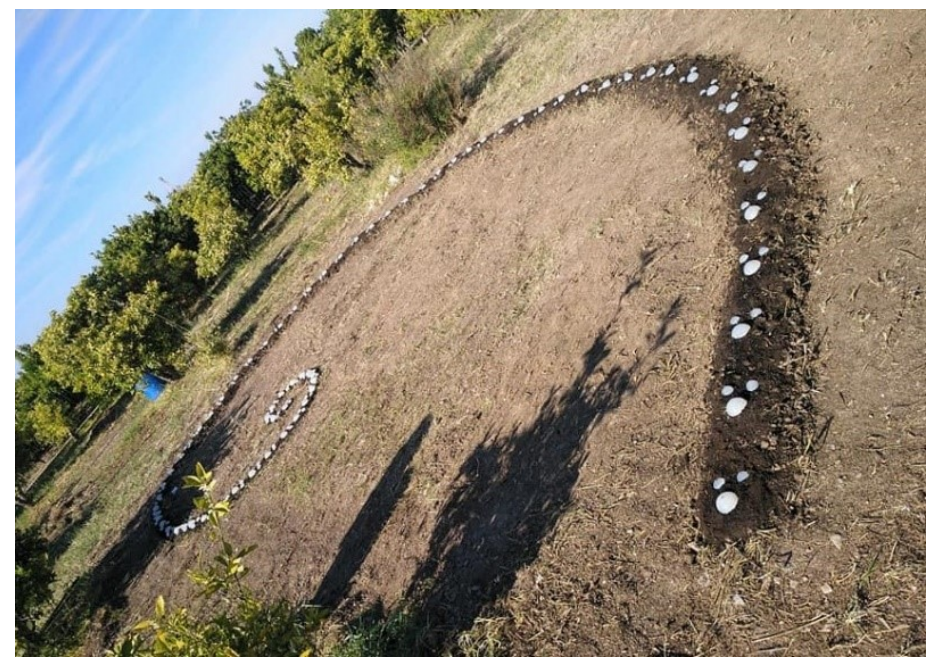

Imagen 257. Espiral de la vida, intervención en Trastellaor. Huerto Mandarina Borda en Palmera, Valencia, 2019. Fuente: propia

La huerta de Valencia es un magnífico paisaje agrícola que ha sido generado y cuidado desde la tradición de sus habitantes, desde la sabiduría de los labradores y las labradoras que durante siglos han ido acumulando una gran cantidad de saberes, técnicas y valores para el cuidado de la tierra. Un lugar emblemático, una tierra rica en nutrientes que ha abastecido a su comunidad durante siglos. En estos campos se han cultivado variedades de frutas y hortalizas qué, con el paso de los años, se ha ido perdiendo el interés en su producción. Esta situación viene dada por la demanda de mercado, la cual favorece a unas pocas especies, dejándose de cultivar las variedades que menos demanda tienen de consumo, a pesar de ser igualmente ricas en 
nutrientes y endémicas del lugar. Es por ello por lo que la mayoría de las parcelas agrarias terminan convirtiéndose en monocultivos, los cuales son más propensos a las plagas y las enfermedades, necesitando más cantidad de fertilizantes, pesticidas y agua.

Todo ello nos lleva a considerar la importancia de contribuir en la recuperación y la preservación de las variedades autóctonas, prestando especial atención al fomento de la biodiversidad. Siendo este concepto esencial para el conjunto de los seres vivos de un ecosistema, generando una tierra más fértil, con cultivos más fuertes, sanos y productivos. Además, las variedades autóctonas son parte de nuestro patrimonio natural, cultural e histórico, durante siglos estas semillas se han adaptado a las inclemencias del lugar, adquiriendo una gran fortaleza y adaptación al medio.

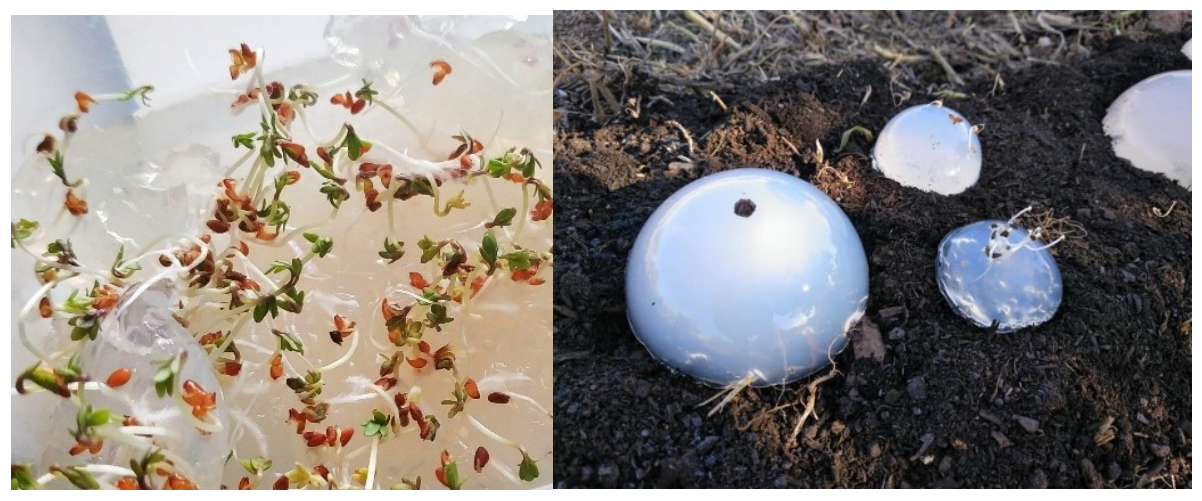

Imagen 258. Vista detalle germinación de semillas en agar agar, Palmera, Valencia, 2019. Fuente: propia Imagen 259. Detalle Espiral de la vida, intervención en Trastellaor. Huerto Mandarina Borda en Palmera, Valencia, 2019. Fuente: propia

Junto a la necesidad e importancia de preservar las variedades autóctonas destacamos la importancia del agua, como elemento generador de vida y biodiversidad. El agua es la sustancia principal que activa la vida, la germinación de la semilla, por eso es el elemento primordial en la pieza escultórica, en la imagen 258 podemos observar las semillas brotando del agar agar (gelatina vegetal). La combinación de agua, luz, tierra y semilla 
como generador de vida, junto a restos orgánicos, son los elementos que conforman la composición. Elementos que forman una espiral áurea como generadora de vida, donde las semillas irán germinando, hasta alcanzar la tierra y completar sus fases de crecimiento. Estás semillas son las variedades de hortalizas endémicas de la huerta de Valencia junto a las flores y hierbas aromáticas, todas ellas se complementan y fortalecen su crecimiento.

Así pues, en la intervención se han abordado todas las cuestiones recién comentadas, se ha dado especial importancia a la recuperación de las variedades autóctonas, al valor del agua en los cultivos y a la biodiversidad, las semiesferas se han dispuesto formando la molécula del agua (H2O). Las dos más pequeñas forman los átomos de hidrógeno y la semiesfera más grande da forma al átomo de oxígeno, en ambas se contienen las semillas como podemos observar en la imagen 259 (las variedades hortícolas en las semiesferas grandes y las variedades medicinales o aromáticas en las pequeñas).

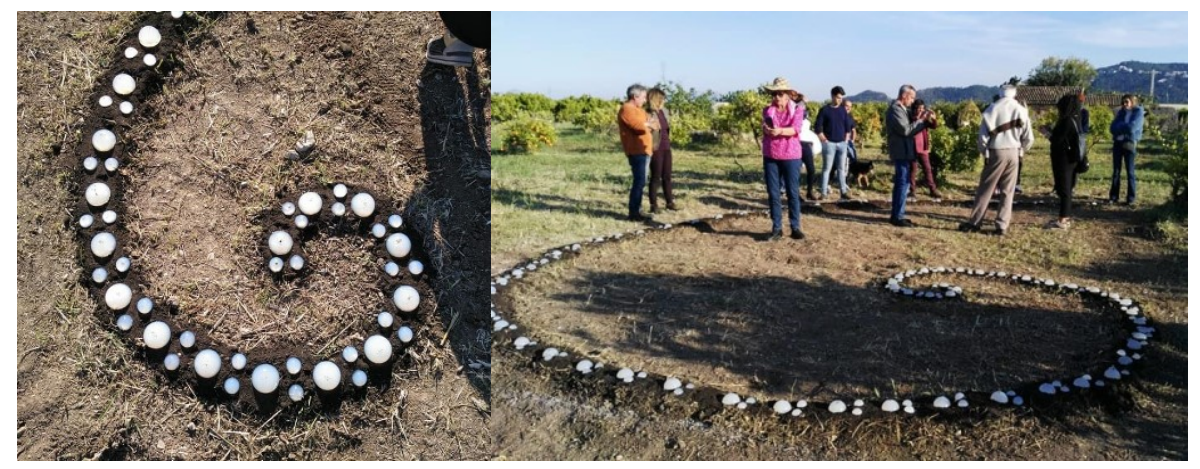

Imagen 260. Detalle Espiral de la vida, intervención en Trastellaor. Huerto Mandarina Borda en Palmera, Valencia, 2019. Fuente: propia Imagen 261. Espiral de la vida, intervención en Trastellaor. Huerto Mandarina Borda en Palmera, Valencia, 2019. Fuente: propia

Como hemos visto en las imágenes, todos los elementos se disponen generando una espiral áurea como manifestación de vida, crecimiento y expansión. La espiral es manifestada en gran número de vegetales y animales, 
siendo una de las formas más extendidas en la naturaleza, mostrando un carácter cíclico donde los ritmos se van repitiendo mientras los seres vivos van creciendo en consonancia a esas etapas. La espiral es un símbolo de fecundidad relacionado con el agua y la luna, siendo una figura geométrica clave en los cultivos permaculturales.

Finalmente, la pieza fue presentada públicamente el día de la inauguración de la convocatoria Trastellaor de 2019 (imagen 261). Los asistentes pudieron observar la obra, hacer preguntas y se generó un dialogo alrededor de la misma tratando cuestiones como las relacionadas con la labor en el campo, la conservación de las semillas, su germinación y la asociación de cultivos. Si bien cabe señalar que, por la falta de mano de obra para el mantenimiento de la huerta y la pieza en los meses posteriores, así como por la escasez de agua y la dureza del terreno, no todas las semillas germinaron y arraigaron. No obstante, la pieza sirvió para investigar nuevas formas de germinar, para practicar con la asociación de cultivos, para profundizar en el estudio de las variedades endémicas, para generar diálogos, compartir aprendizajes y para unir conceptos agrícolas y culturales a través de las estrategias artísticas. 


\section{ÍNDICE DE IMÁGENES}

IMAGEN 1. FIGURILLA PREÑNAA, CON CABEZA DE PILAR DE TIPO HAMANGIA.

CEMENTERIO DE CERNAVODA, DOBRUJA, C. 5000 A. C.

IMAGEN 2. DIOSA DE LA VEGETACIÓN CON MÁSCARA DE CERDO.

RASTU. YACIMIENTO DEL VINCA TEMPRANO, EN EL OESTE DE RUMANÍA.

IMAGEN 3. SELLO DEADDA, 2300 A. C. FUENTE: ART.LOSTONSITE.COM 37

IMAGEN 4. SELLO CILÍNDRICO, PERÍODO URUK. FUENTE: MARIE-LAN NGUYEN 37

IMAGEN 5. TUMBA DE NAKHT, DINASTÍAXVIII.

FUENTE: EGIPTOLOGÍA 2.0

IMAGEN 6. TUMBA DE SENNEDJEM, DEIREL-MEDINA.

FUENTE: EGIPTOLOGÍA 2.0

IMAGEN 7. TUMBADEMENNA, 1420 - 1411 A.C.

FUENTE: ARTE EGIPCIO: ESCULTURA Y PINTURA.

IMAGEN 8. MAQUETA DE MADERA PINTADA, 43 CM. TUMBA DEL IMPERIO MEDIO.

FUENTE: PINTURA EGIPCIA, PÁG. 7

IMAGEN 9. ÁNFORA GRIEGA, PERIODO ARCAICO 520 A. C.

FUENTE: MUSEO BRITÁNICO, LONDRES.

IMAGEN 10. SARCÓFAGO DE ARLES, DETALLE DE LA PARTE IZQUIERDA, SIGLO IVD. C.

FUENTE: DOCPLAYER.ES

IMAGEN 11. SARCÓFAGO DE ARLES, DETALLE DE LA PARTE DERECHA, SIGLO IV D. C.

FUENTE: DOCPLAYER.ES

IMAGEN 12. MOSAICO CATEDRAL DE OTRANTO, SIGLO XII.

FUENTE: ALAMY.COM

IMAGEN 13. CALENDARIO ROMÁNICO DE BELEÑA DE SORBE, SIGLOXII. 
FUENTE: OTRAIBERIA.ES

IMAGEN 14. ALEGORÍA AL BUEN GOBIERNO, PALACIO COMUNAL DESIENA,

AMBROGIO LORENZETTI, SIGLO XIV. FUENTE: REPRODART.COM

IMAGEN 15. LA COSECHA, RENACIMIENTO NÓRDICO,

PIETER BRUEGHELEL VIEJO, 1565. FUENTE: METMUSEUM.ORG

IMAGEN 16. FRUIT STALL, FRANS SNYDERS, 1618-1621.

FUENTE: ARTHERMITAGE.ORG

IMAGEN 17. LAVENDIMIA, FRANCISCO DE GOYA, 1786.

FUENTE: MUSEODELPRADO.ES

IMAGEN 18. LAS ESPIGADORAS, JEAN-FRANÇOIS MILLET, 1857.

FUENTE: MUSEO DE ORSAY, PARÍS.

IMAGEN 19. CARGADORAS DE HENO, JULIEN DUPRÉ, 1880.

FUENTE: REHS.COM

IMAGEN 20. JOVEN CAMPESINA ENCENDIENDO FUEGO,

CAMILLE PISSARRO, 1888. FUENTE: MUSEE-ORSAY.FR

IMAGEN 21. CAMPO DE TRIGO CON CUERVOS, VICENT VAN GOGH, 1890.

FUENTE: MUSEO VAN GOGH, ÁMSTERDAM.

IMAGEN 22. CARTEL CONSEJO DE DEFENSA DEL ESTADO DE INDIANA, 1917.

FUENTE: BIBLIOTECA NACIONAL DE AGRICULTURA

IMAGEN 23. THE PENNSYLVANIA STATE COLLEGE, 1917.

FUENTE: BIBLIOTECA NACIONAL DE AGRICULTURA.

IMAGEN 24. OWI, 1944.

FUENTE: BIBLIOTECA NACIONAL DE AGRICULTURA.

IMAGEN 25. CAMPESINO CATALÁN CON GUITARRA,

JOAN MIRÓ, 1924. FUENTE: MUSEOTHYSSEN.ORG

IMAGEN 26. LA MASÍA, JOAN MIRÓ, 1921-1922.

FUENTE: WWW.NGA.GOV

IMAGEN 27. CAMPESINO COMIENDO, RAFAEL ZABALETA, 1950.

FUENTE: ZABALETAFUNDACION.ORG

IMAGEN 28. GÓTICO ESTADOUNIDENSE,

GRANT WOOD, 1930. FUENTE: LINEASSOBREARTE.COM

IMAGEN 29. FALL PLOWING, GRANT WOOD, 1931.

FUENTE: PICTURINGTHEAMERICAS.ORG

IMAGEN 30. CRADLING WHEAT. THOMAS HART BENTON, 1938.

FUENTE: PIASWEETHOME.COM

IMAGEN 31. NUESTRA BUENA TIERRA, JOHN STEUART CURRY, 1942.

FUENTE: 3MINUTOSDEARTE.COM

IMAGEN 32. FARMYARD, LITOGRAFÍA SOBRE PAPEL. 
MABEL DWIGHT, 1947. FUENTE:AMERICANART.SI.EDU

IMAGEN 33. LA SORPRESA DEL TRIGO, ÓLEO SOBRE LIENZO.

MARUJA MALLO, 1936. FUENTE: SOBREHISTORIA.COM

IMAGEN 34. EL CANTO DE LASESPIGAS, ÓLEO SOBRE LIENZO.

MARUJA MALLO, 1939. FUENTE: MUSEOREINASOFIA.ES

72

IMAGEN 35. LAS LABORES DEL CAMPO, DETALLE MURAL MERCADO ABELARDO L.

RODRIGUEZ. RAMÓN ALVA GUADARRAMA, 1934-1935. FUENTE:

WWW.ELUNIVERSAL.COM.MX

IMAGEN 36. LA INDUSTRIALIZACIÓN DEL CAMPO, DETALLE MURAL MERCADO ABELARDO L.

RODRÍGUEZ. MARION GREENWOOD, 1935. FUENTE:WWW.SCIELO.ORG.MX

IMAGEN 37. FESTIVAL DE LAS FLORES: FIESTA DE SANTAANITA,

ENCÁUSTICA SOBRE LIENZO._MUSEO DEARTE MODERNO DE NUEVA YORK. DIEGO DE

RIVERA, 1931. FUENTE: WHITNEY.ORG

IMAGEN 38. WHEATFIELD - A CONFRONTATION, MANHATTAN.

AGNES DENES, 1982. FUENTE: NYTIMES.COM

IMAGEN 39. WHEATFIELD - A CONFRONTATION, MANHATTAN.

AGNES DENES, 1982. FUENTE: NYTIMES.COM

IMAGEN 40. 7000 OAKS, VISTA FACHADA MUSEO FRIDERICIANUM.

JOSEPH BEUYS, 1982. FUENTE: GALICIAGARDEN.COM

IMAGEN 41. 7000 OAKS, VISTA PLANTACIÓN PRIMER ÁRBOL.

JOSEPH BEUYS, 1982. FUENTE: GALICIAGARDEN.COM

IMAGEN 42. OLINESTONE, TINA, PIEDRA Y ACEITE.

JOSEPH BEUYS, 1984. FUENTE: TESIS JAVIER GARCERÁ, PP. 272

IMAGEN 43. INSTALACIONES DEL C3A EN LAS QUE SE DESARROLLA EL

SIMPOSIOAABAS, 2017. FUENTE: TONI BLANCO, CORDOPOLIS.ES

IMAGEN 44. PARCHE DE BIODIVERSIDAD, VARIEDAD DE HABAS.

SIMPOSIO ABBAS, CULTURHAZA, 2018. FUENTE: LA FRAGUA

IMAGEN 45. PARCHE DE BIODIVERSIDAD, ACCIÓN COSECHA DE LAS HABAS.

SIMPOSIOABBAS, CULTURHAZA, 2018. FUENTE: LA FRAGUA

IMAGEN 46. PARCHE DE BIODIVERSIDAD, DETALLE DE LA ESCANDA.

SIMPOSIO ABBAS, CULTURHAZA, 2018. FUENTE: LA FRAGUA

IMAGEN 47. PARCHE DE BIODIVERSIDAD, COSECHA DE LA ESCANDA.

SIMPOSIO ABBAS, CULTURHAZA, 2018. FUENTE: LA FRAGUA

IMAGEN 48. GRUPO DE TRABAJO INLAND.

CANGAS DE ONIS, 2018. FUENTE: PROPIA

IMAGEN 49. VISTA REBAÑO EN EL CONTEXTO DE INLAND.

ASTURIAS, 2018. FUENTE: PROPIA

IMAGEN 50. VISTA HAPPENING DIGESTING TENSIONS. 
INLAND, 2018. FUENTE: INLAND

IMAGEN 51. ARQUEOLOGÍA DE UNA HUERTA. RUINAS, TIERRA Y CESTOS DE MIMBRE.

LUCÍA LOREN, 2008. FUENTE: TRAMAMIMBRE.COM

IMAGEN 52. AL HILO DEL PAISAJE, SANTA LUCÍA DE OCÓN, LA RIOJA.

LUCÍA LOREN, 2007. FUENTE: LUCIALOREN.COM

IMAGEN 53. AL HILO DEL PAISAJE, SANTA LUCÍA DE OCÓN, LA RIOJA.

LUCÍA LOREN, 2007. FUENTE: LUCIALOREN.COM

IMAGEN 54. \#HORTATTACK, INTERVENCIÓN PÚBLICA.

VALENCIA, 2017. FUENTE: HOMEESPANA.COM

IMAGEN 55. \#HORTAATTACKRELOADED, VISTA PROCESO ELABORACIÓN.

VALENCIA, 2017. FUENTE: MERCAVALENCIA.ES

IMAGEN 56. \#HORTAATTACKRELOADED, VISTA UBICACIÓN EN LA CALLE.

VALENCIA, 2017. FUENTE: MERCAVALENCIA.ES

IMAGEN 57. LOTUS LAND, FIBRA DE VIDRIO, 27 PIEZAS DE POLÍMERO, PINTURA Y MADERA.

DINH Q. LÊ, 1999. ADQUIRIDO POR GALERIA DEARTE DE QUEENSLAND, 2006.

FUENTE: AAA.ORG.HK

IMAGEN 58. VISTA EXPOSICIÓN PURE LAND, BANGKOK.

DINH Q. LÊ, 2018. FUENTE: TANGCONTEMPORANY.COM

100

IMAGEN 59. UNTITLED \#1, LIGHT FROM DARKNESS, TRUTH ALWAYS RISES.

PURE LAND, BANGKOK. DINH Q. LÊ, 2018. FUENTE: TANGCONTEMPORANY.COM

100

IMAGEN 60. MINISTERIO DE SALUBRIDAD PÚBLICA, DEPARTAMENTO DE EDUCACIÓN

SANITARIA, COSTA RICA, 1958. FUENTE: LA AGROECÓLOGA

101

IMAGEN 61. PROTECCIÓN DE LOS SENTIDOS, FOTOGRAFÍAS Y VÍDEO HVD.

102

MARCELA MORAGA, 2010. FUENTE: ARTISHOCKREVISTA.COM

102

IMAGEN 62. WATERED DOWN, CINTA, ALAMBRE Y POMPONES.

NORFOLK ART CENTER, NE. SUZAN SHUTAN, 2016. FUENTE: SUZANSHUTAN.COM 104 IMAGEN 63. AGUA DULCE, ACRÍLICO.

DAVID PIERO OJEDA, 2020.FUENTE: @PIEROOJEDA

IMAGEN 64. FABIAN TOMASI, UNABOMBA QUIMICA NOS EXTERMINA EN SILENCIO,

ROSARIO, PROVINCIA DE SANTA FE. FACUNDO ROMA, 2017.

FUENTE: @ENVENENADOS

IMAGEN 65. ENVENENADOS, MINISTERIO DE SALUD, PROVINCIA SANTA FE.

ESTÉNCILANÓNIMO, 2016. FUENTE: @ENVENENADOS

IMAGEN 66. ENVENENADOS, ROSARIO, PROVINCIA SANTA FE.

ESTÉNCILANÓNIMO, 2016. FUENTE: @ENVENENADOS

IMAGEN 67. HOMENAJEA FABIAN TOMASI, NUESTRAS MAESTRAS Y NINNOS FUMIGADOS,

TRENQUE LAUQUEN, PROVINCIA DE BUENOS AIRES. GERMAN VILLAMOR, 2018.

FUENTE:@ENVENENADOS 
IMAGEN 68. FABIAN TOMASI, CENTRO DE SALUd DE SANTA CLARA, MAR DEL PLATA. CHALA Y SOLE, 2019. FueNTE: PROMOTORES AGROECOLÓgICOS MAR DEL PLATA 114 IMAGEN 69. FABIAN TOMASI, EL COSTO HUMANO DE LOS AGROTÓXICOS, ARGENTINA.

PABLO ERNESTO PIOVANO, 2014-2019. FUENTE: PABLOPIOVANO.COM 115 IMAGEN 70. EL COSTO HUMANO DE LOS AGROTÓXICOS, ARGENTINA.

PABLO ERNESTO PIOVANO, 2014-2019. FUENTE: PABLOPIOVANO.COM 116 IMAGEN 71. LUCAS TECHEIRA, EL COSTO HUMANO DE LOS AGROTÓXICOS, ARGENTINA. PABLO ERNESTO PIOVANO, 2014-2019. FUENTE: PABLOPIOVANO.COM

IMAGEN 72. MONSANTO, LIBRO DE CONJUROS ARTESANAL.

STEVEN LEYBA, 2010-2011. FUENTE: ORGANICAUTHORITY.COM

IMAGEN 73. MONSANTO, VISTA INTERIOR LIBRO DE CONJUROS ARTESANAL.

STEVEN LEYBA, 2010-2011. FUENTE: ORGANICAUTHORITY.COM

IMAGEN 74 E IMAGEN 75. MONSANTO NO ES SANTO DE MI DEVOCIÓN,

EXPOSICIÓN HYBRIS, MUSAC, ESPAÑA. CARMA CASULÁ, 2017.

FUENTE: CARMACASULA.COM

122

IMAGEN 76. LOGO, MONSANTO NO ES SANTODE MI DEVOCIÓN.

CARMA CASULÁ, 2018. FUENTE: CARMACASULA.COM

IMAGEN 77. NIEVES_CLAVEL MORO, MONSANTO NO ES SANTO DE MI DEVOCIÓN.

CARMA CASULÁ, 2018. FUENTE: CARMACASULA.COM

IMAGEN 78. MONSANTO: UNA INVESTIGACIÓN FOTOGRÁFICA.

MATHIEU ASSELIN, 2017. FUENTE: MATHIEUASSELIN.COM

IMAGEN 79. MONSANTO: UNA INVESTIGACIÓN PERIODÍSTICA, EXPOSICIÓN RENCONTRES

D’ARLES. MATHIEU ASSELIN, 2017. FUENTE: MATHIEUASSELIN.COM

126

IMAGEN 80. MONSANTO: UNA INVESTIGACIÓN PERIODÍSTICA, EXPOSICIÓN GALERIA DE

FOTÓGRAFOS DE LONDRES. MATHIEU ASSELIN, 2018. FUENTE: MATHIEUASSELIN.COM 126 IMAGEN 81. BENITO-TRANSGÉNICO, CARTEL. OXACA, MÉXICO.

FRANCISCO TOLEDO, 2010. FUENTE: CASA.OAXACA.GOB.MX

IMAGEN 82. CALAVERA DEL MAIZZ, CARTEL. OXACA, MÉXICO.

FRANCISCO TOLEDO, 2010. FUENTE: CASA.OAXACA.GOB.MX

IMAGEN 83. ESCULTURA DE MAÍZ JUNTO AL ARTISTA, OXACA, MÉXICO.

FRANCISCO TOLEDO, 2014. FUENTE: REGENERACIÓN.MX

IMAGEN 84. SIN MAÍZ NO HAY TOLEDO, GALERÍA POLIVALENTE DE LA UNIVERSIDAD DE

GUANAJUATO, MÉXICO. FRANCISCO TOLEDO, 2015. FUENTE: OAXACA.MEDIA

IMAGEN 85. SIN MAÍZ NO HAY TOLEDO, GALERÍA POLIVALENTE DE LA UNIVERSIDAD DE

GuANAJUATO, MÉXICO. FRANCISCO TOLEDO, 2015. FUENTE: ELUNIVERSAL.COM.MX 133 IMAGEN 86. MAZORCA, PERFORMANCE, TOTONICAPÁN, GUATEMALA.

REGINA JOSÉ GALINDO, 2015. FUENTE: REGINAJOSEGALINDO.COM 135

IMAGEN 87. MAZORCA, PERFORMANCE, TOTONICAPÁN, GUATEMALA. 
REGINA JOSÉ GALINDO, 2015. FUENTE: REGINAJOSEGALINDO.COM

IMAGEN 88. WAM (MUSEO DE AGRICULTURA MUNDIAL), VISTA INSTALACIÓN.

EL CAIRO, EGIPTO.ASUNCIÓN MOLINOS, 2010. FUENTE: ASUNCIONMOLINOS.COM 136 IMAGEN 89. WAM (MUSEODEAGRICULTURA MUNDIAL), VISTA INSTALACIÓN.

EL CAIRO, EGIPTO. ASUNCIÓN MOLINOS, 2010. FUENTE: ASUNCIONMOLINOS.COM 137 IMAGEN 90. WAM (MUSEO DE AGRICULTURA MUNDIAL), VISTA OBRA DE LA INSTALACIÓN.

EL CAIRO, EGIPTO. ASUNCIÓN MOLINOS, 2010. FUENTE: ASUNCIONMOLINOS.COM 138 IMAGEN 91. WAM (MUSEO DE AGRICULTURA MUNDIAL), DETALLE OBRA IMAGEN 88.

EL CAIRO, EGIPTO. ASUNCIÓN MOLINOS, 2010. FuENTE: ASUNCIONMOLINOS.COM 138 IMAGEN 92. PESTICIDE POP, VISTA OBRA EN EXPOSICIÓN.

GALLERY NOME, BERLÍN. KIRSTEN STOLLE, 2020. FUENTE: KIRSTENSTOLLE.COM 140 IMAGEN 93. IT'S TIME, VISTA OBRA EN EXPOSICIÓN.

GALLERY NOME, BERLÍN. KIRSTEN STOLLE, 2020. FuENTE: KIRSTENSTOLLE.COM 141 IMAGEN 94. IT'S TIME, DETALLE OBRA EN EXPOSICIÓN.

GALLERY NOME, BERLÍN. KIRSTEN STOLLE, 2020. FUENTE: KIRSTENSTOLLE.COM 141

IMAGEN 95. NO RISK TO PUBLIC HEALTH, VISTA OBRA EN EXPOSICIÓN.

GALLERY NOME, BERLÍN. KIRSTEN STOLLE, 2020. Fuente: KIRSTENSTOLLE.COM

IMAGEN 96. NO, INTERVENCIÓN DE 60 METROS DE DIÁMETRO. MAIZAL TRANSGÉNICO,

MÉXICO. GREENPEACE, 2007. FUENTE:ARCHIVO-ES.GREENPEACE.ORG

145

IMAGEN 97. MANIFESTACIÓN EN ESTELA DE LA LUZ, MÉXICO.

GREENPEACE, 2013. FUENTE: ECOOSFERA.COM

IMAGEN 98. DI NO A LOS TRANSGÉNICOS, ACCIÓN. MINISTERIO AGRICULTURA,

MADRID. GREENPEACE, 2010. FUENTE: GREENPEACEBLONG.WORDPRESS.COM

146

IMAGEN 99. UNIDOS POR UN MÉXICO SIN TRANSGÉNICOS, ACCIÓN.

CONSEJO DE LA JUDICATURA FEDERAL, MÉXICO. GREENPEACE, 2015.

FUENTE: EFE.COM

IMAGEN 100. LA FRUTILLA DEL POSTRE: EL CASOARROYO LEYES,

PORTADA DEL DOCUMENTAL.

PATRICIO ELEISEGUI, 2019. FUENTE: LARETAGUARDIA.COM

148

IMAGEN 101. AFARM FOR THE FUTURE, FRAME DEL DOCUMENTAL.

REBECCA HOSKING, 2009. FUENTE: BBC.CO.UK

IMAGEN 102. DOS TOMATES Y DOS DESTINOS, FRAME DEL CORTOMETRAJE.

CARLOS ARECES Y JOAQUÍN REYES, 2012. FUENTE: YOUTUBE.COM

IMAGEN 103. DOS TOMATES Y DOS DESTINOS, FRAME DEL CORTOMETRAJE.

CARLOS ARECES Y JOAQUÍN REYES, 2012. FUENTE: MASTERAGROALIMENTARIO.ES 151

IMAGEN 104. FESTIVAL GARGAREN PENELLES,

HARRY JAMES, 2018. FUENTE: GARGARFESTIVAL.COM

170 
IMAGEN 105. TRACCIÓN ANIMAL, FOTOGRAFÍA TRILLANDO EN LA ERA DE PALENCIA, ESPAÑA._FELIPE SIERRA CALVO, 1954. FUENTE: IMÁGENES DE UN MUNDO RURAL IMAGEN 106. NOSTOS, FESTIVAL GARGAR EN PENELLES, ESPAÑA

MIQUEL WERT, 2017. FUENTE: MIQUELWERT.COM 171

IMAGEN 107. RUTA CASAS CON VIDA EN FRESNEDILLAS DE LA OLIVA EN MADRID, ESPAÑA.

ELENA PARLANGE, 2014. FuENTE: ELESPANOL.COM 173 IMAGEN 108. MURAL DE ROMANGORDO, IMÁGENES QUE MARCAN LA IDENTIDAD DE UN PUEBLO, 2019. FUENTE: EFE.COM 174 IMAGEN 109. EQUILIBRIO NA HORTA. ÓLEO SOBRE LIENZO 240X110 CM, MURÚZABAL, 2016. FUENTE: GALERIAMETRO.COM IMAGEN 110. A GRELEIRA DE 50 PIESEN ORDES, MURÚZABAL, 2016. FUENTE: VERNE.ELPAIS.COM 176

IMAGEN 111. LA POPPINS DEL SAR EN SANTIAGO DE COMPOSTELA, MURÚZABAL, 2019. FUENTE: GIL DUCHE 177

IMAGEN 112. MASANOBU FUKUOKA. FUENTE: WWW.ELPAIS.COM 178 IMAGEN 113. VISTA MAQUETA HUERTO, CARTAGENA, 2019.FUENTE: @CULTIVANDOSANANTON 181 IMAGEN 114. DETALLE MAQUETA HUERTO, CARTAGENA, 2019.FUENTE:@CULTIVANDOSANANTON

IMAGEN 115. VISTA PARADA MERCADILLO ARTE, RE.COLECTIVO, 2014.FUENTE: @RECOLECTIVO.RURAL 182 IMAGEN 116. VISTA MURAL EN COLEGIO ANDOLINA DE GIJÓN, ESPAÑA.

RE.COLECTIVO, 2016.FUENTE: @RECOLECTIVO.RURAL 182 IMAGEN 117. VISTA INTERVENCIÓN BANCO DE SEMILLAS EN V TROBADA VORASENDA, VIRIDIAN, 2018. FUENTE: VIRIDIAN 183 IMAGEN 118. VISTA BANCO DE SEMILLASENV TROBADA VORASENDA, VIRIDIAN, 2018. FUENTE: VIRIDIAN

IMAGEN 119. ALUMNAS EN BANCO DE SEMILLAS IV MARXA D'ESCOLES PER L'HORTA, VIRIDIAN, 2019. FUENTE: VIRIDIAN 184 IMAGEN 120. VISTA BANCO DE SEMILLAS IV MARXA D'ESCOLES PERL'HORTA, VIRIDIAN, 2019. FUENTE: VIRIDIAN 184 IMAGEN 121. VISTA DIBUJO SIGNO DE INTERROGACIÓN, CARRÍCOLA, 2015. FUENTE: BIODIVERS2015.WORDPRESS.COM 186 IMAGEN 122. QUEMA DE LAPAJA, CARRICOLA, 2015. FUENTE: BIODIVERS2015.WORDPRESS.COM 186 IMAGEN 123. QUEMA DE LA PAJA, CARRÍCOLA, 2015. FUENTE: BIODIVERS2015.WORDPRESS.COM 
IMAGEN 124. OBRA CON CALÉNDULAS,

CARRÍCOLA, 2015. FUENTE: LUCIALOREN.COM

IMAGEN 125. OBRA CON LAVANDA,

CARRÍCOLA, 2016. FUENTE: LUCIALOREN.COM

187

IMAGEN 126. VISTA DISEÑO COOL PATCH PUMPKINS EN DIXON,

CALIFORNIA, 2016. FUENTE: @COOLPATCHPUMKINS

189

IMAGEN 127. ENTRADA ECOLABERINTO,

CASA GRANDE DEXANCEDA, 2012. FUENTE: CASAGRANDEXANCEDA.COM

189

IMAGEN 128. TURTLEISLAND,

VIRGINIA, 2000. FUENTE: CORNMAZEINTHEPLAINS.COM

190

IMAGEN 129. FLYWITH FREEDOM!,

VIRGINIA, 2003. FUENTE: CORNMAZEINTHEPLAINS.COM

190

IMAGEN 130. BARN TO BE WILD,

VIRGINIA, 2005. FUENTE: CORNMAZEINTHEPLAINS.COM

191

IMAGEN 131. BORN FOR CORN,

VIRGINIA, 2018. FUENTE: CORNMAZEINTHEPLAINS.COM

191

IMAGEN 132. GRAN JA THE CORN MAZE IN THE PLAINS,

VIRGINIA, 2010. FUENTE: CORNMAZEINTHEPLAINS.COM

192

IMAGEN 133. PASEO EN REMOLQUETRACTOR,

VIRGINIA, 2019. FUENTE: @CORNMAZEINTHEPLAINS

192

IMAGEN 134. ILUSTRACIÓN IWAKIYAMA,

INAKADATE, 1993. FUENTE: VILL.INAKADATE.LG.JP

193

IMAGEN 135. ILUSTRACIÓN GIRA DE SIEMBRA Y COSECHA DE ARROZ,

INAKADATE, 2002. FUENTE: VILL.INAKADATE.LG.JP

IMAGEN 136. SIEMBRA Y PRIMERAS VISTAS OSHIN,

INAKADATE, 2019. FUENTE:VILL.INAKADATE.LG.JP

194

IMAGEN 137. VISTAS OSHIN,

INAKADATE, JUNIO 2019. FUENTE: VILL.INAKADATE.LG.JP

194

IMAGEN 138. VISTAS OSHIN,

INAKADATE, JULIO 2019. FUENTE: VILL.INAKADATE.LG.JP

195

IMAGEN 139. VISTAS OSHIN,

INAKADATE, AGOSTO 2019. FUENTE: VILL.INAKADATE.LG.JP

195

IMAGEN 140. VISTAS OSHIN,

INAKADATE, SEPTIEMBRE 2019. FUENTE:VILL.INAKADATE.LG.JP

195

IMAGEN 141. LA COSECHA DE OSHIN,

INAKADATE, OCTUBRE 2019. FUENTE: VILL.INAKADATE.LG.JP

196

IMAGEN 142. VISTA EDIFICIO-MIRADOR DESDE CAMPO DE ARROZ,

INAKADATE, 2019. FUENTE:VILL.INAKADATE.LG.JP 
IMAGEN 143. CARTEL EXPRESARTE DE LA TIERRA,

JOSE CRUZ GARCÍA, MÉXICO, 2013. FuENTE: CUEXCOMATE.COM

IMAGEN 144. VISTA EXPOSICIÓN SEMBLANZA DE LAAGRICULTURA DE LASAMÉRICAS,

CRUZGAALI, 2017. FUENTE: ICA.INT

201

IMAGEN 145. VISTA MURAL SEMBLANZA DE LA AGRICULTURA DE LASAMÉRICAS,

CRUZGAALI, 2017. FUENTE: IICA.INT

201

IMAGEN 146. COSECHA,

NATASCHA DE CORTILLAS, 2019. FUENTE: ARTEINFORMADO.COM

202

IMAGEN 147. COSECHA_NATURALEZAMUETA,

NATASCHA DE CORTILLAS, 2019. FUENTE: ARTEINFORMADO.COM

202

IMAGEN 148. LEVANTAMIENTO ICONOGRÁFICO DEL TERRITORIO DEL RIO BIO-BIOO Y DEL AVANCE DE LAS PLANTACIONES FORESTALES, NATASHA DE CORTILLAS, 2019. FUENTE:

TERREMOTO.MX

203

IMAGEN 149. VISTA INSTALACIÓN COSECHA: SIEMBRA YRESISTENCIA,

NATASHA DE CORTILLAS, 2019. FUENTE: TERREMOTO.MX

203

IMAGEN 150. CUATRO DELANTALES COLGADOS COSECHA,

NATASHA DE CORTILLAS, 2019. FUENTE: TERREMOTO.MX

204

IMAGEN 151. DELANTAL COSECHA,

NATASHA DE CORTILLAS, 2019. FUENTE: ARTEINFORMADO.COM

204

IMAGEN 152. PAN PARA HOY HAMBRE PARA MAÑANA DE LA SERIE CHILE AMASA SU PAN,

NATASHA DE CORTILLAS, 2014. FUENTE: NATASCHADECORTILLAS.CL

205

IMAGEN 153. INTERCAMBIO DE SEMILLAS Y PENSAMIENTO,

JOSE ISMAEL MANCO, 2014. FUENTE: EFIMERO.ORG

206

IMAGEN 154. SEMBRADOR,

JOSE ISMAEL MANCO, 2014. FUENTE: HUELVA24.COM

207

IMAGEN 155. FLOR DE PERMACULTURA, 2015.

FUENTE: VARGUX

IMAGEN 156. VISTA CASA DE BARRO.

FUNDACIÓN LOS MADROÑOS, 2018. FUENTE: PROPIA

220

IMAGEN 157. VISTA PATIO Y EDIFICIO HABITACIONES.

FUNDACIÓN LOS MADROÑOS, 2018. FUENTE: PROPIA

IMAGEN 158. VISTA DE UNA DE LAS HUERTAS.

FUNDACIÓN LOS MADROÑOS, 2018. FUENTE: PROPIA

IMAGEN 159. DETALLE DE UNA DE LAS HUERTAS.

FUNDACIÓN LOS MADROÑOS, 2018. FUENTE: PROPIA

221

IMAGEN 160. GRUPO COMUNIDAD.

FUENTE: CREATIVE COMMONS, S.F.

222

ILUSTRACIÓN 161. CAMPO DE MANZANOS. 
FUENTE: CREATIVE COMMONS, S. F.

IMAGEN 162. DE-COMPOSITION, PERFORMANCE.

NALA WALLA Y TAMARA ASHLEY, 2009. FUENTE: BCOLLECTIVE.ORG

225

IMAGEN 163. DE-COMPOSITION, PERFORMANCE.

NALA WALLA Y TAMARA ASHLEY, 2009. FUENTE: BCOLLECTIVE.ORG

225

IMAGEN 164. MENSAJE DEAMORDE 500 PERSONAS.

MASARU EMOTO, 2002. FUENTE: OSHOGULAAB.COM

230

IMAGEN 165. MENSAJE DE "ME ENFERMAS, jTEVOY A MATAR!"

MASARU EMOTO, 2002. FUENTE: OSHOGULAAB.COM

IMAGEN 166. BOCETOS EN PAPEL HUERTA DEL BOTICARIO, 2019.

FUENTE: PROPIA

IMAGEN 167. VISTA HUERTA DEL BOTICARIO, 2017.

FUENTE: CARLOS GARCÍA DOLZ

IMAGEN 168. VISTAS PRIMERA PARCELA, HUERTA DEL BOTICARIO.

MACASTRE, VALENCIA, 2015. FUENTE: CARLOS GARCÍA DOLZ

IMAGEN 169. VISTAS SEGUNDA PARCELA, HUERTA DEL BOTICARIO.

MACASTRE, VALENCIA, 2019. FUENTE: PROPIA

IMAGEN 170. DETALLE FLOR, HUERTA DEL BOTICARIO.

MACASTRE, VALENCIA, 2019. FUENTE: PROPIA

IMAGEN 171. HUERTADEL BOTICARIO.

MACASTRE, VALENCIA, 2019. FUENTE: PROPIA

IMAGEN 172. CHACRADE ORIGEN KICHWA.

FUENTE: MUSEO Y PARQUEANCESTRAL PUMAPUNGO

235

IMAGEN 173. CUIDADOR DE LACHAKRA.

FUENTE: LA CHAKRA YEL MUNDO ANDINO, MIGUELARÉVALO, EL TIEMPO

IMAGEN 174. MUSEO ISABELLA STEWART GARDNER, JARDINES INTERIORES.

FUENTE: TRAVELER.ES

IMAGEN 175. PHOENIX RECYCLING PLANT.

M. SINGERY L. GLATT, 1993. FUENTE: MICHAEL SInGER

236

IMAGEN 176. ILUSTRACIONES PROYECTO FOOD FOREST.

ARTIST AS FAMILY, 2010 FUENTE: THEARTISTASFAMILY.BLOGSPOT.COM

ILUSTRACIÓN 177. VISTAS CRECIMIENTO PROYECTO FOOD FOREST.

ARTIST AS FAMILY, 2010 FUENTE: THEARTISTASFAMILY.BLOGSPOT.COM

IMAGEN 178. FINALIZACIÓN PROYECTO FOOD FOREST.

ARTIST AS FAMILY, 2010 FUENTE: THEARTISTASFAMILY.BLOGSPOT.COM

IMAGEN 179. VISTA EXTERIOR.

EDIBLE PARK, 2011. FUENTE: ERIC DE VRIES

IMAGEN 180. VISTA INTERIOR DEL PABELLÓN. 
IMAGEN 181. TEJIENDO LAALFOMBRA.

FRITZ HAEG, 2013. FUENTE: FRITZHAEG.COM

IMAGEN 182. DOMESTICINTEGRITIES PART A05: MINNEAPOLIS, MINNESOTA.

FRITZ HAEG, 2013. FUENTE: FRITZHAEG.COM

IMAGEN 183. PROPOSITIONS FOR FREEDOM FARMERS, INSTALACIÓN CON MATERIALES

RECICLADOS Y PLANTAS NATIVAS COMESTIBLES. XIN CHENG, 2013-2014.

FUENTE: XIN-CHENG.INFO

IMAGEN 184. VISTA DETALLE PROPOSITIONS FOR FREEDOM FARMERS.

XIN CHENG, 2013-2014. FUENTE: XIN-CHENG.INFO

IMAGEN 185. VISTA DETALLE PROPOSITIONS FOR FREEDOM FARMERS.

XIN CHENG, 2013-2014. FUENTE: XIN-CHENG.INFO

IMAGEN 186. VISTA DETALLE MAIZE FIELD, EN LA ESQUINA DE BERGEN Y SMITH.

MARIE VILJOEN, 2010. FUENTE: EDIBLEBROOKLYN.COM

IMAGEN 187. MAIZE FIELD, EN LA ESQUINA DE BERGEN Y SMITH.

MARIE VILJOEN, 2010. FUENTE: EDIBLEBROOKLYN.COM

IMAGEN 188. CHINA. XIN CHENG, 2007.

FUENTE: XIN-CHENG.INFO

IMAGEN 189. CHINA. XIN CHENG, 2007.

FUENTE: XIN-CHENG.INFO

IMAGEN 190. VISTA HUERTA CON PALOS DE ESCOBA.

BOCAIRENT, 2019. FUENTE: PROPIA 247

IMAGEN 191. VISTA HUERTA DEL BOTICARIO.

MACASTRE, VAlenCia, 2017. Fuente: CARLOS GarCía DolZ

IMAGEN 192. FINCA LA CASTILLA, 2019.

FUENTE: TRINI

IMAGEN 193. BAÑERA PARA PLANTEL.

FUNDACIÓN LOS MADROÑOS, 2018. FUENTE: PROPIA

IMAGEN 194. BOCETO INTERVENCIÓNARTFARM, 2010.

FUENTE: AFHNY STUDIO

250

IMAGEN 195. INTERVENCIÓN ARTFARM, 2010.

FUENTE: AFHNY STUDIO

IMAGEN 196. DETALLE INTERVENCIÓN ARTFARM, 2010.

FUENTE: AFHNYSTUDIO 250

IMAGEN 197. VISTA AÉREA ASENTAMIENTO NEGEV, 2016.

FUENTE: DAFNA NUDELMAN

IMAGEN 198. VISTA ANOCHECER EN ASENTAMIENTO NEGEV, 2016.

FUENTE: DAFNA NUDELMAN 
IMAGEN 199. CARPA CENTRAL.

ASENTAMIENTO NEGEV, 2016. FUENTE: DAFNA NUDELMAN

IMAGEN 200. ZONA DE LIMPIEZA DE LOS UTENSILIOS DE COCINA.

ASENTAMIENTO NEGEV, 2016. FUENTE: DAFNA NUDELMAN

253

IMAGEN 201. VISTA TERRITORIO TRAS LA RETIRADA DEL ASENTAMIENTO NEGEV, 2016.

FUENTE: DAFNA NUDELMAN

IMAGEN 202. CIUDAD DE LALUZ.

MADJA-GEUSEN, 2014. FUENTE: TAMERA.ORG

255

IMAGEN 203. TRES MUJERES.

SIMON DU VINAGE, 2017. FUENTE: TAMERA.ORG

255

IMAGEN 204. NÃO AO FURO! SIM AO FUTURO.

L. SCHRAMM, K. DELACASA, S. VINAGE, Y. KOVO, SPECTRAL Q, 2017.

FUENTE: TAMERA.ORG

IMAGEN 205. DETALLE ACCIÓN, NÃOAO FURO! SIMAO FUTURO.

L. SCHRAMM, K. DELACASA, S. VINAGE, Y. KOVO, SPECTRAL Q, 2017.

FUENTE: TAMERA.ORG

IMAGEN 206. AUTOBÚS-RESIDENCIA ARTISTICA,

KULTIVATOR, 2019. FUENTE: PROPIA

263

IMAGEN 207. VISTA INTERIOR AUTOBÚS-RESIDENCIA ARTISTICA,

KULTIVATOR, 2019. FUENTE: PROPIA

263

IMAGEN 208. PROTOTIPO EDIFICIO TEJADO VERDE.

KULTIVATOR, 2019. FUENTE: PROPIA

264

IMAGEN 209. SI QUIERES SABER CÓMO ME SIENTO PREGUNTA A MI CABALLO,

KULTIVATOR. SUECIA, 2019. FUENTE: PROPIA

265

IMAGEN 210. REFUGIO CABALLOS,

KULTIVATOR. SUECIA, 2019. FUENTE: PROPIA

266

IMAGEN 211. REFUGIO ARTE YAGRICULTURA,

KULTIVATOR. SUECIA, 2019. FUENTE: PROPIA

266

IMAGEN 212. DETALLE REFUGIO ARTE Y AGRICULTURA,

KULTIVATOR. SUECIA, 2019. FUENTE: PROPIA

266

IMAGEN 213. VISTA HORNOS REFUGIO ARTE YAGRICULTURA,

KULTIVATOR. SUECIA, 2019. FUENTE: PROPIA

267

IMAGEN 214. VISTA INTERIOR REFUGIO ARTE YAGRICULTURA,

KULTIVATOR. SUECIA, 2019. FUENTE: PROPIA

IMAGEN 215. FILTROVERDE,

KULTIVATOR. SUECIA, 2019. FUENTE: PROPIA

268

IMAGEN 216. BIOCONSTRUCCIÓN ASEO SECO,

KULTIVATOR. SUECIA, 2019. FUENTE: PROPIA

269 
IMAGEN 217. CARRITO CON CULTIVADOR,

KULTIVATOR. SUECIA, 2019. FUENTE: PROPIA

IMAGEN 218. ALUMNA CONSTRUYENDO EL HORNO.

ÖLANDS FOLKHÖGSKOLA 2019. FUENTE: PROPIA 270

IMAGEN 219. ESCUELA ÖLANDS FOLKHÖGSKOLA.

ÖLAND, SUECIA, 2019. FUENTE: PROPIA

IMAGEN 220. VISTA AULA ARTE ÖLANDS FOLKHÖGSKOLA.

ÖLAND, SUECIA, 2019. FUENTE: PROPIA

IMAGEN 221. ENTRADA A KULTIVATOR,

KULTIVATOR. SUECIA, 2019. FUENTE: PROPIA

272

IMAGEN 222. VACAS EN GRANJA DE HENRIC STIGEBORN,

KULTIVATOR. SUECIA, 2019. FUENTE: PROPIA

272

IMAGEN 223. TRASTELLAORS. PAU LÓPEZ ANQUELA, 2019.

FUENTE: CESIÓN DEL ARTISTA

IMAGEN 224. CÁPSULA I, DARIO ESCRICHE, 2019.

FUENTE: CESIÓN DEL ARTISTA 276

IMAGEN 225. LA NARANJA BORDE, MIRIAM MARTíNEZ GUIRAO, 2019.

FUENTE: CESIÓN DELARTISTA

IMAGEN 226. RECETARIO HECHO CON AMOR BORDE.

ENRIQUETA ROCHER, 2019. FUENTE: CESIÓN DEL ARTISTA

278

IMAGEN 227. AD INFINITUM. CHIARA SGARAMELLA, 2016.

FUENTE: CESIÓN DELARTISTA

279

IMAGEN 228. VISTA HUERTAY CASA CULTURHAZA.

CÓRDOBA, 2020. FUENTE: PROPIA 284

IMAGEN 229. MOLINO DE HARINA, CULTURHAZA.

CÓRDOBA, 2020. FUENTE: PROPIA 286

IMAGEN 230. VISTA ENTRADA HABITACIÓN MOLIENDA, CULTURHAZA.

CÓRDOBA, 2020. FUENTE:PROPIA 286

IMAGEN 231. PIEZA VINILO, JACOBO CON SU ZANFONA E ISABEL.

CULTURHAZA, 2016. FuENTE: CULTURHAZA

IMAGEN 232. ANTONIO, NAZARET Y SU BURRO, CULTURHAZA.

CÓRDOBA, 2020. FUENTE: PROPIA 290

IMAGEN 233. VISTA ENTRADA KULTIVARTE, BARÃO DE SÃO JOÃO,

PORTUGAL, 2020. FUENTE: CESIÓN DE KULTIVARTE 292

IMAGEN 234. VISTA TIENDA KULTIVARTE, BARÃO DE SÃO JOÃO,

PORTUGAL, 2020. FUENTE: CESIÓN DE KULTIVARTE 292

IMAGEN 235. VISTA AFRICAN DRUM CLASS, EN KULTIVARTE, BARÃO DE SÃO JOÃO, PORTUGAL, 2019. FUENTE: CESIÓN DE KULTIVARTE 
IMAGEN 236. VISTA CREACIÓN MURAL EN KULTIVARTE, BARÃO DESÃO JOÃO,

PORTUGAL, 2018. FUENTE: CESIÓN DE KULTIVARTE 294

IMAGEN 237. VISTA CAMPO CEREAL EN KULTIVARTE, BARÃO DE SÃO JOÃO,

PORTUGAL, 2019. FUENTE: CESIÓN DE KULTIVARTE

IMAGEN 238. VISTA MOLINO EN KULTIVARTE, BARÃO DE SÃO JOÃO,

PORTUGAL, 2019. FUENTE: CESIÓN DE KULTIVARTE

IMAGEN 239. VISTA HORNO EN KULTIVARTE, BARÃO DE SÃO JOÃO,

PORTUGAL, 2019. FUENTE: CESIÓN DE KULTIVARTE

IMAGEN 240. HUERTO MÁNDALA EN QUINTA DAS RELVAS.

299

BRANCA, PORTUGAL, 2020.FUENTE: @QUINTADASRELVAS

299

IMAGEN 241. INTERVENCIÓN EN RESIDENCIA LAND ART, QUINTA DAS RELVAS.

BRANCA, PORTUGAL, 2017. FUENTE: @QUINTADASRELVAS

300

IMAGEN 242. INTERVENCIÓN EN RESIDENCIA LAND ART, QUINTA DAS RELVAS.

BRANCA, PORTUGAL, 2017.FUENTE: @QUINTADASRELVAS 300

IMAGEN 243. PROCESO OBRA, RESIDENCIA UM GRÃO NA ASA, QUINTA DAS RELVAS.

BRANCA, PORTUGAL, 2020. FUENTE: @QUINTADASRELVAS 301

IMAGEN 244. PROCESO OBRA, RESIDENCIA UM GRÃO NA ASA, QUINTA DAS RELVAS.

BRANCA, PORTUGAL, 2020. FUENTE: @QUINTADASRELVAS

IMAGEN 245. BOCETO PROYECTO BIOCONSTRUCCIÓN, QUINTA DAS RELVAS.

BRANCA, PORTUGAL, 2018. FUENTE: @QUINTADASRELVAS

302

IMAGEN 246. PROCESO DISEÑO PERMACULTURA, QUINTA DAS RELVAS.

BRANCA, PORTUGAL, 2019.FUENTE: @QUINTADASRELVAS

302

IMAGEN 247. VISTA CASA KULTIVATOR,

SUECIA, 2019. FUENTE: PROPIA

353

IMAGEN 248. GRANJA DE HENRIC STIGEBORN,

KULTIVATOR. SUECIA, 2019. FUENTE: PROPIA

IMAGEN 249. VISTA HUERTO MÁNDALA, MANDARINA BORDA.

PALMERA, VALENCIA, 2019. FUENTE: ENRIQUETA ROCHER

361

IMAGEN 250. PROTASIA Y AGRIPINO EN CULTURHAZA.

CÓRDOBA, 2020. FUENTE: PROPIA

IMAGEN 251. VISTA PATIO KULTIVARTE, BARÃO DE SÃO JOÃO,

PORTUGAL, 2019. FUENTE: CESIÓN DE KULTIVARTE

IMAGEN 252. VISTA QUINTA DAS RELVAS, BRANCA,

PORTUGAL, 2019.FUENTE: @QUINTADASRELVAS

IMAGEN 253. VISTA DELANTERA, POR LA SOBERANÍA ALIMENTARIA.

A LES BALCONADES, MERCADO DE RUZAFA, VALENCIA, 2017. FUENTE: PROPIA

407

IMAGEN 254. VISTA TRASERA, POR LA SOBERANIA ALIMENTARIA.

A LES BALCONADES, MERCADO DE RUZAFA, VALENCIA, 2017. FUENTE: PROPIA

407 
IMAGEN 255. VISTA DELANTERA, POR LA SOBERANÍA ALIMENTARIA.

CLAUSURA A LES BALCONADES, BARRIO DE RUZAFA, VALENCIA, 2017. FUENTE: PROPIA 408 IMAGEN 256. VISTA TRASERA, POR LA SOBERANIA ALIMENTARIA.

CLAUSURA A LES BALCONADES, BARRIO DE RUZAFA, VALENCIA, 2017. FUENTE: PROPIA 408 IMAGEN 257. ESPIRAL DE LA VIDA, INTERVENCIÓN EN TRASTELLAOR.

HUERTO MANDARINA BORDA EN PALMERA, VALENCIA, 2019. FUENTE: PROPIA 409 IMAGEN 258. VISTA DETALLE GERMINACIÓN DE SEMILLAS EN AGARAGAR, PALMERA, VALENCIA, 2019. FUENTE: PROPIA 410 IMAGEN 259. DETALLE ESPIRAL DE LA VIDA, INTERVENCIÓN EN TRASTELLAOR. HUERTO MANDARINA BORDA EN PALMERA, VALENCIA, 2019. FUENTE: PROPIA 410 IMAGEN 260. DETALLE ESPIRAL DE LA VIDA, INTERVENCIÓN EN TRASTELLAOR.

HUERTO MANDARINA BORDA EN PALMERA, VALENCIA, 2019. FUENTE: PROPIA 411 IMAGEN 261. ESPIRAL DE LA VIDA, INTERVENCIÓN EN TRASTELLAOR.

HUERTO MANDARINA BORDA EN PALMERA, VALENCIA, 2019. FUENTE: PROPIA 


